UNIVERSIDAD POLITÉCNICA DE MADRID

Escuela Técnica Superior de Arquitectura de Madrid

\title{
La Ciudad Neorrealista. \\ Territorio, iconografía y mapas de Roma y Madrid. 1943-1963 \\ Tesis Doctoral
}

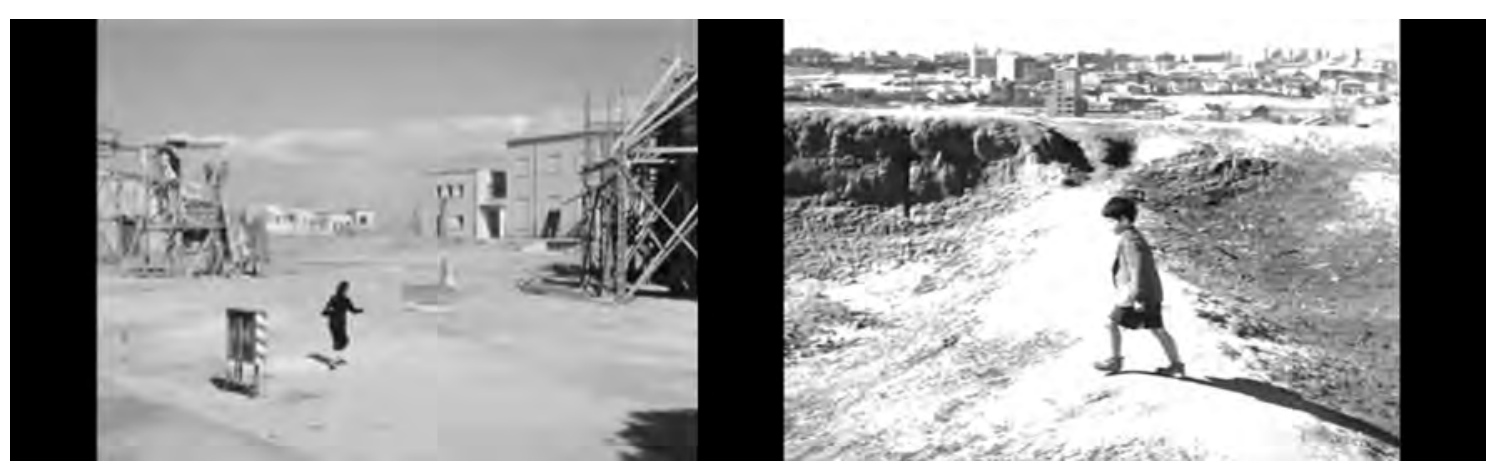

Federico Colella

Arquitecto 

Departamento de Proyectos Arquitectónicos

Escuela Técnica Superior de Arquitectura de Madrid

\section{La Ciudad Neorrealista.}

Territorio, iconografía y mapas de Roma y Madrid. 1943-1963

Autor:

Federico Colella

Arquitecto

Director de la Tesis

Luís Antonio Gutiérrez Cabrero

Doctor Arquitecto 

Tribunal nombrado por el Mgfco. Y Excmo. Sr. Rector de la Universidad Politécnica de Madrid, el día

Presidente D.

Vocal D.

Vocal D.

Vocal D.

Secretario D.

Realizado el acto de defensa y lectura de Tesis el día

en la Escuela Técnica Superior de Arquitectura de Madrid

Calificación:

EL PRESIDENTE

LOS VOCALES

EL SECRETARIO 



\section{INDICE}

- Agradecimientos

- Resumen y Abstract.

Introducción

- Introducción al tema.

- Objetivos e hipótesis

- Antecedentes, Estado de la cuestión y Marco teórico

- Metodología de trabajo y herramientas.

- Estructura del trabajo.

SUPERSTRUCTURA / HISTORIA

\section{LA RECONSTRUCCIÓN EN ROMA Y EN MADRID.}

1.1. El "INA Casa" y el INV.

1.1.1 Trama social, política y económica.

1.1.2 Corporativismo, ocupación e iniciativa privada.

1.1.3 Ley Fanfani y Ley de Renta Limitada.

1.2. Paisaje cultural: la mirada neorrealista en Italia y España.

1.2.1 Del Surrealismo al Neorrealismo: "Las Hurdes de Luís Buñuel"

1.2.2 De Roma ciudad abierta a Surcos: espacio cinematográfico y paisaje urbano.

1.2.3 Del Racionalismo al Neo-empirismo: aspiración a la realidad.

1.3. Ciudades neorrealistas: la dialéctica centro-periferia.

1.3.1 El "Plano Sombra" en Roma y el PGOUM de Madrid.

1.3.2 Territorios periféricos y espacio fílmico.

1.3.3 Topología del rodaje.

1.3.4 Sectores: Vacíos, Poblados y ciudad informal

2. ICONOGRAFÍA NEORREALISTA: EL PAISAJE URBANO EN LAS DOS CAPITALES

2.1. Paisaje - tiempo.

2.1.1 Iconografía neorrealista: hacia la imagen óptica

2.1.2 Dimensión temporal y materia fílmica.

2.1.3 Surcos: Nostalgia del campo.

2.1.4 Arquitecturas vernáculas: realidad y folklore.

2.1.5 Tiempo astronómico y atmosférico.

2.2. Paisaje - movimiento

2.2.1 Movimientos de fondo.

2.2.2 Ciudad nómada.

2.2.3 Movimiento transcendente: paisaje humano y vehículos.

2.2.4 Movimiento inmanente: viajes, llegadas y derivas

2.3. Paisaje - palimpsesto: infraestructuras urbanas y naturales 
2.3.2 Infraestructuras naturales: topografía, vegetación, ríos y canales.

2.3.3 Infraestructuras y ciudad productiva.

2.4. Paisaje - ausencia: espacios cualesquiera, residuos y umbrales

2.4.1 Espacios desconectados y vaciados

2.4.2 Campos de batalla: desechos y ruinas

2.4.3 Poética del descampado.

2.4.4 Fronteras y umbrales.

2.4.5 Ciudad Desertizada / inacabada / en construcción

2.5. Paisaje - permanencia: hábitat y demoras.

2.5.1 Detenerse

2.5.2 Seis niveles.

2.5.3 La casa impropia: planta baja, sótanos, buhardillas, casas-taller.

2.5.4 Paisajes domésticos: espacialidad, elementos y texturas.

\section{CARTOGRAFÍA NEORREALISTA: EXPLORACIONES AL MARGEN DE LA CIUDAD}

3.1. De la Periferia al centro: Val Melaina y el barrio de San Juan

3.1.1 Ladrón de Bicicletas

3.1.2 Mi tío Jacinto

3.2. Entre Centro y Periferia: Prenestino y Legazpi

3.2.1 De Roma ciudad abierta a Accattone

3.2.2 De Surcos a Los golfos.

3.3. Sector Noreste: el barrio Nomentano y la Elipa.

3.3.1 El techo.

3.3.2 Los golfos.

3.4. Sector Sureste. El Tuscolano y Entrevías

3.4.1 Mamma Roma

3.4.2 Cerca de la ciudad.

4. CONSTRUCCIÓN DEL PAISAJE URBANO NEORREALISTA: ROMA VS MADRID

4.1. Recorridos, y exploraciones de los cineastas

4.1.1 Los viajes de las cámaras: topología del rodaje.

4.1.2 Psicogeografias: Elipsis y montajes

4.2. Estancias y hábitats

4.2.1 Ruinas, andamios y armazones

4.2.2 Topografías neorrealistas.

4.3. Paisaje autóctono

4.3.1 Roma y Madrid: entropía y vacío

4.3.2 Materia y textura

4.3.3 La ciudad en blanco y negro. 
CONCLUSIONES

BIBIOGRAFIA Y FUENTES

ANEXOS:

- ANEXO I: Fichas técnicas de las obras cinematográficas analizadas.

- ANEXO II: Cuadros temáticos

- ANEXO III: Línea de tiempo

- ANEXO IV: Paralelos

- ANEXO V: Vuelta

- ANEXO VI: Glosario 


\section{AGRADECIMIENTOS}

- De forma especial, mi director de Tesis: Luís Antonio Gutierrez Cabrero, por haberme enseñado la necesaria inquietud hacia el conocimiento y por las incomparables tardes de exploración cinematografico-arquitectónicas

- Concha Lapayese por su tutela y amistad.

- Carlos Ferran que me contó sus aventuras en la "España neorrealista" a través de algunas de sus arquitecturas más bellas. Gracias también por haberme facilitado el emocionante e indeleble encuentro con uno de los protagonistas de esta maravillosa época, José luís Romany, en su estudio de la Avenida de Portugal.

- Los empleados del Archivo de la Comunidad de Madrid, de la Filmoteca Española, del Cine Doré, de la Casa Encendida y los vecinos de Entrevías, por su ayuda en las varias etapas madrileñas de mi trabajo.

- Todos mis amigos y amigas que han estado cerca de mi en este largo camino, apoyándome e inspirándome: Erandi, Licinia, Silvia y Fernando

- Mis padres y mi hermana; de forma especial, mi madre a quien está dedicado este trabajo. 


\section{RESUMEN}

La "Ciudad Neorrealista" analizada en esta tesis corresponde a la visión propuesta por algunos directores italianos y españoles, quienes entre los años '40 y ' 60 , exploraron el espacio urbano en trasformación en Roma y Madrid. La tesis inscribe al Cinema Neorrealista dentro de la más amplia tradición de investigación artística sobre el fenómeno urbano que se desarrolla a lo largo de todo el siglo XX, desde el futurismo y el surrealismo, pasando por los dadá y situacionistas hasta llegar a la Land-art. Los recorridos urbanos realizados por los directores en la búsqueda de los decorados para sus películas, se pueden comparar con las primeras derivas extraurbanas de André Bretón y los primeros surrealistas, y con los viajes suburbanos de Robert Smithson. El resultado fueron algunas obras cinematográficas en las cuales, a través de los ojos de los protagonistas, se presentó al público una nueva imagen urbana.

El paralelo histórico, social y económico que se establece entre Italia y España en esta tesis, sirve como trasfondo para definir con más precisión los fenómenos urbanos en Roma y Madrid, que, a pesar de las diferentes situaciones políticas, compartieron el mismo desequilibrio entre poder público y privado, desequilibrio que contribuyó a la génesis del paisaje urbano descrito por los directores.

Los fotogramas seleccionados, que constituyen un vocabulario común a los dos contextos, son organizados en categorías que, a partir de algunas reflexiones de Deleuze sobre el Cinema, describen una nueva iconografía urbana: el paisaje-tiempo o paisaje de la memoria; el paisaje-movimiento; el paisaje-palimpsesto o el paisaje de las infraestructuras naturales y artificiales; el paisaje de la ausencia y de la permanencia.

La vinculación de la topología del rodaje a la iconografía desarrollada, permite establecer paralelos entre diferentes narraciones urbanas presentes en las películas. La imagen pintoresca de Roma y Madrid, deja el lugar a una visión inédita, en la cual prevalece la periferia de los lotes vacíos y de los asentamientos informales; las topografías desertizadas; los conjuntos de vivienda social sin acabar, los fragmentos de un mundo rural que conviven con las infraestructuras industriales.

Las tipologías y las morfologías de los sectores urbanos corresponden a los diferentes hábitats de los protagonistas, los lugares en donde comienzan o acaban las derivas urbanas, representadas en los mapas, a través de los vectores de movimiento: Val Melaina y San Juan Bautista; el Prenestino y Arganzuela; el Fosso di Sant'Agnese y La Elipa; el Tuscolano y Entrevías. En todos los territorios periféricos recorridos, se produce la dialéctica entre ciudad formal e informal, presentándose este último como un espacio de resistencia y libertad, a favor de la cual muchas veces los directores parecen tomar posición.

La cinematografía Neorrealista, con sentido crítico, intentó establecer un diálogo creativo con el territorio en expansión.

En la tesis, se plantean como tipologías espaciales y formales de la Ciudad Neorrealista, una serie de estructuras arquitectónicas y paisajísticas reales, o algunas veces resultado de puestas en escena que trascienden el espacio de la pantalla, estableciendo una conexión con las arquitecturas y con el espacio urbano que se iba desarrollando en esta época: se trata de las topografías y de los conjuntos habitacionales horizontales y verticales; las ruinas y las arquitecturas inacabadas de la ciudad informal; los andamios y los armazones presentes bajo 
distintas configuraciones duraderas o efímeras; y, finalmente, la luz y la textura como materiales de proyecto que caracterizan el espacio urbano Neorrealista.

Las derivas urbanas y extraurbanas que los directores cumplen, tuvieron el valor de acciones proyectuales sobre el territorio, aunque finalizadas en la narración cinematográfica. Los vectores trazados y mapeados describen los diferentes psicogeografías de Roma y Madrid presentes en las películas. La imagen de una cartografía-resumen de todos los vectores recorridos en cada película, y de las paradas a lo largo de los recorridos, constituyen una posible imagen planimétrica de la Ciudad Neorrealista.

El presente trabajo de investigación, como resultado de una propuesta metodológica dentro del área de conocimiento denominada "Paisaje cultural", plantea una ampliación de los límites de las disciplinas de la arquitectura, y el urbanismo, a través del espacio fílmico y de los ecos que permanecen en el espacio real después del rodaje. La dialéctica posible entre representación y realidad, entre memoria cinematográfica y memoria del lugar, entre pasado y futuro, deja abiertos nuevos escenarios en investigación y desarrollo del proyecto urbano.

El análisis comparativo permite identificar diferencias entre las dos capitales, italiana y española, y distintos modelos de génesis y expansión del espacio periférico, donde emergen aspectos peculiares de cada ciudad; Madrid se presenta como un territorio vacío y rural alrededor de un centro urbano compacto e inalcanzable; Roma un territorio híbrido y entrópico resultado de la sobreposición de fragmentos urbanizados, infraestructuras y territorio rural. De la misma manera, esta investigación llega a una síntesis iconográfico-espacial de las dos ciudades: "La Ciudad Neorrealista".

Finalmente "La Ciudad Neorrealista" descubierta por los directores cinematograficos, se vuelve una metacategoría capaz de adaptarse e interpretar los fenómenos urbanos actuales, y al mismo tiempo, un "manifiesto" para posibles intervenciones en la ciudad contemporánea. 


\section{ABSTRACT}

The "Neorealist city" analyzed in this thesis corresponds to the vision proposed by some Italian and Spanish directors who, between the 40 s and 60s, explored the urban space in transformation in Rome and Madrid. This work inscribes the Neorealist Cinema within the broadest tradition of artistic research on the urban phenomenon that is developed throughout the entire twentieth century from futurism and surrealism, through given the situationists to Land-art. The urban tours made by the directors in search of the sets for their films can be compared to the first explorations of Andre Bretón and the first surrealists, and to the Robert Smithson suburban journeys. The result was the cinematographic works in which through the eyes of the protagonists, a new urban image was presented to the public.

The historical, social and economic parallel established in this research between Italy and Spain serves as a background to define more precisely the urban phenomena in Rome and Madrid, which, despite the different political situations, shared the same "imbalance" between public and private power, that contributed to the genesis of the urban landscape described by movie directors.

The selected frames, which constitute a common vocabulary for the two contexts, are organized into categories - based on some of Deleuze's reflections on the Cinema - that describe a new urban iconography: landscape of time or landscape of memory; the landscapemovement; the landscape-palimpsest of natural and artificial infrastructures; the landscape of absence and that of permanence.

The action of linking the topology of the filming to the developed iconography, allows to establish parallels between different urban narratives present in the films. The picturesque image of Rome and Madrid, leaves the place to an unprecedented and unexpected vision, in which the periphery of vacant lots and the informal settlements prevail, with deserted topographies, unfinished social housing complexes and fragments of a rural world that coexist with industrial infrastructures.

Typologies and morphologies of the urban sectors, correspond to the different habitats of the protagonists, the places where urban Derivas begin or end up represented in the maps through the vectors of movement: Val Melaina and San Juan Bautista; the Prenestino and Arganzuela neighborhood; the Fosso of Sant'Agnese and La Elipa; the bigs development of Tuscolano and Entrevías. In all the peripheral territories covered, the dialectic between formal and informal city occurs, representing a space of resistance and freedom, in favor of which, directors often seem to take a stand.

Neorealist cinematography, even with a critical sense, tried to establish a creative dialogue with the expanding urban and suburban territory.

In this research work, spatial and formal typologies of the Neorealist City are considered a set of real architectural and landscape structures or sometimes results of cinematografic work of staging, that transcend the space of the screen establishing a connection with the architectures and with the urban space that was developing in this time: it concerns the topographies and the horizontal and vertical housing development; ruins and the unfinished architectures of the informal city; scaffolding systems and frames present under different durable or ephemeral configurations; And finally, light and texture as project materials that defines the Neorealist urban space. 
The urban and extra-urban explorations that the directors fulfill, also had a value in terms of "design actions on the territory", although finalized to the cinematographic narration. The vectors mapped and represented describe the different psychogeographies of Rome and Madrid presented in the films. The image of a vectorial cartography representing all itineraries covered throughout each film and the sum of all these vectors, constitutes a possible planimetric image of "Neorealist city".

The present research work, as a result of the methodological proposal, within the field of research called 'cultural landscape', proposes an extension of the limits of the discipline of Architecture, and Urbanism, through the film space and the echoes which remain in the set after filming. Possible dialectic between representation and reality, between cinematographic memory and memory of the place, between past and future, opens new scenarios in urban research and design.

The comparative analysis allows to identify differences between italian and spanish two capitals and differents models of genesis and growth of peripheral space. However peculiar aspects of each territory emerge. Madrid is represented like an empty and rural territory around an unreachable and compact urban center; Rome as a hybrid and entropic space, combines countryside, infrastructures and urban areas; at the same time this analysis, reaches an iconographic and spatial synthesis of the two cities: The Neorealist City.

Finally, 'The Neorealist City' discovered by cinematographic directors, becomes a metacategory for interpretation, that perfectly works to understand contemporary urban phenomena and, at the same time, to propose a "manifesto" for project interventions in the contemporary city. 


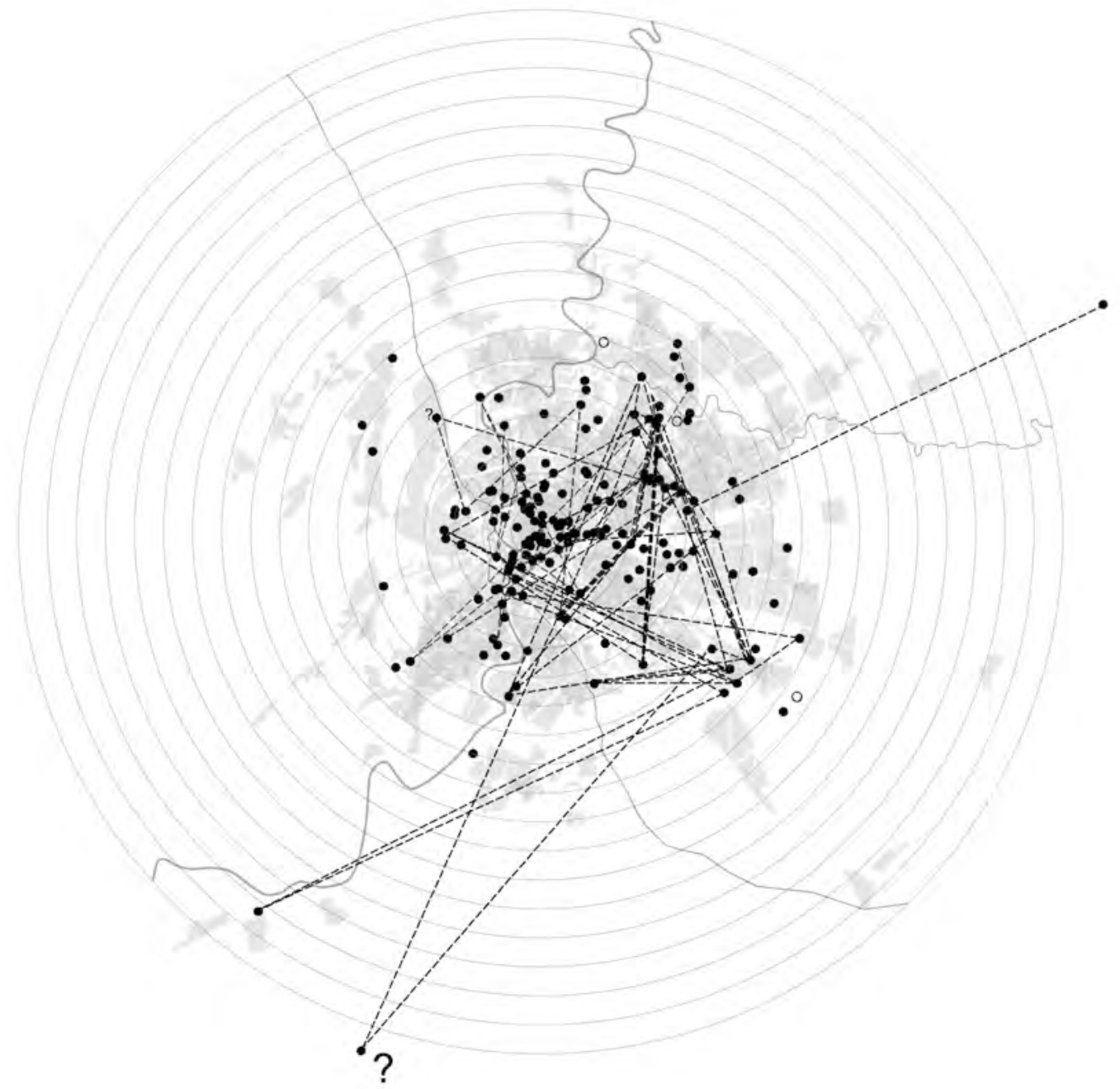

"Vino entonces el cine que hizo volar en pedazos ese mundo-prisión con la dinamita de las décimas de segundo, de modo tal que ahora, en medio de sus ruinas y restos dispersos, realizamos despreocupadamente viajes llenos de aventuras".

(W. Benjamin, 1936)

"Mal que les pese a los nostálgicos de la historia, Roma no está ya en Roma; la arquitectura no mora en la arquitectura sino en la geometría, en el espacio-tiempo de los vectores"

(P. Virilio, 1980)

"El cine no presenta solamente imágenes, las rodea de un mundo. Por eso, tempranamente buscó circuitos cada vez más grandes que unieran una imagen actual a imágenes-recuerdo, imágenes-sueño, imágenes-mundo". (G. Deleuze, 1985) 
Introducción / Superestructura / Infraestructura / Estructura / Resultados / Conclusiones 


\section{Introducción al tema.}

El objeto de la presente investigación es la percepción del paisaje urbano de Roma y Madrid en la Posguerra a través del análisis de algunas películas rodadas sobre todo en estas ciudades entre 1943 y 1963, dentro de la corriente denominada Neorrealismo. El medio urbano se analiza a través de las películas escogidas que se convierten en el otro objeto de estudio de esta tesis.

Se entiende el paisaje urbano según dos sistemas analíticos: el primero que sigue las definiciones de Michael Jacob1, hablando de la necesidad de que el observador-sujeto se vaya alejando del espacio cerrado de la ciudad, contemplando el medio urbano desde un exterior abierto; el segundo sistema, siguiendo las metodología de Gordon Cullen², observa también los elementos que componen este paisaje a una escala más reducida, considerando al observador desde el interior del espacio urbano.

En la etapa de la posguerra en Italia y en España, la cinematografía de influencia neorrealista, introduciendo elementos de ruptura respecto a la tradición, puso al centro de sus realizaciones el paisaje y sus grandes trasformaciones. En muchas películas de la época, el territorio, principalmente de Roma y Madrid, deja de ser un fondo y se carga de valores y significados; se trata de descripciones que no solamente tienen un valor narrativo dentro de la realidad fílmica, sino que operan también una acción crítica y proyectual sobre el espacio representado, a través de la puesta en escena de conflictos e incongruencias junto a posibles soluciones y alternativas.

Roma y Madrid son las reales protagonistas de las obras cinematográficas, sobre las dos capitales pesa todavía la herencia de la guerra, mundial en Italia, y la civil en España. La reconstrucción, después de la destrucción física y moral de la guerra, es el nivel cero que las dos ciudades comparten, reconquistando poco a poco una identidad que ya no puede ser la pasada.

El recorrido es la forma en la cual los directores cuentan una narrativa, buscando la nueva identidad de las dos capitales, y representa una acción práctica y dinámica de intervención en el territorio, ligada al medio cinematográfico utilizado. Esta tesis reconoce en el recorrido y los vectores que lo componen, la forma de estudiar el territorio de la "Ciudad Neorrealista".

A lo largo del recorrido se producen escenarios e iconos que construyen un vocabulario común que es posible articular a través de una estructura-sintaxis que corresponde a la topología del rodaje. Los fotogramas dejan de ser imágenes abstractas y se relacionan con el territorio de Roma y Madrid.

La cartografía de los recorridos y de los decorados de las películas, fija una imagen de la ciudad neorrealista que este trabajo de investigación doctoral reconoce como una posible nueva metodología para el análisis del espacio urbano. Una metodología que, integrando diferentes medios y bases de datos, desarrolla una arquitectura aumentada del territorio, hacia el concepto de paisaje cultural.

La ciudad Neorrealista representada en esta tesis se relaciona con la arquitectura y otras expresiones culturales y artísticas de la época, y se proyecta en el contexto de la vanguardia

\footnotetext{
(Jakob, 2009)

2 (Cullen, 1968)
} 
europea, dentro de la tradición de investigación del medio urbano como escenario de conflicto entre reacción e innovación, entre cultura burguesa y anti-burguesa;

Se identifica un proceso de ósmosis entre el paisaje urbano en construcción y la mirada cinematográfica de los directores que representan este paisaje y lo manipulan haciendo más evidentes sus aspectos positivos y sus contradicciones.

A través de sus recorridos, proponen una ciudad "alternativa y complementaria" a la que se iba generando en estos años de crecimiento urbano descontrolado. La Ciudad Neorrealista aparece entonces como una tabula rasa, un palimpsesto sobre el cual poder re-escribir otras narraciones urbanas: las ruinas que aparecen en la pantalla son literales y metafóricas; se abren escenarios para la reconstrucción y se mira a estos vacíos con optimismo y desconcierto al mismo tiempo: como territorios libres, espacios de oportunidades, pero también como espacios de conflictos y crisis. Este territorio al margen de la ciudad en construcción, que crece desordenada y rápidamente, es el de los descampados o Terrain vague o Vacant lots, donde conviven infraestructuras industriales y chabolas, paisajes naturales y desechos.

Estos espacios abiertos, territorios entre lo urbano y lo anti urbano, permiten una visión alejada que hace posible que la ciudad se convierta en paisaje, facilitando la percepción de sus límites, horizontes y forma. Una imagen de la ciudad que cada vez más se hace borrosa ${ }^{3}$, se contamina y pierde integridad, reflejada en las películas y documentales de Pier Paolo Pasolini, que se opone a esta pérdida de la estructura original estético-cultural, la "forma de la ciudad".

La mirada cinematográfica brinda la ocasión también para una reflexión sobre nuevas formas de habitar y de convivir, para cuestionar la ciudad masiva de los bloques, las periferias sin espacios públicos, "desertizadas", constituidas por "edificios andamios" o topografías informales que dejan perplejos los protagonistas y los directores de las películas de la época, que deciden explorar territorios urbanos desconocidos en búsqueda de alternativas, otros hábitats más dignos o simplemente más humanos, convirtiéndose en nómadas y habitando demoras precarias. Los paisajes y arquitecturas neorrealistas construidos a través de la yuxtaposición entre realidad y ficción del espacio fílmico, parecen responder en parte a estos deseos no satisfechos, plantean estilos de vida y construyen límites indefinidos entre paisajes urbanos y anti-urbanos.

El análisis ha permitido establecer puntos en común y diferencias entre el espacio periférico de las dos capitales, italiana y española, y definir una serie de características que perduran hasta el día de hoy y que permiten comprender los fenómenos de las metrópolis contemporáneas.

El análisis comparativo ha fijado algunas estructuras cinemato-arquitectónicas: acciones proyectuales en el espacio urbano en trasformación, los recorridos, como vectores de una nueva psicogeografía; las ruinas, los paisajes entrópicos; los armazones y las estructuras efímeras; las topografías y los hábitats horizontales que prevalecen todavía sobre el mundo de lo vertical; y en fin los materiales que componen la ciudad neorrealista, la luz, las texturas y el color.

${ }^{3}$ (Sorlin \& Pujol i Valls, 1996) 


\section{Objetivos e hipótesis.}

El punto de partida de este trabajo de investigación ha sido el análisis comparativo de la filmografía neorrealista, entre 1943 y 1963, rodada principalmente en Roma y Madrid, con el objetivo de:

\footnotetext{
Demonstrar que existe una metacategoría de "Ciudad Neorrealista", que permite establecer un paralelo entre el paisaje urbano de la metrópoli contemporánea y sus conflictos, y la ciudad descrita en la cinematografia analizada.
}

La hipótesis es que este espacio cinematográfico, la "Ciudad Neorrealista" se sigua reproduciendo en el paisaje urbano de la ciudad contemporánea, y en lo especifico en Roma y Madrid; se propone un decálogo-manifiesto de esta ciudad dentro de la ciudad, reconociendo este territorio como un espacio alternativo a la ciudad formal para la producción del hábitat y la creación artística.

- Establecer Puntos de contactos y diferencias entre el paisaje urbano romano y madrileño, y como está percibido e imaginado por los directores de la época. A través del análisis iconográfico y cartográfico podemos identificar diferencias morfológicas y tipológicas entre el espacio periférico de las dos capitales.

Por otro lado, está la hipótesis de que el movimiento neorrealista, saliendo de los límites establecidos por el medio cinematográfico, haya propuesto, como otras vanguardias artísticas europeas tales como el Surrealismo, el Situacionismo o la Land-art, una propia investigación estética sobre el espacio urbano y sus contradicciones.

A partir de este planteamiento se establece el tercer objetivo de la tesis:

- Proponer una visión más amplia del movimiento Neorrealista que investigó el espacio urbano y extraurbano a través de las derivas y los recorridos de sus directores, dentro de la tradición de este tipo de exploraciones realizadas por otras vanguardias artísticas europeas a lo largo del siglo XX: dadás, surrealistas, situacionistas, land-artistas, Cobra, fluxus, hasta llegar a las recientes experiencias de artistas como el grupo StalkerObservatorio Nómada.

Otro objetivo está ligado a la definición de la Ciudad Neorrealista como experiencia estética, como territorio de creación artística, por parte de los directores y de todos los que percibieron sus visiones urbanas;

- Esta Ciudad fue capaz de influenciar no solamente las artes de a época sino también las actuales. Su iconografía y cartografía perduran hasta el día de hoy, y se hace la hipótesis de que se haya producido y se siga produciendo una ósmosis entre cinema y espacio urbano-arquitectónico.

El estudio de la cronología del decorado y el regresar a los lugares de antiguos rodajes, permite enrequecer el análisis y generar paralelos entre la Ciudad Neorrealista del pasado y del presente.

Se han definido, a lo largo del desarrollo de este trabajo de investigación, otros objetivos secundarios relacionados con los principales: 
- Aportar al conocimiento sobre las influencias entre cultura italiana y cultura española en la Posguerra, desde una perspectiva multidisciplinaria.

- Asentar las bases para una nueva mirada hacia el Neorrealismo arquitectónico, enfocando la atención sobre los elementos ambientales, urbanos y paisajísticos, más que sobre los estilísticos y técnicos. Cambiando la escala desde la Arquitectura al territorio se hace la hipótesis de que el Neorrealismo puede cobrar un sentido más amplio también dentro del paisaje cultural de Madrid y de España.

Dentro del proceso de investigación, otras hipótesis y objetivos se han generado a partir de los aspectos metodológicos:

- La posibilidad, ejemplificada en esta tesis, de construir un vocabulario iconográfico, a través del análisis de los fotogramas, que permita interpretar el espacio urbano de Roma y Madrid o de otras ciudades europeas; una metodología que puede replicarse para diferentes épocas y territorios a partir de filmografías escogidas.

- Desarrollar una cartografía de Roma y Madrid a partir del análisis topológico del rodaje en las dos capitales, entre los 20 años objeto de esta investigación.

- Proponer el método de análisis iconográfico y cartográfico denominado "topología del rodaje", para asentar las bases de un proyecto profesional que, combinando las informaciones de espacio real y fílmico, constituya una herramienta disciplinaria para la comprensión y el análisis de los fenómenos de la ciudad contemporánea.

\section{Antecedentes, Estado de la cuestión y marco teórico}

El Marco teórico de esta tesis tiene como punto de partida los dos ensayos de Deleuze sobre Cine, "La imagen-movimiento" y "La imagen-tiempo", escritos entre 1983 y 1985. De acuerdo a su filosofía que quiere dejar de ser contemplación y reflexión para volver a reconectarse con la vida, Deleuze ve en el movimiento, la expresión de un capacidad creativa de producción de lo nuevo; Deleuze se interesa al Cinema por la importante relación que se establece entre el rodaje y el movimiento, y en consecuencia con la vida; Deleuze escribió sobre el Cinema, subrayando la capacidad de este medio artístico de transcender la dimensión del arte para convertirse en una forma de pensar y de crear, siendo el Cinema un arte del movimiento. Deleuze no entiende el Cine como una secuencia de elementos separados, puestos en movimientos; el Cine consiste en el movimiento inmanente que conecta los fotogramas.

Otro aspecto es el tiempo, que es materia de la imagen fílmica y se conecta con el movimiento a través del espacio; el arte cinematográfico tiene la posibilidad de representar y alterar las múltiples relaciones entre espacio y tiempo, los cruces entre segunda (el encuadre), tercera (la realidad fílmica) y cuarta dimensión (los tiempos) ${ }^{4}$.

La relación entre Cine y realidad, implícita en las reflexiones de Deleuze, es explorada por el Neorrealismo hasta llegar a las teorías de Pasolini sobre el lenguaje cinematográfico, cuando ya el Neorrealismo había acabado: para el escritor y director italiano, el Cinema es "lingua scritta della realtá" o semiología de la realidad, porque la realidad ya es cine y actuación, y el rodaje solamente es una interpretación de los signos ya presentes en el mundo real.

4 (Deleuze, Conversaciones, 1972-1990, 2014) 
La tesis toma en cuenta del ensayo de estética de Walter Benjamin: "La obra de arte en su época de reproducción mecánica”, y las reflexiones sobre Cine contenidas en este texto fundamental. Según Benjamin, el Cine volvió dinámico un mundo estático a través de los encuadres y de los tiempos de exposición, "hizo volar en pedazos ese mundo-prisión con la dinamita de las décimas de segundo de modo tal que ahora en medio de ruinas y restos dispersos, realizamos despreocupadamente viajes Ilenos de aventuras." ${ }^{5}$

En fin, el trabajo reconoce como marco conceptual para los aspectos metodológicos, las intuiciones de Paul Virilio, quien en su texto de 1994 "The Vision Machine"6, profetiza un futuro de nuevos aparatos que podrán gestionar la visión como una elaboración progresiva de datos que se relacionan con el objeto de la visión: en el caso de este trabajo, el paisaje urbano que se vuelve hipertexto. En consecuencia, de las reflexiones de Virilio reconocemos la necesidad futura de destacar que, a través de los nuevos sistemas cartográficos digitales y de la realidad aumentada, se puedan generar paisajes culturales complejos de los cuales el Cine constituirá la memoria audiovisual del lugar.

Sobre la visión del Ciudad a través del Arte y el tema del recorrido como practica estética, la tesis se basa en la investigación de Francesco Careri en su "Walkscapes" y su análisis de la relación entre nomadismo y cultura arquitectónica.

Se plantea que el Neorrealismo haya sido una etapa importante y no suficientemente analizada dentro de la historia paralela del recorrido urbano y extraurbano trazada por Careri.

No existen estudios comparativos sobre la iconografía y el paisaje urbano neorrealista en Roma y Madrid: ni de la perspectiva cinematográfica y tampoco de un punto de vista urbano y/o arquitectónico. Algunos históricos del Cinema como José Enrique Monterde se han dedicado al análisis de la fortuna comercial y crítica del cine Neorrealista italiano y de sus influencias sobre el español, en su tesis doctoral: "El Neorrealismo en España. Tendencias realistas en el cine español" 8 .

Hay diferentes estudios sobre la relación entre cinema y paisaje urbano Neorrealista, sobretodo en el campo de la geografía, del arte y de la sociología; se señala sobretodo el ensayo de Pierre Sorlin, "Cines y sociedades europeas 1939-1990", en donde se habla del concepto de "imagen borrosa" de la ciudad que se desarrolla en las películas de la época, moviendo el foco de atención del centro a la periferia. Otros estudios son lo de Antonella Licata e Travi, sobre ciudad y cine, y lo de Stephen Barber sobre el espacio urbano en el cine europeo.

Como antecedente de esta tesis el ensayo más importante, por la metodología y el enfoque, es el de Bruno Reichlin, "Figures of Italian Neorealism", en el cual se propone la idea de una sintaxis neorrealista que permita asociar algunas imágenes de la cinematografía a algunos episodios espaciales y realizaciones arquitectónicas de la época. Otros estudios que podemos considerar como antecedentes en la investigación del paisaje de Roma y Madrid a través del cine de ésta época, son los ensayos de Luís Deltell, "Madrid en el Cine de la década de los '50", y el ensayo "Stupendous, Miserable City: Pasolini's Rome", sobre la Roma de Pasolini del historiador John David Rhodes. Los dos son ensayos que intentan buscar relaciones entre las

\footnotetext{
5 (Benjamin, 2013 p.92)

6 (Virilio, 1998)

7 (Careri, Walkscapes: el andar como práctica estética, 2002)

8 (Monterde \& Porter i Moix, 1992)

9 (Reichlin, 2002)
} 
narraciones cinematográficas y el territorio urbano, aunque con un enfoque a partir de la crítica cinematográfica.

No existen trabajos que pongan en relación directa los paisajes y las arquitecturas objeto de esta investigación; tampoco hay investigaciones exhaustivas que pongan en paralelo las experiencias de reconstrucción y las políticas de vivienda en Italia y España en la Posguerra, o la influencia que tuvo cierta arquitectura italiana de la Posguerra en la cultura arquitectónica española. En general todos los estudios y reflexiones sobre esta relación se limitan a aspectos más superficiales de lenguaje y estilo. En el Congreso Internacional de Historia de la Arquitectura organizado por la Escuela Técnica Superior de Arquitectura de la Universidad de Navarra en el 2004 se presentó el seminario "Modelos alemanes e italianos en los años de la Posguerra"; en una de las ponencias, Alberto Grijalba Bengoetxea, analizando la arquitectura española de la Posguerra, habló de una aspiración a la realidad "que pronto se comunicará a este otro lado del 'puente'. Pero el término 'realidad' se entenderá no sólo como la arcadia neorrealista que comunicaba la filmografía de Italia también presente en España (...), sino como una necesidad de encontrar, de un modo crítico, la realidad entre el historicismo clasicista imperante y los idealismos y utopías figurativas y productivas del Movimiento Moderno" ${ }^{10}$.

En el número 301 de 1995 de la revista "Arquitectura" del Colegio oficial de arquitectos de Madrid (COAM), se yuxtaponen algunas experiencias italianas y españolas de los años '50 utilizando la categoría critica del Neorrealismo. En esta revista, en el ensayo de Miguel Ángel Baldellou, "Neorrealismo y arquitectura. El problema de la vivienda en Madrid, 1954-1966"11, se analiza la respuesta que los arquitectos españoles dieron al problema de la vivienda, después del largo periodo de la arquitectura autárquica, en ruptura con la corriente racionalista apoyada por la República, Baldellou dice que finalmente los arquitectos "se pudieron incorporar sin grandes problemas a una nueva situación, ideológicamente en crisis, entre el Neorrealismo y la Guerra Fría, como recién despertados de un largo sueño en el que muchos tuvieron pesadillas". ${ }^{12}$ Se subraya también del concepto de "vida alrededor" para describir la condición de quien después de la guerra vivía en la marginalidad, en la ciudad, pero al mismo tiempo alejado de ella. Es la Arquitectura, junto al Cine que detecta con sensibilidad esta situación: "Igual que el cine de la época se caracteriza por el Neorrealismo, la Arquitectura asumió sin prejuicios su condición de mediador social, pretendiendo elevar el nivel de la vida alrededor". Luis Fernández Galiano habla de tapiz neorrealista, introduciendo el barrio de Caño Roto de Antonio Vásquez de Castro en su Libro "La Quimera moderna"13 asociando el término 'tapiz', utilizado por José Sert para definir sus hábitats urbanos horizontales, y el concepto de Neorrealismo en referencia a un proyecto que "incorporaba elementos vernáculos a las influencias del racionalismo" ${ }^{14}$.

Como antecedentes de esta tesis, en los aspectos metodológicos hay que citar el trabajo de investigación de Michele Mancini y Giuseppe Perella, "Architetture della visione" sobre el cine de Antonioni, que analizaremos en el siguiente párrafo.

Muy importante en la definición del enfoque temático, ha sido la experiencia del curso de doctorado "Arquitectura audiovisual", impartido por el Profesor Luís Antonio Gutiérrez Cabrero -director de esta tesis-, y los ejercicios de análisis sobre medida, levantamiento del espacio

10 (Grijalba, 2004)

11 Arquitectura n.301, COAM, Madrid 1995.

12 Ibídem p.20

13 (Fernández Galiano, Isasi, \& Lopera, 1989)

14 ibídem p.65 
cinematográfico y arqueología del decorado, desarrollados entre 2007 y 2010 por sus alumnos (sobre Sergio Leone y Michelangelo Antonioni); a estos trabajos se relaciona también la tesis de Carlos Pantaleón Panero, leída en el 2012, con el título: "Del espacio fílmico al espacio protofilmico. Del espacio arquetípico al espacio fenomenológico. Una propuesta pedagógica" ${ }^{15}$, en la cual se propone el análisis métrico del espacio fílmico, y de los puntos de vistas de la cámara como propuesta didáctica para la enseñanza de la arquitectura.

Este enfoque está presente también en las investigaciones de Jorge Gorostiza sobre el espacio del decorado y las mediciones de los movimientos de las cámaras, en su tesis doctoral ${ }^{16} \mathrm{y}$ en sus ensayos sobre cultura arquitectónica y cinema ${ }^{17}$.

\section{Metodología de trabajo y herramientas.}

En la recopilación de biografías ilustres de hombres latinos y griegos, Plutarco, en sus "Vidas Paralelas", cumple una operación sencilla de simple yuxtaposición a partir de un contexto cultural muy próximo. En Plutarco, el método comparativo tiene un resultado explícito y uno implícito. El explícito consiste en profundizar, a través de la investigación, en cada uno de los términos de la comparación, y en poder efectuar el análisis comparativo directo desde distintos aspectos. La segunda finalidad es implícita a la yuxtaposición de los dos casos y sirve para hacer resaltar cada término de la comparación en función del otro.

En esta tesis, a través de la yuxtaposición Roma-Madrid se define un conjunto de características iconográficas, urbanas y arquitectónicas que nos ayudan en la definición de un "paisaje compartido", la presentación en paralelo de las obras cinematográficas y de los lugares en los cuales fueron rodadas permite, al final del trabajo, la sincresis: momento de reflexión en el cual se exponen aspectos relevantes de los dos ejemplos presentados, diferencias y características comunes.

En la Posguerra, muchas eran las ciudades europeas que se encontraban en la condición física y moral de las dos capitales italiana y española: Paris, Londres, Barcelona, Milán, hacen parte de un único paisaje de pobreza y devastación en el cual se presenta muy fuerte la necesidad de una rápida reconstrucción de identidad y bienestar ${ }^{18}$.

Lo que más acerca en estos años a Madrid a Roma respecto a otras ciudades europeas, es el puente cultural que se establece a través de la cultura neorrealista no solamente en campo cinematográfico. Otros aspectos económicos-sociales vinculan las condiciones de las dos capitales: las estructuras productivas italiana y española se basan en una economía todavía casi totalmente rural; y en una gestión urbanística que más que en cualquier otra capital europea pierde el control del territorio a favor de la especulación del capital; hay también una fuerte presencia política y cultural de la Iglesia católica, a pesar de situaciones políticas opuestas; y es el fin de la democracia y el comienzo de la dictadura franquista en España, la caída del Fascismo y la génesis de la República democrática en Italia.

Para el análisis del medio urbano-arquitectónico se han utilizado fuentes bibliográficas y trabajo de campo a lo largos de las estancias realizadas en las dos capitales. Para el análisis

\footnotetext{
15 (Pantaleón Panaro \& Gutierrez Cabrero, 2012)

16 (Gorostiza López \& Guterrez Cabrero, 2016)

17 (Gostoriza \& et, 2007)

${ }^{18}$ Más difícil hubiera sido la comparación con Berlín cuya devastación fue superior a la de las ciudades citadas y cuya situación psicológica a final de la guerra está representada en la obra maestra Alemania año cero, de Roberto Rossellini (1948)
} 
del medio cinematográfico se ha utilizado el método desarrollado por Michele Mancini y Giuseppe Perella en su trabajo de investigación sobre el cine de Michelangelo Antonioni "Architetture della visione", que fue presentado en una exposición internacional organizada en España en 1987, por la Filmoteca Española en el Museo Nacional Centro de Arte Reina Sofía de Madrid (MNCARS) ${ }^{19}$. Al centro de la exposición está el fotograma como unidad de información: "se han sustraído mediante procedimientos técnicos diversos fotogramas de la filmografía de Antonioni, de los veinticuatro que pasan ante el ojo humano cada segundo de película. El resultado es un archivo que revela la riqueza de la información escondida en cada uno de ellos, así como la enorme precisión que ponía el director en cada una de sus producciones" ${ }^{20}$. En una sala se proyectan los 5.000 fotogramas seleccionados entre los 10 millones de las más de 20 películas realizadas por Antonioni hasta la fecha. En el catálogo de la exposición, los fotogramas se organizan según un sistema de clasificación que explica la fuerte relación entre el cine del maestro de Ferrara y la narración del espacio. Las clasificaciones presentes son dos: "Arquitectura de la visión" que describe el encuadre y el formato, la desertización del escenario, las epifanías y la superficies-color; y "Vocaciones del lugar" que incluye: interiores, elementos del decorado, ambientes de trabajo, paisajes naturales, la ciudad invisible, la ciudad metafísica, desiertos metropolitanos.

Tanto la exposición como el catalogo incluyen el tema de "los viajes de la cámara" y "las arqueologías del escenario", bajo la clasificación "El tiempo del viaje". A esta sección corresponde en la Exposición del MNCARS la proyección del cortometraje de Antonioni, Inserto girato a Lisca Bianca, en el cual el director italiano regresa a una pequeña isla del archipiélago de las islas Eolias, al Noreste de Sicilia, en la cual 24 años antes había rodado una de las escenas más importante de La aventura: la desaparición de una de las protagonistas. En el cortometraje, Antonioni roda los lugares con la voz en off de los protagonistas y con el sonido original de la película, encuadra las mismas rocas y puntos de observaciones, incluso las ruinas que son parte de la escenografía, y que todavía quedan en el lugar: un pequeño refugio de yeso armado y madera, del cual quedan pocos fragmentos; así se genera un fuerte sentimiento de ausencia y nostalgia, un "falso regreso", como Mancini y Perella llaman a estas investigaciones sobre los antiguos escenarios del rodaje, que en el catálogo de la exposición se acompañan con levantamientos y cartografías.

Este último aspecto metodológico se convierte en elemento central de esta investigación sobre el espacio urbano Neorrealista: la "topología del rodaje" que se formaliza en un mapeo a diferentes escalas de los diferentes decorados y de los vectores de movimiento que describen los recorridos de los cineastas. Respeto al trabajo de Mancini y Perella, la tesis propone algunos aportes metodológicos. Antes de todo, la iconografía desarrollada a través de la selección de los fotogramas se vincula a la cartografía del rodaje, la estructura o sintaxis del presente trabajo; en segundo lugar se relacionan las prácticas estéticas desarrolladas por los cineastas a través del medio cinematográfico, con la construcción real del paisaje urbano, de la Ciudad Neorrealista a través de las exploraciones urbanas y la representación de estructuras arquitectónico-espaciales que proponen una nueva imagen del espacio urbano. Por último, siendo el trabajo una comparación entre dos términos, se organizó de forma binaria la catalogación de los elementos iconográficos y de la información cartográfica con diferencia respeto a la exposición del MNCARS.

\footnotetext{
${ }^{19}$ Previamente a la muestra ya existía un extenso catálogo en dos volúmenes editado solo en italiano, que con ocasión de esta muestra en el Centro de Arte Reina Sofía, se traduce al español y se resume en un solo volumen. (Mancini \& Perrella, 1986)

${ }^{20}$ Fuente: MNCARS Museo Nacional Centro de Arte Reina Sofía :

http://www.museoreinasofia.es/exposiciones/michelangelo-antonioni-architetture-della-visione, consultado el 24 de julio de 2017.
} 
Para la definición de la iconografía neorrealista se han seleccionado y yuxtapuesto algunos fotogramas seleccionados por cada una de las películas, entre las 20 películas de cada país, en un lapso de tiempo de 20 años, desde 1943 (año de Obsesión de L. Visconti, considerada como la primera película neorrealista) hasta 1963 (año del Verdugo de L. G. Berlanga la última película española que puede adscribirse a este género), privilegiando las realizaciones ambientadas en Roma y Madrid $^{21}$. Además de los largometrajes, se completará la investigación con el análisis de documentales y cortometrajes de la época o más recientes, para enfocar aspectos más complementarios o más específicos. El resultado de este trabajo de investigación se concretiza en 27 fichas temáticas de análisis iconográfico, que construyen el léxico o vocabulario que será utilizado para generar un catálogo de tipologías, morfologías y contenidos que caracterizan el paisaje urbano en trasformación, en las dos capitales en los años de la Posguerra. En el análisis comparativo, se aplicará el vocabulario iconográfico desarrollado en la definición de los lugares mapeados en la cartografía del rodaje. Para la realización de esta cartografía se utilizará una base de datos tradicional, los mapas de los PGDU de Roma y Madrid en los años 1962 (Roma) y 1964 (Madrid), obtenida a través de fuentes bibliográficas, y una base de datos cartográficos satelitales ofrecidos por la red $y$ conocida como G-Earth y G-Maps, que está desarrollada a partir de fotos aéreas satelitales de alta resolución de distintos años ${ }^{22}$. Esta base de datos cartográficos es una potente herramienta que se ha utilizado para comprobar las numerosas informaciones encontradas sobre la geolocalización de las 40 películas rodadas en Italia y en España, enfocando la atención sobre las películas de ambientación romana y madrileña. Algunas fuentes cartográficas más específicas permitirán puntualizar informaciones a una escala más de detalle.

La información sobre la ubicación de los decorados, se ha encontrado en fuentes bibliográficas sobre el Cinema Neorrealista, guías urbanas sobre Cine y Arquitectura y sobretodo en Sitios Web especializados en este tipo de investigaciones de tipo amatorial. Se subrayan sobretodo dos fuentes que han sido fundamentales para este trabajo:

- Para los decorados romanos se ha utilizado la Base de Datos Internet conocida como "Davinotti" desarrollada por el crítico cinematográfico y escritor Mauro D'Avino autor de varios libros-guías sobre decorados cinematográficos de algunas ciudades italianas ${ }^{23}$. La página web desarrollada a través de la contribución de los mismos usuarios de la red es un database de películas de distintos países con un especial enfoque hacia el Cinema Italiano. En las películas italianas es posible acceder a una cartografía geo-referenciada, con muchos decorados verificados por los administradores de la página www.davinotti.com ${ }^{24}$

- Para los decorados madrileños el GRIMH: Grupo de Reflexión sobre la Imagen en el Mundo Hispánico, con las páginas sobre Madrid en el Cine, concebidas y desarrolladas por el Prof. Jean-Claude Seguin Vergara ${ }^{25}$ : www.grimh.org ${ }^{26}$

\footnotetext{
21 Se han incluido algunas películas rodadas fuera de Roma y Madrid por la importancia que tuvieron en el desarrollo de la cinematografía Neorrealista y de su iconografía.

${ }^{22}$ En el caso de Roma a partir de 1943.

23 (D'Avino \& Rumori, 2012)

${ }^{24} \mathrm{http}: / /$ www.davinotti.com/index.php?option=com_frontpage

${ }^{25}$ Jean-Claude Seguin Vergara es catedrático de estudios Hispánicos del Departamento de Lenguas Romanas de la Facultad de Lenguas de la Université Lumiére-Lyon II (Francia), autor de ensayos y estudios sobre el Cinema Español.

${ }^{26}$ http://www.grimh.org/index.php?lang=es
} 
Estas informaciones se han cruzados con otros datos presentes en la red en blogs que se ocupan de historia urbana a través de documentos y fotos originales, muchas enviadas por los mismos usuarios, como "Historias Matritenses" 27 o "Roma Sparita".

Por la necesidad de averiguar la autenticidad de la información presente en la web se han confrontado los fotogramas de todos los decorados utilizados en la presente investigación con las imágenes de Google Street-view y Google Earth. Este trabajo ha permitido confirmar la autenticidad de la mayoría de la información encontrada; corregir la información equivocada; proponer nuevas ubicaciones de los decorados y nuevas interpretaciones de los posibles recorridos realizados por los cineastas. En algunos casos se han descubierto ubicaciones de decorados y de locations cinematográficas hasta ahora nunca analizados por otras fuentes, este material se considera parte del material original de esta investigación, junto con las fichas iconográficas y cartográficas.

La información comprobada, gestionada y ordenada a través de la geo-referenciación en GEarth, ha sido luego trasferida en mapas de formato vectorial a diferentes escalas, desde la escala territorial- urbana, hasta la escala barrial y vecinal. Entre las numerosas localizaciones encontradas a través del análisis de las 40 películas, se han reagrupado las películas a partir de 4 sectores urbanos identificados en las dos ciudades, según una lógica temática y geográfica (del Centro a la Periferia, entre Centro y Periferia, sector Noreste, sector Sureste); por cada sector se ha escogido principalmente una película por cada país, a excepción del sector "Entre Centro y Periferia", en donde se han tenido en cuenta todas las películas rodadas en el área.

El análisis fílmico se acompaña con la investigación en archivos y bibliotecas. Se han utilizado fuentes bibliográficas de bibliotecas italianas y españolas, materiales audiovisuales presentes en la Filmoteca Nacional de España (FNE), como los documentales NO-DO. Se han estudiado algunos documentos originales conservados en el Ministerio de Fomento de España (MFE) y del archivo regional de la Comunidad de Madrid (ARCM) así como los contenidos en el Fondo Fotográfico Santos Yubero, conservados en el ARCM.

Fundamental ha sido el dibujo como herramienta de análisis en la realización de cartografías y mapas originales, así como el levantamiento fotográfico de los territorios y las arquitecturas analizadas, tal como se presentan en la actualidad.

Podemos resumir las diferentes etapas de desarrollo de esta tesis a partir de las metodologías empleadas:

- PRIMERA ETAPA: Selección y análisis de la filmografía por cada país. Redacción de fichas técnicas.

- SEGUNDA ETAPA. ESTANCIAS: viajes y estancias en Roma y Madrid.

En Roma: visitas y análisis del barrio Tuscolano, Tiburtino y Torres de Avenida Etiopia; investigación documental sobre INA-Casa ${ }^{28}$. Recorridos y visitas de los decorados y los escenarios cinematográficos en la Capital italiana.

En Madrid: Investigación sobre documentos audiovisuales en la FNE; análisis de los documentales NO-DO. Recorridos y visitas de los decorados y los escenarios

\footnotetext{
${ }^{28}$ Istituto Nazionale delle Assicurazioni (instituto nacional de seguros)
} 
cinematográficos en la capital española. Visitas y análisis de los poblados de Entrevías, Fuencarral, Caño Roto y al poblado de Entrevías y análisis de fuentes bibliográficas y cartográficas en el ARCM; investigación documental sobre el antiguo Instituto Nacional de Vivienda (INV) y los programas oficiales de viviendas.

Conversaciones con dos protagonistas madrileños (junio-diciembre 2012): Antonio Vázquez de Castro y Carlos Ferrán Alfaro.

- TERCERA ETAPA: BASE DE DATOS: desarrollo a distancia (plataformas virtuales) de las bases de datos iconográficas (fotogramas) y cartográficas (mapas).

- CUARTA ETAPA. DIFUSIÓN. Parte del desarrollo de este trabajo se ha difundido en publicaciones académicas internacionales. Destacan los artículos:

"Políticas habitacionales en Italia y España en la posguerra 1949-1954".

Publicado en la revista "Cuadernos de vivienda y urbanismo" n.17, enero-junio 2016

"Paisajes Neorrealitas. Cultura y arquitectura en Italia y España en los años de la posguerra". Publicado en la Revista "CONTEXTO" Vol. X N 12 (marzo 2016) Revista de la FA UANL (Universidad Autónoma de Nuevo León)

"El paisaje de Entrevías. Estructuras ambientales y territoriales en el poblado dirigido de Francisco J. Sáenz de Oíza". Publicado en la revista "Bitácora Arquitectura" № 31 (julionoviembre 2015) Revista de la FA-UNAM (Facultad de Arquitectura de la Unam)

"El paisaje del hábitat horizontal: la Unidad del Tuscolano en Roma y el Poblado de Entrevías en Madrid". Publicado en la revista "Revista de Arqutectura" Vol. 18 № 2 (juliodiciembre 2016) Revista de la UCC (Universidad Católica de Colombia).

"La Ciudad neorrealista. Territorio, iconografía y mapas de la Roma de Ladrones de Bicicletas". Publicado en la revista "Bitácora Arquitectura" № 40 (julio-noviembre 2018) Revista de la FA-UNAM (Facultad de Arquitectura de la Unam).

\section{Estructura del trabajo.}

El presente trabajo de investigación se desarrolla a través de cuatros capítulos y las conclusiones. En los primeros tres capítulos se desarrolla el análisis comparativo, y en el cuarto se exponen los resultados y las deducciones.

CAPÍTULO 1: SUPERESTRUCTURA / HISTORIA. LA RECONSTRUCCIÓN EN ROMA Y EN MADRID.

En este capítulo se define el trasfondo histórico, económico, social y cultural en los dos países, Italia y España, y en las dos ciudades objeto de la investigación: Roma y Madrid. La Segunda Guerra Mundial, en Italia y la Guerra Civil, en España, determinaron dos destinos diametralmente opuestos: la liberación del Fascismo y el comienzo de la República democrática en Italia y el fin del sueño republicano y la instauración de la dictadura fascista de Franco en España. En este escenario se produjo la reconstrucción de física, económica y social de los dos países, con destinos diferentes a partir de una situación parecida de retraso económico, una estructura corporativa de la sociedad, una fuerte influencia de la cultura católica en la política y en la sociedad. La migración del campo a la ciudad es el fenómeno que caracterizó a toda Europa y en lo especifico Roma y Madrid; las políticas urbanísticas en Roma y en Madrid, más que en cualquier otro contexto urbano europeo, son incapaces de contrastar los intereses privados en la gestión de los territorios de expansión determinado un ambiente urbano incoherente y excluyente. Las tímidas y sin embargo logradas propuestas públicas al problema de la vivienda, son los programas de INA-Casa, en Italia, y los del INV, en España, que no serán suficientes para satisfacer las necesidades de alojamiento de los 
ciudadanos, provocando la incontrolada y enorme expansión del sector informal y los desarrollos privados.

En este contexto se analiza el fenómeno neorrealista, su origen y sus conexiones con otros movimientos y expresiones culturales en el campo artístico en general en el Cine y la Arquitectura. Se analiza el conjunto de las 20 películas seleccionadas por cada país en relación al territorio nacional y urbano de las dos capitales. A través de esta cartografía se detecta una diferencia entre el territorio madrileño, más compacto y con una densidad mayor de escenario en el centro histórico, y el territorio romano, más disperso y con un rodaje que pierde totalmente la referencia del centro histórico. A partir del análisis del espacio fílmico se ubican, en los mapas, los sectores urbanos que serán analizados en el tercer capítulo, y la presencia en ellos de vacíos, territorios de la informalidad y de conjuntos de vivienda popular.

CAPÍTULO 2: INFRAESTRUCTURA / VOCABULARIO. ICONOGRAFÍA NEORREALISTA: EL PAISAJE URBANO EN LAS DOS CAPITALES.

Se trata del análisis fílmico del paisaje urbano en Roma y Madrid con el fin de construir una iconografía neorrealista; un léxico común para la interpretación espacial del territorio de las dos capitales. Este análisis se hace a través de la selección de los fotogramas de las 20 películas escogidas por cada país, preferentemente las rodadas en Roma y Madrid. Para la definición de categorías y sub-categorías que corresponden a la numeración de los párrafos y subpárrafos y al código de las fichas gráficas, se han utilizado algunas definiciones de Deuleze sobre cine, contenidas en sus ensayos, otras tantas presentes en la Investigación de Mancini y Perella y algunas más desarrolladas por el autor de esta tesis.

CAPÍTULO 3: ESTRUCTURA / SINTAXIS. EPLORACIONES AL MARGEN DE LA CIUDAD.

En este capítulo se toman en consideración cuatro de los seis sectores urbanos definidos en el primer capítulo: "De la periferia al centro", "Entre Centro y Periferia", "Sector Noreste" y "Sector Sureste".

Se desarrolla un análisis comparativo entre dos películas escogidas por cada sector, dentro del cual se ubica el hábitat de los protagonistas, el punto de partida o de llegada respecto a los recorridos urbanos que los protagonistas desarrollan a lo largo de la película. Estos decorados están seleccionados a partir de analogías del espacio físico o por similitudes del guión cinematográfico. Los recorridos se analizan a través de un mapa general de todo el perímetro urbano de las capitales en el periodo objeto de esta investigación, mapeando los vectores de movimientos entre los principales decorados a lo largo de toda la película, tomando nota de los tiempos fílmicos de desplazamiento y de las distancias reales recorridas.

Se demuestra la fuerte correspondencia entre narración fílmica, distancias recorridas y tiempos pasados, en muchas de las películas rodadas.

En el estudio de los hábitats se buscan analogías entre los lugares presentes en las dos ciudades, en relación con el vocabulario iconográfico desarrollado en el anterior capitulo.

CAPÍTULO 4: RESULTADOS / DEDUCCIONES. CONSTRUCCIÓN DEL PAISAJE URBANO NEORREALISTA. ROMA Vs MADRID

El paisaje de la ciudad neorrealista se construye a través de una serie de acciones e imágenes que transcienden el espacio fílmico e influyen sobre las prácticas de producción del espacio. El conjunto de los puntos que representan los decorados seleccionados en el espacio urbano y suburbano, y los vectores que los conectan, fijan las narraciones urbanas de los diferentes directores que se van entrelazando entre ellas generando una trama de lugares y recorridos que representa la imagen de una nueva ciudad: la Ciudad Neorrealista. Podemos añadir esta visión urbana a las muchas que se desarrollaron a lo largo del siglo XX, como la ciudad de los surrealistas y de los situacionistas, estableciendo un paralelo entre las psicogeografías urbanas de los situacionistas y las elipsis espaciales y temporales presentes en la 
cinematografía neorrealista; el montaje de estos saltos e incongruencias o simplemente la yuxtaposición de territorios y lugares distantes y cualitativamente diferentes, como los fragmentos de un mapa psicogeográfico, nos devuelve la imagen de una ciudad hasta ahora desconocida, fuente de inspiración para las artes.

Elemento generedor de la Ciudad Neorrealista es el recorrido y la exploración, y los vectores que describen estos movimientos conectando diferentes escenarios y decorados.

La imagen del armazón en sus diferentes tipologías y formas es una de las visiones que construyen la ciudad neorrealista, estableciendo una fuerte relación con la cultura y con el arte de los dos países; los muchos andamios y las estructuras de concretos y acero que aparecen en la pantalla, establecen un diálogo con las arquitecturas de la época.

Las ruinas permanecen y se reproducen en la ciudad contemporánea: son los restos arqueológicos del pasado y del presente; son el testimonio de la guerra, los edificios derrumbados y abandonados, los barrios chabolistas, que todavía nacen y crecen en los espacios de frontera de las dos capitales.

La ciudad neorrealista es una ciudad que se desarrolla como una topografía horizontal. Un palimpsesto donde muchos signos se sobrescriben.

La ciudad Neorrealista se construye a partir de materiales, texturas y atmósferas, que nos hablan de una ciudad totalmente diferente a la del monumentalismo y del racionalismo de la época anterior que utiizaba mármoles y superficies blancas. La luz, los fenómenos atmosféricos y la obscuridad de la noche se oponen a esta materialidad, disuelven el contorno de la ciudad hasta hacerla desaparecer.

\section{CONCLUSIONES}

Se propone un manifiesto de la Ciudad Neorrealista como metacategoría para la descripción del paisaje urbano en distintas épocas, hasta la metrópoli contemporánea. Se propone este espacio como territorio de resistencia, libertad, producción del hábitat y creación artística.

Veintidós años después en el homenaje de Almodóvar a Pasolini, de Madrid a Roma, encontramos la misma mirada de las dos actrices protagonistas -Carmen Maura y Anna Magnani- hacia su ciudad. Espacios urbanos que dejan de ser fondos escenográficos y se convierten en interlocutores. El diálogo entre Cine y Arquitectura es la posibilidad metodológica de ampliar los límites de la disciplina hacia una arquitectura aumentada del paisaje urbano, que incluya el análisis de los fotogramas y la topología del rodaje como técnicas de análisis para el proyecto, la investigación y la producción del espacio, y el mismo rodaje como herramienta de exploración del territorio urbano.

\section{BIBLIOGRAFÍA}

Textos, fuentes cinematográficas, digitales y de archivos.

\section{ANEXOS}

Contiene las fichas técnicas de las películas; una tabla de síntesis del análisis iconográfico y la "Línea de Tiempo del Neorrealismo" Italia / España / Ambiente internacional, que permite comparar fechas de películas y acontecimientos culturales, artísticos, arquitectónicos y políticos. También se incluyen algunas fichas con mapas y fotos de "regresos" a los lugares de rodaje cinematográfico. 


\subsection{El "INA Casa” y el INV.}

\subsubsection{Trama social, política y económica}

En la época de la gran reconstrucción, a partir del final de los años ' 40 y los comienzos de los años '50, España e Italia, a pesar de situaciones económicas y sociales parecidas, se encuentran en condiciones políticas distintas. España, sin participar en la Segunda Guerra Mundial, con la Guerra Civil, vive el mismo drama de muerte y destrucción de los otros países europeos; después de la victoria de Franco en abril del 1939, España pasará de la República a la dictadura, un año antes de que Mussolini, llevando Italia a la segunda guerra Mundial como aliado de Alemania, comience su decadencia y el fin de un poder dictatorial que terminó en 1943 con su destitución. En la fase de confusión que siguió, con la presencia en Italia de los aliados, los fascistas, los nazis y las tropas de los partisanos, los italianos, también como los españoles, conocieron la guerra de resistencia, el horror que muchas veces conlleva una lucha entre connacionales. El recorrido de Italia fue opuesto al de España, y después de 20 años de dictadura, a través de la Guerra de Liberación conquistó la democracia y el ordenamiento republicano. En los dos países estos acontecimientos dramáticos generaron un clima de intensa inestabilidad ideológica que afectó a la sociedad y se reflejó en el arte y en la arquitectura. ${ }^{1}$ Esta crisis se manifestó culturalmente a través del debate de la época sobre ciudad y los modelos de reconstrucción, y en Italia tomó la forma de disputa entre arquitectura racional y orgánica. Como escribe Manfredo Tafuri ${ }^{2}$, una "difficile dialettica tra il conoscere e l'agire si impone all'indomani della Liberazione". Existe, en esos años, la conciencia de que haría falta refundar la profesión arquitectónica, a través de una participación activa de la vida política, y con la investigación sobre técnicas y argumentos como aquel de la arquitectura residencial que fueron descuidados durante el Fascismo.

La pobreza aplastaba a los dos países; tanto la Economía española como la italiana se caracterizaban por un fuerte retraso en el proceso de industrialización. Italia en poco tiempo iba a recuperar esta situación con lo que se suele llamar el "boom" económico de los años sesenta, cuando los italianos pasaron de una economía casi totalmente agrícola (si excluimos los centros de Milán y Turín) a una prevalentemente industrial. España, a causa del Franquismo, permanecería aislada y con un crecimiento más contenido y gradual caracterizado por modelos autárquicos.

La guerra civil había comprometido la producción agrícola e industrial de España, y estas condiciones estaban peores todavía al final de los ' 40 , por la falta de ayuda y de relaciones con el extranjero; la imposibilidad de recibir los fondos del Plan Marshall, que los otros países europeos como Italia aprovecharon desde 1947 hasta 1951, fue causada por las condiciones políticas del País, y alejó todavía más España de Europa.

En este contexto de difícil situación económica, se agrava la situación sanitaria y alimentaria, se incrementa el desempleo y los fenómenos de migración del campo hacia las grandes ciudades alcanzan proporciones desconocidas hasta entonces. Madrid y Barcelona, en España; Roma y Milán, en Italia, representan la ilusión de mejorar condiciones de absoluta pobreza y falta de oportunidades que caracterizaban la vida en los pueblos rurales. Algunas obras literarias y sobretodo las del Cine Neorrealista de la época, documentan estos fenómenos de migración hacia las grandes ciudades y los consecuentes problemas de falta

\footnotetext{
1 (Baldellou, Editorial, 1995)

2 (Tafuri, Storia dell'architettura italiana, 1944-1985, 1986 p.5)
} 
de vivienda. La vida urbana, sin embargo, es tan dura como las de los campos, los migrantes no se adaptan fácilmente y junto a los problemas económicos también surgen los psicológicos y los sociales. Las condiciones de vida en los barrios informales que crecían alrededor de las grandes ciudades, eran difíciles porque un rescate, a falta de empleo estable para los trabajadores, era casi imposible. Así describe Eugenio Montés esta condición de los nuevos migrantes en los títulos iniciales de la Película "Surcos" de Nieves Conde:

"Hasta las últimas aldeas llegan las sugestiones de la ciudad convidando a los labradores a desertar del terruño, con promesas de fáciles riquezas. Recibiendo de la urbe tentaciones sin preparaciones para resistirlas y conducirlas, estos campesinos que han perdido el campo y no han ganado la muy difícil civilización, son árboles sin raíces, astillas de suburbio, que la vida destroza y corrompe. Esto constituye el más doloroso problema de nuestro tiempo." ${ }^{3}$

Sin embargo por encima de estas circunstancias puramente económicas, quizá lo más doloroso en España era ver como se desvanecía la capacidad de protesta y reivindicación de la población ${ }^{4}$ : son los años más duros de un régimen que poco a poco se va estructurando y consolidando, con el aval del dolor y la sangre de la guerra civil, basado en un orden autárquico para regenerar una nación que debía crecer "grande" y "libre" de espaldas a cualquiera de las ideologías extranjeras. ${ }^{5}$

En este panorama, otro punto de contacto entre los dos países es la influencia y el protagonismo que tuvo la Iglesia católica en la reconstrucción física y moral de los dos países. En Italia las óptimas relaciones entre Vaticano y gobierno italiano que se establecieron con el régimen de Mussolini, no mudaron en los años de la Nueva República. La presencia casi constante al poder del Partido de la DC, (Democracia Cristiana) mantuvo fuertes en Italia las raíces de la cultura católica, sobretodo en defensa de la amenaza Comunista, representada en Italia por el $\mathrm{PCl}$, el partido comunista que llegará a ser el más poderoso entre todos los países occidentales. En Italia y en España, los curas aparecen en las inauguraciones de los proyectos arquitectónicos, en la evangelización de los barrios chabolistas, en el cinema, como ejemplo de grandes virtudes, así ocurre en Roma ciudad abierta y Cerca de la ciudad.

Los problemas ligados a la falta de viviendas son los problemas que preocupan también la Iglesia. Una de las figuras de más relieve dentro de la DC fue Amintore Fanfani, que creó el Programa INA-Casa para la construcción de viviendas para trabajadores. La familia no puede nacer sin trabajo y sin casa, son estos los pilares de la sociedad fundada sobre los valores cristianos. La pobreza hay que contrastarla a través de las caritas cristiana, pero principalmente generando trabajo que, en Italia en esta época, significaba incrementar la producción edilicia. La Iglesia católica fue el soporte ideológico del Franquismo, mucho más que para el Fascismo Italiano, donde Mussolini había creado su propia estructura cultural, sus santos y sus mitos. Los franquistas tuvieron que enfrentarse a la miseria, sinónimo para ellos de vergüenza, y usaron a la Iglesia Católica como medio de acercamiento cultural hacia los pobres. Pero no es un camino fácil y esta obra de evangelización en los suburbios y en los pueblos sólo conseguirá el efecto contrario: "En 1955 los focos de descristianización siguen siendo los mismos que antes de la guerra civil: los suburbios obreros y las zonas de miseria campesina. Para los pobres, la identificación de la Iglesia con el poder del Estado o de los

\footnotetext{
${ }^{3}$ Esta descripción del humanista y político falangista Eugenio Montés, aparece en los títulos iniciales de la Película Surcos de José Antonio Nieves Conde (1951).

${ }^{4}$ (García de Cortázar \& Gonzáles Vesga, 1994)

5 Ibidem
} 
ricos, no hace más que subrayar su responsabilidad en la injusticia social y en una represión permanente que les impide expresarse." ${ }^{16}$. A pesar de este juicio, fue indudable la importancia de la actividad de algunas figuras, como la del Padre Llanos en la reivindicación de los derechos de estas poblaciones al margen ${ }^{7}$ (fig. F.1.1.1/1) ${ }^{8}$.

Otro tema que pone en paralelo las políticas económicas de los dos países, es la consideración sobre la calidad y la cantidad de la fuerza trabajo; la necesidad de buscar una fuerza de trabajo de bajo nivel para abaratar los costos de producción, tenía como consecuencia que se hacía vista gorda de las invasiones de suelo y de la creación de barrios informales ${ }^{9}$.

En Italia esta fuerza laboral será la misma empleada en la construcción de casas a las cuales estos obreros en muchos casos no tenían acceso. Así que, no obstante, los esfuerzos en la producción de viviendas protegidas, los dos países no alcanzaron nunca la solución definitiva al problema del chabolismo que, tanto en Roma como en Madrid, siguió de forma masiva hasta la mitad de los '70, por la siempre creciente demanda de casas. En muy poco tiempo la iniciativa privada sustituyó a la pública, causando la definitiva imposibilidad de acceso a la vivienda para los sectores más débiles de la población. Además de esto, en Italia la lentitud en la asignación y entrega de las casas en un sistema burocrático siempre al límite del colapso, obligó a mucha gente a seguir viviendo en asentamientos precarios, que tanto en Italia como en España alimentaban un mercado inmobiliario paralelo clandestino en manos de especuladores.

En 1956, las chabolas en Madrid y en los alrededores eran cerca de $50.000^{10}$ mientras que en Roma, en el 1957, las familias que vivían en tugurios, chabolas y grutas resultaban ser $13.000^{11}$. Frente a estos números y al crecimiento demográfico constante en las dos capitales por todos los años '60, podemos decir que las políticas adoptadas no consideraron al problema con la idea de solucionarlo definitivamente: este mundo sumergido empieza a ser descubierto y narrado en estos años por escritores, fotógrafos, artistas y cineastas.

En Madrid siempre se utilizó el mecanismo de los planos de emergencia, sin adoptar programas a largo plazo. Estos mismos planos "estaban fomentando la marginalidad y el chabolismo al concentrarla en la periferia especialmente en el sureste" ${ }^{12}$. Los mecanismos en Roma y Madrid fueron los mismos, una edificación a manos de los privados de baja calidad y periferias sin dotaciones. Una época que produjo segregación territorial y una costumbre a desarrollar la ciudad sin urbanismo o con una mala planificación.

\footnotetext{
${ }^{6}$ (Témime, Broder, \& Chastagnaret, 1982. P. 314)

${ }^{7}$ El Padre Llanos será uno de los más activos en las operaciones de remodelación de los barrios chabolistas de Entrevías y del Pozo, no es una casualidad que tuviera el apodo de "Cura Rojo".

${ }^{8} \mathrm{~A}$ partir de esta nota y a lo largo de todo el texto de este trabajo de investigación la $\mathrm{F}$ mayúscula se refiere a "Ficha" y la numeración corresponde tanto a la ficha como al párrafo correspondiente. Si hay más de una ficha por párrafo se indica con numero árabe después del símbolo "/".

9 Matilde Alonso explica esta situación subrayando que, desde este punto de vista, "ya no se consideraba tan dramático que la ciudad se revistiese con un manto de pobreza ya que estas bolsas de parados constituidas por los braceros del campo, a pesar de carecer de formación, llegaban en plena edad productiva, lo que les convertía en un esplendoroso ejército industrial de reserva, tan dócil como necesario para el quebrantado desarrollo de las fábricas a cambio de salarios de subsistencia”. (Alonso, 2001 p. 209)

10 (Franco Alonso, 2005)

11 (Clementi \& Perego, 1983)

12 (Franco Alonso, 2005)
} 

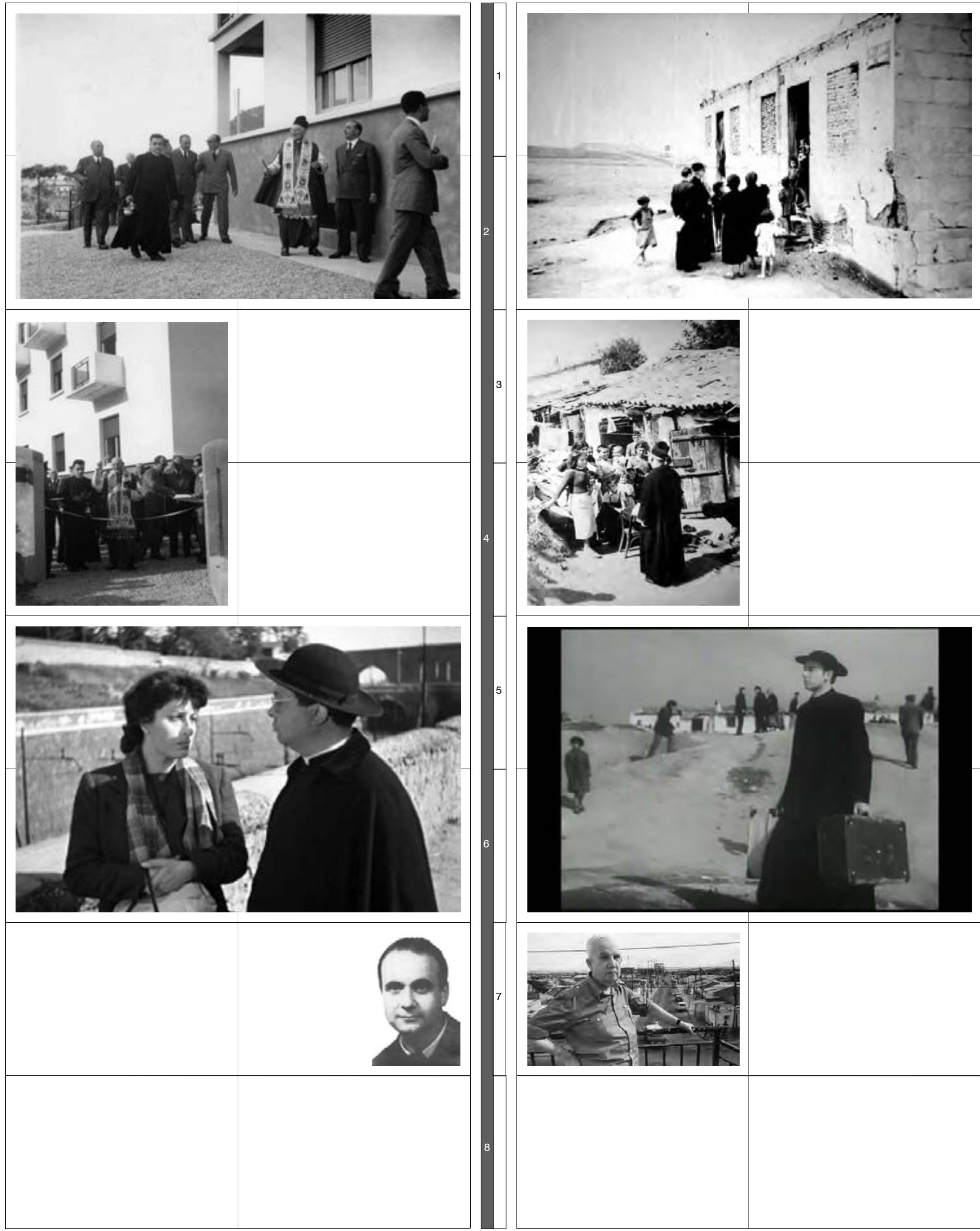

RM 1-2-3-4. Inauguración de INA-CASA en Dongo (Como) en 1952: bendicion del párroco RM 5-6. Fotograma de la pelicula "Roma ciudad abierta (Rossellini 1945): El cura interpretado por Aldo Fabrizi hablando con Pina interpretada por Anna Magnani.

RM 7. El Giuseppe Morosini que inspiró Don Pietro de "Roma ciudad abierta".

MD 1-2-3-4. labor de apostolado en el barrio de Entrevías en Madrid (1941). Fuente: Fondo Fotográfico Santos Yubero. ARCM (Archivo Regional Comunidad de Madrid).

MD 5-6. Alfonso Marsillach interpretando el cura protagonista de la película "Cerca de la ciudad" (Lucía 1952): el cura llega a la barriada de Ventas. MD 7. El padre Llanos: "el cura rojo".
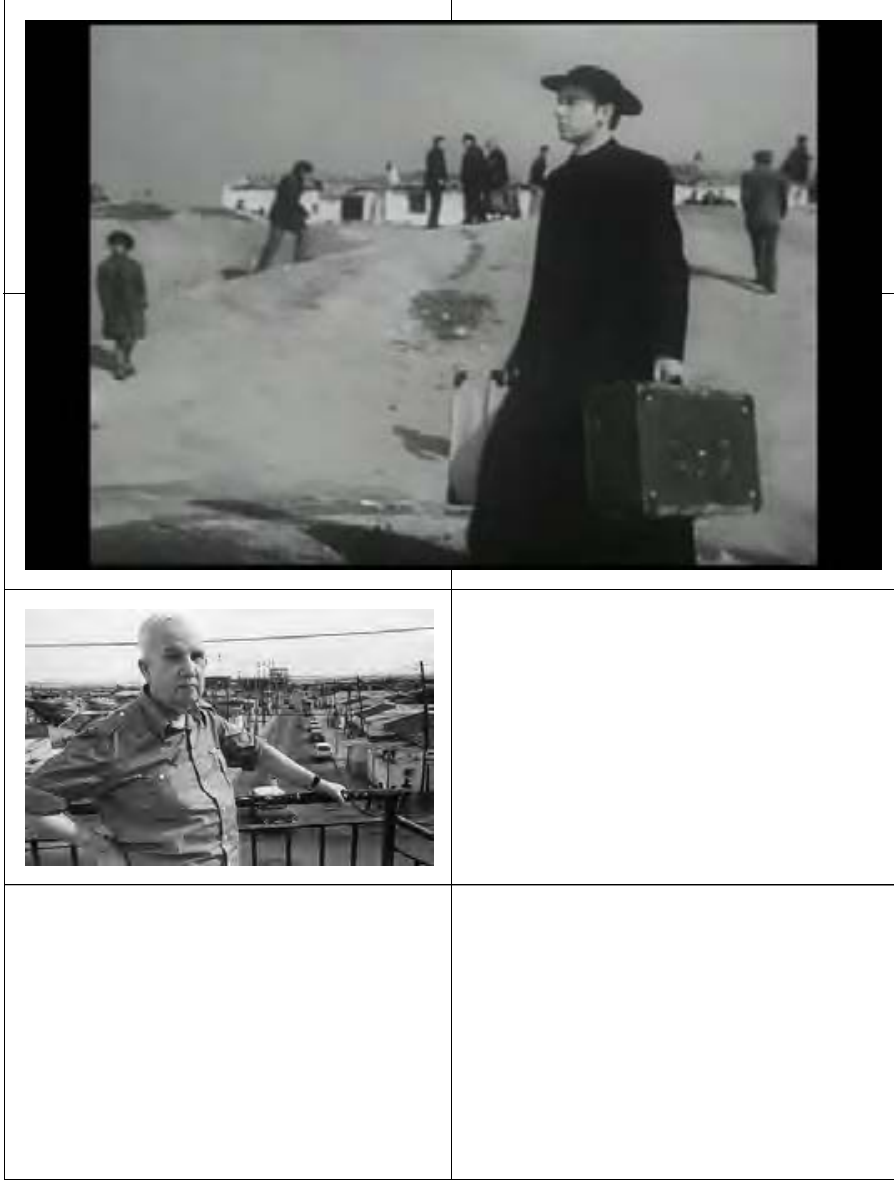
Si para Madrid la solución al problema del chabolismo fue una lucha débil pero constante a través de normativas y programas de emergencias en el intento de hacer frente al fenómeno. Podemos decir que, en Roma, como en la mayor parte de la península, el problema no fue solucionado directamente. Las políticas adoptadas para la emergencia de la vivienda no tomaban a los chabolistas como directos beneficiarios, no se produjo una relación directa entre barrios informales y nuevos barrios para el realojamiento, como pasó en Madrid y en Barcelona. El problema lo solucionaron los italianos individualmente; para salir de manera rápida del infierno de las "Borgate" de chabolas se adquiría privadamente un lote de terreno agrícola en la amplia campiña que rodea Roma, y se construía una casita para sí y la familia, hecha poco a poco, con cuidado y de mucho mayor calidad de la chabola de origen, pasando de la situación abusiva de tipo precario a una abusiva más consolidada. La actitud del ayuntamiento frente a este fenómeno será de total indiferencia, hasta la intervención a posteriori y después de mucho tiempo con programas de urbanizaciones secundarias y a veces primarias. Así que estos núcleos de las "Borgate" darán vida a nuevos centros de expansión periférica sin ningún control por parte de la administración de la ciudad, incapaz de planear y programar su expansión (F.1.1.1/2).

\subsubsection{Corporativismo, ocupación e iniciativa privada ${ }^{13}$}

La manera de enfrentarse formalmente a los problemas que hemos descrito, se concretizó en los programas nacionales de construcción de viviendas: a través del Plan Fanfani del 1949, en Italia, y del Programa Nacional de Viviendas (P.N.V.) del 1955, en España con el Ministro de la Vivienda José Luís Arrese. La construcción fue el fin de estos programas junto a la eliminación del desempleo, "una forma elocuente de disolver las contradicciones entre el capital y el trabajo". ${ }^{14}$

Tanto en Italia como en España era presente una visión corporativa de la sociedad y de la economía. En Italia esta visión llegaba del fascismo, y su estructura permanecía también en la democracia y era apoyada por el Ministro Fanfani, autor del Plan; para él, las iniciativas individuales tenían que estar subordinadas a un control público de tipo corporativo, a juntas económicas regionales y nacionales, constituidas por representantes profesionales y sindicales. En Fanfani el apoyo al corporativismo de tipo fascista tiene su fundamento en la teoría que explica que la economía tiene que ser regulada por la política. Esta idea la encontramos en esta primera fase de la Posguerra, con la diferencia que ya no se basa en el modelo económico del estado de Mussolini, sino en el de Estados Unidos, del New Deal de Roosevelt, expresión práctica de las teorías americanas del Neo-voluntarismo que Fanfani miraba con interés: se critican las teorías del liberalismo económico, en favor de formas de control social en la vida económica. Se miran también a las teorías de Keynes sobre la utilización del gasto público para la realización de políticas de empleo. ${ }^{15}$ En la España franquista el Corporativismo actúa a través del sistema de la Democracia orgánica, un sistema político en el que la representación popular se ejerce a través de las relaciones sociales "naturales" como la familia, el municipio y el sindicato. ${ }^{16}$ Se crea el Sindicato vertical, la única institución sindical permitida en España hasta el fin de la dictadura que a través de la O.S.H, la Obra sindical del hogar, tuvo el encargo de construir las nuevas viviendas. Además del OSH y del I.N.V. el instituto Nacional de Viviendas, otras organizaciones-corporaciones fueron

\footnotetext{
13 Para este párrafo y el siguiente: (Colella, Políticas habitacionales en Italia y España en la posguerra 1949-1954 / Postwar Housing Policies in Italy and Spain 1949-1954, 2016)

14 (Franco Alonso, 2005)

15 (Nicoloso, 2001)

${ }^{16}$ (Quesada Marco, 1997 p. 145)
} 

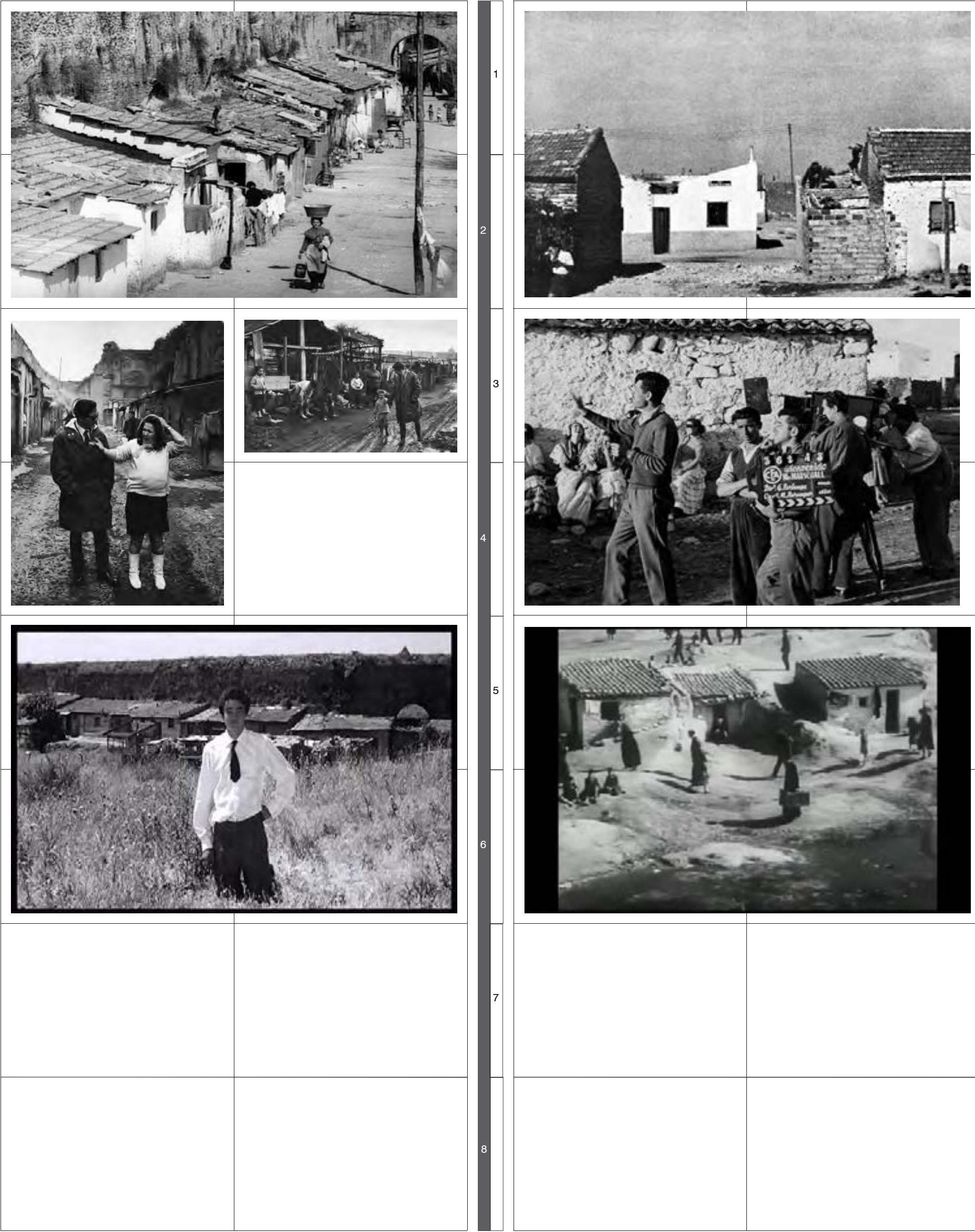

RM 1-2. Vista de I asientamiento informal del Acueducto Claudio en el Tuscolano. RM 3-4. Pierpaolo Pasolini de visita en el asientamento informal "Mandrione" $y$ en otro asientamiento informal cerca de la vía Tuscolana.

RM 5-6. La barriada del Acueducto Claudio en el Tuscolano en un fotograma de "Mamma Roma" (Pasolini 1962)

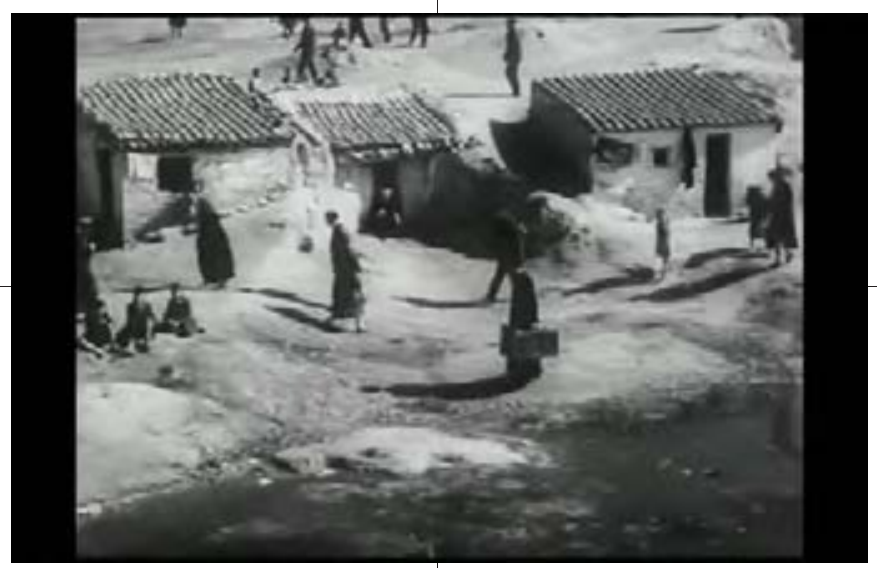

MD 1-2. Barrio chabolista de "el Pozo", Madrid

MD 3-4. Berlanga rodando Bienvenido Mr. Marshall.

MD 5-6. Alfonso Marsillach interpretando el cura protagonista de la película "Cerca de la ciudad" (Lucía 1952): imagen de "El Pozo del tío Raimundo". 
promotoras de la construcción: los patronatos de casas militares o municipales y las instituciones religiosas como la mariana H.E., el Hogar del Empleado.

En los dos países la condición rural y agraria caracteriza la sociedad y la economía en la posguerra. Italia y España siguen en un fuerte retraso en la industrialización de la economía en comparación con otros paises de Europa, como Inglaterra, Francia y Alemania; un retraso menor en Italia, gracias al desarrollo de las áreas de Milán y Turín, más grave en España, en donde faltaban grandes centros de producción industrial. La guerra detendrá ulteriormente este proceso de industrialización, así que, en áreas urbanas como las de Madrid y de Roma, las condiciones sociales y económicas eran muy parecidas.

En Italia se tomó la dirección de un crecimiento económico, basado en el fomento de la industria y de la producción edilicia: este crecimiento fue muy rápido, también por el impulso inicial de las ayudas del plan Marshall, con un cambio traumático desde una sociedad rural a una urbana en menos de 20 años.

En España, el Franquismo y el consecuente aislamiento político y económico ralentizaron el proceso de industrialización e hicieron tomar la única dirección en este momento posible, la de una política de "autarquía rígida fundamentalmente hacia la agricultura" ${ }^{17}$. Se miraba a la nueva política agrícola como un soporte del proceso de industrialización del país y al mismo tiempo se buscaba una economía agraria de tipo industrial con la idea de "suplir durante un tiempo una economía industrial" ${ }^{18}$. Así que en los primeros 10 años, desde 1939 hasta 1948, España conoció un desarrollo agrícola de tipo autárquico, que no poca influencia tuvo en las políticas urbanas y arquitectónicas; en la fase sucesiva, a partir de 1949, se empezó el impulso a nuevos modelos de producción económica a través de la construcción de viviendas ${ }^{19}$.

Estas estrategias politico-economicas influenciaron la producción del hábitat urbano y suburbano desarrollada en España y en Italia; determinando por un lado la matriz cultural, popular y campesina, por el otro el uso de sistemas constructivos artesanales y tecnologías tradicionales. En España sobre todo en los primeros siete años de actividad de actuación del P.N.V. A esta condición rural y autárquica de la economía se unen las condiciones de pobreza extrema, la escasez de materiales y de recursos, y el uso de mano de obra no calificada, determinando un bajo nivel tecnológico, y una arquitectura en general hecha con ladrillo. En Italia el mismo nivel tecnológico, (excepto por un mayor cuidado en el detalle de ejecución y mayores intentos de estandarización), tiene en la base una decisión estratégica de tipo político: la necesidad de poder emplear el mayor número de personas en la construcción de la vivienda. Detrás de escusas de tipo estilístico, psicológico y de la idea de una arquitectura en línea con la tradición, se celaban claros intereses de tipo político y económico. Como subraya el Tafuri:

"Claras son las finalidades del programa, alejar la subida del niveles de desempleo; utilizar la construcción en función subordinada a los sectores que fomentan la economía, dejándola parada a un nivel pre-industrial y en función del desarrollo de las pequeñas empresas, mantener inalterado, cuanto más tiempo, un

\footnotetext{
17 (Sambricio, Que coman república:introducción a un estudio sobre la reconstrucción en la España de la postguerra, 1977 p.22)

18 ivi

${ }^{19}$ (Sambricio, De la arquitectura del nuevo estado al origen de nuestra contemporaneidad: el debate sobre la vivienda en la década de los cincuenta, 2000)
} 
sector de la clase obrera flexible, chantajeable y no masificable; hacer de la intervención pública un soporte para la intervención privada". ${ }^{20}$

A pesar de la posibilidad de una industrialización de los procesos constructivos gracias al desarrollo, sobre todo del norte de la Peninsula, Italia eligió una edificación de bajo nivel tecnológico. El Plan de Urgencia Social tenía, como el italiano, la finalidad de disminuir el paro obrero, pero en el régimen de Franco prevaleció la decisión de acabar con los asentamientos informales, fastidiosos y nocivos para el Generalísimo, alojando en nuevos hogares sus habitantes y estimulando al mismo tiempo la iniciativa privada en el sector de la construcción. Cuando el Ministro Arrese dio el encargo al Comisario Julián Laguna de "acabar con el Chabolismo", este último pensó en los métodos más eficaces para lograr el resultado con los menores costos; así se explican la búsquedas de métodos más eficientes y baratos, de un lado la autoconstrucción, del otro un mínimo de industrialización; se investigó esta última posibilidad a través de la organización del concurso de viviendas experimentales del 1956 y reuniendo el grupo de jóvenes arquitectos, futuros protagonistas de la estación de los poblados dirigidos ${ }^{21}$.

\subsubsection{Ley Fanfani y Ley de Renta Limitada}

En Italia y España prevaleció un modelo socio-económico capitalista en donde el control del estado fue solo aparente a pesar de las diferentes ideologías, la Socialista Cristiana en Italia y el Franquismo en España.

"Un ideale di solidarietá umana e di giustizia sociale è a fondamento del 'Piano Incremento Occupazione Operaia", con estas palabra se presenta el proyecto de desarrollo de nuevas viviendas para la población Italiana ${ }^{22}$. Se subraya cómo el empleador y el empleado están tasados a favor de los que están en paro, con el apoyo del Estado. Se plantea un programa que teóricamente debería beneficiar a "los que no tienen antes de los que tienen", solucionar el problema de la vivienda, pero antes de todo impulsar el desarrollo de la industria de la construcción, para incrementar la ocupación. Los obreros de la construcción en paro e Italia después de la guerra (registrados en la oficina de paro) eran 300.000 , de estos el $17 \%$ fueron los trabajadores involucrados en los desarrollos de INA-Casa ${ }^{23}$.

La gran diferencia entre los programas italiano y español, fue el modelo de financiación: si el italiano prevé un sistema de subvención fraccionado entre todas las categorías de trabajadores dependientes, prescindiendo de su beneficio en el aprovechar la casa de promoción pública, en España, con la Ley de Renta Limitada no existen categorías privilegiadas en base a la renta, todos pueden acceder a las casas a través de un sistema en el cual el estado se hace cargo de los gravámenes de los préstamos, como si se tratara de una institución bancaria, pero sin hacer pagar los intereses. En Italia, el sistema se funda en el sistema de impuestos y sobre la renta, quien tiene más, contribuye más a financiar la vivienda pública. Un sistema, el italiano, que en apariencia corresponde a los valores de solidaridad católica, de socialismo cristiano en los cuales la Ley del ministro del partido de la DC se

20 (Tafuri, Storia dell'architettura italiana, 1944-1985, 1986)

${ }^{21}$ Este grupo de jóvenes innovadores, en posición antagónica respeto a los arquitectos del Obra Sindical del Hogar (OSH) la institución "oficial" del régimen, retomando las investigaciones europeas entre las dos guerras, empujarán el debate hacia la estandarización y la industrialización de la arquitectura como posible solución al problema de la vivienda, aunque la ciudad que se desarrolló no correspondía a estos ideales

22 (INU, 1952 p.25)

23 Ibidem 
inspira. La tasación para la recaudación de fondos involucra a todos los trabajadores dependientes, inclusive a los que por renta no tienen derecho y también a los que no tendrán acceso a la casa, aunque lo hayan solicitado. Se excluyen de los beneficios de la ley para la casa muchos sectores de la población, braceros, trabajadores del campo, los pequeños artesanos, todos los que era difícil de ubicar y tasar pero que constituyeron la mayoría de los que no tenían un techo, la población de bajos recursos. Es esta asignación la falla más grande del sistema que tendrá repercusiones en toda la sociedad italiana, incrementando el fenómeno de la informalidad. La construcción no estaba incluida en un proyecto orgánico a nivel nacional para satisfacer las reales necesidades de casas de los ciudadanos italianos. No es una casualidad que en la película Mamma Roma los protagonistas, entre ellos una ex prostituta, miren al barrio INA-Casa del Tuscolano como a un barrio de gente de clase elevada, lejos de los barrios informales o los suburbios de donde ellos proceden.

Los recursos y las obras, se distribuyeron en el territorio, con relación a las necesidades de cada Provincia, teniendo en cuenta no tanto las tasas de marginalidad de la población o la presencia de infravivienda, sino exclusivamente los datos estadísticos sobre paro, hacinamiento de la población y condiciones de las localidades en seguida de las destrucciones bélicas. El Plano INA-Casa se relaciona también con el número de contribuyentes presentes en el lugar, determinando una mayor o menor inversión según las capacidades fiscales. El programa de Fanfani fue claramente un plan de sector para la ocupación de mano de obra no calificada en la producción edilicia, que proponía un nuevo régimen de suelos y una producción masiva de viviendas de calidad. Faltó una visión más orgánica, una diversificación de las tipologías de desarrollo y de los instrumentos que tomara en cuenta las grandes peculiaridades geo-económicas de Italia, la gran separación entre Norte y Sur, cosa que sí se hizo, pero sólo a nivel de una búsqueda en la expresión arquitectónica de los conjuntos proyectados (F. 1.1.2).

Las diferencias presentes en la Ley de España entre beneficios directos e indirectos, las diferentes categorías de viviendas y la posibilidad de la prestación personal, representan soluciones menos "abstractas" que intentan satisfacer distintas condiciones sociales y económicas de la sociedad española. Además, a lo largo del tiempo en la península lbérica se siguió con este modelo legislativo "orgánico" que diferenciaba la oferta y las posibilidades de acceso a la vivienda; en el modelo español las leyes, programas y organismos que se siguen creando también después de la muerte de Franco, son el testimonio de un compromiso y una toma de responsabilidad. Se crea una base normativa que si de un lado es fragmentada, temporalmente discontinua y variable -sobre todo en comparación con el sistema INA-Casa, más compacto y orgánico-, conseguirá mantener una oferta constante de vivienda pública que intentó, fracasando, ser una alternativa a la creciente especulación edilicia privada. Por estas razones, no es una coincidencia que el fenómeno de la construcción abusiva fuese tan desarrollado en Italia, por la falta de políticas reales de apoyo hacia la promoción pública. Se desarrolló en Italia una arquitectura informal "de calidad", sobretodo en la capital, así que, en muchos casos, si se empezaba con chabolas, se acababa con viviendas más que dignas.

El Plan Nacional Español tenía probablemente el límite de un excesivo costo para los que necesitaban acceder; este aspecto, quizá es lo que más claramente nos revela las contradicciones de un régimen, el Franquista, fuertemente reaccionario e influenciado por las ideologías capitalistas. Muy a menudo, para los que por ejemplo llegaban a Madrid y gastaban todos sus ahorros en el comprar un pequeño terreno y construir una pequeña chabola, era después imposible soportar el coste de una deuda para comprar una casa de verdad ${ }^{24}$.

\footnotetext{
${ }^{24}$ (Fernández Galiano L. , 1977 p.19)
} 

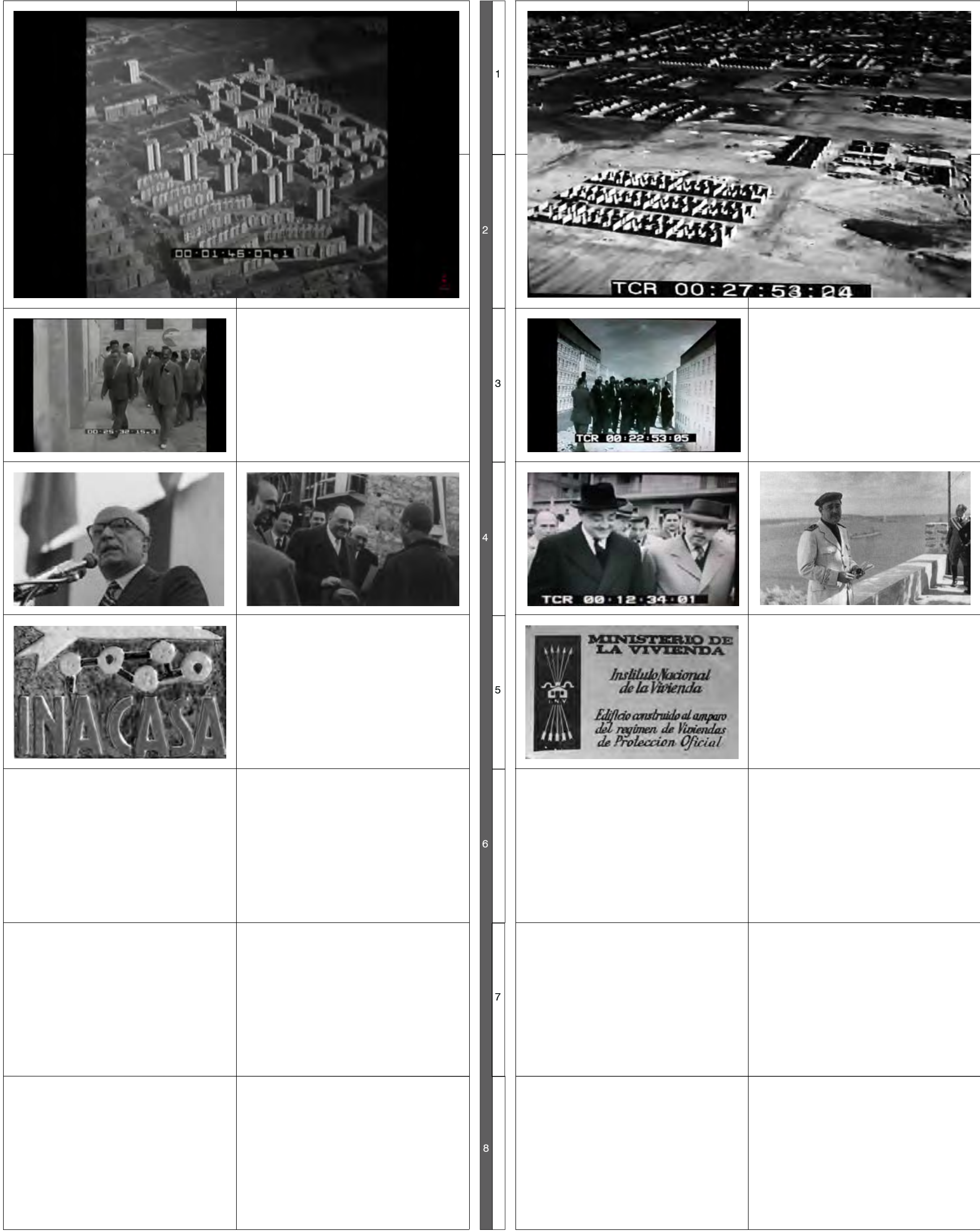

RM 1-2. Vista aerea del barrio tuscolano en el documental "Case per lavoratori" (Luce 1954).

RM 3. Inauguración de viviendas en Tor Marancia (Roma) documental "Una casa per Tutti" (Luce 1954)

RM 4. El ministro Amintore Fanfani promotor del Plan "Ina-Casa"

RM 4. Arnaldo Foschini director de INA-Casa

RM 5. Placa de las intervenciones "Ina Casa"

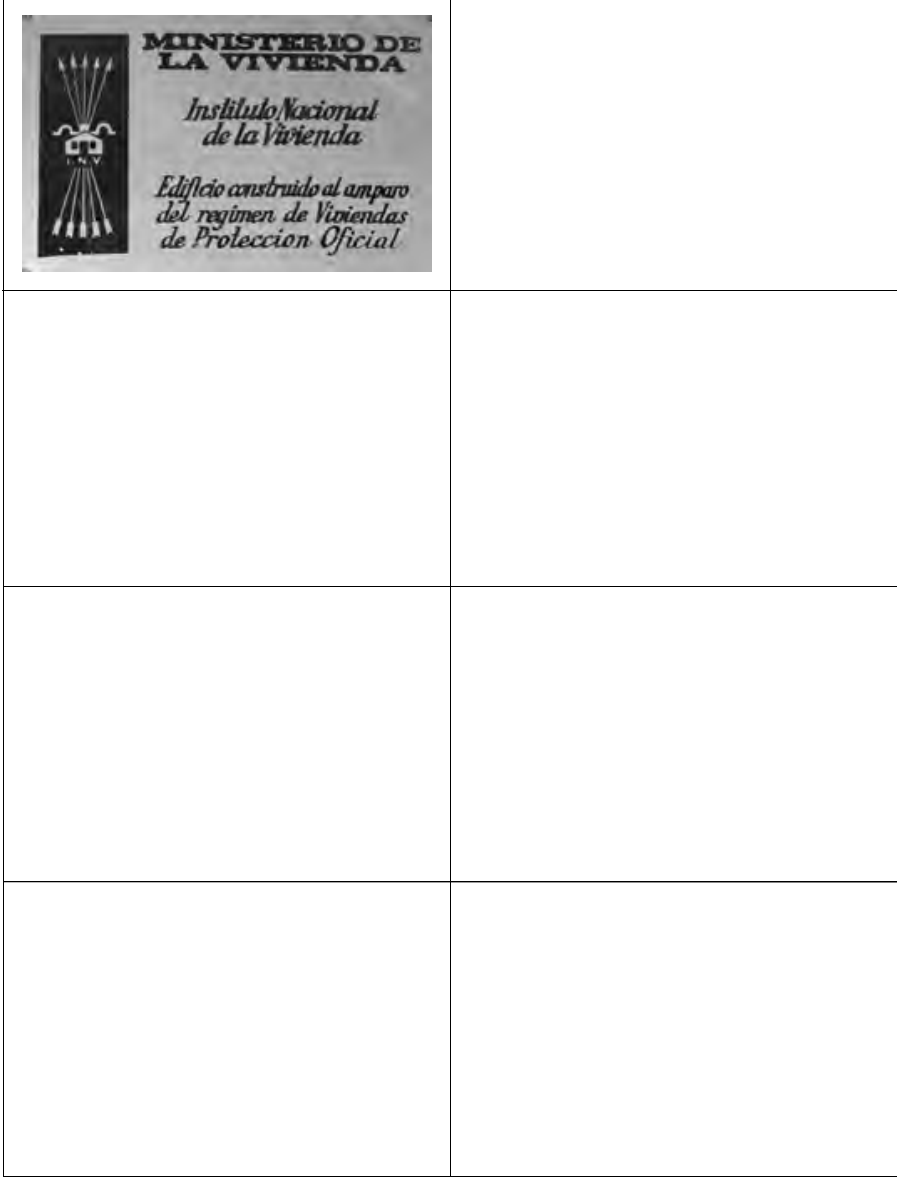

MD 1-2. Vista aerea del poclado de Entrevías en el documental "Sesenta mil viviendas. Plan de urgencia social de Madrid" NO-DO, 1957

MD 3. Inauguración del poblado de Entrevías (NO-DO 1956)

MD 4. José Luís Arrese Ministro de la vivienda (NO-DO 1956)

MD 4. Julian Laguna, comisario de ordenación urbana de Madrid.

MD 5. Placa del INV, puesta en los nuevos desarrollos 
La prestación personal en la ley española, fue una gran ayuda para este sector de la población que con no pocos esfuerzos pudo acceder al crédito del restante $80 \%$ del coste de la vivienda, todavía el estado y las varias instituciones involucradas, siempre actuando como un banco, no aportando ayudas directas en el coste de las viviendas, cosa que sí haría el estado italiano. Sin embargo, el costo del rescate en el sistema italiano era en promedio más alto y por un menor plazo de tiempo en comparación con el de España. Podemos decir que en comparación con el Italiano, el programa de ayuda Español se caracterizó por un mayor pragmatismo en el enfrentarse a las relaciones entre Público y Privado, fomentando la participación de empresas privadas también en la construcción de las viviendas protegidas en una forma dinámica y efectiva, pero con el claro interés de favorecer las empresas, las cuales no tenían mucho interés en producir vivienda popular para sectores de poblaciones de muy bajos recursos prefiriendo la pequeña y media burguesía. El italiano parece ser influenciado por cierto abstractismo católico, y por la convención que creando ocupación se podían solucionar todos los problemas, inclusive los de la vivienda, la idea del "impulso Keynesiano" de la economía ${ }^{25}$. Las viviendas construidas en España e Italia en 10 años fueron menos de la mitad de las que se habían anunciado, y, además, en este panorama de escasez productiva se fueron privilegiando los sectores de la pequeña y mediana burguesía, que -con sacrificios- podían acceder a un mercado cada vez más inalcanzable para sectores pobres de la población que quedaban fuera del sistema de ayudas y tenían que volver a encontrar soluciones en el mundo de la informalidad. Es un proceso lento de aburguesamiento de la sociedad al que se hace referencia también en películas de la época como Mamma Roma, de Pasolini, hablando de las aspiraciones de la protagonista; sin embargo, el ensanchamiento del mercado de bienes, no siempre llega a satisfacer las necesidades básicas de todos.

Para la mayoría de la población la casa representó el epicentro de consumo individual, de alejamiento de la dimensión pública para acercarse al mundo del confort privado: es suficiente analizar cómo cambia la imagen de los internos domésticos en las revistas o en los documentales de la época, como en los reportes cinematográficos de NO-DO, en donde se hace fuerte énfasis en el contraste entre las humildes cocinas de las chabolas, y los salones con sofá y comedores de las nuevas viviendas. Las mismas inquietudes estarán presentes en las expresiones culturales artísticas de la época, en las cuales con ojo neorrealista se intentará desvelar estas muchas contradicciones y será sobretodo el arte cinematográfico el que tendrá un papel fundamental, describiendo cada véz más estos fenómenos sociales con la potencia critica del medio artístico (F.1.1.3).

\footnotetext{
${ }^{25}$ Hay que mencionar dos aspectos positivos: Las soluciones proyectuales planteadas tanto en España como en Italia, establecieron unos estándares de calidad y marcaron una clara diferencia entre lo que hubiera tenido que ser una vivienda de protección en comparación con una del mercado libre, y se formó así una generación de profesionales que demostraron el valor de la arquitectura como disciplina social.
} 

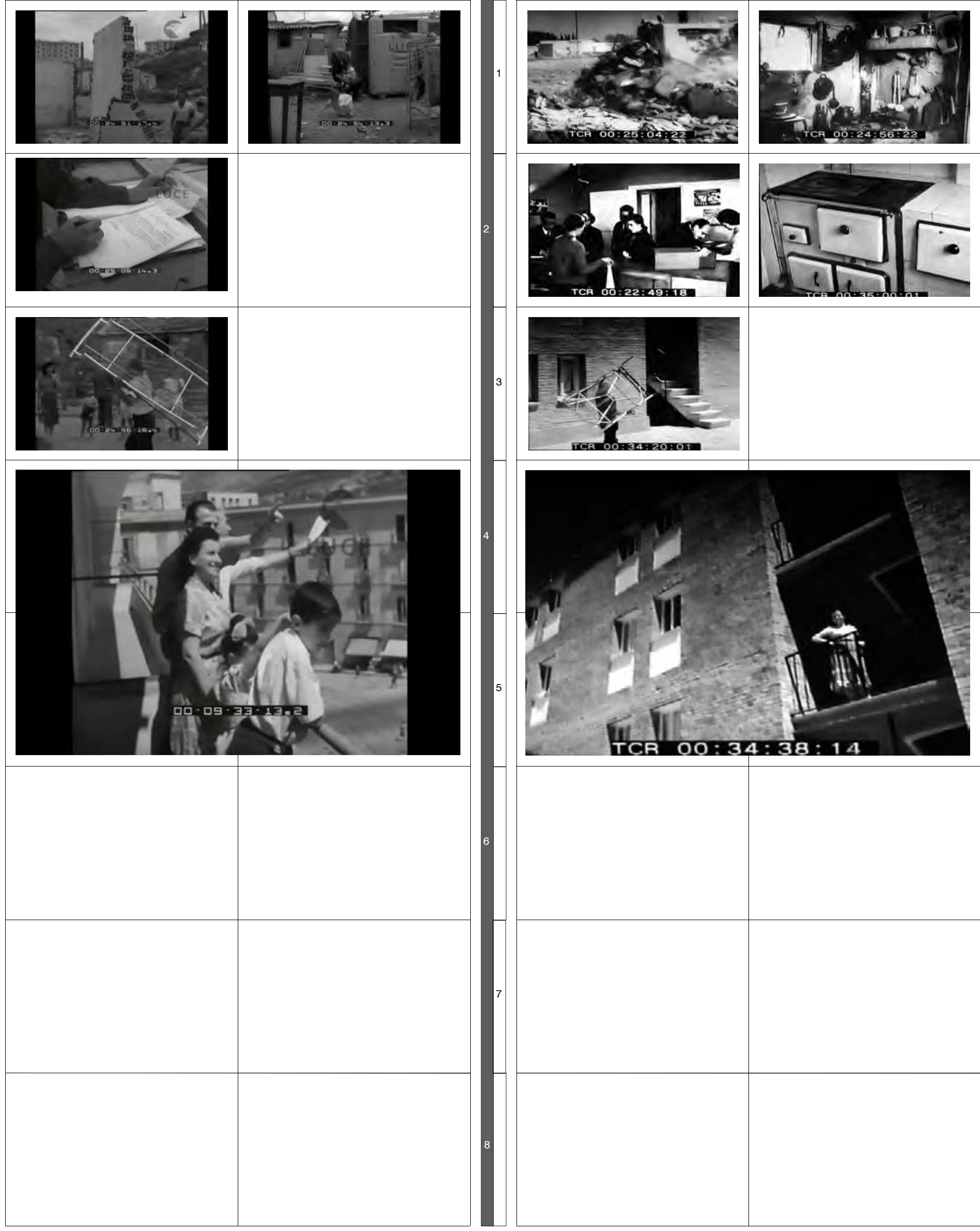

RM 1-2-3. Fotogramas del documental "Una casa per tutti" (Luce 1954).

RM 4-5. Fotograma del documental "L' INA CASA consegna 600 nuovi alloggi a Napoli" (Luce 1951).

MD 1. Fotogramas del documental "Nuevos Hogares" en "Imagenes NO-DO" 1965 MD 2-3-4-5. Fotogramas del documental"Sesenta mil viviendas. Plan de urgencia social de Madrid" NO-DO, 1957
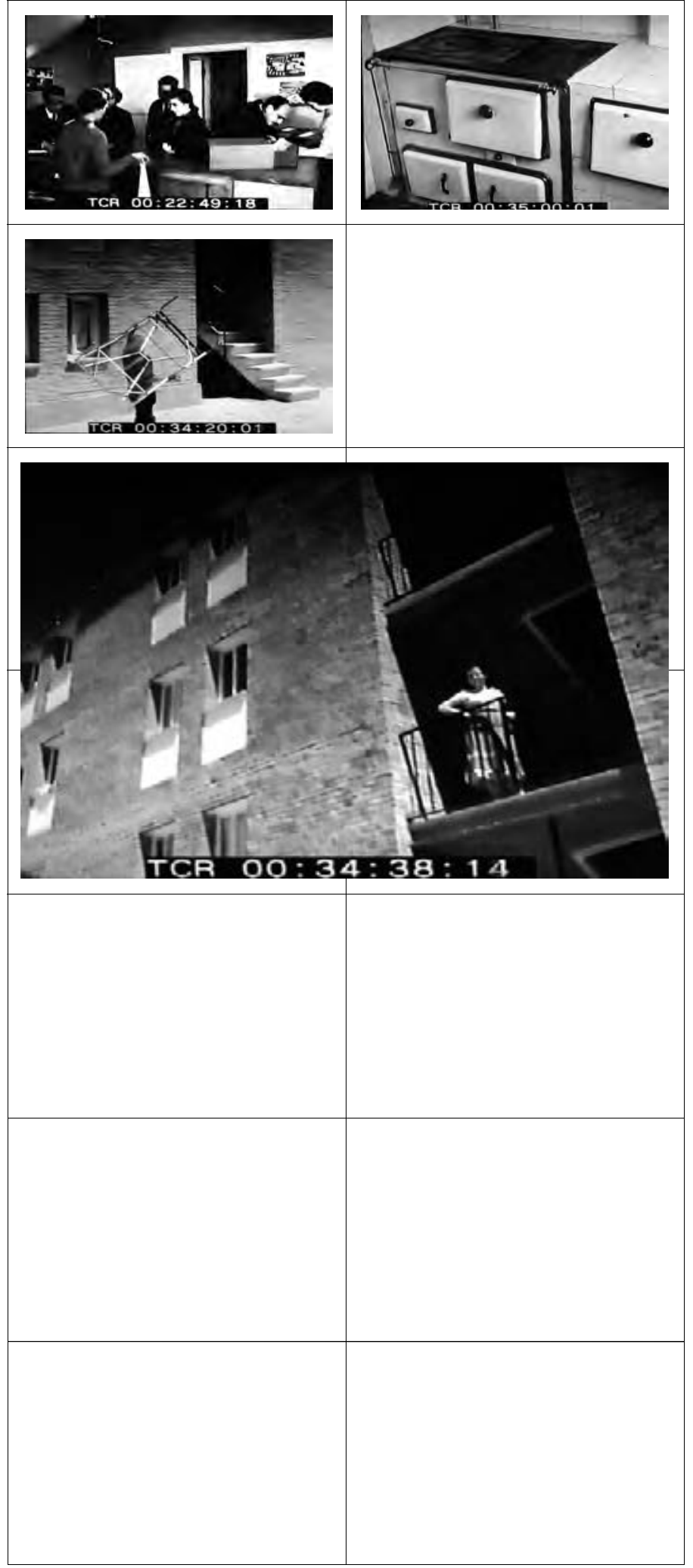


\subsection{Paisaje cultural: la mirada neorrealista en Italia y España}

\subsubsection{Del Surrealismo al Neorrealismo: "Las Hurdes de Luís Buñuel"}

Nos interesa analizar los orígenes del fenómeno realista que caracteriza el cine de Italia y España en la Posguerra. Las obras literarias e figurativas del Naturalismo francés, con una narración a base de una objetividad documental, representan las últimas experiencias de una visión artística que, a partir de 1895, con la primera proyección de los hermanos Lumiere, tuvo que replantearse.

Con la primera proyección cinematográfica, quedaba claro que la objetividad de la representación cinematográfica iba a re-definir los paradigmas del realismo como práctica artística. En principio los Lumiére no creían en las posibilidades narrativas del Cinema, sus primeras proyecciones fueron con cámara fija y sin montaje, representaciones de eventos de la cotidianidad. Con Alice Guy se produce la primera verdadera película narrativa de ficción $L a$ Fée aux Choux de 1896, y con los experimentos de George Méliés, las variaciones en la continuidad narrativa a través de los planos de raccord, nace el cine moderno como expresión artística capaz de manipular la realidad.

En el primer documental de la historia del cinema, Nanook of the North dirigido por el cineasta estadounidense Robert Flaherty, en 1922, se hace evidente el conflicto entre necesidades estéticas del cine como expresión artística y las necesidades éticas de representar la verdad: los rodajes de Flaherty son puestas en escena con el intento de hacer compatible el tiempo y el espacio de la narración cinematográfica para el público, junto con la descripción de la vida cotidiana de una población Inuit, con todas las dificultades de rodar en un ambiente muy hostil.

En el mismo año de Nanook, en Rusia el director Dziga Vertov empieza a desarrollar su KinoPravda o cine-verdad, una serie de 23 noticiarios de 20 minutos en los cuales el director teoriza un nuevo cine en el cual a diferencia de Flaherty la expresión y el contenido de lo que se quiere decir sea consecuencia directa del rodaje sin ningún tipo de artilugio o manipulación; siete años después del Kino-Pravda en 1929, su obra maestra El hombre de la cámara hará incursión en el mundo de las "sinfonías de las ciudades" con la narración de un día, del amanecer hasta la noche, en una ciudad soviética a través de los ojos de un operador de cámara. Como en las contemporáneas Berlín, sinfonía de una gran ciudad (1927) de Walter Ruttmann o Paris duerme (1925) de René Clair en la película de Vertov se describe la ciudad en la época industrial, su paisaje dinámico y en transformación, como el de un organismo vivo. En Italia y España las proyecciones de los hermanos Lumiére se presentaron ya a partir de 1896. Podemos seleccionar dos etapas en los inicios de la historia del séptimo arte en los dos Países, que marcan y contienen "in nuce" las características de la cinematografía que se desarrollará. En Italia el cine histórico que alcanza su máxima expresión en el "colosal" ${ }^{26}$ de Cabiria de Giovanni Pastrone rodado en 1914; en España el cine de la Españoladas o las versiones cinematográficas de las Zarzuelas, producidas en Barcelona, entre las cuales destacan las obras de Florián Rey, actor director de una célebre versión de La Revoltosa en $1924^{27}$.

Frente a un cine, que a nivel mundial se encaminó definitivamente hacia la ficción, después de un inicio que parecía favorecer el Cine documental, el Cinema Neorrealista italiano representó

${ }^{26}$ El "colossal" es un género cinematográfico.

27 (Gubern, 2015) 
un nuevo punto de arranque en la línea de Vertov hacia un cine-verdad, replanteando las relaciones entre técnica y narración y rodaje y montaje.

En 1932, 11 años antes del estreno de Obsesión de Visconti, considerada como la primera obra cinematográfica del Neorrealismo Italiano ${ }^{28}$, y 15 antes del documental Gente del Po de Antonioni y de La Tierra tiembla de1948 siempre de Visconti, Luis Buñuel, padre del surrealismo cinematográfico, roda en España el documental Las Hurdes tierra sin pan. Se trata de un cortometraje de 30 minutos que describe las inhumanas condiciones de vida de la homónima comarca en el norte de Extremadura, basado en el estudio antropológico de 1927 de Maurice Legendre, Las Jurdes: étude de géographie humaine, que Buñuel había leído antes del rodaje ${ }^{29}$. Buñuel toma este ensayo como punto de partida de la descripción cinematográfica de una condición humana que genera incredulidad en el espectador.

Las Hurdes tierra sin pan es la tercera obra cinematográfica del maestro aragonés, y fue rodada con muy escasos recursos dos años después de sus dos obras surrealistas más conocidas, Un perro andaluz y La edad del oro. Este documental antropológico es un cambio radical en comparación con sus trabajos anteriores, y parece tomar la dirección de un cine realista y con ciertas preocupaciones de tipo social y político, anticipando algunos de los temas del Neorrealismo español, de Nieves Conde, de Berlanga o Saura; sin embargo, este cambio de ruta respeto a su cine anterior, realmente no existe, así como explica Luis Vidal en su estudio sobre Buñuel:

"Hay quien piensa (como Ado Kyrou y Carlos Saura) que no hay nada más surrealista que el implacable verismo de Las Hurdes. (...) Los surrealistas apreciaban mucho los documentales, cuanto más asépticos mejor, y el propio Buñuel los había utilizado en La edad de oro. En realidad, el superrealismo no era sino una forma integradora de diversos realismos antes parciales, y a Buñuel lo que más interesaba era el fondo moral y superar los cenáculos parisinos para iniciados. En este aspecto no hay la menor contradicción entre su obra anterior y Las Hurdes sino una perfecta continuidad ${ }^{30}$.

Retomando la polémica ya surgida con el cine de Flaherty ${ }^{31}$, se habla de Las Hurdes como de un trabajo de falso realismo porque Buñuel reconstruye los acontecimientos, (como la escena de la muerte de la cabra), selecciona los actores utilizados y los dirige; sin embargo esto es lo que pasa en cualquier trabajo realista, siendo un error confundir verdad y realismo. La misma búsqueda realista y no "verdadera" con el fin de documentar, está presente por ejemplo en los primeros documentales de Antonioni o Visconti. Es imposible pensar que, en "Gente del Po", Antonioni se haya limitado a poner la cámara y "esperar"; las escenas rodadas dentro del barco, que describen la vida de la familia de trabajadores fluviales, son claramente una puesta en escena como las que aparecen en Las Hurdes de Buñuel.

Un punto de contacto importante entre Las Hurdes y Gente del Po es la representación de una des-jerarquización entre ser humano y medio natural, hablando del santuario de Las Batuecas,

\footnotetext{
${ }^{28}$ Luchino Visconti, en una entrevista al semanal "El europeo" afirma: Con Obsesión, hace veinte años, se habló por la primera vez de Neorrealismo. (Revista: "Europeo", año XVIII - n 34 - 28 agosto 1962).

${ }^{29}$ (Sánchez Vidal, 1984)

30 (ibídem p.87-88)

${ }^{31}$ Es interesante evidenciar que en la trilogía dirigida por Robert J. Flaherty, compuesta por Nanook of the North (1922), Moana (1926) y Man of Aran (1934), encontramos el mismo tema de lucha con el medio natural, y aislammento de la civilización, el tema principal de La Hurdes. Man of Aran además tiene ciertas analogías con La tierra tiembla (1948) de Visconti, también una historia de pescadores basada en la novela Verista del esritor siciliano G. Verga.
} 
descrito en la película, se dice que "primero lo habitaban los carmelitas y ahora las víboras y los sapos". Quizá este aspecto sea más fuerte en Buñuel, con esta actitud surrealista de mirar al mundo natural y al hombre como parte de un universo de conexiones profundas, visibles e invisibles. Lo que queda claro es que esta experiencia cinematográfica acerca a Buñuel a la mirada de un nuevo cinema, que pone al centro el lugar y el paisaje y que fortalecerá en su siguiente etapa mexicana. El Surrealismo de Buñuel se convierte a partir de ahora en un "Súper-realismo", siguiendo la etimología de la palabra: el director Aragonés mezcla elementos reales y elementos del subconsciente para llegar a una realidad más verdadera.

Con el Dadá y el Surrealismo empieza este viaje de exploración urbana y anti-urbana a lo largo de todo el siglo XX que se desarrollará a través de diferentes movimientos artísticos como el Situacionismo y el Land-art, y como hipotizamos en esta tesis, a través del aporte fundamental del nuevo Cine Neorrealista.

Antes de los surrealistas, algunos futuristas italianos como Mario Sironi, a final de los años '10 desarrollarán una nueva mirada hacia el paisaje, enfocando su trabajo hacia una ciudad marginal vacía, industrial y en construcción, anticipando la iconografía urbana del Cine Neorrealista. Una década después de los futuristas, en mayo del 1924, André Bretón organiza un viaje nómada extraurbano sin un destino prestablecido. Se trata de un recorrido por un vasto territorio en las afueras de Paris "conversando y caminado durante varios días seguidos, como una exploración hasta los límites entre la vida consciente y la vida soñada. A la vuelta del viaje escribe la introducción de Possion soluble, que más tarde se convertirá en el Primer Manifiesto de Surrealismo" ${ }^{32}$. El interés por espacios "al margen de la civilización" que Bretón enfoca en estos paseos y exploraciones, está presente en Las Hurdes de Buñuel, como una vuelta a lo primitivo, a los orígenes del ser humano en búsqueda de una condición olvidada del hombre habitante de las grandes ciudades.

Hablamos de Las Hurdes como posible origen de un neorrealismo cinematográfico español, a pesar de la distancia cronológica con las películas analizadas en este trabajo de investigación. La siguiente etapa en el proceso de desarrollo del súper-realismo de Luís Buñuel sucede en México, y algunas fechas nos ayudan a establecer un paralelismo con el Neorrealismo Italiano. En el festival de Cannes de 1951 dos películas destacan, una es Milagro en Milán de Vittorio de Sica, con guion de Zavattini, que gana el premio a la mejor película, y la otra es Los Olvidados de Luís Buñuel, que gana el premio al mejor director. Siempre se ha comparado esta película sobre la vida de algunos niños y adolescentes de los suburbios de la Ciudad de México, con El limpiabotas, de De Sica que tiene como protagonistas a dos niños callejeros de Roma y que es una cinta que Buñuel admiraba.

En Milagro en Milán y en Los O/vidados hay la presencia de una dimensión onírica totalmente diferente, que explica también la diferente idea de realismo de los dos directores. En De Sica, los efectos especiales, los ectoplasmas y ensoñaciones que aparecen, sirven para convertir una historia de denuncia social en un cuento mitológico, fuera del tiempo; hablan de la imposibilidad de solucionar los conflictos sociales sin la intervención del elemento sobrenatural; en cierta medida para Zavattini y de Sica lo sobrenatural sirve para fortalecer la realidad, hacerla más intensa, sin posibilidad de redención y solución de los conflictos sociales.En Buñuel la presencia del elemento onírico representa una dimensión interna a la realidad descrita, sirve para completar la descripción de lo real con elementos que existen en el subconsciente, en el sueño y en la psique, pero en ningún caso -como en cambio pasa en Milagro en Milán- este elemento es externo a la realidad descrita (F.1.2.1/1).

32 (Careri, Walkscapes: el andar como práctica estética, 2002 p.66) 

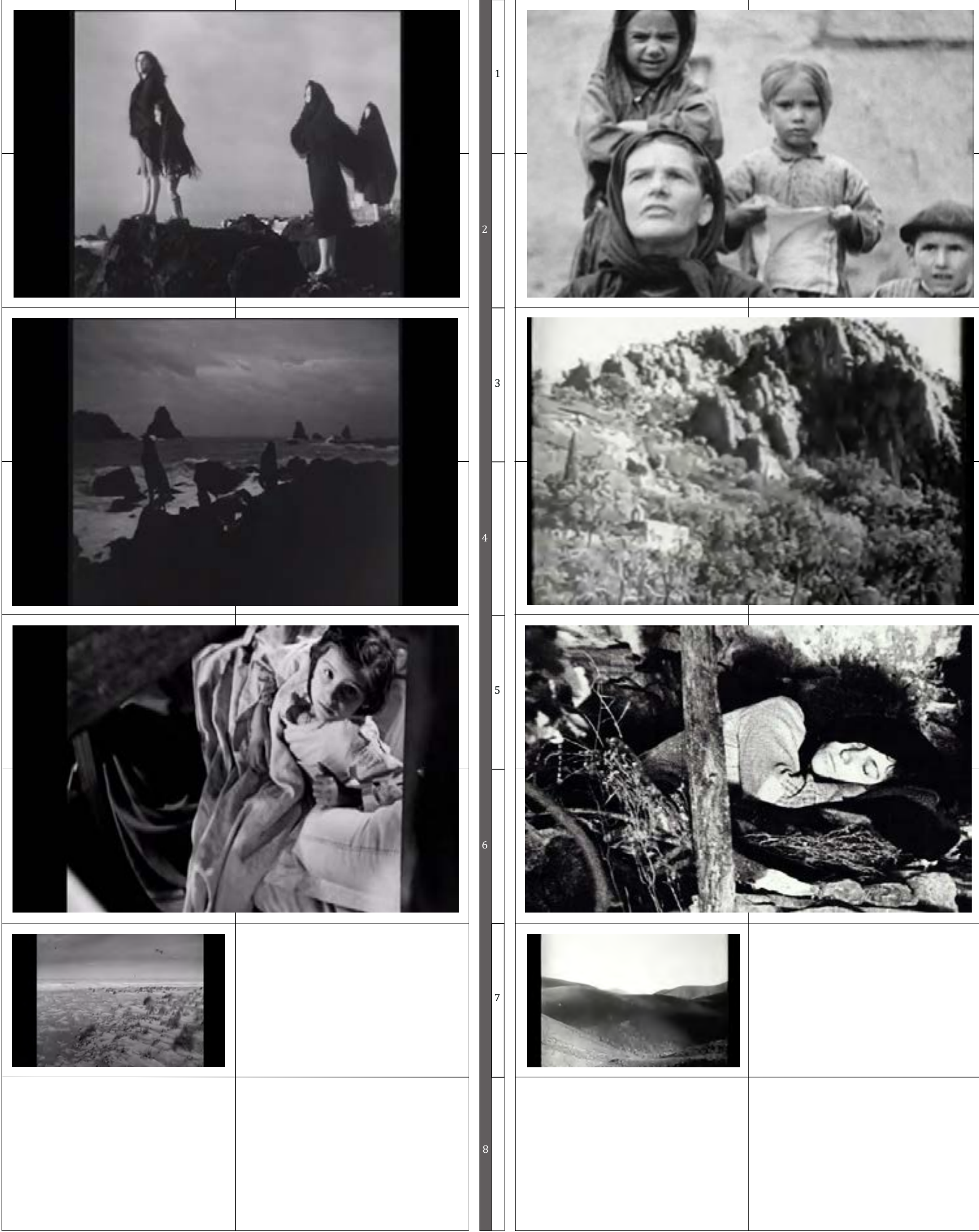

RM 1-2. La Tierra tiembla (Visconti) RM 3-4. La Tierra tiembla (Viscont)

RM 5-6. Gente del Po (Antonioni)

RM 7. Gente del Po (Antonioni) 
Otras fechas fundamentales para completar este paralelismo Buñuel - Neorrealismo Italiano son las entre 1953 y 1957; en estos años sabemos que tanto Zavattini como De Sica, están en México. De Sica se divorcia en la Ciudad de México en 1954 de su primera esposa Giuditta Rissone, actriz turinesa, siendo imposible hacerlo en Italia en esta época; y se casa en 1959 en la Ciudad de México con la actriz barcelonesa Maria Mercader ${ }^{33}$. No se han encontrado noticias sobre las actividades de De Sica en México $^{34}$ por ejemplo sobre una eventual frecuentación por parte de De Sica a la casa de Buñuel en la Colonia del Valle de la Ciudad de México, un lugar abierto a intelectuales mexicanos e internacionales.

En 1954 también Cesare Zavattini se encontraba en México, trabajando junto al cineasta español Carlos Velo -antiguo colaborador de Buñuel afincado en México-, a una película para el productor mexicano Manuel Barbachano titulada "México mío", que finalmente no llegó a rodarse $^{35}$. Zavattini había visitado México en 1953, y también regresará en este país en 1957 durante todo el verano, escribiendo y participando en la vida cultural del país ${ }^{36}$.

Buñuel encontró Zavattini seguramente en 1953 porque tenemos registro de este acontecimiento en el texto de la conferencia que Buñuel impartió en La Universidad Nacional Autónoma de México, en el mismo año, con el título "El cine instrumento de poesía". En esta conferencia Buñuel explica la diferencia entre su mirada hacia la realidad, diferente a la mirada del Neorrealismo Italiano, contando una anécdota sobre su encuentro con Cesare Zavattini en la ciudad de México:

"Lo más admirable de lo fantástico -ha dicho André Breton- es que lo fantástico no existe, todo es real". Hablando con el propio Zavattini hace algún tiempo, expresaba mi inconformidad con el neorrealismo: estábamos comiendo juntos, y el primer ejemplo que se me ocurrió fue el vaso de vino en el que me hallaba bebiendo. Para un neorrealista, le dije, un vaso es un vaso y nada más que eso: veremos cómo lo sacan del armario, lo llenan de bebida, lo llevan a lavar a la cocina, en donde lo rompe la criada, la cual podrá ser despedida de la casa o no, etc. Pero ese mismo vaso contemplado por distintos hombres puede ser mil cosas distintas, porque cada uno de ellos carga de afectividad lo que contempla, y ninguno lo ve tal como es, sino como sus deseos y su estado de ánimo quieren verlo. Yo propugno por un cine que me haga ver esa clase de vasos, porque ese cine me dará una visión integral de la realidad, acrecentará mi conocimiento de las cosas y de los seres y me abrirá el mundo maravilloso de lo desconocido, de lo que no puedo leer en la prensa diaria ni encontrar en la calle" ${ }^{37}$.

Con el "realismo integral", Buñuel incluye en su representación del mundo real, aspectos de un conocimiento más profundo para superar los límites del Neorrealismo, punto de partida de su futura obra cinematográfica. Este realismo multi-dimensional de Buñuel, expresado desde Las Hurdes, tiene una fuerte analogía con la obra del cineasta francés Georges Franju autor del cortometraje Le sang de bêtes, un documental en el cual alterna imágenes de un suburbio parisino con las de la matanza de animales dentro del matadero de la ciudad (F.1.2.1/2).

\footnotetext{
${ }^{33}$ Maria Mercader era además la hermana de Ramón Mercader agente secreto soviético quien en 1940 mató a Lev Trockij (León Trostskj) y fue encarcelado durante 20 años en la Ciudad de México. La frecuentación de la ciudad de México por parte de De Sica y su segunda esposa, estaba destinada también a un apoyo a la madre de María que luchó por la liberación de Ramón Mercader.

${ }^{34}$ Sería interesante investigar esta presencia y las relaciones culturales establecidas por el director.

35 (Fernández, 2007 pp.243-247)

36 (Boccolari, 2017)

37 (Buñuel, 2003)
} 

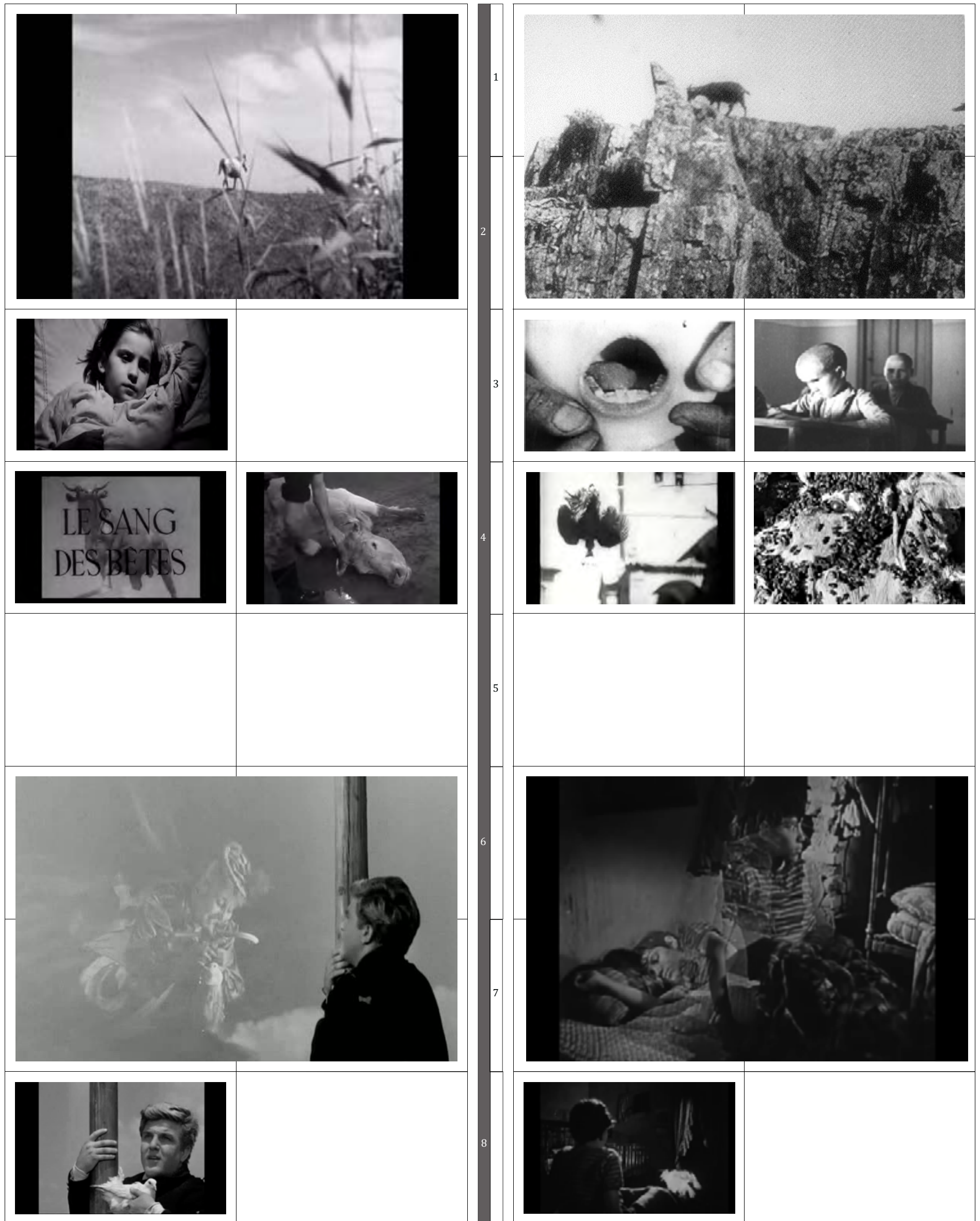

RM 1-2-3. Gente del Po (Antonioni)

RM 4. Le sang des betes (Franju)

RM 6-7-8. Milagro en Milán (De Sica)

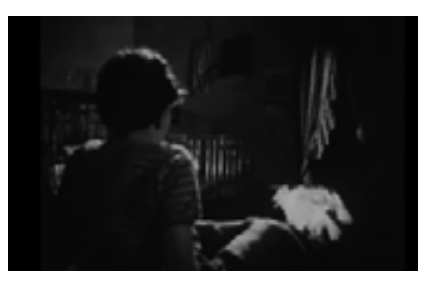

MD 1-2-3-4. Las Hurdes -Tierra sin pan (Buñuel) MD 6-7-8. Los Olvidados (Buñuel)

\section{MADRID}


En la génesis de la película encontramos cierta actitud flaneur del director, una búsqueda de casualidad e improvisación típica de los primeros surrealistas: el autor declara que cuando tomó la decisión de rodar la película que documenta la vida casi banal de un suburbio parisino se dio cuenta de que la localización era el canal de Ourcq, alrededor del matadero de la capital francesa. Franju afirmó que "empleando un formato de filme documental, podía usar ambas localizaciones como contrapuntos líricos y 'explicarlo' como un realismo mientras mantenía un surrealismo desplazando el objeto a otro contexto. En este nuevo emplazamiento, el objeto redescubre su calidad como objeto' ${ }^{38}$. Este proceso es evidente en una secuencia que Franju muestra con la banda sonora de "La mer", de Charles Trenet: un primer plano de unas cabezas de ovejas esperando la muerte / un charco de sangre en el piso del matadero / dos monjas paseando fuera del matadero. Sang de betes podría adscribirse al género de las películas "Sinfonía de una ciudad", por la estructura de la narración del amanecer a la noche en la capital francesa. En ella, desde los primeros fotogramas se aclara que estamos au ports de Paris en un territorio al límite de la ciudad, en un área industrial, entre terrenos baldíos, ferrocarriles y canales, y rodeando el matadero, que progresivamente parece contaminar con su presencia la serenidad de este paisaje suburbano, que se carga de otros valores y significados.

\subsubsection{De "Roma ciudad abierta" a "Surcos": espacio cinematográfico y paisaje urbano.}

En el campo de la Literatura, sugestiones neorrealistas se revelan en la narrativa de algunos escritores españoles, entre los cuales destaca Jesús Fernández Santos quien con su novela Los Bravos, de 1954, y con los cuentos agrupados bajo el titulo Cabeza Rapada de 1958, describe la realidad social de la época, llegando a criticar a la España franquista. Se reconoce claramente en este trabajo la influencia de los escritores neorrealistas italianos como Vittorini, Pratolini, Moravia y Pavese, sobretodo este último. ${ }^{39}$

En la fotografía, si yuxtaponemos las fotos de autores españoles de la época de la Guerra y de la Posguerra, como Carlos Saura, Francesc Catalá-Roca, Eugeni Forcano o Joan Colom y la de italianos como Franco Pinna, Nino Migliori o Enrico Pasquali, cualquier de las imágenes fotográficas podría pertenecer a uno u otro país: retratos de vida cotidianas, escuelas, celebraciones religiosas y escenas urbanas: el realismo era una forma de documentar una realidad social desfavorable. Otro aspecto interesante es que las fotografías de autores italianos y españoles, se pueden considerar también como una crónica del abandono del campo y del consiguiente desarrollo industrial y urbano ${ }^{40}($ F.1.2.2/1).

Si de Neorrealismo Español podemos hablar no cabe duda que es en el Cinema donde hay más influencia italiana. La mayor casa de Producción Española, la CIFESA, había quebrado en los años ' 40 por haber invertido en producciones demasiado ambiciosas y por eso, a partir de los años cincuenta empiezan a rodarse películas de bajo presupuesto, con actores no profesionales, y en lugares reales de la ciudad o del campo, "a la maniera Neorrealista". 1951 es un año clave; en la escuela de cinema IIEC ${ }^{41}$ en una semana dedicada al cine Italiano se proyectaron: Roma ciudad abierta, Ladrones de bicicletas, Milagro en Milán, Paisá, Crónica de un amor, y siempre en el mismo año salió a la pantalla la película de José Antonio Nieves Conde, Surcos con una historia y un guion parecido a la pelicula italiana Rocco y sus Hermanos, de Luchino Visconti ${ }^{42}$.

\footnotetext{
${ }^{38}$ (Franju, 2004)

39 (Kim \& Díaz Navarro, 2002)

40 (Balsells, Bonet, \& Taramelli, 2006)

${ }^{41}$ Instituto de Investigaciones y Experiencias Cinematográficas, creada en el 1947

42 (Cerón Gómez, 1998)
} 

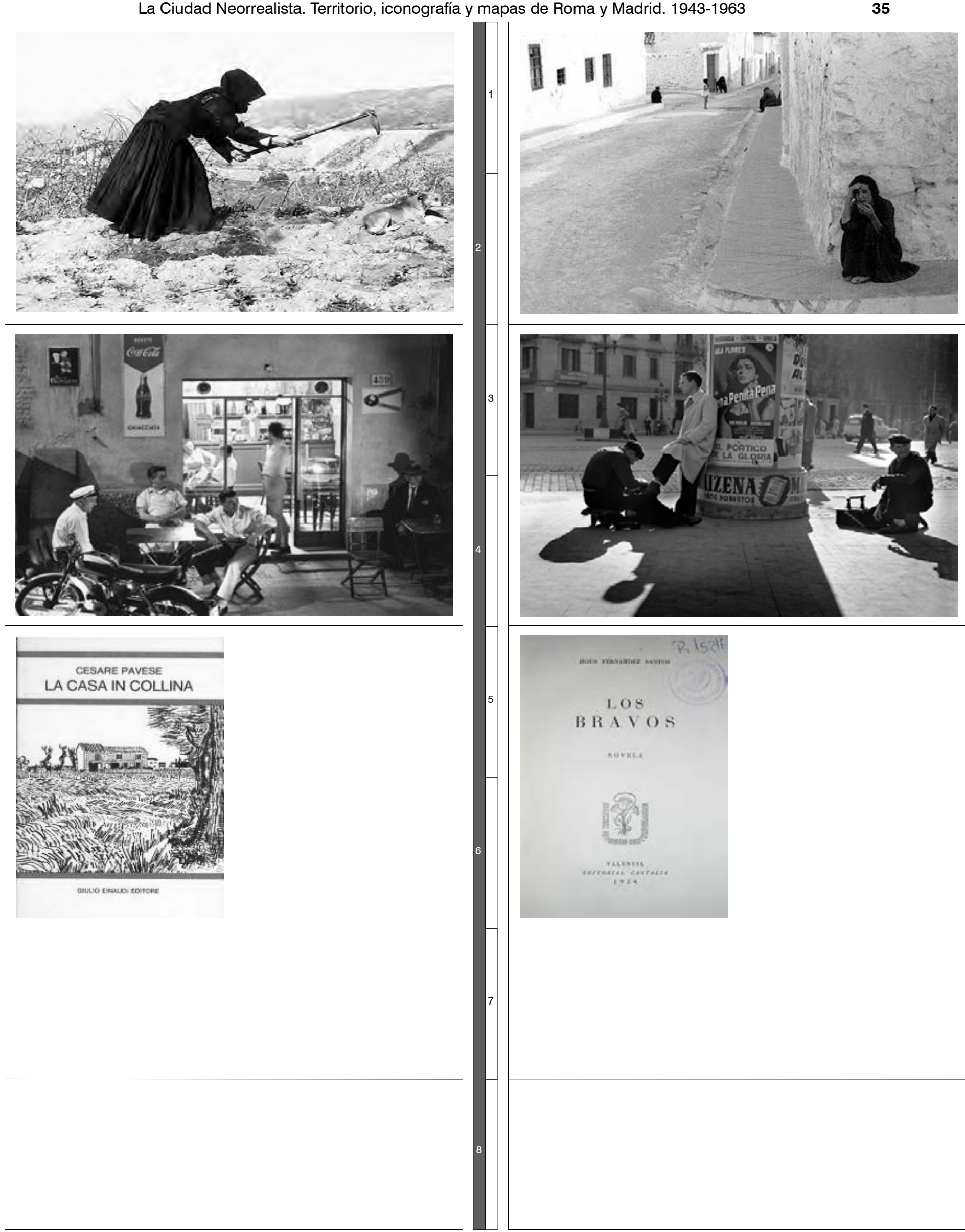

RM 1-2. Franco Pinna: "Donna lavorando la terra" 1960

RM 5-6. Cesare Pavese: "La casa in collina" 1948

MD 1-2. Carlos Saura: "Por tierras de Castilla" 1955

MD 3-4. Frances Catalá Roca: "Pena Penita"

MD 5-6. Jesus Fernandez Santos: "Los bravos" 1954 
Hay una propuesta de espacialidad que emerge claramente de los fotogramas, y que es testigo de la ciudad existente y de la proyectada por los arquitectos en estos años, la del Plan de Urgencia del INV y del INA-Casa.

El cine, a través del Neorrealismo, se planteó analizar la realidad críticamente presentándola como fenómeno físico, sin artilugios o efectos cinematográficos. El hecho de que algunas películas estuvieron rodadas con pocos recursos representó una ventaja a la hora de crear un nuevo lenguaje; pues la pobreza de medios amplifica el efecto realístico de las escenas descritas, y los directores utilizan un lenguaje esencial pero no minimalista ${ }^{43}$.

Podemos hablar de la ciudad como principal escenario de las cintas Neorrealistas, aunque tanto en Italia como en España hay algunas que están rodadas en pueblos y escenarios rurales. La ciudad es el lugar donde se generan los conflictos sociales y en donde las injusticias se hacen más profundas. Las dos secuencias iniciales de Rocco y sus hermanos y de Surcos son idénticas, y hablan de los fenómenos de emigración que hemos analizado en este capítulo: dos familias sureñas que llegan en la estación de trenes de la gran ciudad con sus pertenencias, desde el mundo rural, desorientados y preocupados.

La ciudad es el escenario ideal para contar los efectos devastadores de la guerra. En Roma, ciudad abierta, de Roberto Rossellini, una de las primeras obras del neorrealismo italiano, la ciudad de Roma es uno de los protagonistas, literalmente golpeada y herida como sus habitantes. Por sus espacios urbanos, la gente se mueve con miedo, caminando rápida en las calles en la búsqueda sin fin de un lugar seguro: el espacio doméstico se convierte en un refugio sin garantizar la seguridad total. En la obra de Rossellini la casa ha perdido su cualidad de hogar privado donde los habitantes pueden sentirse protegidos y dueños de la vida íntima, lo público y lo privado se mezclan; no hay distinción. La misma emoción la tenemos en una escena de El Inquilino, donde el protagonista vive la experiencia surreal y trágica de ver en ruinas su propia casa, en una escena que más que un derribo parece una imagén sacada de la guerra; esta pelicula de José Antonio Nieves Conde se enfrentó a la censura a causa de su fuerte critica hacia la situación social del momento, exponiendo temas como la falta de derecho a la vivienda, la burocracia y la especulación en la España Franquista.

En dos películas rodadas en Roma y Madrid, aparece la vida alrededor de los protagonistas: en Ladrón de Bicicletas la pareja se mueve en una de las "borgate" de Mussolini, que convirtieron a muchos romanos en exiliados en su propia ciudad. Los protagonistas viven alejados del centro de la ciudad, en un barrio al margen donde Roma parece acabarse. Se mueven en un paisaje ni rural ni urbano, entre laderas empinadas y áridas que marcan el horizonte. En El pisito, después del fracaso en la búsqueda de una casa donde poder empezar su vida, los dos parecen buscar tranquilidad y confort en la naturaleza, una ladera verde aislada, un perro y un desayuno; al fondo la ciudad que los rechaza. Esta dimensión suburbana, de lotes baldíos y topografías áridas, es el nuevo paisaje urbano en el cual los personajes se desplazan (F.1.2.2/2).

\footnotetext{
${ }^{43}$ El rodaje De Roma ciudad abierta, de Rossellini en la Roma de 1945 y se hizo en condiciones precarias - los alemanes se habían marchado hacía poco tiempo - sea por la escasa disponibilidad del material técnico, comprendida la película y por no estar disponibles los estudios de Cinecittà, ya saqueda de las maquinarias de cine y llegada a ser un gran refugio por los exiliados, que no pudieron ser acogidos en otro lugar, Rossellini y el equipo improvisaron el rodaje de algunos interiores en el viejo teatro Capitani, en calle de los Avignonesi 32, atrá de la calle del Tritón en Roma. (Brunetta, 2000)
} 

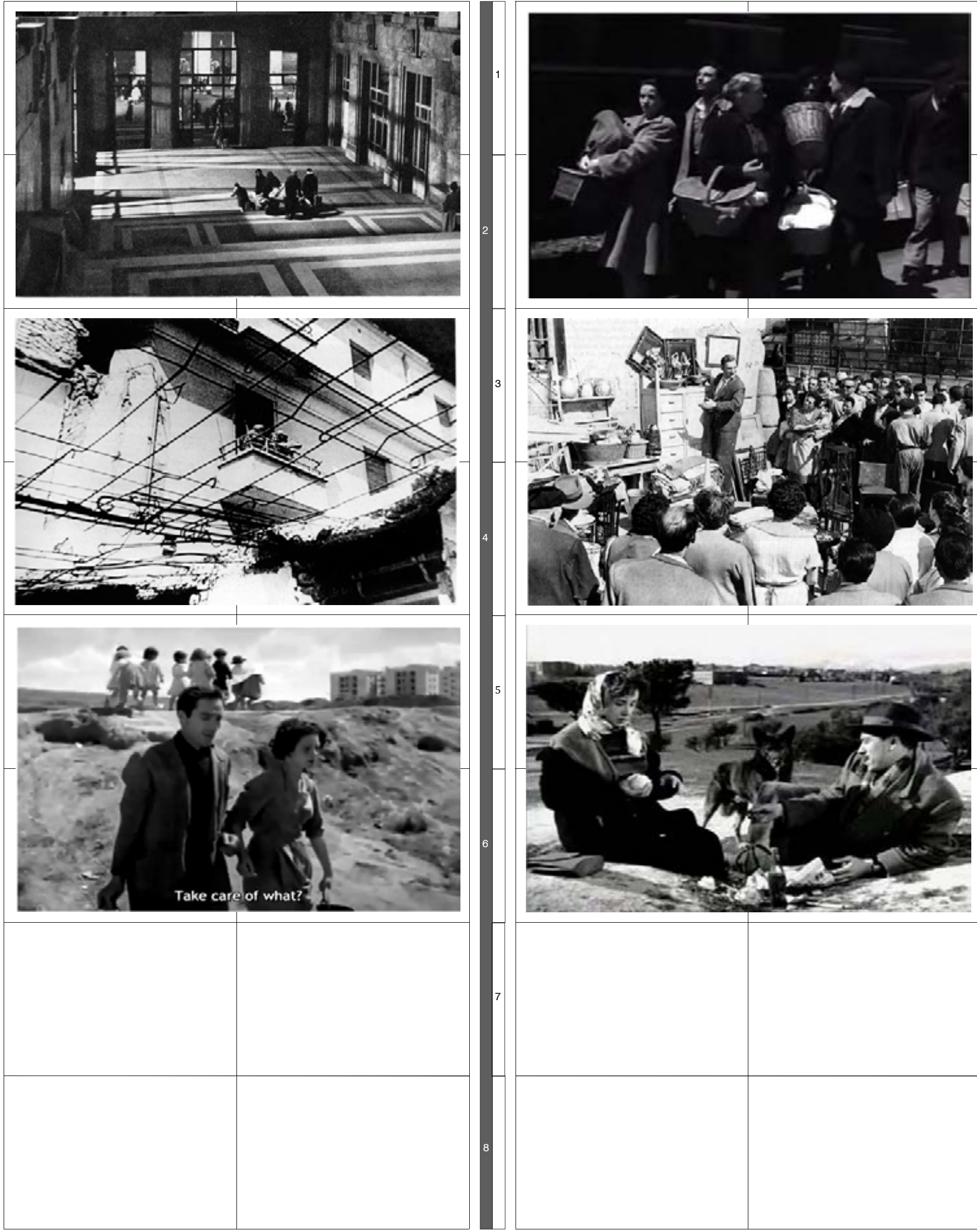
En Surcos también hay esta condición de vagabundeo y dificultad de integración en la ciudad formal. El hijo menor, después de muchos fracasos encontrará su hogar en la ciudad informal, hallando el calor y la humanidad ausentes en el centro y en los ensanches recién construidos; se trata del mismo desinterés presente en el barrio chabolista de Milagro en Milán, en el cual la ciudad formal de la especulación inmobiliaria se opone al paisaje urbano de los territorios vacíos, de las laderas y de las chabolas.

En las películas Neorrealistas los protagonistas son nómadas, se mueven entre la ciudad y los suburbios en la búsqueda de un territorio en donde asentarse; los directores describen estos desplazamientos a veces muy largos y sin medios de transporte, cuidando la coherencia entre espacio y tiempo real y fílmico. La ciudad que se define a través del rodaje parece estar formada por distintas ciudades, y la distancia entre los fragmentos de este universo urbano parece enorme, como en un mapa situacionista: vemos una ciudad histórica que ya ha perdido su centralidad, los fragmentos de la nueva ciudad en construcción hechos de andamios y de edificios sin acabar con enormes vacíos indefinidos, y los asentamientos de la ciudad informal, como injertos en los espacio residuales ${ }^{44}$.

\subsubsection{Del Racionalismo al Neo-empirismo: utopías y derivas.}

Al final de la segunda guerra mundial en Italia se manifiesta como urgente, la necesidad de encontrar nuevas expresiones artísticas, en particular en el campo de la arquitectura y la urbanística; La utopía fracasada del Fascismo correspondía a los lenguajes y en parte a los contenidos del racionalismo que la dictadura había promovido. En España por otro lado, con la guerra civil y la instauración del régimen, los artistas y arquitectos más avanzados tuvieron que adaptarse a convivir con un clima cultural poco abierto al debate; se manifestó por eso la necesidad de reanudar vínculos con el movimiento moderno que la guerra civil había cortado. En Italia el Neorrealismo representó un punto de arranque en el debate sobre arte y sociedad en la posguerra; el cine fue el mejor medio de expresar esta transformación cultural, y el espacio urbano fue el escenario de este proceso de revisión. Así, la cámara de los directores representará la bitácora para registrar nuevos fenómenos y sugestiones. Esta nueva interpretación de la ciudad y de sus alrededores se produce casi contemporáneamente a las experiencias de los situacionistas, sobre todo en Francia de principios de los años '50: es la Internacional Letrista, que en 1957 se convierte en Internacional Situacionista. El Neorrealismo Italiano se genera y se afirma en los años de transición entre las propuestas de Dadá de "visitas" a lugares banales de la ciudad, las deambulaciones de los Surrealistas en los territorios naturales de los suburbios, y las derivas letristas y luego situacionistas que proponen el acto de andar como práctica estética.

Las derivas letristas-situacionistas, que tuvieron analogías con los recorridos rodados por los cineastas neorrealistas, tenían otro enfoque respeto a todas las anteriores: si las surrealistas daban mucha importancia al inconsciente y al azar para producir una ciudad "soñada", las derivas letristas-situacionistas "se reconducían al plano de la realidad mediante un determinado método de indagación que debía tener como campo de acción la vida, y por tanto la ciudad real. La deriva letrista desarrollaba la lectura subjetiva de la ciudad iniciada por los surrealistas, pero se proponía transformarla en un método objetivo de exploración" ${ }^{45}$. Esta necesidad de realidad, poniendo de un lado el sueño de los surrealistas, se concretará en las

\footnotetext{
44 Sobre las relaciones entre cinema Neorrealista y espacio urbano en las dos capitales véase: Colella, Federico, Paisajes Neorrealistas. Cultura y arquitectura habitacional multifamiliar en Italia y España en la posguerra. 1943-1963, 2016 y La Ciudad neorrealista. Territorio, iconografía y mapas de la Roma de Ladrones de Bicicletas.

45 (Careri, Op. Cit. P.74)
} 
teorías para un nuevo urbanismo a través de la construcción de situaciones en la vida cotidiana. La objetividad y la realidad como herramientas para narrar un cambio, en oposición a una "incapacidad burguesa de materializar, en la realidad, un nuevo estilo de vida" ${ }^{46}$, es también la necesidad que había movido a Buñuel en la realización de Las Hurdes, donde describe la realidad a través de imágenes "al límite de lo real", para representar una realidad "expandida", que incluya también lo que no es visible.

El Cine Neorrealista se concentró en la descripción de las condiciones sociales de sus personajes y buscó en la iconografía del paisaje urbano y de sus rápidas mutaciones, una dimensión que pudiera transcender la narración, para referirse a una dimensión más subjetiva. En el nuevo cinema fue evidente la dimensión política en la exaltación de un "paisaje urbano de los últimos" que se identificaba con las nuevas fuerzas populares de catolicismo y socialismo, en oposición a la clase burguesa representativa del antiguo régimen.

En algunas de las arquitecturas propuestas en estos años, que tomaron la definición de Neorrealistas en relación con la experiencia cinematográfica, se buscó una nueva visión de la ciudad rechazando el racionalismo identificado con el Fascismo y adoptando un nuevo estilo capaz de manifestar una renovada expresión democrática y popular. Estas ideas se concretaron en algunas obras de la primera mitad de los años ' 50 , sobre todo en el sector de la vivienda social. El ejemplo más citado es el barrio Tiburtino de Ridolfi y Quaroni; en el cual se realizan las aspiraciones de reproducir las condiciones de vida de un pueblo; sobre este conjunto influyen las ideas de Zevi y del APAO ${ }^{47}$ para una arquitectura orgánica, la publicación en revistas italianas de las obras del Nuevo Empirismo Sueco, como las viviendas sociales en Gröndal, Estocolmo, de los arquitectos Backström \& Reinius, la cultura tradicional y la arquitectura vernácula Italiana, que ya Giuseppe Pagano había descubierto a partir de su exposición de 1936 a la VI Triennale de Milán.

En su artículo "Il paese dei barocchi" 48, Quaroni reflexiona sobre la experiencia del Tiburtino, siete años despues de su construcción. El barrio llamado, con cierta ironia, "el pueblo de los barroccos", hace referencia al "paese dei balocchi" de Pinocchio, en especial a "el país de los Juegos", la feria de atraciones donde los chicos se pierden, convertiendose en burros. Quaroni nos explica las motivaciones de este barrio que mira tomando una cierta distancia, como una arquitectura donde, nos explica: "nos interesaba hacer algo que estuviera lejos de ciertos errores de un cierto pasado al que reprochábamos la esterilidad y el fracaso a nivel humano, sin importarnos cuanto costaria esto después, a nosotros, al INA y a los futuros habitantes de los nuevos barrios" 49 .

A la figura de Pagano se vuelve a mirar no solamente por sus pioneras investigaciones sobre la arquitectura vernácula italiana, sino también por ser un padre espiritual y moral de la arquitectura italiana, por su calidad de animador cultural y por haber sido de los pocos que se enfrentaron al régimen a la luz del día, pagando las consecuencias de su elección con la muerte. Antes de la Segunda Guerra, sus posiciones sobre la arquitectura eran claras y con extraordinaria coincidencia -totalmente coincidentes con el pensamiento de Gramsci-; Pagano

\footnotetext{
46 Ibidem

47 "Associazione Per l'Architettura Organica" fundada por B.Zevi con L. Piccinato y S.Radiconcini en 1945.

48 (Quaroni, 1957 pp. 29-40)

49 Ibidem p.29 Sigue Quaroni explicando los límites del Tiburtino, afirmando que "un estado de ánimo puede crear una arquitectura" pero no puede servir para proyectar un barrio en el cual participaron muchos "diéz o veinte profesionales diferentes". También el arquitecto critica el lenguaje por su querer ser algo Italiano, sobrepuesto a las teorias urbanas suecas, llegando "a hacerle hablar incluso romanesco".
} 
estaba convencido que un gran arte arquitectónico solo puede nacer después de una fase transitoria de carácter práctico en la cual solamente se busca una satisfacción máxima de las necesidades básicas de un pueblo con la conveniencia máxima. ${ }^{50}$

En Italia las mejores arquitecturas producidas por el Fascismo fueron expresión de los más grandes talentos del Racionalismo italiano. Estos Arquitectos apoyaron la causa del régimen, tratando a menudo de hacer convivir las mejores instancias de renovación social y cultural, presentes en el Funcionalismo, con los aspectos más progresistas de la cultura fascista; sin embargo, hay que subrayar que el monumentalismo mussoliniano siempre fue inconciliable con las instancias de renovación presente en muchos de los arquitectos de la época. Pagano, Terragni, Figini Pollini, Libera, Ridolfi, no pocas veces tuvieron que enfrentarse con horizontes culturales bastante limitados, y menos europeos que aquellos soñados y buscado por ellos a través de la arquitectura.

No cabía duda que la reconstrucción tenía que producirse a través de una arquitectura que mirara a una Italia renovada. El Fascismo fue identificado con la blancura y la pureza geométrica del racionalismo, muchos arquitectos, también los mismos que fueron protagonistas de la estación anterior, se sintieron traicionados por ideales que expresaron por una arquitectura qué después de la guerra había perdido su sentido. Había entonces la conciencia de que hacía falta refundar la profesión a partir de una participación activa en la vida política, de la investigación sobre técnicas y temas como aquel de la arquitectura residencial, que fueron descuidados durante el Fascismo. Una necesidad, por lo tanto, de gran pragmatismo o más bien de redescubrir los valores éticos de la profesión; por otro lado, hacía falta para encontrar una identidad común que pudiera dar forma a estas instancias de renovación. El Neorrealismo arquitectónico podía satisfacer estos deseos de un lenguaje renovado.

La diferente situación política y cultural no nos impide encontrar paralelismos y analogías con Italia, en el debate arquitectónico español, aunque sea difícil poder hablar de arquitectura Neorrealista Española. Se habla de Neorrealismo en España en el ensayo de Miguel Ángel Baldellou "Neorrealismo y arquitectura. El problema de la vivienda en Madrid, 1954-1966" 51 donde se analiza la respuesta que los arquitectos españoles dieron al problema de la vivienda, después del largo periodo de la arquitectura autárquica, en ruptura con la corriente racionalista apoyada por la República, Baldellou dice que finalmente los arquitectos "se pudieron incorporar sin grandes problemas a una nueva situación, ideológicamente en crisis, entre el neorrealismo y la guerra fría, como recién despertados de un largo sueño en el que muchos tuvieron pesadillas". ${ }^{22}$ Se subraya también el concepto de "vida alrededor" para describir la condición de quien, después de la guerra, vivía en la marginalidad, en la ciudad, pero al mismo tiempo alejado de ella. Es la arquitectura, junto al cine, la que detecta con sensibilidad esta situación: "Igual que el cine de la época que se caracteriza por el Neorrealismo, la arquitectura asumió sin prejuicios su condición de mediador social, pretendiendo elevar el nivel de la vida alrededor". Luis Fernández Galiano habla de tapiz neorrealista introduciendo el barrio de Caño Roto, de Antonio Vásquez de Castro en su libro "La Quimera moderna" 53 asociando el termino tapiz utilizado por José Sert para definir sus hábitats urbanos horizontales, y el concepto de Neorrealismo en referencia a un proyecto que “incorporaba elementos vernáculos a las influencias del racionalismo" ${ }^{54}$.

50 Gramsci, Antonio, Quaderni dal Carcere vol. II, Einaudi, Torino, 1975 p. 407 cit. en: (Saggio, 1984 p.21)

${ }^{51}$ (Baldellou, Neorrealismo y arquitectura. El 'problema de la vivienda' en Madrid, 1954-1966, 1995)

52 Ibídem p.20

${ }^{53}$ (Fernández Galiano, Isasi, \& Lopera, 1989)

54 ibidem p.65 
Pero la toma de conciencia hacia la realidad histórica del presente y la sensibilidad social, parecen ser los verdaderos y más profundos rasgos distintivos del Neorrealismo y punto en común en la arquitectura de la época en los dos países. Una lectura más profunda del significado del Neorrealismo como "una forma de realismo", refuerza un posible paralelismo España-Italia. En sus estudios sobre el realismo Gregotti ${ }^{55}$ define la época de los años cincuenta Italiana como una "aspiración de realidad" para explicar el periodo de la arquitectura italiana entre 1951-58. Para el citico y arquitecto italiano, La amplitud del término realismo siempre hace necesario precisar los términos del discurso. Un primer matiz se puede dar en referencia a la finalidad. La obra del realismo es "descriptiva", en cuanto devela las contradicciones de lo real, es "cognoscitiva", en cuanto permite un "cruce diagonal de la realidad", es "propositiva", en cuánto redefine un sentido alternativo a las cosas. Esta es la connotación predominante en el Realismo Crítico, de Gregotti, entendido no tanto como reflejo, sea incluso interpretativo de una realidad, sino más bien como crítica a la realidad y reconocimiento-desvelamiento de sus contradicciones, para superarle por los medios y los objetivos específicos de la obra de arte.

A través de esta definición podemos entender el realismo más como un "método" o como una "poética meta-histórica", que no tiene relación con ideologías o lugares; si algunos críticos han intentado relacionar el funcionalismo más radical de los años ' 20 con el realismo socialista en Rusia e indirectamente con el neorrealismo ${ }^{56}$, no pocos autores toman la distancia de esta definición que parece no adaptarse a contextos más complejos como el Italiano. En el debate entra también Manfredo Tafuri que en su ensayo sobre realismo nos da una definición contundente del concepto: "un área de los confines para nada determinados y no es geográficamente tendencia unitaria y cronológicamente ubicable, más bien es una mentalidad que recorre transversalmente las áreas del "moderno", introduciéndose en ello como elemento de resistencia o inquietud" ${ }^{57}$.

En el ensayo de Alberto Grijalba Bengoetxea titulado "Equívocos, amigos y dos puentes. Italia / España" se habla de realismo y de neorrealismo refiriéndose a los estudios de Gregotti y ese valor ético del Neorrealismo que llegará a España; sin embargo "el término 'realidad' se entenderá (...) como una necesidad de encontrar, de un modo crítico, la realidad entre el historicismo clasicista imperante y los idealismos y utopías figurativas y productivas del Movimiento Moderno". ${ }^{58}$ Grijalba cita arquitecturas españolas que llegan a este equilibrio crítico, como Caño Roto de Íñiguez de Onzoño y Vázquez de Castro y Entrevías de Oíza, Alvear y Sierra; e indica una analogía evidente un paralelo entre las cubiertas inclinadas y la articulación planimétrica de Juan XXII', de Ferrán, Mangada y Romany de 1962 con el barrio De Carlo en Spine Bianche de 1955.

En España, se miró al movimiento moderno como una reacción al monumentalismo y al tradicionalismo autárquico y como herramienta para desarrollar conjuntos de viviendas con un tiempo mínimo disponible para el diseño. En los documentales NO-DO de aquellos ${ }^{59}$ años se hace énfasis en la importancia del uso del hormigón y del hierro en algunas de las realizaciones más avanzadas, se exalta la luz, el agua y el sol de los nuevos barrios, con una mirada higienista típica de la arquitectura funcionalista de los años '20 y '30; Una situación bastante distinta a la de Italia, donde en los mismos años se hablaba en de la necesidad de enfocar la investigación arquitectónica sobre los aspectos psicológicos que los nuevos barrios

55 (Gregotti, 2004)

${ }^{56}$ (Casciato, 2001)

57 (Tafuri, Architettura e realismo, 1985 p.123)

${ }^{58}$ (Grijalba, 2004)

59 Documental NO-DO “25 años de Paz" 1964 
podían causar sobre sus habitantes, yendo hacia una arquitectura más orgánica, para lograr "efectos vermiculares". Para encontrar una referencia más cercana a la del Organicismo de los barrios neorrealistas Italianos, habría que mirar en la actuaciones del "hogar del Empleado" en Madrid, como el ya citado conjunto de Juan XIII sobre todo los barrios de Batán y la unidad residencial de Loyola donde se reflejan los conocimientos de Romany sobre Neo-empirismo Escandinavo ${ }^{60}$.

A pesar de la formación alemana de muchos de los arquitectos y de su interés hacia el racionalismo entre las dos guerras, hubo un gran interés por la experiencia INA-CASA y por las investigaciones italianas sobre la vivienda, por los aspectos gestiónales, por los aspectos técnicos, muchos menos por los aspectos de lenguaje y psicología de los habitantes. EI INV estudia el Plan Fanfani, sobre todo en la búsqueda tipológica de viviendas y en la revista "Informe de la Construcción" del 1954 aparece este interés con un artículo dedicado a la solución del problema de la vivienda en Italia ${ }^{61}$ (F.1.2.3).

60 Romany viajó a Dinamarca y Sueciaen los años ' 50 y vuelve con mucho material gráfico y fotográfico, sobre barrios de vivienda social. (fuente. Material conservado en el estudio PLANARQ de Carlos Ferrán visitado entre 2012 y 2013)

61 (Vagnetti, 1954) 

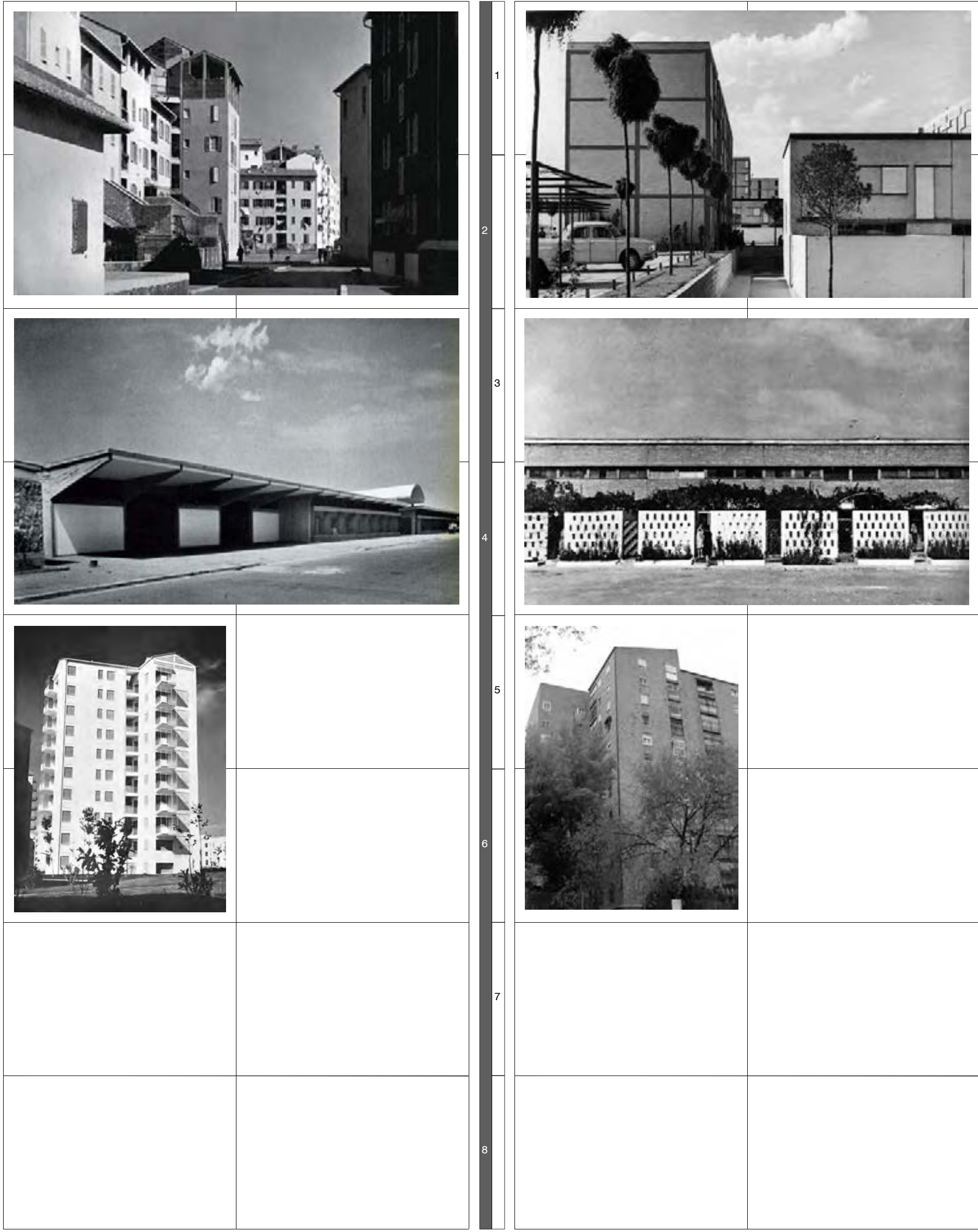

RM 1-2. M. Ridolfi, L. Quaroni: Quartiere Tiburtino

RM 3-4. A. Libera: Unidad de habitación horizontal en el Tuscolano

RM 5-6. M. De Renzi: Torres del Tuscolano
MD 1-2. A. Vasquez de Castro, I. de Onzoño: Poblado dirigido de Caño Roto MD 3-4. F. J. Sáenz de Oíza: Poblado dirigido de Entrevías

MD 5-6. F. J. Sáenz de Oíza, J. L. Romany: Torres en el poblado de Batán 


\subsection{Ciudades neorrealistas: la dialéctica centro-periferia.}

\subsubsection{El "Plano Sombra" en Roma y el PGOUM de Madrid.}

La ciudad neorrealista presente en el espacio fílmico de las películas seleccionadas en esta tesis es el territorio fragmentado de Roma y Madrid, entre final de los años ' 40 y los años ' 50 , con grandes espacios vacíos, y con una precaria separación entre territorio rural y urbano, entre ciudad formal e informal, entre ciudad histórica y periferia, entre ciudad acabada e inacabada. Este desorden derivó de la falta de control en las políticas de gestión del suelo urbanizable en las dos capitales.

Leonardo Benevolo habla de este destino común a lo largo del siglo XX por la falta de un equilibro entre ciudad y territorio, como el que se logra mantener en los países escandinavos, en Holanda, en Suiza y en Austria, como explica el historiador italiano: "Italia y España fracasan en cambio en el pasaje a una planificación territorial, las dos dictaduras impiden renovar las leyes urbanísticas como en el resto de Europa, y los intereses consolidados confirman esta situación también con el regreso de la democracia, respectivamente en 1945 y en 1975"62. Para el historiador italiano la dialéctica entre público y privado es fundamental en un buen planeamiento urbano, pero siempre y cuando se produzca de forma equilibrada entre las dos partes. Esto no se produjo ni en España ni en Italia en donde "las grandes cantidades edilicias se juegan casi exclusivamente en áreas privadas" ${ }^{63}$. No hubo visión de conjunto, así que a partir de los años ' 40 y '50 "alrededor de los centros históricos nacen periferias deformadas por la especulación" 64 .

Si cualquier tipo de planteamiento alternativo a este sistema de tipo capitalista es imposible en la España Franquista, algunos en Italia intentaron oponerse a la especulación, a través de soluciones que reconfiguraran el régimen de suelos, pero sin éxito. El Ministro de las obras públicas de la DC, Fiorentino Sullo, en 1962 propuso una nueva ley urbanística que hubiera permitido a Italia una legislación moderna y avanzada: El esquema de Sullo modificaba profundamente el régimen propietario de las áreas: de propiedad privada quedaba solamente una parte de las áreas ya edificadas, las otras áreas edificadas o edificables pasaban gradualmente a ser propiedad de los comunes, que cedían a los privados el derecho de superficie para las utilizaciones previstas por los Planos de Ordenación. Es un cambio demasiado fuerte que va en contra del sistema especulativo de gestión de suelos, es casi superfluo decir que la Ley no fue aprobada y que empezó una furibunda campaña de información y difamación contra el Ministro Sullo y su ley, llegando a decir que quería quitar la casa a los Italianos ${ }^{65}$.

La falta de legislación se reflejó en los acontecimientos urbanísticos que interesaron a Roma y Madrid. En Roma el primer paso hacia una mala urbanística es la del Plano de 1931, realizado por la comisión instituida en 1930 por el gobernador Boncompagni Ludovisi, cuando para realizar los "esplendores imperiales" requeridos por Mussolini, se realizaron las grandes demoliciones, que ya a partir de 1926. La gente que habitaba las áreas de las ciudades interesadas por estas operaciones monumentales fue desplazada hacia las nuevas "borgate", los nuevos barrios queridos por el Duce en las extremas periferias de la capital y que aparecen en algunas películas como "Europa 51" de Rossellini, y "Ladrones de bicicletas" de De Sica. El

\footnotetext{
62 (Benevolo, La città nella storia d'Europa, 1993 pp. 212-213)

63 ibidem

64 ibidem

65 (Salzano, 2010)
} 
plano de 1931 no tuvo una estructura adecuada, su finalidad era la máxima utilización de los suelos, el crecimiento no era articulado en barrios reconocibles, sino que estaba atomizado y ubicado en cualquier área de la ciudad. El Plano de ordenación del '31 entrega la ciudad a la "palazzina", la tipología que más tendrá éxito, llenando la capital de esta edificación perfecta para la naciente media-burguesía y para generar una ciudad compacta y monótona. A este plano siempre durante el Fascismo, sigue el del 1942, el "Plano sombra" como viene denominado por muchos críticos, porque a pesar de no haber sido nunca aprobado, tendrá una gran influencia en el desarrollo urbanístico de Roma hasta el plan de 1962 de los arquitectos Petrucci, Furitano y Samperi. Dentro del Plano de 1942 se desarrolló el plan parcial para el EUR, el nuevo barrio de la exposición universal, fue este proyecto el que desplazó todo el baricentro de la capital hacia el mar. El Plano sombra confirmó esta estrategia de crecimiento de la capital, donde no solo se planteaba en la dirección Sur-Oeste, uniendo la ciudad al nuevo barrio del Eur y hacia Ostia (la playa de Roma), sino que planteaba en general otras áreas de expansión hacia el Norte, Este y Oeste en "macchia d'olio" ${ }^{66}$, incrementando la plusvalía de las áreas agrícolas y verdes residuales e impulsando así la especulación edilicia.

No fue muy diferente la política urbana de Madrid a principios de los años ' 40 . La propuesta del PGOUM de Madrid del 1941 fue desarrollada por el urbanista Pedro Bigador, aprobada en 1944, y ejecutada en 1946. Este Plan es el híbrido entre el triunfalismo de la raíz tradicionalistafalangista, y "la realidad de más determinaciones técnicas esencialmente funcionales que mantienen una notable continuidad con los planeamientos de preguerra" ${ }^{67}$, los proyectos de Secundino Zuazo y Hermann Jansen, desarrollados en 1929. La retórica del régimen Franquista de hacer de la ciudad la capital de un imperio fue muy parecida a la retórica Mussoliniana y sus ideas para una nueva Roma. Muchas de las propuestas de Bigador no tuvieron influencia en la realidad contemporánea de la ciudad, porque fueron concebidas a largo plazo. Las ideas falangistas encontraron su desarrollo en las propuestas de "capitalidad" de Madrid, como ciudad símbolo de España, en el "Ensanche del Generalísimo" en la prolongación de la Castellana, que extiende la ciudad de los ensanches del Plan del 1846, hacia el Norte. Los planteamientos más modernos eran la nueva ordenación ferroviaria, las carreteras radiales de acceso, los anillos verdes, o cinturones, la reforma de la ciudad antigua, la zonificación y por supuesto la creación de nuevos suburbios y poblados satélites. La propuesta de los cinturones verdes es la que se retoma del plan de Zuazo y Jansen con el modelo teórico de núcleo central limitado y cerrado, con una corona periférica de unidades autónomas separadas entre sí y del núcleo central por anillos y cuñas verdes. Estos anillos fueron importantes por el intento de definir los límites de la ciudad estableciendo un margen de crecimiento, pero encontraron la oposición de las inmobiliarias "en un momento de fuerte especulación, (...) deseosas de ocupar suelo céntrico y barato ${ }^{68}$. Así que, si en la realidad estas ideas quedaron en los planos, representaron un intento de buscar un crecimiento más orgánico, seguramente más justo y avanzado, del que se produjo en Roma en los mismos años. El arquitecto e historiador Justo F. Isasi, nos describe de forma eficaz la situación en Madrid a principios de los '50 como "una mezcla de la situación de la posguerra europea, que propone la organización del suburbio moderno, y de la situación de la primera revolución industrial, que propone simplemente la solución del problema de higiene y hacinamiento"69. De la primera situación, se usan las herramientas básicas del Urbanismo moderno la como zonificación, trazados racionales y vivienda mínima, para modernizar la ciudad. De la segunda,

${ }^{66}$ en forma de manchas de aceite. (Insolera 2004)

67 (Bataller Enguix y López de Lucio 2004)

68 (Sambricio, La vivienda en Madrid en la década de los 50: el Plan de Urgencia Social., 1999 p.25)

69 (Fernández Galiano, Isasi, \& Lopera, Op.Cit. p. 105) 
"la urgencia, la falta de coherencia urbana, la carencia de transporte y de infraestructura, la vivienda primero y el urbanismo después"70.

En el 1950 el COUM, la Comisaría de Ordenación Urbana, en Madrid, tomando como referencia algunas de las ideas anteriores, plantea una solución al problema del chabolismo, a través de unos poblados -núcleos satélites, separados por la ciudad por un cinturón verdeCuando en 1954 Julián Laguna fue nombrado director del COUM, interviene como "gestor eficaz, hombre de acción apoyado por Franco"71 y se plantea la necesidad de actuar con rapidez, determinando soluciones "urgentes" que intentan sanear la ciudad, pensando en poner bajo control la especulación; en este escenario los poblados de Laguna no se piensan dentro de un diseño urbanístico orgánico, nacen sin cinturones o áreas verdes de separación con la ciudad más compacta, simplemente buscan suelo barato, alrededor de la Capital. Lo mismo pasa con los barrios romanos, en adición a la inexistencia de cualquier tipo de preocupación, aunque sólo aparente, para controlar la intervención privada. Los barrios INACASA romanos, como pasó en todas las grandes ciudades italianas, no proponían una solución al problema de la vivienda, la cantidad de realizaciones no es ni lejanamente, adecuada para responder a la demanda de alojamientos en la capital italiana. En este contexto tanto los poblados madrileños cómo los barrios INA-Casa romanos, funcionaron como atractores de las plusvalías de suelos rurales y suburbanos, activando y fortaleciendo los capitales privados y la especulación.

Tanto en Italia como en España hay una visión urbanística común inspirada por la teoría de la ciudad satélite. Se piensa que sea posible la construcción de la ciudad a través de unidades autónomas, los Quartieri en Italia y los poblados en España como núcleos de expansión en la periferia. En Italia se imagina que estos barrios puedan representar también unidades sociales para fomentar la vida en comunidad de los ciudadanos; para lograrlo no sólo se proyectan viviendas, sino también espacios públicos, zonas verdes y servicios. El urbanista italiano Giovanni Astengo habla de estos conceptos afirmando que para lograrlo se necesitan "planos urbanísticos que no sean solamente trazados geométricos sino el resultado de un desarrollo coherente de un pensamiento social. Los ejemplos de las ciudades-jardín inglesas, de las Greenbelts americanas, de los barrios suecos son demostraciones concretas de que estas unidades sociales no son puras utopías". ${ }^{72}$

Muchos arquitectos vieron los poblados de forma ilusoria, como fragmentos para contrastar el crecimiento incontrolado de la ciudad ${ }^{73}$ : pasará todo lo contrario, y estos desarrollos se tomarán como pretexto para justificar un crecimiento de la ciudad especulativa alrededor de las áreas ya edificadas. En la Roma y en la Madrid de hoy, los poblados protegidos mantienen su melancólica autonomía dentro de una periferia sin calidad urbana y arquitectónica. Peliculas como Mamma Roma, de Pasolini, contarán perfectamente estos fracasos urbanosarquitectónicos (F.1.3.1).

\footnotetext{
70 ibidem

71 ibidem

72 (Astengo, Giovanni, Nuovi quartieri in Italia, in "Urbanistica", 1953, n.12 pp. 9-10 cit. en: Di Biagi, Paola, op.cit. p. 22)

73 (Di Biagi, Paola, “La cittá pubblica e L'INA-casa” en Di Biagi, Paola, op. cit. p. 21)
} 


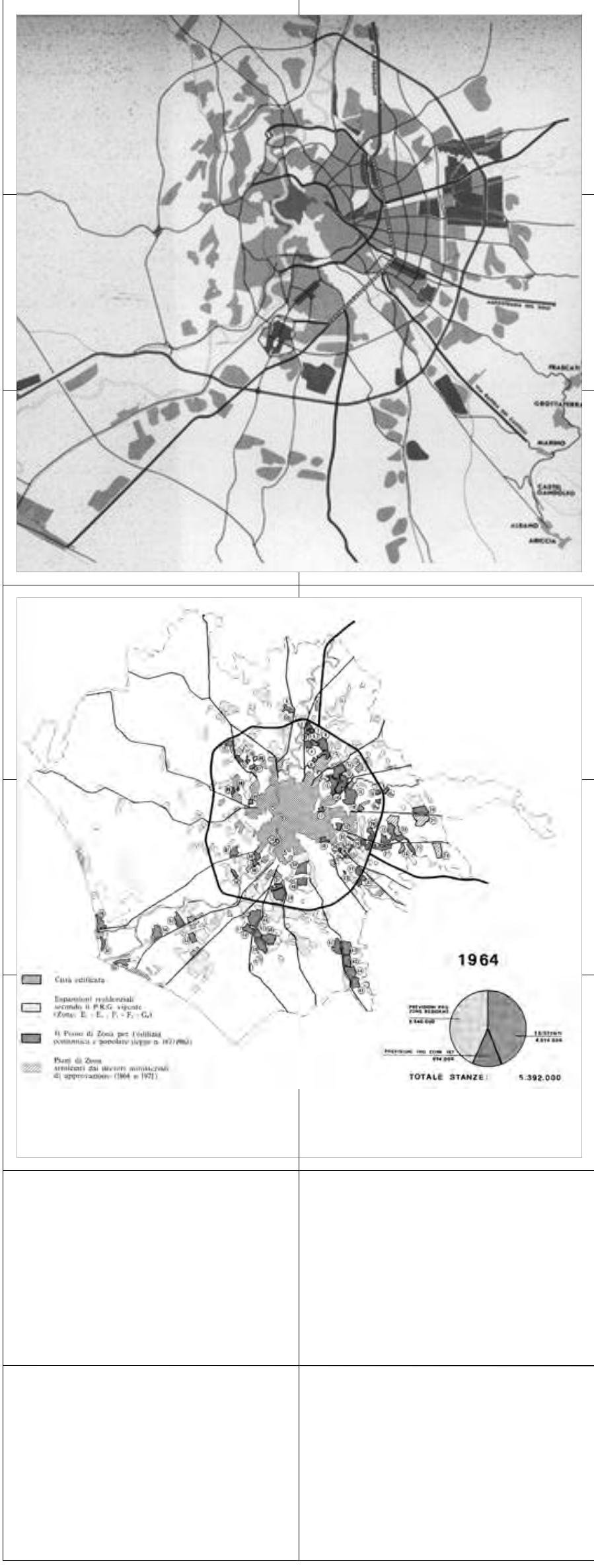

RM 1-2-3. Esquema de Plan general (PRG) de 1956 (rechazado); En grís obscuro lo nuevos nucleos de expansión.

RM 4-5-6. Plan general (PRG) de 1962 con las nuevas áreas de expansión. En grís obscuro lo nuevos nucleos de expansión.

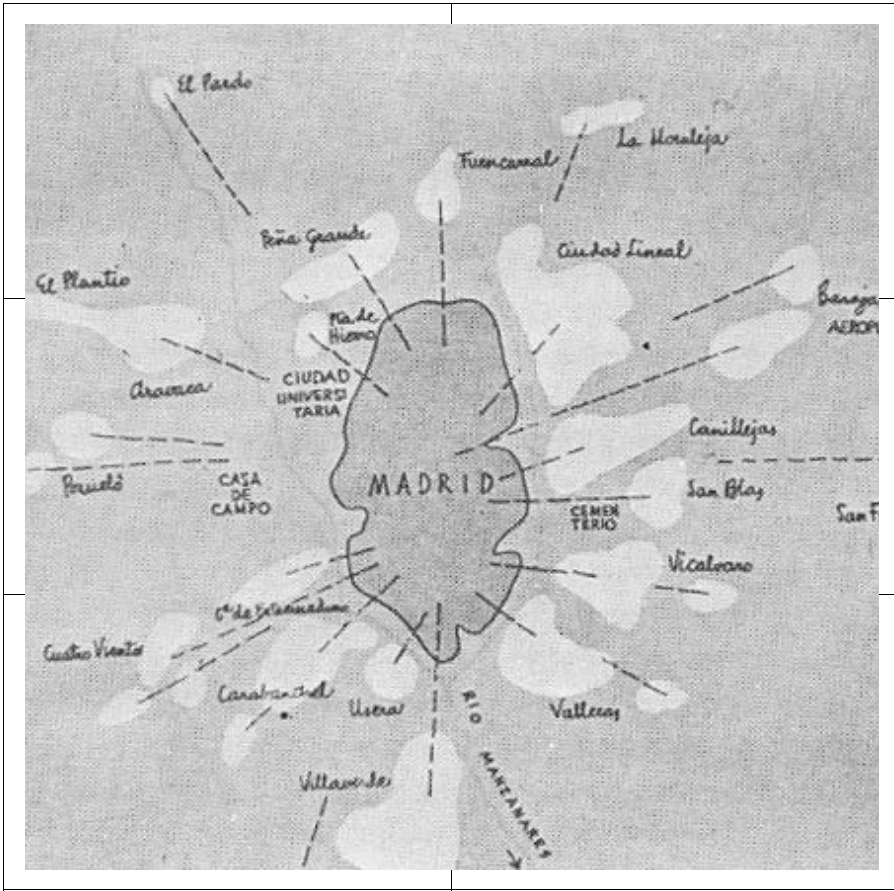

TRANSPORTES Y POBLADOS SATELITES

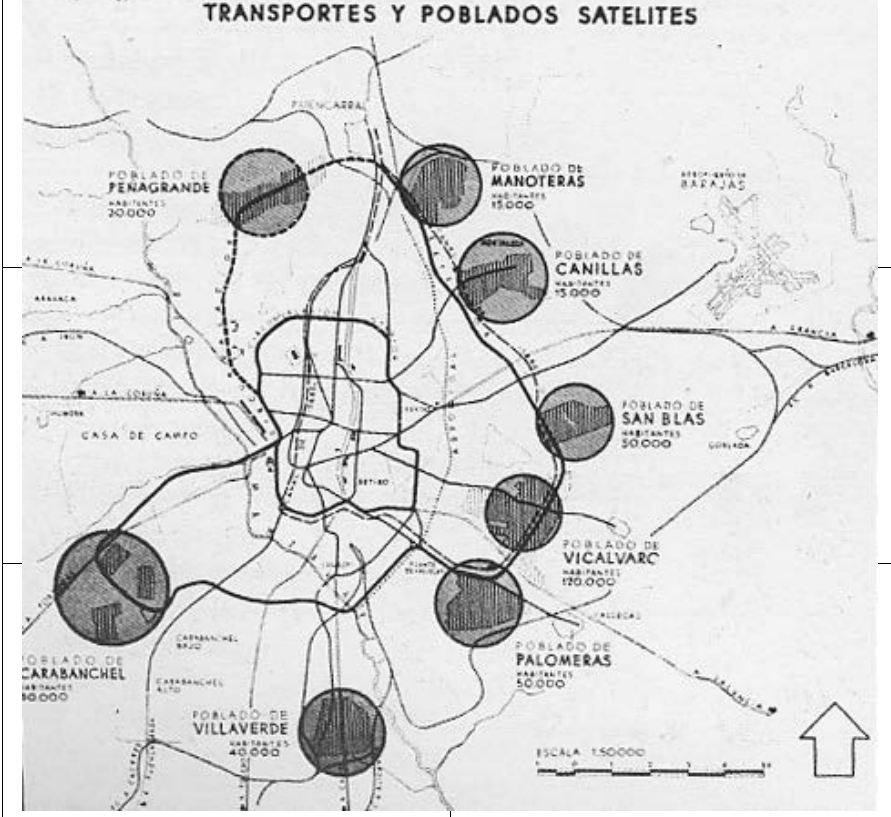


Para los urbanistas, estos barrios representaban una verdadera isla utópica, no se cuestionan tampoco la distancia que estos barrios tienen respecto a la ciudad, porque esta representa una ventaja en favor de una mayor libertad de los proyectistas al ser las nuevas áreas desvinculadas de los trazados del plan general existente. ${ }^{74}$ Los núcleos satélites, se conciben con "una disposición abierta, una vivienda racional y unas unidades vecinales" 75 , este ultimo concepto, incluso, se vuelve una traducción literal del americano neighbourhood unit que se aplica antes de la guerra en el plan de Londres de Abercrombie y que se traduce en Italia como Unitá di vicinato. Los poblados y los "Quartieri" producen también la ilusión de que se puede controlar, con este instrumento, la dicotomía ciudad-campo, produciendo un ambiente más adecuado para la población que emigraba a las capitales. A principios de los años '40, se había producido un contacto directo entre el urbanismo español y el italiano, sobre el tema de la "la ciudad campesina", con las influencias de Piacentini, arquitecto de la ciudad fascista del Agropontino Romano y las nuevas ciudades de colonización rural españolas bajo Franco.

El paso de estas ciudades coloniales a los nuevos poblados alrededor de la ciudad nos es tan difícil, se aplican muchas de las soluciones urbanas ya experimentadas en estas experiencias. Algunos documentales NO-DO, de los años '50 y '60, sin detenerse en observaciones y consideraciones sobre el tono propagandístico de estos documentos cinematográficos, nos ayudan a fijar algunos aspectos políticos y urbanísticos de los programas de viviendas en Madrid, facilitando algunos paralelismos con la situación romana. En el noticiario-documental 25 años $^{76}$, la vivienda en la ciudad histórica se percibe como un mal por el hacinamiento, y se exaltan, con cierta complacencia, los derribos a través de las excavadoras de chabolas y tugurios, para la construcción de "una nueva ciudad"; se habla de una vivienda, amplia, alegre, racionalmente distribuida, se aclama la presencia de agua y sol, estas iconografías aparecen en la narración de Nieves Conde de 1957: El inquiino. En otra escena del noticiario un grupo de jóvenes profesionales realizan una maqueta, otros dibujan planos sobre amplias mesas de dibujo en un luminoso despacho, comunicando una sensación de eficiencia y pragmatismo. En el documental 60.000 viviendas $^{77}$, el título hace referencia al número de alojamientos construidos en dos años en Madrid dentro del Plan de Urgencia Social; el narrador especifica, con tono satisfactorio, la "acertada combinación de la iniciativa privada con la promoción oficial" que reflejaba las "esperanzas" de Franco de fomentar la iniciativa particular: el logro estaba representado por el "saber traer la iniciativa privada a la gloriosa empresa del hogar". Ya con sesenta mil viviendas, según lo que reporta el documental, "se completan las consignas de Franco para la creación de un Gran Madrid"; así como en Italia, se disimuló en la propaganda la ridiculez de los números en comparación con la real necesidad de viviendas. Se subraya, además, que se construye no solamente vivienda mínima sino también casas para familias de nivel medio, no dejando dudas en el tipo de operaciones inmobiliarias que el régimen está promoviendo. Entre los aspectos técnicos descritos en el noticiario, se exalta positivamente la adquisición de todos los terrenos por la Comisaria Urbana de la Capital, que operaba las expropiaciones de terrenos, sobre todo en los barrios chabolistas, sin encontrar soluciones provisionales para sus habitantes. Se construyen las viviendas del Plan de urgencia "en substitución del chabolismo donde anidaban la desesperación y el odio" una idea confirmada en una imagen de un noticiario en la cual el mismo ministro de la vivienda Juan Luís Arrese conduciendo un buldócer derriba sonriente un grupo de chabolas ${ }^{78}$.

\footnotetext{
${ }^{74}$ (Astengo, Giovanni, op. cit. p.10): "La elección de áreas externas contribuye al descentramiento urbano y es entonces fundamentalmente sana".

75 (Fernández Galiano Luís, Isasi, Justo, Lopera, Antonio, Óp. Cit. P. 105)

76 Se treta del documental NO-DO realizado en ocasión de las celebraciones de los 25 años de Paz

77 ibidem

${ }^{78}$ NO-DO n.764-A año XV - fundo FNE. Filmoteca Nacional Española.
} 


\subsubsection{Territorios periféricos y espacio fílmico.}

Hablando de paisaje urbano, concepto analizado en esta tesis a través de la narración cinematográfica, Michael Jakob utiliza el término 'problemático' para definir esta locución, por el creciente éxito que ha tenido en la época reciente ${ }^{79}$. Se trata de una confusión que es posible generar por haber sido históricamente el paisaje algo opuesto al concepto de ciudad: una no-ciudad. Jakob habla de las diferentes calidades del paisaje, y de la ciudad en relación con el tiempo: el primero está caracterizado por el tiempo de la naturaleza, el segundo por el ritmo de las actividades humanas. El paisaje que ha penetrado en la ciudad, bajo la forma de parques y jardines, tiene una calidad heterónoma, mientras que el paisaje "evoca la idea de autonomía y libertad" 80 . El paisaje necesita una cierta relación con el horizonte, con una espacialidad abierta, lo que implica un alejamiento del sujeto que lo observa; "la ciudad necesita por parte del sujeto que mira a la distancia, la condición visual de un territorio contemporáneamente urbano y anti urbano" ${ }^{81}$. Para Jakob el paisaje se genera a través de un sujeto, una naturaleza y una relación entre ellos, y lo explica con una sencilla fórmula de "vocación práctica y heurística" ${ }^{22}$ :

$$
\mathrm{P}=\mathrm{S}+\mathrm{N}
$$

El observador-sujeto, establece una relación con un espacio extra muros, un espacio producido por la necesidad de alejarse del espacio cerrado de la ciudad, una necesidad de contemplación desde fuera, desde un exterior abierto.

El Neorrealismo reconoce en el paisaje un valor y "una función no solamente artística, sino también documental y proyectual" ${ }^{3}$. En esta época se describe un nivel cero del paisaje, un espacio caracterizado por ruinas de la guerra, para luego proponer una re-definición del territorio a través de una nueva iconografía del paisaje. Una iconografía que nace fuera de la ciudad, mirando como punto de partida al campo, a la estructura rural del territorio, como se planteó también en las políticas de aquel tiempo, que ponen la tierra al centro del desarrollo económico. Sin embargo, si por un lado la realidad del campo aparece en las películas neorrealistas como el lugar de los valores en oposición al cinismo del ambiente urbano, por otro aparece también como territorio de explotación, pobreza y falsas esperanzas, como en La tierra tiembla o en Bienvenido Mr. Marshall.

Con el fenómeno de la migración por la falta de empleo, la ciudad se convierte cada vez más en el principal escenario cinematográfico de una cultura artística que quiere poner sus producciones al centro de la historia.

El dualismo ciudad-campo corresponde a la imposibilidad de los protagonistas de las películas, de sentirse totalmente parte de la ciudad, así como la imposibilidad de regresar al campo; habitan una zona intermedia del espacio urbano: los territorios periféricos. Al dualismo ciudad-campo corresponde lo de presente-pasado. El paisaje neorrealista es capaz de absorber una dimensión de carácter temporal. Aunque el cine neorrealista se enfoca sobre el tiempo presente que constituye una dimensión absoluta, borrando un pasado demasiado incomodo, todavía existe una "memoria no procesada" que contamina el paisaje del presente: "siempre hay una relación disturbada con el tiempo, (...) una enfermedad de la

79 (Jakob, 2009, p.129)

80 lbídem

${ }^{81}$ lbídem p.130

82 Ibídem p. 30

${ }^{83}$ (Conti \& Bonavero, 2004 p.51) 
temporalidad" ${ }^{84}$; se trata de la "imagen-tiempo" de la cual habla Deleuze en su estudio homónimo, tomando como referencia muchas de las películas del Neorrealismo italiano. Para Deleuze, a partir de Resnais o Godard, y con el Cine Neorrealista, el tiempo deja de ser simplemente la medida del movimiento para convertirse en la materia misma de la imagen fílmica, su objetivo primordial ${ }^{85}$. La centralidad del paisaje y la dimensión temporal constituyen los elementos más novedosos de la cinematografía neorrealista, que introducen la modernidad en esta disciplina artística. El tiempo y la memoria se convierten en fotogramas en películas como Paisá de Rossellini, con sus paisajes humeantes y repletos de ruinas, condición compartida por el cine español de la época, aunque de una forma menos directa, más filtrada y metafórica por el pudor del franquismo: las ruinas de las casas urbanas derribadas en El inquilino o en Surcos, no son nada más que "imágenes-tiempo", imágenes subliminales que se refieren a los bombardeos recientes de la Guerra.

En el espacio real de la ciudad, los directores reflexionaron sobre el paisaje urbano a través de exploraciones en búsqueda de los decorados, que consistieron en un alejamiento respecto al centro de la ciudad y a los estudios cinematográficos: esta tesis atribuye a estos recorridos un valor que transciende la historia del cine. Los viajes de los directores/actores que se mueven en Roma y Madrid, en las periferias y en los grandes vacíos urbanos, permiten identificar un nuevo horizonte físico y cultural: el desarrollo de una nueva iconografía, fusión de lo urbano y lo anti-urbano: se trata de áreas indefinidas, terrain vague, descampados o áreas en espera de ser edificadas; áreas erosionadas, áridas, marcadas por infraestructuras y asentamientos informales.

Al mismo tiempo, se trata de espacios de conjunción virtual, a través de las conexiones establecidas por los cineastas a través del montaje, los que Deleuze define como "espacios cualquiera" ${ }^{86}$. Mediante de estas conexiones, la técnica cinematográfica permite establecer a través de las elipsis espacios-temporales. Los directores no se limitan a describir la ciudad, sino que proponen una nueva imagen y la estructura de la misma.

\subsubsection{Topología del rodaje.}

Entre las 40 obras cinematográficas analizadas se han seleccionado algunas películas rodadas fuera de las capitales, en otros lugares de la península italiana e ibérica. En Italia sin contar los lugares muy cercanos a Roma que hacen parte de la iconografía de la capital, como Fiumicino u Ostia, podemos considerar como otras zonas de rodaje Milán (Milagro en Milán y Rocco y sus hermanos), el Delta del Po (Gente del Po y Obsesión) y algunos lugares del Sur de Italia: Nápoles en Paisá y Aci Trezza en Sicilia por el rodaje de La tierra tiembla. En el Cine español, los lugares muy cerca de Madrid, hacen referencia a unos ambientes rurales genéricos de Castilla, sin que haya posibilidad de identificarlos en la narración fílmica. Los que aparecen en la pantalla son: El Espinar, en Segovia para Marcelino pan y vino, Alcalá de Henares en El último caballo, y Guadalix de la Sierra, para Bienvenido Mr. Marshall. Otras ambientaciones lejos de Madrid, y relevantes en la filmografía seleccionada son Palencia, Cuenca y Logroño para Calle Mayor y la Cataluña con Manresa para Placido y Peñiscola para Calabuch, que además constituye un excelente documento histórico como testimonio de la imagen original de este pueblo antes de su desarrollo turístico (F.1.3.3/1).

\footnotetext{
84 (Minghelli, 2013)

85 (Deleuze, 1987)

${ }^{86}$ Para un análisis de este concepto véase el párrafo 2.4.1
} 


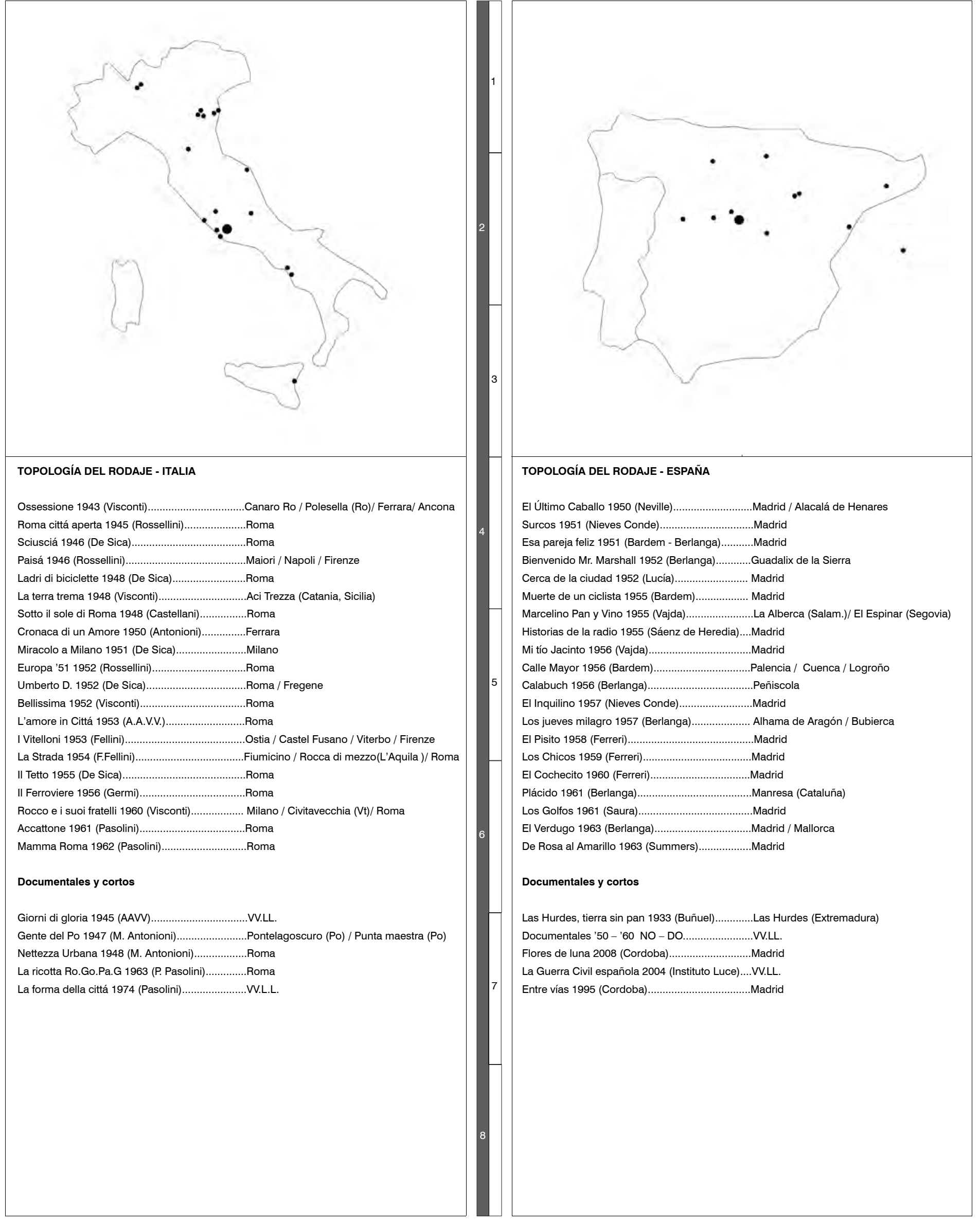

ITA 1-2-3. Topología del rodaje: Italia

ESP 1-2-3. Topología del rodaje:España 
Para las películas rodadas en las dos capitales se ha tomado en consideración la "mancha urbana" con referencia al año 1962, para Roma y 1964 para Madrid, fechas que corresponden al planteamiento de los nuevos PGDU y a la fecha límite del intervalo temporal de la investigación que abarca obras cinematográficas desde 1943 hasta 1963.

La diferencia entre las morfologías urbanas de las dos capitales afecta las distancias de los escenarios escogidos por los directores respecto al centro de la ciudad y a la posición de los principales estudios cinematográficos: Cinecittá en Roma y los CEA en Madrid. La capital española es una ciudad más compacta y alargada en dirección del eje Norte-Sur, mientras que la italiana es una ciudad, más dispersa y con una morfología expansiva de tipo radial más manifiesta.

Como ya hemos analizado en este capítulo, la construcción de nuevas viviendas sociales alimentó la especulación, incrementando el valor de los terrenos adyacentes. En Roma el crecimiento desordenado e ilimitado determina un territorio municipal - actualmente es el más extenso de Europa en términos de superficie administrada-, en el cual vastas áreas rurales conviven con urbanizaciones masivas de alta densidad. A través del análisis cuantitativo y cualitativo de la distancia de los decorados del centro urbano es posible evidenciar analogías y diferencias entre los dos paisajes urbano-cinematográficos.

En la cartografía desarrollada para identificar la topología del rodaje, los puntos de color negro indican los principales lugares de rodaje de las películas analizadas y cada anillo concéntrico corresponde a la distancia de un kilómetro respeto al centro de la mancha urbana representada en gris ${ }^{87}$. Comparando las nubes de puntos en los mapas de las dos ciudades, es evidente la mayor compacidad presente en Madrid, en la cual muchas películas tienen como escenario el centro histórico; en Roma, la nube se extiende perdiendo su referencia hacia el centro. A pesar de estas diferencias, podemos afirmar que, en las dos capitales, el centro de la ciudad, pierde poco a poco su función representativa de espacio urbano, dejando cada vez más espacio a las periferias urbanas.

La dialéctica centro / periferia es objeto del análisis de Pierre Sorlin en su ensayo "Cines europeos, sociedades europeas 1939-1990"; en estos estudios el sociólogo francés subraya que "El tándem centro/periferia es más común durante la década de los cincuenta, mientras que los suburbios se representaron más durante los sesenta". Sorlin analizando sobre todo las películas del Neorrealismo Italiano, sugiere que una nueva imagen urbana aparece tras $E I$ techo de De Sica de 1955, que denomina "la borrosa imagen de la ciudad". Esta imagen corresponde a un "descentramiento" de la imagen de las ciudades en el cine que cada vez más se enfoca en el paisaje de las periferias urbanas, que antes se presentaban "como entidades complementarias" ${ }^{8}$ de los centros urbanos y que ahora se representan como autónomas; se trata de un fenómeno de escala europea que marca un cambio en la percepción de la imagen de la ciudad (F.1.3.3/2).

\footnotetext{
${ }^{87}$ A partir de ahora se utilizará este código gráfico en todo el trabajo de investigación. Los vectores que representan los recorridos aparecen en línea punteada. Los puntos de color negro indican los escenarios del rodaje. Los círculos concéntricos indican la distancia del centro medida en Kilómetros. Los íconos de las cámaras indican el punto de vista y la dirección del encuadre cinematográfico.

${ }^{88}$ (Sorlin \& Pujol i Valls, 1996)
} 


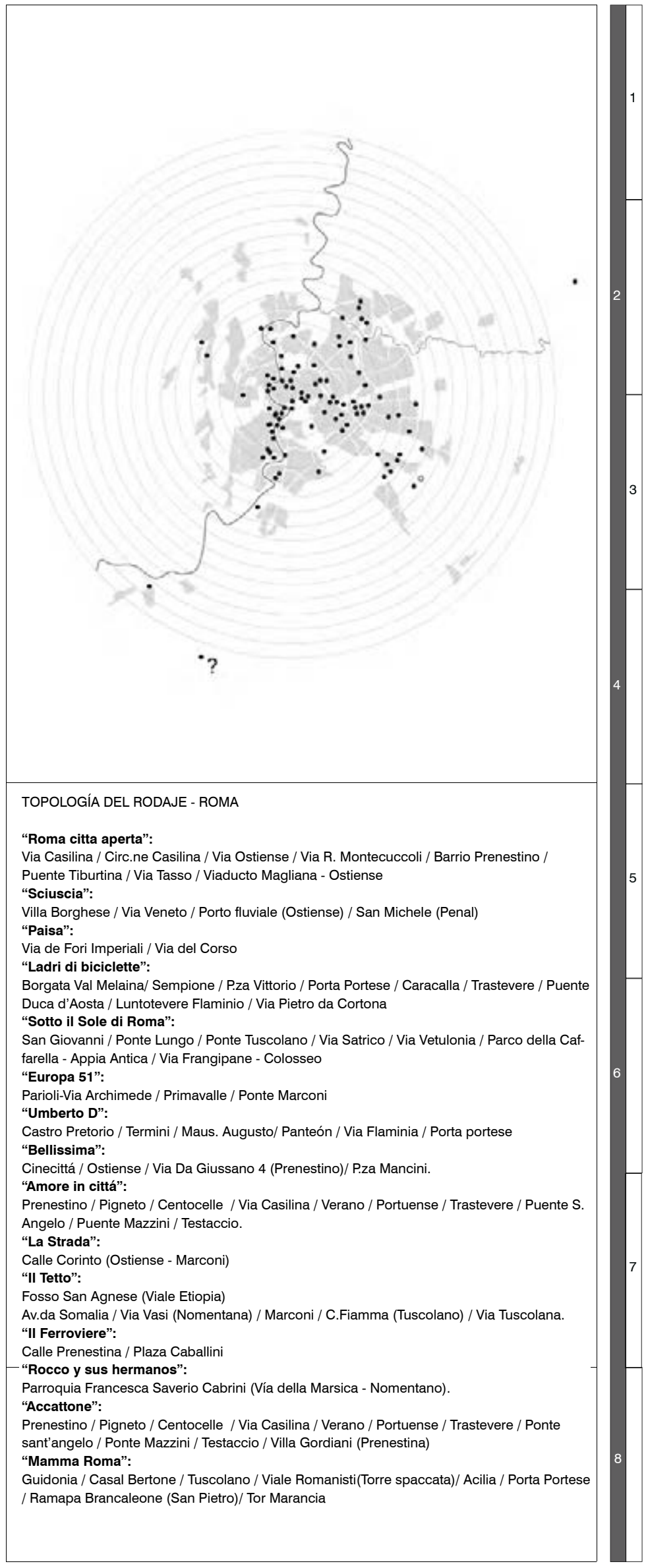

TOPOLOGÍA DEL RODAJE - MADRID

"El último caballo":

Pradera de San Isidro / cava baja - arco cuchilleros / Grán Via / Arena Ventas "Surcos":

Lavapiés / Latina / Delicias / Legazpi

"Esa pareje felíz":

Calle Moratín 8 (Centro) / Casa de Campo

"Cerca de la Ciudad"

Calle Alcalá / Calle de faustina peñalver ciudad lineal (San Juan Bautista) / Pozo del Tío Raimundo / Calle San Marcelo - Calle Ricardo Ortíz (La Elipa).

"Muerte de un ciclista":

Paseo y C.ra de Extremadura / C.U. / Calle S. Leonardo (P.za de España) / Hipodromo Zarzuela

"Historias de la radio":

Av.da Concha Espina / Gl.ta Alonso Martinez (Chamberi)

"Mi tío Jacinto":

Traviesa Parada / Calle Normas, Barrio San Juan Bautista (Ciudad Lineal). / Centro - Rastro La Latina / Plaza Mayor / Tirso de Molina (Metro) / Av.da Carabanchel Alto.

"El Inquilino":

Calle de la Palma (Malasaña) / Latina-Carabanchel

"El pisito":

Gran vía (centro) / San Blás / Arturo Soria / Cebada / Calle de los Realojos (San Blás) "Los chicos":

Callao / Calle del Rosario / Calle de San Francisco / La Latina / Instituto San Isidro / Ventas (plaza de toros) / Viaducto Segovia / Calle Antonia Mercé (Goya)

"El Cochecito":

Chamberi / Moncloa / Plaza Comendadores / Cementerio Almudena / Prado / Retiro.

"Los golfos":

Avd.a Marques de la Corbera / Calle Francisco Villaespesa. (Ventas) / Legazpi / Arena Vista Alegre

"El verdugo":

Plaza de la Marina (Centro) / Paseo de recoletos (Centro) / Areopuerto de Barajas "Del Rosa al Amarillo":

Calle Juan Bravo / Plaza Marqués de Salamanca / Calle Lagasta
RM 1. Topología del rodaje en la capital italiana y distancia del centro.

Cartografía desarrollada a partir del Plan general de 1962
MD 1. Topología del rodaje en la capital

italiana y distancia del centro.

Cartografía desarrollada a partir del Plan general de 1953 
Analizando las películas escogidas rodadas en Roma y Madrid, teniendo en cuenta de las fechas de rodaje podemos confirmar una tendencia progresiva al descentramiento sobre todo desde los rodajes de los primeros años '40 hasta los de principios de los '60. Este cambio corresponde a un cambio de la imagen urbana, una forma diferente de mirar hacia el centro histórico. En Ladrón de bicicletas o Surcos, ya no hay búsqueda del pintoresco como en obras cinematográficas anteriores; de Madrid y Roma se muestran vistas inusuales, barrios más populares o industriales: las zonas de Trastevere, de Porta Pórtese, de Termini en Roma o La Latina, el Rastro, la zona de San Francisco El Grande y el puente de Segovia en Madrid.

Cambia, también la narración de las zonas monumentales de la ciudad, se mira de la misma forma en la cual se observa a la periferia, se describen lugares "al margen", ruinas y lotes baldíos, o se representa escenas cotidianas, o tomas desde puntos de vistas inusuales y antipintorescas. Si analizamos, por ejemplo, el pequeño documental de Antonioni, Nettezza Urbana, nos damos cuenta de este evidente cambio de valores en la representación urbana.

Barrios como el Prenestino en Roma, teatro de la mayoría de las escenas principales de Roma ciudad abierta (1946), a pesar de su gran cercanía con el centro histórico, son considerados por los mismos romanos, todavía el día de hoy, como "zonas de periferia", un concepto ligado a aspectos arquitectónicos y sociales. Lo mismo pasa en la capital española con barrios como la Latina, el Rastro, Arganzuela o Delicias presentes en varias películas anteriores a la fecha establecida por Sorlin.

En las dos ciudades la distancia media de las ambientaciones del centro de la ciudad, no supera un radio de 16 kilómetros. Algunas películas, sobretodo italianas, expanden este territorio, ambientando las películas en pequeños pueblos rurales o ciudades en las afueras de Roma, en el campo o a lo largo del litoral, es el caso de Fellini que busca el mar y las montañas en las películas La calle y Los inútiles o Pasolini con la migración de Mamma Roma del pueblo rural de Guidonia hacia la urbe o el viaje en moto hacia los suburbios de Ostia cerca del litoral.

En las periferias, es posible identificar unos polos de atracción en los estudios de CINECITTÁ en el Barrio Tuscolano, en el Sector Sureste de la capital italiana y los estudios CEA ${ }^{89}$ en la ciudad lineal en el sector este de la periferia de Madrid. La economía y facilidad de desplazamientos de materiales y recursos humanos desde estos importantes estudios cinematográficos explica la elección de varias ambientaciones, sobre todo a partir de los años ' $50^{90}$, que utilizan estos escenarios adyacentes de la ciudad en expansión cerca de los estudios, como representación paradigmática de suburbios y periferias. Las mismas condiciones caracterizan la zona alrededor de los estudios CEA de Madrid, en la cual se rodan cuatro películas de las veinte analizadas.

La película italiana Belissima de Visconti está rodada en gran parte en Cinecittá al ser el Cinema y este lugar el objeto de la película.

Otros lugares de rodaje se aglutinan en Roma al sector Noreste, alrededor del barrio Tufello, Montesacro, y el Río Aniene en donde se rodaron partes de trés películas. Importante es el Río

\footnotetext{
${ }^{89}$ Los Estudios CEA (Cinematografía Española Americana) fueron unos estudios cinematográficos españoles en Ciudad Lineal (Madrid), a la altura del puente que tomó su nombre (cruce entre la calle de Arturo Soria con la carretera de Barcelona, y cercano a la Avenida de América. Los estudios cerraron el 11 de noviembre de 1966 acabando un capítulo importante de la producción cinematográfica española, con unas quince películas de media por año. (Fuente Wiki)

${ }^{90}$ Ver nota 40
} 
Tiber, con las zonas periféricas de Testaccio, de la vía portuense y Porta Portese, en donde se registran varios decorados.

En Madrid además de las zonas de Arturo Soria, La Elipa, San Blas, Ventas, San Juan Bautista y Ciudad Lineal, zonas que gravitan alrededor de los estudios CEA, podemos identificar la zona de Carabanchel, el Pozo, en donde se han podido ubicar algunos decorados, y más cerca del centro, los distritos de Legazpi, Delicias y Arganzuela y la pradera de San Isidro presente en tres peliculas.

Diferente y única por localización es la Madrid que aparece en la película Muerte de un ciclista, que se roda en la periferia Oeste de la capital española, en la Universidad Complutense y sus instalaciones, en la Avenida Portugal y en la Carretera de Extremadura.

En los siguientes capítulos se completará el análisis cualitativo de la topología del rodaje añadiendo la manipulación del espacio urbano y su percepción a través de las elipsis espaciotemporales. Se tomará como punto de partida no solamente el escenario sino también el tiempo del escenario ${ }^{91}$, analizando los vectores de movimiento de los directores-personajes, y la congruencia entre espacio y tiempo real y fílmico; estas cartografías selectivas, como "mapas psicogeográficos", construyen un nuevo paisaje urbano: la Ciudad Neorrealista.

\subsubsection{Sectores de análisis: Vacíos, Poblados y ciudad informal}

Para lograr un nivel más profundo de análisis de la ciudad neorrealista a través de la topología del rodaje, se han perimetrado unos sectores más específicos dentro de la cartografía de los principales decorados neorrealistas. La delimitación de las áreas se ha hecho a partir de dos aspectos: el ser áreas periféricas o al límite entre centro y periferia, y la presencia de los decorados de una o más películas entre las seleccionadas.

En los sectores definidos se ha detectado la presencia de conjuntos de vivienda social de reciente construcción, de asentamientos informales y de grandes vacíos urbanos, elementos que caracterizan las transformaciones urbanas de la ciudad neorrealista que hasta ahora hemos analizados como fenómenos histórico-urbanos. En el tercer capítulo se analizarán más detenidamente los decorados de las películas rodadas, una por cada sector.

El sector primero de Roma ubicado al Este de la capital, correspondiente a los barrios de Prenestino y Casilino, es una zona entre centro y periferia caracterizada por la presencia del ferrocarril que llega a la estación central de Termini, un pequeño asentamiento espontáneo denominado "Pigneto" y algunas manzanas de vivienda popular de alta densidad, en un tejido urbano formado por manzanas regulares.En Madrid, en el primer sector, que incluye los barrios de Lavapiés, Delicias, Anrganzuela y el área de San Francisco el Grande, cerca de la Latina, encontramos un trazado regular de manzanas de vivienda popular que se alternan con fábricas y asentamientos informales como lo de Jaime el conquistador, uno de los más grandes de Madrid, derribado en 1957; al límite de esta área el río Manzanares y la glorieta de Legazpi, donde se ubican el Matadero y el grande mercado de mayoreo.

El segundo sector analizado corresponde a la Capital italiana, específicamente a una gran área al límite de la mancha urbana en la zona Noreste. Se ubican en esta área los barrios del Nomentano y de Val Melaina, este último caracterizado por los bloques de la homónima "borgata" construida por Mussolini; esta área se caracteriza por inmensas praderas áridas entre la borgata, el río Aniene y la avenida Nomentana, y muchos asentamientos informales en

91 (Mancini \& Perrella, 1986 p.227) 
los espacios residuales en la ribera del río y alrededor de los bloques de la ciudad formal en construcción. En Madrid, el segundo perímetro es el territorio entre Concha Espina y San Juan Bautista, con un paisaje muy parecido a lo que hemos descrito para el segundo perímetro, una gran terraza separada de la ciudad por la cañada del antiguo arroyo Alboñigal.

El tercer perímetro en Roma corresponde a la zona de Torre Spaccata y Centocelle, un territorio de grandes áreas entre lo urbano y lo rural de las praderas de la campiña romana, entre restos arqueológicos y ovejas; paisaje que todavía conserva estas características hasta hoy. En este enorme vacío se desarrollaron los grandes asentamientos informales adyacentes a los conjuntos de vivienda oficial: borgate e INA-Casa. El tercer sector en Madrid corresponde a los barrios de El Carmen, La Elipa y San Blas, una zona de gran expansión no lejos de los estudios CEA de la Ciudad Lineal, caracterizada por bloques de vivienda social recién construidos, y por los grandes descampados correspondientes a las cañadas de los antiguos ríos Abroñigal y Elipa, alrededor de los cuales se asientan pequeñas actividades productivas y asentamientos informales.

El cuarto sector en Roma es el territorio del Tuscolano, el barrio de la especulación edilicia entre el INA-Casa y los estudios de Cinecittá el paisaje es idéntico a lo ya descrito para el tercer perímetro de Torre Spaccata, un enorme asentamiento informal que se construyó a partir de la posguerra a lo largo de lo que hoy es denominado Parque de los Acueductos, parte del parque arqueológico de la Vía Appia, una enorme cuña verde que llega hasta el Coliseo. Cuarto y quinto sector en Madrid corresponden a la zona del Pozo-Entrevías al límite sureste de la Capital y a la zona de Carabanchel-La Latina en el cuadrante Suroeste. Se trata de las zonas más periféricas y alejadas de la ciudad, caracterizadas por un paisaje árido con asentamientos informales entre los más extensos y alejados de la Capital, y sin mucho desarrollo urbano hasta los primeros poblados asistidos de 1956, como el de Entrevías.

El perímetro cinco en Roma es un área alrededor del Tíber que aparece en cuatro diferentes películas, es la prolongación del área industrial de la Avenida Ostiense, unos terrenos de fuerte expansión inmobiliaria como el Tuscolano. Se caracteriza por la presencia de uno de los primeros conjuntos INA-Casa realizados: Valco San Paolo, de 1949.

En Roma hemos considerado también un sexto sector, el único en el Oeste de la ciudad e interesado por el rodaje de la película Europa '51 de Roberto Rosseliini, un sector caracterizado por las particularidades comunes a los otros perímetros de Roma y Madrid hasta hora descritos: enormes descampados, asentamientos informales que se condensan alrededor de un núcleo de vivienda social, en este caso la borgata Primavalle construida bajo el Fascismo, que funciona como polo atractor también para los nuevos desarrollos privados (F.1.3.4/1). 

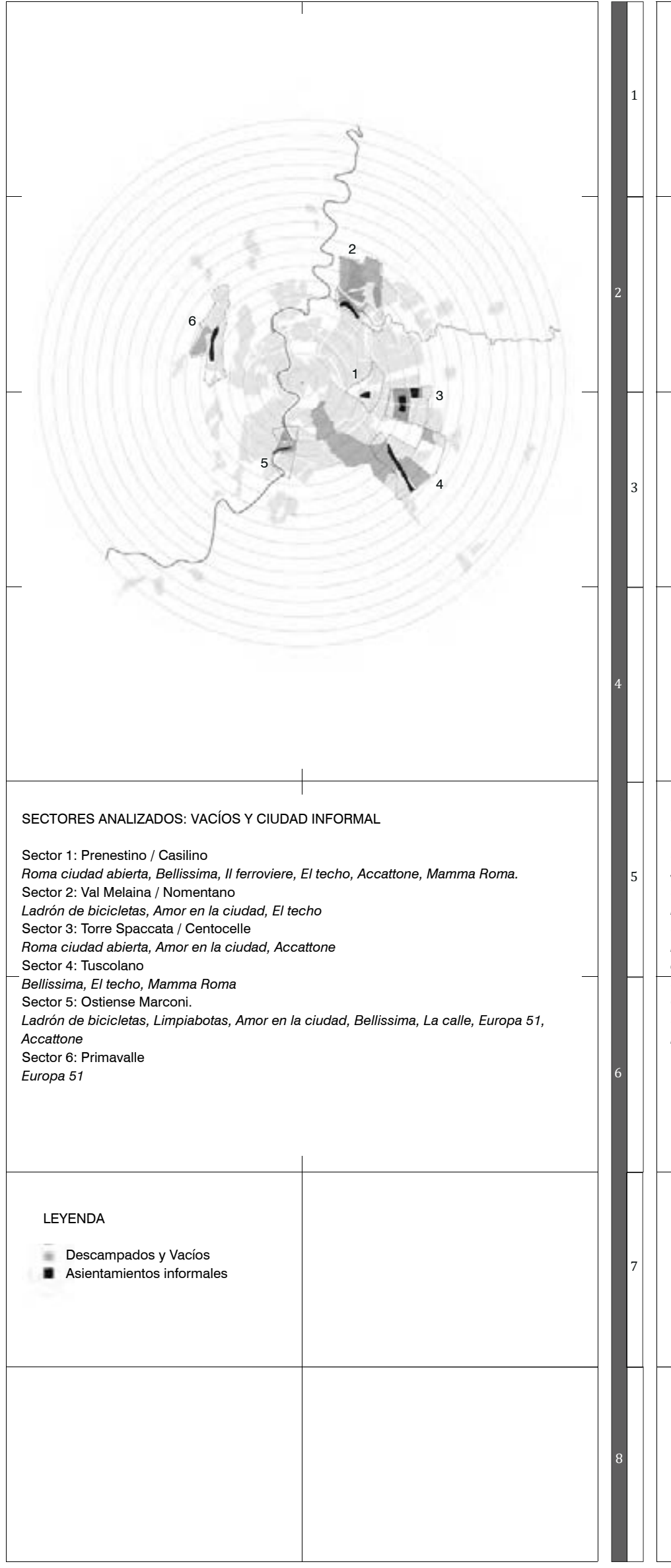

SECTORES ANALIZADOS : VACÍOS Y CIUDAD INFORMAL

Sector 1: Delicias / Arganzuela / San Francisco el Grande

Surcos, El inquilino, Los chicos, Los golfos

Sector 2: San Juan Bautista / Arturo Soria

Mi tío Jacinto, Cerca de la ciudad, El pisito

Sector 3: Ventas / El Carmen / La Elipa / San Blás

El último caballo, Mi tío Jacinto, Cerca de la ciudad, Los chicos, Los golfos, El pisito, El cochecito

Sector 4: El Pozo / Entrevías

Cerca de la ciudad

Sector 5: Carabanchel / Latina

El último caballo, El inquilino, Mi tío Jacinto, Los golfos 
Se han identificado los conjuntos de vivienda que aparecen en la filmografía seleccionada. Es evidente, en la comparación Roma-Madrid, la diferencia de cantidad entre las dos capitales. Además de un efectivo retraso de la producción de vivienda en España ${ }^{92}$, también se ha detectado un mayor interés en la primeras películas españolas hacia la descripción de las viviendas hacinadas del centro histórico y los barrios chabolistas, mientras que en Italia aparece muy clara la imagen de la ciudad de las nuevas viviendas en construcción. En las películas romanas aparecen todas las tipologías de vivienda popular presentes en la Capital: la vivienda hacinada del centro (1) ${ }^{93}$; la manzana popular con patio de los grandes bloques de manzanas con patio construidos entre finales del siglo XIX y principios del XX (2-5-7); las borgate fascistas, construidas en un territorio muy periférico de la ciudad y caracterizadas por un diseño y una construcción de baja calidad (9-10); los desarrollos de INA-Casa (8-11-12-1516); los desarrollos de bloques intensivos privados de la especulación edilicia (13).

En la Cinematografía Española la vivienda burguesa es inaccesible, se le aparece en sueños al protagonista de El inquilino. En las películas seleccionadas aparecen 4 tipologías de viviendas urbanas: La casa corrala del centro (1); los bloques de manzana con patio de principios del siglo XX (2); los conjuntos de promoción oficial (7-8); y las torres de desarrollos para la clase burguesa en los ensanches (5) (F.1.3.4/2).

A pesar del desfase temporal en el desarrollo de la vivienda de promoción pública en las dos capitales, podemos identificar algunas diferencias y características comunes. Tanto los barrios italianos como los madrileños tienen una ubicación lejana del centro a una distancia radial media mayor de 5 kilómetros. Los que planearon su ubicación, tanto en Roma como en Madrid, miraron a áreas de bajo costo, y cuando fueron construidos carecían de la presencia de servicios, sufriendo cierto aislamiento. Esto es más evidente en los poblados de la capital española, en donde la urgencia y la economía de los planteamientos fue causa de falta de escuelas, centros de atención médica, mercados y centros recreativos, en el diseño original de los conjuntos. La presencia de estos servicios es una de las grandes diferencias de los barrios romanos respecto a los madrileños. Por la idea del plan Fanfani y el tipo de financiación, la situación en Italia favoreció las construcciones de edificios con otras funciones.

\footnotetext{
92 El primer programa INA-Casa se acabó en 1955, año en el cual empezó la primera etapa de los poblados dirigidos en España

${ }^{93}$ Los números entre paréntesis se refieren a los números indicados en la ficha F.1.3.4/2
} 

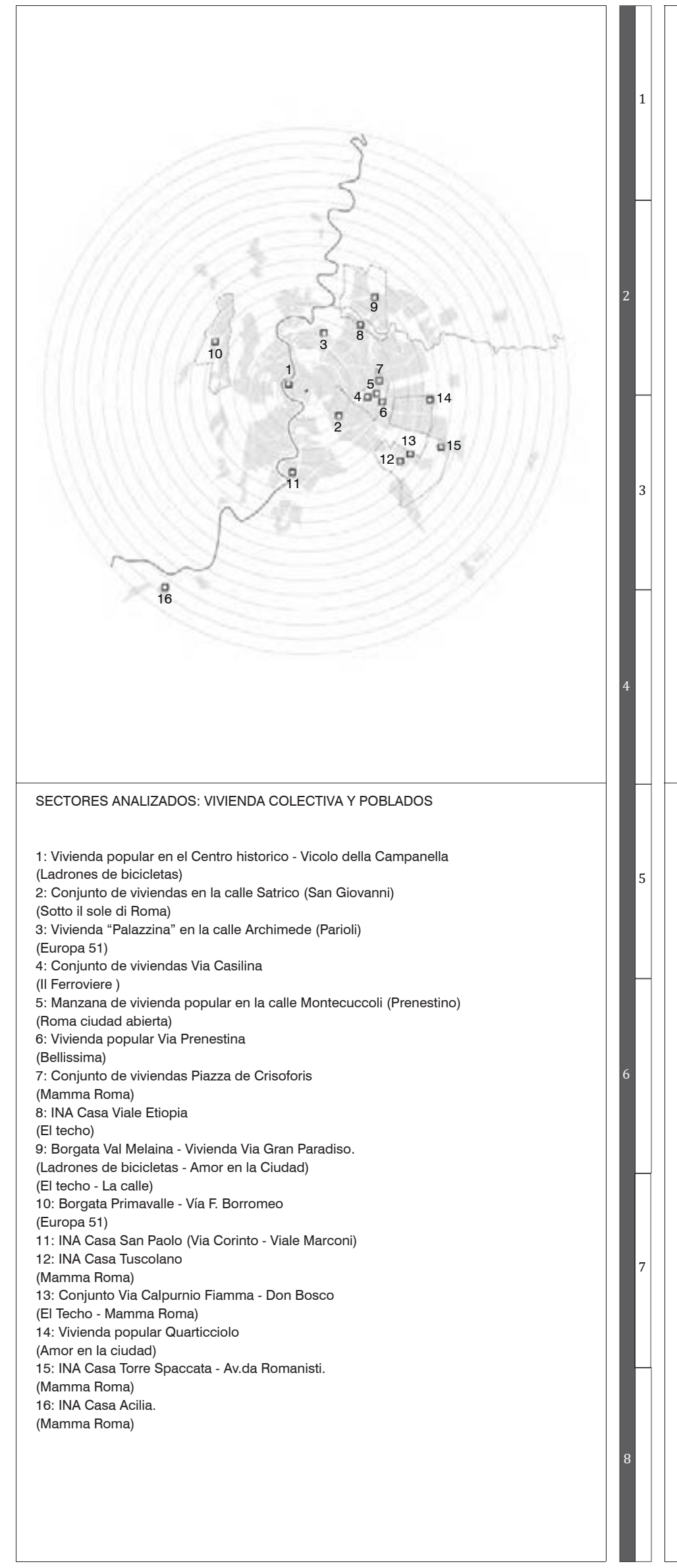

SECTORES ANALIZADOS: VIVIENDA COLECTIVA Y POBLADOS

1: Corrala de Lavapiés

(Surcos)

2: Conjunto habitacional en Paseo de la Chopera

(Los Golfos)

3: Bloque de vivienda en la calle Lagasca (B. Salamanca)

(Del rosa al amarillo)

4: Bloque de vivienda en la Calle Antonia Mercé (Goya)

(Los chicos)

5: Torres de vivienda en Av.da Concha Espina

(Historias de la Radio)

6: Bloques de vivienda en la Calle Ortíz (La Elipa)

(Cerca de la ciudad)

7: Poblado dirigido en la Elipa - Calle Santa Prisca

(Los Golfos)

8: Conjunto F. Franco (Av.da Hm.nos García Noblejas)

(El pisito) 
Los barrios de promoción oficial madrileños tuvieron una superficie media de casi 18 hectáreas contra los 15 de los romanos, un número medio de viviendas de casi 1800 unidades, mientras que en Italia no se alcanzan las 1400 unidades. Los barrios españoles son más densos con un número de viviendas por hectárea de 108 contra las 96 de Italia ${ }^{94}$. Estos datos nos confirman la mayor "urgencia" con la cual España se enfrentó al problema de la casa. Estas explicaciones valen también por el tema del trazado: al planeamiento orgánico de la mayoría de los barrios romanos de inspiración Neo-empirista sueca, se contrapone el trazado ortogonal de los poblados dirigidos madrileños con la clara referencia a los conjuntos racionalistas alemanes y holandeses de los años treinta.

El diseño del espacio público fue seguramente uno de los aspectos que más caracterizó a los barrios romanos y madrileños de los años ' 50 y que los diferenció del resto de la periferia que crecía, con el tiempo, alrededor de estos conjuntos, englobándolos. Todavía al día de hoy, se pueden distinguir muy bien estas intervenciones dentro de una ciudad ya consolidada por la calidad de estos espacios verdes.

\footnotetext{
${ }^{94}$ Comparación entre las primeras 7 intervenciones INA - Casa romanas (1949-55) en comparación con
} los primeros 7 poblados dirigidos madrileños (1956.58) 


\subsection{Paisaje - tiempo}

\subsubsection{Iconografía neorrealista: hacia la imagen óptica.}

En su ensayo "La imagen-tiempo", segunda parte de sus estudios sobre el medio cinematográfico, Gilles Deleuze se ocupa de la memoria y del tiempo como materia de la imagen fílmica. Si en la primera parte de sus estudios había relacionado el tiempo al movimiento para definir el únicum de la "materia cinematográfica", y la imposibilidad de separar la imagen presente en los fotogramas, del movimiento que los une, ahora evidencia cómo el arte cinematográfico tiene la posibilidad de representar y alterar las múltiples relaciones entre espacio y tiempo, los cruces entre segunda (el encuadre), tercera (la realidad filmada) y cuarta dimensión (los tiempos).

Deleuze toma como punto de partida el cambio que en la Historia del Cinema fue producido por el Neorrealismo. Hablando de las características de esta cinematografía y su ruptura con el Cine anterior, Deleuze subraya como va tomando importancia la presencia de "situaciones puramente ópticas, fundamentalmente distintas de las situaciones sensorio-motrices de la imagen-acción en el antiguo realismo"1, y compara esta conquista a la del espacio puramente óptico de la revolución de la pintura impresionista; la obra deja de estar concebida como un instrumento para la mera observción, y se rebasa la representación directa de una realidad para proponer un movimiento necesario al pensamiento. El gran cambio es que "no sólo el espectador sino también los protagonistas impregnen medios y objetos con la mirada"; antes de que se produzca una acción-reacción frente a una imagen. El protagonista se detiene a observar y la situación se vuelve "óptica y sonora", se carga de los sentidos. Este "aflojamiento de los nexos sensorio-motrices" lleva a un cine que ya no centra su atención en la acción sino en la detención y en el registro de las imágenes, transformando a los protagonistas de las películas en espectadores. Podemos añadir que los personajes de las películas neorrealistas tienen cierto grado de autonomía que corresponde a un realismo de nivel superior al anterior, y al mismo tiempo se vinculan más profundamente con la visión del director.

Esta nueva forma de hacer Cine enfoca la atención en aspectos que anteriormente jugaban un papel secundario. Por primera vez, el lugar, el paisaje, la ciudad y la arquitectura, toman el papel de protagonista en el espacio fílmico, siendo como hemos visto el producto de la observación directa de los protagonistas-espectadores. Estas características llegan a sus extremas consecuencias en el cine de Antonioni, en el cual aparecen "paisajes deshumanizados, espacios vacíos que se diría han absorbido personajes y acciones hasta dejar de ellos tan solo una descripción geofísica, un inventario abstracto"².

También los encuadres, desenfocan la atención en los protagonistas que ocupan una posición asimétrica respeto al cuadro y ponen al centro "el fondo" ${ }^{3}$. Estas características de la cinematografía neorrealista son las que facilitan el análisis de esta tesis, que a partir de estos "encuadres vacíos" o encuadres asimétricos respecto a los protagonistas, construye una nueva iconografía del paisaje urbano de las dos capitales.

\footnotetext{
1 (Deleuze, 1987 p.97)

2 Ibídem p.16

${ }^{3}$ (González Cubero, 2005)
} 


\subsubsection{Dimensión temporal y materia fílmica}

El cine permite una alteración del espacio temporal operando en la relación que se establece entre el tiempo fílmico (o tiempo de la narración) y el tiempo de proyección, que pocas veces coinciden. La coincidencia entre los dos tiempos, corresponde a la utilización del planosecuencia, que constituye un gran desafío técnico-lingüístico para los directores ${ }^{4}$.

Otras alteraciones son posibles a través de las operaciones de montaje, y la posibilidad a través de esta técnica de alterar la percepción espacio-temporal, que Eisenstein codificó en 5 métodos: métrico, rítmico, tonal, armónico, intelectual ${ }^{5}$. La posibilidad más evidente con el montaje es la de la alteración del orden cronológico de la narración, de juntar acciones en el presente con las del pasado y las del futuro.

El relato en el tiempo, la crónica, es el objeto de la película de Antonioni Crónica de un amor, que "tiene por consecuencia provocar ella misma la prolongación de un primer amor, y por efecto hacer resonar dos deseos de asesinato, en futuro y en pasado. Es todo un mundo de crono-signos que bastaría para hacer dudar de la falsa evidencia según la cual la imagen cinematográfica está necesariamente en presente." 6 . Hay toda una serie de matices en la imagen cinematográfica que se generan por la existencia de un "fuera de campo", del cual Antonioni será un maestro, que influye sobre el campo ocupado por la narración, eventos y acontecimientos distantes en el espacio, y también en el tiempo que determina la acción descrita en el encuadre.

Deleuze utiliza la metáfora del cristal para describir la acción del cine que filtra el tiempo, remplaza el futuro con el presente y conserva el pasado en la profundidad de su materia. El cristal se puede descomponer, como pasa en toda la obra de Visconti que el filósofo pone como ejemplo de perfección de esta posibilidad del cristal-tiempo de fragmentarse. Mirando el ejemplo neorrealista de Rocco y sus hermanos, que podemos poner en relación por la semejanza del guion, con Surcos de Nieves Conde, Deleuze habla de los cuatros tiempos del cine de Visconti: los aristócratas como personajes "fuera de la historia y de la naturaleza" como Rocco y el hijo Pablo de Surcos; la acción corruptora del tiempo que cambia a las personas haciendo imposible la vuelta al pueblo de origen; la Historia que cambia los destinos y los lugares y el demasiado tarde que genera remordimientos y acciones irreversibles. Estos cuatros elementos son característicos del Cinema de Visconti y explican muy bien esta dimensión temporal, que se convierte en materia fílmica del Neorrealismo.

Ya hemos analizado en el capítulo anterior la relación que es posible establecer entre la dimensión temporal y los viajes: los viajes de la cámara, que hemos analizado desarrollando una cartografía romana y madrileña de las ambientaciones cinematográficas neorrealistas. Esta topografía del rodaje corresponde a los desplazamientos de los protagonistas en el espacio urbano y suburbano, movimientos que tienen una duración real y fílmica.

Existe también otro aspecto de la dimensión temporal: "el tiempo es también tiempo astronómico, o meteorológico, que cada escenario al aire libre, debe tener en cuenta" ${ }^{\text {. El }}$ Cine Neorrealista, como nunca antes, se sale de los estudios cinematográficos, fortalece su relación con el medio natural a través de los fenómenos atmosféricos que aparecen sin filtros en los fotogramas, casi acentuados. La oscuridad de las escenas nocturnas que aparecen en

${ }^{4}$ Los experimentos más logrados son los de Hitchcock ("La soga” 1948) y Sokúrov ("El Arca rusa” 2002)

5 (Eisenstein \& Montani, 1985)

6 (Deleuze, op. cit. P.40)

7 (Mancini \& Perrella, 1986 p.228) 
muchas de las películas analizadas, establece una demarcación temporal fuerte, que se asocia con acontecimientos de intensa carga emocional.

\subsubsection{Surcos: Nostalgia del campo.}

Los sueños y la memoria, que son materia fílmica según el análisis deleuziano, están presentes en el análisis iconográfico de la Ciudad Neorrealista, en los fotogramas que muestran lugares y situaciones de un pasado difícil de recuperar.

Se ha analizado en el primer capítulo cómo en la época de la reconstrucción, tanto en Italia como en España, el mundo rural es considerado como una posible solución para la regeneración del tejido social y cultural, y como punto de partida para la reorganización espacial del territorio ${ }^{8}$. El campo es el fundamento de una posible autosuficiencia económica, sobre todo en España, a través de la recuperación de las raíces culturales nacionales; es también portador de valores estéticos, que la población puede comprender y apreciar. Si por un lado el paisaje rural que aparece en las películas parece vehicular este mensaje político de autenticidad y pureza, en oposición a un territorio urbano que parece deteriorado y lacerado por la guerra y la especulación edilicia, por otro lado, aparece también la perplejidad por parte de los mismos protagonistas sobre un efectivo regreso a estas raíces culturales. En muchas películas prevalece una mirada escéptica y una nostalgia por algo que se considera imposible de recuperar. La imagen del campo cultivado y de los surcos es presente en varias películas analizadas que se asocian a este dolor de una perdida. La escena de Bienvenido Mr. Marshall que describe el sueño de una familia campesina que asiste a la aparición, en su campo de un enorme paracaídas que llega desde el cielo con las ayudas enviadas por la aviación de EEUU, es una imagen que describe metafóricamente esta pérdida de identidad, de contaminación cultural; esta misma metáfora está presente en la misma pelicula, en las escenografías efímeras que los habitantes del pueblo de Villar del Rio, en Castilla y León, montan para disfrazarse de andaluces y recibir de esta manera más ayudas de los americanos.

En Surcos la imagen del campo arado abre y cierra la película; la llegada y la partida de Madrid de los protagonistas se produce a través del campo arado y su contraste con el territorio urbanizado. Así, Zumalde de Arregui describe el significado de la imagen del campo y de los surcos, que dan el titulo a la obra cinematográfica de Nieves Conde:

"A través de una hendidura que surca los campos (la vía del tren) la familia arriba a la ciudad, un desgarro en una media de cristal echará al traste la ilusa felicidad de Tonia, los talones del cuerpo inerte de Pepe arrastrado por don Roque roturan en la tierra dos Surcos paralelos que anuncian el acto que se materializa en breve (el lanzamiento del cuerpo a las vías del tren) y su inmediata consecuencia (el enterramiento del cadáver). La circularidad del fil es recobrada merced a estas reminiscencias acreditadas por el motivo del surco, y queda definitivamente certificada en ese fundido encadenado que clausura el film en el que se anudan la imagen de una tumba abierta en el cementerio y el primer plano de un campo perfectamente roturado". ${ }^{9}$

Una imagen que asocia el origen rural a un destino dramático e ineluctable como en otras películas italianas que tratan el argumento, Gente del Po y La tierra tiembla; o como el pueblo de Peñiscola utilizado como escenario para la grabación de Calabuch. (F. 2.1.3).

${ }^{8}$ (Turco, 2004)

9 (Zumalde Arregi, 1997) 

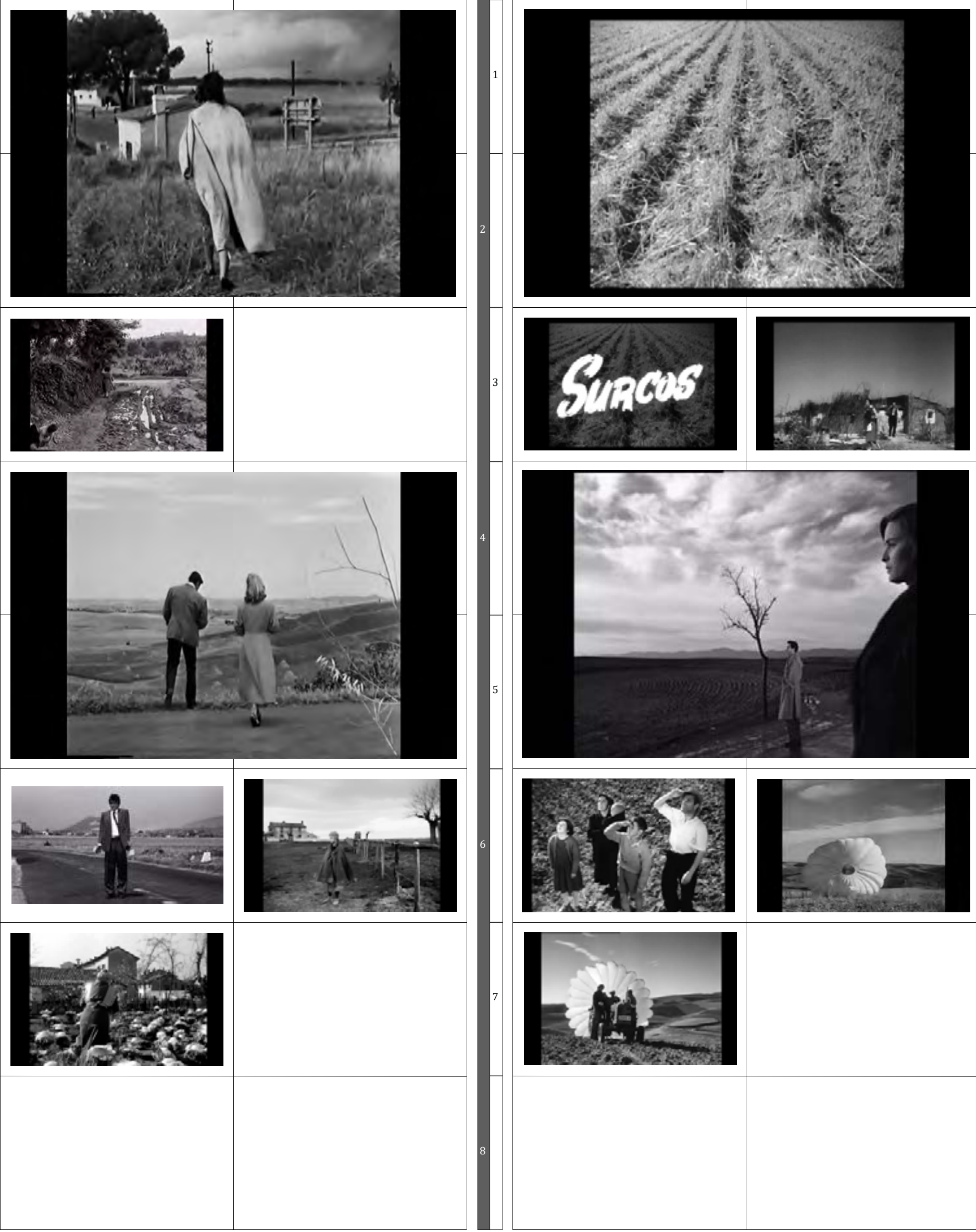

RM 1-2. Amor en la ciudad (AAVV)

RM 3. Amor en la ciudad (AAVV)

RM 4-5. Amor en la ciudad (AAVV)

RM 6. Mamma Roma (Pasolini)

RM 6. La calle (Fellini)

RM 7. Milagro en Milán (De Sica)

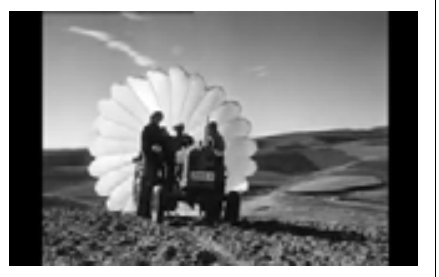

MD 1-2. Surcos (Nieves Conde)

MD 3. Surcos (Nieves Conde)

MD 3. El último caballo (Neville)

MD 4-5. Muerte de un ciclista (Bardem)

MD 6-7. Bienvenido Mister Marshall (Berlanga) 
Estas obras cinematográficas, que describen las condiciones de miseria del contexto rural, una vida difícil como la desarrollada en las grandes ciudades, tienen valor como documento de una realidad ya desaparecida. En Roma y Madrid, la iconografía de los surcos corresponde a la idea de un orden territorial prexistente al de las periferias en expansión; la imagen inicial de Surcos del tren que penetra en la ciudad con los carriles paralelos a las hendiduras de los campos arados, es la imagen de una compresencia y de un contraste ${ }^{10}$, Roma y más Madrid, aparecen en las películas como ciudades en las cuales el territorio rural se mezcla con el espacio urbanizado en expansión, generando un paisaje híbrido. Esta iconografía y superestructura geométrica influye en la futura organización del territorio y su arquitectura, como en el Tuscolano y en Entrevías, sectores de Roma y Madrid que se analizarán adelante.

Cuando la acción se mueve muy en las afueras de la ciudad, como en las escenas iniciales y finales de Muerte de un ciclista, rodadas en la Carretera de Extremadura, en el sector Suroeste de Madrid, también se produce un sentimiento de nostalgia; los campos arados de Castilla aparecen en estas escenas y, a pesar de que no aparezca ningún signo de la presencia de la cercana capital, tanto los diálogos, como la aparencia de los protagonistas, el tiempo atmosférico y la fotografía, transmiten la idea de una definitiva pérdida de identidad cultural.

\subsubsection{Arquitecturas vernáculas: realidad y folklore.}

Hay un vínculo muy estrecho entre el mundo campesino y la lucha de resistencia que se desarrolló en Italia después del 8 de septiembre de 1943. Las casas rurales, las aldeas, los pueblos de montaña aislados, son los lugares donde los partisanos se refugiaron, apoyados por las poblaciones locales, como se muestra claramente en la película-documental Días de Gloria. Las arquitecturas de granjas, de cabañas y edificios rurales que aparecen en Días de Gloria son las mismas de Gente del Po, de Antonioni, que Giuseppe Pagano presentó en la exposición sobre arquitectura rural en la trienal de Milán en 1936, punto de partida de una nueva arquitectura en reacción al funcionalismo y al movimiento moderno ${ }^{11}$. Estas experiencias son las que alimentarán también el Neorrealismo arquitectónico del Tiburtino III en Roma o las realizaciones de Ridolfi en la ciudad deTerni.

En las películas españolas de la época no falta la celebración de la dimensión vernácula, no solamente en las películas ambientadas en pueblos (Calabuch, Calle Mayor, Marcelino Pan y Vino, Good bye Mr Marshall, Los jueves, milagro) sino también en las de ambientación urbana como El último caballo. Más que en las películas italianas (en donde prevalece la ambientación urbana) en las españolas aparece el mundo de los pueblos y sus arquitecturas humildes.

En las películas rodadas en Roma la arquitectura vernácula coexiste con la capital moderna y en trasformación, de matriz funcionalista y anónima, una ciudad dentro de otra ciudad; la vivienda de algunos basureros que aparecen en el cortometraje de Antonioni Nettezza Urbana, contrasta con el paisaje de las estructuras industriales visibles al fondo de la escena. Esta iconografía contribuye al desarrollo de una imagen urbana híbrida, en donde la arquitectura de hormigón armado de los conjuntos habitacionales en construcción convive con la arquitectura tradicional, vernácula, neoclásica y barroca de las épocas anteriores, y con la "noarquitectura" de los asentamientos informales. En Roma los habitantes de las chabolas conviven con los habitantes de las viviendas oficiales, aprovechando la cercanía de los servicios; en Madrid la separación entre ciudad formal e informal aparece más marcada, así como entre arquitectura oficial y arquitectura informal (F.2.1.4/1).

\footnotetext{
${ }^{10}$ La fuerza de esta imagen es todavía más evidente en el cartel que anunciaba la película.

11 (Tafuri, Storia dell'architettura italiana, 1944-1985, 1986)
} 

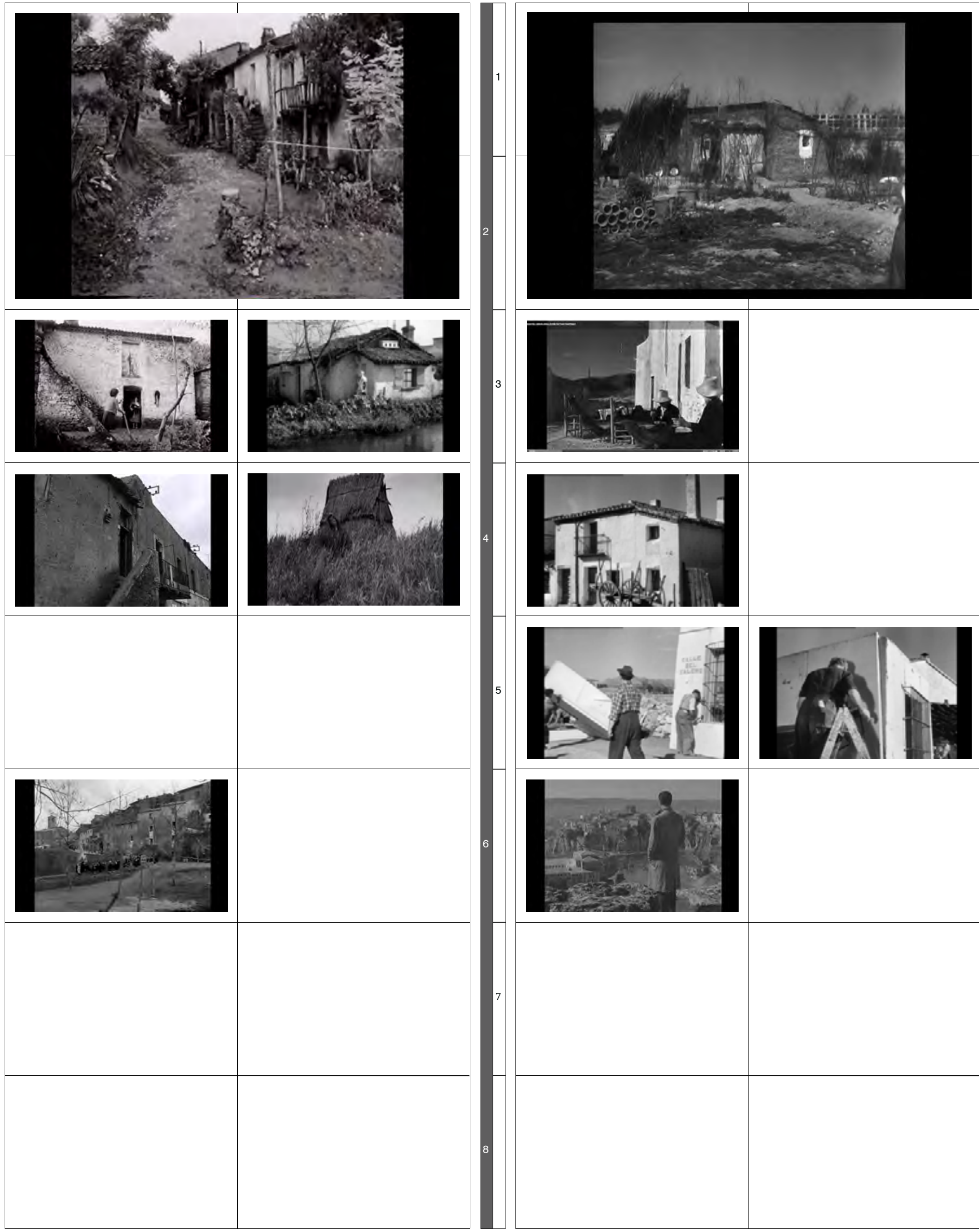

RM 1-2. Amor en la ciudad. Ep. Historia de Caterina (Maselli) - Lo vernaculo rural cerca de la ciudad

RM 3. Amor en la ciudad. Ep. Historia de Caterina (Maselli)- Lo vernaculo rural cerca de la ciudad

RM 3. Milagro en Milán (De Sica) - Lo vernaculo rural cerca de la ciudad

RM 4. El techo (De Sica) - Lo vernaculo rural cerca de la ciudad

RM 4. Gente del Po (Antonioni) - Arquitectura de paja en el Río Po

RM 6. La calle (Fellini) - Pueblo del Lazio

MD 1-2. El último caballo(Neville) - Lo vernaculo rural cerca de la ciudad MD 3. Calabuch (Berlanga) - Arquitectura vernacula en Peñiscola

MD 4. Bienvenido Mr. Marshall (Berlanga) - Lo vernaculo rural cerca de la ciudad: Guadalix de la Sierra.

MD 5. Bienvenido Mr. Marshall (Berlanga) - Construyendo un "falso andaluso"

MD 6. Calle Mayor (Bardem) - Pueblo de Cuenca 
ANIMALES: TRANSFERENCIAS CAMPO - CIUDAD.

Las trasferencias de formas y contenidos del campo a la ciudad sirven para expresar esta metamorfosis incompleta de los habitantes que no se adaptan totalmente al estilo de vida urbano, y viven importando en la ciudad usos y costumbres propios del medio rural.

Se ha detectado, en muchas de las películas italianas y españolas, la presencia de animales, como expresión de una resistencia de los personajes de las películas hacia la artificialidad del medio urbano, de tradiciones y estilos de vidas, expresiones de la cultura rural que sobrevive en la ciudad. En las escenas iniciales de Surcos, el director Nieves Conde se detiene en observar y describir la presencia de una gallina y la imposibilidad de su sobrevivencia adentro de la casa corrala de Lavapiés, en donde desaparece, perseguida en el patio de la vivienda por los niños de la vecindad.

En Limpiabotas de De Sica y en El último caballo de Neville, las imágenes de los protagonistas montando los caballos en medio del centro urbano expresan este conflicto entre libertad y constricción: en las dos películas los animales y sus amos tropiezan con la dificultad de la vida en la ciudad, de encontrar un lugar adecuado para poder ser cuidados; el ambiente urbano tiene una escala y unas condiciones de vida que no permiten la sobrevivencia. En la película italiana, Limpiabotas, el caballo, necesita mucho dinero para poder ser hospedado y cuidado, todo estos para permitir a los dos niños propietarios pocas horas de serenidad y evasión. En El último caballo, el protagonista encontrará en la pradera de San Isidro un rincón de ciudad que mágicamente ha mantenido una condición de vida rural, casi un paraíso que le permitirá plantear otro estilo de vida. Otra iconografía interesante aparece en la película E/ cochecito, de Marco Ferreri: la vaquería de uno de los amigos del protagonista está instalada en un patio muy chiquito de una vivienda-corrala de la capital, una imagen que probablemente a pesar de los tonos surreales de la película, no hubiera debido ser muy diferente de la realidad de la capital española en esta época de autarquía económica, una ciudad en la cual sus habitantes buscaron formas de adaptación a partir de su cultura campesina. (F.2.1.4/2) 

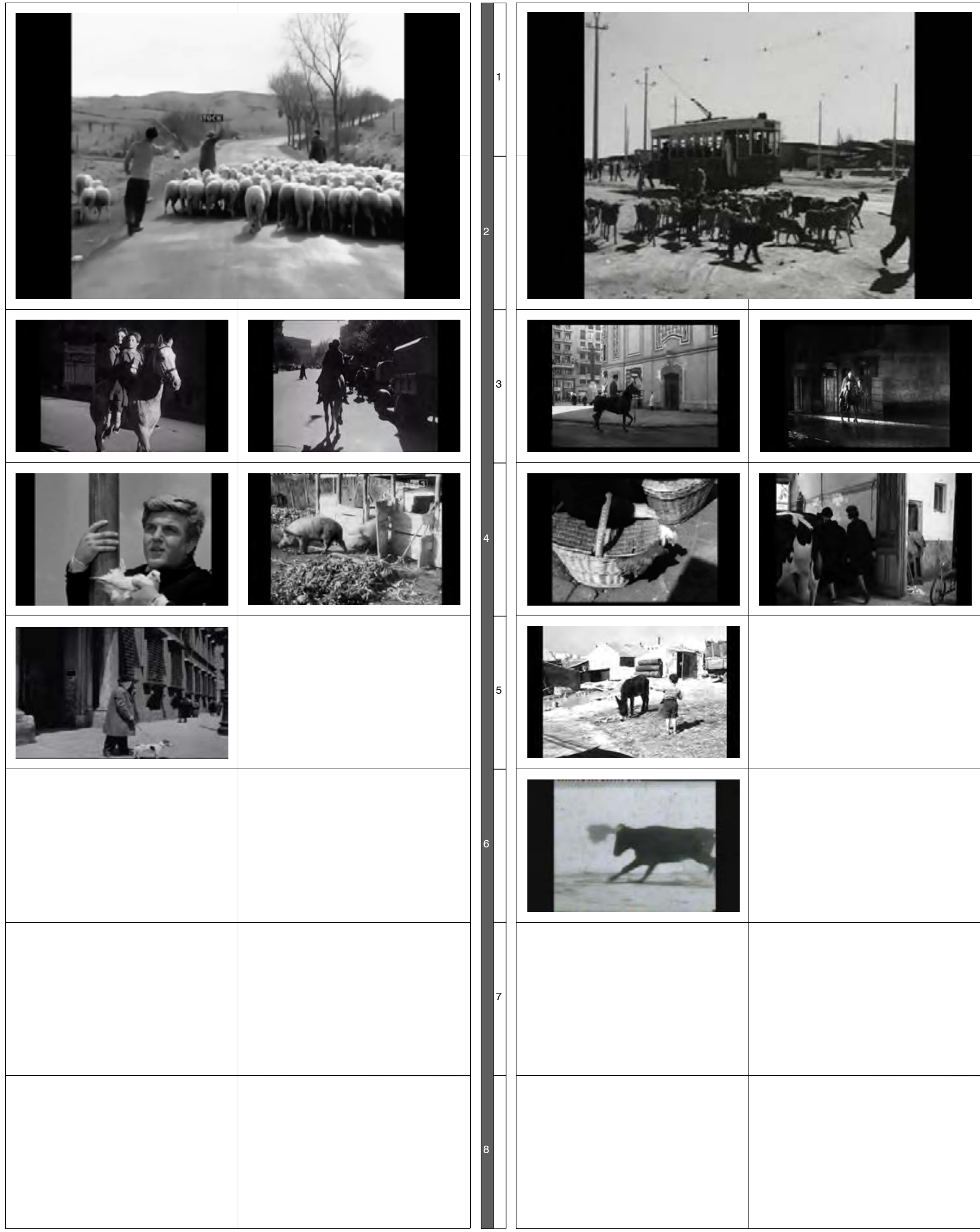

RM 1-2. La calle (Fellini)

RM 3. Limpiabotas (De Sica)

RM 4. Milagro en Milán (De Sica)

RM 4. Nettezza urbana (Antonioni)

RM 5. Umberto D. (De Sica)
MD 1-2. El pisito (Ferreri)

MD 3. El último caballo (Neville)

MD 4. Surcos (Nieves Conde)

MD 4. El cochecito (Ferreri)

MD 5. Mi tío Jacinto (Vajda)

MD 6. Los golfos (Saura) 


\subsubsection{Tiempo astronómico y atmosférico.}

Saliendo de los estudios cinematográficos, el Cine Neorrealista se enfrenta a otra dimensión temporal: la del tempo atmosférico. La niebla y la lluvia son los fenómenos más presentes, y tenían la función de potenciar los estados de ánimo de los protagonistas. A veces la niebla es el humo de los trenes en una estación de ferrocarril, como en Calle Mayor, en otros casos es el efecto de un espejismo en una guerrilla urbana, como en Milagro en Milán. La niebla, así como la lluvia, se volvió elemento escenográfico para generar efectos fotográficos hasta ahora inéditos en la historia del cine: filtrando la luz se disuelven los límites físicos de la arquitectura y del paisaje urbano, afectando también la percepción del tiempo transcurrido.

La noche es un elemento que, como la niebla, genera una suspensión espacio-temporal y borra los límites físicos de la ciudad. A través de la noche se quiere representar la supresión del espacio urbano después de la guerra, "la nulificación icónica del territorio" ${ }^{12}$, un grado cero desde el cual poder empezar a reconstruir. La noche representó la presencia del elemento natural-atmosférico que envuelve a escenario y personaje; en la noche la ciudad se convierte en un paisaje más cercano a una ensoñación, aparecen líneas y puntos luminosos que marcan horizontes y caminos, el espacio se abstrae, y se reduce en sus elementos esenciales.

(F.2.1.5)

12 (Turco, 2004 p.51) 

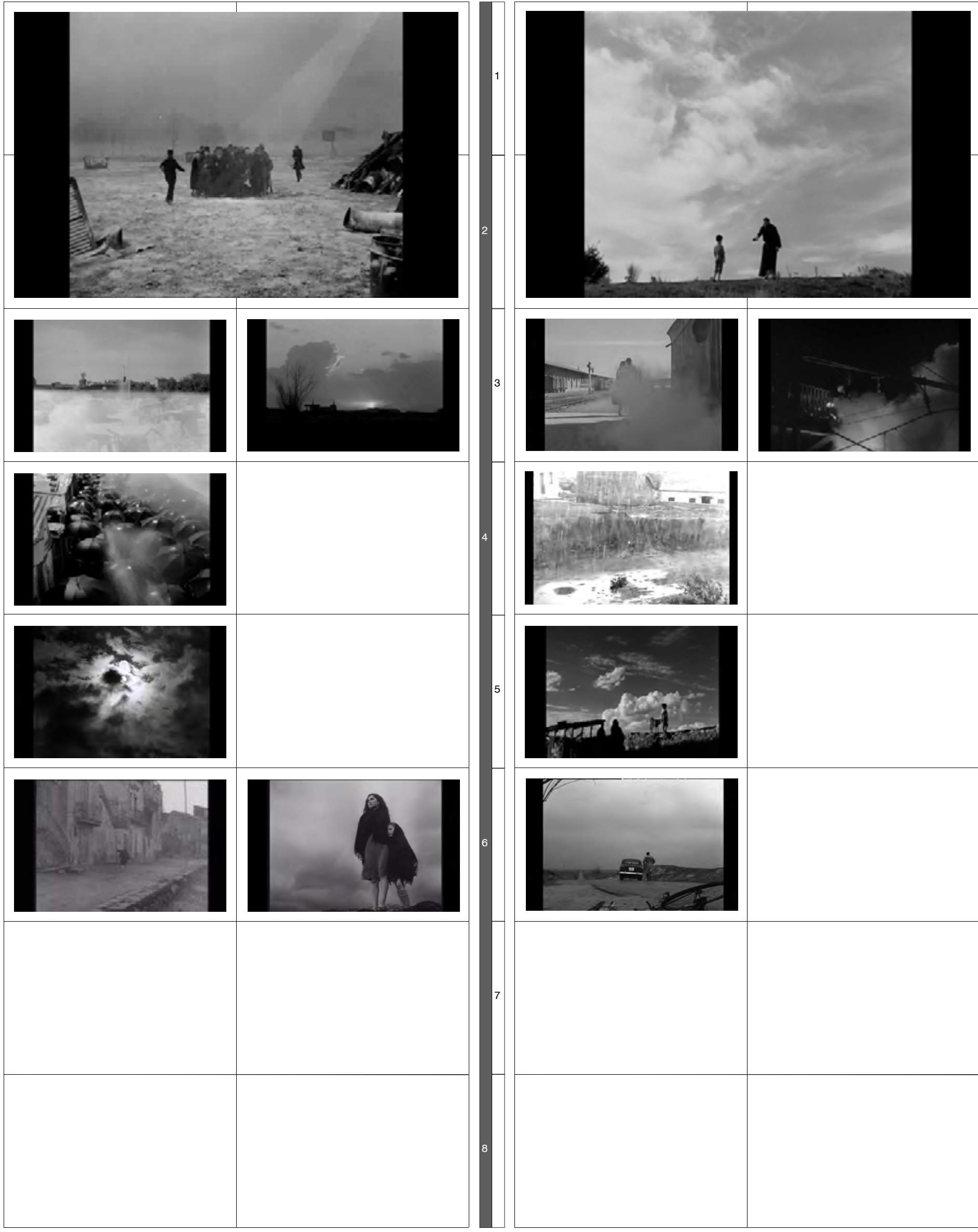

RM 1-2-3-4. Milagro en Milán (De Sica)

RM 5. El Techo (De Sica)

RM 6. La tierra tiembla (Visconti)

MD 1-2. Marcelino pan y vino (Vajda)

MD 3. Calle Mayor (Bardem)

MD 3. Surcos (Nieves Conde)

MD 4. Mi tío Jacinto (Vajda)

MD 5 Marcelino pan y vino (Vajda)

MD 6. Muerte de un ciclista (Bardem)

\section{MADRID}




\subsection{Paisaje - movimiento}

\subsubsection{Movimientos de fondo.}

Deleuze habla de la imposibilidad en el arte cinematográfico de fragmentar el movimiento en poses, "elementos formales transcendentes"; sólo es posible recomponer el movimiento a través de cortes, "elementos materiales inmanentes" ${ }^{13}$. Hay una relación estrecha entre el movimiento y el tiempo: "por una parte, es lo que acontece entre objetos o partes; por la otra, lo que expresa la duración o el todo. Él hace que la duración, al cambiar de naturaleza, se divida en los objetos, y que los objetos, al profundizarse, al perder sus contornos, se reunan en la duración" ${ }^{14}$. Hemos visto, en el párrafo "Paisaje-tiempo", la relación que se establece entre la noción de movimiento, y la duración de este cambio de posición en el espacio. El Cine Neorrealista se diferencia del Cine Holliwodense, por el hecho de que, en el primero, la acción y el movimiento de los protagonistas no llenan todos los encuadres cinematograficos; los personajes se detienen a mirar, se paran para observar las escena y los acontecimientos. En la construcción de la iconografía del paisaje no entendemos, por supuesto, el movimiento así como aparece en las peliculas de Hollywood, sino un "movimiento de fondo", el movimento observado por los protagonistas y que crea una "escenografía", un paisaje en movimiento.

\subsubsection{Ciudad nómada.}

En general podemos definir como "nómada" a la cinematografía neorrealista: los directores, abandonaron los estudios cinematográficos y empezaron a rodar en la ciudad.

Muchos de los protagonistas de las películas analizadas experimentan, aunque sea por un lapso de tiempo limitado, la existencia nómada: "cualquier ciudadano puede convertirse en una criatura errante; él mismo es un mutante: ciudadano urbano y nómada del desierto metropolitano (...) Las criaturas del desierto metropolitano no tienen vida propia, ni tampoco raíces en lugares y territorios. Son criaturas errantes que viven en el espacio y el tiempo de la orilla de la ciudadmutante" 15 .

La Ciudad que perciben y en la cual se mueven es una ciudad distinta a la representada por las películas anteriores al Neorrealismo, que describen un espacio urbano en relación a los "estanciales": personajes que viven la ciudad como algo exterior respeto a su propio hogar, centro y origen de su condición de urbanitas. (F.2.2.2)

En "The new city", Hilberseimer habla de la diferenciación entre cultura sedentaria y cultura nómada. Los sedentarios tienen un sentido del espacio centrifugo, porqué están arraigados en el suelo como árboles y tienen una cultura religiosa de tipo místico, que no tiene distinción entre materia y espíritu, porque para ellos todo tiene un alma, todo es animado. Los nómadas, al contrario, tienen una cultura religiosa de tipo mágico, cada cosa inmaterial es extraña, y se percibe sólo lo que es material y físico. Los animales son el centro de la vida de los nómadas; su concepción del espacio es de tipo centrípeto, sus movimientos libres en el territorio convergen hacia un centro, un espacio que ocupan a través de tiendas y cobijos, cambiando de lugar según las necesidades ${ }^{16}$. La característica cultural que subraya Hilberseimer es la de un profundo sentido de la realidad en oposición a todo lo que es irracional; podemos leer en esta interpretación una analogía con la cultura Neorrealista, que en sus películas favorece el nomadismo en oposición a la cultura estancial.

13 (Deleuze, La imagen-movimiento: estudios sobre cine 1, 1984. P.17)

14 lbídem p.26

15 (Mancini \& Perrella, 1986. P.217)

16 (Hilberseimer, The New City. Principles of Planning, 1944. P.19) 

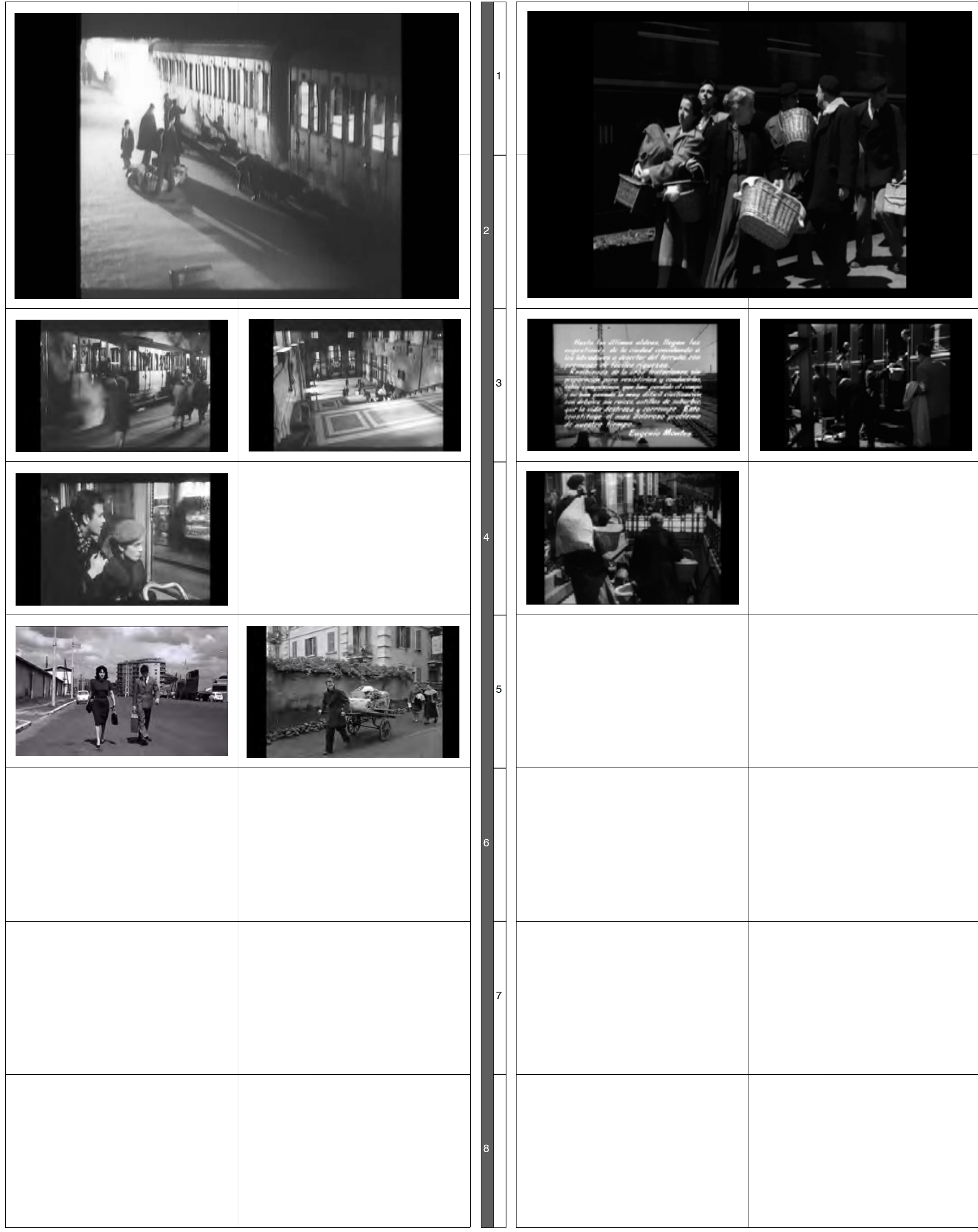

RM 1-2-3-4. Rocco y sus hermanos (Visconti)

RM 5. Mamma Roma (Pasolini)

RM 5. El Techo (De Sica) 
La cultura nómada, desde siempre, se percibe como una condición existencial que niega la arquitectura; ésta según la opinión más común "habría nacido a partir de la necesidad de un espacio del estar en contraposición al nomadismo, entendido como espacio del andar" ${ }^{17}$. En realidad, como subraya Francesco Careri, esta separación tan sencilla y radical no corresponde a la real condición cultural y antropológica que ha generado la arquitectura, y es posible definir una relación profunda entre arquitectura y nomadismo, inclusive replantear el origen de la arquitectura como producto de las culturas nómadas.

En las películas neorrealistas nace una nueva iconografía de la ciudad. La condición nómada de los personajes y sus exploraciones urbanas y suburbanas genera dos tipologías de paisaje que se relacionan el uno con el otro. La primera tipología corresponde al paisaje constituido por los movimientos fuera del protagonista; se trata de un "paisaje transcendente" hecho de mercados, manifestaciones y marchas junto a movimientos de vehículos: carros, trenes y transporte público en general, éste último muy presente en las películas de esta época, en donde los coches privados representan un lujo. La segunda tipología es la de un paisajemovimiento inmanente, y está generada por los desplazamientos de los protagonistas, una dinámica que coincide con la topología de la cámara y los movimientos de los mismos directores en el territorio. Es posible distinguir en esta segunda tipología de paisaje inmanente tres diferentes categorías: la primera, que corresponde al paisaje observado en movimiento, desde un vehículo motorizado; este tipo de paisaje no aparece muy a menudo ya que caminar es la forma más común de desplazarse en estas películas; la segunda corresponde al descubrimiento de un territorio diferente que los personajes exploran, de forma dinámica caminando, corriendo o escapando, como en Ladrón de bicicletas; al ser nómadas urbanos, los protagonistas observan la ciudad a lo largo de sus desplazamientos, desde territorios y puntos de observaciones nuevos y distintos: se trata de los recorridos al borde de la ciudad, en las periferias, a través de los grandes descampados y de los terrenos en construcción.

\subsubsection{Movimiento transcendente: paisaje humano y vehículos}

Según Bazín en las películas Neorrealistas hay una cierta predilección en la descripción de lo individual, "ya que la masa es raramente considerada como una fuerza social positiva. Cuando se la evoca es de ordinario para mostrar su carácter destructor y negativo con relación al héroe: el tema del hombre entre el gentío" ${ }^{18}$.

No cabe duda que después de los eventos masivos del Fascismo, no había mucha intención de representar estos tipos de experiencias espaciales, asociadas a la represión y a la guerra; todavía esta iconografía está presente en las películas neorrealistas, cobrando otro valor y significado. (F.2.2.3/1). En la película documental Días de gloria, en el cine-periodismo de los NO-DO o en el episodio romano de Paisá, las masas de personas, a pesar de los distintos significados políticos, está presentes en comicios y celebraciones; sin embargo, en la mayoría de las películas de ese tiempo, este elemento iconográfico cambia de valor, ajustándose a la reflexión de Bazín, y las masas se representan en oposición al individualismo de los protagonistas.

\footnotetext{
17 (Careri, 2002 p.28)

18 (Bazin, 1990 p.293)
} 

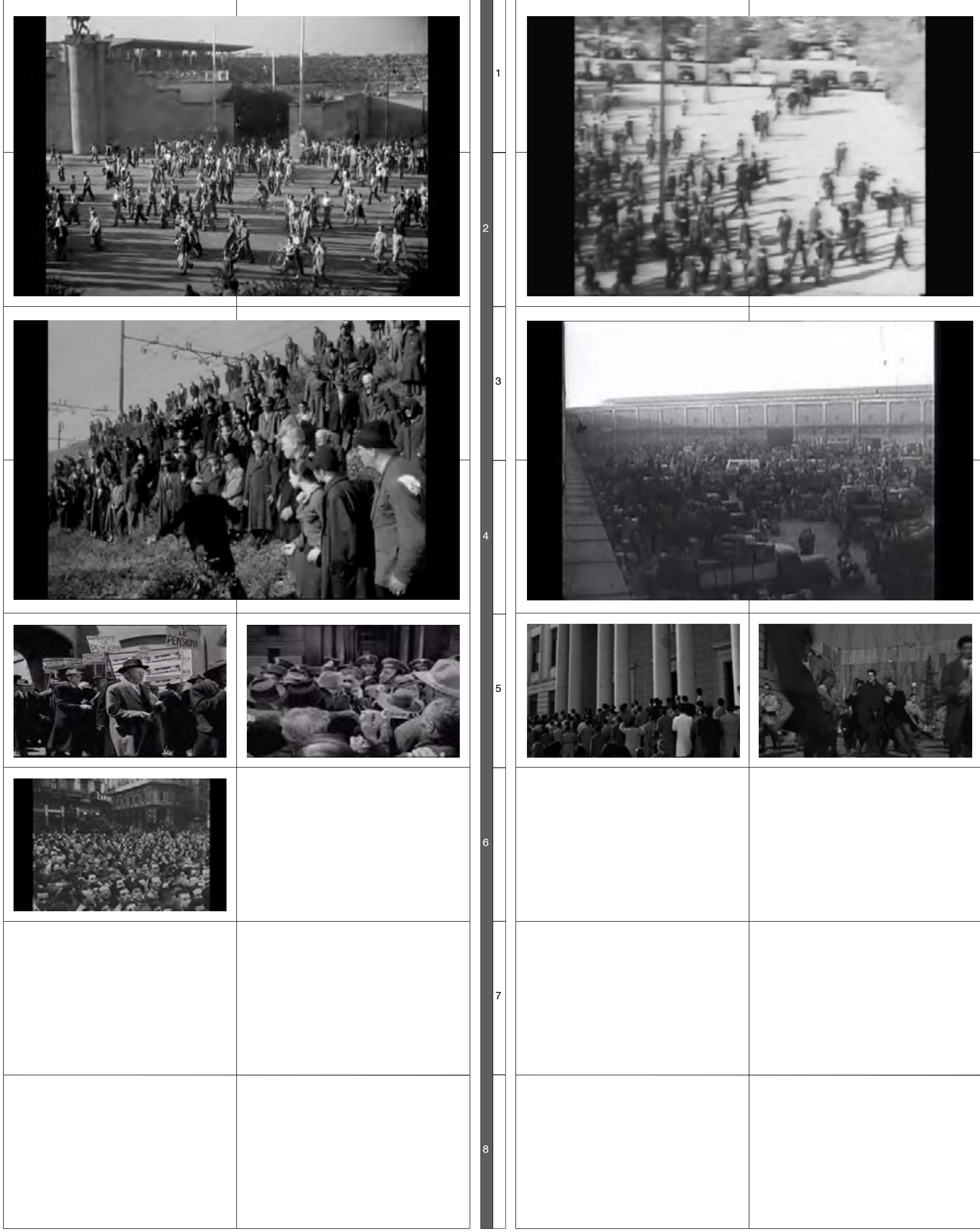

RM 1-2. Ladrones de bicicletas (De Sica)

RM 3-4. Milagro en Milán (De Sica)

RM 5. Umberto D. (De Sica)

RM 6. Días de gloria (A.A.V.V.)
MD 1-2-3-4. Los Golfos (Saura)

MD 5. Muerte de un ciclista (Bardem)

MD 5. Flores de Luna (Cordoba) 
En Humberto $D$, la secuencia inicial de la protesta de los jubilados es funcional a su epilogo, en el cual los manifestantes son dispersados por los policías y el protagonista regresa a su soledad, que parece más intensa.

Marchas, mítines, colas, peleas, y manifestaciones, que ocupan los grandes vacíos de plazas, calles, y avenidas, también describen una ciudad viva, una imagen de movimientos desordenados, muy distinta a los comicios del fascismo y del franquismo; una imagen urbana profundamente viva y reactiva que se convierte en paisaje dinámico que se describe con tomas largas, o panorámicas, ocupando todo el encuadre; las plazas y las calles se convierten en lugares de permanencia y/o desplazamientos, cobran vida a través del movimiento de las multitudes o de los protagonistas que buscan el paso en ellas.

La iconografía urbana del movimiento se manifiesta también a través de las actividades productivas o de ocio que se desarrollan en la ciudad; terrazas de bares, cafés y restaurantes, las bodegas que se relacionan con el exterior a través de sus escaparates y de los movimientos de entradas y salidas de los clientes generan movimientos menos impactantes de los producidos por las multitudes pero más frecuentes, relaciones que describen la imagen de una ciudad que vive en los exteriores, calles y plazas, en las banquetas y en los patios de las viviendas-corralas en donde los niños también pueden moverse, desplazarse jugar o buscarse la vida.

Por último, podemos hablar de una iconografía de las multitudes en total antítesis con la del pasado, analizando las descripciones en campo total de fiestas, procesiones y sobre todo mercados. Este último es un escenario muy presente en la cinematografía neorrealista; en Roma desde Ladrón de Bicicletas hasta Mamma Roma, en Madrid desde Mi Tío Jacinto hasta Los golfos el mercado es un lugar "nudo", en donde los protagonistas se pierden y se encuentran entre la multitud. Los mercados de Porta Portese en Roma y del Rastro en Madrid son escenarios tópicos y se repiten en diferentes películas analizadas.

\section{VEHICULOS}

Hablando de la introducción del ferrocarril en Europa a principios del siglo XIX, Michael Jakob señala cómo el tren modificó para siempre la percepción del paisaje. Por un lado, una serie de infraestructuras como puentes, viaductos y túneles transforma materialmente el medio natural y la imagen de la ciudad, por el otro la posibilidad de observar desde el tren un paisaje en movimiento genera una nueva estética cinética, un paisaje-película. La iconografía del tren y, a partir de la posguerra, la del coche, modificarán para siempre la imagen pintoresca del paisaje estático e idílico, nace una estética efímera e inestable, un paisaje que se relaciona con el paso del tiempo ${ }^{19}$ (F.2.2.3/2).

Esta nueva iconografía de una ciudad de vehículos motorizados se refleja en la iconografía neorrealista a través de líneas e infraestructuras que marcan el territorio, generando espacios residuales, barreras y líneas de vehículos en movimiento., líneas humeantes como las generadas por los trenes Las calles empiezan a convertirse en lugares en donde los peatones entran en conflicto con los vehículos y estas luchas aparecen en las pantallas. Los vehículos motorizados poco a poco modificarán la imagen de las periferias urbanas que se construirán a medida del coche. En las películas Neorrealistas aparece este cambio, de una ciudad para andar a una ciudad para desplazarse a través de vehículos motorizados.

\footnotetext{
${ }^{19}$ (Jakob, 2009 pp.112-113)
} 

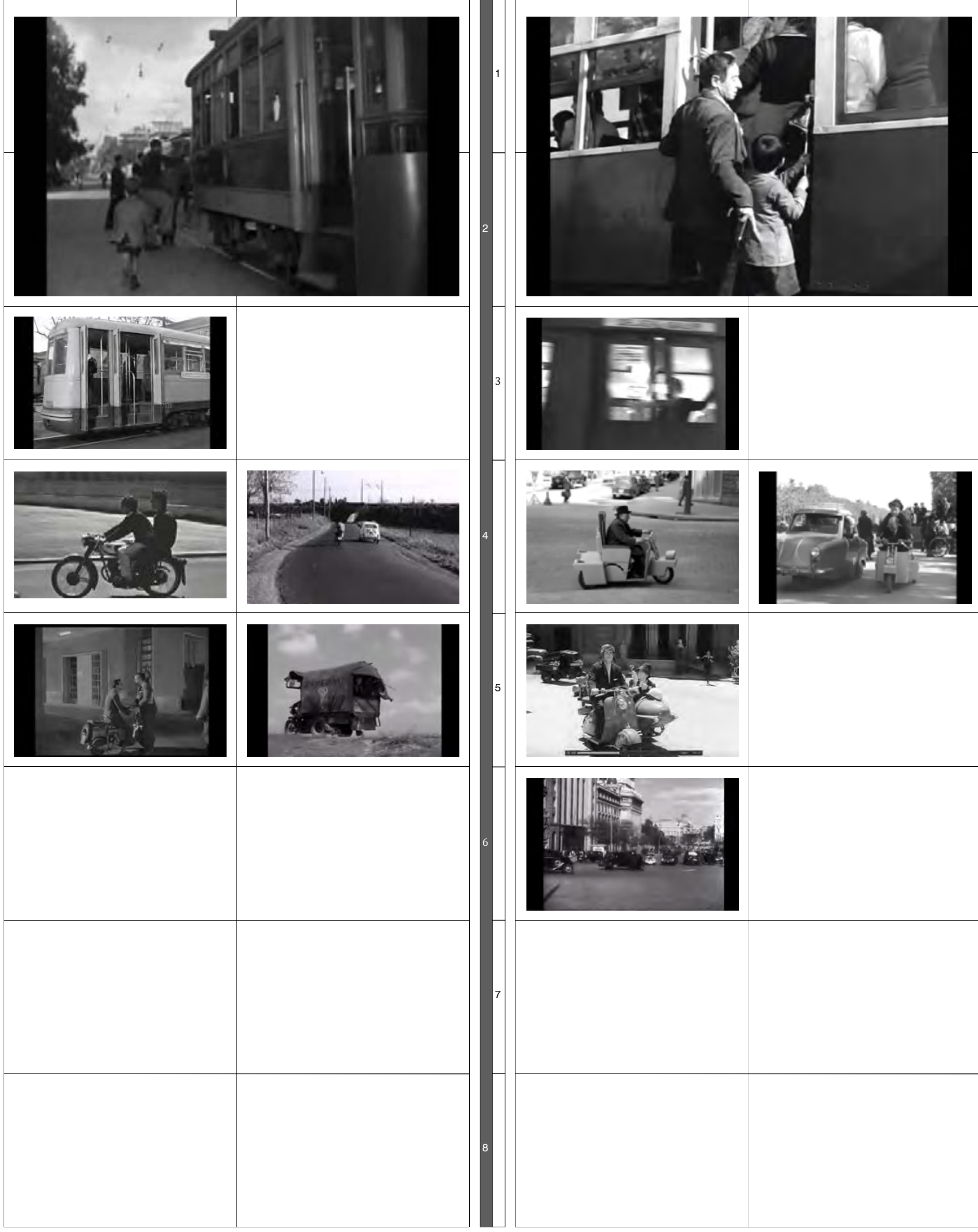

RM 1-2. Ladrones de bicicletas (De Sica)

RM 3. El Techo (De Sica)

RM 4. Mamma Roma (Pasolini)

RM 5. Bellissima (Visconti)

RM 5. La Calle (Fellini)

MD 5. El Verdugo (Berlanga)

MD 6. El Último Caballo (Neville)
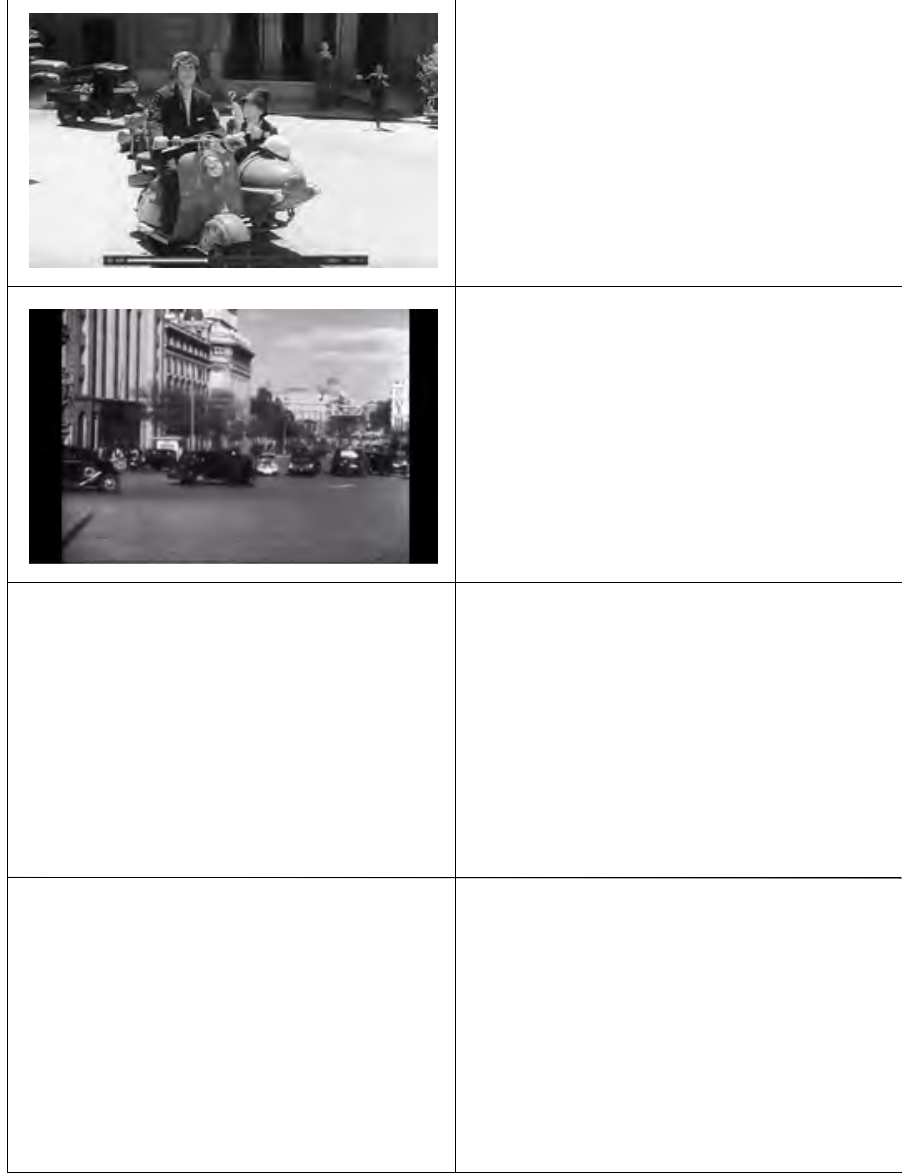
En películas como El último caballo, esta transición es el tema central de la película, el desplazamiento a caballo del protagonista por la Gran Vía genera un atasco, que nos habla de la victoria de los coches sobre cualquier otra forma de desplazarse. Los nómadas urbanos se desplazan andando o con medios públicos de transporte, tranvía, autobuses y metro, que son la única forma de llegar al centro de la ciudad. El tranvía es el vehículo protagonista del Neorrealismo en Roma y Madrid: aparece en diferentes películas al ser el medio de transporte más económico.

En El Pisito, de Ferreri, el tranvía llega al barrio de Carabanchel cruzándose con una grey de ovejas, el mismo contraste entre el mundo rural y urbano que hemos visto en El último caballo, y que encontramos también en el uso frecuente que los personajes de estas películas hacen de carros de madera para transportar objetos, herramientas del mundo campesino, que contrastan con la vida metropolitana. En El cochecito, también de Ferreri, el deseo del protagonista por el pequeño triciclo motorizado, no solamente es la necesidad de ser aceptado entre sus amigos, sino también el deseo de fuga y de libertad, la voluntad de recorrer a velocidad los territorios abiertos fuera de la ciudad, el Retiro y los desiertos metropolitanos, como los que poseen un coche para convertirse en un ciudadano moderno.

\subsubsection{Movimiento inmanente: viajes, llegadas y derivas}

\section{LLEGADAS}

La Ciudad Neorrealista es un territorio desconocido y los migrantes que llegan por primera vez necesitan explorarlo; tampoco es conocida por los que nacieron en ella, porqué su constante crecimiento modifica sus límites externos, y los derribos su imagen interna. La ciudad se vuelve un territorio hostil para los que llegan de fuera: se desconocen las reglas implícitas de la vida urbana, las reglas no escritas, hechas por los que desde siempre han vivido en la ciudad, como describe Pierre Sorlin en su análisis de las desaventuras del protagonista de Ladrón de bicicletas, probablemente emigrado desde el campo a la ciudad ${ }^{20}$.

La llegada y el viaje son elementos iconográficos importantes que aparecen en la mayoría de las películas analizadas. La memoria de la primera migración hacia la ciudad se convierte en una imagen-recuerdo a través de la iconografía frecuente de lugares que hacen alusión al viaje: estaciones, ferrocarriles, carreteras y el paisaje infraestructural en general. Al mismo tiempo los movimientos que los personajes cumplen dentro del espacio urbano son verdaderos viajes, por ser excluidos de la ciudad: se trata de trayectos muy largos, no solamente por la distancia física, sino también por la condición de distancia cultural, psicológica y económica.

En Surcos y en Rocco y sus hermanos, dos películas con historia muy parecida, una familia campesina llega en la grande ciudad -Madrid en Surcos, Milán en Rocco y sus hermanos-, y se enfrenta a las dificultades de la vida urbana, conociendo corrupción y vicios, sin por eso poder evitar un destino trágico. En los fotogramas iniciales de Surcos, el tren que llega a la estación de Madrid, deja a la familia en el andén, en una atmósfera de miedo, excitación e incertidumbre. La cámara encuadra unos bultos de la familia y registra la presencia de una gallina. Nieves Conde sigue el recorrido de la gallina junto a la familia, en este primer viaje en la ciudad. Después de la estación la familia baja en la estación de metro, una boca oscura que los lleva a una dimensión desconocida; en el coche del tren su condición de migrantes es imposible de esconder, la gallina la pone en evidencia frente a las risas de los usuarios, una dureza y un destino de discriminación que parece ya definido desde estas primeras escenas. 
La película de Visconti, aunque ambientada en Milán, contiene elementos útiles también para la realidad de Roma. Seguramente la ambientación milanesa era más adecuada para alimentar el fuerte contraste entre el origen meridional y campesino de los protagonistas y la realidad de la Milán industrial, fría y dura descrita en la película. "La Milán de Rocco es realista, violenta, así como aparecía a los inmigrados meridionales en aquel periodo. Los lugares como la catedral, la base de hidroaviones, son arquetipos de un paisaje inmueble, indiferente al drama, como en toda la tragedia clásica" 21.

La llegada de la familia y sus futuras dificultades están expresadas en la película de Visconti a través de una toma desde arriba, de la doble altura del vestíbulo de la estación central, que con su escala monumental contrasta con la familia recién llegada que aparece minúscula en el encuadre, moviéndose con incertidumbre y dificultad con sus trajes negros típicos de las regiones sureñas.

Las migraciones permiten también una visión crítica hacia la ciudad que enriquece su iconografía, su forma de ser percibida y analizada. El cine permitía cristalizar esta mirada llevándola a la pantalla, dándole la dignidad que no tenía en la vida real, y alimentando el debate sobre la ciudad.

El movimiento inverso, de la ciudad al campo, se ve en la película de De Sica, El techo, y sirve para confirmar que la migración a la ciudad era la única solución posible para una vida más digna. Un paisaje arcaico es el escenario que la pareja recién casada, protagonista de la película, encuentra en la visita que hace a la familia de la esposa; la mirada de los jóvenes al observar los duros trabajos domésticos de la madre, la sensación de extrañeza al llegar al pueblo con su arquitectura vernácula y su escasez, cuenta de una imposibilidad de regreso, por una alteración cultural que ha cambiado definitivamente a una generación, se trata de lo que Pasolini describe como un genocidio, lo que el Fascismo no había podido, lo logró el consumo y los modelos de vida burgueses. La imposibilidad de hablar con el padre pescador, enfadado con la hija que no pidió permiso para casarse, en la escena en la cual los jóvenes van a la playa para una reconciliación, describe esta imposibilidad de regresar, una ruptura definitiva con el mundo rural; De Sica a pesar de la mirada indulgente hacia los jóvenes, no esconde en esta escena una mirada nostálgica hacia la vida digna del padre y la belleza del paisaje marino. En el viaje de regreso hacia Roma este paisaje arcaico se convierte en lo de la Tuscolana, en la mirada de los jóvenes a través de la ventanilla, un paisaje que exalta a los jóvenes, felices de regresar, aunque sea el paisaje de los suburbios ${ }^{22}$.

\section{DESDE VEHICULOS}

La mirada hacia el paisaje, en el viaje de regreso a la ciudad de los protagonistas de El techo se fracciona a través de las ventanillas del autobús: aparecen unos frames que se relacionan con el movimiento y con el tiempo del recorrido. Así el encuadre-ventanilla creado por De Sica, nos cuenta la modificación de un paisaje desde el pueblo de la familia de la esposa, hacia Roma; desde las chozas de paja en el litoral romano, hacia los edificios en construcción de la vía Tuscolana, una separación de un mundo arcaico y opresivo que los dos viven con entusiasmo y felicidad, el todo a través de una secuencia de frames desde el transporte público. Este mismo entusiasmo lo volvemos a encontrar en Rocco y sus hermanos, la imagen de una Milán nocturna evanescente por la lluvia y las luces de los escaparates que seducen los protagonistas. En Surcos, la imagen de la llegada de la familia a la estación de Madrid, es anticipada por la imagen del paisaje en movimiento bajo los títulos iniciales; en esta secuencia

${ }^{21}$ (Licata \& Mariani Travi, 1985 p.24)

${ }^{22}$ Para los fotogramas de la llegada de las dos familias en Madrid y en Milán: cap. 1 (F.1.2.2/2) 
la cámara está montada en la cabeza del tren, casi una toma subjetiva del maquinista que transporta a los protagonistas y que representa la transición de lo rural a lo urbano; una secuencia parecida a la del El techo de De Sica, pero en donde no podemos averiguar si los protagonistas están mirando lo que ven los espectadores, si el paisaje se revela a los protagonistas de una forma tan impactante como en las tomas de Nieves Conde. (F.2.2.4/1)

\section{DERIVAS}

En la Ciudad Neorrealista "cualquier ciudadano puede convertirse en una criatura errante(...)y nómada del desierto metropolitano" ${ }^{23}$. Con estas palabras Mancini y Perella en su trabajo de investigación Arquitecturas de la visión describen las características de los habitantes de la ciudad desertizada, descrita en las películas de Michelangelo Antonioni.

Utilizamos el término nómada y derivas, para describir los personajes y sus recorridos urbanos en las películas italianas y españolas analizadas; considerando el término deriva según las características que hemos analizado en el primer capítulo hablando del Situacionismo.

Los movimientos que los personajes cumplen, son de tipo pendular entre centro y periferia, o interesan exclusivamente a la periferia. Con El techo de De Sica, la acción se traslada definitivamente a la periferia, la que Sorlin define como "imagen borrosa de la ciudad". Más adelante en la cinematografía italiana y española se harán muy frecuentes los movimientos dentro de la periferia, en los bordes de la ciudad. Pocas veces los protagonistas, como en el caso de La calle de Fellini, son verdaderos nómadas, casi siempre se trata de una condición temporal y forzosa, debido a una búsqueda o a una pérdida. A veces se trata de un gesto de rechazo hacia la vida urbana debido a un episodio de fracaso y/o desilusión, como en Mamma Roma, o en Surcos, en donde los protagonistas se refugian en los territorios de la incertidumbre y de la informalidad, los descampados y los asentamientos informales, buscando otros estilos de vida, lejos de las instituciones.

Los vagabundeos de Accattone rodado en 1961 por Pasolini, también tienen que ver con la búsqueda de territorios libres del control legal, espacios fuera de la dimensión infraestructural y planeada de la ciudad, espacios de informalidad, que mantienen una dimensión popular y auténtica a pesar de la pobreza y del descuido. A veces el nomadismo corresponde a la búsqueda de un hogar y de un terreno, como en el viaje de los protagonistas de Pajaritos $y$ pajarracos donde padre e hijo emprenden una larga caminata hacia Roma para pedir una moratoria en el embargo de una pequeña finca; se trata de un viaje surreal en una Roma periférica que ya ha perdido su identidad geográfica con carteles que indican destinos improbables (Estambul $4.253 \mathrm{Km}$. y Cuba a $13.257 \mathrm{Km}$.). La pérdida de "la forma de la ciudad" que Pasolini denunciará en algunos documentales posteriores.

\footnotetext{
${ }^{23}$ (Mancini \& Perrella, 1986. P.217)
} 

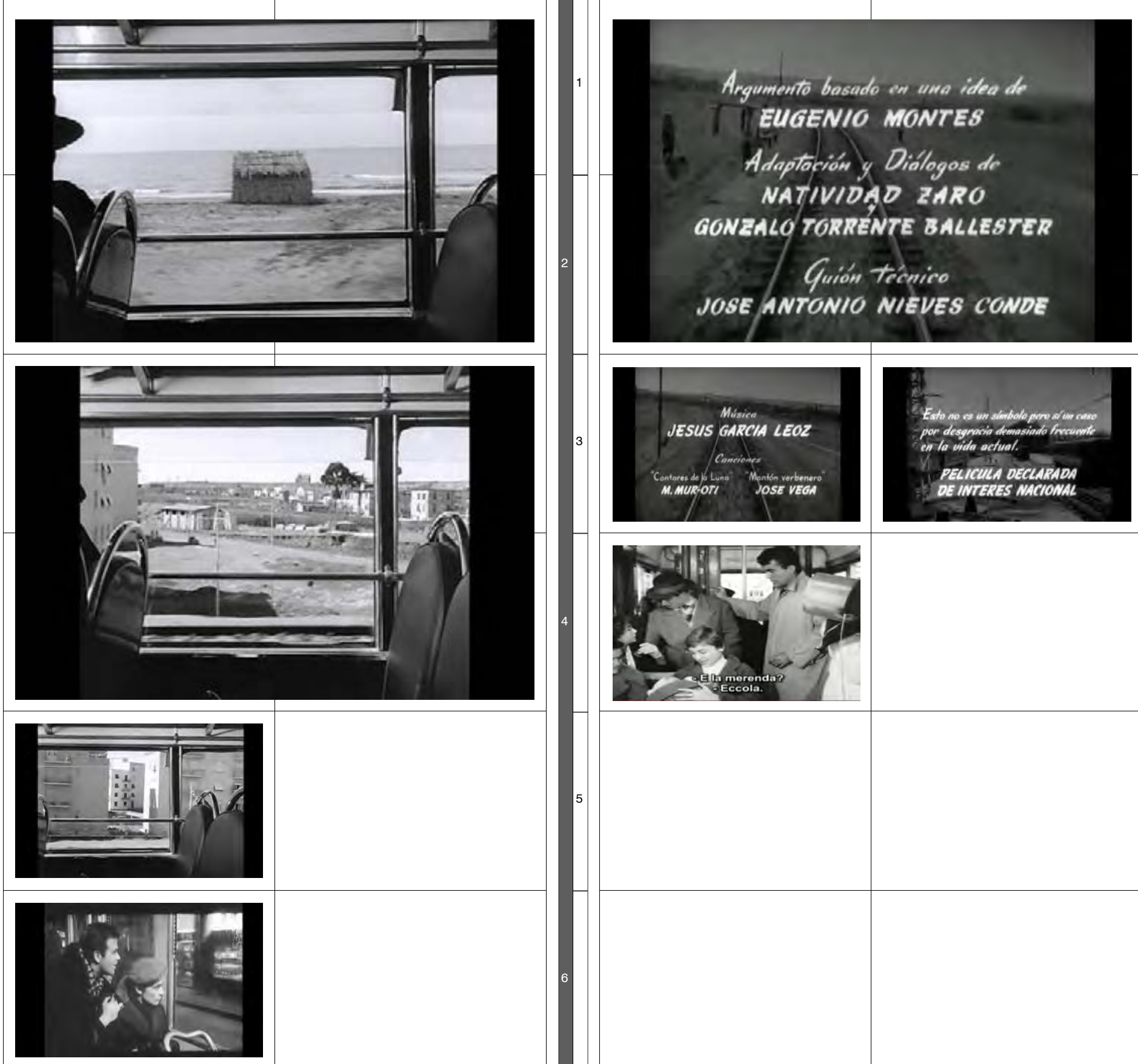
La búsqueda de una demora puede ser extenuante, al punto que los protagonistas se arriesgan a dormir en la calle, esto pasa en El inquilino, en El pisito, en El techo y en Milagro en Milán, en donde el personaje principal Totó, después de largos recorridos en el centro, recién salido del orfanato, llega a su futuro barrio, un terreno totalmente baldío en donde se acampa, esperando construir su chabola. A veces el nomadismo depende de una búsqueda de dinero o de trabajo, como en Mi tío Jacinto en el cual los protagonistas todos los días llegan al centro desde el arrabal donde viven, en búsqueda de sustento; es un desplazamiento en tranvía que parece un largo viaje, sobre todo por las diferencias entre el lugar donde viven y la ciudad.

En Ladrón de bicicletas, los recorridos urbanos se en una verdadera odisea neorrealista, en donde el regreso a casa no se puede producir hasta haber cumplido con el desafío de recuperar la bicicleta robada. La búsqueda de padre e hijo, se convierte en un largo recorrido en territorios desconocidos, una Roma que aparece vasta y compleja. En esta cinta, como en pocas anteriores en la historia del $\mathrm{cine}^{24}$, por un par de días, los protagonistas hacen de la ciudad entera su demora; todas las emociones, las necesidades, los conflictos padre e hijo, se producen en el ambiente urbano exterior que coincide con las calles y los barrios de Roma.

Los movimientos pendulares centro-periferia son trayectos muy largos, difíciles de recorrer en un solo día; los protagonistas entonces, buscan terrenos baldíos, parques y espacios residuales escondidos en la vegetación, para descansar y esperar. Estos territorios marginales se convierten en el centro de la acción en algunas películas como en La historia de Caterina de Citto Maselli, episodio contenido en la película colectiva El amor en la ciudad, de 1953, en donde la madre soltera duerme en parques y en descampados en espera de encontrar el trabajo que le permitiría salir adelante. Cuando decide dejar a su niño, lo hace dentro de un parque en un barrio de la burguesía romana, escondiendose entre la vegetación para controlar que todo salga bien. A lo largo de todo el episodio, se describe su vida como una vida "fuera de la ciudad", a pesar de estar en ella; la necesidad de vivir clandestinamente, por la falta de trabajo, la convierte en un nómada, que prefiere los territorios no urbanizados, con vegetación, en donde es más fácil esconderse y seguir esperando que "ingresar" a la verdadera ciudad.

En el espacio urbano renovado por la noche, que envuelve la ciudad y modifica su percepción, los protagonistas producen sus derivas nocturnas, como los paseos nocturnos en El último caballo o Mamma Roma. En estos paisajes nocturnos, la suspensión física y temporal de la ciudad, facilita la introspección psicológica, el fluir de los pensamientos y de las frustraciones, como en el paseo de Anna Magnani con su hija en las escenas finales de Bellisima de Visconti, el regreso a casa que las dos protagonistas retrasan, paseando en los suburbios recién construidos y bien iluminados, hasta llegar a un pequeño parque desierto, sin vegetación y una tienda de circo al fondo, metáfora de la ilusión y de la falsedad del mundo del Cine que acaba de decepcionar a las protagonistas.

Aunque en el Neorrealismo hay una profunda búsqueda de congruencia entre geografía urbana y rodaje, no siempre los desplazamientos de los personajes siguen una lógica de coherencia. Las ambientaciones corresponden a los requerimientos estéticos y narrativos de los directores o a veces de economía y comodidad; por esa razón encontramos a las playas de Emilia Romagna en el litoral Romano en Los inútiles, o una iglesia milanesa en la periferia de Roma en Rocco y sus hermanos. La búsqueda de la bicicleta en Ladrón de bicicletas, así como el recorrido de los protagonistas de Surcos, nos permite reconstruir una Psico-geografía neorrealista, una imagen de Roma y de Madrid como un enorme collage de fragmentos (F.2.2.4/2).

\footnotetext{
${ }^{24}$ Un antecedente importante podría ser "The kid" de Charlie Chaplin, de 1921.
} 

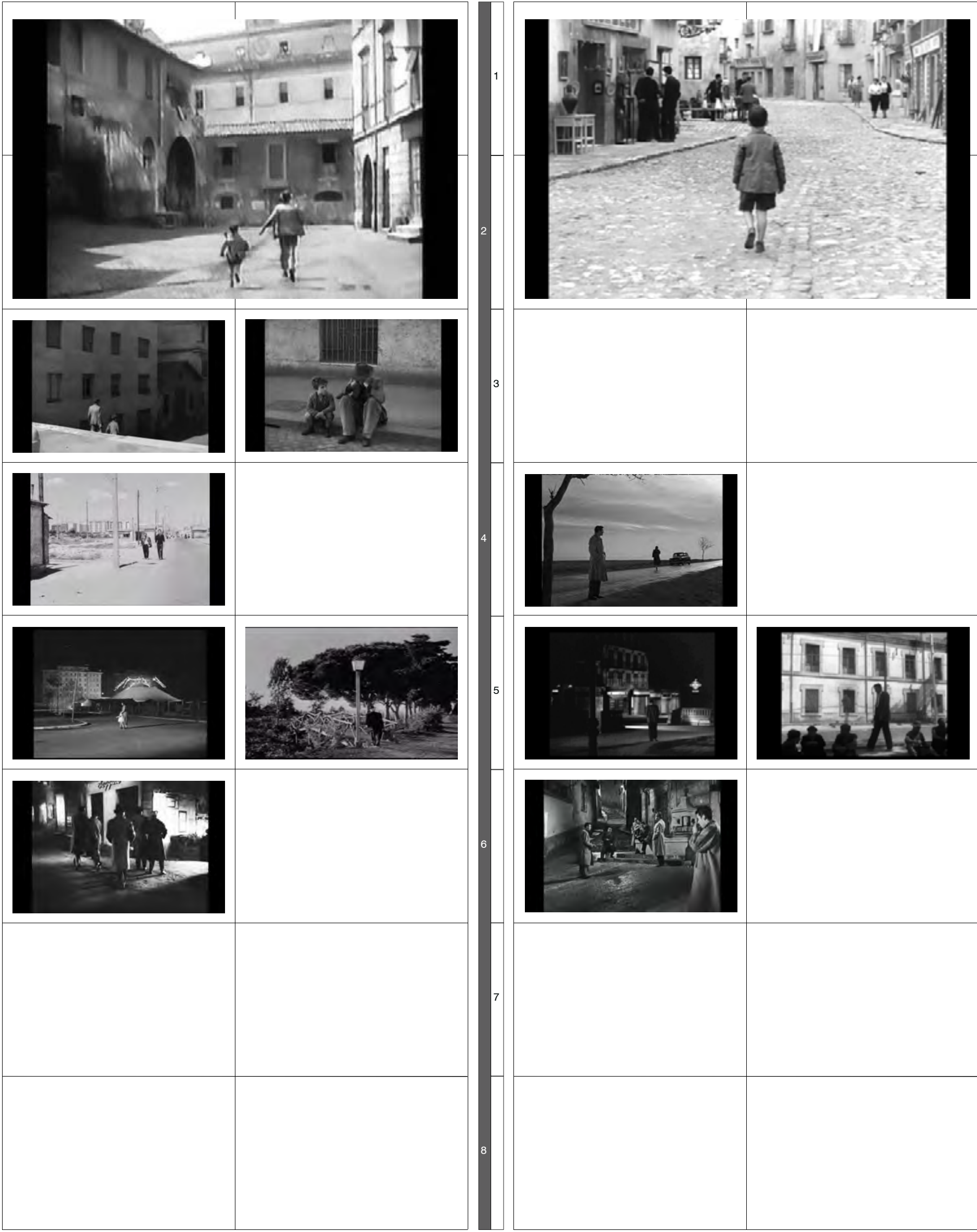

RM 1-2-3. Ladrones de bicicletas (De Sica)

RM 4. Accattone (Pasolini)

RM 5. Bellissima (Visconti)

RM 5. Umberto D. (De Sica)

RM 6. Los Inutiles (Fellini)

MD 5. Surcos (Nieves Conde)

MD 3. Calle Mayor (Bardem) 


\subsection{Paisaje palimpsesto: infraestructuras urbanas y naturales}

Reducida a una baba oscura, / una huella en las zanjas recién / excavadas, en la toba - abatida toda rabia / de destrucción - trepa contra ralos edificios / y pedazos de cielo, inanimada, / una excavadora... ${ }^{25}$

\subsubsection{Superposición y transcripción}

La palabra palimpsesto proviene del griego antiguo $\pi \alpha \lambda i \mu \psi \eta \sigma \tau o v$, que literalmente significa grabado nuevamente y se aplica a algo que, en su momento actual, muestra trazos de algo anterior. En geología, por ejemplo se llama palimpsesto a un cauce cuyo patrón de drenaje ha sido modificado súbitamente (en relación al tiempo geológico), pudiendo evidenciarse ambos patrones como resultado del proceso ${ }^{26}$. La condición de palimpsesto es presente en el paisaje urbano neorrealista al estar la ciudad interesada por fenómenos de expansión rápida; es muy común por esta razón la presencia de territorios agrícolas o de pastoreo junto a líneas de tranvía (El pisito);de asentamientos irregulares juntos a armazones de hormigón (El techo); fragmentos de paisaje natural que poco a poco se van deteriorando por la presencia del hombre y que mantienen la condición rural dentro del contexto urbano (El último caballo y Mamma Roma). En este constante proceso de escritura y reescritura, es posible identificar líneas y trazados que definen las morfologías de los territorios urbanos y que podemos catalogar en dos tipologías: las naturales y las artificiales. En las primeras consideramos todos los elementos geológicos, hidrológicos y de la vegetación; en las segundas incluimos las infraestructuras de la ciudad y sus sistemas de producción.

\subsubsection{Infraestructura natural: topografía, vegetación, ríos y canales.}

\section{TOPOGRAFÍAS Y SUELOS.}

En muchas películas los protagonistas alcanzan cumbres y zonas elevadas para observar la ciudad identificando la línea del cielo. Las características topográficas de Roma y Madrid, junto a los movimientos de los protagonistas que se producen desde el interior hacia el exterior menos urbanizado de la ciudad, facilitan la percepción de la ciudad como paisaje urbano, según las condiciones de alejamiento que describe Michel Jakob; una secuencia paradigmática de esta necesidad de reflexión a través del alejamiento puede considerarse la última escena de Roma, ciudad abierta con los niños bajando de una ladera y mirando San Pedro desde el norte de la ciudad: una iconografía de Roma potente e inédita.

Los espacios recorridos por los protagonistas se presentan como paisajes secos, con una vegetación escasa y topografías irregulares, que casi revelan la condición geológica de las ciudades: se trata de las laderas que aparecen en las películas en proximidad de un río (EI techo) o que esconden los barrios chabolistas (Cerca de la ciudad, Mi tío Jacinto, etc.), desvelando las estratificaciones del terreno. A veces esta topografía irregular es el resultado de la acumulación de desechos, como aparece en la secuencia de un niño jugando entre escombros en la escena de la cita del protagonista Vittorio con Stella en Accattone. Las laderas son fronteras y marcan la separación entre dos mundos el informal y el formal. La informalidad a veces solo corresponde a un terreno elevado en el cual descansar y hablar como en algunas secuencias de El pisito y de El techo, otras veces se trata de una ladera con un puente que conecta dos áreas de la ciudad formal (F.2.3.2/1).

\footnotetext{
${ }^{25}$ (Pasolini, La religión de mi tiempo, 1997 p.21)

${ }^{26}$ Fuente R.A.E. y Wikipedia
} 

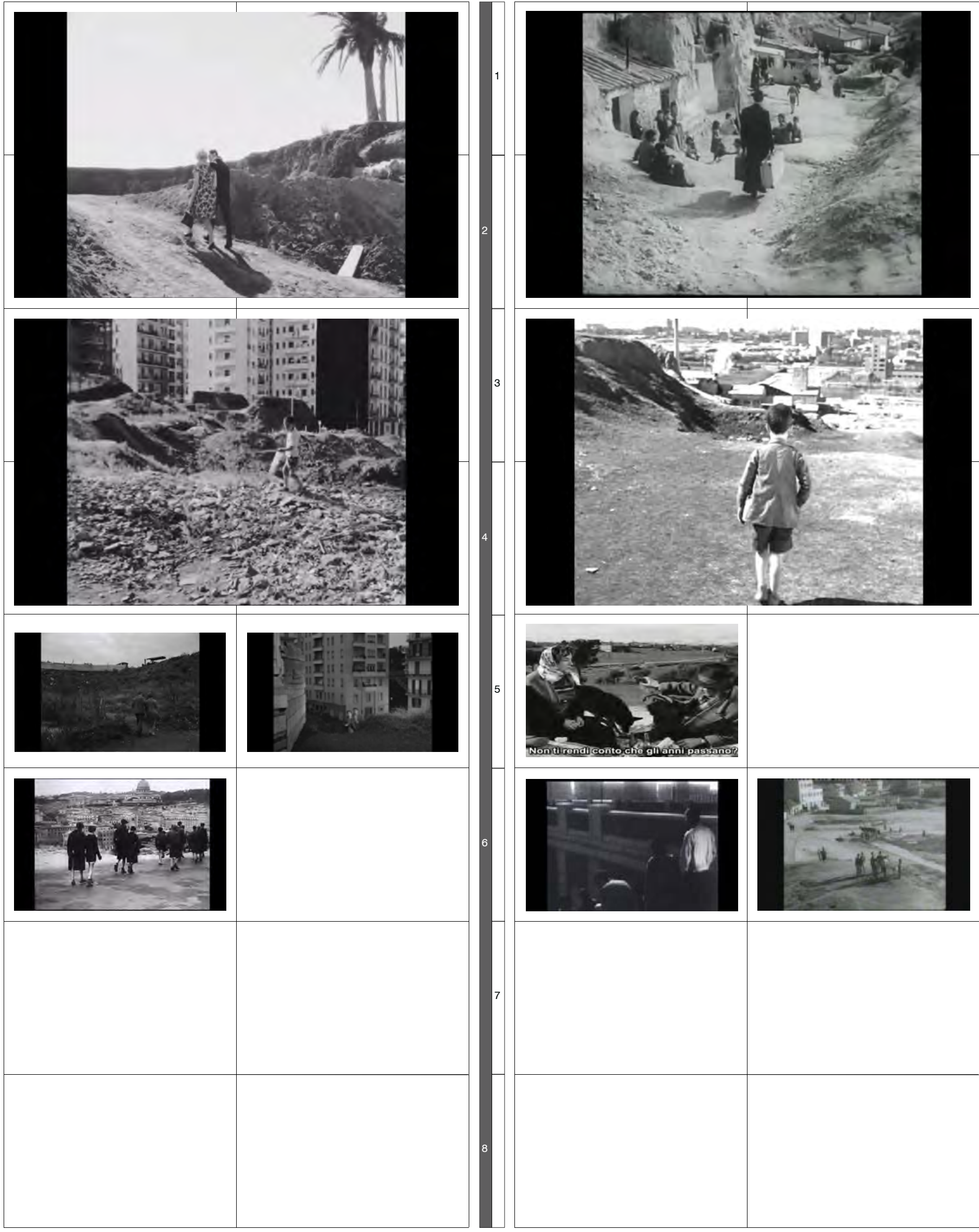

RM 1-2. Accattone (Pasolini)

RM 3-4. Accattone (Pasolini)

RM 5. El Techo (De Sica)

RM 6. Roma ciudad abierta (Rossellini)
MD 1-2. Cerca de la ciudad (Lucía)

MD 3-4. Mi tío Jacinto (Vajda)

MD 5. El pisito (Ferreri)

MD 6. Los Golfos (Saura) 
Por abajo del puente se asientan los barrios de chabolas como los del antiguo arroyo de La Elipa, el hogar de los cinco protagonistas de Los golfos de Saura.

\section{VEGETACIÓN: PARQUES URBANOS Y SUBURBANOS.}

La existencia de espacios no-construidos dentro de la ciudad compacta, corresponde a diferentes manifestaciones del medio natural dentro de la ciudad. "De los prados de los alrededores de la ciudad a los parques-oasis del centro, el desierto metropolitano traza lugares donde predomina el vacío y el no-construido, espacios abiertos al errar, que se prestan a los encuentros casuales (...). Los parques pueden mostrarse como espacios de las transparencias, de la pura visibilidad, páginas blancas de lo urbano donde el paso por la grava no deja huellas" ${ }^{27}$.

En este trabajo de investigación interesa la relación vacío-construido al margen de la ciudad más que en su centro, donde los vacíos son los de los parques urbanos. Aunque algunas ambientaciones, sean los jardines, y las avenidas del centro, el espacio natural y la vegetación más representada en la Ciudad Neorrealista corresponde a los territorios en los límites de la mancha urbana, umbrales entre naturaleza y ciudad, un paisaje que "Ilama a la mente la idea de autonomía y libertad" 28 En las pocas escenas ambientadas en parques urbanos hay dos diferentes iconografías: el parque como interrupción de la narración y momento de reflexión y drama, que encontramos más en el Cine Italiano (Amor en la ciudad, Humberto $D$ ) y el parque como diversión que encontramos también en el Cine español (El cochecito, El verdugo). Se trata de parques como lo de Villa Borghese, el Retiro, la pradera de San Isidro y la Casa de Campo (F.2.3.2/2).

\section{AGUA: RÍOS, CANALES, LAGUNAS}

La zona del Norte de Italia alrededor del delta del Po tiene suma importancia para la cinematografía Neorrealista y, como ya se ha analizado, cuatro películas son ambientadas en este lugar ${ }^{29}$. Se trata de un paisaje totalmente horizontal que se carga de valores simbólicos: en Paisá, de Rossellini tiene un papel determinante en la narración en el último episodio de los seis que articulan la película. En la escena inicial aparece un partisano asesinado navegando en las aguas del Río Po, con un siniestro cartel aplicado por sus asesinos, los nazistas: el flotar del cuerpo sin vida en el río turbio prepara al espectador al drama que se desarrolla en las siguientes escenas. En otra secuencia del mismo episodio, los protagonistas tienen que mantener baja la cabeza para no ser balaceados por los nazis, aplastados entre cielo y agua, entre la cámara y la línea de horizonte. André Bazin describe esta condición en algunas de sus célebres páginas sobre el neorrealismo italiano:

"la participación dramática del pantano es debida en gran parte a ciertas cualidades muy intencionadas de la toma de vistas. Por eso la línea del horizonte está siempre a la misma altura. Esta permanencia de las proporciones entre el agua y el cielo a través de todos los planos del filme pone de manifiesto una de las características esenciales de ese paisaje. Es el equivalente exacto, las condiciones impuestas por la pantalla, de la impresión subjetiva que deben tener unos hombres que viven entre el cielo y el agua y cuya vida depende constantemente de un ínfimo desplazamiento angular con relación al horizonte".

\footnotetext{
27 (Mancini \& Perrella, 1986 p.215)

28 (Jakob, 2009 p.129)

29 "Gente del Po" y "Crónica de un amor" de Antonioni, "Obsesión" de Visconti y "Paisá" de Rossellini.
} 

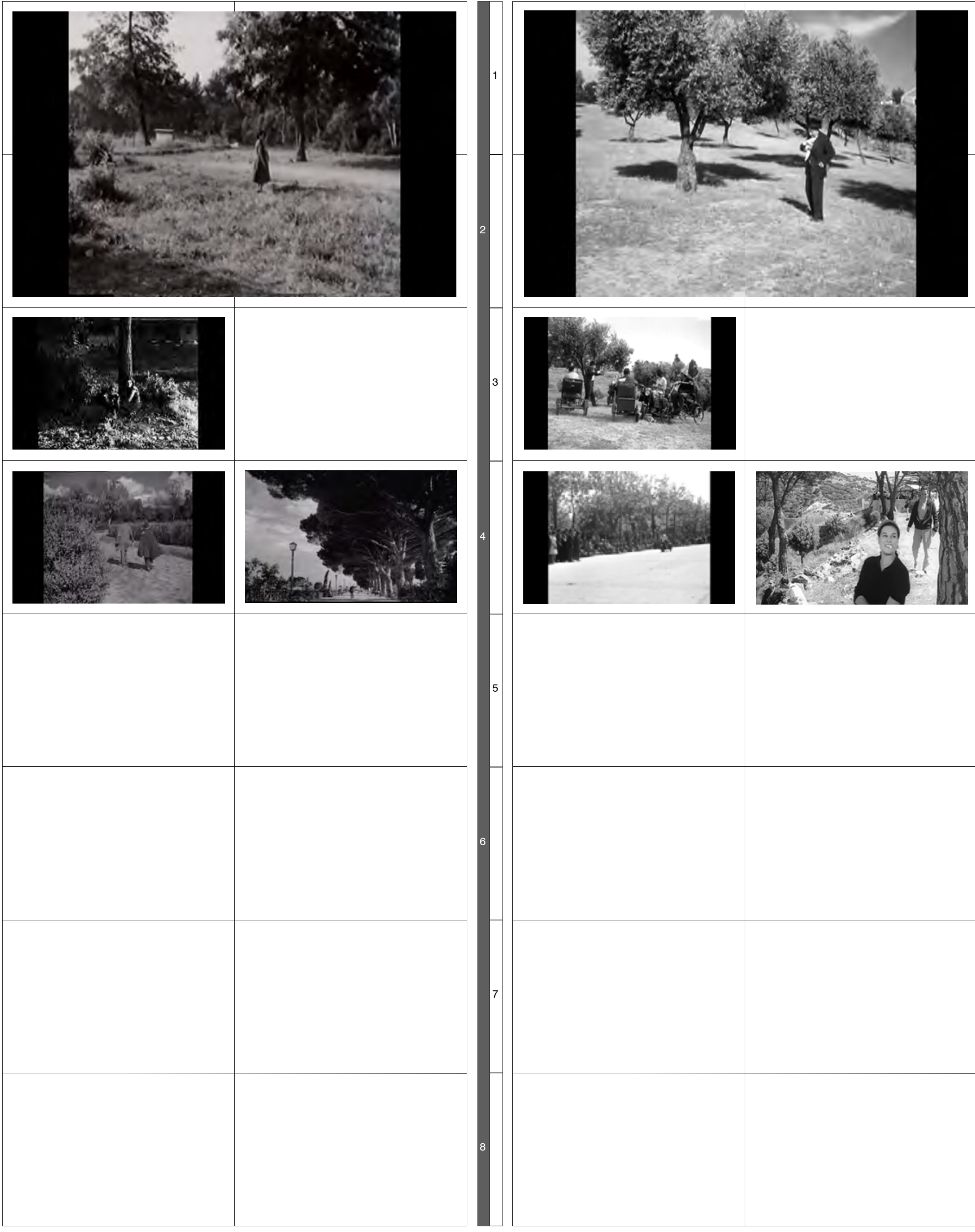

RM 1-2-3. Amor en la ciudad - Ep. Historia de Caterina (Maselli)

RM 4. Limpiabotas (De Sica)

MD 1-2-3. El cochecito (Ferreri)

MD 4. El cochecito (Ferreri)

MD 4. El Verdugo (Berlanga) 
El mismo paisaje aparece en las escenas finales de "Obsesión", las playas del delta del Po donde la pareja se duerme olvidando ser perseguida por los policías; un paisaje, en el cual el cielo se funde con el agua, y la tierra se reduce a líneas delgadas de arena y fango; un paisaje totalmente atmosférico y onírico que contribuye a provocar la suspensión del recuerdo en los protagonistas.

Maestro en el describir este paisaje es Antonioni, que nació en Ferrara, la ciudad más cercana al delta: al final de Gente del Po, su primer cortometraje, este director describe el rio Po como en ninguna otra película antes, "el río es el protagonista, un protagonista caracterizado por su voluntad colosal de llegar al mar, pero sin mostrar jamás impaciencia. Cuando lo alcanza, el mar, en lugar de abrazarlo, le echa una mano para que se suba a la cama blanca del cielo" ${ }^{30}$.

La playa marina de Peñiscola es uno de los escenarios principales de la película Calabuch, uno de los pocos escenarios marinos del Cinema Neorrealista español, que no es una playa veraniega y que comunica sentimientos de nostalgia, y soledad. Los protagonistas de Los inútiles de Fellini, miran hacia la mar en una playa de invierno, hablando del futuro y de la vida y se mueven entre las casetas-vestuarios en un escenario desierto. En El techo la playa es el teatro de la fracasada reconciliación entre padre e hija, una playa arcaica de pescadores, como la playa rocosa de La tierra tiembla, el áspero paisaje marino del pueblo siciliano de Aci Trezza. Las playas, las riberas, los ríos y el mar, asumen dos diferentes valores iconográficos: por un lado, se representan como en un paisaje rural, la iconografía de los orígenes de la memoria y del recuerdo; por otro lado, al ser espacios-umbrales entre tierra y agua, son usadas para describir atmósferas de suspensión y nostalgia. En la ciudad esta misma iconografía se produce a través de ríos y canales.

Roma mantiene una relación más profunda con el Tíber, respecto a la que Madrid establece con el Manzanares: casi nunca aparece el río madrileño en el cine español. En Los golfos, los protagonistas descansan en una playa, presumiblemente del Manzanares": es una escena de idilio que acaba con la pelea de dos de los protagonistas, que luchan entre la arena y el agua, una imagen de naturaleza en la ciudad, muy parecida a las que aparecen en las películas italianas de la época como Bajo el sol de Roma de Castellari; ríos y arroyos son los escenarios de los Ragazzi di vita de Pasolinii ${ }^{31}$, que ahí se encuentran para el descanso, como se ve también en Accattone. Las otras películas españolas en donde aparecen ríos están rodadas en pueblos, como Calle Mayor o Bienvenido Mr. Marshall, aunque en estas ambientaciones el agua no tiene un valor en la narración y es puro escenario.

Canales de desagüe aparecen en Cerca de la ciudad y en Amor en la ciudad: en esta última película Antonioni desarrolla parte de su cuento sobre los suicidios por amor, en Centocelle, una borgata al Sureste de la capital, que el director describe a través de un plano general con un canal artificial entre una urbanización y un descampado, y en la ribera del Tíber presentando una iconografía totalmente inédita de la capital, mirando la ciudad desde abajo hacia arriba; Antonioni busca lugares insólitos lejos de cualquier imagen pintoresca de la capital, como hará más adelante con la película El eclipse, y como ya hizo en el cortometraje "Nettezza urbana".

En algunas escenas de Cerca de la ciudad y en Los golfos aparecen canales de desagües y charcos, que nos hablan de los problemas de higiene e inundación de estos asentamientos informales. Estos problemas se describen de una forma divertida en una escena de Mi tío Jacinto, en la cual Pablito Calvo juega con la cascada de agua que peligrosamente baja de la ladera puesta atrás de su choza de madera y chapa (F.2.3.2/3).

\footnotetext{
30 (Berger, 2012)

${ }^{31}$ (Pasolini, Ragazzi di vita, 1979)
} 

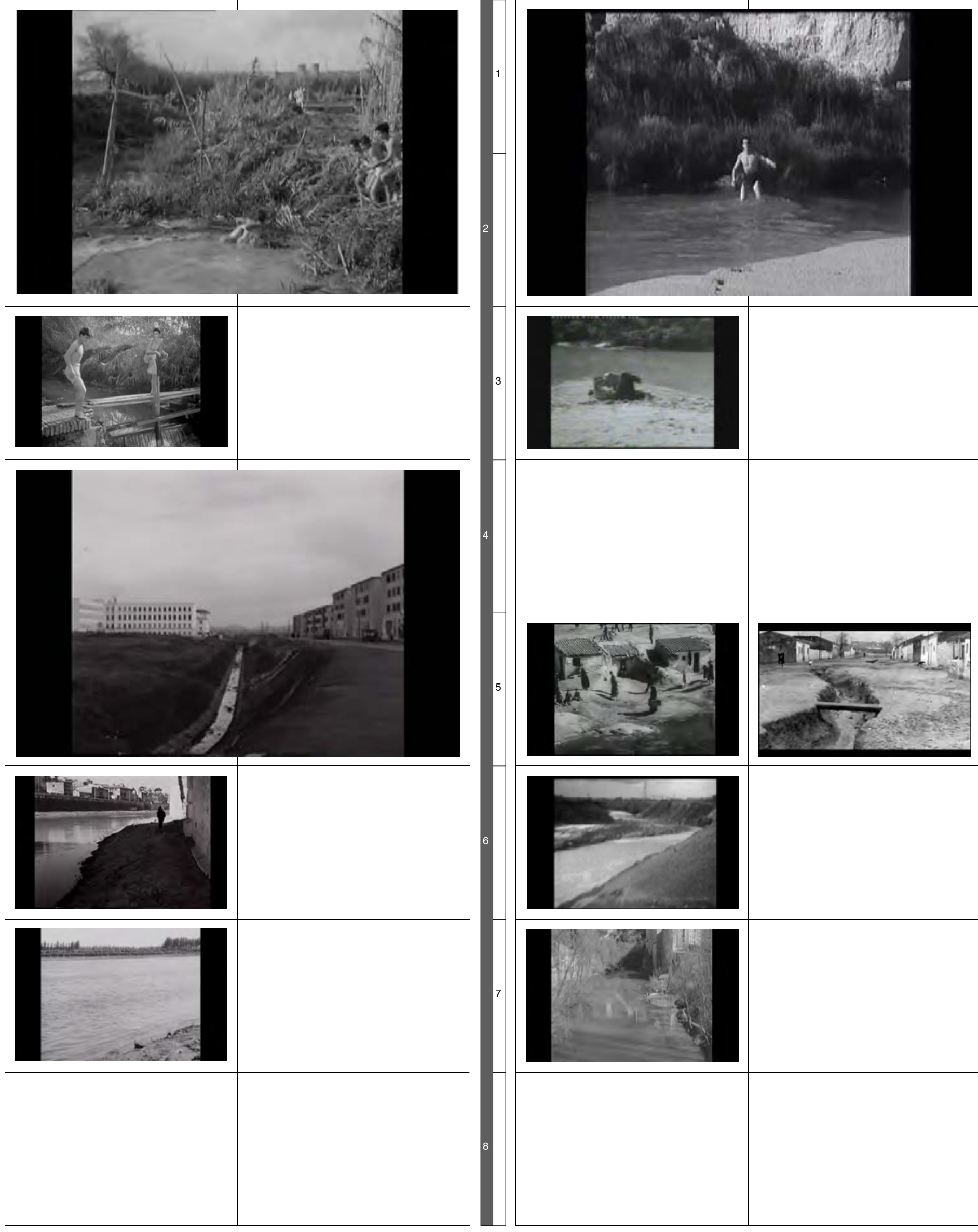


\subsubsection{Infraestructuras y ciudad productiva}

\section{INFRAESTRUCTURAS PUENTES Y CARRETERAS}

Hemos analizado el "paisaje - movimiento" observando los vehículos que aparecen en la pantalla, y que facilitan los viajes de los protagonistas en el espacio urbano y extraurbano y establecen relaciones diferentes con el paisaje dependiendo del punto de observación de la cámara.

Los vehículos se desplazan a través de infraestructuras lineales que atraviesan el territorio generando fracturas dentro del espacio urbano; mientras las calles urbanas funcionan como articulación que une, las carreteras y las infraestructuras en el "paisaje palimpsesto" generan fracturas dentro del tejido urbano.

Las carreteras en la ciudad desertizada de las películas neorrealistas, son recorridos rápidos para escapar de la ciudad que cruzan los vacíos y los terrenos agrícolas de los suburbios, como aparece en los filmes españoles Muerte de un ciclista y El cochecito o en los italianos Los inútiles y Obsesión; se trata de vectores que indican un horizonte lejano, metáfora de esperanza o angustia hacia lo desconocido, lo imprevisible. En Muerte de un ciclista los eventos más importantes de la narración, se ruedan en la carretera de Extremadura en las afueras de Madrid. Dos árboles secos a los lados de la autovía marcan un territorio desértico, con campos arados hasta el horizonte hacia el cual miran los protagonistas bajando del coche; el cielo nublado y la luz del atardecer dramatizan esta escena que se repite dos veces a lo largo de la película protagonizadas por Alberto Closas y Lucía Bosé. Esta escena tiene una analogía con Obsesión de Visconti, en donde la carretera extraurbana se convierte en un elemento de resolución del guión en varias escenas a lo largo de toda la película, que es casi una road-movie: la historia de los protagonistas italianos, Massimo Girotti y Clara Calamai, como en la película española, se resume en la imagen de la pareja caminando en la carretera, sin destino, en un espacio vacío con un horizonte lejano, marcado por algunos elementos verticales.

Otra infraestructura típica de la iconografía neorrealista es el puente, presente en muchas películas como elemento escenográfico de articulación espacial. Por un lado, los puentes enmarcan una escena definiendo un fondo permeable y accesible. Por el otro, en muchas escenas, dependiendo de la topografía, determinan una división entre dos niveles, el "mundo de abajo" muchas veces espacio residual e informal, lugar para esconderse, refugio para nómadas urbanos y el mundo de arriba que en muchos casos corresponde a lo de la ciudad "oficial". Estos valores iconográficos de la infraestructura puente están presentes en varias secuencias en las españolas Los golfos o Los chicos, Surcos y en las italianas El techo, Ladrón de bicicletas, Bellssima o Accattone (F.2.3.3/1). 

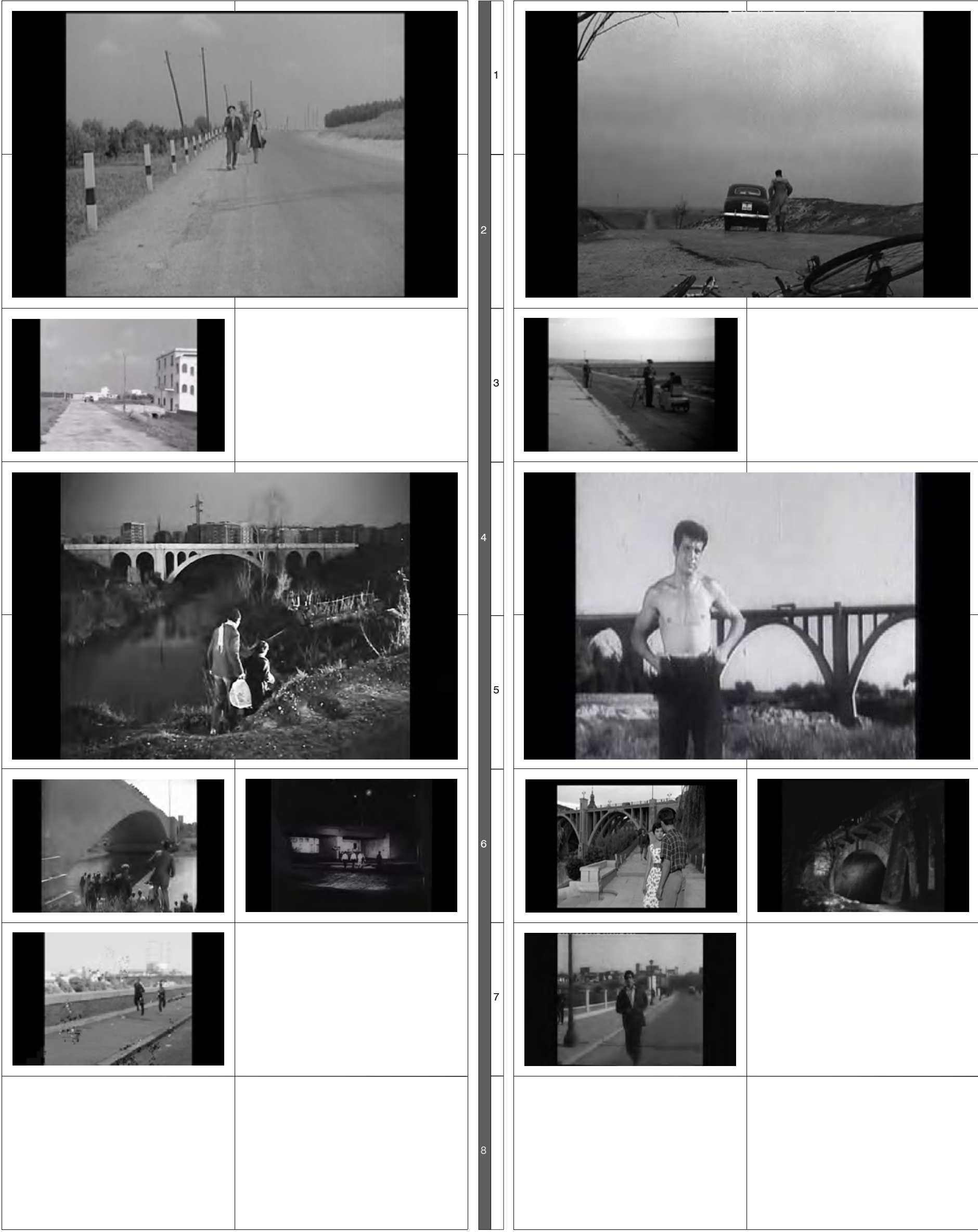

RM 1-2. Ossessione (Visconti)

RM 3. La Calle (Fellini)

RM 4-5. El techo (De Sica)

RM 6. Ladrón de bicicletas (De Sica)

RM 6. Accattone (Pasolini)

RM 7. Accattone (Pasolini)
MD 1-2. Muerte de un ciclista (Bardem)

MD 3. El cochecito (Ferreri)

MD 4-5. Los golfos (Saura)

MD 6. Los chicos (Ferreri)

MD 6. Muerte de un ciclista (Bardem)

MD 7. Los golfos (Saura) 
HITOS, CABLES Y TELÉGRAFOS.

En el territorio de la ciudad en construcción los amplios espacios libres, permiten observar más fácilmente un paisaje infraestructural, hecho de líneas y elementos puntuales. El cableado de la red eléctrica y telegráfica, los postes y las estructuras verticales metálicas, desde sus primeras apariciones en el paisaje urbano y suburbano, han empezado a ser descritos por artistas, fotógrafos y directores de cine.

En las películas neorrealistas estas líneas funcionan en la ciudad desertizada o destruida, para marcar recorridos, vectores direccionales y puntos de fuga, para poner en evidencia que existe un paisaje familiar que nos habla de la comunicación que se produce entre lugares distantes. Es un paisaje visible, pero podemos relacionarlo al cripto-paisaje presente en la ciudad, el paisaje subterráneo de las redes infraestructurales, un sistema escondido que produce movimientos de vehículos y seres humanos, de trasmisión de señales, de fluidos, gases y energía.

Los hitos y elementos verticales, acentúan en el espacio fílmico la dimensión horizontal de las periferias urbanas, la condición de espacios vacíos, como tótem en tierras de conquista; estos hitos también nos hablan de avances económicos, de movimiento y velocidad.

Cuando en algunos fotogramas, los cableados recortan el espacio del cielo, producen una imagen abstracta, que expresa la condición de artificialidad que caracteriza el ambiente urbano, los cableados funcionan como un filtro entre el hombre y la textura natural del cielo; la pérdida de un contacto directo con los fenómenos atmosféricos, con el elemento natural, esta imagen aparece en un fotograma de las secuencias finales de Surcos, amplificando la atmósfera de opresión y drama. Otra imagen sugerente de esta iconografía del paisaje palimpsesto de las infraestructuras es la imagen de los postes de la red eléctrica que marca los lados de una gran avenida desierta de Roma en la secuencia final del atardecer en Nettezza urbana, de Antonioni (F.2.3.3/2). 

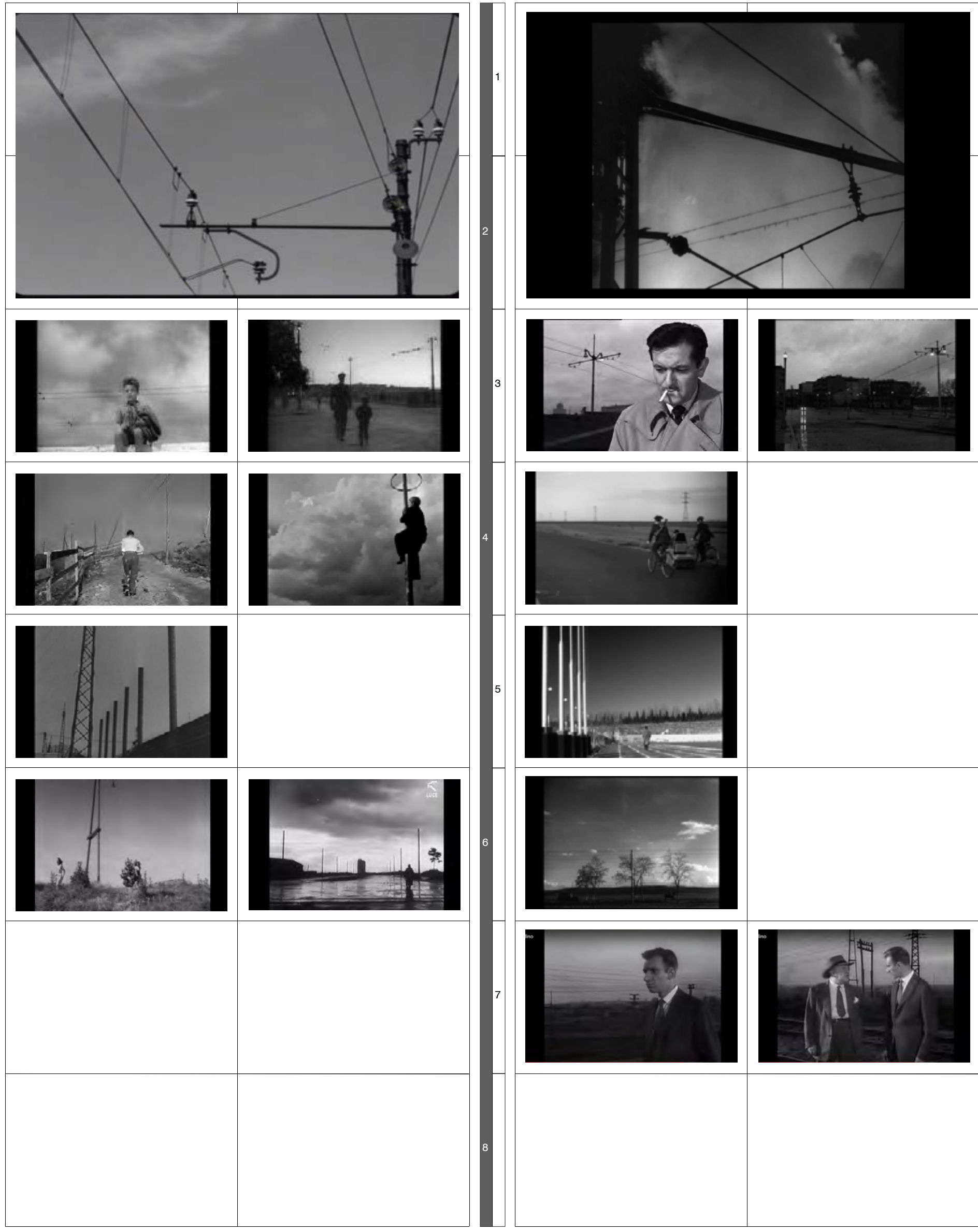

RM 1-2. Umberto D. (De Sica)

RM 3. Ladrones de bicicletas (De Sica)

RM 4. El Techo (De Sica)

RM 4. Milagro en Milán (De Sica)

RM 5. Días de Gloria (AAVV)

RM 6. Gente del Po (Antonioni)

RM 6. Netteza Urbana (Antonioni)
MD 1-2. Surcos (Nieves Conde)

MD 3. Muerte de un ciclista (Bardem)

MD 4. El cochecito (Ferreri)

MD 5. Muerte de un ciclista (Bardem)

MD 6. El último caballo (Neville)

MD 7. El inquilino (Nieves Conde) 


\section{AMBIENTES PRODUCTIVOS Y CIUDAD PRE-INDUSTRIAL}

Roma y Madrid no desarrollaron a lo largo del siglo XIX y XX un tejido productivo e industrial comparable a lo de otras ciudades europeas; la guerra además hundió parte de las infraestructuras productivas de las dos capitales.

En Días de gloria, al final de la película, el collage de fotogramas que querían representar la realidad productiva de un país, Italia, que seguía en pie a pesar de la destrucción física y psíquica, muestra actividades industriales, talleres mecánicos, transatlánticos y trenes, después de una larga secuencia de carcasas de aviones, ruinas y desechos. Estas imágenes optimistas celebran el fin de la guerra y la lucha de resistencia, aunque sin encajar con la realidad presente en el territorio, en donde las pocas actividades industriales que quedaban ofrecían muy pocas oportunidades laborales. Por eso la escasa iconografía industrial presente sobre todo en Roma y Madrid no tiene la relevancia y la potencia decadente presente por ejemplo en los escenarios parisinos de Le sang de vetes, de Georges Franju, o de las fábricas que aparecen en las películas de Antonioni de los años '60; igualmente las ambientaciones industriales de las capitales italiana y española tienen cierto impacto sobre la iconografía de la ciudad neorrealista, contribuyendo al génesis de un paisaje que, "al erguirse en el horizonte, muestra la masa de detritos y escorias, haciendo coincidir dos extremos: la voluntad de potencia y la degradación inevitable" ${ }^{32}$. El paisaje representado, quiere evidenciar más que la potencia de su escala o el optimismo de lo que representa, la cantidad de entropía que estos elementos generan dentro del tejido urbano: los desechos, la contaminación, el tráfico de medios pesados para el transporte y la desertización de la ciudad alrededor. Muy pocos de los protagonistas de las películas analizadas logran entrar en el mundo de la producción industrial como empleados, ya que en los primeros años de la posguerra era un sector de la economía muy poco desarrollado. El padre, protagonista de Surcos, en su primer día de trabajo formal se irá a un taller siderúrgico -ubicado en la zona de Plaza Castilla y Chamartín-, entre las calles de una ciudad desertizada. Su experiencia laboral se acabará el mismo día habiéndose desmayado por cansancio. Una situación parecida es la que vive Ingrid Bergman en Europa 51, su experiencia de un día en una fábrica es una experiencia devastadora; para Deleuze, Rossellini representa la fábrica como un "abstracto visual" y lo conforma en un indefinido "espacio lunar", un lugar que rompe con las coordenadas espaciales, unos de los lugares que el filósofo francés describe utilizando la definición de "espacios cualesquiera" ${ }^{33}$. En la película Limpiabotas se muestra el río Tíber junto a la zona industrial de la Vía Ostiense con un monumental gasómetro que aparece en el fondo del encuadre del otro lado del río. Las embarcaciones para el transporte aparecen en un contexto informal, y las infraestructuras industriales contrastan con el paisaje salvaje de la ribera. La luz, el humo y el desorden de esta zona de la ribera del Tíber, contribuyen en la creación de una iconografía que acentúa la imagen "entrópica" del paisaje industrial, como un paisaje de degradación más que de progreso. Los familiares de los dos limpiabotas no parecen ser parte del mundo laboral formal y productivo y se dedican a "la bolsa negra" y a otras actividades ilegales.

En la Roma y en el Madrid neorrealista, aparece un paisaje industrial en decadencia todavía antes de nacer y desarrollarse, un destino común a las dos ciudades. Más adelante Pasolini en una famosa entrevista, hablará de Roma, como muchas periferias de las ciudades europeas, como de un lugar a-histórico, una "ciudad pre-industrial en la cual "la gente vive como en el mundo preindustrial, como en África, en El Cairo, en Argel, o en Bombay" ${ }^{34}$ (F.2.3.3/3).

\footnotetext{
32 (Mancini \& Perrella, 1986 p.219)

${ }^{33}$ (Deleuze, La imagen-movimiento: estudios sobre cine 1, 1984, p.175)

${ }^{34}$ (Pasolini, L'intervista a Pier Paolo Pasolini , 1975)
} 

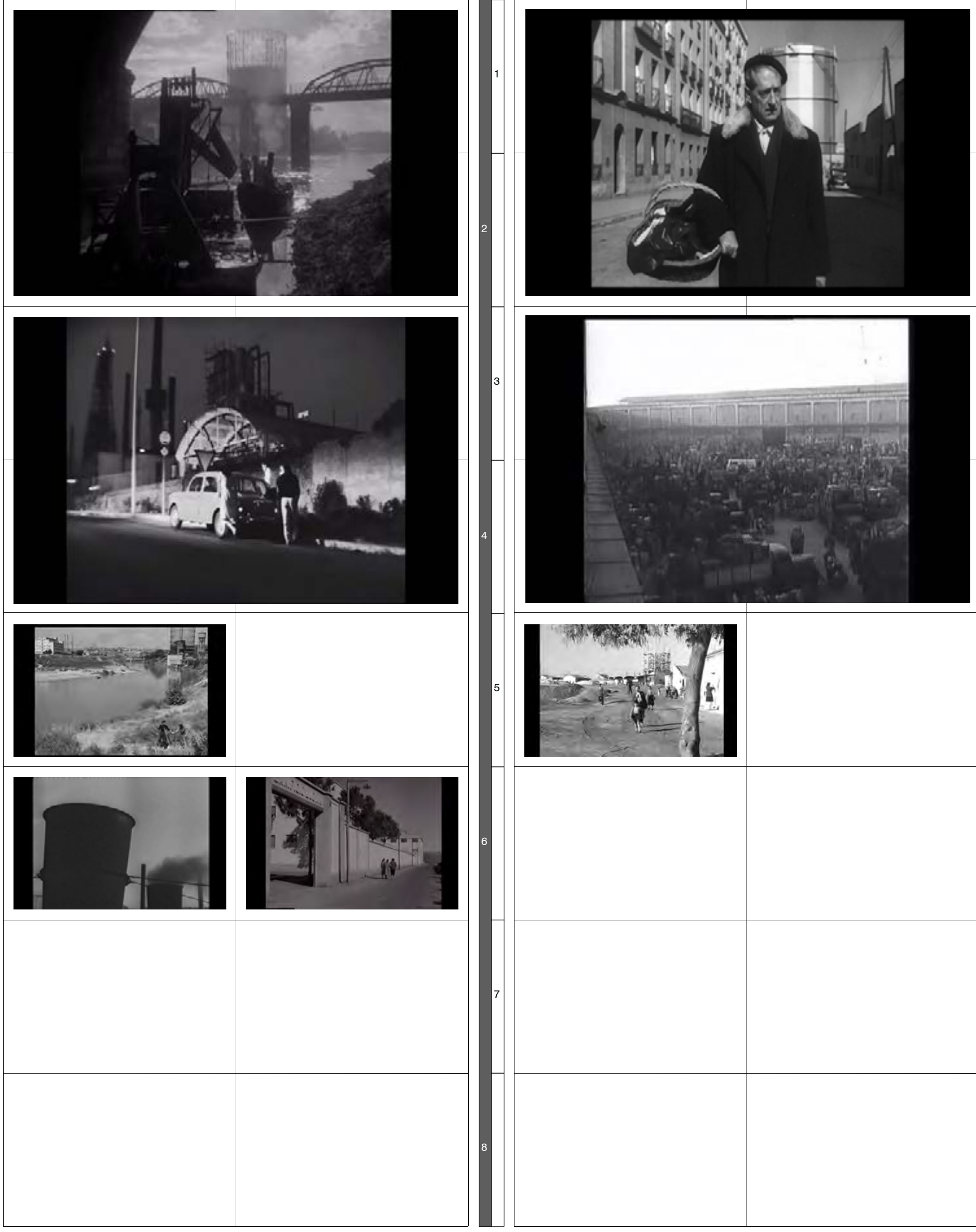

RM 1-2. Limpiabotas (De Sica)

RM 3-4. Accattone (Pasolini)

RM 5. Bellissima (Visconti)

RM 6. Días de gloria (A.A.V.V.)

RM 6. Amor en la ciudad - Ep. Suicidas (Antonioni) 
LUCES Y TEXTOS.

Si las estructuras de las redes eléctricas y telegráficas son líneas verticales y las carreteras y los ferrocarriles líneas horizontales, las luces del alumbrado que iluminan plazas y calles son puntos luminosos que enfatizan la oscuridad de la noche. En los paseos nocturnos de los protagonistas la tabula rasa que borra el espacio y el paisaje, el alumbrado no sirve para iluminar zonas, sino para enfatizar el espacio totalmente vacío en el cual se mueven los personajes. En estos recorridos personas y escenografías aparecen y desaparecen de las tinieblas, como en el célebre paseo de Anna Magnani, en Mamma Roma, en el cual las caras y los cuerpos de los clientes se iluminan y se disuelven en las carreteras nocturnas iluminadas por el alumbrado público.

La transformación de la ciudad en espacio de consumo se evidencia en las películas por el "tráfico de signos" ${ }^{35}$, letreros y comerciales que invaden las calles y los espacios públicos. La sensación resultante es la de una forma de limitación de la libertad personal, el usuario del espacio urbano se convierte en objeto-receptor del mensaje publicitario; la calles se convierten en el escenario de una restricción: "por muy descaradamente publicitario, veladamente represivo y optimistamente 'político' que sea, el signo urbano tiende al ideal del recorrido señalizado, del canal unidireccional, dentro de cualquier conducta está programada" ${ }^{36}$. La máxima expresión de esta ciudad-objeto de consumo- aparece en la española Bienvenido $\mathrm{Mr}$. Marshall en la cual un pueblo entero de Castilla La Mancha, se convierte en escenografía publicitaria para disfrazarse y venderse como pueblo andaluz, y poder obtener finalmente las ayudas estadounidenses del Plan Marshall: la ciudad como escenografía de la cultura "Pop"; un paralelo interesante en este sentido, se puede establecer en dos fotogramas; la famosa escena de Ricci el protagonista de Ladrón de bicicletas, pegando el cartel de la película de Hollywood, Gilda, tocando la cara de Rita Hayworth, y la escena de Los chicos, en Madrid, mirando extasiados el sensual cartel cinematográfico fuera del Teatro de la Plaza de Callao (F.2.3.3/4).

35 (Mancini \& Perrella, 1986 p.194)

36 (Ibidem p.196) 

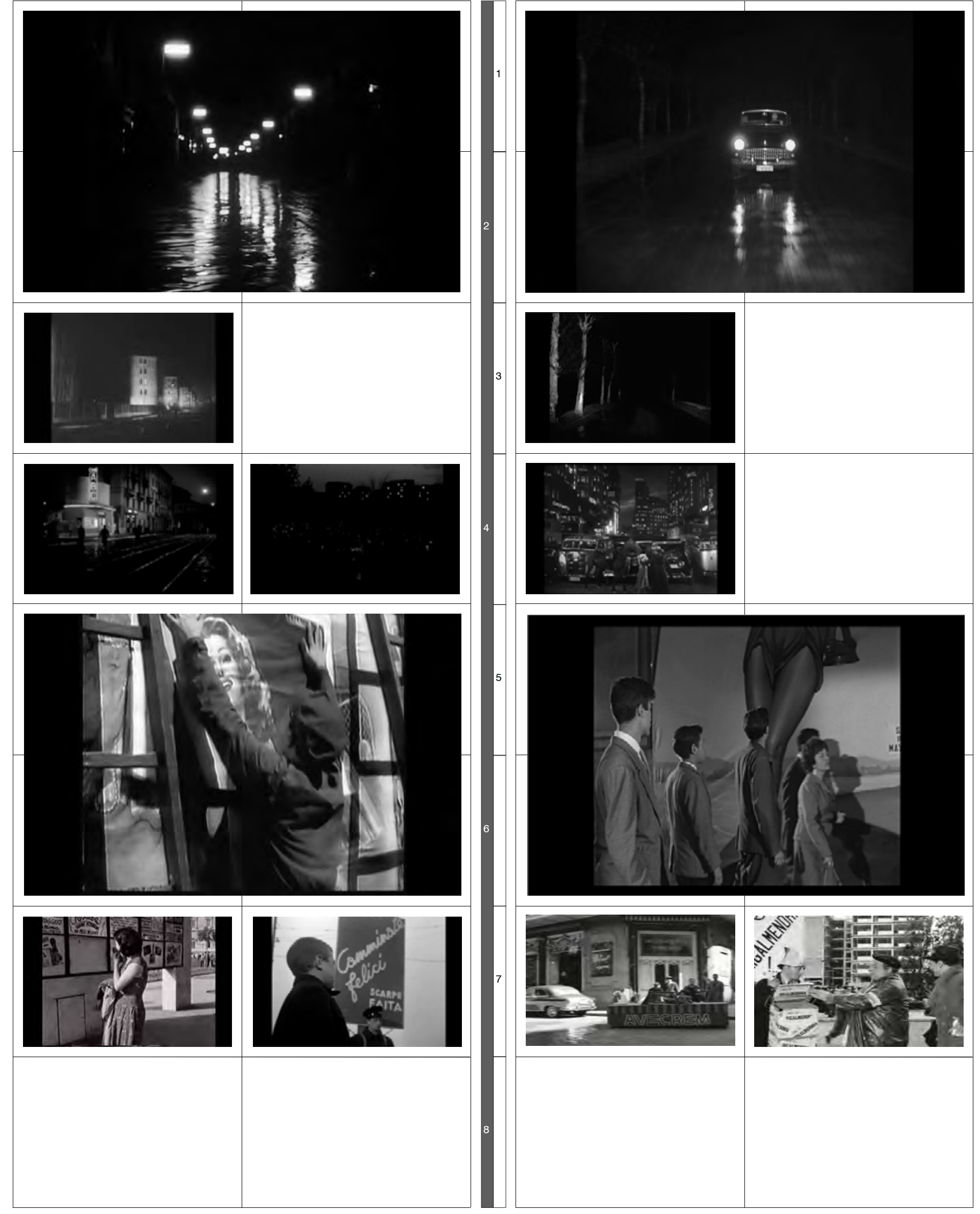

RM 1-2. Cronica de un amor (Antonioni)

RM 3. Rocco y sus hermanos (Visconti)

RM 4. Milagro en Milán (De Sica)

RM 5-6. Ladrones de bicicletas (De Sica)

RM 7. Amor en la ciudad. Ep. Historia de Caterina (Maselli)

RM 7. Milagro en Milán (De Sica)
MD 1-2-3. Muerte de un ciclista (Bardem)

MD 4. El último caballo (Neville)

MD 5-6. Los chicos (Ferreri)

MD 7. El pisisto (Ferreri) 


\subsection{Paisaje - ausencia: espacios cualesquiera, residuos y umbrales}

\subsubsection{Espacios desconectados y vaciados}

En el cinema neorrealista ya no es posible imaginar un espacio cinematográfico lleno y englobante como en todo el cine clásico. La novedad consiste en la capacidad de sus protagonistas de recorrer el paisaje y detenerse para observar "desde fuera" la escena y el contexto, una característica que determina la aparición de otras tipologías de espacios, como las que Deleuze describe usando el término "espacio cualquiera", definiendo "un espacio que ha perdido su homogeneidad, es decir, el principio de sus relaciones métricas o la conexión de sus propias partes, hasta el punto de que los raccords pueden obtenerse de infinidad de maneras. Es un espacio de conjunción virtual, captado como puro lugar de lo posible" ${ }^{37}$. El recurso al espacio cualquiera es para Deleuze una herramienta que, aplastando la dimensión espacial y atmosférica, potencia la cuarta y quinta dimensión, la temporal y la espiritual y permite realizar conexiones a través del montaje.

La condición del territorio urbano y extraurbano en la Posguerra, y al mismo tiempo la crisis de la imagen-acción determinan una multiplicación de estos espacios cualesquiera y de espacios desconectados, vaciados e indefinidos.

"La primera (influencia), independiente del cine era la situación de la posguerra, con sus ciudades demolidas o en reconstrucción, sus terrenos baldíos, sus barrios de chabolas e, incluso allí donde la guerra no había llegado, sus tejidos urbanos 'des-diferenciados', sus vastas zonas desafectadas, docks, depósitos, cúmulos de viguetas y de chatarra. (...) Los personajes se encontraban cada vez menos en situaciones sensorio motrices 'motivantes', más bien se hallaban en un estado de paseo, vagabundeo o errar que definía situaciones ópticas y sonoras puras. La imagen-acción tendía entonces a estallar, mientras que los lugares determinados se difuminaban dejando emerger unos espacios cualesquiera en los que se desplegaban los afectos modernos del miedo, despreocupación, pero también de frescura, velocidad extrema y espera interminable" 38 .

Deleuze cita la película Paisá para indicar este nuevo realismo que elimina puntos de referencias y coordenadas: la toma más representativa de esta desconexión describe el cadáver del partisano que flota en el Po, siguiendo la corriente del río en la luz gris del paisaje fluvial; a esta iconografía en el Cine español corresponde la escena con el protagonista de $E I$ cochecito, José Isbert, que se escapa en las afueras de Madrid con su triciclo en un espacio totalmente desierto, con los postes de la alta tensión que marcan el horizonte ${ }^{39}$.

\subsubsection{Campos de batalla: desechos y ruinas}

Las ruinas, los fragmentos y los escombros que aparecen en muchas de las películas analizadas son una presencia real y metafórica que hace referencia a los conflictos recién acabados. Esta imagen de la ciudad como la de un campo de batalla (F.2.4.2/1) -es suficiente

37 (Deleuze, La imagen-movimiento: estudios sobre cine 1, 1984 pp. 160-165)

38 (Deleuze, La imagen-movimiento: estudios sobre cine 1, 1984 pp. 174-175)

39 El concepto de espacio cualquiera planteado por Deleuze es distinto al de no-lugar del sociólogo francés Marc Augé (Augé, 1992), que pone el acento en una nueva sensibilidad que identifica estos lugares más con "la circulación que, con la permanencia, más con los medios de transporte que con la arquitectura"; podemos pensar a los no-lugares en oposición al lugar geométrico o antropológico, en donde "las personas se encuentran al cruzarse" (Vila Mustieles, 1997 pp. 48-49). 

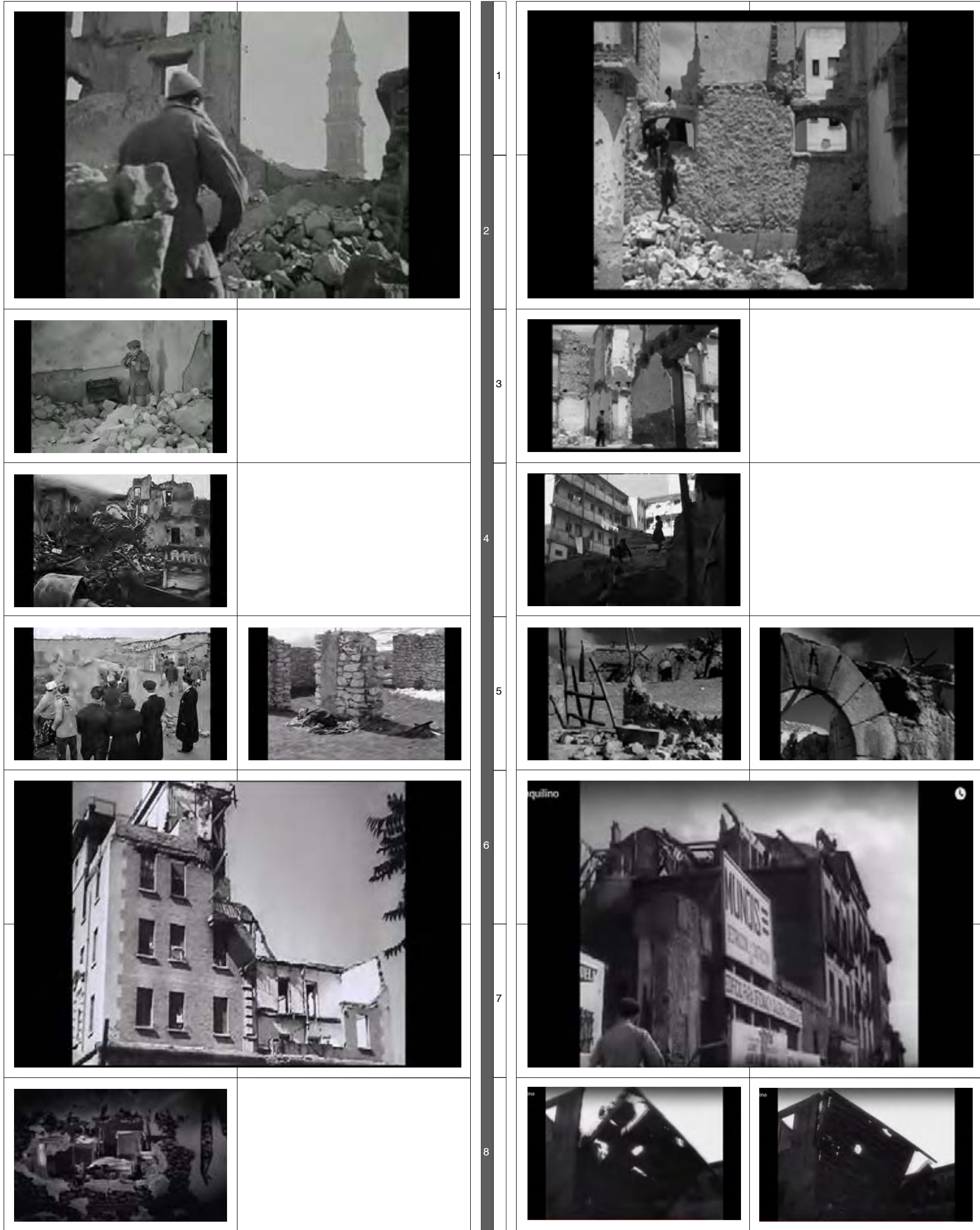

RM 1-2-3. Paisá (Rossellini)

RM 4. Días de gloria (AAVV)

RM 5. El techo (De Sica)

RM 5. La calle(Fellini)

RM 6-7. Roma ciudad abierta (Rossellini)

RM 8. Umberto D (De Sica)

4. Muerte de un ciclista (Bardem)

MD 5. Marcelino pan y vino (Vajda)

MD 6-7-8. El inquilino (Nieves Conde) 
pensar en películas como Alemania año cero y Paisá de Rossellini- hace alusión a un "nivel cero" de la condición de los dos países, un punto desde el cual volver a empezar yendo hacia adelante, porqué atrás no queda nada. Las ruinas arqueológicas que aparecen en las películas romanas y las viviendas derribadas para nuevas edificaciones en Madrid, se presentan como heridas en la ciudad, monumentos ${ }^{40} \mathrm{y}$ expresión del recuerdo.

Las ruinas, como los residuos y los escombros que aparecen en los fotogramas, hacen parte de un paisaje en transformación, expresión de la entropía que se genera en estos cambios de la ciudad, correspondiente a un aumento de desorden dentro del sistema urbano, causado por las nuevas construcciones en progreso y también por los daños originados por la guerra. En las dos películas de Rosselini citadas, aparece un nivel máximo de entropía. En las películas españolas la referencia a la Guerra Civil es más sutil; casi siempre los acontecimientos de la guerra eran presentados de una forma celebrativa, como gestas heroicas, nunca como causa de muerte y destrucción; así que, por la censura, que en estos años se preparaba para su actividad más intensa, las ruinas aparecen pocas veces, encontradas por casualidad por los protagonistas en sus recorridos.

A veces los escombros corresponden a derribos para facilitar nuevas construcciones, como en la película El inquilino; sin embargo, estas imágenes por el reciente pasado, tenían que causar fuertes emociones en los espectadores. Entre las ruinas, la ciudad cambia su lógica espacial, se vuelve "umbral" y aparecen otras estructuras: los terrenos baldíos y los residuos que los ocupan. En Roma, ciudad abierta, en Surcos o en El inquilino la destrucción llega hasta el espacio doméstico, en algunos fotogramas, las casas pierden su privacidad, abiertas por los derribos, como en la famosa escena de Roma, ciudad abierta, en donde un grupo de la SS puede alcanzar a ver a través de las varillas de la losa de la planta superior: la máxima violación de la intimidad representada por el hogar; misma condición del protagonista de EI inquino que es víctima de un desahucio y tiene que llevar todas sus pertenencias en la calle; o del protagonista de Surcos que a causa de un robo se queda sin vestimentas, en medio de un edificio en ruinas, en donde se había parado a descansar a lo largo de su deriva.

\section{ESCOMBROS Y FRAGMENTOS.}

La Ciudad neorrealista vive paralelamente a la imagen de la ciudad oficial, y se alimenta de los desechos producidos por la segunda; esta nueva iconografía urbana aparece en el cortometraje de Antonioni Nettezza Urbana, en el cual el director de Ferrara, describe la jornada de un grupo de basureros en la Capital italiana. Si en Gente del Po el paisaje de frontera correspondía claramente a un territorio que expresaba esta condición, el rio y su delta, en Nettezza urbana esta dimensión está definida a través del cuento de una ciudad dentro de otra ciudad, que descubrimos a través de las tomas subjetivas de personas que trabajan con lo que la ciudad desecha. Interesante es la descripción de la central de acopio, en donde la dimensión rural de la periferia romana, dominada por la arquitectura neo-barroca y surrealista del instituto religioso del Buon Pastore ${ }^{41}$, se funde con el paisaje de desechos en un lugar entre depósito industrial y aldea rural, con vehículos y chatarra junto a cerdos, un paisaje que Antonioni describe con una sensibilidad e interés que parecen los de Robert Smithson en Passaic. La iconografía de Nettezza urbana regresa en algunos fotogramas finales de la película Los golfos, donde también se describe una zona de acopio, con personas recolectando basura junto a cerdos; a esta actividad se dedican también algunos niños en Cerca de la ciudad, y los dos protagonistas de Mi tío Jacinto, que recuperan colillas en la explanada de la Arena de Ventas para sacar los residuos de tabacos y venderlos (F.2.4.2/2).

\footnotetext{
${ }^{40}$ De la palabra latín monere: advertir recordar

${ }^{41}$ Se trata de un colegio religioso construido por el arquitecto Armando Brasini entre 1929 y 1933.
} 

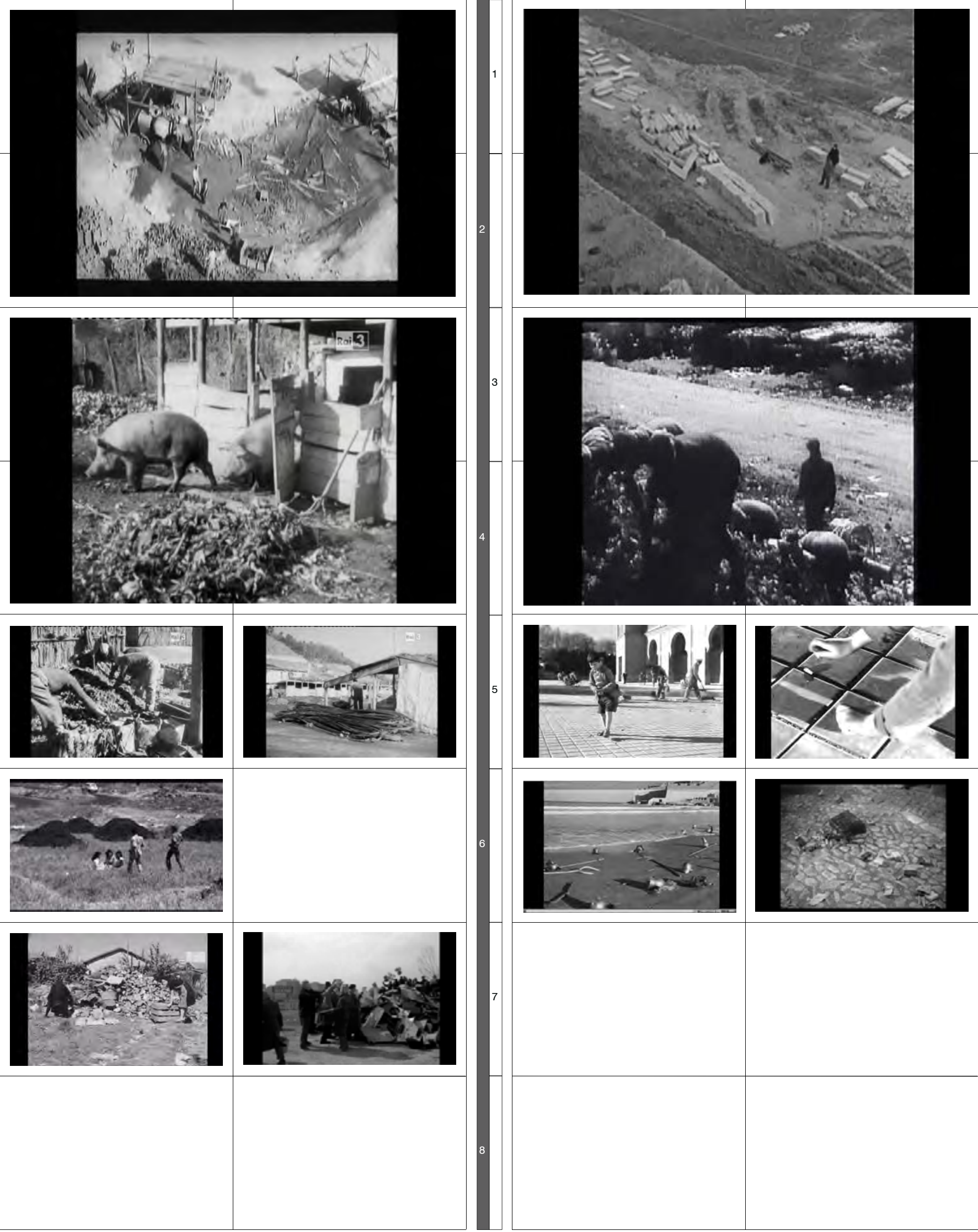

RM 1-2. Rocco y sus hermanos (Visconti)

RM 3-4. Nettezza Urbana (Antonioni)

RM 5. Nettezza Urbana (Antonioni)

RM 6. Mamma Roma (Pasolini)

RM 7. Accattone (Pasolini)

RM 7. Milagro en Milán (De Sica)
MD 1-2. Calle Mayor (Bardem)

MD 3-4. Los golfos (Saura)

MD 5. Mi tío Jacinto (Vajda)

MD 6. Calabuch (Nieves Conde)

MD 6. Surcos (Nieves Conde) 


\subsubsection{Poética del descampado.}

El concepto de "Terrain Vague" en relación a su doble etimología latina de Vacuum, en el sentido de vacío y Vagus en el sentido de incierto, describe la naturaleza de los espacios urbanos y suburbanos que son el teatro de muchas de las acciones presentes en las películas neorrealistas; por primera vez después de las derivas dadaístas y surrealistas, aparecen en la pantalla estos territorios de la incertidumbre. Analizando estos espacios, el Arquitecto Solá Morales los describe y explica la razón por la cual los artistas se refugian en ellos:

"Son sus bordes faltos de una incorporación eficaz, son islas interiores vaciadas de actividad, son olvidos y restos que permanecen fuera de la dinámica urbana, convirtiéndose en áreas simplemente des-habitadas, in-seguras, im-productivas. En definitiva, lugares extraños al sistema urbano exteriores mentales en el interior físico de la ciudad que aparecen como contra-imagen de la misma tanto en el sentido de su crítica como en el sentido de su posible alternativa. (...) Los realizadores cinematográficos, los fotógrafos, los escultores de la periferia instantánea buscan refugio en los márgenes de la ciudad precisamente cuando esta ciudad les ofrece una identidad abusiva, una homogeneidad aplastante, una libertad bajo control" 42 .

Se trata de un territorio que corresponde a una "imagen borrosa de la ciudad" 43 , un espacio que ha perdido sus límites y su forma, un territorio hibrido en el cual se mezclan distintas funciones y actividades, territorio de incertidumbre y de aislamiento y al mismo tiempo de libertad y posibilidad, espacios en donde tanto los directores como sus personajes, encuentran refugio, un espacio en el cual es posible mirar la ciudad críticamente, "desde fuera" y buscar su morfología, sus características naturales, sus horizontes y líneas de cielo. Como ya hemos analizado, a través del alejamiento es posible reflexionar sobre los cambios en proceso en el espacio de la ciudad, y hablar de paisaje urbano. Estos espacios son los lugares donde los protagonistas se pierden como en Surcos, donde encuentran una forma de ser libres, como en Mamma Roma o donde regresan a una realidad rural anti-urbana y feliz como en El último caballo; son también lugares para aclararse, para reflexionar, para discutir, para encontrar soluciones, actividades que los ruidos y los tiempos de la ciudad parecen negar, esta es la función de los descampados en El pisito.

A veces son los espacios residuales en donde se generan los arrabales, de un día a otro, como en Milagro en Milán o en El techo. Estos espacios residuales están muchas veces vinculados a la presencia de infraestructuras como ferrocarriles y topográficamente se caracterizan por la presencia de laderas y cañadas, como aparece por ejemplo en Milagro en Milán, en Cerca de la ciudad, en Los golfos y en Mamma Roma; estas características dificultan el acceso, y al mismo tiempo esconden estos lugares a la vista de la ciudad. Son espacios donde se generan formas precarias de vida, donde se busca un refugio temporáneo que algunas veces se convierte en definitivo.

También la pradera de San Isidro, que se nos presenta en la escena final de El último caballo, aparece como un espacio de libertad, en donde es posible desarrollar una forma de resistencia hacia la vida urbana convencional; a veces estos espacios se convierten en campos de batallas como la que se produce en el final de Milagro en Milán, entre habitantes de las chabolas y los propietarios del área (F.2.4.3/1).

\footnotetext{
42 (Solà Morales, 1996 pp.39-40)
}

43 (Sorlin \& Pujol i Valls, 1996) 

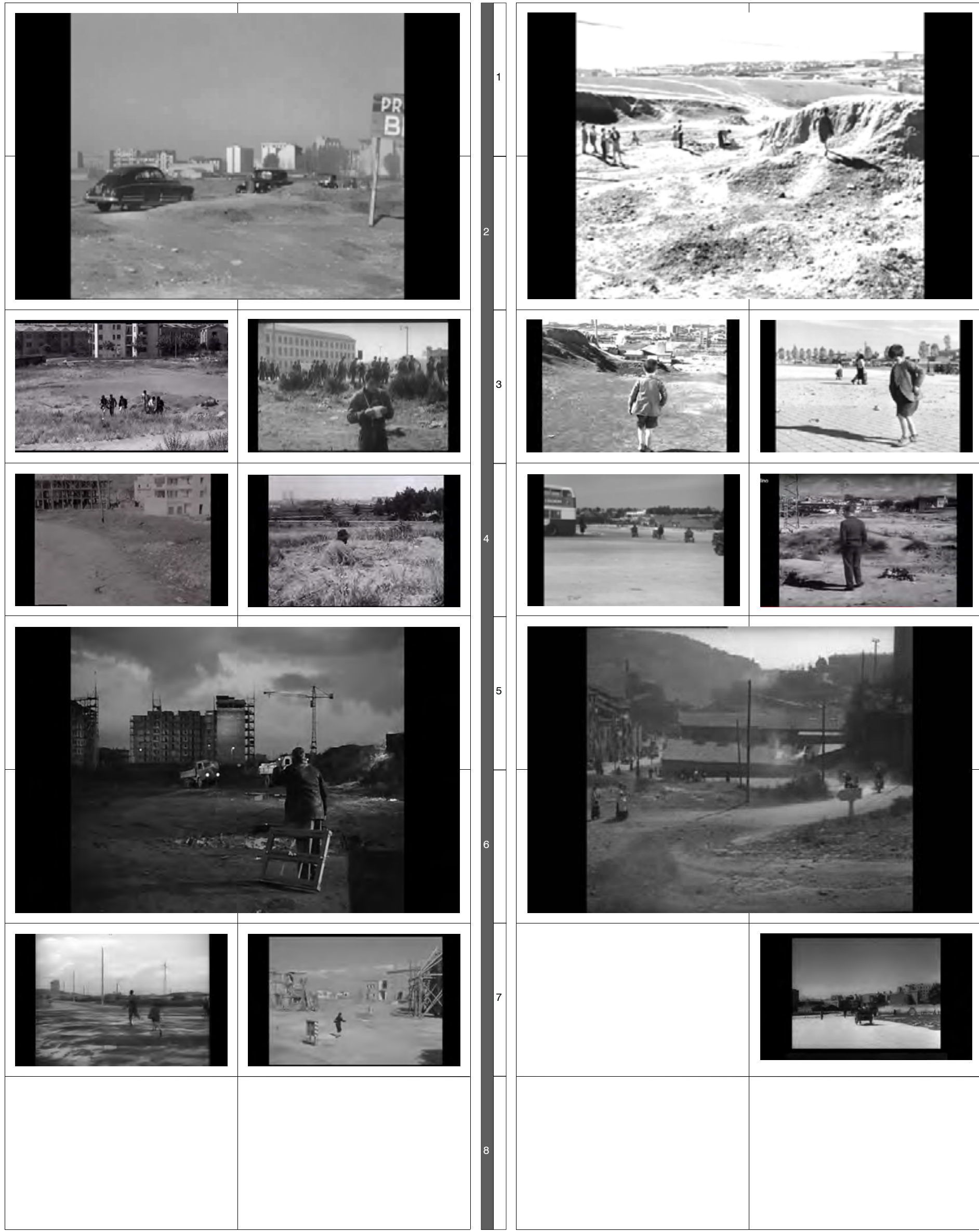

RM 1-2. Milagro en Milán. (De Sica)

RM 3. Mamma Roma (Pasolini)

RM 3. Rocco y sus hermanos (Visconti)

RM 4. Amor en la ciudad (AAVV)

RM 4. Roma ciudad abierta (Rossellini)

RM 5-6. El techo (De Sica)

RM 7. Ladrones de bicicletas (De Sica)

RM 7. Bellissima (Visconti)
MD 1-2-3. Mi tio Jacinto (Vajda)

MD 3. Muerte de un ciclista (Bardem)

MD 4. El cochecito (Ferreri)

MD 4. El inquilino (Nieves Conde)

MD 5-6. Placido (Berlanga)

MD 7-8. El último caballo (Neville) 
Podemos resumir las características de estos espacios en Roma y en Madrid, así como aparecen en las películas seleccionadas: se trata de paisajes secos, delimitados por infraestructuras, con la presencia de variaciones topográficas que generan relieves y barrancos; están caracterizados por la presencia de desechos, residuos, ruinas; tienen una fuerte conexión con el horizonte permitiendo percibir los límites de la ciudad, la línea de cielo y las periferias en expansión.

A veces se caracterizan por áreas de juegos improvisadas para la pelota (Mamma Roma) o pequeñas corridas (Mi tío Jacinto): son los "campos de juegos" que el mismo Pasolini frecuentaba con amigos y futuros actores de sus películas.

En cuanto a espacios de gran libertad de expresión, es posible en esos lugares encontrar sentimientos y afectos perdidos (Surcos), o pelear (Mamma Roma), y separarse definitivamente (Rocco y sus hermanos; Muerte de un ciclista); los horizontes, las vistas hacia la ciudad distante, el cielo y los fenómenos atmosféricos enfatizan estos aspectos sensitivos y psicológicos.

A veces como en Crónica de un Amor y Muerte de un ciclista son espacios en donde se produce una suspensión marcadas por efectos atmosféricos como la niebla. La más absoluta ausencia de puntos de referencia convierte estos lugares en la periferia en espacios en donde los hombres y las mujeres se enfrentan con la vida y el tiempo ${ }^{44}$.

\section{TALUDES Y LADERAS.}

Los Terrain vague se caracterizan por ser espacios con topografías irregulares y geometría orgánicas, en oposición a la ciudad formal, plana y ortogonal. En las películas analizadas aparecen taludes y laderas que los protagonistas suben o bajan, dinamizando las secuencias del rodaje a través de planos de picado y contrapicado, con el punto de vista del cámara acentuando elementos dramáticos de la narración. En la mayoría de los casos la vegetación está ausente, o es muy escasa y descuidada, la bajada y la subida resultan difíciles, como aparecen en algunas escenas de Ladrón de bicicletas y a veces el agua de la lluvia convierte las laderas en peligrosas cascadas (Mi tío Jacinto). Las laderas caracterizan las áreas al lado de infraestructuras como puentes y viaductos, y marcan la diferencia entre dos niveles topográficos que corresponden a mundos diferentes: en Cerca de la ciudad, en Los golfos, en Europa '51 o en Milagro en Milán, este bajar marca el pasaje de una condición social a otra; de la ciudad oficial a la informal. En Los golfos y en Mamma Roma dos fotogramas muy parecidos describen esta espacialidad: el contrapicado del director mira a la parte superior de la ladera hacia los protagonistas quienes se detienen en el borde del talud, se trata de fotogramas que describen la perspectiva de lugares inaccesibles y, por eso, en ocasiones son teatro de eventos violentos y luctuosos (F.2.4.3/2).

\footnotetext{
${ }^{44}$ Estos aspectos presentes en todo el Cine de Antonioni y en la Novele vague francesa se desarrollaron a partir del Neorrealismo.
} 

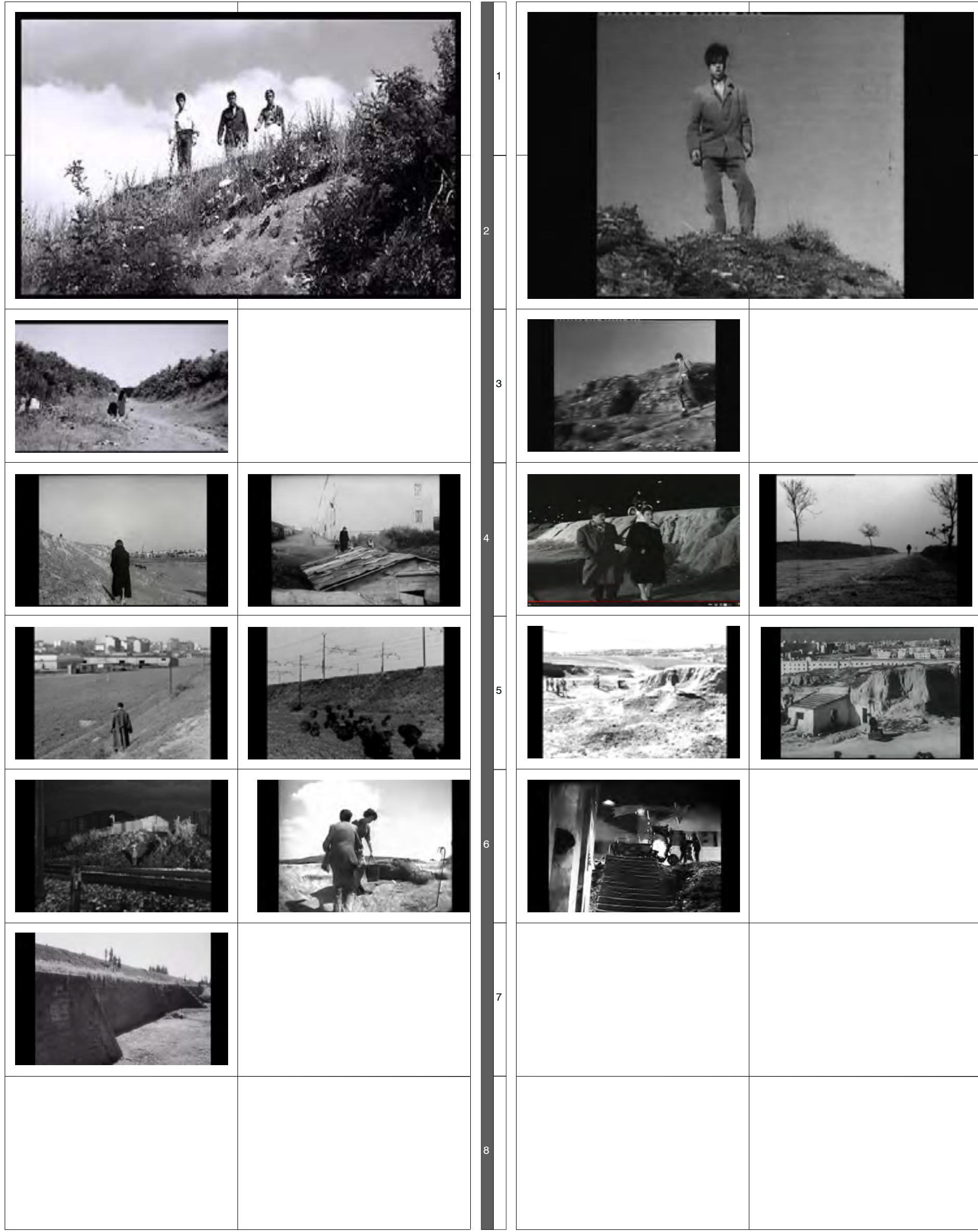

RM 1-2-3. Mamma Roma (Pasolini)

RM 4. Europa 51 (Rossellini)

RM 5. Milagro en Milán (De Sica)

RM 6. El techo (De Sica)

RM 6. Ladrones de bicicletas (De Sica)

RM 7. Gente del Po (Antonioni)
MD 1-2-3. Los golfos (Saura)

MD 4. El pisito (Ferreri)

MD 4. Muerte de un ciclista (Bardem)

MD 5. Mi tío Jacinto (Vajda)

MD 5. Cerca de la ciudad (Lucía)

MD 6. Placido (Berlanga) 


\subsubsection{Fronteras y umbrales}

No solamente las infraestructuras, sino también otras estructuras arquitectónicas, materializan la separación entre partes diferentes de la ciudad: se trata de muros, y de las aberturas que se originan en ellos. La segregación física del espacio urbano acompaña a la percepción de un espacio fragmentado por las propias características del medio cinematográfico; éste produce una nueva forma de observar a través de la fragmentación espacial producida por el movimiento de la cámara que sigue el desplazamiento de los personajes; esta nueva forma de ver, "encuentra su sistema narrativo más adecuado en el montaje cinematográfico, articulado por el movimiento de los fotogramas. Con la movilidad de la cámara, la ilusión de viaje será característica inherente a toda narración fílmica, considerable siempre como relación significante entre diversos espacios" 45 .

Los directores representan la fragmentación, la separación y la segregación, porque esta es la característica del rodaje cinematográfico y porque es también la forma urbis de la ciudad en la cual se mueven: una ciudad de muros y espacios cerrados.

En el episodio de Antonioni de El amor en la ciudad -que trata de los suicidios por amor- la imagen de un grande telón escenográfico de más de seis metros de altura en los estudios de Cinecittá, es la toma inicial de este episodio, en la cual unas parejas entran en el grande teatro. La entrada de estos personajes está rodada con un campo total, con la cámara mirando las espaldas, en dirección del telón-muro que hace de fondo y que esconde la gigantografía de una típica fachada urbana de Roma; casi la misma toma se repite algunos minutos más adelante, en una escena que representa las murallas blancas del Tíber, con una rampaescalera a través de la cual la protagonista baja al río, dejando arriba la ciudad, para alcanzar el aislamiento y la separación de la realidad necesaria para que se cumpla el suicidio, en la toma final las parejas regresan del teatro, siempre pasando por el telón-muro blanco y saliendo del encuadre. Estos dos muros blancos, uno real y uno ficticio, tienen para el director el mismo valor semántico. Se trata de una ciudad que ya no es real, y que tiende a fragmentarse y a partirse como en una escenografía efímera.

La misma iconografía aparece en el grande muro blanco del patio de $E$ I verdugo, por donde el protagonista es empujado hacia sus deberes profesionales, un destino no aceptado. Como sucede con el telón de Cinecittá, esta ambientación de la película española marca muy fuertemente un límite entre dos mundos, en este caso, entre un exterior y un interior, del cual el actor protagonista no puede escaparse.

El enorme muro de la Plaza de toros de Ventas, que en Mi tío Jacinto, el niño protagonista, Pepote, mira desde la plaza exterior, es un límite que separa la vida cotidiana llena de miserias y dificultades, del éxito esperado para su tío como torero. Los muros y las barreras en las películas analizadas, se cargan de estos valores simbólicos, relacionándose con los estados de ánimos de los protagonistas en la ciudad y con las formas de vivir en ella (F.2.4.4/1).

45 (Vila Mustieles, 1997 p.147) 

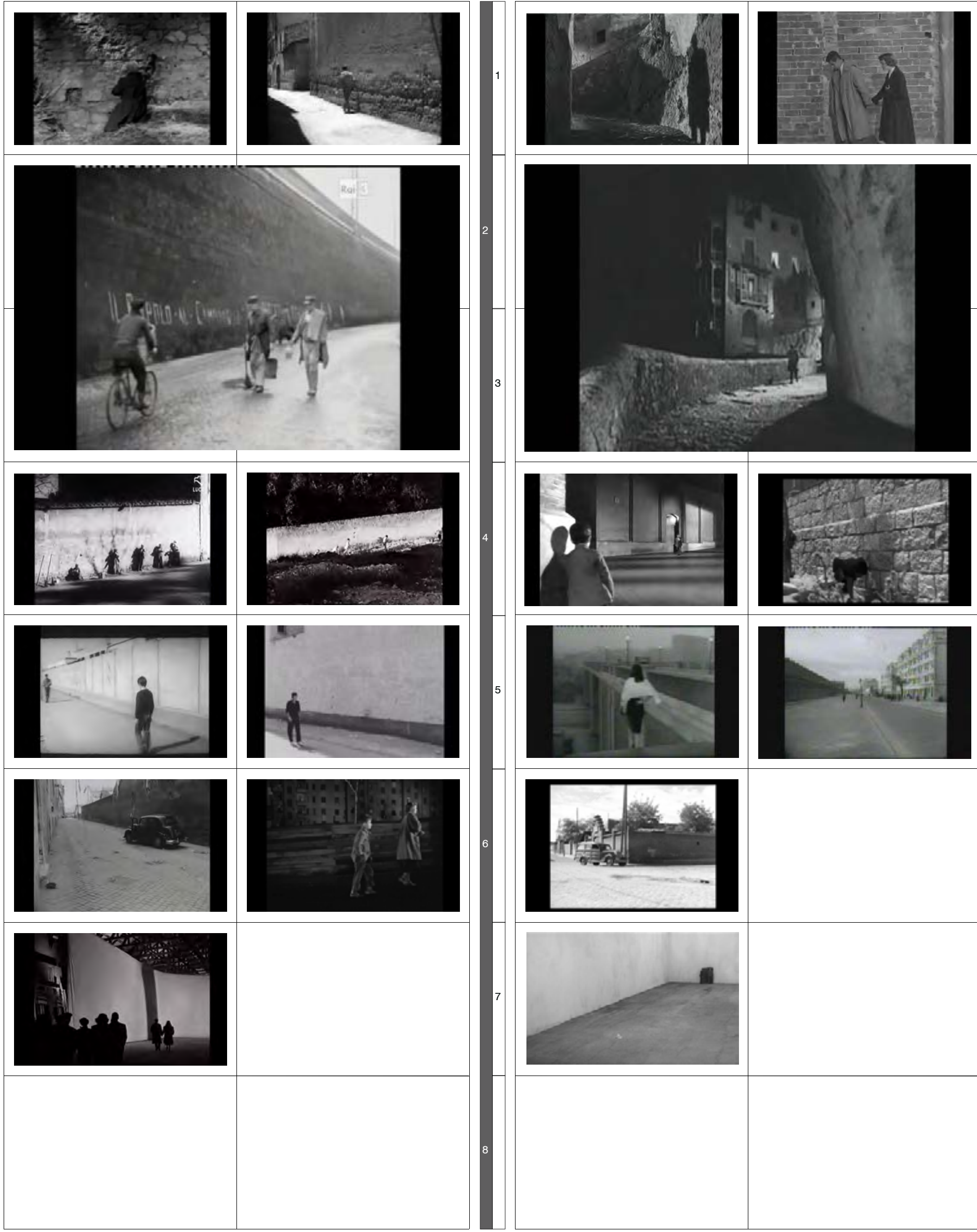

RM 1. La calle (Fellini)

RM 1. Ladrones de bicicletas (De Sica)

RM 2-3-4. Nettezza urbana (De Sica)

RM 4. Amor en la ciudad. Ep. historia de Caterina (Maselli)

RM 5. Rocco y sus hermanos (Visconti)

RM 5. Accattone (Pasolini)

RM 6. I vitelloni (Fellini)

RM 6. El techo (De Sica)

RM 7. Amor en la ciudad. Ep. Los suicidas (Antonioni)
MD 1-2-3. Calle Mayor (Bardem)

MD 4. Mi tío Jacinto (Vajda)

MD 4. Surcos (Nieves Conde)

MD 5. Los golfos (Saura)

MD 6. Surcos (Nieves Conde)

MD 7. El verdugo (Berlanga) 


\section{ARCOS Y PORTALES.}

$\mathrm{Si}$ en el espacio urbano existen barreras y límites, también existen umbrales que marcan las entradas y las salidas. El valor de estos elementos corresponde a un cambio de la condición física y psicológica de los personajes; y en el espectador produce la imagen de una frontera hacia lo desconocido.

La diferencia entre claridad y oscuridad, se produce al pasar desde una zona exterior hacia una interior, o por la profundidad del mismo umbral, o por la tipología y la calidad de la delimitación que atraviesa. Esta calidad luminosa del umbral, corresponde según Bruno Reichlin, a una condición típica de la experiencia de la guerra, que se refleja no solamente en las películas sino también en algunas arquitecturas de la época. La experiencia del movimiento desde la luz hacia la sombra, corresponde al recuerdo muy vivo en la memoria colectiva de los refugios antiaéreos, los sótanos y los bunkers, muchas veces hundidos en el suelo o ubicados en túneles o bajo viaductos, en algunos casos como en Nápoles, generando barriadas subterráneas construidas en las antiguas minas de la ciudad, una visión que causa el desconcierto del militar estadounidense en la película Paisá de Rossellini. Para Reichlin estas sensaciones y recuerdos se condensan en la arquitectura del monumento de las Fosse ardeatine $^{46}$; según el crítico suizo hay una escena de Ladrón de Bicicletas en la cual aparecen las mismas calidades espaciales de este monumento. Se trata de los fotogramas que describen las preocupaciones del padre que baja al Tíber pensando que su hijo se ha ahogado; esta escena está ambientada en la penumbra del arco del puente Flaminio, que el protagonista atraviesa para alcanzar el lugar del accidente ${ }^{47}$.

En las películas españolas e italianas los umbrales están enfatizados a través de formas arquitectónicas. La imagen del arco caracteriza el paisaje urbano, marcando entradas y salidas. En Mamma Roma, el director Pier paolo Pasolini se detiene con su cámara en la imagen del arco monumental del conjunto de viviendas en el cual madre e hijo se mudan a vivir temporalmente antes de la asignación de su vivienda INA-Casa, en la cual los atiende otro arco, un portal de arquitectura racional con sus vigas de concreto, que subraya irónicamente hacia una nueva vida burguesa y urbana. Al fondo de la calle del barrio INA-Casa, aparece otro arco que enmarca el paseo de madre e hijo, así como la carrera de la protagonista en la escena final; se trata del arco parabólico de la Unidad horizontal de Libera. En Madrid el arco de la entrada de la plaza de Toros en Ventas y el Arco de Cuchilleros en la Plaza Mayor, aparecen en Mi tío Jacinto y en El último caballo y se cargan de valores simbólicos, como espacios de transición hacia una vida mejor, "umbrales de oportunidades".

La escena principal de la película Los jueves, milagro, se desarrolla en la entrada de un túnel de ferrocarril. En un tramo de las vías del tren bajo el umbral obscuro del arco algunos de los personajes principales de las películas se esconden preparando la puesta en escena del falso milagro. Desde el túnel los fuegos artificiales, las luces y los efectos especiales crean la ilusión de la aparición de San Dimas frente a los ojos del tonto del pueblo. Un contraste marcado entre la sencillez del pueblo y de sus habitantes y la irracionalidad de este espacio oscuro que se convierte en el origen de la ilusión, el umbral que rompe la tranquilidad y la rutina del pueblo, generando caos e incertidumbre para los habitantes, la tranquilidad se altera por apetitos y deseos de riqueza, y el túnel y el ferrocarril se convierten en símbolos de esta aspiración hacia lo urbano (F.2.4.4/2).

\footnotetext{
${ }^{46}$ Primera arquitectura moderna después del fascismo, construido en Roma después de un concurso nacional en la Italia democrática ganado por el grupo de Mario Fiorentino en 1944 e inaugurado en 1949. 47 (Reichlin, 2002)
} 


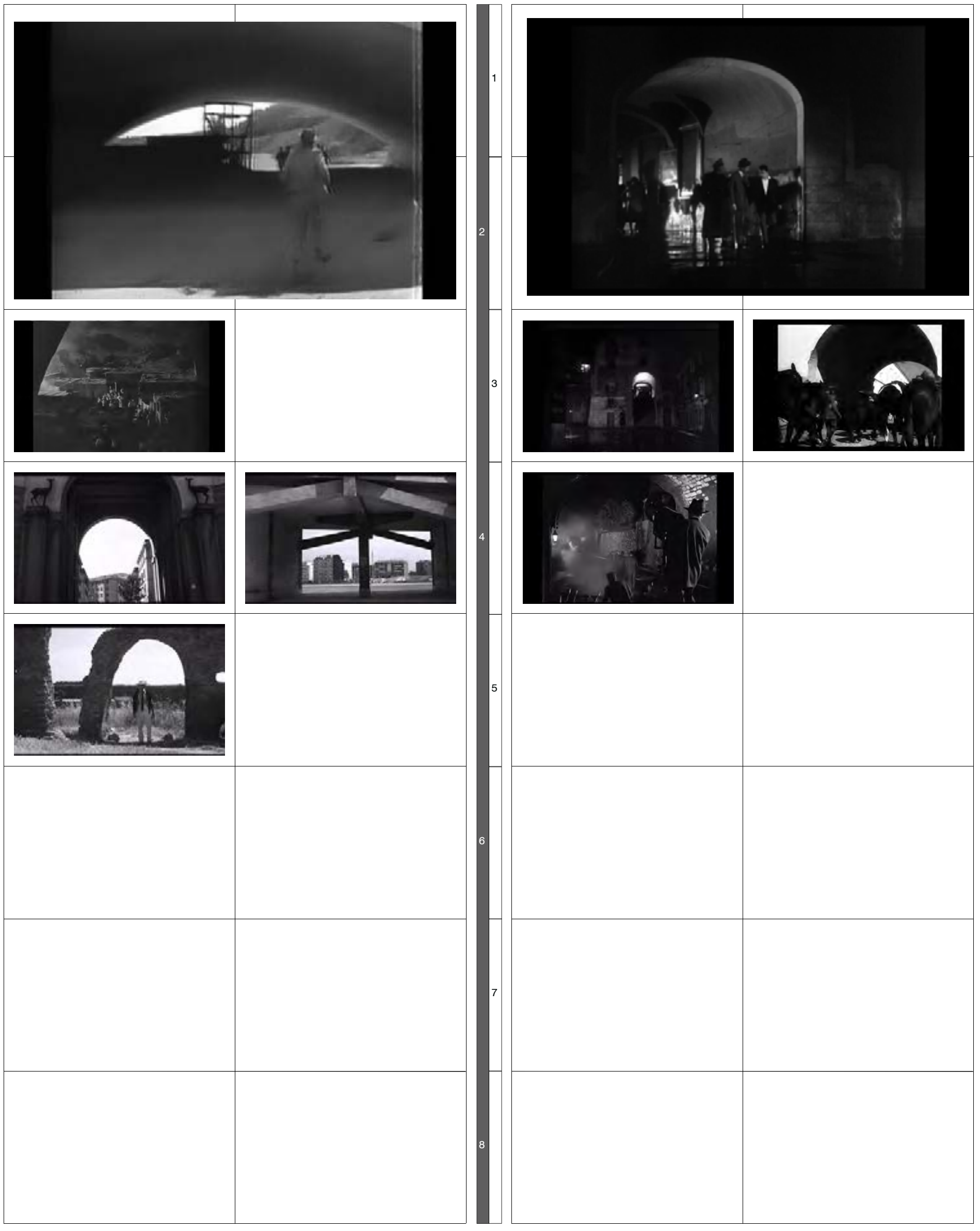




\subsubsection{Ciudad Desertizada / inacabada / en construcción}

\section{ANDAMIOS}

La icónica estructura-andamio de Tubi Innocenti ${ }^{48}$ en el enorme descampado de los estudios de Cinecittá, que aparece en las escenas finales de la película de 1962, 8 11/2 de Fellini, tuvo un gran impacto en la estética artística de los años ' 60 y más adelante todavía. Es una iconografía presente en la arquitectura italiana a lo largo de todo el siglo XX, en los montajes de Edoardo Pérsico para exposiciones efímeras en la Italia fascista y en la posguerra, con las originales contribuciones a la museografía de arquitectos como Albini, y hasta las arquitecturas efímeras posmodernas para eventos culturales y políticos de los años '70 y '80. Esta iconografía del andamio, tuvo sus antecedentes en las muchas películas neorrealistas, en las cuales la ciudad se configura como una gran obra in fieri, una ciudad desertizada e inacabada, en donde solares desocupados, terrenos, plazas y calles están caracterizados por estas estructuras provisionales. El andamio de $81 / 2$, tiene un antecedente en la toma panorámica que aparece en Bellisima, de Visconti, diez años antes de la película felliniana. En el paisaje polvoriento de Cinecittá, la monumental estructura de andamios de madera genera un contraste con el frenesí de las personas empujándose y gritando en la cola para las audiciones, y con la corsa desesperada y cómica al mismo tiempo, de Anna Magnani, en búsqueda de su hija. El director utiliza un recurso escenográfico para potenciar el mensaje presente en el guión, que plantea la imposibilidad de realismo en el mundo del cine, una reflexión del mismo Visconti sobre la falsedad y la ilusión que rodean este arte que pretendía contar lo real. También $81 / 2$ es una película sobre el Cine y sobre ilusión y realidad en la vida; el desfile lúdico de los personajes, actores y clowns, es una escena que intenta condensar reflexiones, significados y dudas que se desarrollan a lo largo de la historia-autobiografía felliniana, a través de un paisaje artificial. Los andamios acompañan muchas escenas de obras en construcción en donde los protagonistas trabajan, como en Rocco y sus hermanos: Ios andamios en edificios de vivienda en construcción ocupan todo el encuadre con sus claroscuros, y genera un efecto de extrañamiento respecto a la escala diminuta de los personajes que se desplazan por él.

A veces las estructuras efímeras son construcciones ligeras, a punto de caerse, como ocurre con el cableado suspendido que viaja sobre una precaria estructura de palos de madera desde la ferrovía hasta el asentamiento chabolista de Milagro en Milán; la estructura-puente parece construida por los mismos pobladores, a punto de derrumbarse, fortalece la iconografía del efímero presente en toda la película de De Sica, en donde los únicos elementos sólidos están representados por la línea de Ferrocarril y los coches de los especuladores inmobiliarios. Precario es el hogar de Mi tío Jacinto, un ambiente totalmente ficticio, "inventado" y construido por el director Ladislao Vajda en las afueras de Madrid; en una toma de picado, se ve la valla que encierra la chabola en la cual viven los protagonistas, una estructura de palos de madera, totalmente inconsistente, bajo una lluvia que parece arrastrarla y derrumbarla. Otra estructura precaria es la canalización-puente de madera que atraviesa un canal en Madrid, y que uno de los protagonistas de Los golfos atraviesa buscando su compañero. El fotograma quizá más contundente que representa esta iconografía, sin embargo está rodado en Cuenca ,y es el puente colgante en el cual se detiene el protagonista de "Calle Mayor" de Bardem a lo largo de un paseo nocturno; la cámara desde abajo en contrapicado, encuadra la estructura metálica reticular iluminada por la luz artificial, que contrasta con la pared de roca en la cual es empotrada; sobre esta estructura evanescente se mueve el protagonista que detiene por un instante su camino, y se sujeta al pasamanos mirando hacia abajo como perdido (F.2.4.5/1).

\footnotetext{
${ }^{48}$ Se trata de una patente de 1935 del empresario italiano Ferdinando Innocenti de un sistema de andamios constituido por tubos metálicos y una junta atornillada del tipo Ring lock, muy común en Italia
} 

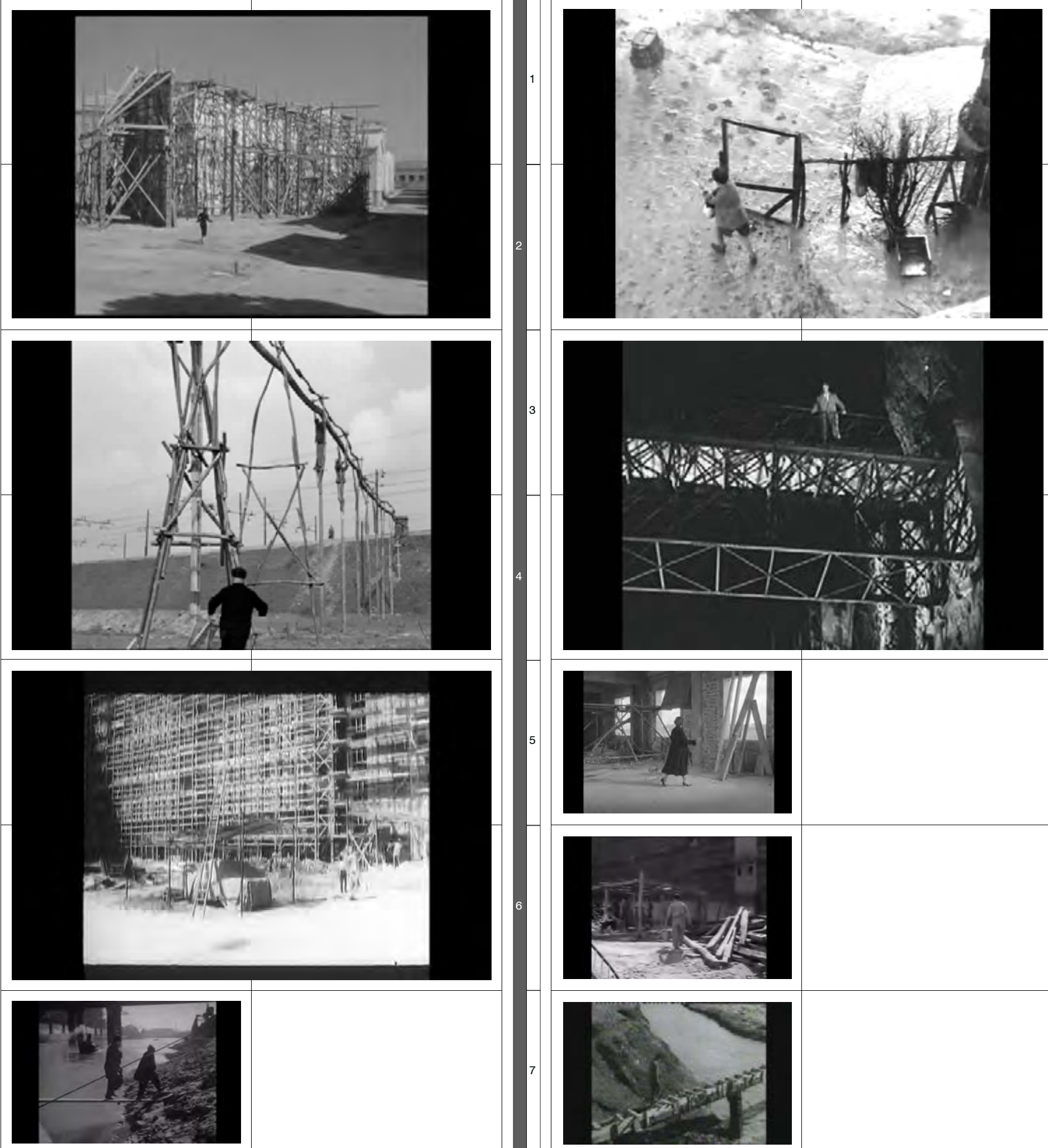

RM 1-2. Bellissima (Visconti)

RM 3-4. Milagro en Milán (De Sica)

RM 5-6. Rocco y sus hermanos (Visconti)

RM 7. Limpiabotas (De Sica)
MD 1-2. Mi tío Jacinto (Vajda)

MD 3-4. Calle Mayor (Bardem)

MD 5. Calle Mayor (Bardem)

MD 6. El Inquilino (Nieves Conde)

MD 7. Los Golfos (Saura) 
ARMAZONES.

La ciudad neorrealista se construye en tiempo real durante el rodaje de las películas; muchos directores aprovechan las obras en construcción como decorados para sus películas, que cuentan la ciudad en construcción como oportunidad de rescate social y económico (Rocco y sus hermanos, El techo, etc.). Los armazones de hormigón armado con las maquinarias moviéndose alrededor, representan la iconografía perfecta para describir la ciudad que cambia. No se trata sin embargo de "La ciudad que surge" de las pinturas futuristas de Boccioni, que pone en el fondo de su cuadro la imagen de unos andamios de un edificio en construcción, la imagen de estos esqueletos en construcción genera más alienación e inquietud que optimismo; los armazones se acompañan a grandes lotes baldíos, escenarios en los cuales la realidad parece suspendida, y los actores parecen perdidos y desorientados, como en una secuencia de Historia de la Radio, de Sáenz de Heredia, en la cual aparecen los límites de la ciudad con terrenos vacíos en espera de ser urbanizados en las proximidades de la Avenida Concha Espina, en Madrid. Los armazones de hormigón armado constituyen la tecnología más utilizada para el desarrollo urbano de Roma y Madrid, y generan un paisaje que marca de forma persistente la iconografía urbana de las dos capitales, un paisaje que, junto a la iconografía de los andamios, describe una ciudad "en espera", una actividad frenética de construcción y un cambio que al mismo tiempo desarrolla una imagen de precariedad y suspensión: una siniestra semblanza con la iconografía de las ruinas de la guerra, imagen que todavía persiste en los paisajes urbanos y en los recuerdos de sus habitantes. En algunas películas el rodaje se desarrolla dentro de estas estructuras vacías, los armazones de la vivienda en construcción se animan con la presencia de sus futuros habitantes como en las escenas de $E l$ verdugo de Berlanga en las cuales la pareja recién casada, junto al padre de la esposa, visita el bloque en construcción de su futura casa, intentando descifrar con muchas dificultades las proporciones de su futuro hogar. En Calle Mayor película ambientada en Palencia, Cuenca y Logroño, una importante escena de diálogo entre los protagonistas está rodada en un edifico en construcción, su futura vivienda, en el cual apenas están levantados los tabiques de ladrillo; en esta película no hay espacio para ironía como en la obra de Berlanga, la obra inacabada llena de peligros se convierte en el escenario del engaño entre la pareja, el armazón inhóspito e inseguro como metáfora de la falsa ilusión de la protagonista (F.2.4.5/2). 

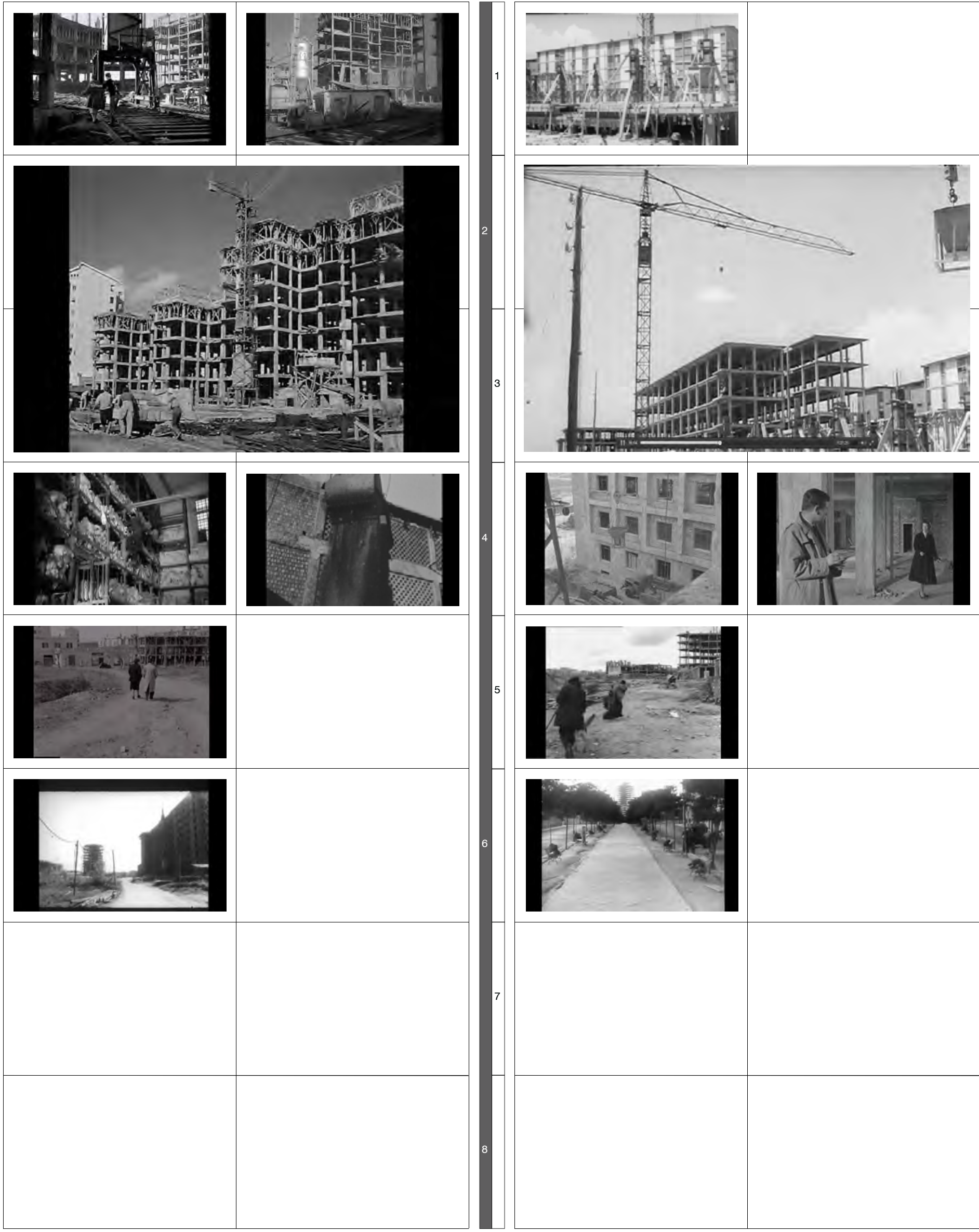

\section{RM 1-2-3. El techo (De Sica)}

RM 4. Ladrones de bicicletas (De Sica)

RM 4. Días de gloria (AAVV)

RM 5. Amor en la ciudad. Ep. suicidas (Antonioni)

RM 6. Rocco y sus hermanos (Visconti)
MD 1-2-3. El verdugo (Berlanga)

MD 4. Calle Mayor (Bardem)

MD 5. Historias de la radio (Sáenz de Heredia)

MD 6. Esa pareja feliz (Berlanga - Bardem) 
CIUDAD INACABADA, VACÍA

La ciudad de los andamios y de los armazones es una ciudad Inacabada y vacía, estas estructuras no son habitadas hasta su finalización, la ciudad compuesta de estas estructuras, se convierte, sobre todo en la noche, en un escenario surreal, en el cual permanece el recuerdo de la guerra y de sus ruinas. Cuando las obras se acaban, la ciudad sigue desertizada; la presencia de los pocos habitantes no es suficiente para generar vida entre sus calles que permanecen en una atmósfera de suspensión. En la escena final de Gli Italiani si voltano ${ }^{49}$ sexto y último episodio de la película colectiva Amor en la ciudad, dirigido por Alberto Lattuada, las mujeres son observada y perseguidas por los hombres a lo largo de todo el cortometraje, con un machismo arcaico que contrasta con el ambiente del centro de Roma, ciudad que aparece desarrollada económica y socialmente pero no culturalmente. Al final uno de los usuarios decide bajar del tranvía para acercarse a la mujer que había mirado en el vehículo a lo largo de todo el recorrido; la mujer bajando, corre rápida hasta lo que parece su hogar y se refugia en él, el hombre queda solo en la calle desierta en un barrio de la periferia Suroeste de Roma cerca de la vía Ostiense y la actual Avenida Marconi, el director aleja la cámara describiendo con un plan total el paisaje urbano: un edificio aislado en una manzana vacía, con banquetas sin adoquín, la avenida polvorienta con el tránsito de camiones pesados, la total ausencia de otros habitantes, un rótulo publicitario luminoso sobre el techo del edificio, algunos postes de la red de alta tensión en el fondo; el protagonista del acoso parece ahora perdido en este no-lugar, en plena periferia en expansión de una capital que ha logrado suprimir sus instintos (F.2.4.5/3).

\footnotetext{
49 Trad.: "Los Italianos se voltean"
} 


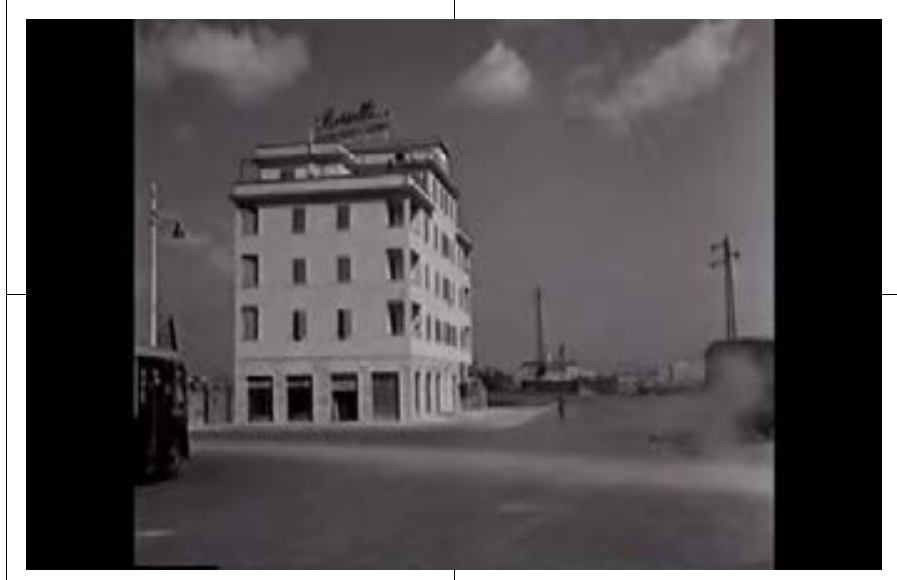

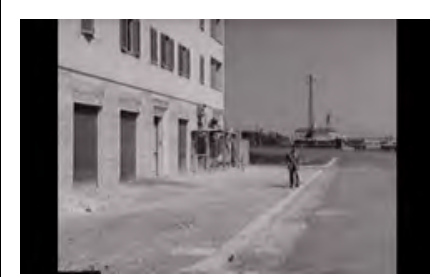
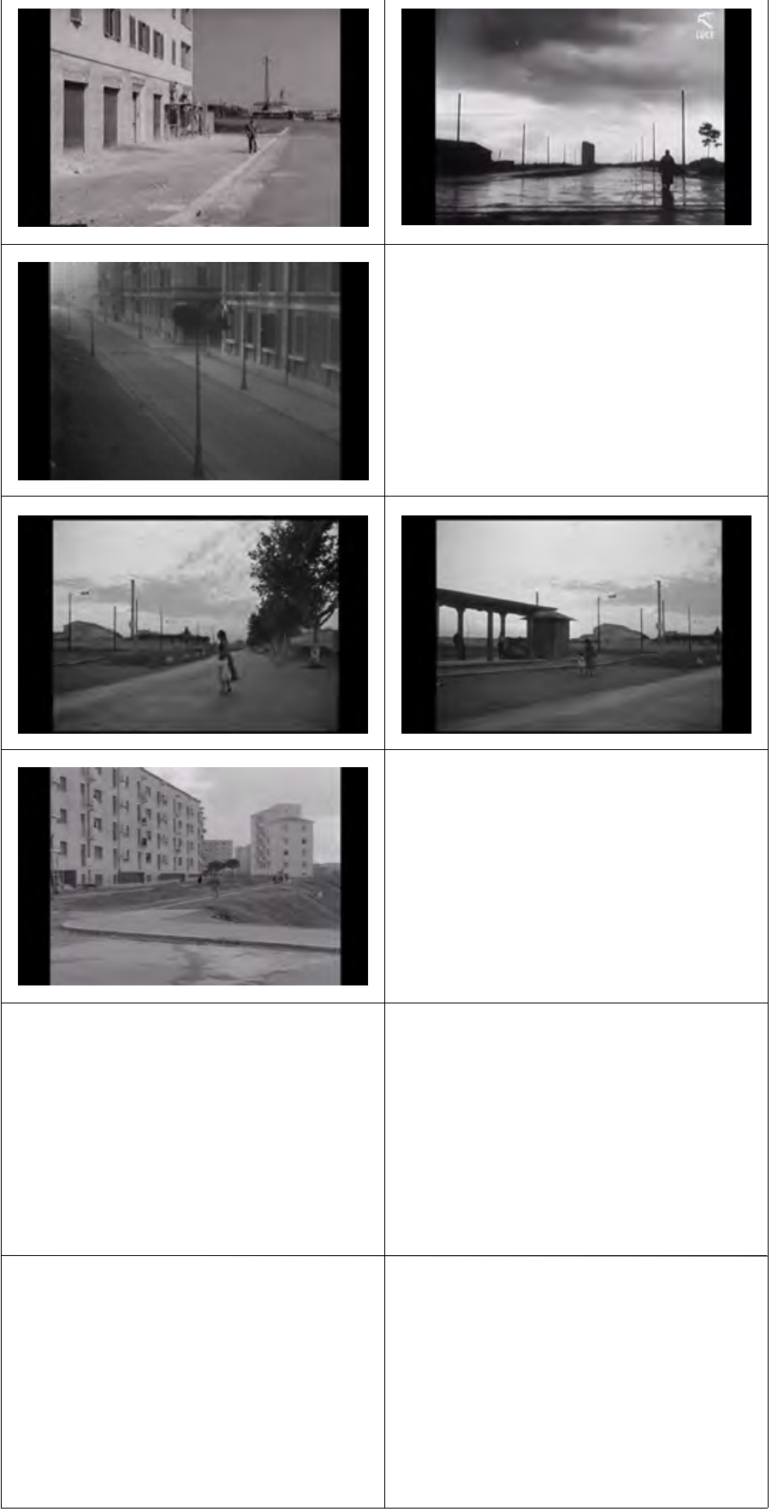

RM 1-2. Amor en la ciudad. Ep. Gli Italiani si voltano(Lattuada)

RM 3. Amor en la ciudad. Ep. Gli Italiani si voltano(Lattuada)

RM 3. Nettezza urbana (Antonioni)

RM 4. Días de Gloria (AAVV)

RM 5. Bellissima (Visconti)

RM 6. La calle (Fellini) - Pueblo del Lazio
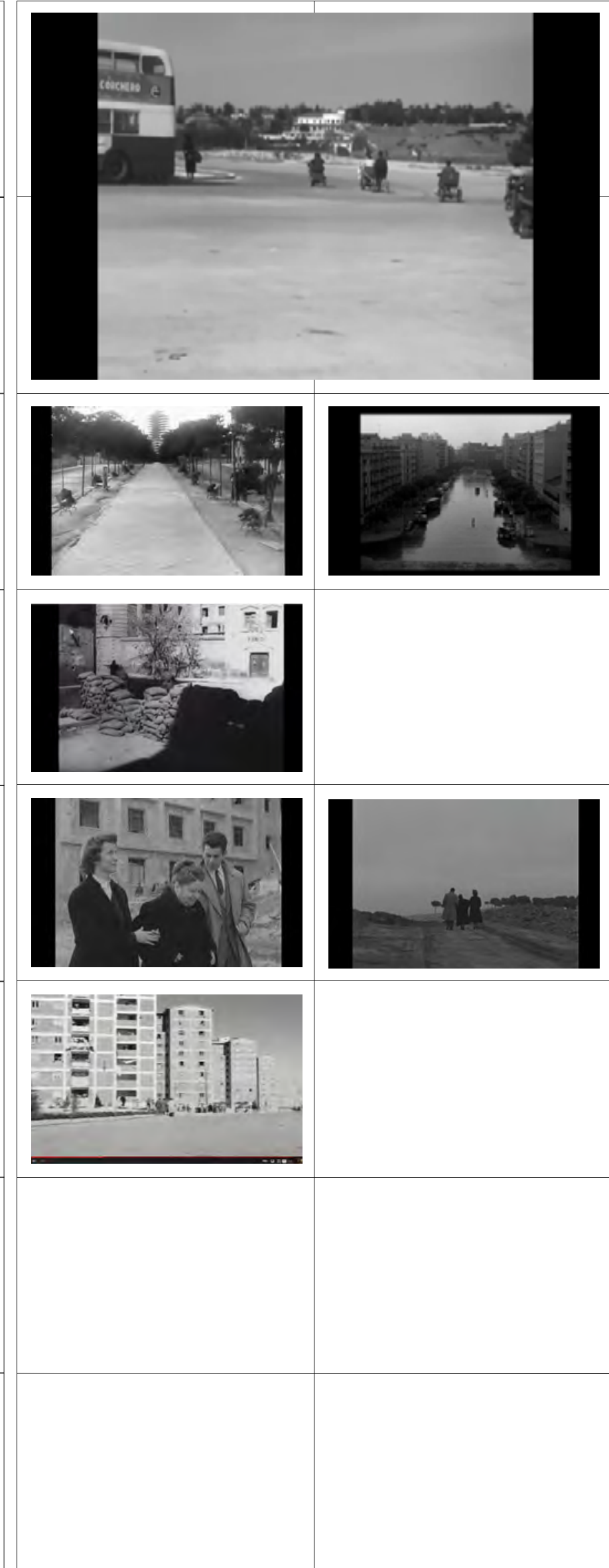

\section{1-2. El cochecito (Ferreri)}

MD 3. Esa pareja felíz (Bardem - Berlanga)

MD 3. Los chicos (Ferreri)

MD 4. La Guerra Civil - Instituto LUCE (AAVV)

MD 5. Calle Mayor (Bardem)

MD 6. El pisito (Ferreri) 


\subsection{Paisaje - permanencia: hábitat y demoras.}

\subsubsection{Detenerse}

A cada movimiento de los protagonistas, cada vagabundeo por los márgenes urbanos y los "espacios cualesquiera", sigue la necesidad de pararse, de detenerse para descansar, reflexionar, y cumplir con las actividades que sería imposible desarrollar en movimiento. Como explica Careri el parar en relación al movimiento se califica dependiendo de su duración: "de la pausa de un momento en el caminar nómada a una parada prolongada casi sedentaria. El paseo parecía expresar una naturaleza 'anti arquitectónica' (...). En cambio, en el detenerse la relación con la arquitectura parecería más fácil y directa: cuando uno se detiene surge la arquitectura" ${ }^{50}$. Entonces caminar y detenerse podrían ser dos partes de un mismo proceso en el cual el pararse presupone un movimiento anterior, una exploración del territorio, una interpretación abierta del lugar que influye sobre la forma de actuar.

En este análisis asociamos al estacionarse en un territorio, dos conceptos relacionados con la arquitectura: el demorar y el habitar. Como índica la etimología el demorar está relacionado con una idea de provisionalidad del parar: viene del latín demorari que significa propiamente detenerse y sus componentes lexicales son de y morari, que significa retardarse, entretenerse, de esta raíz llega también la palabra morada. El termino hábitat, en cambio, implica una costumbre o un hábito que presupone una duración más larga de la acción de demorar, un cambio del nomadismo a lo estancial. La palabra viene del latín habitare, frecuentativo del verbo habere (tener), y podemos entender este verbo como la acción de tener de manera reiterada un lugar físico y un territorio. La falta de posesión de un lugar en el tiempo es la condición de muchos de los protagonistas, lugar que buscan y rechazan al mismo tiempo, por ser nómadas, migrantes o caídos en desgracia: estas condiciones derivan de las injusticias sociales que no se solucionan con el fin de la guerra. El no tener una vivienda de su propiedad, no tener una vivienda digna o vivir en condiciones de hacinamiento, presupone una actitud de desapego hacia el mundo urbano, y al mismo tiempo produce una voluntad de exploración y conocimiento de toda la ciudad. Los movimientos de los protagonistas se extienden por radios muy amplios, muchos son los lugares en los que los protagonistas se mueven con desenvoltura.

\subsubsection{Seis niveles.}

Las dificultades existenciales de los protagonistas de las películas analizadas determinan "una vida en movimiento" en la cual la acción de demorar ocupa un pequeño porcentaje de la existencia en el tiempo fílmico. Las tipologías de demoras y hábitats analizados, corresponden a diferentes niveles sociales y económicos en un orden creciente; podemos agrupar los tipos identificados en una escala con seis diferentes niveles.

NIVEL 1 Y 2

El primer nivel corresponde al nomadismo: la condición de no tener un hogar que presupone el vivir entre el vagabundeo y la búsqueda de lugares provisionales para el descanso. Esta condición puede ser temporal, debido por ejemplo a la excesiva distancia de la propia casa y a la incapacidad psicológica de un regreso antes de haber solucionado un problema: el famoso fotograma de Ladrón de bicicletas que representa a padre e hijo sentados en la acera, cansados por la búsqueda sin fin del vehículo robado, expresa muy bien esta condición (F.2.5.2/1).

\footnotetext{
50 (Careri, Stopscapes, un glosario, 2015 p.49)
} 

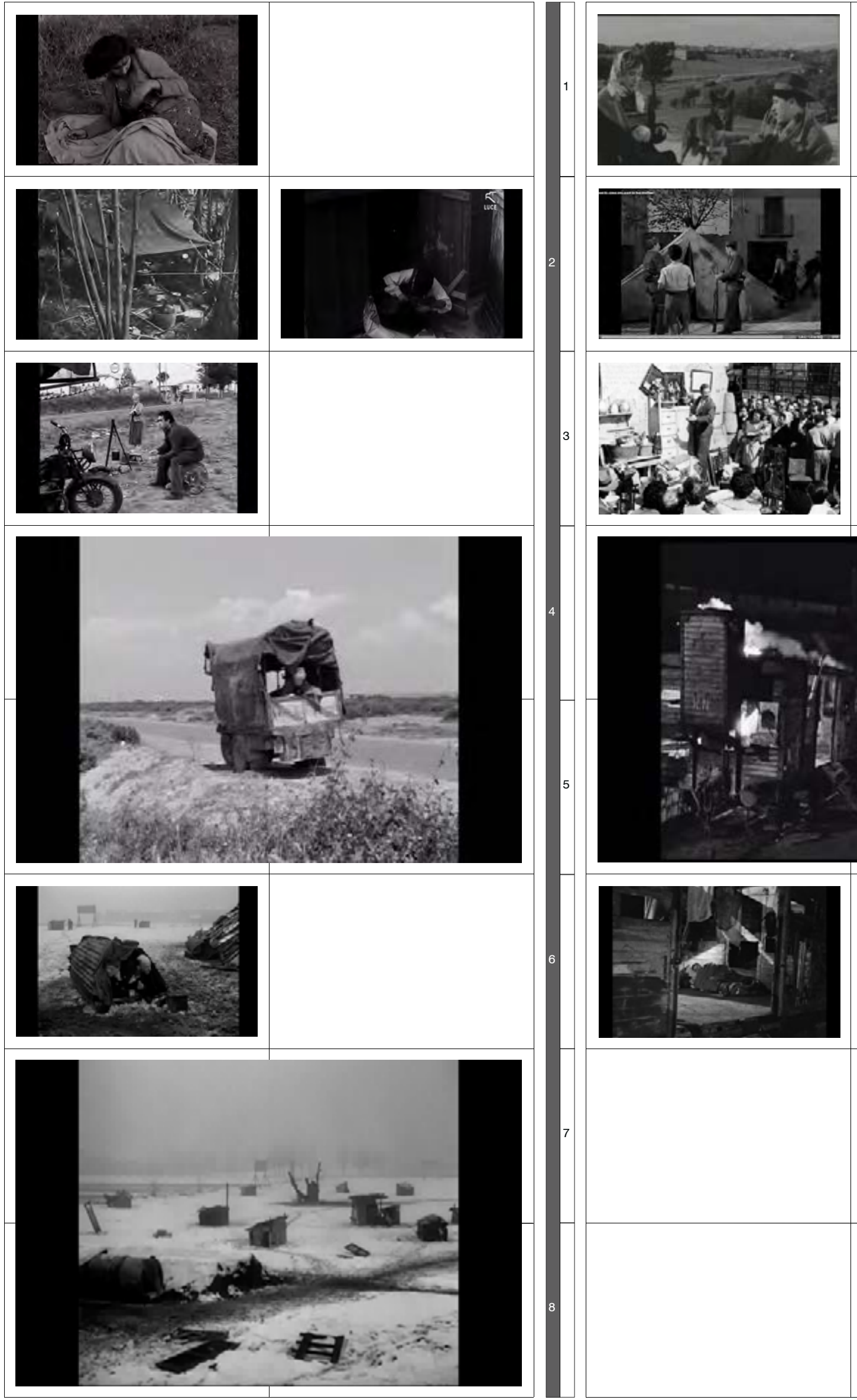

RM 1. Amor en la ciudad. Ep. Historia de Caterina. (Maselli)

RM 2. Días de gloria (A.A.V.V.)

RM 2. Nettezza urbana (Antonioni)

RM 3-4-5. La calle (Fellini)

RM 6-7-8. Milagro en Milán (De Sica)
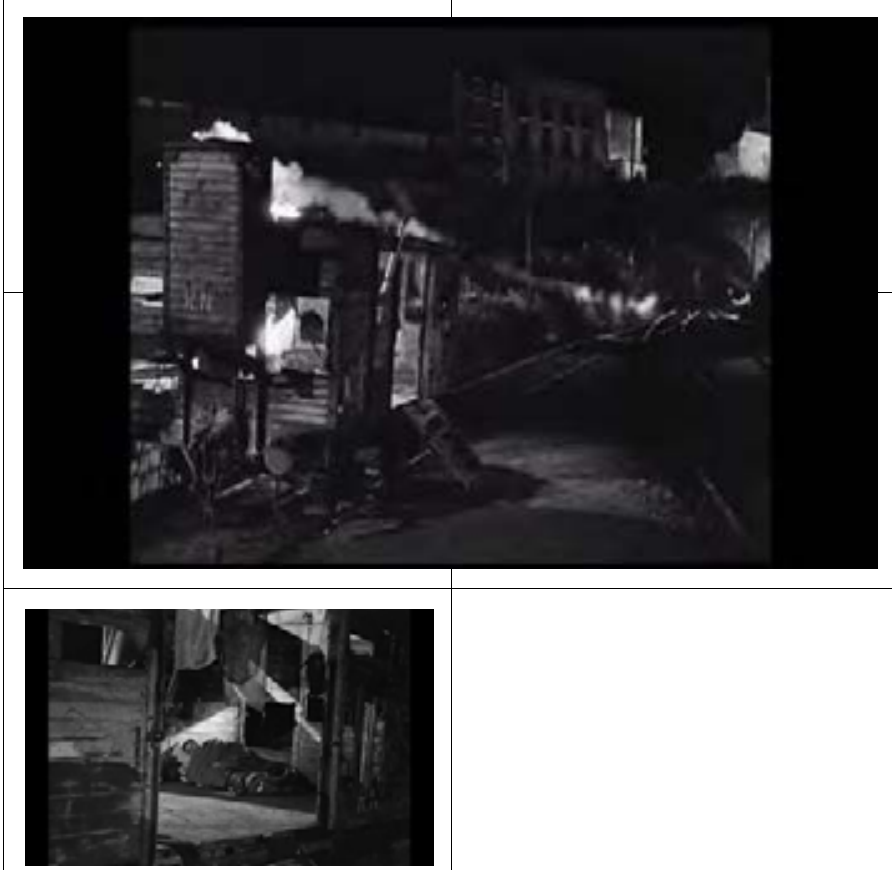

MD 1. El pisito (Ferreri)

MD 2. Calabuch (Berlanga)

MD 3. El inquilino (Nieves Conde)

MD 4-5-6. Los jueves milagro (Berlanga) 
Otros ejemplos son los de la Historia de Caterina, episodio de Amor en la Ciudad, dirigido por Francesco Maselli, con la protagonista que duerme en un campo por la excesiva distancia de la casa rural donde vive del centro de Roma donde busca trabajo.

La protagonista necesita ganar dinero para no tener que abandonar a su hijo. Otra representación iconográfica de vida nómada es la escena pausa de la pareja protagonista de El pisito, en una ladera en las afueras de Madrid en la desafortunada búsqueda de una vivienda digna; estos nómadas urbanos, protagonistas de las películas, ocupan el espacio, buscando lugares aislados, seguros y lejos de los ojos de los demás ciudadanos, muchas veces lugares que pertenecen al mundo natural, parques, laderas, terrenos baldíos.

El segundo nivel, corresponde ya a una ocupación del suelo urbano con pequeñas estructuras temporales, refugios improvisados como las cajas de cartón que ofrecen una demora nocturna para el protagonista de Milagro en Milán. En Nettezza urbana, de Antonioni, la ocupación corresponde a un "reciclaje arquitectónico": uno de los basureros duerme en el kiosco de un florero en las horas nocturnas, probablemente también por la excesiva distancia del lugar de origen. Con un plano conjunto, el director describe la salida del trabajador del kiosco en el amanecer, una manifestación de pobreza y adaptación extrema que Antonioni describe sin tonos dramáticos. Esta iconografía de la ocupación de un habitáculo se produce también en el cine español con la secuencia de la aparición de San Dimás al tonto del pueblo, que duerme dentro del coche de un tren al lado del ferrocarril. Otra escena que pertenece a este universo de precariedad extrema es la descripción de la "ocupación forzosa" de la calle por parte de Fernando Fernán Gómez en El inquilino de Nieves Conde: el final no censurado de esta película de 1957. En La calle de Fellini los protagonistas son nómadas "profesionales", viven en los descampados a lado de avenidas y carreteras, y se desplazan con una caravanafurgoneta; así como vive acampado el extraño profesor de la película Calabuch de Berlanga.

NIVEL 3 Y 4

El tercer nivel corresponde al habitar -ya no se trata solo de demorar- en chozas de pura chapa metálica o madera, como las que el protagonista de Milagro en Milán levanta junto a sus compañeros, construyendo en poco tiempo un pequeño poblado, o la de Mi tío Jacinto, una estructura de chapas y materiales reciclados, pegados a una ladera en el barrio de San Juan Bautista a lado del antiguo río Abroñigal.

El cuarto nivel está representado por la ocupación de estructuras más duraderas, chabolas hechas de ladrillos, como las de El techo o de Cerca de la Ciudad, que pueden generar pequeñas agrupaciones informales dentro del territorio urbano. Estructuras ilegales que se construyen en una noche como "flores de luna" ${ }^{51}$, en estos edificios no cambian las condiciones de vida: las inundaciones, el hacinamiento y la precariedad, se producen en un hogar arquitectónicamente y psicológicamente más digno, no por el tamaño o el lugar escogido, sino por los materiales y los acabados más durables, que a veces hacen semejar estas barriadas a los pueblos de origen de los inmigrantes que las ocupan. Estos tipos de construcciones aparecen en Roma en películas como Europa 51 de Rossellini o en una escena nocturna de Amor en la ciudad en el primer episodio dirigido por Lizzani; estas apariencias son muy breves, y habrá que esperar El techo de De Sica (1956), para que esta realidad sea descrita detenidamente. En el Cine rodado en Madrid, en cambio y de forma sorprendente, los asentamientos chabolistas de tierra y ladrillos están representados claramente ya con Surcos, de 1951, y aparecen también como protagonistas en Cerca de la ciudad y en El inquilino (F.2.5.2/2).

\footnotetext{
${ }^{51}$ Véase el documental Flores de luna (2008) de Juan Vicente Córdoba
} 

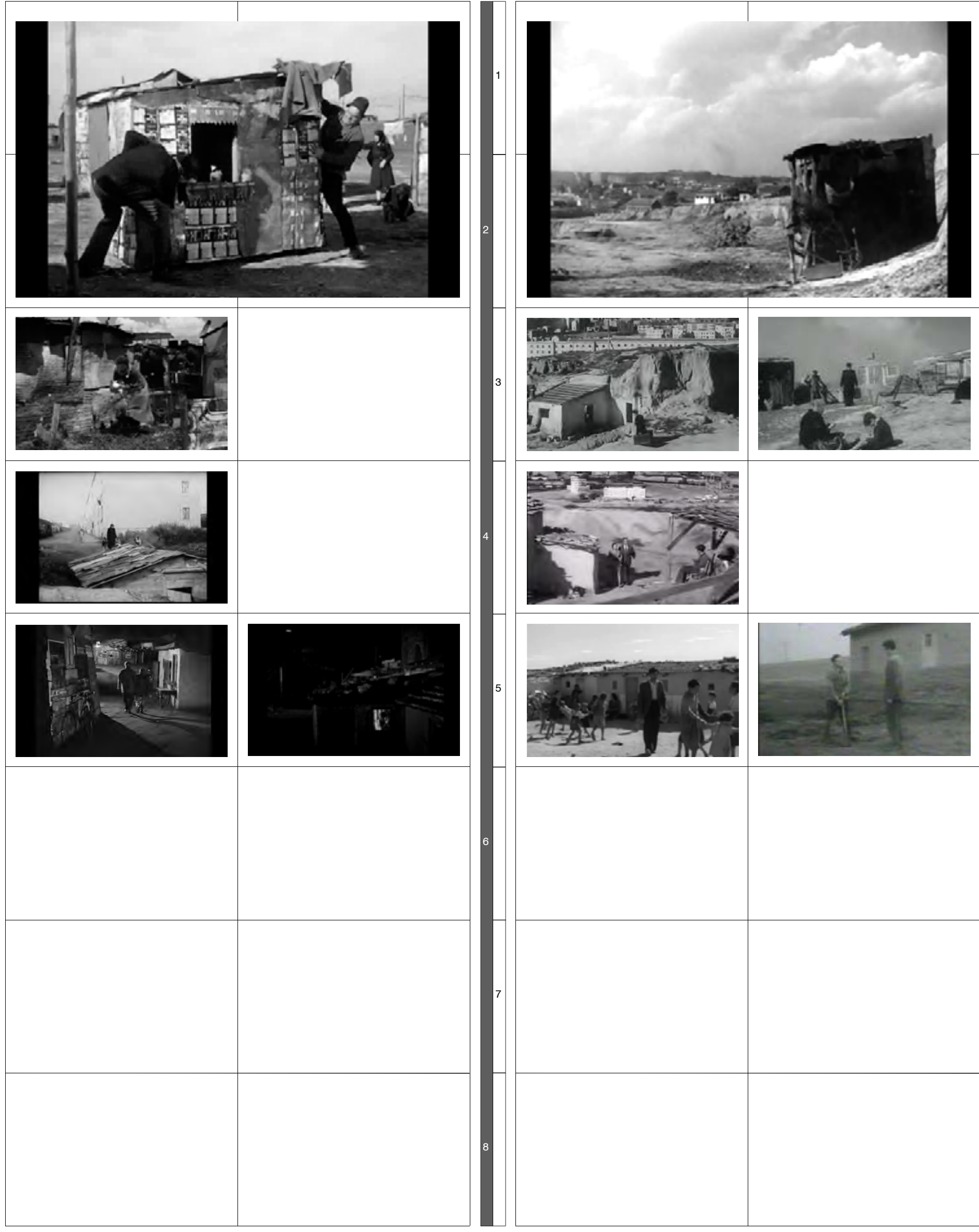

RM 1-2-3. Milagro en Milán (De Sica)

RM 4. Europa 51 (Rossellini)

RM 5. Umberto D. (De Sica)

RM 5. L'amore in citta episodio "El amor se paga" (Lizzani)

MD 1-2. Mi tío Jacinto (Vajda)

MD 3. Cerca de la ciudad (Lucía)

MD 4. El inquilino (Nieves Conde)

MD 5. Surcos (Nieves Conde)

MD 4. Los golfos (Saura)
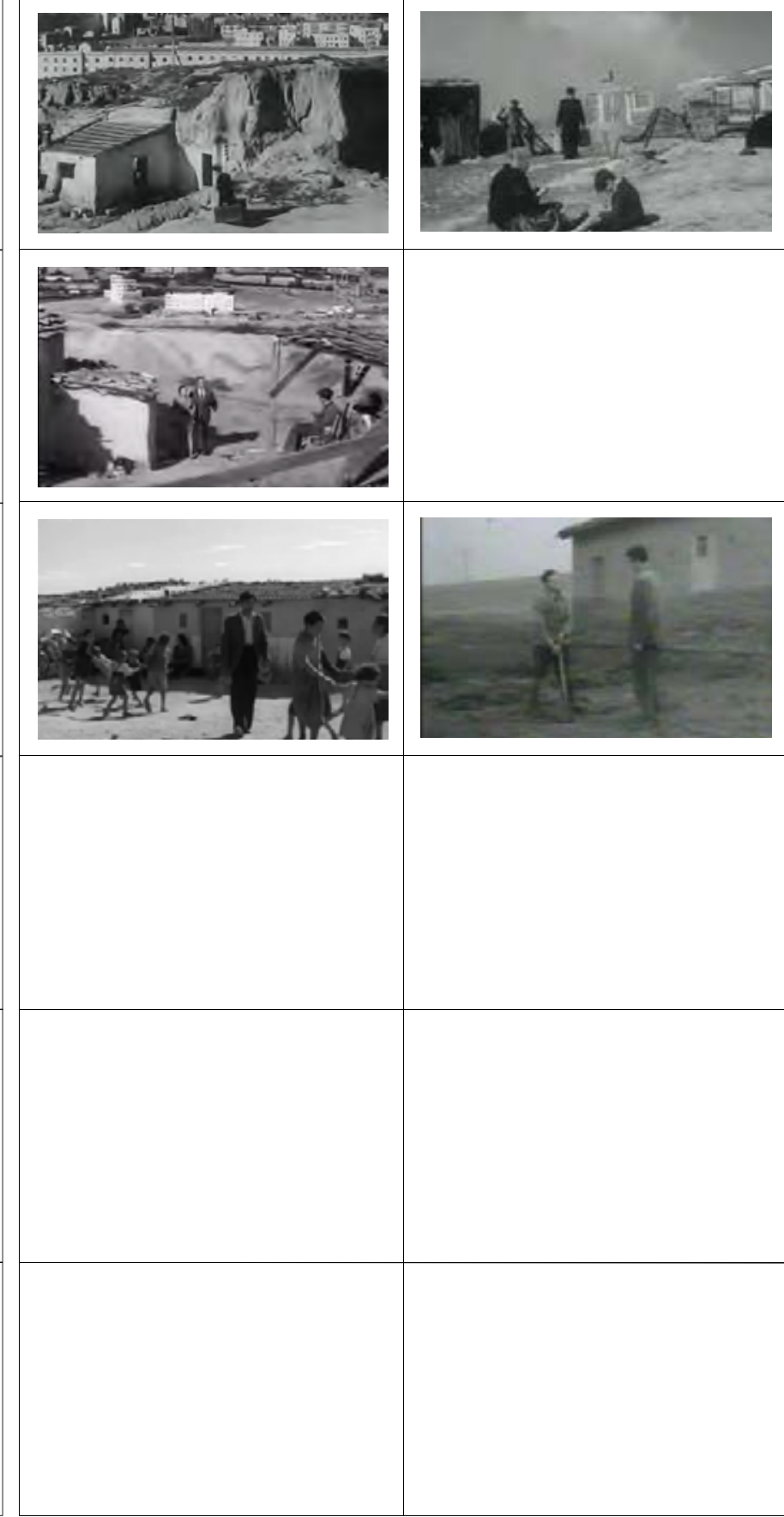
NIVEL 5 Y 6

El quinto nivel, pero no por calidad de vida, sino más por ser un habitar formal y legal de un punto de vista urbanístico, está representado por las casas hacinadas en los cascos históricos de las ciudades, las casas corralas, las viviendas en los patios de manzanas, departamentos mínimos que comparten, habitando, diferentes núcleos familiares en condiciones de higiene escasa y con falta de iluminación. Esta iconografía tiene un papel protagónico en Surcos rodada en una corrala del barrio de Lavapiés; En Roma aparece una situación de hacinamiento en $E I$ techo, aunque se trata de una vivienda obrera de dos plantas, compartida por varias familias; en este caso también, como en el nivel anterior, hay una diferencia en la "cantidad de realismo" entre cine italiano y español: la iconografía del hacinamiento en las viviendas populares está más realísticamente representada en las películas españolas. Ejemplo importante del cine italiano podría ser Humberto $D$, en el cual el protagonista renta una habitación en una gran manzana de un ensanche, muy cerca de la estación de Termini no lejos del centro de la ciudad; sin embargo, se trata de un departamento burgués de grandes dimensiones, con sirvienta, una vida bastante digna de la cual el protagonista y su perrito van a ser excluidos.

El último nivel, que muy pocos de los protagonistas alcanzan, es el de la vivienda social, la casa en alquiler que corresponde a la condición de vida pequeño-burguesa muy deseada, una vivienda en bloques o en torres, urbana, en una manzana de los ensanches en zonas semicentrales o en las periferias recién construidas. Este nivel está casi ausente en el Cine español en comparación con el italiano, por el desfase temporal que hubo en Madrid y en España entre la producción cinematográfica y la reconstrucción del patrimonio habitacional, y por el más bajo nivel socioeconómico descrito en las cintas.

Dentro de este nivel de seguridad alcanzada por los protagonistas hay que distinguir diferentes situaciones. Pierre Sorlin, en sus investigaciones sociológicas sobre Cine europeo, habla de la condición de La familia de Ricci en Ladrón de bicicletas que vive en la borgata Val Melaina una de las barriadas construida por Mussolini realojando migrantes chabolistas, o reubicando a los desalojados por los derribos 'hausmanianos' en el centro de la capital. Además de la distancia de más de 8 kilómetros, "el núcleo urbano de Valmelaina aún no está terminado, no hay agua corriente en los apartamentos, las calles no están asfaltadas pero tampoco hay ni dinero ni ganas de finalizarlo" ${ }^{52}$. El nivel de la vivienda de la familia Ricci es como escribe Sorlin, superior a la barraca de El limpiabotas, pero podemos añadir que no alcanza el nivel del INA-Casa. A esta pequeña diferencia en el hogar, corresponde un nivel social bien preciso; "De Sica nos describe a un grupo realmente peculiar, una familia nuclear cerrada como las que ciertamente existían en Italia en esos tiempos, pero que en la pantalla es mucho más rara que el modelo de familia grande y abierta" ${ }^{33}$, la que por ejemplo aparece en Rocco y sus hermanos que habita en un semisótano del conjunto habitacional de Fabio Filzi construido en 1932 por el IFCP ${ }^{54}$ con proyecto de Franco Albini. Otro conjunto habitacional construido en el Fascismo, que presenta los mismos problemas de segregación urbana y falta de servicios, es el conjunto habitacional de Borgata Primavalle que aparece en Europa 51, de Rossellini; La protagonista Ingrid Bergman, se mueve entre dos mundos con condiciones sociales no tan diferentes: pegados a los bloques de 3 plantas, construidos por el Duce, conviven en una cañada adyacente las chabolas de los que no tuvieron la posibilidad de acceder a la vivienda popular. (F.2.5.2/3).

\footnotetext{
52 (Sorlin \& Pujol i Valls, 1996 p. 118)

${ }^{53}$ Ibídem p. 119

${ }^{54}$ Instituto Fascista de Casas Populares.
} 

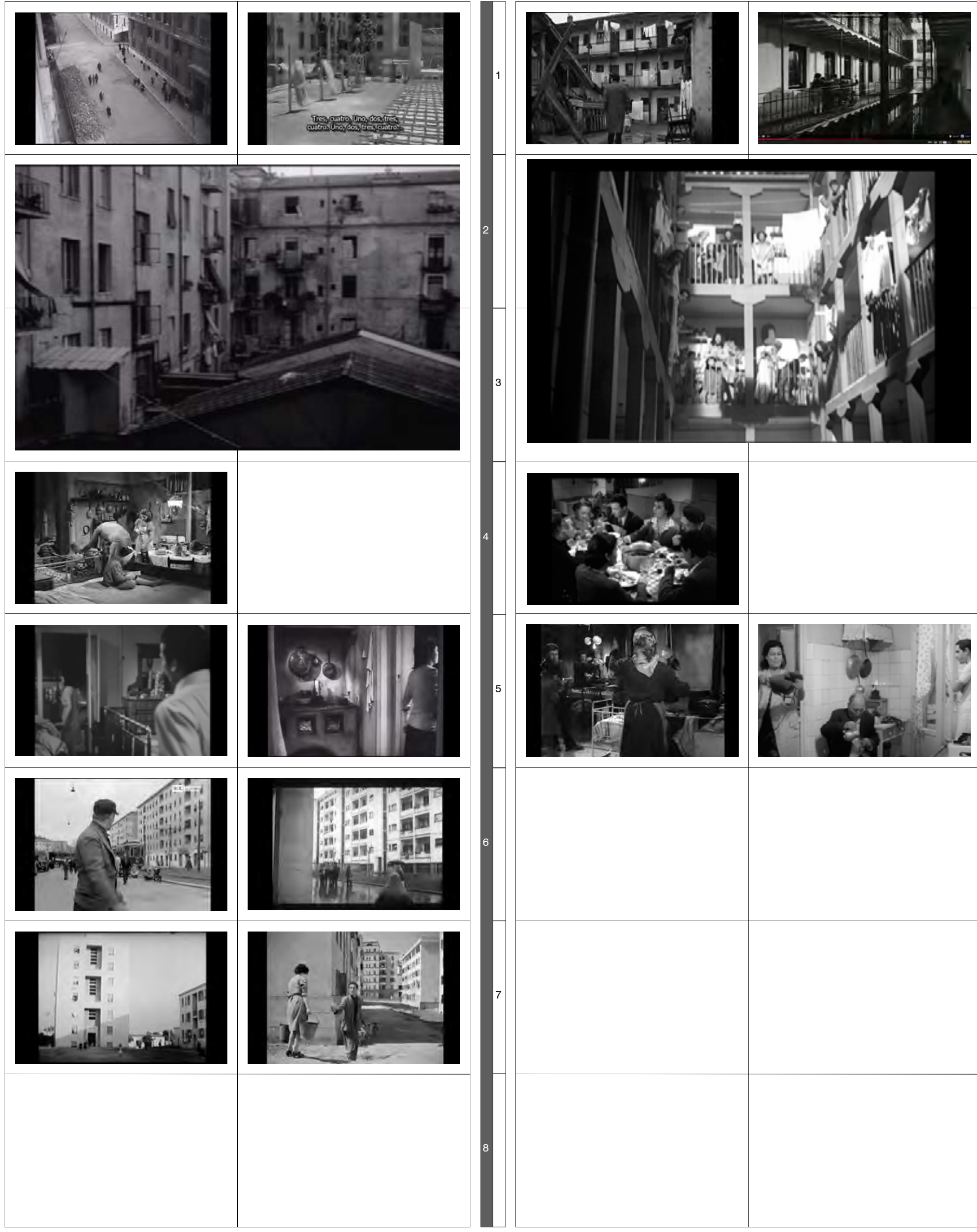

RM 1. Roma ciudad abierta (Rossellini) RM 1. Bellissima (Visconti)

RM 2-3. Umberto D. (De Sica)

RM 4. El Techo (De Sica)

RM 5. Bajo el Sol de Roma (Castellani)

RM 5. Roma ciudad abierta (Rossellini)

RM 6. II Ferroviere (Germi)
RM 6. Rocco y sus hermanos (Visconti)

RM 7. Europa 51 (Rossellini)

RM 7. Ladrones de bicicletas (De Sica)
MD 1. Muerte de un Ciclista (Bardem)

MD 1. El pisito (Ferreri)

MD 2-3-4. Surcos(Nieves Conde)

MD 5. Palcido (Berlanga)

MD 5. El Verdugo (Berlanga) 
ASPIRACIONES BURGUESAS: BLOQUES Y TORRES.

La vivienda digna de aspiración burguesa solo es una ilusión para los españoles así como aparece en la ensoñación de Fernando Fernán Gómez en El inquilino, en la cual el protagonista sueña el triunfal ingreso con su familia al "Barrio de la felicidad" un conjunto moderno de viviendas en bloque, muy parecido al "Barrio Esperanza" que aparece en el final alternativo de esta película, después del cambio operado por la censura franquista, que no toleraba que la familia protagonista, después de tanto buscar se tuviera que quedar en la calle. A lo largo de la película, en otra ensoñación, el protagonista se imagina a sí mismo viviendo en un departamento de lujo de estilo moderno, con muebles de diseño, una camarera personal, y coktails, como en una película Hollywoodense; ese era la imagen de casa ideal para muchos de los protagonistas que, sobre todo a partir de la segunda mitad de los años '50, asumen modelos y aspiraciones de la clase media de Estados Unidos, que llega a través de películas, programas de la radio y revistas.

El inquilino de Nieves Conde, en todo el Cine Neorrealista -incluyendo el italiano- es la película que más profunda y directamente toca el problema de la vivienda en la posguerra; las imágenes desde el helicóptero del Barrio de la Esperanza que impone Franco al final de la película, son las mismas que aparecen en los noticiarios NO-DO de la propaganda, y que no corresponden a la real posibilidad de acceso a estos programas de promoción por parte de la clase social más necesitada, como evidencia Nieves Conde en su película. En Italia, en cambio, la vivienda de promoción oficial aparece en la pantalla, pero solo en Mamma Roma, de Pasolini, se muestra como una aspiración burgués por parte de los protagonistas, mientras que en las otras películas, la vivienda popular también de recién construcción, no corresponde a la idea de bienestar realmente deseada; al final, también en la película Mamma Roma, a pesar de los convencimientos de la protagonista, Anna Magnani, el barrio INA-casa del Tuscolano, donde se muda a vivir, no será garantía de un destino mejor para ella y su hijo.

En Roma, los ambientes domésticos de la clase alto-burguesa están representados en Europa 51 , para reforzar el contraste con el estilo de vida que la protagonista adoptará después de la muerte del hijo: se trata de un departamento en una "palazzina" en el barrio más lujoso de la capital: el barrio Parioli (F.2.5.2/4). 

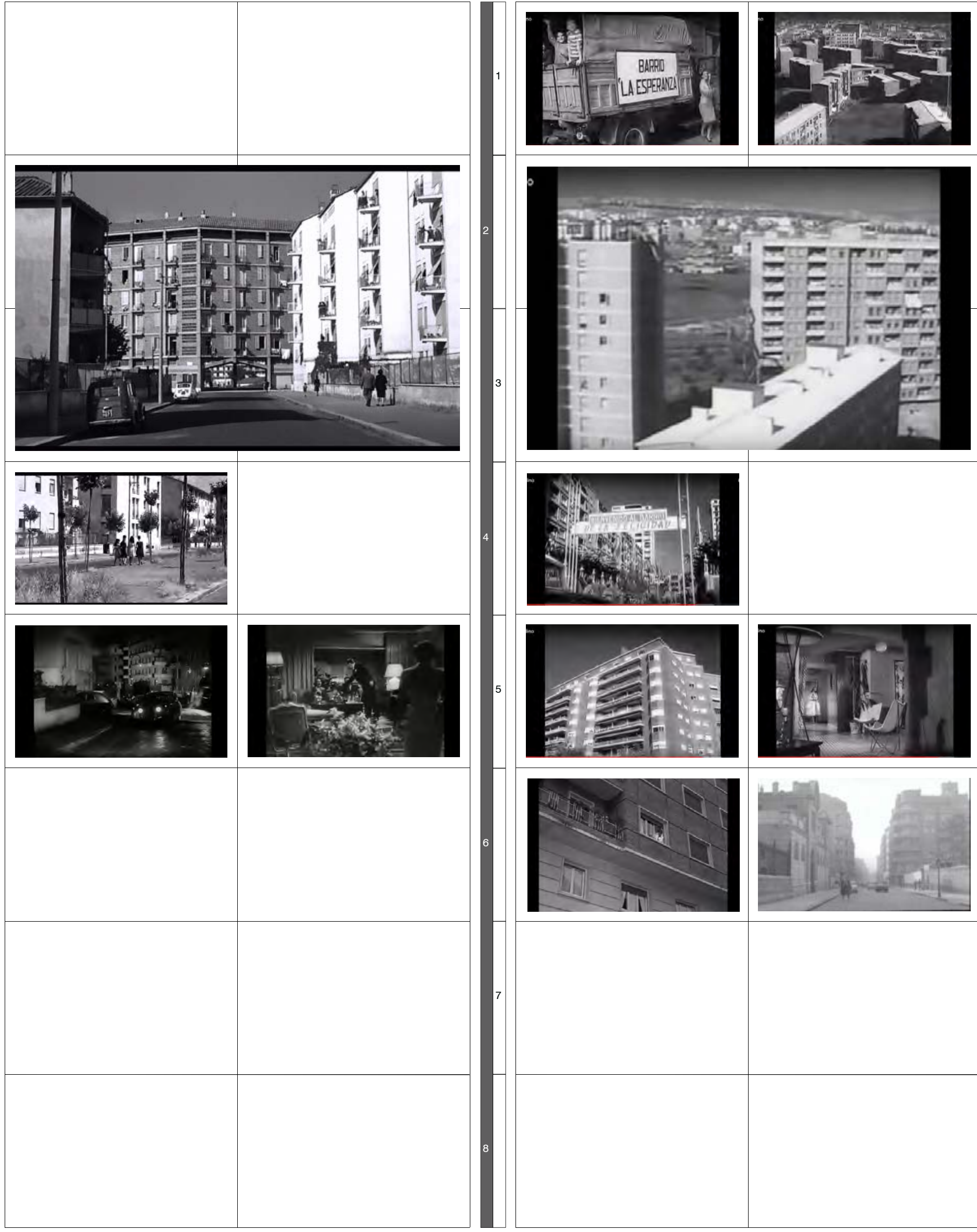
2.5.3 La casa impropia: planta baja, sótanos, buhardillas, casas-taller.

A los refugios de una noche de los nómadas urbanos en los terrenos baldíos y a las chabolas de la ciudad informal, tenemos que añadir una serie de "casas impropias" precarias o hibridas, que completan el "catálogo" de paisajes domésticos presentes en la filmografía neorrealista. Estas demoras precarias, que aparecen en muchas de las películas analizadas, nos cuentan de las adaptaciones de los protagonistas diferentes formas del habitar.

En Gente del Po, la familia protagonista de la película vive en una casa-barco, el hogar coincide con el lugar del trabajo, una vida de nómadas agotadora y precaria a lo largo del extenso río del Norte de Italia; la cámara del director a través de una serie de planos medios, medio-cortos y primeros planos, nos describe la vida de los protagonistas y las características espaciales de este hogar, a través de los sencillos detalles con acabados de madera.

En la película "El Verdugo" de Berlanga, como en "Gente del Po" la vivienda coincide con el lugar de trabajo; el protagonista antes de casarse, vive en la vivienda-taller de su hermano sastre, junto con la cuñada y la sobrina; en una escena los personajes expresan la incomodidad por la difícil convivencia y por la baja calidad del espacio al ser esta vivienda ubicada en un sótano, con una escasa ventilación e iluminación. Sótanos también son los departamentos de los protagonistas de Bellísima de Visconti y de Rocco y sus Hermanos del mismo autor: memorable, en este sentido, es la escena de la nevada, que los hermanos miran desde la estrecha ventana a nivel de calle, felices para las oportunidades laborales que este fenómeno atmosférico ofrece. En un sótano está ubicado también el calabozo del profesor, protagonista de Calabuch de Berlanga.

En Rocco y sus Hermanos y en El techo de De Sica, aparece otra tipología de "vivienda impropia": se trata de las casitas de obra, en donde los protagonistas, se refugian de forma provisional, aprovechando de sus empleos de albañiles, otra vez el lugar de trabajo coincide con el lugar para "demorar" aun sea por algunas noches.

Desde siempre las plantas bajas, "los bajos", están asociadas a una condición de precariedad e incomodidad de la vida doméstica; el ruido, el hacinamiento y la falta de privacidad, caracterizan esta tipología de viviendas. En El techo la casa de los padres del protagonista es una construcción en una periferia de la capital italiana, una casa de dos plantas que parece pertenecer a un contexto rural y la planta baja con sus grandes ventanas es un lugar abierto hacia la vida de la calle; en una de las escenas finales, la esposa, llama al cuñado, peleado con su esposo, para pedirle ayuda, corriendo alrededor de la casa de sus parientes, llamando a través de las ventanas abiertas, la comunicación con los familiares, se produce a través de esta permeabilidad de la planta baja, una falta de privacidad que corresponde a la vida precaria de sus moradores. Viviendas en plantas bajas hacia patios interiores aparecen en Placido, en El verdugo y en El cochecito, se trata de lugares que sufren de esta falta de privacidad, de este exceso de abertura hacia lo público. En la escena final de "Placido" el protagonista se pelea de noche desde la ventana de su vivienda reducida en planta baja, asomándose y mirando hacia la larga escalera que sube la ladera, debajo de la cual se encuentra su edificio.

Una buhardilla es la vivienda de uno de los hermanos protagonistas de Surcos, que, junto a su novia, va adaptando un espacio de almacenaje bajo un techo de madera de propiedad de su jefe, en un hogar, dejando la corrala en donde vivía con su familia y empezando una vida independiente con su pareja (F.2.5.3). 

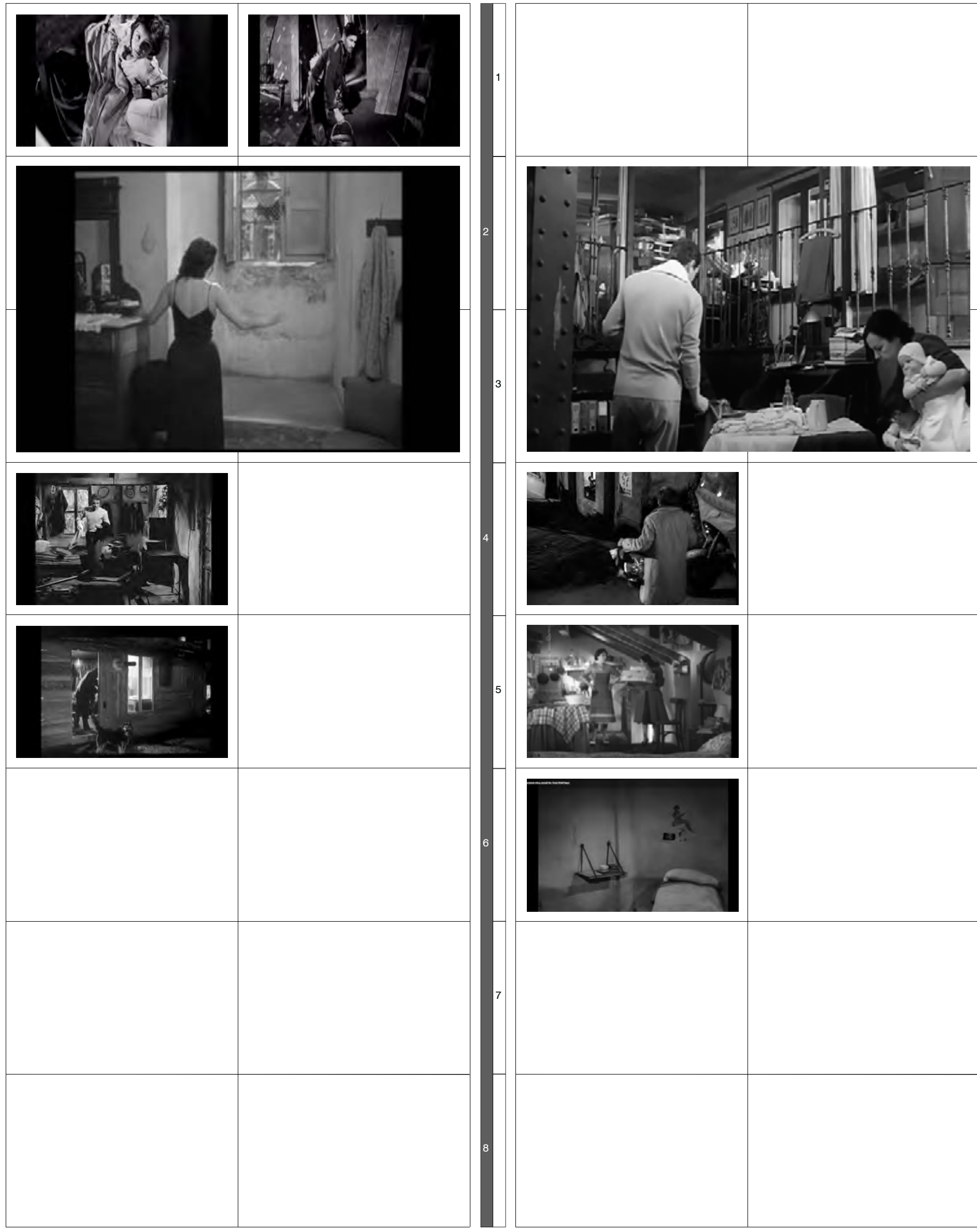

RM 1. Gente del Po (Antonioni)

RM 2-3. Bellissima (Visconti)

RM 4. El Techo (De Sica)

RM 5. Rocco y sus hermanos (Visconti)
MD 2-3. El Verdugo (Berlanga)

MD 4. Placido (Berlanga)

MD 5. Surcos (Nieves Conde)

MD 6. Calabuch (Berlanga) 
2.5.4 Paisajes domésticos: espacialidad, elementos y texturas.

\section{COCINAS}

Las viviendas descritas en las películas neorrealistas -con excepción de las de tamaño muy reducido (Mi tío Jacinto, Cerca de la Ciudad, El Techo, Accattone, etc.)-, tienen su centro en la cocina, el hogar alrededor del cual se desarrolla la vida de los núcleos familiares. A la cocina está dedicada la larga secuencia en la cual De Sica describe las actividades de la sirvienta en Humberto $D$, una escena innovadora según Bazín, al ser simplemente la narración de la existencia en su normalidad y cotidianidad ${ }^{55}$. La cocina se convierte en el lugar donde se produce una pausa de reflexión dentro de la vida urbana, un lugar para la recuperación de las tradiciones rurales. En muchos de los proyectos de vivienda social de estos años, como los de Libera y Sáenz de Oíza para el Tuscolano y Entrevías, se pone un cuidado particular en el diseño de estos espacios, teniendo en cuenta las necesidades de los futuros habitantes, y en el cinetambién se lee la centralidad de este espacio en la casa.

PERMEABILIDAD: BALCONES, VENTANAS, ESCALERAS, PATIOS Y PASILLOS.

Analizando el espacio doméstico en la iconografía neorrealista, se puede leer una fuerte permeabilidad entre el interior y el exterior de las viviendas. Esta ósmosis se produce a través de algunos elementos arquitectónicos presentes en muchas de las películas analizadas; se trata de escaleras, vestíbulos y patios. En la película Surcos, una escena repetida a lo largo de la película representa la secuencia del acceso a la vivienda-corrala desde la calle: el pasillo de acceso, el vestíbulo con la escalera y la corrala con las galerías de distribución. Una secuencia parecida aparece en $E I$ verdugo, donde a la vivienda del suegro del protagonista se accede a través del patio interior, así como sucede con la vivienda del amigo de José Isbert, en EI cochecito. Esta fuerte relación entre espacio doméstico y espacio público la encontramos en Italia en el edificio de residencia de Anna Magnani, el bloque con patio central en el barrio Tiburtino, con un vestíbulo de ingreso por el cual entran los nazis, violando la tranquilidad y la privacidad del edificio.

Como los patios, la escalera protagoniza algunas escenas de carácter dramático, como en la como en la secuencia del accidente del hijo de la protagonista de Europa '51, y de carácter cómico en el primer episodio de Historias de la radio, en donde el protagonista se pelea con un concurrente para alcanzar el primer lugar en la competición radiofónica.

Otro elemento de conexión dentro-fuera, está representado por las ventanas, las terrazas y los balcones, desde los cuales los personajes de la película establecen un dialogo con el barrio, la calle y sus habitantes. Se trata de lugares predilectos de la Cinematografía Neorrealista que sirven para generar una ligazón muy fuerte entre el espacio interior de la vivienda y el espacio exterior, hasta convertirse en el punto de vista privilegiado del director hacia la ciudad, como en la película El inquilino, de Nieves Conde. Muchas veces los balcones se convierten en púlpitos, lugares desde los cuales poder empezar una conversación o intercambiar información con los vecinos, como ocurre en Bellísima de Visconti, o en Del rosa al amarillo de Manuel Summers (F.2.5.4/1).

55 (Bazin, 1990) 

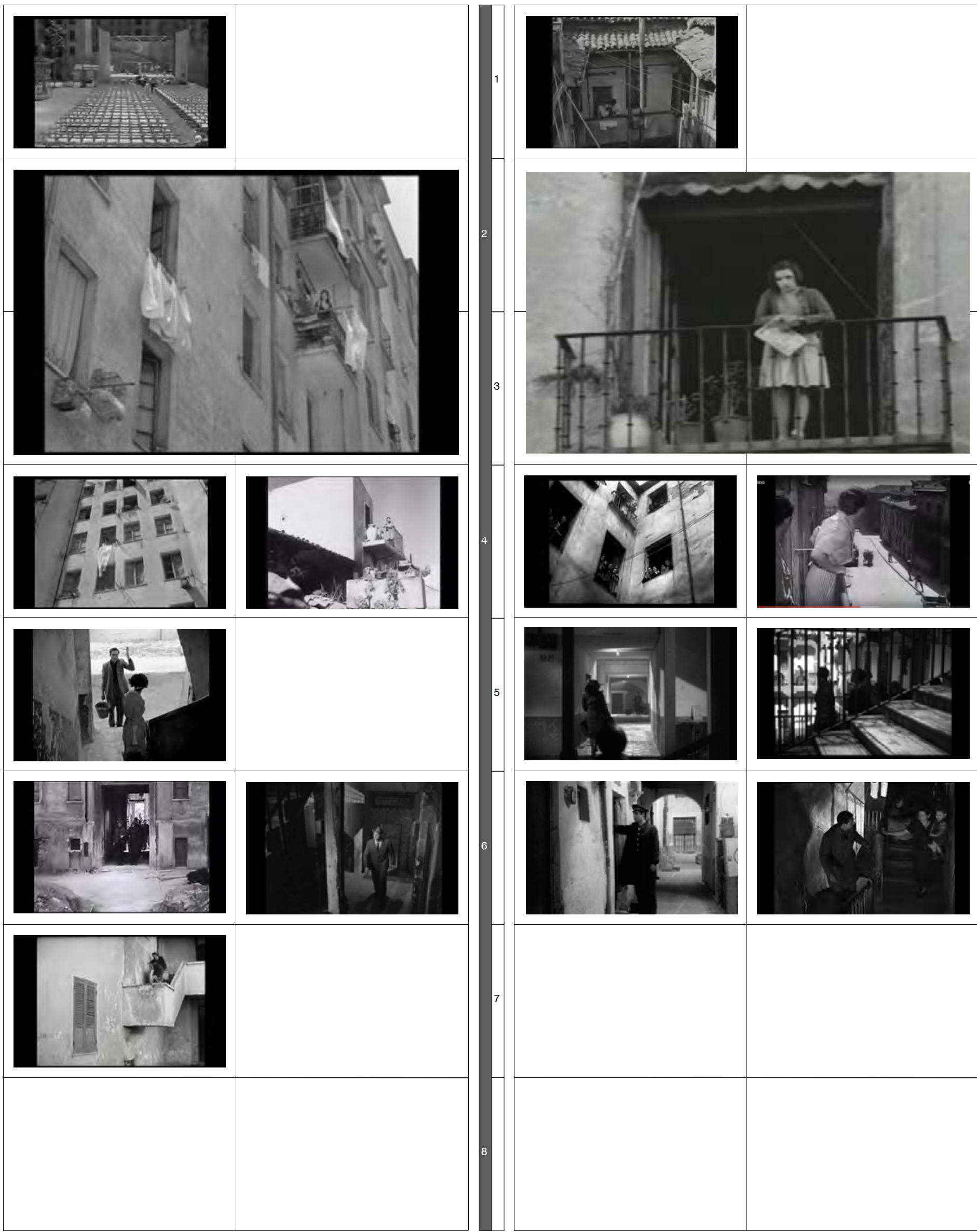

RM 1-2-3. Bellissima (Viscont)

RM 4. Bellissima (Visconti)

RM 4. La Tierra tiembla (Visconti)

RM 5. Ladrones de bicicletas (De Sica)

RM 6. Roma Ciudad abierta (Rossellini)

RM 6. El Techo (De Sica)

RM 6. Europa 51 (Rossellini)
MD 1-2-3. El pisito (Ferreri)

MD 4. El último caballo (Neville)

MD 4. El inquilino (Nieves Conde)

MD 5. Surcos (Nieves Conde)

MD 6. El verdugo (Berlanga)

MD 6. Muerte de un ciclista (Bardem) 
CIUDADES DE BARRO.

"Ciudades de barro": así podemos definir Madrid y Roma en esta época por la extensa utilización de este material en la construcción de viviendas: se trata de ladrillos en el levantamiento de muros de carga y de ladrillos huecos en combinación con armazones de hormigón. Este material aparece amontonado en las obras, o ya montado en estructuras que exhiben su textura y regularidad, a veces mostrando el contraste entre las imperfecciones de las construcciones de la ciudad informal y las de la ciudad oficial'. La iconografía de la 'ciudad de barro' es central en la narración en Calle Mayor de Bardem. En una de las secuencias más impactantes, la pareja protagonista se reúne a platicar en una obra de viviendas colectivas, en las afueras de la ciudad, teniendo como escenario grandes paredes de ladrillo visible, utilizado como cerramiento de las estructuras de concreto.

La historia contada en el El techo, de De Sica, es la narración del aprendizaje, en el oficio de la construcción, de Natale, el protagonista, desde sus primeras experiencias en las obras, en las cuales trabaja con la ayuda y experiencia del hermano y su cuadrilla. Al final de la película el protagonista y su esposa lograrán acabar la construcción de su casa ilegal. En unos fotogramas de la escena final, el policía que ha venido para desalojar a Natale y su familia se pone a mirar la pared de ladrillos de doble hueco, observando en el detalle el aparejo de baja calidad y puesto con prisa, una mirada que es un juicio sobre el trabajo y el aprendizaje del protagonista, que, sin embargo, por la compasión del guardia logrará quedarse en su nuevo hogar, y quizá un día mejorar su vivienda.

Los techos de tejas constituyen unas de las iconografías más reconocibles del paisaje neorrealista; se trata de las topografías de barro en pueblos campesinos, en los cascos históricos de las grandes ciudades o en los barrios chabolistas en las periferias urbanas. (F.2.5.4/2). 

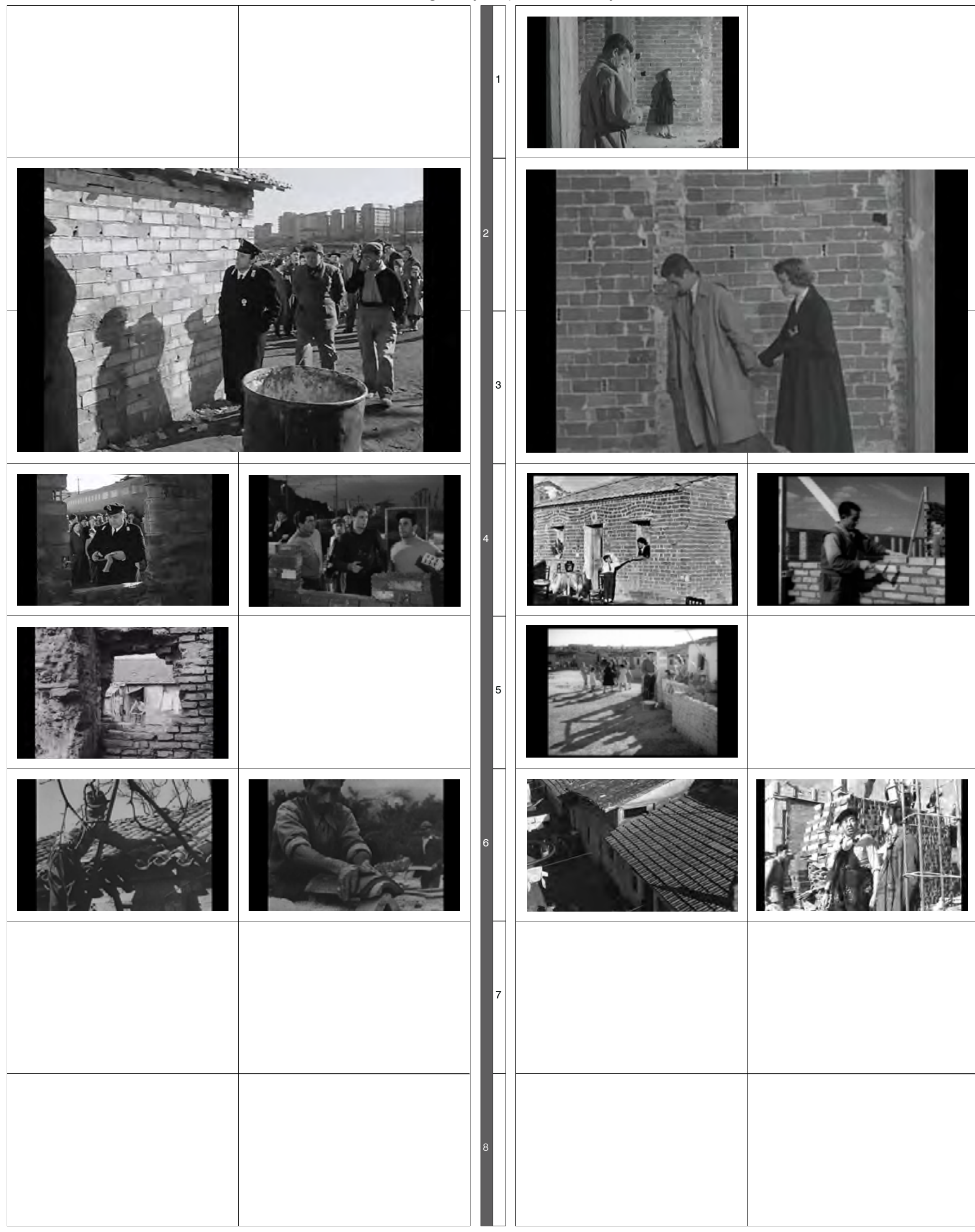


\subsection{De la Periferia al centro: Val Melaina y el barrio de San Juan.}

\subsubsection{Ladrones de Bicicletas}

\section{RECORRIDO}

En el Cinema Neorrealista los directores abandonan progresivamente el centro de la ciudad, menos interesados en la dialéctica centro-periferia: las historias contadas ya hablan exclusivamente de una ciudad periférica, de una iconografía urbana distinta, lejos de la Madrid y la Roma pintorescas, contadas en la cinematografía anterior; se exploran los territorios desconocidos, los espacios vacíos de las capitales en expansión.

En las primeras dos películas escogidas, italianas y españolas, este movimiento oscilante centro-periferia está todavía presente, aunque ocurren dos fenómenos que en parte se han analizado en la definición del vocabulario neorrealista en el capítulo anterior: antes de todo la iconografía del centro y los decorados escogidos ya no corresponden a la 'imagen clásica' de las dos capitales; en Roma por ejemplo Rossellini en 1945 con Roma, ciudad abierta y Antonioni en 1948 con Nettezza urbana habían ofrecido una nueva iconografía de la ciudad, una imagen humilde, cotidiana, sin espectáculos; el segundo fenómeno es el descubrimiento por parte de los directores de nuevos escenarios en la ciudad en expansión. A través del análisis cartográfico se han podido identificar estos nuevos territorios urbanos, los vacíos explorados por los directores neorrealistas en las capitales italiana y española. Se analizan estos territorios en paralelo, describiendo características comunes y diferencias entre las dos ciudades, fortaleciendo la hipótesis que el Neorrealismo, a través de los recorridos y las puestas en escena de sus cineastas, produjo una nueva investigación estética sobre el paisaje urbano de la Posguerra capaz de influenciar otras expresiones artísticas.

Analizando las ambientaciones de la película Ladrón de bicicletas podemos detectar tres viajes de desplazamiento de la periferia Noreste de Roma, la borgata de Val Melaina a $7 \mathrm{Km}$ de distancia del centro, hacia las zonas centrales de la capital; estos viajes se cumplen en tres días de viernes a domingo. De los primeros dos viajes el director nos enseña el regreso a casa; el tercero es un recorrido por la ciudad con una vuelta al hogar que sólo suponemos. El primer desplazamiento centro-periferia corresponde a la aceptación del empleo, por parte del protagonista Antonio Ricci, acompañado por su esposa; el segundo es el primer día de trabajo que se interrumpe con el robo de la bicicleta, y sigue con la visita de Antonio a la comisaría de policía. El tercer recorrido, que el protagonista cumple con su hijo Bruno, se convierte en una deriva interminable, un viaje sin meta, que padre e hijo cumplen desplazándose en el casco histórico, que recorren hasta sus límites, terminando este viaje en la zona norte en proximidad del estadio Flaminio, fuera de las murallas Aurelianas (que marcaron durante algún tiempo el limite centro-periferia), donde el protagonista cumplirá el último desesperado gesto de recuperar su bicicleta, y con ella su trabajo. "El centro de la ciudad es el único lugar en el que Ricci puede acceder a su medio de supervivencia; pero tras el robo de su bicicleta, esa supervivencia se ve amenazada de modo que va a la deriva entre la ciudad y los suburbios, excluido de la actividad ciudadana y del regreso a los suburbios, donde no hay ninguna posibilidad de sobrevivir entre los monótonos bloques"1.

Se ha analizado esta deriva en términos de duración y de distancia total recorrida, trazando en un mapa de la capital, el recorrido, en base a las ambientaciones rodadas, en la secuencia temporal presentada en el espacio fílmico.

\footnotetext{
1 (Barber, 2006, p.68)
} 
Tomando en cuenta el recorrido marcado en la cartografía (F.3.1.1/1) y los datos sobre la duración del cuadro $\mathrm{C} 1$, en la misma ficha gráfica podemos poner en evidencia el fuerte vínculo que el director establece entre espacio y tiempo reales y fílmicos.

A través del análisis de los distintos lugares que aparecen en las secuencias que marcan las etapas de la deriva de los dos protagonistas, hemos calculado un distancia entre los lugares del rodaje de más de $37 \mathrm{Km}$. Distancia que se reduce a $13 \mathrm{Km}$ si quitamos el primer tramo del recorrido que los dos protagonistas recorren presumiblemente en transporte público por la elevada distancia $(7,5)$ de Val Melaina, el Barrio donde viven hacia Piazza Vittorio, en donde intentan buscar las refacciones de la bicicleta robada, y los tramos que corresponden a dos secuencias de rodaje no congruente con la geografía del recorrido (tramos que suman 16 $\mathrm{Km}$.). Las distancias entre los otros escenarios que aparecen en la película suman un recorrido compatible con el tiempo calculado en la narración fílmica definiendo un trazo congruente con la realidad geográfica de la capital italiana. Hemos calculado un tiempo de 8 - 9 horas para recorrer los 13 kilómetros calculados, teniendo en cuenta que el recorrido de búsqueda empieza en la mañana temprana y acaba en Vía Flaminia, en el horario de salida de los espectadores del partido de futbol, entre las 4 y las 5 de la tarde. Podemos deducir por la presencia de este evento, que se trata de un domingo, hecho confirmado también por la abertura del mercado de Porta Portese, el mercado de pulgas romano que abre sólo en estos días. Todo el recorrido de búsqueda está concentrado en una hora de película, un tiempo "fílmico" razonable en relación con las distancias recorridas. Todo el cine de De Sica se caracteriza por esta fuerte correspondencia entre duración del rodaje, tiempo real y espacios recorridos que logra, favoreciendo el uso del plano-secuencia típico de sus películas: un realismo en las relaciones espacio-temporales que alcanza la máxima expresión en la película Humberto $D$. Hablando del cine de De Sica, Bazín escribe de cómo "es quizá la estructura del relato la que resulta radicalmente trastocada. Hay que respetar la verdadera duración del suceso. Los cortes que la lógica exige podrían ser todos los más descriptivos; la planificación no debe añadir nada a la realidad que subsiste" ${ }^{2}$.

La iconografía de Roma que aparece en esta deriva en zonas centrales, semi-centrales y periféricas de la ciudad, es diferente a la iconografía clásica de la ciudad Eterna. Antes de todo desaparece cualquier referencia a monumentos singulares, palacios o panoramas pintorescos. Es una Roma popular, la que aparece en la película de De Sica, una Roma de callejones y de mercados. Ya Antonioni había logrado esta desaparición de la Roma pintoresca en su Nettezza Urbana, llegando a un desafío todavía más valiente al representar alguna mirada clásica como el contrapicado de San Pedro, de Piazza del Quirinale al amanecer o Plaza de España o de las ruinas romanas, trasfigurando lo pintoresco a través de encuadres descentrados y personajes en primer plano trabajando.

La Roma de De Sica es la de Trastevere o la de los callejones en la zona de Piazza Navona, en donde el presunto ladrón se refugia, defendido por sus vecinos. De Sica escoge una periferia del centro, desarrollando una topología totalmente inédita. Si miramos en el mapa los lugares del rodaje marcados, podemos ver cómo se define una concentración alrededor del río Tíber. Esta elección no es casual, en parte corresponde a una cierta facilidad de desplazarse alrededor del Rio por parte de la troupe cinematográfica aprovechando las grandes avenidas a su lado, y al mismo tiempo a la amplitud de los planos que es posible rodar. Al mismo tiempo esta elección corresponde a un preciso ideal estético del director que encuentra en el Rio Tíber una fuente de sugestiones de tipo paisajístico. Ya hemos visto el Río de la Capital italiana en otras películas, en donde se fortalece este papel del Tiber o del Aniene (el otro río de la

2 (Bazin, 1990, p.348) 
Capital) como "vacío urbano" como paisaje de la ausencia; los directores bajan hacia las riberas del Tíber con el mismo espíritu y con la misma expectativa de cuando se meten en los grandes descampados de la ciudad en construcción; podemos citar, sobre todas, la secuencia del episodio de "los suicidas" de Antonioni en "Amor en la ciudad" que hemos analizado en el anterior capítulo, como ejemplo de esta nueva relación iconográfica entre río y ciudad (F.3.1.1/1).

En la escena de Porta Portese De Sica opera una elipsis espacial, utilizando el arco de la antigua puerta que da el nombre al famoso mercado de pulgas romano, como elemento de raccord para juntar dos diferentes planos de rodaje que describen la secuencia de la carrera de Antonio Ricci para intentar atrapar al presunto ladrón. Del otro lado de la puerta la cámara se desplaza a 2 kilómetros de distancia en la zona de Avenida Marconi un gran descampado ubicado en la ribera del río; al fondo se aprecia la basílica de San Pablo y la zona industrial de la Vía Ostiense con las estructuras del Gasómetro que son representadas a través de una única toma panorámica de $180^{\circ}$.

Otra imagen de Tíber es la del puente Palatino, con la isla Tiberina al fondo, en donde los dos protagonistas intentan retener el anciano amigo del joven presunto ladrón, en una toma de plano conjunto y plano medio largo para disimular lo pintoresco de esta porción del río, con la isla Tiberina muy cercana. Después de esta secuencia, la escena se desplaza a un kilómetro de distancia, a la Iglesia en frente de las termas de Caracalla, para después desplazarse con un raccord esta vez muy poco realístico a 6 kilómetros hacia el Norte en el puente Duca d'Aosta, para describir la secuencia en donde el padre pierde por algunos instantes al hijo, buscándolo bajo el puente a lo largo de los taludes y de las riberas verdes de este punto del río. En esta secuencia de gran valor paisajístico, la representación de las laderas, los descampados y el puente, sirven como soporte escénico para fortalecer momentos dramáticos del guión: como en la escena de Avenida Marconi la ciudad histórica ya no es suficiente para describir los estados de ánimos y la estética del nuevo cinema, se busca en el Tíber una iconografía de "frontera", una fractura dentro del tejido urbano. Ya hemos analizado en el anterior capítulo como Bruno Reichlin habla de esta carrera de Ricci bajo la arcada oscura del puente, estableciendo un paralelo emocional con el monumento de la Fosse Ardeatine, y el recuerdo que tenían los italianos de los sótanos y los refugios bajo tierra para defenderse de los bombardeos ${ }^{3}$. Otra etapa a lo largo del Tíber antes de la búsqueda del ladrón en los callejones alrededor de Plaza Navona, es la del restaurante, en el cual la pareja come, tomando la decisión de un merecido descanso, apoyados en el barandal del río desde la Avenida Lungotevere.

En la escena final, el paisaje humano de las multitudes saliendo del partido, se produce en otro lugar muy cercano al río Tíber, se trata de los alrededores del estadio Falminio y del Puente Duca de Aosta, que ya había aparecido anteriormente en la elipsis espacial que describía el alejamiento del hijo de Ricci. En la convulsa secuencia final de la película, De Sica describe un paisaje del movimiento donde vehículos, peatones y bicicletas cruzan desordenadamente la explanada y la avenida Flaminia en frente del estadio, generando una sensación de desorientación también en el espectador de la película.

\footnotetext{
3 (Reichlin, 2002)
} 


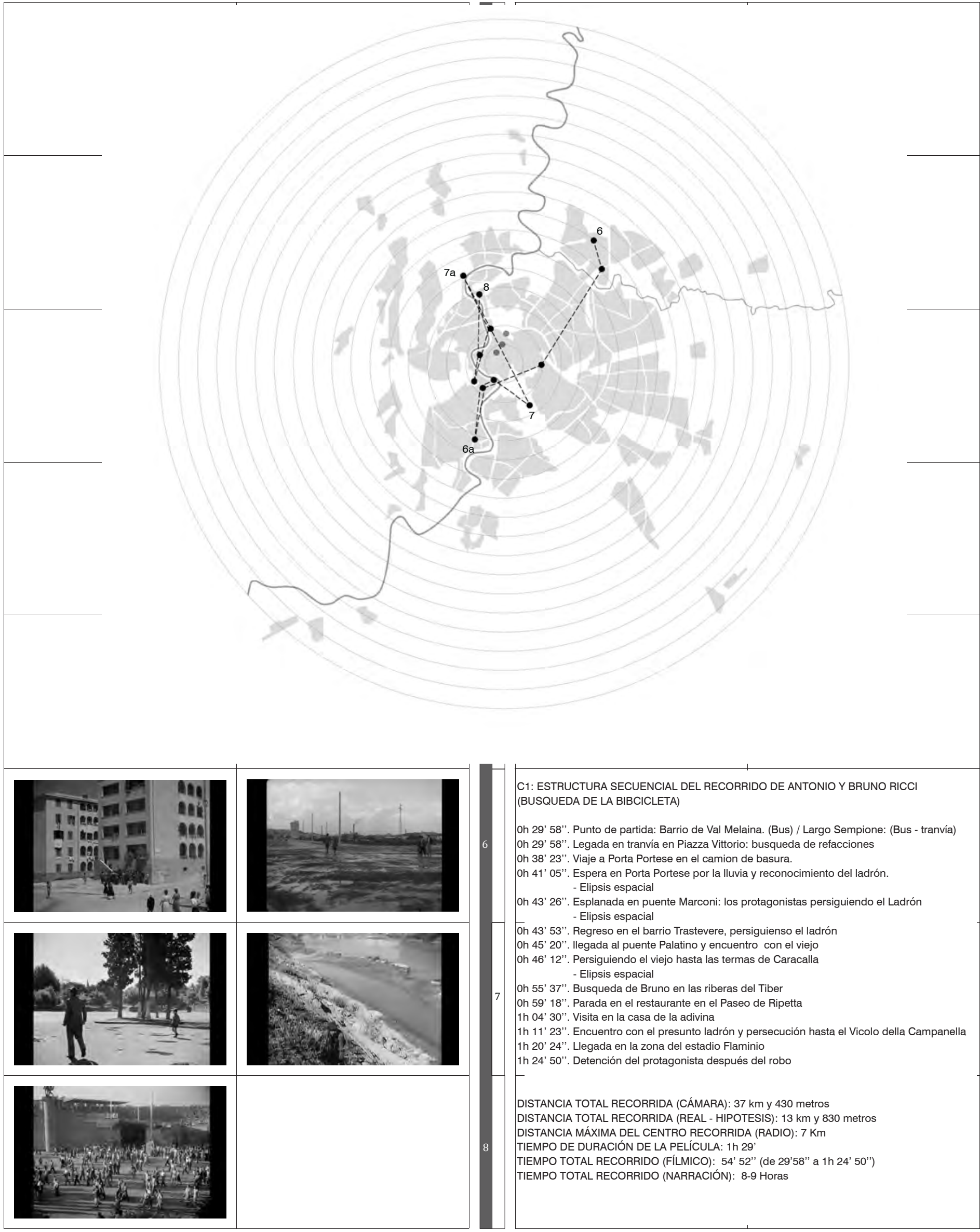

Puntos más distantes del recorrido.

RM 6. Val Melaina

RM 6a. Puente Marconi

RM 7. Caracalla

RM 7a. Puente Duca d'Aosta

RM 8. Estadio Flaminio
UBICACIÓN EXACTA LUGARES DEL RODAJE (secuencia)

1. Val Melaina

2. Largo Sempione

3. Piazza Vittorio

4. Porta Portese

5. Puente Marcon

6. Piazza dei Mercanti (Trastevere)

7. Puente Palatino
8. Terme di Caracalla (Ss. Nereo e

Achilleo)

9. Puente duca d'Aosta

10. Paseo di Ripetta (restaurante)

11. Calle G. Venezian

12. Calle della Campanella (P.za Navona)

13. Estadio Flaminio. 
VAL MELAINA

En el análisis del movimiento contrapuesto centro-periferia que se produce en las películas escogidas, uno de los dos polos está representado por el barrio en donde residen los protagonistas, la borgata Val Melaina en la periferia Norte de Roma. El barrio de Val Melaina se encuentra en el sector Noreste de la capital, uno de los seis sectores que se han definido en el trabajo de mapeo de la cinematografía neorrealista de la capital. En este sector denominado "2" se ha rodado también la película El techo, de De Sica que analizaremos más adelante en este mismo capítulo. Otra película rodada en este sector es el episodio de Tentato suicidio de Antonioni, dentro de la película colectiva Amor en la ciudad. Tres son los decorados presentes cerca de los escenarios de Ladrón de bicicletas; el primero es una toma de Plaza Sempione, un nudo que aparece también en la película de De Sica y que representa el nudo de conexión de esta zona periférica con el centro de la ciudad a través de la Vía Nomentana; (F.3.1.1/2) otra escena del episodio de Antonioni está grabada en la Calle Scarpanto esquina con la Calle Stampalia, una zona que aparece todavía en construcción, con calles de tierra y esqueletos de hormigón armado, que finalizarán en una de las muchas palazzine que caracterizan esta zona residencial de la clase burguesa, muy diferente del conjunto donde vive la familia Ricci. En fin, en una escena es muy reconocible la manzana de la Calle Montebianco, justo al lado del bloque de los Ricci. Se trata de una gran manzana con patios interiores, construida en 1932, de estilo neo-barroco ${ }^{4}$.

Val Melaina construida por el régimen y finalizada en 1943 para dar una nueva vivienda, a los muchos que después de las grandes obras de 'haussmanización' de Roma solicitadas por el Duce, habían quedado sin hogar, se pobló también de los muchos que después de la guerra llegaban del campo y que, aunque no encontraron departamentos en los conjuntos habitacionales oficiales, empezaron a desarrollar clusters de vivienda informal. En la primera media hora de la película se puede apreciar la condición de esta zona de la capital, totalmente aislada del resto de la ciudad. En la secuencia inicial de la llegada del camión proveniente de la ciudad es posible percibir la casi total ausencia de obras de urbanización, de arboles, de alumbrado y de pavimentaciones; los bloques de viviendas, aparecen en un paisaje completamente desertizado.

\footnotetext{
${ }^{4}$ (Angeletti, 2009 pp.76-79)
} 
S2

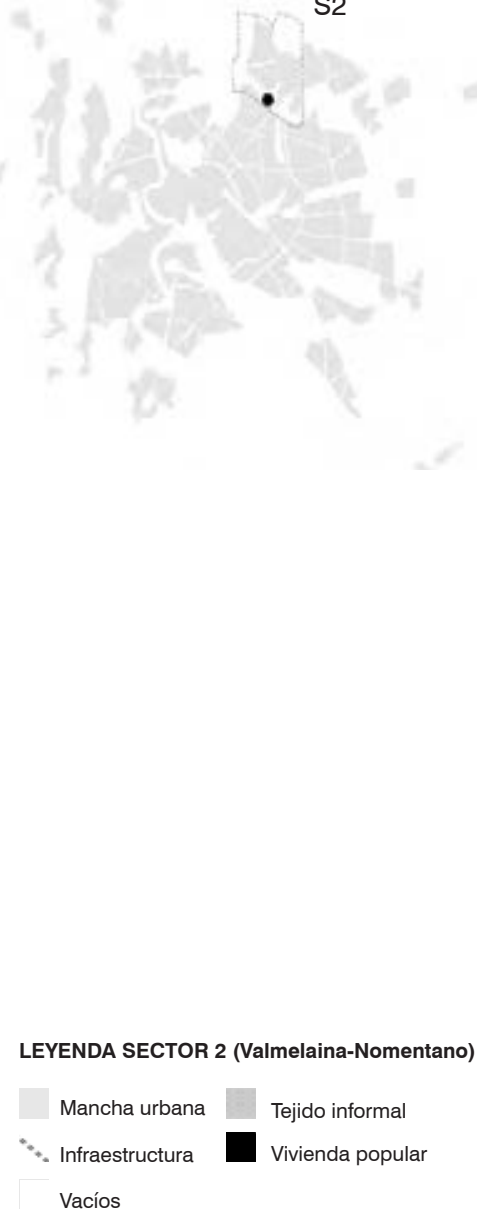

PELICULAS RODADAS

1. Ladrón de bicicletas (De Sica)

2. Amor en la ciudad (Antonioni)

3. El techo (De Sica)

4. Rufufú (Monicelli)
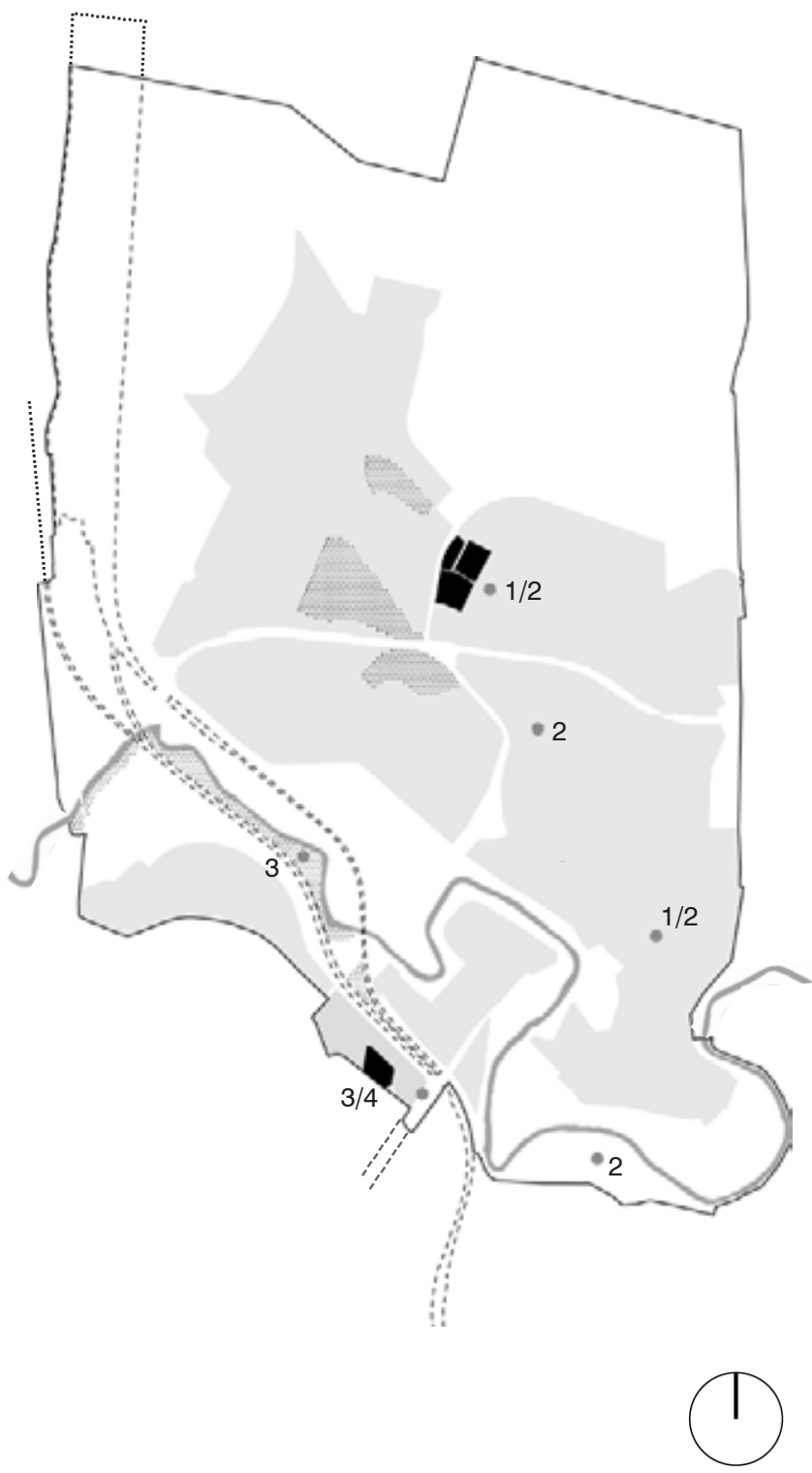

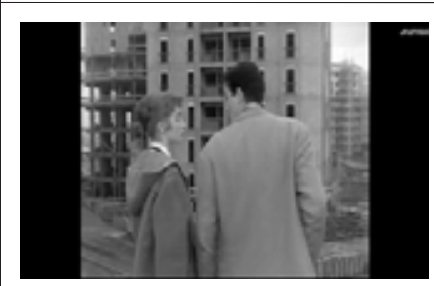

RM 8. Rufufu (Monicelli). Vista lado Sur del conjunto hab itacional deViale Etiopia de Ridolfi en construcción
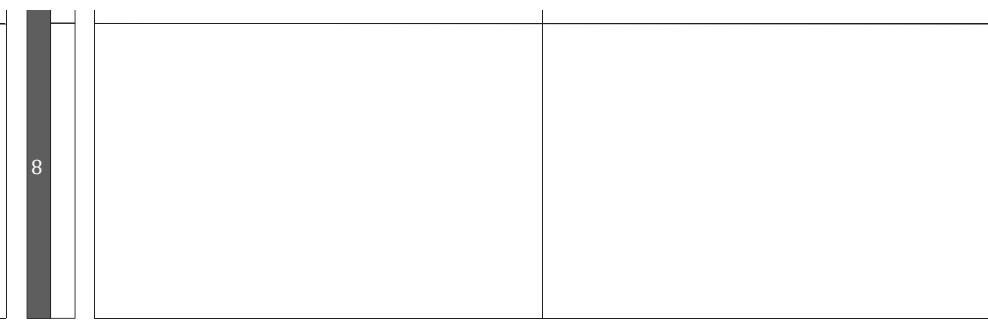
La cartografía presentada en este párrafo, así como todas las que mapean el rodaje en la capital italiana, se ha desarrollado utilizando como referencia una foto satelital de Roma de 1943 almacenada en Google Earth, una planta del I.G.M de 19495 , el mapa del Plan General de Roma de 1962, la planimetría actual de la capital, y los mismos fotogramas de la película, para ubicar los elementos visibles de la escala urbana. Se puede establecer que, en la época del rodaje, el conjunto habitacional donde viven los protagonistas se ubicaba en una zona casi totalmente agrícola, entre terrenos improductivos en espera de una futura urbanización, con la total ausencia de servicios y como única construcción un instituto religioso en un relieve en la zona Sureste, a 300 metros de distancia respeto a la vivienda de los Ricci, en un área no completamente urbanizada. Al Oeste se encontraba un asentamiento informal de baja altura, mientras en la zona Noreste una pequeña urbanización de bloques de cinco plantas (F.3.1.1/3).

\footnotetext{
${ }^{5}$ Instituto Geográfico militar, fuente: ibídem
} 


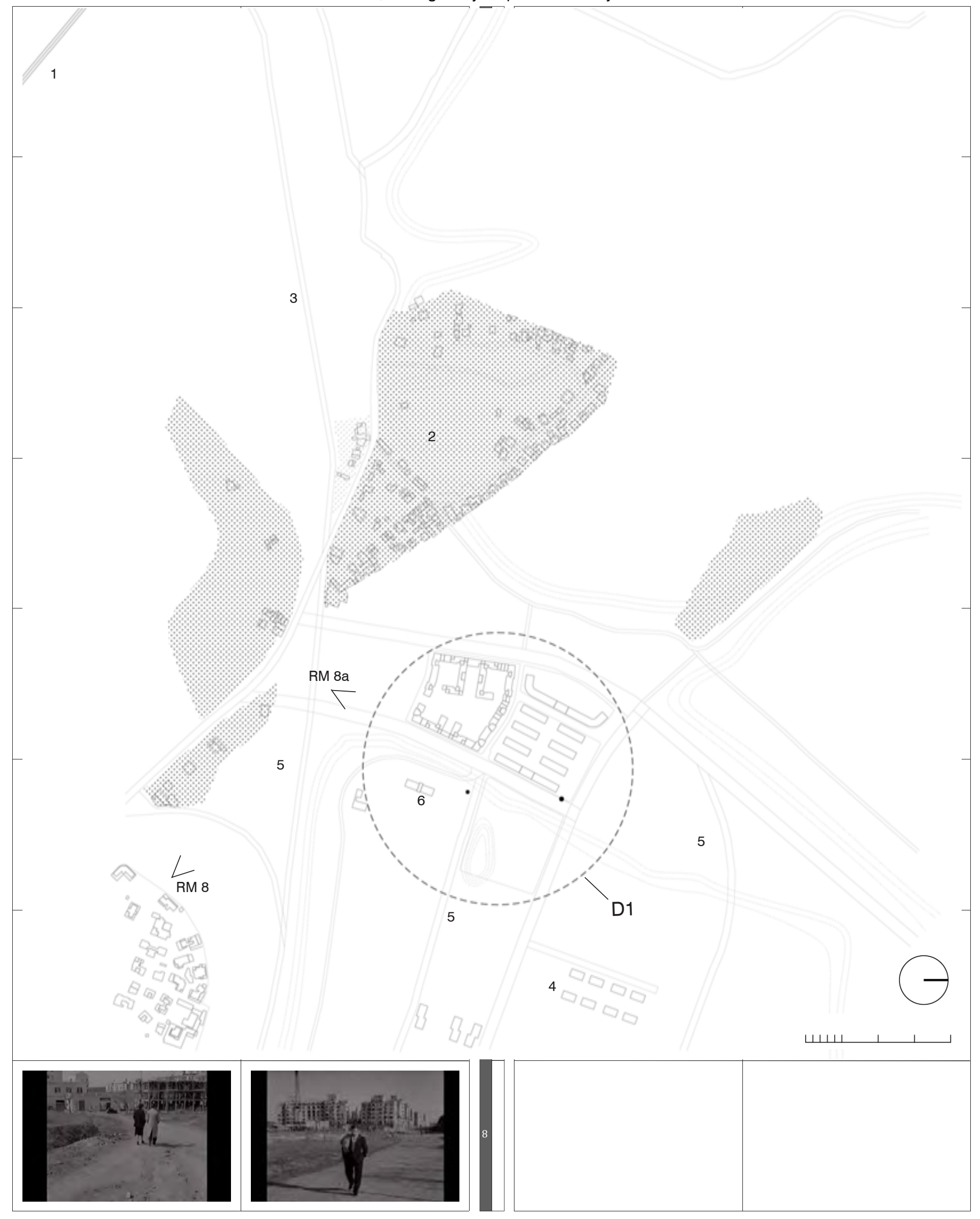

RM 8. Amor en la ciudad (ep. "Tentato Suicidio) (Antonioni). Vista lado Sur del conjunto habitacional de Calle Scarpanto esq. Calle Stampalia

RM 8a. Amor en la ciudad (ep. "Tentato Suicidio) (Anton-

ioni) Calle MonteBianco en construcción

1. Linea de Ferrocarril Roma-Orte (FR-1)

2. Asientamiento informal de la Calle Monte Amiata (fuente

G-Earth 1943)

3. Avenida Prati Fiscali

4. Conjunto de vivienda social en la calle Monte Epomeo.

5. Descampados

6. Instituto religioso 
La llegada del transporte público en estas zonas es un hecho de relieve, ya que se trata de la única conexión con la "verdadera" ciudad, y De Sica fortalece este aspecto, relacionando la llegada del camión con la llegada del funcionario de la oficina de empleo que dará la buena noticia a Ricci. Esta escena está tomada en la esquina Sureste del edificio, en donde la rampa de escalera de acceso del edificio funciona como una especie de púlpito. Después de haber recibido la noticia, Antonio Ricci da vuelta en la esquina Suroeste, aunque en el siguiente plano general aparece recorriendo el lado Sur-oriental del edificio hasta llegar a la esquina Noreste, en donde se encuentra con su esposa para darle la noticia. En esta carrera del protagonista aparece la arquitectura típica de estas intervenciones urbanas, bloques masivos, a los cuales se intentaba dar una cierta imagen "romana" a través de pocos elementos decorativos, como las logias con arcos, o el ligero almohadillado de la planta baja. Pero más que el estilo arquitectónico en esta secuencia De Sica nos habla otros aspectos: la ausencia de ciudad; faltan calles, banquetas, los bloques de otras viviendas que aparecen al fondo, que distan 300 metros y parecen más alejados todavía, por los enormes descampados que separan las dos intervenciones; en segundo lugar De Sica nos muestra las condiciones de vida en estos conjuntos en donde falta el agua corriente dentro de los departamentos, tanto así que las mujeres tienen que hacer la cola en una pequeña fuente, que además está encerrada con alambre en una especie de corral con palos de madera, dentro de la cual se llega a ver dos mujeres casi peleando por su turno; es difícil no pensar, mirando esta escena, en las imágenes de la guerra recién acabada. En fin, las dificultades que encuentra la esposa de Ricci al bajar la ladera que separa la entrada al conjunto de la vivienda, nos habla de una incomodidad general del lugar, de una accesibilidad reducida, que solo los niños aparentemente disfrutan, como se ve en la imagen del grupo de niños que suben divertidos en contraposición con las dificultades y el cansancio físico y psicológico de la pareja. La condición social de aislamiento de la familia de Ricci, está expresada perfectamente por el fragmento de ciudad en la cual la pareja vive, en donde el robo de una bicicleta puede significar la pérdida del empleo y el aislamiento: Pierre Sorlin hace una análisis sociológico de la familia Ricci a partir de una comparación con la familia de El limpiabotas: "en otras palabras De Sica nos describe a un grupo realmente peculiar, una familia nuclear cerrada como las que ciertamente existían en Italia en esos tiempos, pero que en la pantalla es mucho más rara que el modelo de la familia grande y abierta" ${ }^{6}$. A pesar de la condición de los Ricci que poseen una ayuda de la asistencia social, de una casa, de un hijo que trabaja en una gasolinera, su condición familiar no tiene la ventaja de la "solidaridad mutua" que tiene la familia, seguramente más pobre, de la otra película de De Sica, que vive hacinada en una barraca.

Para ambientar esta condición social, De Sica "inventa" o más bien descubre un fragmento de Roma desconocido hasta aquel momento, un paisaje urbano que parece explicar parte de los problemas contados en la película, y que al mismo tiempo es el espejo de estas nuevas categorías sociales aisladas y sin raíces. Val Melaina, con sus enormes praderas, sus terrain vague, sus calles polvorientas, su falta de agua y su topografía "hostil", es un valle segregado de la ciudad, un paisaje en el cual el bloque de vivienda de los Ricci, aparece casi como una fortaleza inexpugnable (F.3.1.1/4).

\footnotetext{
${ }^{6}$ (Sorlin \& Pujol i Valls, 1996, p.119)
} 


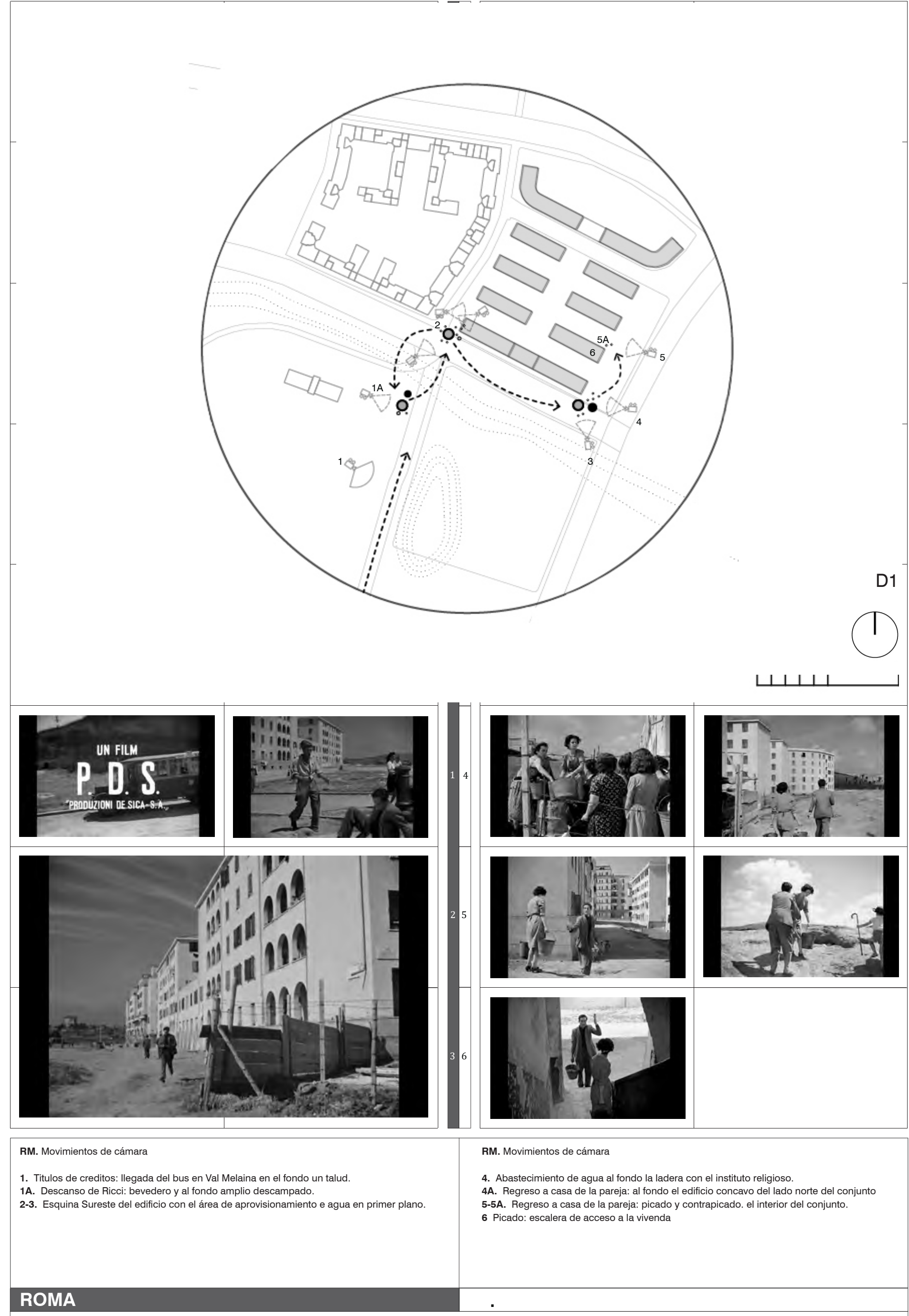




\subsubsection{Mi Tío Jacinto}

Se ha analizado la película Mi tío Jacinto de Ladislao Vajda con los mismos criterios utilizados para Ladrón de bicicletas, enfocándonos en el largo recorridos que los dos protagonistas, Jacinto y su sobrino, (un adulto y un niño como en Ladrón de bicicletas) cumplen en la búsqueda del dinero necesario para la renta de traje de torero, que le permitirá al tío participar a la charlotada y ganar las 1.500 pesetas ofrecidas: tanto el traje como la bicicleta son objetos que marcan la diferencia entre la sobrevivencia y el hambre.

Como la película de De Sica, Mi tío Jacinto, se puede dividir en tres tiempos. Los primeros 11 minutos en el asentamiento informal de San Juan, en donde los protagonistas viven, y los últimos 10 minutos en la plaza de Toros de ventas; la parte central de 58 minutos de duración, está ocupada por el recorrido que los protagonistas cumplen en búsqueda del dinero, para torear (C.2).

El primer tramo del viaje que Jacinto y Pepote cumplen es un recorrido en tranvía de la línea 12 con itinerario Canillejas-Manuel Becerra, que los dos toman para empezar su día como recolectores de colillas en la plaza de Ventas. Sin embargo, el punto en donde los dos toman este tranvía resulta estar ubicado en la Avenida Carabanchel alto entre las calles muralla de Ávila y Allariz, en donde los dos protagonistas se ponen en cola para subirse al coche. Podemos suponer esta decisión con la idea de buscar una parada de tranvía en un área no urbanizada que pudiese encajar con el escenario hasta ahora descrito por el director Vajda, el asentamiento informal en donde residen Pepote y Jacinto ${ }^{7}$. El gran plano general describe esta grande área vacía en el barrio de Carabanchel con al fondo el depósito de agua en construcción ubicado en la calle Alfonso Fernández, en donde ahora se encuentra el "Centro de juventud de Carabanchel alto". En la derecha de la toma se ven algunas casas de una planta de ladrillo pintadas de blanco, algunas de las cuales todavía quedan hoy, al fondo junto al depósito, algunas naves industriales, algunas abovedadas y en la izquierda algunos montículos de tierra de derribo, en primer plano un árbol, plantado donde hoy se encuentra el acceso a unas instalaciones escolares. Jacinto y Pepote recorren este espacio de tierra, con algunas huellas de llantas que marcan la dirección de esta avenida: un paisaje que incluye muchos elementos de la iconografía neorrealista.

Como en la película de De Sica, hay una fuerte correspondencia entre el tiempo de la narración y el espacio fílmico recorrido, pero en un tiempo superior al de De Sica, un día entero desde la mañana hasta la noche, cuando Jacinto debe torear en Ventas, después de haber logrado obtener el traje de luces. Las distancias y la secuencia entre los lugares recorridos son coherentes con el tiempo de narración, calculando que los protagonistas recorren el último tramo de $10 \mathrm{Km}$, desde la Plaza Tirso de Molina hasta Ventas en Metropolitana; otros $5 \mathrm{~km}$. - del Retiro hasta el Rastro- son recorridos en un camión-cisterna del ayuntamiento. Se plantea aquí la hipótesis de que la mayoría de los restantes $13 \mathrm{Km}$. hayan sido recorridos andando, distancia compatible con el tiempo a disposición. Sin embargo, debemos tener en cuenta que, en comparación con Ladrón de bicicletas el día de Jacinto y su sobrino es mucho más denso: los dos trabajan, descansan, son juzgados en la comisaría, rentan el traje, etc. Todas actividades que los dos

cumplen en un radio de 4 kilómetros. Estas experiencias hacen menos real la correspondencia entre realidad y narración, que parece más exacta en Ladrón de bicicletas (F.3.1.2/1).

\footnotetext{
7 Véase también el Blog "Historias matritenses" consultado en Agosto 2016: http://historiasmatritenses.blogspot.mx/2012/02/el-tranvia-12-uniendo-canillejas-y.html
} 


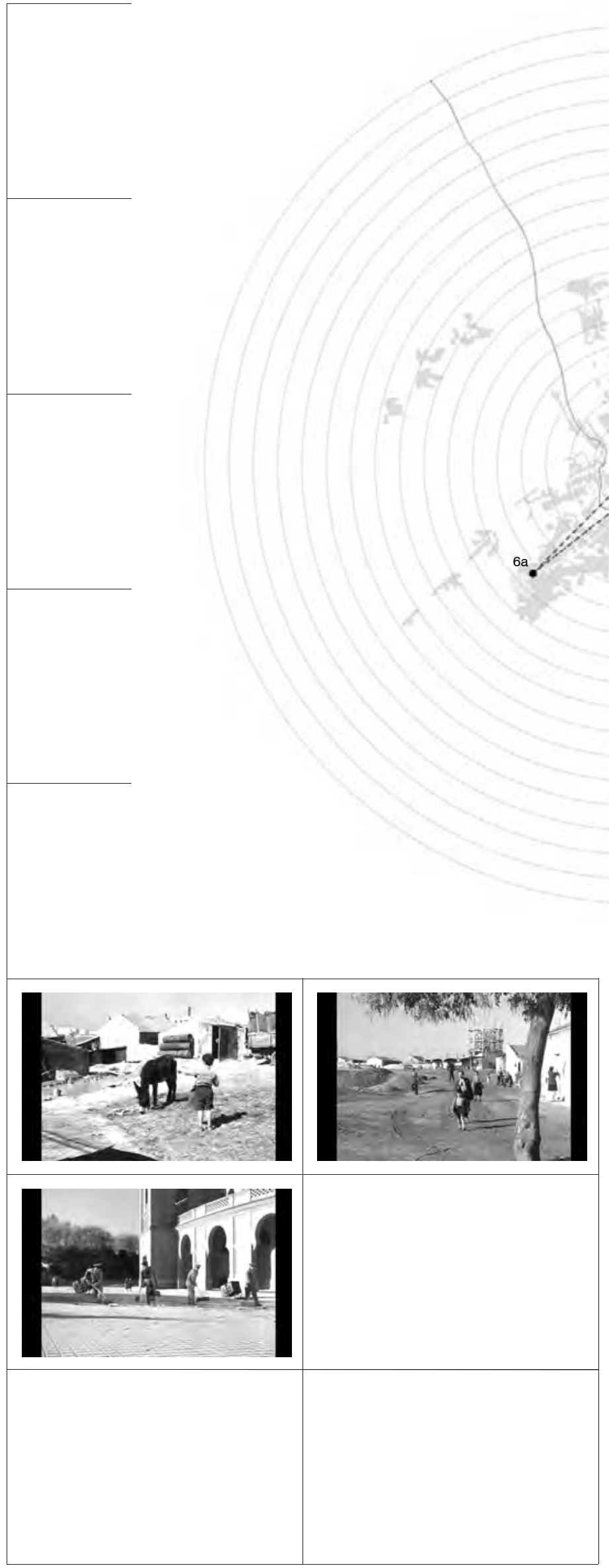

C2: ESTRUCTURA SECUENCIAL DEL RECORRIDO DE JACINTO Y PEPOTE

Oh 11' 37'. Punto de partida: chabola en San Juan Bautista - Quinta de la Paloma Oh 11' 43". Movimiento hacia la vaguada del Río Albroñigal - Elipsis espacial

Oh 12' 22". Espera del tramvía en Carabanchel Alto.

Oh 26' 00 ". Recolectando colillas en Ventas

Oh 28' 33'. Sacando el tabaco en el parque del Retiro

Oh $45^{\prime} 06^{\prime \prime}$. Viaje en el camión -cisterna.

Oh 58' 02 '. Llegada al Rastro.

Oh 59' 00 ". Movimientos en la Latina.

1h 00 ' 12". Busqueda de trabajo de Pepote hasta a la Plaza Mayor

1h 11 ' 09 ". Movimientos en la Latina.

1 h 23 ' 14 '. Toma del Metro en Tirso de Molina

1h 16 ' 01 ". Llegada en la Plaza de Toros de Ventas.

DISTANCIA TOTAL RECORRIDA (CÁMARA): $86 \mathrm{~km}$

DISTANCIA REAL RECORRIDA (REAL - HIPOTESIS): $28 \mathrm{Km}$. y 800 Metros

DISTANCIA MÁXIMA DEL CENTRO RECORRIDA (CÁMARA): $7 \mathrm{Km}$

TIEMPO DE DURACIÓN DE A PELÍCULA: 1h 26' 30'

TIEMPO TOTAL RECORRIDO (FÍLMICO): 57' 59'" (de 11'37' a 1h 16')

TIEMPO TOTAL RECORRIDO (NARRACIÓN): 1 día: sábado de mañana a noche

Puntos más periféricos del recorrido.

MD 6. Asientamiento informal en San Juan Bautista MD 6a. Av.da Carabanchel Alto

MD 7. Plaza de Ventas

UBICACIÓN DE LOS LUGARES DEL RECORRIDO: (Secuencia)

1. San Juan Bautista (ciudad lineal)

actual calle Torrelaguna

2. Ramón y Cajal

3. Av.da Carabanchel Alto

4. Plaa de toros de Ventas (explanada)

5. Parque del Buen Retiro (Lago)

6. Porta Portese
6. Calle Ribera de Curtidores (Rastro)

7. Calle Cava Baja (?)

8. Plaza Mayor

9. Tirso de Molina (Metro)

10. 4. Plaa de toros de Ventas (parque)

\section{MADRID}


La Madrid descrita en el viaje de los dos protagonistas, es en realidad dos ciudades diferentes. Los dos extremos geográficos, San Juan Bautista y Carabanchel, representan los arrabales donde viven los protagonistas, y muestran una Madrid de absoluta pobreza, un paisaje seco, de casas bajas o chabolas, de fábricas, naves depósitos, calles polvorientas, descampados y topografías variadas, con pocos elementos verticales que se contraponen a la horizontalidad, chimeneas o andamios. Este paisaje contrasta con la imagen del casco histórico, el lugar en donde los personajes buscan la suerte. En este recorrido en anillo que empieza y acaba en la plaza de las Ventas, el centro de la ciudad está representado como un lugar denso de población, en oposición a la ciudad desertizada presentada en los primeros 10 minutos de la película. En la primera etapa del recorrido, Vajda celebra una especie de corrida en el espacio abierto exterior a la entrada de la Plaza de Ventas: una faena entre Jacinto y los basureros. El contrapicado, enfatiza la monumentalidad de la plaza, mientras que las tomas a la altura del piso quitan cualquier tipo de pintoresquismo a la escena, enfocando la atención sobre la humilde operación de los protagonistas, que se dedican a recoger colillas del suelo. Jacinto lo hace casi con elegancia de torero, utilizando el paraguas como un estoque para levantar la basura del suelo, mientras que la cuadrilla de basureros se acerca rápida y amenazante barriendo la plaza.

Los aspectos pintorescos del retiro, la segunda etapa del recorrido de los protagonistas, están disimulados por la presencia del camión cisterna en los cuales los dos suben tomando un aventón hacia la siguiente etapa del viaje, el mercado del rastro. También la operación efectuada por los dos, que sentados en un banco se dedican a sacar el tabaco de las colillas, genera un contraste con la atmósfera idílica del parque madrileño.

El rastro y la zona de la calle Ribera de Curtidores es el escenario de toda la parte central de la película en la cual los dos protagonistas intentan varias soluciones, legales e ilegales para ganar las 300 pesetas necesarias para la renta del traje de luces. Una Madrid popular de multitudes de gente muy parecida a la Roma de Ladrón de bicicletas. Otras etapas son las de una obra de un edificio, en donde Jacinto es echado habiendo pedido el anticipo para un trabajo de vigilante, y las arcadas de la Plaza Mayor, en donde Pepote hace amistad con un limpiabotas. Después de haber conseguido rentar el vestido gracias a las lágrimas del niño que conmueven al dueño de la tienda de trajes, los dos se dirigen hacia la Plaza de Tirso de Molina, en donde la pareja toma el metro: Jacinto, con el traje puesto, aparece en un encuadre desde los carriles que muestra al torero esperando el tren, en medio de los otros usuarios mirándolo.

\section{SAN JUAN BAUTISTA}

La zona de Madrid ubicada al Noroeste de Ventas corresponde, al segundo sector de los cinco que se han seleccionado para definir el mapa del rodaje neorrealista en la capital española. Este sector se ubica entre la ciudad lineal, no lejos de los estudios cinematográficos CEA, y en la actual parada de metro Concha Espina, dentro del sector se ubica el barrio denominado San Juan Bautista. Esta zona se caracteriza, desde el punto de vista topográfico, por ser una terraza en el borde de la cañada del antiguo río Abroñigal, hoy ocupado por la autovía M-30. En esta área se rodaron algunas escenas de El último caballo de Neville y la película Cerca de la ciudad, que se analizará más adelante en este mismo capitulo; el rodaje de Cerca de la ciudad se realizó en la explanada de la iglesia de San Juan Bautista, a unos metros de los decorados de Mi tío Jacinto. Otros decorados cercanos son los de la Avenida Concha Espina, con algunos bloques de vivienda en construcción que aparecen como escenario en algunas tomas del episodio del concurso radiofónico en la película Historias de la radio de Sáenz de Heredia. (F.3.1.2/2). 
S2

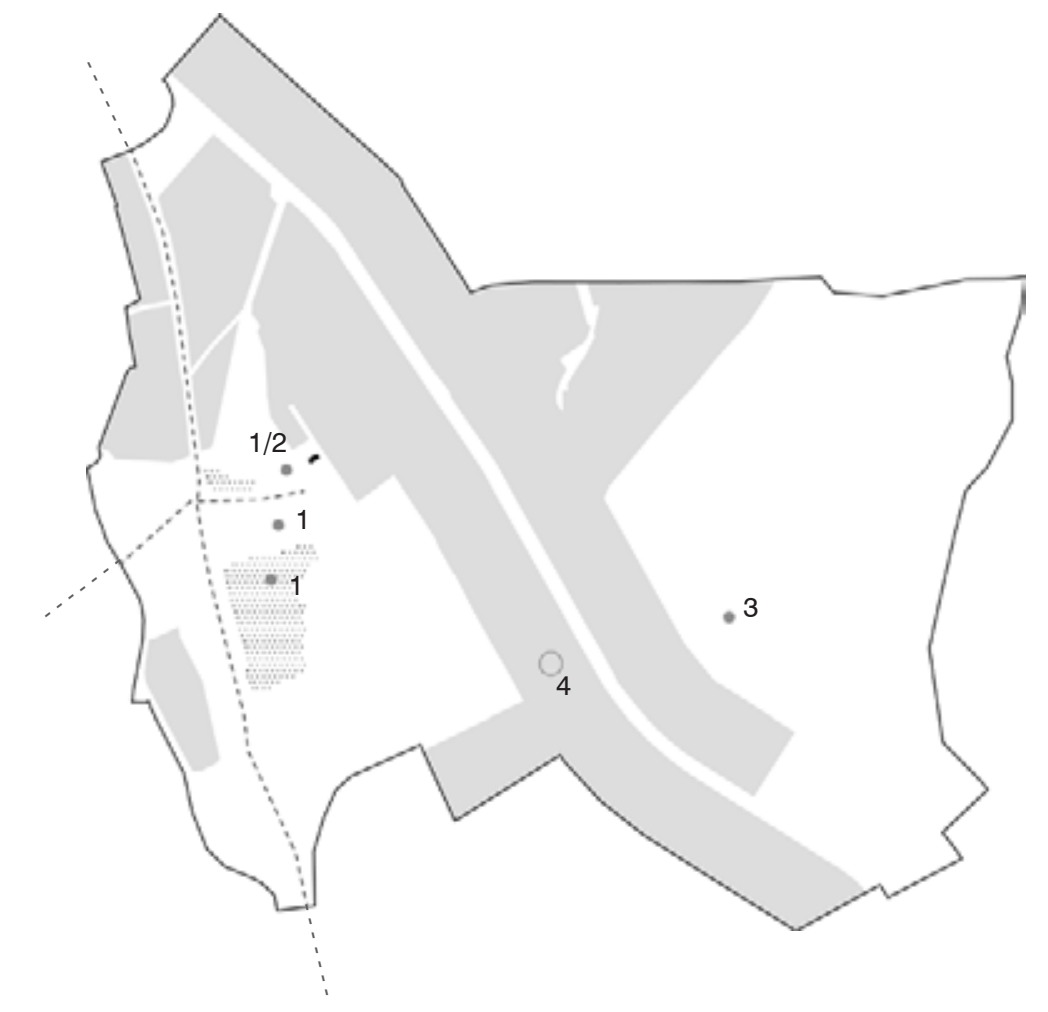

LEYENDA SECTOR 2 (Valmelaina-Nomentano)

\footnotetext{
Mancha urbana Tejido informal

$\because$ Infraestructura Q Vivienda popular

Vacíos
}

PELICULAS RODADAS

1. Mi tío Jacinto (Vajda)

2. Cerca de la ciudad (Lucía)

3. El pisito (Ferreri)

4. Estudios DEA 
El lugar donde residen Jacinto y Pepote, descrito por Vajda, es un gran vacío en la zona noroeste de la capital española, en espera de una futura urbanización como la Val Melaina de Ladrón de bicicletas. Sin embargo, el lugar descubierto por Vajda es un lugar distinto al de los protagonistas de la película de De Sica, así como distinta es la condición de vida de los protagonistas de las dos películas. La zona de San Juan Bautista, ubicado a menos de un kilómetro de los estudios CEA en la Ciudad lineal se encuentra muy cerca también de los estudios cinematográfico Chamartín que produjeron la película. Es la misma zona se rodó también parte de la película de Luís Lucía Cerca de la ciudad, que tiene al centro de la historia la parroquia de San Juan Bautista. Hemos desarrollado una cartografía del lugar de rodaje a partir de una cartografía de 1956 del departamento de urbanística del Ayuntamiento de Madrid $^{8}$, en la cual se han indicado las escenas.

Es evidente la diferencia de nivel social entre los protagonistas de Ladrón de bicicletas y Jacinto y Pepote: los dos protagonistas madrileños, comparten con la pareja italiana el total aislamiento, la falta de servicios del barrio periférico en el cual viven, pero la condición social de los dos personajes españoles resulta la peor: un tío ex torero, sin empleo y su sobrino de 6 o 7 años, viviendo en una chabola bajo una ladera, sin relaciones parentales y vecinales. La condición de los dos es más parecida a los protagonistas de El Limpiabotas de De Sica, aunque la familia de los dos jóvenes protagonistas, parece un recurso que ofrece más seguridad y bienestar psíquico.

Vajda define el lugar construyendo como decorado una cabaña bajo la ladera, entre la calle Norma y el asentamiento de la Quinta de la Paloma en el cual se encuentra la lechería en donde Pablito Calvo va a pedir el desayuno en la primera escena de la película; la chabola, aparece como un objeto totalmente aislado separada del cercano poblado por una colina. La única relación de vecindad que el niño establece es con el dueño de la lechería, aunque este último desprecia a su tío Jacinto. Pepote no parece ser amigo de los otros niños del barrio que se burlan de él. El niño parece el único que cuida el vínculo familiar con el tío que pasa la mañana en la cama borracho.

El segundo de los planos que componen la secuencia inicial antes de que los dos tomen el tranvía para Ventas, es un plano general que describe el paisaje de este fragmento periférico de ciudad. En la escena Pablito Calvo se disfraza de toro para ganar un poco de dinero con otros niños que se divierten toreando. La pequeña "plaza de toros" es una vaguada entre dos laderas, un sistema topográfico sin ningún tipo de vegetación; arriba está el descampado enfrente de la iglesia de San Juan, al horizonte Madrid, con la zona de Prosperidad y Concha Espina. Sobre el lado derecho de la cañada, pegadas a la calle Norma, se ve una agrupación de casas pequeñas conocidas como Los Tejares, en donde se producían tejas, como se ve en un encuadre de la cámara que roda el regreso del protagonista a la cabaña para despertar a su yío. Sobre el lado derecho del barranco, pegada a lo que hoy está soterrado bajo la M-30 y que antes era el río Abroñigal afluente del Manzanares, está la fábrica, hoy desaparecida, llamada Lasical, un edificio de dos plantas con una alta chimenea, destinada a la producción de ladrillos silico-calcareos; del otro lado de la M-30 otro edifico industrial caracterizado por una alta torre, conocido al tiempo como Perlofil, donde hacían fibras sintéticas. En este paisaje urbano-industrial se ve constantemente humo en el horizonte; la barranca atrás de la chabola de Jacinto y Pepote está caracterizada por líneas verticales rasgadas, que son testigo de la extracción del barro para la producción de la cerámica ${ }^{9}$ (F.3.1.2/3).

\footnotetext{
${ }^{8}$ Fuente: blog "Historias matritenses" consultado en Agosto 2016 http://historiasmatritenses.blogspot. $\mathrm{mx} /$ search?q=mi+tio +jacinto

${ }^{9}$ lbidem.
} 


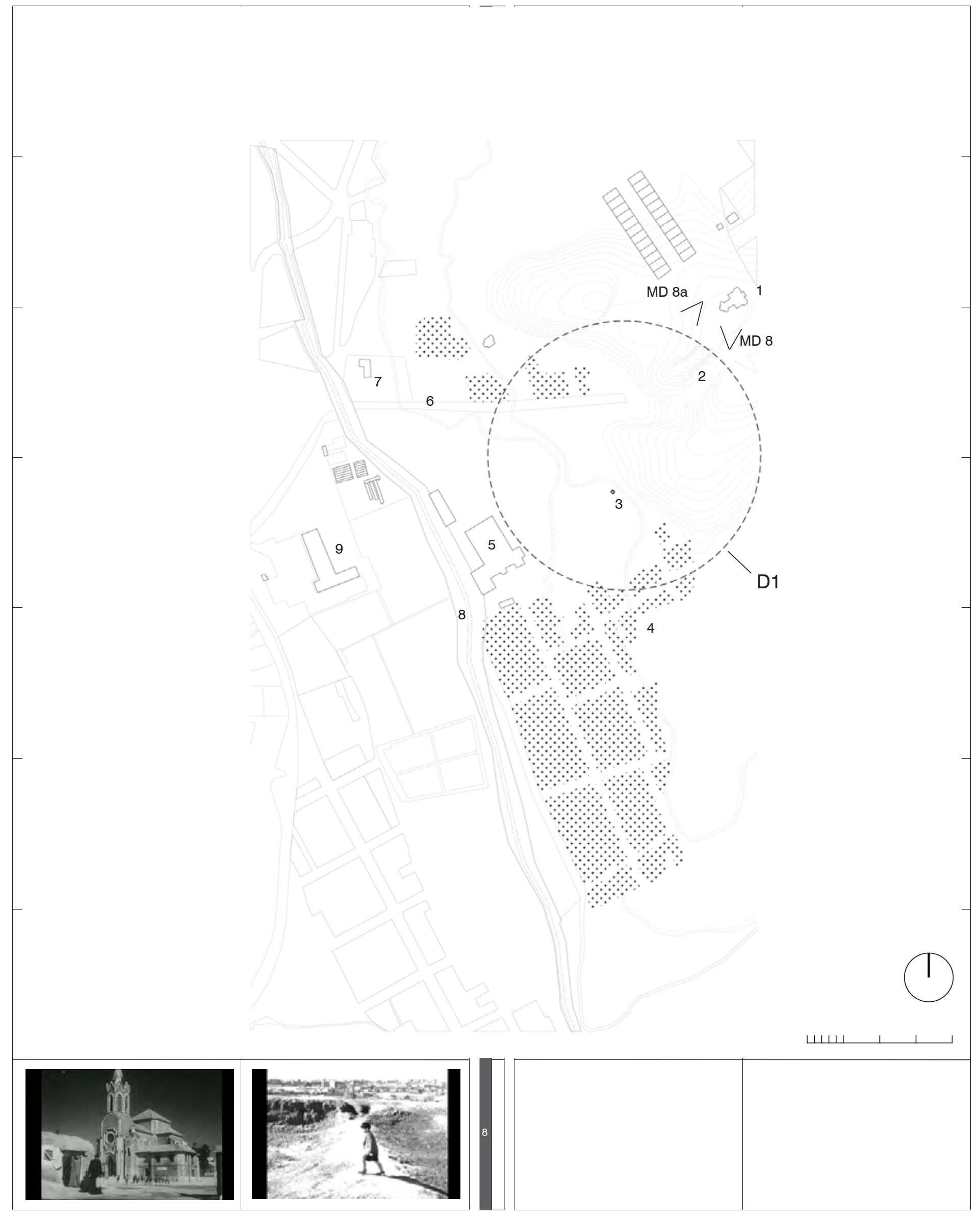

MD 8. Cerca de la ciudad (Lucía): Iglesia de San Juan Bautista

MD 8a. Mi tío Jacinto (Vajda): Altollano frente la iglesia de San Juan Bautista.

1. Iglesia de San Juan Bautista

2. Vaguada de la "Corrida de niños"

3. Chabola de Jacinto y Pepote (decorado)

4. Quinta de la Paloma (lecheria)

5. Fábrica de ladrillos "Lasical"

6. Camino prolongacion actual Av.da Ramón y Cajal

7. "Los tejares" (producción de tejas)

8. Rio Abroñigal

9. Fábrica Perlofil (fibras sinteticas)

\section{MADRID}


En esta ladera el niño juega con la lluvia recién levantada y antes de ir a pedir la leche, ha construido un pequeño molinillo que va empotrando en la ladera; excavando el barro el niño genera una pequeña cascada que acciona el movimiento de la rueda. Es una escena poética que nos recuerda el pequeño "arroyo de leche" en el cual el pequeño Totó de Milagro en Milán, de De Sica, juega junto a su abuela. Al mismo tiempo, esta escena relacionada con el agua, así como la escena de la incómoda cola para el agua en Ladrones de bicicletas, nos habla de la dificultad de la vida en estos lugares, en donde el exceso o la escasez de este elemento son características muy comunes.

El paisaje 'construido' por Vajda aparece como un gran anfiteatro natural que se abre hacia Madrid, hacia el centro de la ciudad que parece más lejano de lo que es realmente, separado por unos edificios industriales y por el humo que producen. En este escenario, los habitantes y sus casas parecen alejados el uno del otro, los niños se distraen aprendiendo a torear como los adultos mientras que el tío del protagonista, un ex torero, duerme en una chabola medio inundada.

En De Sica, el barrio de Val Melaina en Roma aparece en la pantalla como una periferia desertizada de la ciudad, sin límites, dentro de la cual, el masivo bloque de la edilicia social fascista es totalmente aislado; en cambio el hogar de Mi tío Jacinto, es presentado como un espacio residual, una pequeña pausa "rural" dentro de un sistema de diferentes capas urbanas e industriales que se sobreponen como en un palimpsesto, con el skyline de Madrid siempre presente como fondo. En estos espacios vacíos se mueven los protagonistas y las cámaras de los directores que los rodan, trazando los vectores que hemos representado en la cartografía de detalle. En la secuencia inicial de 11 minutos, Pepote cumple un recorrido anular alrededor de la chabola en donde vive, la cámara sigue al pequeño a la que parece ser la rutina de cada mañana, esperando el despertar de su tío; el recorrido es rápido con un tiempo escaso para socializar con otros niños y jugar con un burro en el adyacente caserío del Tejar, el conjunto de casas que producen tejas.

Las tomas de Vajda describen un lugar ficticio, en una reconstrucción escenográfica adentro de un espacio real, un espacio de frontera entre las adyiacentes quintas suburbanas. A través de la construcción del decorado, el pequeño corral con cerca de madera y la chabola en la cual demoran los protagonistas, el director reinterpreta el lugar, generando un nuevo paisaje urbano. (F.3.1.2/4). 

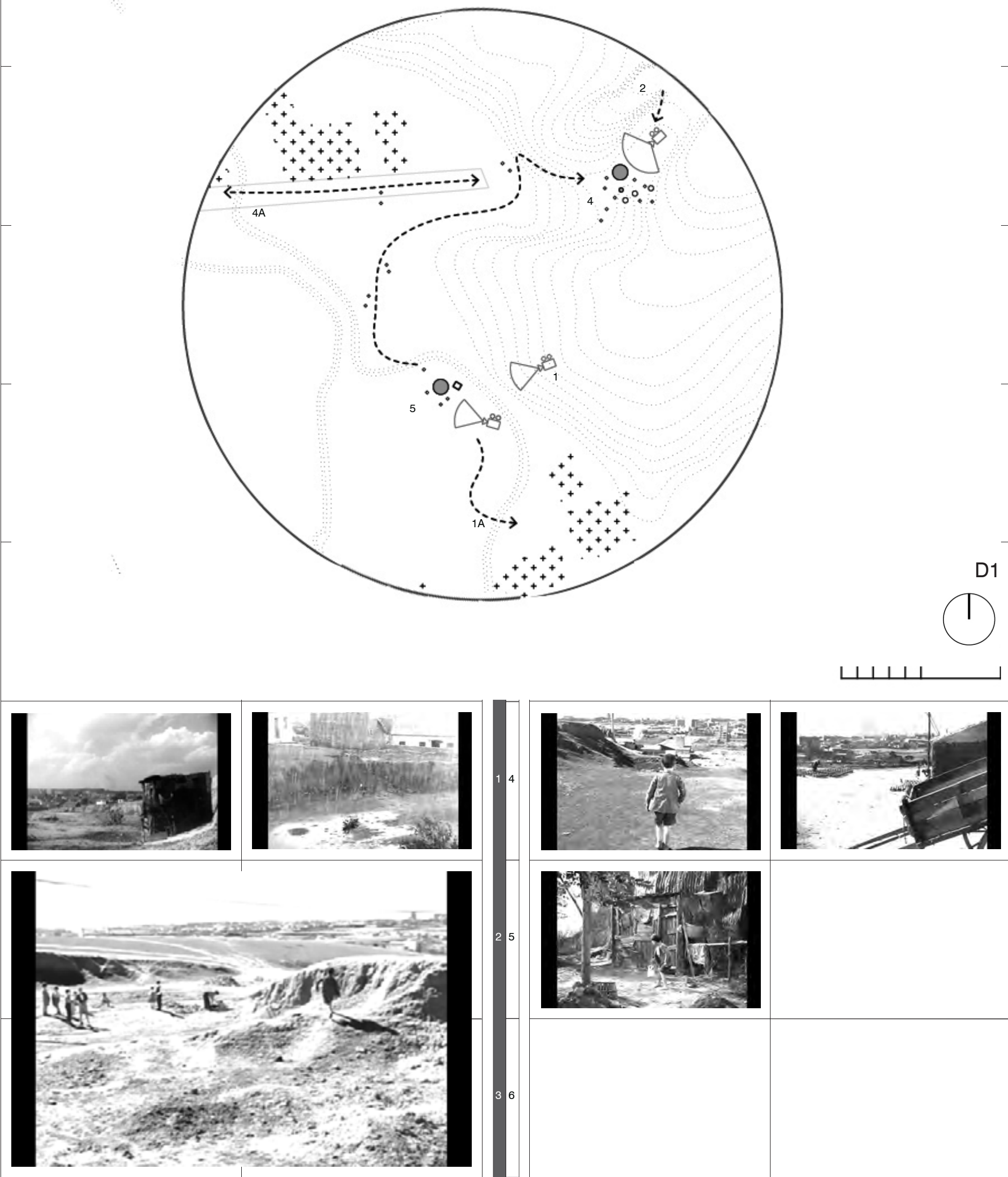

\section{Movimientos de cámara}

1. Panoramica: chabola de los protagonistas

1A. Plano conjunto: Hacia Quinta de la Paloma (lecheria)

2. Plano general: vaguada de San Juan Bautista, hacia

el Abroñigal
MD. Movimientos de cámara

4. Plano conjunto: al fondo la fábrica Lasical

4A. "El tejar" al fondo la fábrica Perlofil

5. Plano conjunto: Pepote regresa a casa. 


\subsection{Entre Centro y Periferia: Prenestino y Legazpi}

\subsubsection{De Roma, ciudad abierta a Accattone.}

Como se ha podido observar, analizando de los aspectos iconográficos del paisaje urbano en las dos ciudades, los centros urbanos representados en las películas cambian porque, como subraya el sociólogo Pierre Sorlin, los directores "tomaron conciencia del florecimiento de las zonas urbanas e intentaron expresar, cinematográficamente, las complejas relaciones que existían entre los viejos centros y las nuevas periferias" ${ }^{10}$. A este intento corresponden las exploraciones y las derivas de los directores, los "viajes de la cámara" con los cuales definen un nuevo espacio urbano: "en el reino de las imágenes socialmente constituidas hubo un cambio cuando los directores dejaron de contemplar las ciudades como potenciales obras de arte (...). Hacia mediados del siglo, una palabra idéntica e intacta, 'ciudad', se refería, al menos en las películas, a imágenes distintas e incoherentes" ${ }^{11}$.

En esta exploración urbana, los directores se mueven del centro a la periferia, descubren territorios cada vez más lejanos; en paralelo con la expansión urbanística de estos años, intentan fijar una iconografía a partir de antiguos trazos y vestigios naturales, como en un paisaje palimpsesto. Empiezan el recorrido a partir de áreas muy cercanas al centro histórico, que han quedado fuera de las descripciones del cine de los años '40. Barrios populares e productivos: el barrio de Arganzuela, de Legazpi, y algunas calles alrededor de Francisco el Grande en Madrid, la zona de Roma denominada Pigneto y las cercanas zonas de Mandrione, o Casal Bertone y Torpignattara.

El Pigneto es un triángulo incluido entre tres calles: la vía Casilina, la vía Prenestina y la calle del Acqua Bullicante. Al lado de la Prenestina y de la Casilina corren dos líneas de ferrocarriles que llegan a la cercana estación Termini, la estación central de la capital. Esta condición de área residual es la que en parte ha limitado el desarrollo de esta zona que se caracterizó por asentamientos al margen de la planeación general, en donde pequeñas cooperativas obreras y de empleados del ferrocarril desarrollaron gran parte de las viviendas presentes. Es un barrio ligado a la Segunda Guerra Mundial y a la lucha de resistencia antifascista, como el cercano barrio San Lorenzo, e igual que éste, sufrió los bombardeos aliados de 1943 y de 1944. En el cercano barrio de Torpignattara se concentraba la lucha, tanto que los soldados de la Wehrmacht renunciaban a entrar. De la calle Casilina llegaron los aliados declarando a Roma ciudad abierta, y en la Iglesia de Santa Elena, ubicada en esta calle, Rossellini pone la residencia del cura protagonista de su obra maestra. Pasolini describe así esta zona, en donde irá rodando su primera película, Accattone:

Aquí está la Casilina, / sobre la que tristemente se abren las puertas de la ciudad de Rossellini... / aquí , el épico paisaje neorrealista, / los hilos del telégrafo, el empedrado, los pinos, / las tapias desconchadas, la mística / muchedumbre sumida en la faena diaria, / la sombría forma de la dominación nazi... / Casi emblema ya, el grito de la Magnani, / bajo los mechones revueltos y absolutos, I resuena en las desesperadas panorámicas / y condensa en sus miradas expresivas y mudas / el sentido de la tragedia. / Ahí es donde se disuelve e mutila / el presente, donde el canto de los aedos se ensordece ${ }^{12}$.

\footnotetext{
10 (Sorlin \& Pujol i Valls, 1996 p.133)

${ }^{11}$ Ibidem

12 (Pasolini, 1997 p.51)
} 
En esta zona de la ciudad, se rodaron un gran número de películas, entre las cuales sobresalen Roma, ciudad abierta, Accattone, Bellisima, El ferroviario, Rufufú, entre muchas más, hasta el día de hoy. A esta popularidad del barrio en el mundo cinematográfico contribuyó seguramente el alma popular, la cercanía con el centro, y con los estudios de Cinecittá $(5 \mathrm{Km}$.), que después de la inactividad de la posguerra, poco a poco regresaban a su actividad normal. Las películas de Rossellini, de Germi y de Visconti, hablan de la zona formada por grandes manzanas cerradas y regulares de edificación popular donde viven los protagonistas. En Bellísima y en Roma ciudad abierta, se ve la tipología característica de esta arquitectura popular de principio de siglo $\mathrm{XX}$, que caracteriza muchas zonas de la capital italiana: los grandes patios interiores, ajardinados, con grandes árboles, muchas veces pinos. De uno de estos barrios se lanzará Anna Magnani hacia la calle exterior, la calle Montecuccoli, en donde morirá balaceada por un soldado nazi, durante uno de los muchos rastreos que sufrió este barrio y que Rossellini describe en esta escena. El director escogió esta vía probablemente por ser una calle sin salida y no ponía problemas logísticos por el tráfico y el paso de las personas ${ }^{13}$. Esta relación interior-exterior, está marcada en estas arquitecturas populares, a través de grandes portales, que quedaban abiertos a lo largo de todo el día.

Un edificio parecido a lo de Rossellini, es lo que aparece en la película Mamma Roma rodada en el barrio de Casal Bertone, muy cerca de la calle escogida para filmar Roma, ciudad abierta. En la escena que describe Pasolini, madre e hijo entran pasando por un gran arco, a la vivienda provisional, en espera de mudarse al INA-Casa del Tuscolano, lo que la protagonista otra vez Anna Magnani- considera una "verdadera casa", una casa digna, de nivel social adecuado. Es evidente el paralelo entre las dos películas: Mamma Roma y Roma ciudad abierta; la misma zona de la capital y una distancia de ochocientos metros entre los dos edificios, la misma actriz, la misma tipología edilicia, el bloque de manzana popular con patio interior, pero describiendo una realidad histórica, social y urbana totalmente diferentes. En el primer caso la vivienda humilde y digna de una comunidad de ciudadanos que lucha por la libertad, que ve su propia casa ocupada por los nazis; en el segundo caso la vivienda provisional de una pareja, madre e hijo, de las afueras, que intentan realizar en la capital el sueño de una vida burguesa. Para lograrlo ya no es suficiente el Barrio Prenestino, esta Roma no corresponde a las altas aspiraciones de la Mamma Roma, que quiere una vivienda moderna, en un barrio nuevo, 'sin pasado'. Un pasado que como los soldados Nazi en la peli de Rossellini, se presenta nuevamente a la puerta de la casa del Prenestino: el antiguo protector de la mujer.

Accattone describe la otra cara del Pigneto, la de la ciudad informal, que aparece muy poco en las películas italianas hasta 1956 año de El techo, de De Sica, que Sorlin pone como línea de demarcación a nivel europeo, en la génesis de lo que define como "imagen borrosa de la ciudad". En realidad, la presencia de chabolas aparecía como fondo en algunas de las películas anteriores, como Amor en la ciudad, El limpiabotas, Europa '51 y Milagro en Milán, aunque en esta última se trata de un barrio chabolista no real, una escenografía creada por De Sica. En cambio, ya se ha subrayado cómo la iconografía del chabolismo se hace más presente en las películas españolas de la época, en las cuales se muestra el fenómeno sin temor, a pesar de la censura. En Accattone, de Pasolini, rodado en el mismo barrio de Roma ciudad abierta y de las otras películas citadas en este párrafo, aparece toda la contradicción de la capital italiana, en la cual la formalidad e informalidad conviven: junto a huertas, descampados, y lotes baldíos, es posible encontrar las obras de la nueva ciudad de hormigón armado de las nuevas viviendas de las clases medias. En Accatone, Pasolini describe la otra cara del barrio hecho de una edificación de dos o tres plantas, de bares y bodegas

${ }^{13}$ (Crespi, 2003) 
artesanales, de gente sentada en terrazas bebiendo, de barracas y chabolas de ladrillo como en la cual vive el protagonista. En el caso de Pasolini, la exploración del lugar, la creación de una cartografía, va más allá de la experiencia cinematográfica, el director amaba pasar el tiempo en estas calles de casitas diminutas, tomando junto a los amigos-actores y aprendiendo de ellos, de sus historias, de su jerga, alimentando también su mundo poético y literario. Pasolini rodó algunos documentales como apuntes tomados para la preparación de otras películas, en estos apuntes lo que interesaba al director era la búsqueda de lo auténtico ${ }^{14}$; En el barrio del Pigneto, Pasolini tiene a disposición de toda la humanidad y los escenarios que necesita para contar su historia: los personajes que cuentas en sus narraciones, coinciden perfectamente con el lugar. El director, dentro de cierta polémica con el Cine de Antonioni, amaba decir que el sería incapaz de representar planos vacíos, "no pasaría mucho tiempo, que estaría diciendo a Delli Colli (el fotógrafo, n.d.r.) acerca de cerrar el encuadre sobre uno de los personajes"15; se trata de un coincidir antropológico de los personajes con sus hábitats y sería imposible contar estos lugares sin que aparezcan los seres que viven en aquel. Pasolini describe la periferia romana como un lugar no disímil de la de países del tercer mundo como India o África. El poeta habla de una condición pre-industrial de estos espacios al margen de la ciudad, y de una condición a-histórica, que vivirían sus personajes, como el personaje principal de Accattone, "que vive en un estado de salvajismo total y le obligan a aceptarlo todo, incluido el sacrificio de aquellos que él desea que sobrevivan (...); los arrabales como universo aparte en el que la gente se ve obligada a afrontar, dolorosamente, sus responsabilidades. Entre el capitalismo y el proletariado, entre la explotación y el robo, ellos viven en el tercer mundo"16.

La película de Accattone está casi en su totalidad rodada en la periferia, como en Los golfos de Saura, el centro ya ha desaparecido o es un centro que no tiene nada de turístico, como el Tíber de Puente San Ángel, en Roma, desde el cual el protagonista se lanza para ganar una apuesta; una escena en el cual aparece un Ángel del Bernini junto al cuerpo desnudo de Accattone en traje de baño listo para lanzarse; en las siguientes escenas aparece el paisaje de las riberas del Río romano que en verano se convertía en playa popular para muchos ciudadanos. La casa donde el protagonista vive con las mujeres que hospeda, es un minúsculo edificio de un ambiente único, y una pequeña cocina en una sola planta ubicada en la calle Giovenale, con un paisaje de edificios bajos y pequeñas huertas, que ha permanecido prácticamente intacto hasta el día de hoy. Se trata de edificios de una sola planta que se alternan a otros de dos y tres, junto a la presencia de emparrados vegetales y pérgolas, de huertos vallados con rejas y estacas de madera, rodando espacios interiores semi-públicos, pequeñas plazas de tierra para dar acceso a las diferentes viviendas. Un paisaje parecido es el conjunto de chabolas en donde vive la ex mujer y el hijo del protagonista, una especie de cortijo de barracas de una planta, alrededor de un polvoriento espacio central, al centro del cual aparece la ruina de un edificio, aparentemente rural. Un paisaje arcaico, o anti histórico, para usar dos adjetivos pasolinianos. En uno de los numerosas 'derivas' de "Accattone" en la periferia, se describe este lugar en sus límites sur-orientales, en la zona denominada Borgata Gordiani: esta parte de ciudad, aparece como un gueto, un enclave dentro de la ciudad, en el fondo del encuadre los altos condominios recién construidos, al centro un tejido incoherente que alterna viviendas de una plantas y grandes descampados. (F.3.2.1).

\footnotetext{
${ }^{14}$ viajó por ejemplo en Palestina para buscar los lugares para rodar su Evangelio y rodó Sopralluoghi in Palestina per il Vangelo secondo Matteo. Lo que encontró y contó en el documental era un país contaminado poe el mundo del consumo y, no encontrando ni personajes ni paisajes adecuados, decidió ambientar la película en el sur de Italia en la ciudad de Matera.

15 (Pasolini, II mio cinema, 2015 p.44)

${ }^{16}$ (Sorlin \& Pujol i Valls, 1996 p.127)
} 
LEYENDA SECTOR 1 (Prenestino / Pigneto / Casilino)

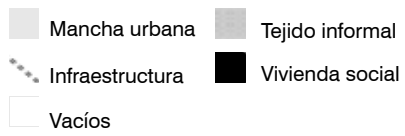

1. Accattone (Pasolini)

2. Roma citta aperta (Rossellini)

3. II Tetto (De Sica)

4. II Ferroviere (Germi)

5. Bellissima (Visconti)

6. Mamma Roma (Pasolini)

S1 (Sector 1)
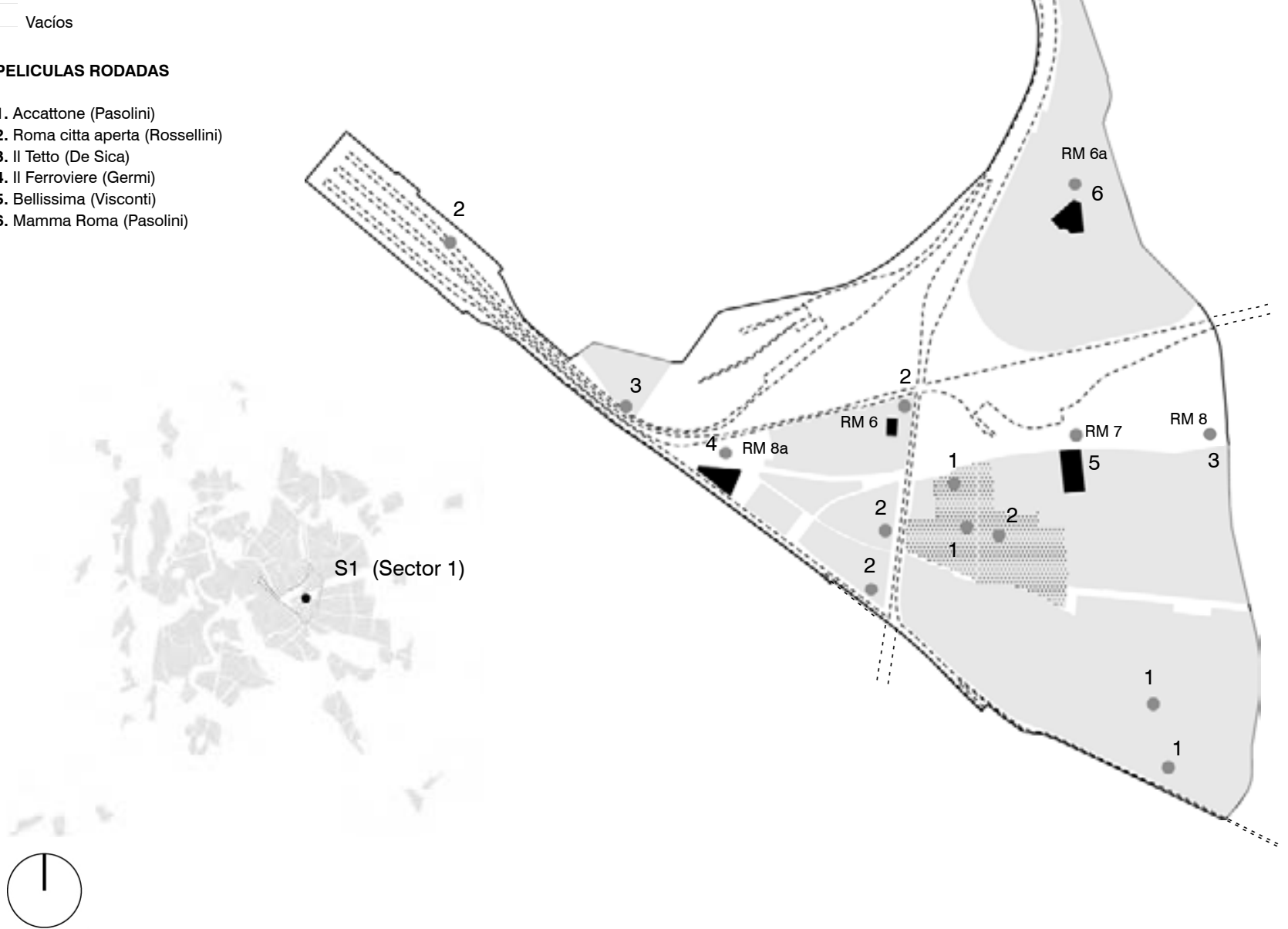

\section{$\sqcup \amalg ل$}
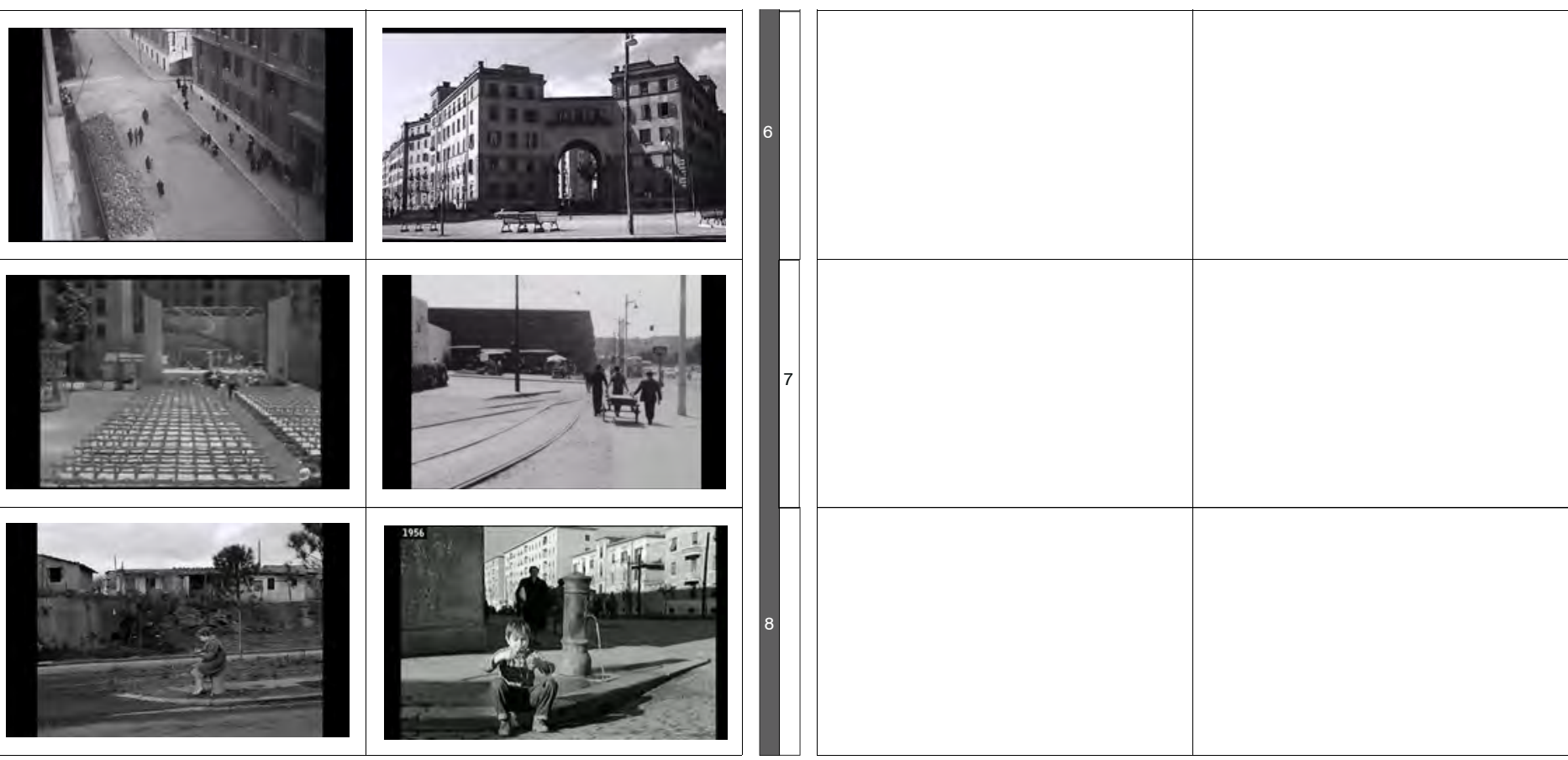

RM 6. Roma citta aperta (Rossellini)

RM 6a. Mamma Roma (Pasolini)

RM 7. Bellissima (Visconti)

RM 7a. Accattone (Pasolini)

RM 8. II Tetto (De Sica)

RM 8a. II Ferroviere (Germi)

"Roma citta aperta":

Via Casilina / Circonvallezione Casilina / Via R. Montecuccoli / Quartiere Prenestino

"Mamma Roma":

Casal Bertone

"Bellissima":

Via Da Giussano 4 (Prenestino)

"Accattone":

Prenestino / Pigneto / Via Casilina / Villa Gordiani (Prenestina)

"II Ferroviere":

Calle Prenestina / Plaza Caballini 
En medio de la calle, en un pequeña banda de asfalto, pasea el protagonista, sin preocuparse de la poco probable presencia de coches, transporte público y/u otro vehículo motorizado (en una escena solo se ven aparcados sus motocarros y un pequeño coche Fiat); al lado de la calle no aparecen banquetas, sino caminos polvorientos con postes de madera de la iluminación y del cableado al centro, en otros fotogramas aparecen unos escombros, ropa tendida en la calle frente a una casita, un cartel de un teléfono público, probablemente dentro de un pequeño bar, y una procesión de un funeral que atraviesa la calle -una escena que regresará al final de la película- en un sueño del protagonista. En otro famoso fotograma rodado en la borgata Gordiani, aparece el protagonista caminado con un edificio abandonado al fondo, en ruinas, con un graffiti que dice "vogliamo una casa civile"17, una referencia a lo que había sido esta borgata, una de las tantas construidas por el Duce, para liberar el centro histórico de la Capital, como ya hemos visto en Val Melaina en Ladrón de bicicletas. En este caso, no se llegó a construir viviendas en un bloque, sino que se diseñó un retículo ortogonal de calles, un "Castrum" que se edificó con desechos de otras obras o los derribos mussolinianos, algunas casitas de una planta, sin agua ni luz eléctrica. La deriva de Accattone, tiene este valor de viaje en el "tercer mundo romano", una situación de precariedad e infravivienda que, en este lugar, como en otros de Roma, no se solucionó hasta los años '80. La estética del terrain vague romano probablemente alcanza en esta película su máxima expresión. En el barrio Gordiani Pasolini cuenta todo lo que era Roma en estos años, y que en parte sigue siendo: un territorio incoherente de ruinas, escombros y desechos, de topografías artificiales, por las muchísimas obras residenciales, que por su estilo arquitectónico y su tamaño contrastan con los tejidos formales e informales de las borgate históricas, un paisaje de constantes subidas y bajadas, en donde es posible encontrar "dunas de tierra" con palmeras tropicales, huertas, ruinas romanas y árboles de pino, viaductos ferroviarios con edificios industriales iluminados en la noche, de prostitutas y de santas que viven reciclando basura (como hace el personaje de Stella la novia del protagonista Vittorio/Accattone), de mamas y ladrones.

La forma de rodar de Pasolini es la del Neorrealismo, la de seguir sus personajes con la cámara, un rodaje que se mueve en el espacio, un uso del travelling y de la cámara a mano, con primeros planos de las caras de los personajes en los diálogos rápidos. Pero a diferencia de De Sica, el autor de Accattone, utiliza el montaje para fragmentarlo todo, sin la secuencialidad espacio-tiempo que habíamos visto en el Neorrealismo. Esta voluntad de relectura a través del montaje, corresponde a la voluntad de crear un 'collage urbano', un mapa situacionista que trascienda la misma iconografía neorrealista de la periferia. El objetivo es componer la imagen de una nueva periferia, imaginaria e irreal al mismo tiempo, una híperperiferia hecha de lugares muy cercanos entre ellos, todos ubicados en el cuadrante Sureste de la capital. A través del montaje pasoliniano todos estos decorados se trasfiguran y se potencian en una iconografía del paisaje al límite entre el sueño y la realidad.

\subsubsection{De Surcos a Los golfos.}

Los directores españoles, tanto como los italianos exploran la ciudad, a partir del centro histórico y de sus límites, buscando los vacíos y las incoherencias dentro del tejido urbano; en esta búsqueda, progresivamente se alejan más del centro, y se acercan a los suburbios. "En la comedia de finales de los '50, Madrid básicamente es el eje formado por el Retiro, por el paseo del Prado y la Gran Vía. En último lugar aparecerían las terrazas del parque del Oeste y el estadio de Chamartín" ${ }^{18}$. La imagen de Lavapiés de la película Surcos, es una imagen de

17 "queremos una casa digna"

18 (Deltell \& Garcia Fernandez, 2006 p.265) 
ruptura con el pasado, la representación de un barrio popular de Madrid, fuera de la lógica de la tradición popular folclórica castiza, una Lavapiés neorrealista con el patio interior de la casa corrala como soporte de todos los acontecimientos narrados, un lugar claustrofóbico que se conecta con la calle a través de un pasillo del cual nunca está la salida o la entrada. En el patio se mueve "una manada de niños voraces, que arrasan cualquier objeto que pueda parecer abandonado" 19 .

A pocas calles de distancia de la Latina y del Rastro, hay una Madrid más periférica, que los directores exploran. Alrededor de la iglesia de San Francisco el Grande se encuentran dos manzanas históricas, que conservan un aspecto doméstico y anónimo y conviven con algunos terrenos baldíos, al límite de las terrazas al Oeste, que separan la capital de la cuneca del Manzanares. En esta área se rodó parte de El inquilino y una escena muy interesante de Los chicos, de Ferreri, ambientada en la calle Rosario; en esta calle se describe la llegada de los protagonistas a la cita del domingo para pasar la tarde con algunas chicas del barrio. En esta escena se ve el descampado al lado de la iglesia de San Francisco, con los muros laterales de mampostería que parecen parte de una ruina; se ve el límite de la ciudad y al horizonte los terrenos de la pradera de San Isidro, y a la derecha la zona que hoy corresponde a Puerta del Ángel. Subiendo la cuesta de la calle Rosario se encuadran una serie de camiones y caravanas aparcados, muy probablemente de los artistas y comerciantes de la Feria de la Latina a la cual el grupo de jóvenes se dirige. Es la representación de un paisaje diferente, en donde con mucha dificultad podemos reconocer como una zona central de la ciudad: el descampado con el muro medianero de la iglesia, y los tráileres, podría confundirse con uno de los muchos que existe en Carabanchel, o en Ciudad lineal.

Otro distrito entre centro y periferia que aparece en las películas analizadas, es lo de Arganzuela. Se trata como en el caso del Prenestino en Roma, de una parte, de la ciudad que tiene su centro de gravedad en la estación central de trenes Termini, en Roma y Atocha en Madrid; esta zona de la capital española se extiende hasta el Manzanares, llegando al antiguo matadero y al mercado de Legazpi. En las zonas cercanas al paseo de Delicias se rodaron algunas escenas de Surcos, en especifico las del taller de siderurgía, en donde el abuelo empieza su agotador trabajo como ayudante. En una de estas calles aparece un tanque de agua metálico al fondo, cerca de la actual estación de Cercanía. Otra escena de Surcos está rodada un poco más al Sur, enfrente del Mercado de Legazpi y del matadero. Esta Madrid industrial aparece también en Los golfos de Saura, en varias secuencia de la pelicula. El Madrid de la primera pelicula de Saura es la ciudad de la miseria y de la pobreza extrema ${ }^{20}$; en Legazpi la pandilla de los golfos se dedicará al robo de alimentos dentro del recinto del mercado de mayoreo, en la acera del matadero, frente a las grandes manzanas de vivienda sociales del Paseo de la Chopera, Paco, uno de los protagonistas, se escapa calándose en una de las alcantarillas, perseguido por los viandantes que apoyaban al taxista, víctima de uno de los atracos de los jóvenes. La miseria de la Madrid descrita en Los golfos, como la de Accattone es un miseria de tercer mundo, una miseria que llega casi hasta el centro, se produce en las orillas del manzanares, en los espacios residuales del cauce del Río, entre escombros y laderas secas; no es una coincidencia que Los golfos de Saura sea la única película en la cual aparece el río Manzanares como se presenta en los suburbios, lejos del pintoresquismo de la iconografía tradicional de la ciudad. También el tema taurino, tipico de la cinematografía española de los años ' 40 y ' 50 , se mostra en esta pelicula de una forma inedita, y es interesante la visión de este mundo folklórico en comparación con otra pelicula de la época que hemos analizado en el parrafo anterior, Mi tío Jacinto, de Vajda, en donde la

19 (Torres Hortelano, 2011 p.24)

${ }^{20}$ (Deltell \& Garcia Fernandez, 2006 p.265) 
imagen del torear, a pesar del fracaso final de la faena, que las dos peliculas comparten, es todavía una imagen romántica o picaresca, como aparece en la escena de Jacinto en la estación del Metro. En Los golfos la imagen divertida y romántica desaparece, y las plazas de toros escogidas cuentan estas diferencias: si para Mi tío Jacinto se rodó en la plaza de Ventas para los exteriores y en la de Malaga para los interiores (por problemas climaticos) ${ }^{21}$, para Los golfos, se utilizó la plaza de Vista Alegre para la escena final y "la Taurina" o Placita de Ventas, para las escenas de entrenamiento además de algunas secuencias de toreo al aire libre en la Casa de campo. La Placita de Ventas, fue utilizada especialmente para el entrenamiento de los toreros, y se encontraba entre algunas antiguas viviendas del barrio de Ventas aproximadamente donde hoy en día están ubicadas las torres del barrio de la Concepción,

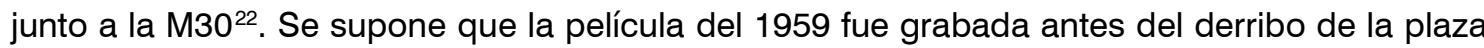
que se produjo justo en estos años entre final de los '50 y los primeros años de los '60. La iconografía de esta plaza representa para el director este carácter salvaje del torear, algo que es un don de la naturaleza; Los golfos ven en este don de uno de ellos -Juan- la posibilidad de tener un futuro mejor. La Placita de Ventas no tiene nada de heróico, son unas cuantas gradas empotradas en un conjunto de casas blancas, podría ser un rincón pobre de Andalucía, sin embargo es un fragmento de la ciudad que Saura descubre para su pelicula, "una ciudad preindustrial casi de tercer mundo", como la Roma descrita por Pasolini, pero que mantien intacta su raíz campesina (F.3.2.2).

\footnotetext{
21 (Jiménez, 2013)

22 (Márquez, Recorrido visual por las plazas de toros de Madrid, 2016)
} 
LEYENDA SECTOR 1 (Arganzuela / San Franciso el Grande)

\section{Mancha urbana \\ $\because$ Infraestructura \\ Vacíos \\ Tejido informal \\ Vivienda social}

\section{PELICULAS RODADAS}

1. Los Golfos (Saura)

2. Surcos (Nieves Conde)

3. El Inquilino (Nieves Conde)

4. Los Chicos (Ferreri)

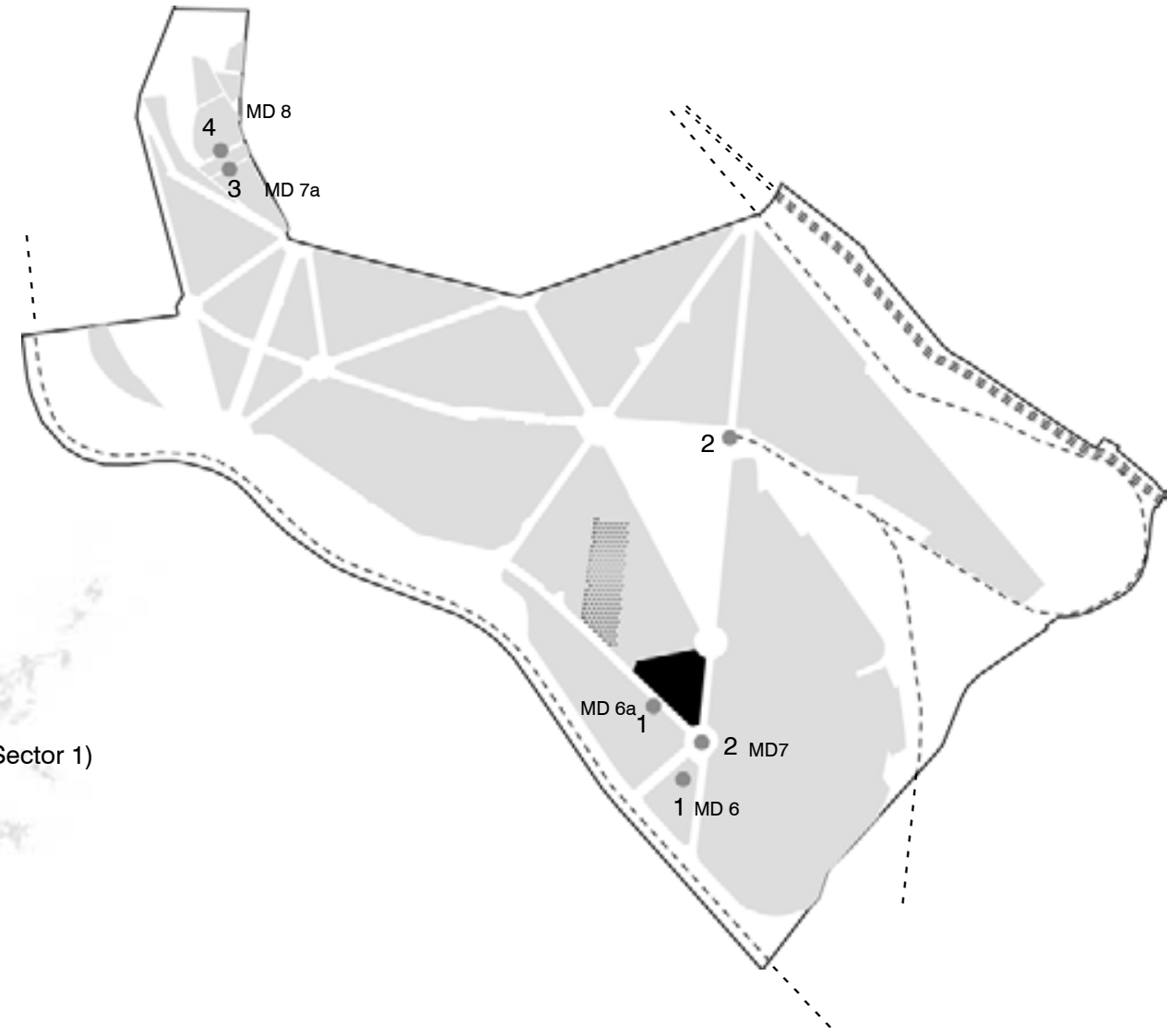

S1 (Sector 1)

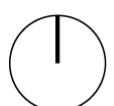

\section{$\mathrm{L \perp \perp \perp \perp}$}
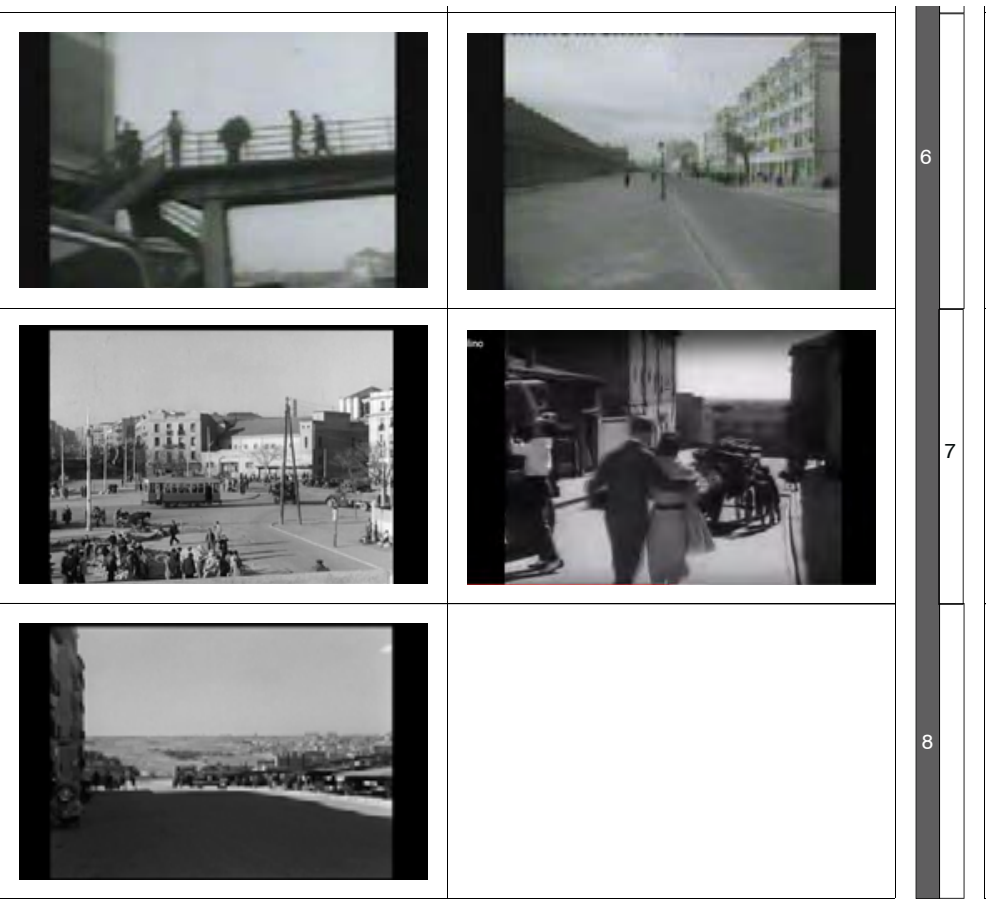

RM 6. Los Golfos (Saura)

RM 6a. LosGolfos (Saura)

RM 7. Surcos (Nieves Conde)

RM 7a. El Inquilino (Nieves Conde)

RM 8. Los Chicos (Ferreri)

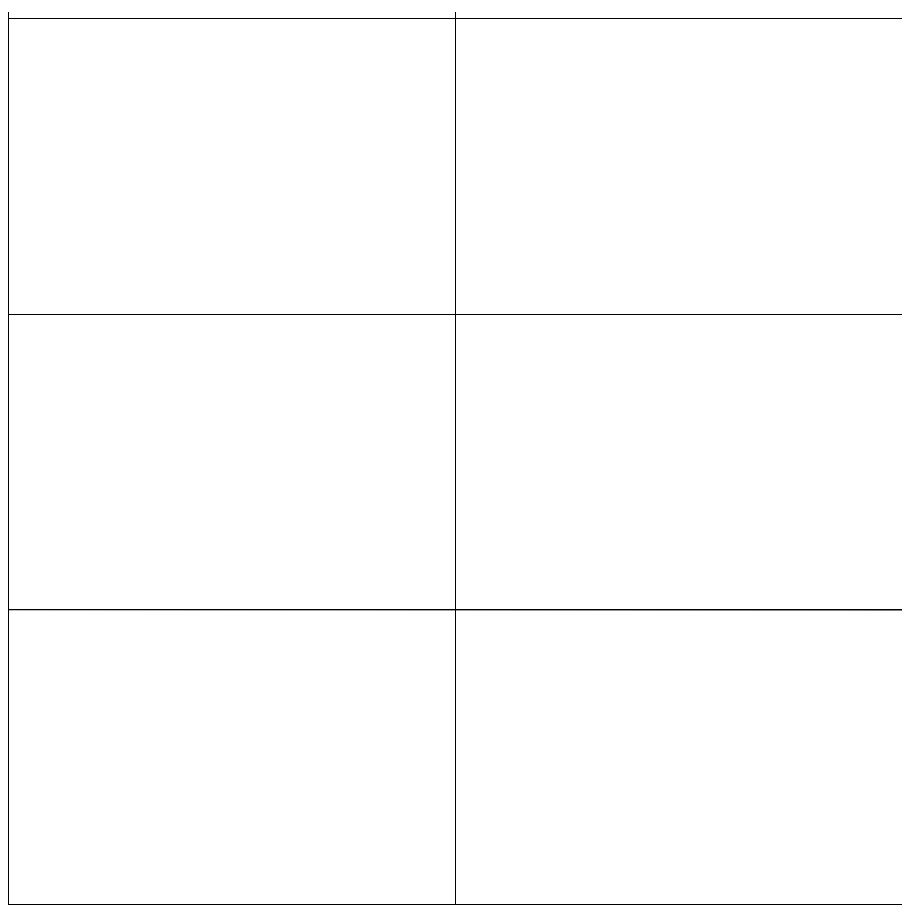

"Los Golfos":

Legazpi (Mercado) / Paseo de la Chopera

"Surcos":

Delicias / Legazp

"EI Inquilino":

San Francisco El Grande (Calle S. Barnabé)

"Los chicos":

San Francisco El Grande (Calle Rosario)

\section{MADRID}




\subsection{Sector Noreste: el Barrio Nomentano y la Elipa.}

\subsubsection{El techo.}

\section{RECORRIDO}

La "borrosa imagen de la ciudad" de la cual habla Sorlin en sus investigaciones, se desarrolló a partir de la película de De Sica, El techo de 1956. Es en esta obra cinematográfica que "el fuerte sistema que asociaba el centro a la periferia, presentadas como entidades complementarias, se desvaneció y la imagen de las ciudades empezó a descentrarse" ${ }^{23}$, un cambio que afectó a toda la Cinematografía europea.

Más que en cualquier otra película anterior de este director, se representan los arrabales periféricos de una forma real, y sin ningún tipo de referencia hacia el centro de la ciudad ${ }^{24}$, la acción se desarrolla casi exclusivamente en la periferia, sin ningún tipo de contraposición. Los lugares más próximos al centro contados en la película se encuentran en la proximidad del anillo de la Muralla Aureliana, como la vivienda que la joven pareja quiere rentar ubicada en la calle de Porta Labicana, en el barrio de San Lorenzo, separada de la ciudad por la línea de ferrocarril, a poca distancia del barrio del Pigneto y la calle de Castro Pretorio, cerca de la estación Termini.

En esta película están presentes todas las posibles soluciones habitacionales disponibles en estos años en la capital, y los problemas que una pareja de recién casados podría encontrar para conseguir un alojamiento; temas que acercan esta obra cinematográfica a las contemporáneas españolas El inquilino de Nieves Conde y El pisito de Ferreri.

En la cartografía se ha podido evidenciar cómo la Roma de El techo excluye totalmente al centro histórico. De Sica compone un triángulo, con la única excepción del viaje fuera de la ciudad que la pareja recién casada cumple en visita a la familia de Luisa. No se ha podido ubicar el pueblo de pescadores, que casi seguramente se encuentra en la costa del Mar Tirreno probablemente al Sur-Oeste de la Capital. Los vértices del triángulo están ocupados por los tres lugares más importantes de la historia: en el Norte, el Barrio Nomentano, donde se ubica la casa del cuñado y de los padres de Natale; en el vértice Sur-Este el Barrio Tuscolano, el lugar del primer encuentro de la pareja, lugar donde Luisa trabajaba donde su esposo aprende el oficio de albañil; en la periferia Sur-Oeste, cerca de Avenida Marconi, se encuentra la obra de viviendas donde Natale encuentra trabajo, una cierta seguridad económica y los amigos-compañeros que lo ayudarán en la construcción de su chabola. En el centro geométrico de este triángulo isósceles la calle de la Puerta Labicana en el barrio de San Lorenzo, el lugar más céntrico de la historia, en donde la pareja fracasará en el intento de rentar una habitación.

La película se abre con una imagen de un edificio en construcción en proximidad de la vía Tuscolana, y sigue con la boda de los protagonistas, Natale y Luisa, en la iglesia de Santa Costanza, y con el viaje en camión de los dos hacia el pueblo de la esposa, de visita a su familia. Este viaje concluye con las panorámicas desde el camión: la cámara puesta en los asientos laterales encuadra la ventanilla de frente entre los dos protagonistas sentados del lado opuesto de la cámara. En la ventanilla aparecen diferentes paisajes, de lo rural a lo

\footnotetext{
23 (Sorlin \& Pujol i Valls, 1996 p.124)

${ }^{24}$ La única imagen del centro histórico son dos planos con el Coliseo como fondo, en la escena del regreso hacia el barrio Nomentano después del primer intento de autoconstrucción de la pareja en el barrio Prenestino.
} 
urbano; desde las cabañas de paja en la playa hasta los bloques de vivienda de 6 plantas construidos a lo largo de la vía Tuscolana. En el siguiente plano se representa el camión recorriendo algunas calles de Don Bosco, la gran iglesia en construcción en proximidad de Cinecittá, cerca de las obras que se ven en los títulos iniciales de la película; después, a través de un falso raccord, en la misma secuencia se incluye una toma del barrio Nomentano, con las torres de Avenida Etiopía de Ridolfi como fondo. Con este raccord geográfico, De Sica quiere crear una mayor congruencia de las ambientaciones escogidas, creando una fusión entre dos barrios en realidad, diferentes y distantes geográficamente; en esta elipsis, hay que tener en cuenta de la comodidad para muchas películas de la época de la avenida Tuscolana como escenario, por la cercanía de los estudios cinematográficos de Cinecittá.

Este primer viaje es en realidad una fuga de los lugares de orígenes; la esposa no logra solventar los conflictos con el padre, que, enfadado por no haber sido consultado en la decisión de casarse, se niega a cualquier tipo de apoyo económico a la joven pareja, y regresa a la ciudad definitivamente. En las miradas de los jóvenes que llegan al pueblo de pescadores de la familia de ella, está también el rechazo hacia un mundo demasiado lejano y primitivo. Pero al escapar de la incomodidad de la vida rural y de los conflictos familiares, los dos se enfrentarán a los mismos problemas esta vez en la dimensión urbana. La tensión en la casa de la familia del esposo, especialmente con el cuñado y el hacinamiento de este hogar, llevarán los dos a tomar la decisión de salirse de la casa de los familiares, buscando otro alojamiento. El lugar de la residencia de la familia del esposo, la Calle Giuseppe Vasi en el Barrio Nomentano, a 4,5 kilómetros de distancia del centro, nos cuenta de una condición de fuerte contraste social presente en la capital, presente a lo largo de toda la película, y que el director De Sica cuenta a través de las arquitecturas y de los paisajes escogidos. La casa del padre es una diminuta vivienda, viven en ella 8 personas en un espacio de alrededor de 30 metros cuadrados; la vivienda está rentada por el cuñado, en la planta baja de un edificio de dos plantas, al parecer es una pequeña vivienda obrera de primeros años del siglo, en muy mal estado de conservación. La vivienda ha sido fraccionada en distintos apartamentos en renta, de muy pequeño tamaño; está rodada en edificios residenciales de la tipología de la palazzina, de 5 plantas, edificios para el sector medio-alto de la población, con departamentos de gran tamaño, en promedio dos por planta. El departamento de la familia de Natale se compone de una habitación, una cocina con comedor y un pasillo con baño. En la habitación duermen los padres, con la hermana menor de aproximadamente 14 años. En el pasillo, frente a la puerta del baño, en una cama se acomodan dos de los tres hijos (en una única cama) de la hermana mayor; y en la cocina duerme la hermana con el cuñado, y en una camilla, el otro niño más pequeño. Natale y su esposa se acomodan en la habitación de los padres, aunque por la falta de intimidad de la primera noche, intentará mover la cama al pasillo, bloqueando la puerta de acceso exterior y causando el enfado del cuñado. Por la falta de privacidad y los constantes regaños del cuñado-locatario los dos decidirán buscar otro piso en renta, y el día después de una pelea decidirán irse definitivamente.

Así que la pareja empieza a recorrer la ciudad y sus barrios periféricos en búsqueda de un lugar para quedarse. Si comparamos la búsqueda de El techo, con la de las contemporáneas El inquilino o El pisito, podemos detectar una mayor ingenuidad de los dos recién casados, la 'seriedad' del tono de De Sica, es reflejo de los sentimientos de los dos protagonistas, sin espacios para la picardía y el sarcasmo que caracterizan en general casi todas las comedias realistas españolas analizadas. Los dos jóvenes son capaces de enfrentar cualquier situación y contemplar cualquier posibilidad hasta rendirse, un espíritu más parecido a lo de la película de Nieves Conde, y muy distinto a lo de la pareja resignada y cínica de la película de Ferreri. 
Al salir de la casa de los padres, la pareja trae un carrito, en donde cargan sus pocas pertenencias, y se dirigen hacia el Sur. En la primera etapa del recorrido, los dos regresan al primer departamento visitado, para rentarlo, pero encuentran el edificio cerrado y vigilado porque está en peligro de caerse. Se trata de un edificio de ladrillo aparente, frente a un alto muro de contención que separa la calle de la vía de trenes: el estado del edificio y sus muros desgastados nos acuerdan que el barrio donde está ubicado, San Lorenzo, fue bombardeado por los aliados en el Julio de 1943; es este el único edificio en el cual la joven pareja puede permitirse rentar un piso: para encontrar algo más barato solo se puede ir al Prenestino "donde viven los salvajes" como les comenta el dueño del departamento.

Es el Prenestino es la siguiente etapa, esta vez coherente con la geografía de la capital y con los tiempos fílmicos. Se trata de un asentamiento informal entre la calle Prenestina y la vía del tren en un extenso descampado que después de la demolición de las chabolas en los años '60, todavía al día de hoy sigue sin edificar: este predio es parte de una cintura de lotes baldíos, terrenos agrícolas, zonas deportivas, que se extiende hacia las dos siguientes calles radiales, la Casilina y la vía Tuscolana. Esta barriada, en donde los protagonistas ubican un pequeño lote disponible para construir su chabola, con la ayuda de unos pobladores y de los compañeros albañiles, se desarrollaba sobre un gran talud, que la separaba de la calle Prenestina y que la esposa jalando al marido sube entre orgullosa y emocionada, porqué cree haber encontrado la solución para todos los problemas. El subir y el bajar es un gesto que aparece varias veces en la películas neorrealistas y en esta película de De Sica; se trata de la subida de un talud contiguo para mirar el horizonte y encontrar un poco de intimidad cuando los dos viven todavía en casa de los padres de Natale; o el subir los taludes de tierra que separan la obra en donde la el protagonista ha encontrado un trabajo, -otro conjunto de vivienda social que aparece en la película- y un refugio temporal en la caseta de obra; $y$, en fin, el bajar y subir la cuesta que separa el predio ubicado en el Fosso de S.Agnese, donde la pareja, con el apoyo de muchos amigos albañiles, incluyendo al cuñado, logra construir la chabola, en una sola noche de trabajo, aunque sin acabar del todo el techo.

Este lugar, cerca del barrio Nomentano, es la etapa final del recorrido, aunque De Sica nos muestra también el hogar provisional de Luisa en la habitación de una amiga sirvienta, en el Tuscolano ${ }^{25}$ y la visita de Natale a la mamá quien les entrega el dinero necesario para la compra del material de construcción (F.3.3.1/1).

\footnotetext{
${ }^{25}$ Se trata de la Calle Calpurnio Fiamma: la misma calle que aparece en la secuencia del regreso a Roma después de la visita a los padres de ella, y que aparece en los títulos iniciales de la película.
} 


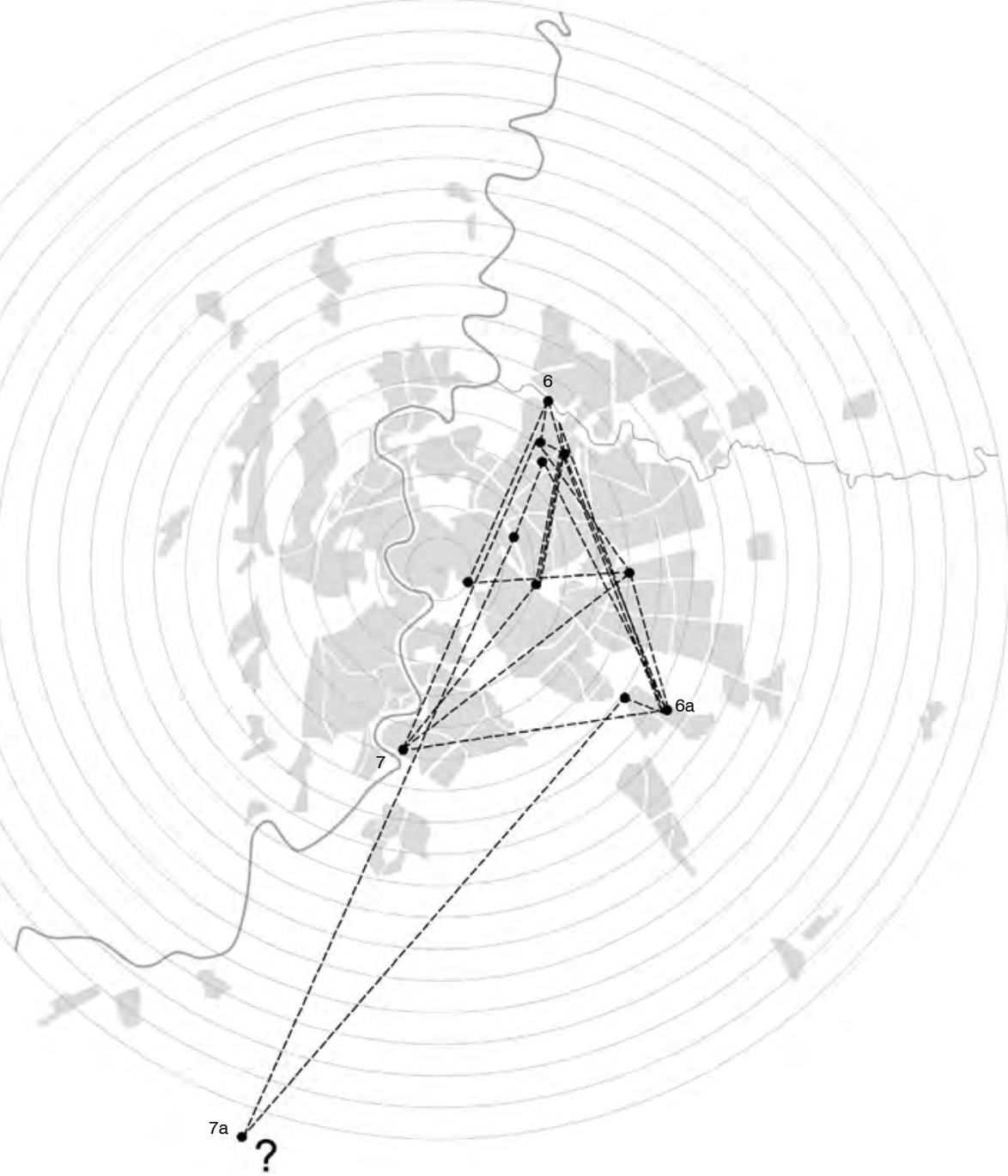

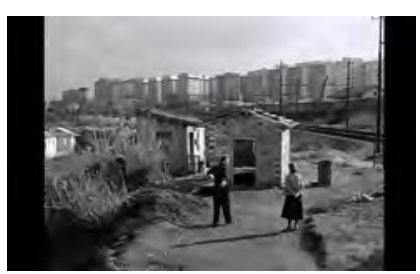
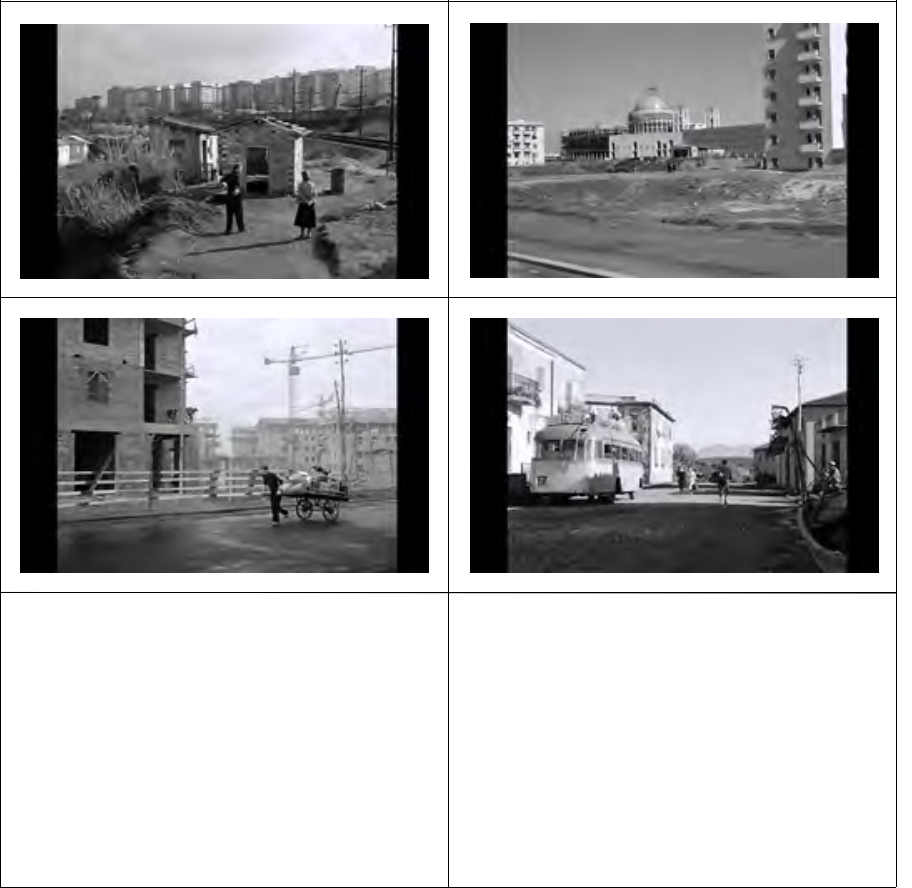

PUNTOS MÁS DISTANTES DEL RECORRIDO (VERTICES)

RM 6. Fosso de S. Agnese

RM 6a. Don Bosco (Tuscolano)

RM 7. Valco San Paolo (Ostiense-Marconi)

RM 7a. Lugar desconocido: pueblo al Sur de Roma (hipotesis)
ESTRUCTURA SECUENCIAL DE LOS RECORRIDOS DE LUISA Y NATALE Oh 00' 00". Titulos de crédto-

Oh 01 ' 21". Casamiento en la Iglesia de Santa Costanza.

Oh 07' 09". Viaje al Pueblo de Luisa (camión de Csatro Pretorio).

Oh 08' 22". Regreso en Camión al Barrio Tuscolano.

Oh 26' 00 ". Regreso a la Casa de los padres de Natale en el barrio Nomentano.

Oh 28' 33". Busqueda casa en Renta

Oh 45' 06". Regreso en la Casa de los padres de Natale.

Oh 58' 02 '. Salida definitiva de la casa de los padres.

Oh 59' 00". Visita al departamento en San Lorenzo

$1 \mathrm{~h} 00$ ' 12". Permanencia en la Obra de Largo Veratti (Ostiense - Marconi)

1h 11' 09". Paseo en el Tuscoano (departamento amiga de Luisa) en Via Calpurnio Fiamma.

1h 23' 14". Visita de Luisa en el barrio chabolista del Prenestino.

$1 \mathrm{~h} 26^{\prime} 54^{\prime \prime}$. Primer intento de autoconstruccion al Prenestino

$1 \mathrm{~h} 36^{\prime} 58^{\prime}$ ". Visita en el Nomentano para el prestamo (Via Asmara)

1h 40'08'. Primer intento de autoconstruccion al Prenestino

Oh 45' 43". Autoconstrucción en el Fosso di Santa Agnese.

DISTANCIA TOTAL RECORRIDA (CÁMARA): $112 \mathrm{~km}$.

DISTANCIA MÁXIMA DEL CENTRO RECORRIDA (RADIO): $5 \mathrm{Km}$

TIEMPO TOTAL RECORRIDO (FÍLMICO): 1 32' 12"' (de 30'10"' a 1h 28' 09')

TIEMPO TOTAL RECORRIDO (NARRACIÓN): 1 semana
UBICACIÓN LUGARES DE RODAJE (secuencia)

1. Iglesia de Santa Costanza (Nomentano)

6. Via di Porta Labicana (San Lorenzo)

2. Av.da Castro Pretorio (estación de Autobuses) 7. Largo Veratti (Ostiense - Marconi)

3. Lugar desconocido (pueblo padres de Luisa) 8. Calle Calpurnio Fiamma (Tuscolano)

4. Via Tuscolana

5. Via Vasi en el Nomentano(casa de los padres

de Natale) 9. Barrio chabolista en la Calle Prenestina

10. Calle Asmara (Nomentano)

11. Calle Prenestina

10. Fosso di S. Agnese (Av.da Somalia) 


\section{EL FOSSO DE SANT'AGNESE.}

Si Ladrones de bicicletas estaba enfocada en el tema del trabajo y su escasez en la posguerra, El techo, a ocho años de distancia, mostraba un país y una ciudad en donde el problema principal ya era otro. Como en El inquilino o en El pisito, nunca se habla de la preocupación de no encontrar un empleo, sino de no ganar lo suficiente para adquirir o rentar un hogar digno. Ladrón de bicicletas, es una película sobre dos personas con hogar, en búsqueda de un trabajo -o del medio para tenerlo-, que se convierten en nómadas por dos días; El techo, en cambio, trata de una pareja nómada, pero con trabajo, que busca desesperadamente un hogar. La vivienda es el verdadero protagonista de la película, en todas sus declinaciones, que ya hemos analizado hablando de lo que hemos definido como iconografía del 'paisajepermanencia': la ocupación, la vivienda popular, la vivienda informal, la vivienda burguesa, la vivienda social y la vivienda en construcción. Se podría decir que en esta película se toca el tema del habitar también de un punto de vista técnico-constructivo y, como subraya Bruno Reichlin ${ }^{26}$, el ladrillo doble hueco mal puesto o puesto de prisa, por albañiles inexpertos o apresurados, contrasta con las torres de Avenida Etiopía de Ridolfi, autor del Manual del Arquitecto, torres que aparecen más de una vez en la película, en donde el ladrillo se alterna al armazón de concreto aparento, aparentando solidez y elegancia en las soluciones de detalle. Reichlin detecta también otros dos aspectos en esta contraposición del proyecto de Ridolfi, con el autoconstrucción de Natale y Luisa: el subrayar por parte de De Sica la inexperiencia de los trabajadores -como la del mismo protagonista- que se involucraban en la obra, de acuerdo con las esperanzas de la Ley Fanfani, de absorber el mayor número de desempleados, como se ha analizado en el primer capitulo. El segundo aspecto es el contraste entre la masividad de la arquitectura de estado, con su grid perfecto y homogéneo que elimina cualquier diferencia entre los hombres y las miserias individuales representadas por las chabolas autoconstruidas ${ }^{27}$.

El lugar en donde se ruedan las secuencias finales y resolutivas de la película, está escogido con atención por De Sica y su equipo técnico, que tiene un conocimiento extraordinario de la capital en la posibilidad de identificar los 'territorios desconocidos' de Roma. Este lugar pertenece al sector Noroeste que hemos denominado como "Sector 2", ya analizado en este capítulo y escenariode varios rodajes neorrealistas (F.3.1.1/2 p. 141) ${ }^{28}$. Las torres de Ridolfi, que ya habían aparecidos en los fotogramas iniciales del viaje de regreso en la capital, aparecen ahora en el skyline nocturno y diurno que domina el descampado del Fosso de Sant'Agnese. Como subraya Bruno Reichlin, estos edificios eran bastante conocidos en paisaje urbano de la época y habían salido en varias fotografías aéreas de la prensa nacional. De Sica los pone en varios planos de la película y sobretodo en las secuencias finales, casi para representar la síntesis construida de todo lo que se ve a lo largo de toda la cinta: una serie de armazones y edificios en construcción en diferentes zonas de la capital, que De Sica va montando como en un collage para describir una Roma como una única grande obra sin acabar. Otras torres en la misma avenida, proyectadas por el discipulo de Ridolfi, Mario Fiorentino y todavía en construcción, aparecen también en otra película muy exitosa de la época, Rufufú de Monicelli (F.3.3.1/2).

\footnotetext{
26 (Reichlin, 2002)

27 (Reichlin, 2002 pp.118-120)

${ }^{28}$ Para el análisis de sector de El techo, mirar la ficha de Ladrón de Bicicleta en el primer párrafo (3.1.1/2)
} 

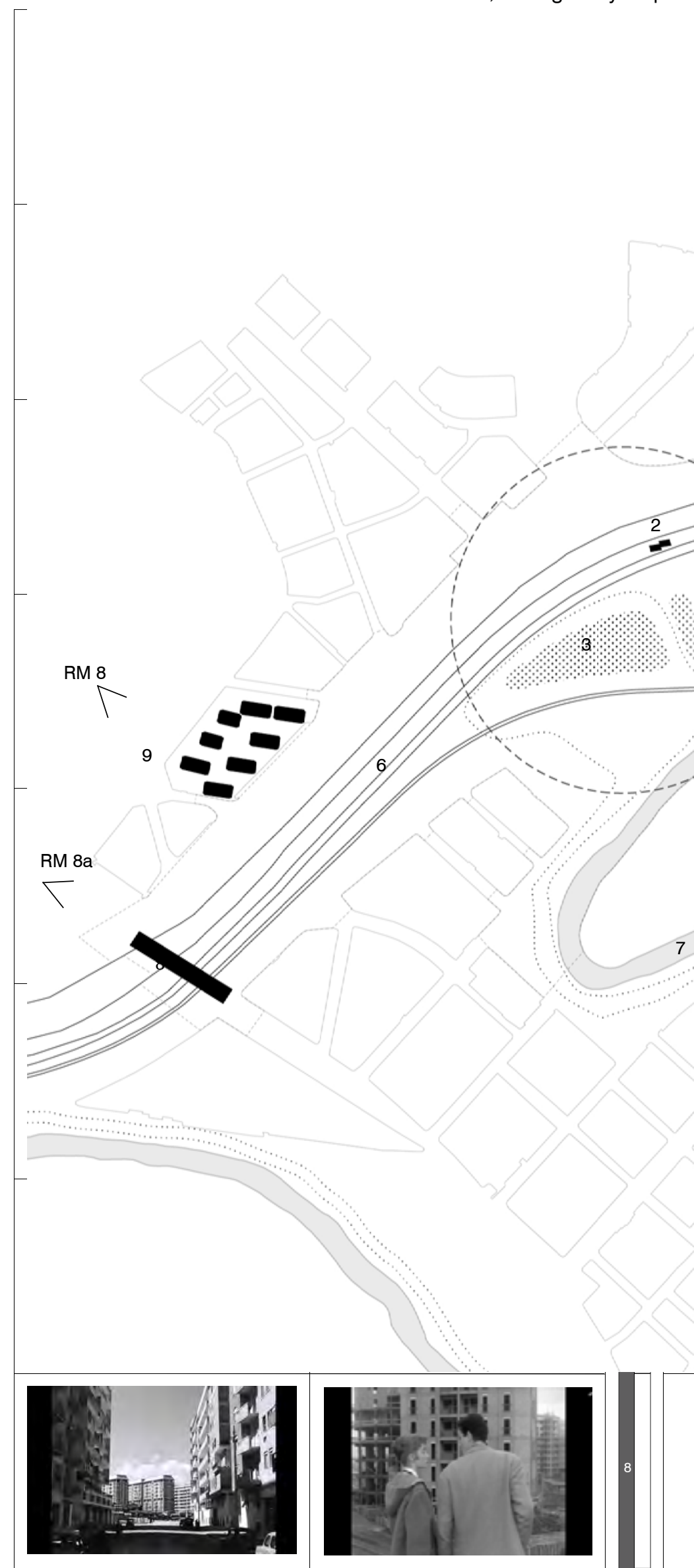

7

3

2

$4 \quad 4$

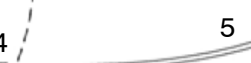

RM 8. El Techo (De Sica): Torres de Ridolfi RM 8a. Rufufu (Monicelli)
1. Chabola autoconstruida por los protagonistas

2. Edificio rural prexistente

3. Asientamiento informal prexistente

4. Puente "Delle Valli"

5. Linea de Ferrocarril interregional

6. Linea de Ferrocarril metropolitana: Nomentano

7. Rio Aniene

8. Puente Batteria Nomentana

9. Torres INA de "Viale Etiopia" de M. Ridolfi 
El área escogida después del intento fracasado en la Prenestina, es una zona relativamente cercana a la casa de los padres, en el Barrio Nomentana, y esto es compatible geográficamente con el recorrido nocturno a pie de Luisa, para pedir ayuda al cuñado. Por la Avenida Etiopía -en donde se ubican las torres de Ridolfi- llega el camión con el material para la obra, parándose justo en el punto en el cual empieza la curva que da acceso al Fosso de Sant'Agnese, tramo caracterizado por una topografía más acentuada, antes de la línea del ferrocarril. En el siguiente plano, con la cámara puesta del otro lado de la vía de tren, casi en forma de contrapicado por la diferencia de nivel, se representan las dificultades en la descarga y el transporte del material de construcción hacia el área escogida, con el atravesamiento del ferrocarril y del talud del cauce del Río Aniene, un afluente del Tíber que dos kilómetros más al Oeste se junta con este río (que ya había aparecido en un plano de Ladrón de bicicletas). El lugar está totalmente aislado y peligroso por las inundaciones; se trata de un descampado de forma trapecioidal, encerrado por la línea de ferrocarril al Oeste, el río Aniene al Norte, el Puente delle valli al Este y un asentamiento informal al Sur, en una terraza todavía más baja y hoy ocupada por unas instalaciones industriales abandonadas. En los siguientes planos se ve a la protagonista bajar hasta la ribera del Aniene para tomar el agua para la obra, el esposo la alcanza para ayudarla, ya que la mujer está embarazada; esta secuencia acaba con un plano encuadrando los albañiles trabajando bajo la luz de la luna, y un plano de la luna llena en un cielo anublado. Es una escena en donde aparece el medio natural, en una ciudad, casi totalmente construida, en la cual solo hay descampados y estructuras de hormigón, ladrillo y acero; la presencia de la vegetación de ribera, la luz nocturna y el agua del río con el arco del puente, caracterizan este terrain vague que se presenta como un paisaje-palimpsesto.

En otra escena el padre de familia de la chabola colindante con el predio escogido por Natale para la construcción, sale para pedir si pudiesen construir "tres metros más allá" para facilitar la futura ampliación de su casa, esta distancia se reduce, si ninguna discusión a dos metros; se trata de una mirada crítica de De Sica ya presente en Milagro en Milán sobre el tema de la especulación inmobiliaria: entre los pobres, los problemas de 'diseño urbano' se solucionan en dos minutos con un acuerdo tomado con educación y respeto.

En la última secuencia de la película, De Sica utiliza planos conjuntos, para representar el esfuerzo colectivo de la construcción, con todos los albañiles, amigos y vecinos alrededor de la casa y al fondo, la línea del ferrocarril por donde aparecerá un policía llegado para revisar la estructura recién levantada y carente del muy importante techo ${ }^{29}$, decidiendo al final, por pura compasión, de no demoler la casa aplicando solamente una multa. El último plano es un eficaz travelling con grúa, en el cual poco a poco se desvela la condición del lugar, todos los elementos que lo caracterizan, la condición topográfica aislada, la vegetación de ribera, y, sobre todo, el fuerte contraste arquitectónico-social con los edificios de Avenida Etiopía, que aparecen en la línea de horizonte (F.3.3.1/3).

\footnotetext{
${ }^{29}$ La ley italiana de la época impedía la demolición, si la vivienda informal recién contruida, tuviese el techo.
} 

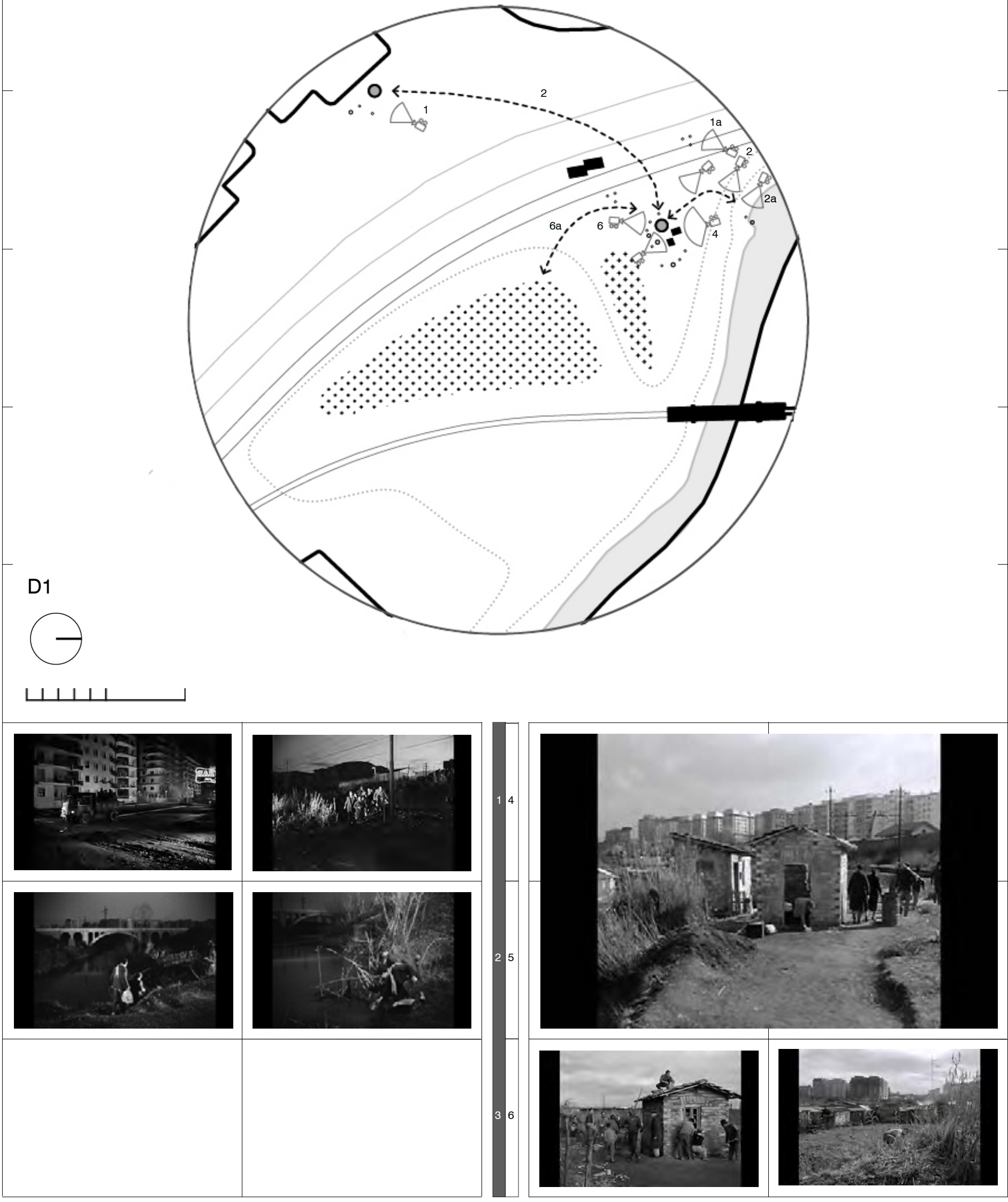

RM. Movimientos de cámara

1. Llegada con el camión en Av.da Somalia 2. Cruzando la línea de ferrocarril

3. abastecimiento de agua en el río Aniene

4. Plano conjunto en la ribera del río
RM. Movimientos de cámara

5. Plano general con las torres de Ridolfi en el fondo 6. Vista de la entrada de la chabola en construcción

7. Plano totale con el asientamiento informal 


\subsubsection{Los Golfos.}

\section{RECORRIDOS}

La Película de Saura Los golfos es muy diferente respeto a El techo, de De Sica, por el guion, el tono de la narración y el lenguaje cinematográfico; sin embargo, se han descubierto varias similitudes en los elementos que caracterizan los dos lugares escogidos como demoras para los protagonistas: es posible establecer un paralelo entre el arrabal en donde viven los golfos de Saura, y el Fosso de Sant'Agnese, descrito por De Sica. Los golfos es una película que reinterpreta al Neorrealismo, cambiando totalmente el lenguaje cinematográfico que hasta ahora había caracterizado la comedia realista española. Sin duda es una película que por estética y dureza está más cercana a las dos primeras películas de Pasolini, Accattone y sobre todo Mamma Roma, que analizaremos más adelante.

En la película de Saura se concretiza la idea de desarrollar una película de ficción mezclando elementos típicos de los documentales. Saura buscaba otro estilo, diferente al del Neorrealismo italiano, que consideraba como superado, y buscaba otra definición para este Cine $^{30}$. En este intento de de renovar el realismo cinematográfico de su país, Saura cambia la forma de mirar el paisaje urbano de Madrid y la geografía del rodaje. Ya se han analizado los decorados escogidos por este director, como etapas de la larga deriva que los cinco amigos cumplen para realizar robos y atracos en búsqueda del dinero necesario para ayudar a Juan con su primera corrida de toros. Como El techo, Los golfos es seguramente la primera película en la cual desaparece totalmente el centro de la ciudad; la única referencia podrían ser unas calles diminutas - probablemente la Latina - en donde un músico toca una canción flamenca. Se trata de una Madrid más parecida a un pueblo de Andalucía, no es posible reconocerla como la capital. Otros lugares representados, se encuentran en este "anillo periférico" que el director traza alrededor de la ciudad. En unas escenas aparece el área de toreo en la Casa de Campo, o una playa del Manzanares en las afueras de la capital, en un punto del río que no se ha logrado identificar; en esta la cámara parece ubicada entre los personajes, con algunos de los actores que caminan hacia el espectador, como si éste último se encontrara en el escenario, el río se convierte en el decorado de una pelea muy dura, muy parecida a la pelea que el protagonista de Accattone tiene con el hermano de su ex mujer, en un descampado polvoriento en la borgata Gordiani. La arena y el polvo y el agua del ambiente natural se asocian al comportamiento salvaje de los personajes. Los Golfos es la única película, entre las analizadas, en donde hemos encontrado representado el Manzanares y sus riberas, paisaje que regresa al final de la película, en un escenario muchos menos idílico, una zona del Manzanares (o podría ser el Abroñigal) entre basureros, descampados, precarios ductos de maderas, uno de los cuales es utilizado por uno de los protagonistas, como puente para cruzar hacia el otro lado. La de Cerca de la ciudad de Luís Lucía o la de Mi tío Jacinto, de Vajda, es la Madrid de la pobreza extrema, sin embargo, la de Los Golfos es la misma miseria sacada sin ningún intento estetizante, que todavía estaba en las películas anteriores, como si se tratara de un documental. "La cinta de Saura se niega a lo bello. No hubiese resultado extraño que los personajes cometieran un atraco en las calles del barrio de Salamanca o en la Gran Vía. Sin embargo, todo lo que se ve es miserable, cutre, pobre" ${ }^{31}$ (F.3.3.2/1).

La escena enfrente del estadio de Chamartín incluye una toma panorámica desde el techo de un edificio representando la gente saliendo del evento: un paisaje humano que invade las calles aledañas; este plano de Saura es prácticamente idéntico -como ya se ha analizado en el capítulo anterior- al tomado por De Sica en Ladrón de bicicletas y también idéntica es la

30 (Deltell \& Garcia Fernandez, 2006 p.260)

31 (ibidem pp. 262-263) 


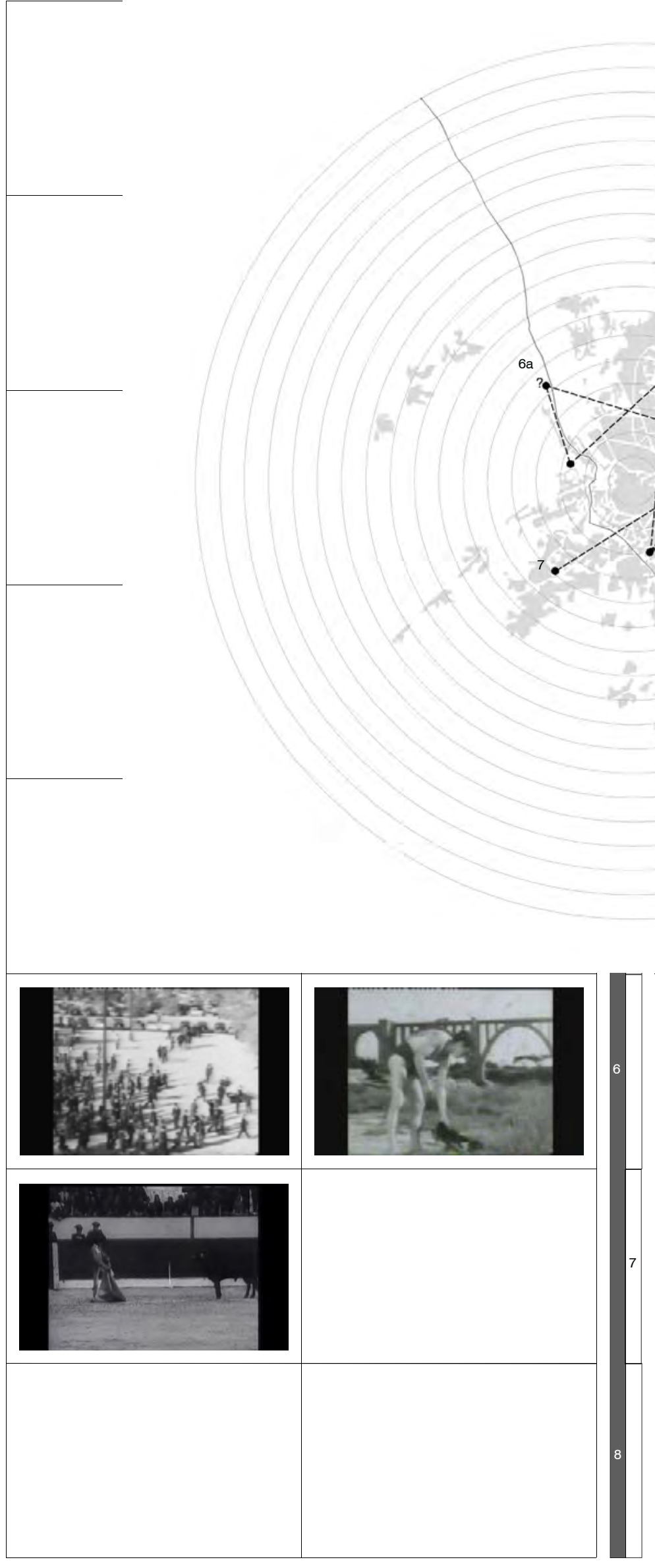

ESTRUCTURA SECUENCIAL DE LOS RECORRIDOS DE LOS GOLFOS

Oh 01' 21". Llegada desde "La Placita" en Ventas

Oh 07 ' 09". Bajando desde el puente de La Elipa.

Oh 08' 22'. Robos en el mercado de Legazpi.

Oh 26' 00". Robos en Chamartin (estadio)

Oh 28' 33". Toreo en Casa de Campo

Oh $45^{\prime}$ '06". Descanso en Lugar desconocido

Oh 58' 02 ". Regreso en La Elipa.

Oh 59' 00". Fuga en Legazpi

1h 00 ' 12". Regreso en La Elipa

1h 11'09". Corrida en Vista Alegre.

DISTANCIA TOTAL RECORRIDA (CAMARA): $37 \mathrm{~km}$ y 430 metros DISTANCIA MÁXIMA DEL CENTRO RECORRIDA (RADIO): $7 \mathrm{Km}$

TIEMPO TOTAL RECORRIDO (FÍLMICO): 52' 59" (de 30'10"' a 1h 28' 09") TIEMPO TOTAL RECORRIDO (NARRACIÓN): $8-9$ Horas

\section{Puntos más distantes del recorrido.}

MD 6. Estadio de Chamartin

MD 6a. ? (playa río Manzanares)

MD 7. Vista Alegre (Plaza de toros)

\section{UBICACIÓN LUGARES DEL RODAJE:}

1. La Placita en Ventas

2. La Elipa: Av.da Marqués de Corbera

3. Legazpi (mercado)

4. Estadio de Chamartín

5. Casa de Campo

6. Lugar desconocido (hipotesis: playa río

Manzanares) (secuencia)

8. Paseo Chopera (Legazpi)

9. Río Albroñigal.

10. Arena en Vista Alegre

\section{MADRID}


acción que sigue: el robo. La diferencia está en este lado miserable de Los golfos, en la falta de cualquier remordimiento o conciencia por parte de los protagonistas.

La plaza de toros de la escena final es en realidad la de Vista Alegre en la periferia Sur-Oeste de Madrid, o podría ser la de la Casa de Campo ${ }^{32}$; no cambia, sin embargo, el valor iconográfico de lugar de la tradición castiza como escenario de una gran decepción, generando inquietud y contraste. Si miramos en el mapa de Madrid la ubicación de los escenarios escogidos por el director, podemos trazar una especie de anillo poligonal exterior a la ciudad que deja fuera todo el casco histórico, una imagen circular que recuerda la de la arena de toros: "Ios espacios de la ciudad y del margen se representan simbólicamente en un eje horizontal, en una dinámica centrípeta, de la periferia hacia el centro del que la plaza de toros es una sinécdoque" ${ }^{\prime 3}$. Como De Sica, Saura demuestra su conocimiento de los lugares más periféricos de la ciudad y con esos compone una iconografía inédita y libre de cualquier estereotipo urbano.

Este anillo está definido por una estructura pentagonal irregular, con a los vértices los lugares más representativos de la historia. En el Este el Barrio de la Elipa: el "hogar" de los cinco protagonistas; En el Sur el mercado de Legazpi y el matadero, el lugar donde los golfos roban comida, y en donde uno de los protagonistas se esconde en el alcantarillado para escapar del taxista y de la gente que lo persigue. Al Noroeste hemos ubicado, como hipótesis, el lugar en donde los protagonistas pasan una tarde de descanso en las playas del Manzanares; este vértice del polígono podría estar ubicado también en la casa de campo el lugar donde el Chato/Juan se entrena como torero frente a sus amigos. En el norte el estadio de Chamartín, lugar donde los protagonistas se dedican a robar refacciones de vehículos. Conectando los vértices, según la lógica temporal de la película se genera una estructura en forma de estrella. Dentro de este polígono el trayecto más recorrido es la conexión entre Legazpi y la Elipa; ninguno de los vectores toca el centro histórico o los ensanches de Chamberí o Salamanca, que quedan al centro de este anillo, fuera de la cartografía y de la iconografía madrileña desarrollada por Saura.

\section{LA ELIPA}

Como "hábitat" para los protagonistas de la película, Saura encuentra un lugar en la periferia Oeste de la capital, no muy lejos de los estudios CEA en la Ciudad Lineal. Es un territorio en el cual podemos identificar diferentes capas sobrepuestas, cada una correspondiente a un aspecto de la iconografía neorrealista, que hemos definido en el apítulo dos utilizando el término de paisaje-palimpsesto. Como en El techo, el hogar de Los golfos está caracterizado por un río, en este caso entubado, que define la topografía del lugar, se trata del arroyo La Elipa que a la altura de la actual M-30, confluye con el Abroñigal. En el lugar escogido por las escenas de llegadas y salidas de los cincos amigos, existe un puente denominado "puente de la Elipa", con una gran arcada central y dos secundarias más pequeñas, en hormigón y ladrillo aparente. Este espacio determina dos mundos: el de arriba y el de abajo, con unas escaleras que corren paralelas al puente y se convierten en una senda que baja a lo largo de la ladera hasta el asentamiento informal donde los protagonistas viven. Las escaleras son un lugar importante para el rodaje, en este punto, con un efecto de picado el director pone su cámara, tomando desde arriba el descampado bajo el puente, en donde se departen los caminos que distribuyen a las distintas zonas del asentamiento informal; esta estructura arquitectónica representa un umbral: en este punto los personajes se detienen antes de la bajada, o se paran en espera de alguien, mientras los niños se sientan en el barandal, conversando. (F.3.3.2/2).

\footnotetext{
${ }^{32}$ Como en la hipótesis de Luís Deltell (ibídem)

${ }^{33}$ (Bloch-Robin, 2009 p.163)
} 


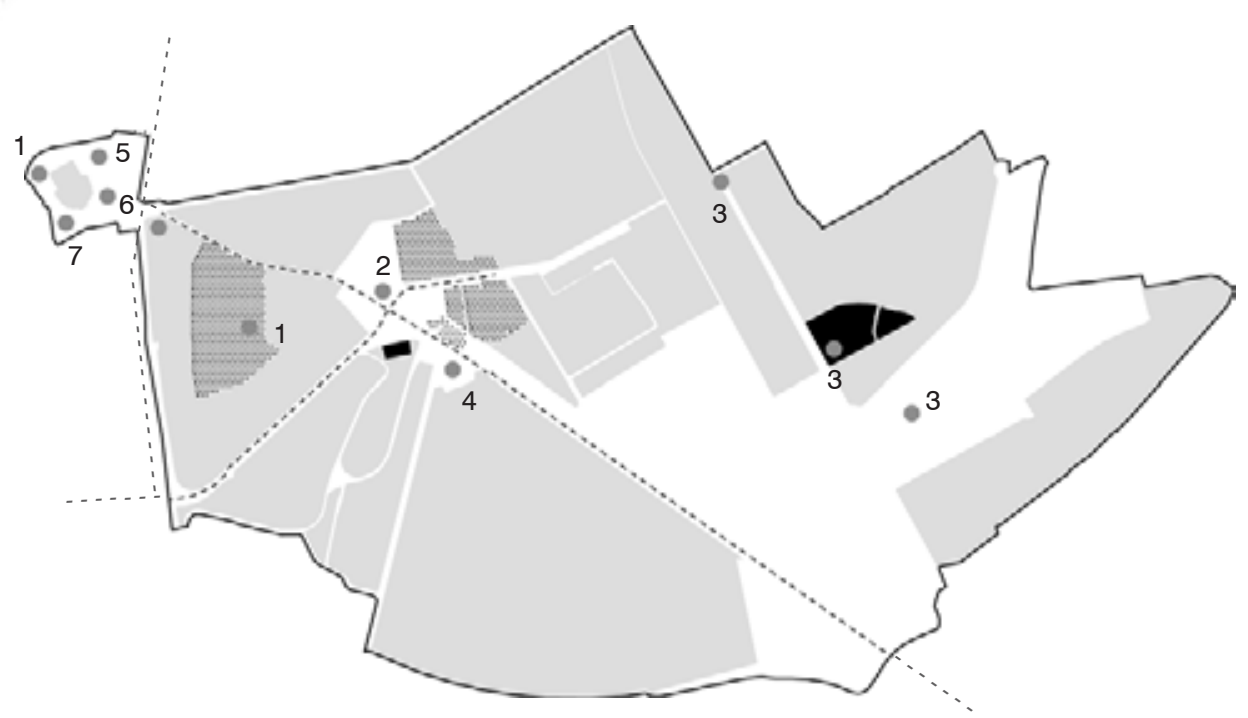

LEYENDA SECTOR 2 (Valmelaina-Nomentano)

\footnotetext{
Mancha urbana Tejido informal

$\because$ Infraestructura $\square$ Vivienda popular

Vacíos
}

PELICULAS RODADAS

1. Cerca de la ciudad (Lucía)

2. Los golfos (Saura)

3. El pisito (Ferreri)

4. El cochecito (Ferreri)

5. Los chicos (Ferreri)

6. El último caballo (Neville)

7. Mi tío Jacinto (Vajda)

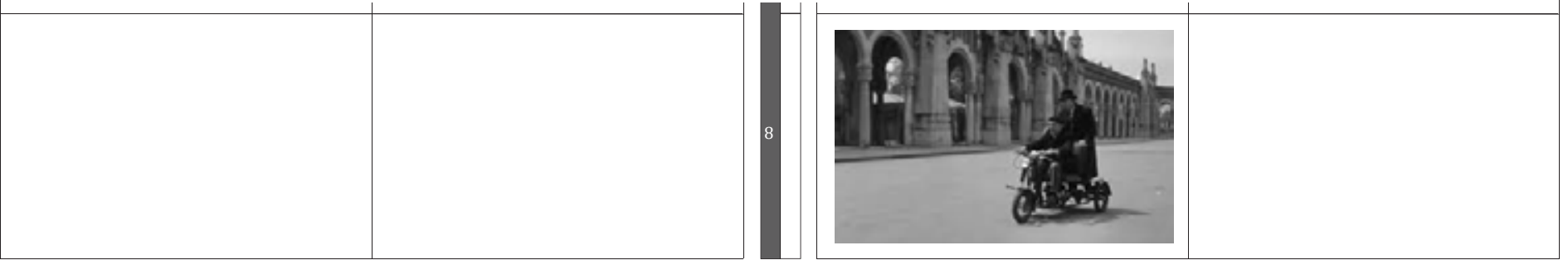

\begin{tabular}{|l|l|}
\hline & \multicolumn{1}{|l|}{$\begin{array}{l}\text { MD 8. El Cochecito (Ferreri). Esplanada en frente del } \\
\text { Cementerio de la Almudena }\end{array}$} \\
& \\
& \\
\hline SECTOR 3 / Este / . & MADRID \\
\hline SEC.3.2/2
\end{tabular}


Las escaleras se filman también en la subida, la cámara puesta esta vez abajo, toma en contrapicado el camino de los personajes hacia el puente que lleva hasta el centro pasando por la plaza de toros de Ventas, frente la cual se encuentra "la Placita", en donde se entrena el Chato. Este puente marca también la separación entre Este y Oeste de la ciudad: el primero corresponde a los asentamientos informales y el segundo al mundo de la vivienda oficial, representado por una serie de bloques-torres que aparecen alineados y casi pegados al puente de La Elipa. Estos bloques tienen una analogía muy fuerte con las torres de Ridolfi en el Nomentano: se trata de edificios que aparentan su estructura vista en hormigón blanco, en contraste con el cerramiento no estructural de ladrillos. Al principio de la película, en una panorámica de gran belleza y realismo realizada desde arriba el puente, al amanecer, aparece todo el barrio en su totalidad, envuelto en la niebla, con una luz escasa. Esta originalidad y cuidado en el estilo de iluminación y en la fotografía, caracteriza la película, y se debe a Juan Julio Baena quien realizó "la primera iluminación realista del cine español. Cada escenario, cada lugar que se retrataba, imitaba la luz exacta que tenía en ese lugar y en ese momento" ${ }^{34}$. Los edificios que aparecen en muchas tomas, caracterizando la zona Sur del lugar, del otro lado del puente, hacen parte de una urbanización desarrollada a partir de los años ' 50 por iniciativa pública y privada. La construcción de unos bloques a largo de la actual Avenida Marqués de Corbera, antes calle de La Elipa, dieron a esta vía el ancho actual, aunque el asfaltado llegó mucho después ${ }^{35}$. El INV en el 1961 construyó el poblado dirigido que constituye, junto al desarrollo que aparece en la película, la más grande urbanización del Barrio: "El poblado dirigido de La Elipa pertenece a la segunda generación de poblados y es bastante más eclético en su selección de tipos de edificación. En la fase construida en 1961, al Sur de Marqués de Corbera (...), se alcanza una densidad seguramente elevada (184 viv/Ha) dentro de un ejercicio de composición urbana mediocre ${ }^{1136}$. La construcción de los bloques de doble crujía con el armazón de hormigón visto, es seguramente anterior al poblado dirigido descrito por Sambricio, siendo el año del rodaje el de $1959^{37}$. Como las torres de Avenida Etiopía, los edificios tienen un alzado abstracto con las ventanas que ocupan toda la altura del marco estructural de piso a techo diferenciando el color del antepecho y del dintel. La presencia de armazones, en las periferias de Roma y Madrid, genera un tema iconográfico presente en el cine y un hito para la arquitectura de la época, esta imagen explica otra vez los métodos de "apropiación cultural" usados por la arquitectura en la época del Neorrealismo ${ }^{38} \mathrm{y}$ al mismo tiempo la sensibilidad del cinema que absorber la iconografía construida por los arquitectos (F.3.3.2/3).

Dentro del mismo sector urbano de Los golfos que hemos denominado 'Sector Tres' se ubica otro edificio de 'vivienda-armazón' que aparece en la película El pisito: en esta obra de Ferreri de 1959 se usó como decorado el conjunto habitacional Francisco Franco, realizado por el Obra Sindical del Hogar, en 1957 y ubicado en la calle Hermanos García Noblejas esquina con Castillo Uclés. Nos interesa la imagen que Ferreri genera a través de varios planos generales en un paisaje casi totalmente seco, con pocos árboles recién plantados, con los protagonistas que aparecen al centro del encuadre casi aplastados por estos bloques con estructuraarmazón en hormigón aparente, una imagen masiva y dura, una malla racional y geométrica que como en Ladrón de bicicletas, expresa el contraste entre el individuo, con sus necesidades y pasiones el rígido orden social.

\footnotetext{
${ }^{34}$ (Deltell \& Garcia Fernandez, 2006 p.261)

${ }^{35}$ Fuente Wiki: https://es.wikipedia.org/wiki/La_Elipa

${ }^{36}$ (Sambricio, La vivienda en Madrid en la décāda de los 50: el Plan de Urgencia Social., 1999 p.139)

${ }^{37}$ Esta primera parte de la intervención ubicada entre las actuales calles Santa Prisca, Santa Felicidad y Santa Genoveva, tiene una calidad urbana y paisajística superior a la de 1961, con los bloques que se insertan en la topografía del lugar.

38 (Reichlin, 2002)
} 


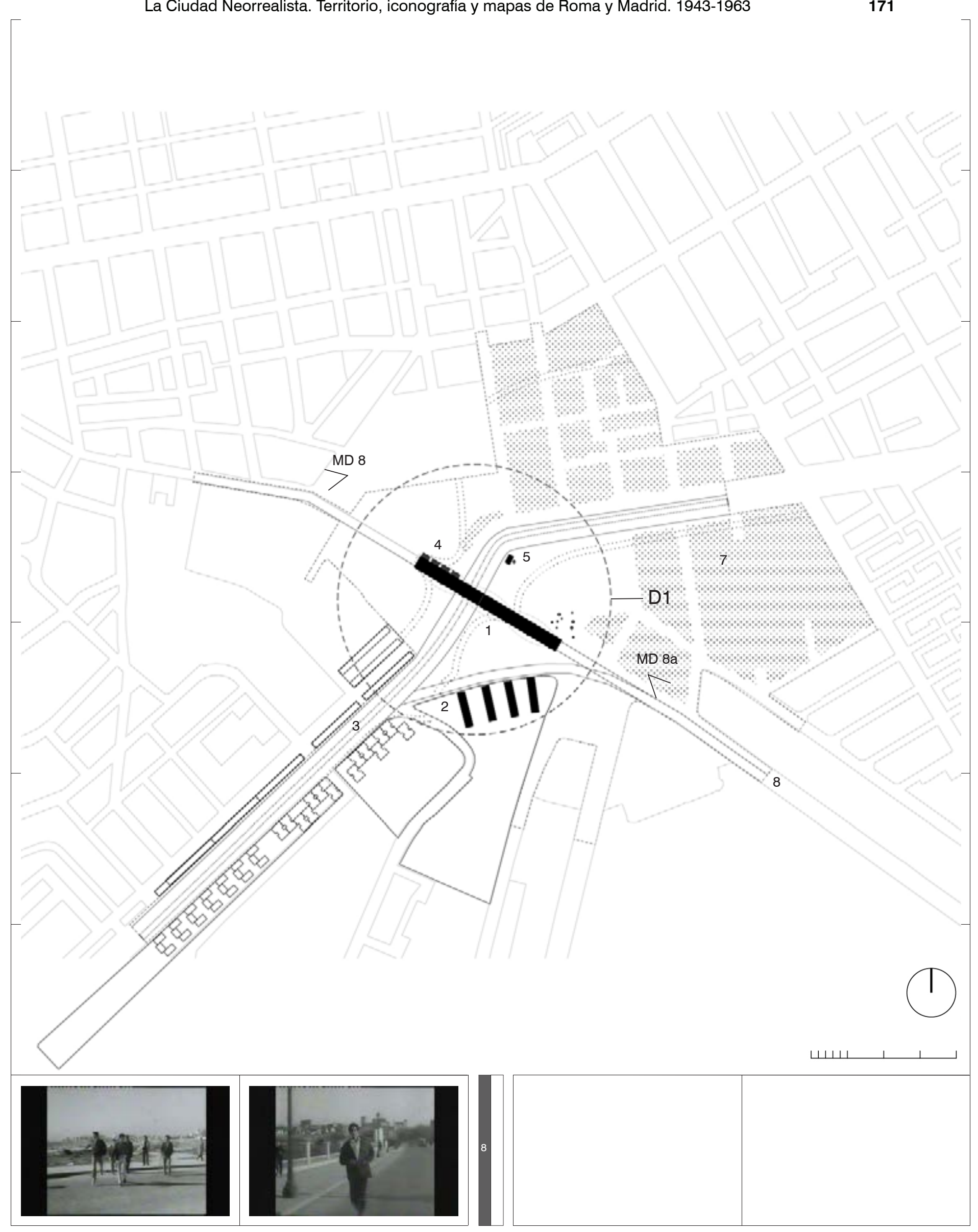

MD 8. Los golfos(Saura): puente de La

1. Puente de La Elipa.

MD 8a. Los golfos(Saura): puente de La

Elipa

2. Torres del conjunto de vivienda social en la

calle Santa Prisca.

3. Av.da Marqués de Corbera

4. Escalera de acceso a la barriada.

5. Fuente pública

6. Depositos de marmol y granito

7. Asientamiento informal de La Elipa

8. Av.da Daroca 
La pareja de El pisito, decepcionada por el coste de la vivienda, en el siguiente plano se refugia en una ladera de San Blas, alejándose de la ciudad. En Los Golfos, los edificiosarmazón, también aparecen como una presencia amenazadora, sin embargo, se encuentran del otro lado del puente de La Elipa y pertenecen a un mundo socialmente demasiado distante para los que viven en la miseria del asentamiento informal.

Otro elemento que caracteriza el lugar escogido por Saura, es la fuente, en donde la gente espera su turno para tomar provisiones, en el plano conjunto usado por el director, se ve también un carro con un tanque metálico, jalado por un burro; iconografía presente también en Ladrón de bicicletas y en El techo, un fenómeno común en la época por la escasez de agua y no solamente entre los habitantes de infraviviendas. Otro elemento que caracteriza el lugar es un cantero marmolista, ubicado del lado opuesto del puente de La Elipa, en donde el grupo de amigos se reúne y que aparece dos veces en la película, antes y después del atraco que cumplen en el garaje. Una famosa escena rodada en este lugar se abre con un guitarrista tocando flamenco, sentado entre bloques de granitos, la cámara se desplaza con un travelling y se detiene con un plano de conjunto en el cual los cinco amigos sentados en los bloques de granito, cuentan el dinero robado; en el siguiente plano Manuel y el Chato se levantan, y la cámara con ellos y con un plano medio aparece el barrio de La Elipa en el fondo. Hoy todavía existen dos actividades de cantería, con dos naves y depósitos de bloques de mármol, actividad comercial todavía presente ${ }^{39}$. El escenario de los bloques de piedra entre los cuales se reúnen los golfos, es un paisaje que nos recuerda las ruinas romanas de Mamma Roma; un paisaje fuertemente a-histórico, sin tiempo, una hipérbole en la representación de la asperidad de las condiciones de vida y del ambiente en el cual los protagonistas viven.

Los golfos como subraya la crítica, es una película que desarrolla un montaje a través de escenas abiertas, una "construcción temporal y espacial de una forma radicalmente novedosa y ajena a los cánones clásicos" ${ }^{40}$. El critico cinematográfico Luís Deltell, habla de que, a diferencia del cine neorrealista de los años anteriores, "que se empeña a mostrar con claridad todos los espacios e incluso los viajes por el interior de Madrid, en Los golfos el espacio es completamente libre e indefinido" ${ }^{41}$.

Es indudable que, como para El techo de De Sica, se ha perdido la coherencia que por ejemplo tenían películas como Ladrón de bicicletas o Mi tío Jacinto y en muchas escenas de atracos o reuniones, nos cuesta entender en que zona o a qué distancia de la ciudad estamos. Aparece una ciudad como un "mapa psico-geografico", más ligado a las las ideas estéticas de los directores que a una coherencia espacial. La iconografía del paisaje urbano, sin embargo, sigue siendo neorrealista, rodada con el gran aporte de la fotografía de Baena. Aunque la Madrid de Saura sea un collage, el análisis desarrollado en esta tesis evidencia cómo el territorio donde residen los protagonistas está "explorado" por el director en profundidad, como hizo De Sica con el barrio Nomentano para El techo, utilizando panorámicas o travelling con grúas para lograr un control espacial y escogiendo escenarios coherentes entre ellos: la ubicación de la placita de Ventas, muy cerca de La Elipa, y la dirección de llegada de los cinco amigos hacia el Puente, son compatibles. La coherencia espacial se refleja también en el escenario del depósito de bloques de granito, al lado del puente, y en la presencia de un río, en las escenas finales, que bien podría ser el Abroñigal, ubicado cerca del arroyo La Elipa, que había que cruzar para llegar a la ciudad (F.3.3.2/4).

\footnotetext{
${ }^{39}$ una de las empresas, "Mármoles Mena" está activa desde el 1947, y podemos formular la hipótesis de su presencia a lado del puente, desde esta fecha, y compatiblemente con el año de rodaje de Los golfos.

40 (Deltell \& Garcia Fernandez, 2006 p.265)

${ }^{41}$ Ibidem
} 

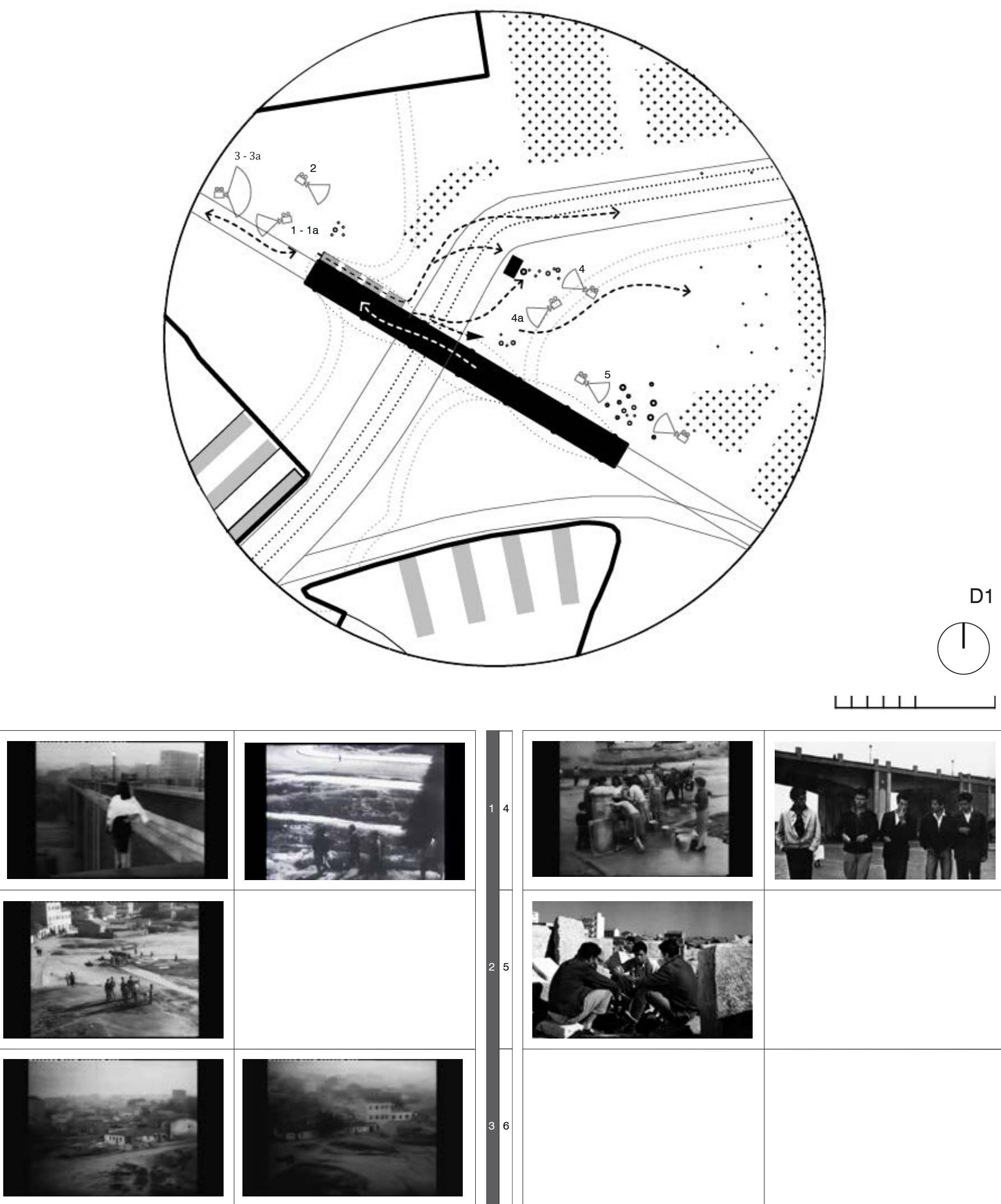

MD. Movimientos de cámara

1. Plano conjunto: la escalera del puente de La Elipa 1a. Bajando el puente: terrazas

2. Plano general: vaguada hacia la barriada de La Elipa 3 - 3a. Panoramica del barrio
MD. Movimientos de cámara

4. Plano conjunto: fuente pública

4a. Plano conjunto: Reunión de los 5 amigos

5. Reunión en el deposito de bloques de granito. 


\subsection{Sector Sureste. El Tuscolano y Entrevías}

\subsubsection{Mamma Roma}

\section{RECORRIDOS}

La película Mamma Roma fue rodada en el 1962 por Pier Paolo Pasolini que el año anterior había presentado Accattone, su primera prueba como director. Se trata, como también Los golfos de Saura, de una obra cinematográfica que, partiendo del Neorrealismo, buscaba otras formas de contar la realidad, con respecto a la década anterior. Mamma Roma es la historia de un viaje de una madre con su hijo, en diferentes etapas, hasta alcanzar la meta final: el hogar, el "barrio digno" y "el trabajo digno", que cumpla con los ideales pequeño-burgueses de la protagonista Anna Magnani: una ex prostituta que logra, con muchos sacrificios, liberarse de su proxeneta.

El punto de partida del viaje es el lugar de origen del hijo Ettore - y de Mamma Roma también, aunque ella vive en Roma para poder trabajar como prostituta -, el pueblo de Guidonia en los suburbios de la Capital, a $20 \mathrm{Km}$ de distancia del centro. Pasolini describe este lugar a través de algunos planos que evidencian las características paisajísticas del lugar, y sus costumbres. La primera escena es el banquete de boda de su protector Carmine, que representa para la protagonista y su hijo, todavía pequeño, la ocasión de liberarse de su antigua vida y empezar una nueva. El lugar de la comida, es un espacio "arcaico" que Pasolini describe inspirándose en la pintura del Quattrocento, expresión de una cultura rural, profundamente ligada a la tierra: un gran salón de doble altura con un arco empotrado en las paredes espesas y pintadas de blanco, con una mesa dispuesta en herradura que Pasolini encuadra con una perfecta perspectiva central: en el piso algunos cerdos buscando comida.

En la siguiente escena Pasolini monta distintos planos en campo/contracampo, para representar el amor de Mamma Roma hacia su hijo, el control que quiere ejercer sobre su vida y destino: la protagonista anuncia al hijo la decisión de irse a vivir a Roma, no obstante, el desacuerdo del hijo. El plano que abre la escena representa a Ettore dando vuelta en unos caballitos de un carrusel, muy aburrido, y el contracampo representa la mamá que llega mirando el hijo desde una calle de grava blanca en una llanura de campos agrícolas, con unas montañas al fondo. La mamá pierde de vista al hijo que, dando la vuelta sobre los caballitos, baja y toma la calle puesta atrás; un primer plano, nos revela la preocupación de la mamá, que dura muy poco, porqué ve al hijo en la calle lateral, en una zona del pueblo con algunas tiendas, vendedores ambulantes, y gente comprando y platicando. Mamma Roma, quien sigue con la mirada al hijo, lo ve robando dulces de un puesto, para poco después alcanzar a su grupo de amigos. La mamá decepcionada por el gesto, sonríe poco después en el ver a su hijo con sus amigos. El grupo se encamina por una carretera, la única vía asfaltada hasta ahora, hasta que la mamá llama al hijo y empieza a lamentarse para buscar su atención; los amigos saludan a Ettore quien se queda solo con su madre, que lo regaña por su forma de hablar y le da la noticia de la mudanza a la capital italiana. En el fondo de este encuadre aparecen unos terrenos agrícolas al lado de una carretera y unas colinas, se trata del pueblo de Guidonia ${ }^{42}$. Es un territorio que, sobretodo en la segunda posguerra, iba perdiendo sus elementos tradicionales, para convertirse en una periferia de la capital. En los escenarios rodados por Pasolini, podemos todavía ver sus aspectos rurales y populares: niñas con vestidos de la primera comunión, el carrusel, puestos ambulantes frente a una tienda de

\footnotetext{
42 una ciudad fundada por Mussolini en un territorio famoso por su aeropuerto da la aviación militar italiana, que había triunfado en la Segunda Guerra Mundial. Mussolini había anexado a esta ciudad de arquitectura racionalista, un pequeño e pintoresco pueblo medieval, Montecelio.
} 
mayoreo de alimentos, campos agrícolas, y las montañas al fondo con las minas de travertino, cerca de la ciudad de Tívoli a pocos kilómetros de distancia. Pasolini escoge un pueblo que encaja con una idea de tierra sin muchas oportunidades, en donde hay una dimensión rural, pero también una condición de suburbio: es decir, en Roma, la campiña ya perdió su identidad rural, convertiendose en una periferia de la capital.

La siguiente escena representa la segunda etapa del viaje, un alojamiento provisional, el departamento de Mamma Roma, antes de la mudanza definitiva al Tuscolano, el lugar donde la Magnani pone todas sus esperanzas de rescate social; se trata de un edificio de vivienda popular construido en la Plaza de Cristóforis, en el barrio denominado Casal Bertone, no lejos de la vía Tiburtina y del Ferrocarril, se trata de un enorme bloque de edificaciones populares de los años '20, un edificio obrero, pensado para los dependientes del ferrocarril, con un amplio patio central y un arco monumental de acceso ${ }^{43}$.La actriz protagonista, Anna Magnani, antes de entrar, tranquiliza el hijo sobre la provisionalidad del alojamiento (en espera de la consigna del departamento INA-Casa). Siempre con la técnica muy sencilla del picadocontrapicado, Pasolini hace dialogar a escenario y personajes: en la primera toma, en un plano general aparece el edificio de vivienda, en el segundo, el contracampo, aparecen madre e hijo caminando en una calle desierta, entre naves industriales y los bloques de viviendas de la Vía Tiburtina que aarece como fondo. Otra vez la capacidad de Pasolini no está en la técnica cinematográfica sino en la capacidad de narrar a través de la iconografía urbana y humana escogida. En aparencia, esta etapa intermedia no tiene mucho peso en la narración, se trata de una vivienda popular en un barrio periférico de Roma, una condición no tan diferente a la de la meta final: el Tuscolano. Sin embargo, a los ojos de la Magnani, y del director, no cumple con este ideal pequeño-burgués, de vida digna, que ella persigue sobre todo para su hijo. El lugar está cerca de la Prenestina, que como hemos analizado antes en El techo, era considerado como un lugar de "salvajes", así como el no tan distante Pigneto, y sus chabolas representadas en Accattone, cerca de la Calle de la Pina-Magnani de Roma Ciudad Abierta; se trata de una Roma más central geográficamente pero más popular, con edificios antiguos, con paredes con grietas, con vistas no agradables, en un paisaje de naves industriales y ferrocarriles, todos paisaje que habían triunfado como escenarios neorrealistas. Superado el acceso al pequeño departamento, Mamma Roma se queja de las vistas hacia el cementerio monumental de la ciudad, exaltando la calidad de la futura vivienda. La Magnani desea para ella y su hijo un barrio de recién construcción, de estilo moderno, con vecinos burgueses, de la clase social a la cual la protagonista quiere pertenecer.

Así que la arquitectura neo-renacentista de "ciudad ideal" del edificio popular en la Plaza de Cristofóris, con sus columnas con ciervos de bronce y su grande arco que marca el acceso al patio interior, sobre el cual la cámara de Pasolini se detiene, no satisface Mamma Roma que quiere más; además Carmine, el ex chulo de la protagonista, conoce esta dirección y sube al departamento para extorsionarla, pidiéndole dinero, y por eso decide quedarse otras dos semanas en el lugar, ya que quiere entrar "limpia" en El Tuscolano, sin vínculos con su antigua actividad.

En la siguiente escena nocturna, no distinguimos nada de la capital, solo las luces del alumbrado público probablemente de un aparcamiento, que crean una retícula cartesiana, el único elemento que nos ayuda en la lectura de un espacio totalmente sin referencias, que ilumina a la Magnani y los personajes que se acercan bromeando con ella, en su último día de trabajo como prostituta

43 (Angeletti, 2009) 
El siguiente plano es un plano vacío, muy raro en el cine de Pasolini, donde siempre la presencia de personaje; se trata de un plano general que regresará otras cuatro veces a lo largo de la película y como plano final en la última escena. una toma que en la intención del director representa la mirada panorámica desde la ventana del nuevo departamento de Mamma Roma, pero que en realidad está tomado desde el lado opuesto de la Avenida Tuscolana, desde un edificio en proximidad de la actual Calle Papiria. En este encuadre aparece la iglesia de San Giovanni Bosco, que vimos en construcción en algunos fotogramas de la película El techo de De Sica. Ahora, esta parte de la ciudad, aparece casi acabada, con sus bloques intensivos, en unos de las zonas de la Capital más densa de población, levantada a través de una especulación inmobiliaria salvaje; la cuarta parte inferior del fotograma está ocupada por algunos lotes baldíos con una topografía removida, y un camino de tierra: territorio en espera de nuevas construcciones.

La siguiente escena sucede en la iglesia, madre e hijo salen de misa, observando y hablando de sus futuros vecinos: Mamma Roma con un velo negro, después de haberla vista hace dos planos, como prostituta en las calles de Roma. El destino último de su mudanza, que los protagonistas alcanzan al salir de la Iglesia, es la vivienda INA-Casa que la madre ha conseguido en el Bloque en "V" ubicado en Plaza Espartaco dentro del conjunto denominado Tuscolano II. Un edificio diseñado por Saverio Muratori. La madre está orgullosa de su nuevo barrio, y sobre todo de la vivienda, sus acabados, los vecinos, su trabajo en su puesto de hortaliza. Pero Ettore no comparte esta felicidad y busca otros lugares y otras compañías. Ettore encuentra su equilibrio fuera del conjunto habitacional en el parque de los acueductos, y en algunas derivas y recorridos, solo, con su amiga Bruna o con sus nuevos amigos.

En la Roma recorrida por Ettore, aparece el conocimiento profundo de Pasolini de la capital, que el director, como Saura con Madrid, fragmenta para luego re-montar y crear su propia iconografía urbana. El punto de partida es la casa en Largo Spartaco, o la pradera del parque de los acueductos, y las derivas de Ettore siempre tienen un regreso hacia este hogar.

Algunos escenarios no son coherentes con la narración y corresponden a la búsqueda estética de Pasolini. Así, por ejemplo, aparecen otros dos conjuntos INA-Casa que el director utiliza para describir la iconografía de su periferia ideal. En el recorrido en moto con su madre, se ve como escenario el Barrio INA Casa de Acilia, un suburbio en el Suroeste hacia la playa de Ostia; Pasolini está seguramente interesado en la arquitectura de este conjunto ${ }^{44}$, y su adaptarse a la topografía como un pueblo antiguo, un pueblo de casas modernas, de aspiración pequeño-burguesa como el Tuscolano; después de esta toma en Acilia, la moto pasa el arco que separa la Vía Appia del barrio Tuscolano y toma el Appia hacia al sur, con una elipsis espacio-temporal.

En otra escena cuando Ettore entrega la cadenita de oro a Bruna, la acción se desplaza en la Avenida de Romanisti en la borgata de Torre Spaccata, a 1,5 kilómetros al Noreste del Tuscolano. Podemos suponer esta elección siempre con el interés de crear una variedad de ambientaciones, que pudieran corresponder a una específica imagen urbanístico y arquitectónica, no es una casualidad que se trate otra vez de una intervención de Ina-Casa, esta también del primer septenio, denominada Torre Spaccata ${ }^{45}$. En este lugar, con un campo y contra campo, el director describe las características de esta gran avenida, parecida a las del Tuscolano, que termina en otro enorme descampado, con la ruina de la Torre Spaccata ${ }^{46}$, una de las tantas que definen el paisaje de la campiña romana en esta zona. (F.3.4.1/1).

\footnotetext{
44 proyectado por Giuseppe Perugini en 1958 y finalizado en 1960,

45 proyectada por Plinio Marconi en 1958 y finalizada en 1960.

${ }^{46}$ Se trata de una torre de origen medieval (IX siglo)
} 

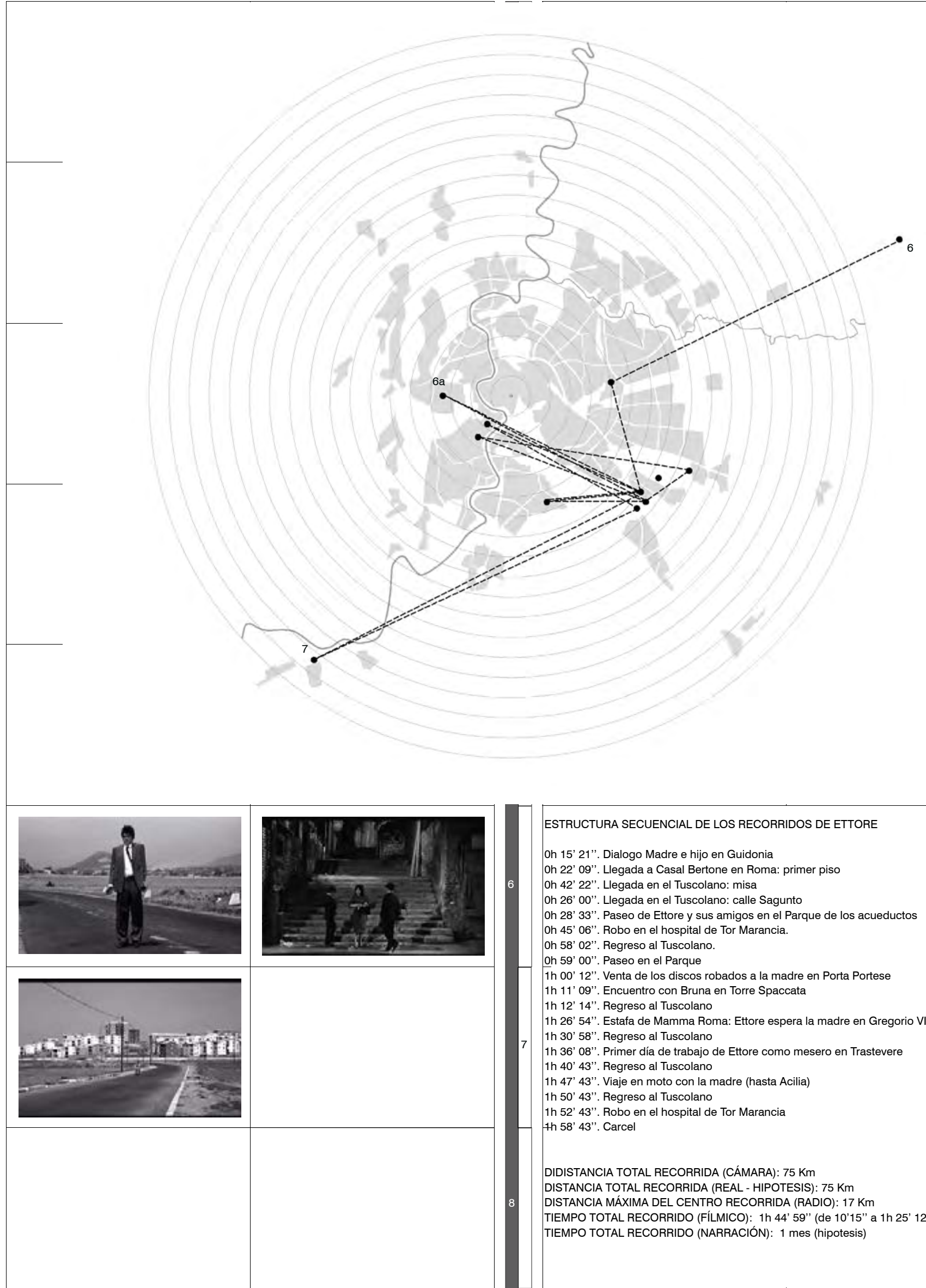

Puntos más distantes del recorrido.

RM 6. Pueblo de Guidonia

RM 6a. Rampa Brancaleone (Gregorio VII) RM 7. Acilia (INA Casa)

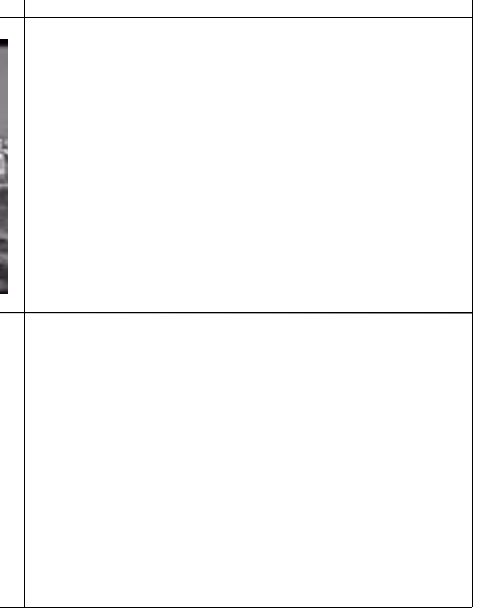

ESTRUCTURA SECUENCIAL DE LOS RECORRIDOS DE ETTORE

Oh 15' 21". Dialogo Madre e hijo en Guidonia

oh 22 ' 09 ". Llegada a Casal Bertone en Roma: primer piso

Oh 42' 22". Llegada en el Tuscolano: misa

oh 26' $00^{\prime \prime}$. Llegada en el Tuscolano: calle Sagunto

Oh 28' 33". Paseo de Ettore y sus amigos en el Parque de los acueductos

Oh 45' $06^{\prime \prime}$. Robo en el hospital de Tor Marancia.

Oh 58' 02 '. Regreso al Tuscolano.

Oh 59' 00". Paseo en el Parque

1h 00 ' 12". Venta de los discos robados a la madre en Porta Portese

1h 11' 09". Encuentro con Bruna en Torre Spaccata

1h 12' 14". Regreso al Tuscolano

$1 \mathrm{~h} 26$ ' 54 '. Estafa de Mamma Roma: Ettore espera la madre en Gregorio VII

1h 30 ' $58^{\prime \prime}$. Regreso al Tuscolano

1h 36' $08^{\prime \prime}$. Primer día de trabajo de Ettore como mesero en Trastevere

1h 40' $43^{\prime \prime}$.' Regreso al Tuscolano

1h 47 ' $43^{\prime \prime}$. Viaje en moto con la madre (hasta Acilia)

1 h 50 ' $43^{\prime \prime}$. Regreso al Tuscolano

1h 52 ' 43 ". Robo en el hospital de Tor Marancia

1h 58' 43". Carcel

DIDISTANCIA TOTAL RECORRIDA (CÁMARA): $75 \mathrm{Km}$

DISTANCIA TOTAL RECORRIDA (REAL - HIPOTESIS): $75 \mathrm{Km}$

DISTANCIA MÁXIMA DEL CENTRO RECORRIDA (RADIO): $17 \mathrm{Km}$

TIEMPO TOTAL RECORRIDO (FíLMICO): 1h 44' 59"' (de 10'15" a 1h 25' 12")

TIEMPO TOTAL RECORRIDO (NARRACIÓN): 1 mes (hipotesis)

\section{UBICACIÓN EXACTA LUGARES DEL \\ (secuencia)} RODAJE

\section{Guidonia}

2. Largo de Dominicis

3. INA Casa Tuscolano

4. Parque de los acueductos

5. Tor Marancia

6. Porta Portese

7. Av.da Romanisti (Torre Spaccata)
8. Rampa Brancaleone (Gregorio VII) 9. Plaza dei Mercanti (Trastevere)

10. Autovía Appia Nuova

11. INA Casa Acilia

\section{ROMA}


El conocimiento de Pasolini de este sector Sureste de la capital es profundo, no tan lejos de estas zonas, un poco más al Norte, Pasolini había rodado Accattone, donde el director concentraba su interés hacia los territorios de la informalidad, en contraste con los esqueletos de los condominios en construcción. El hilo conductor iconográfico y narrativo del director es la descripción de un hábitat en transformación con la vivienda popular de la INA Casa, y de los barrios de la especulación edilicia, que logra con el collage arquitectónico presente en esta película. Otro lugar presente en las derivas de Ettore es el hospital donde cumple los atracos junto a sus compañeros, ubicado en el barrio de Tor Marancia, otra zona de la periferia sur de la capital, que Pasolini conocía bien. Las únicas dos incursiones cumplidas en el centro por Ettore serán hacia Porta Portese, para vender los discos de la mamá, y la del Barrio Aurelio, cerca de San Pedro, donde el hijo acompaña a la madre sin saber que iban a chantajear a su futuro proveedor de trabajo; y el restaurante en Trastevere, en donde Ettore empieza a trabajar como mesero, con la madre orgullosa mirándolo y llorando. Estas últimas dos escenas son nocturnas, y la imagen de Porta Portese corresponde a un sector del mercado ocupado por chatarra y desechos. Así que no existe una imagen del centro que se contraponga a la de la periferia, como en Los golfos o en El techo. Mamma Roma está rodada totalmente en la periferia, y rechaza cualquier imagen que pueda reconducirse a la tradición y al pintoresco. En esta película Pasolini se desplaza mucho más que cualquier director anterior (133 Km.), llegando a lugares, entre suburbios y periferias, hasta ahora inexplorados y que nunca habían salido a pantalla, como Acilia o Guidonia. El trabajo de Mamma Roma revela un conocimiento arquitectónico y urbano de la ciudad que va más allá de su trabajo como director de cine, y deriva de su constante interés a lo largo de su carrera de poeta y literato, hacia los fenómenos urbanos $^{47}$.

\section{EL TUSCOLANO}

Analizando la cartografía, podemos fijar estructura y la forma del paisaje de la capital, que Pasolini desarrolló para la película, aunque en el caso del cine de Pasolini sería más correcto hablar de fondo ${ }^{48}$. El fondo del cual habla Pasolini siempre está relacionado con sus personajes, con sus miradas, como si la cámara coincidiera con el ojo de los personajes o del espectador, una mirada de cine documental parecida a la de Saura. Como en una composición pictórica del Quattrocento, es el hombre al centro de la composición, y la imagen está construida más a partir de lo estático, que del movimiento con el punto de vista del espectador, siempre de frente, como alguien que detiene la escena de una pintura en una iglesia; "también, cuando la cámara se mueve de lado en panorámica a develar un paisaje o un grupo de personajes en espera, se desliza como el movimiento de una mirada" 49 .

El sector donde se ubica la vivienda del Tuscolano es el área donde se rodaron más películas, debido a la presencia de los cercanos estudios de Cinecittá, entre otras las que se han analizado en el anterior capítulo: El techo, Bellísima y del episodio de Carlo Lizzani Amor que se paga, de la película colectiva El amor en la ciudad; en esta última se filma una de las chabolas pegadas al acueducto Claudio ${ }^{50}$, la demora de una joven prostituta, que cuenta de sí en una escena nocturna de vida doméstica, con la oscuridad de la noche que esconde, en parte, la precariedad y el degradado de la imagen exterior de la vivienda (F.3.4.1/2).

\footnotetext{
47 Véase por ejemplo el ya citado pequeño documental de Pasolini: "La forma della cittá" de 1974

${ }^{48}$ Explica el mismo director: "Amo el fondo, no el paisaje, no se puede concebir una pala de altar con las figuras en movimiento. Detesto el hecho que las figuras se muevan. Por eso ninguna de mis tomas puede empezar con el campo, o sea con en el paisaje vacío. Siempre estará, aunque muy pequeño, el personaje. Muy pequeño por un instante, porque grito al fiel Delli Colli para poner el sesentaicinco: $y$ entonces llego sobre una figura: un rostro en detalle. Atrás el fondo, el fondo, no el paisaje (Pasolini, II mio cinema, 2015 pp. 43-44)

49 (Spila, 1999 p.27)

${ }^{50}$ Es una de las primeras en Italia en la cual está rodado un asentamiento informal.
} 
LEYENDA SECTOR 2 (Valmelaina-Nomentano)

\footnotetext{
Mancha urbana Tejido informal

$\because$ Infraestructura $\square$ Vivienda popular

Vacíos
}

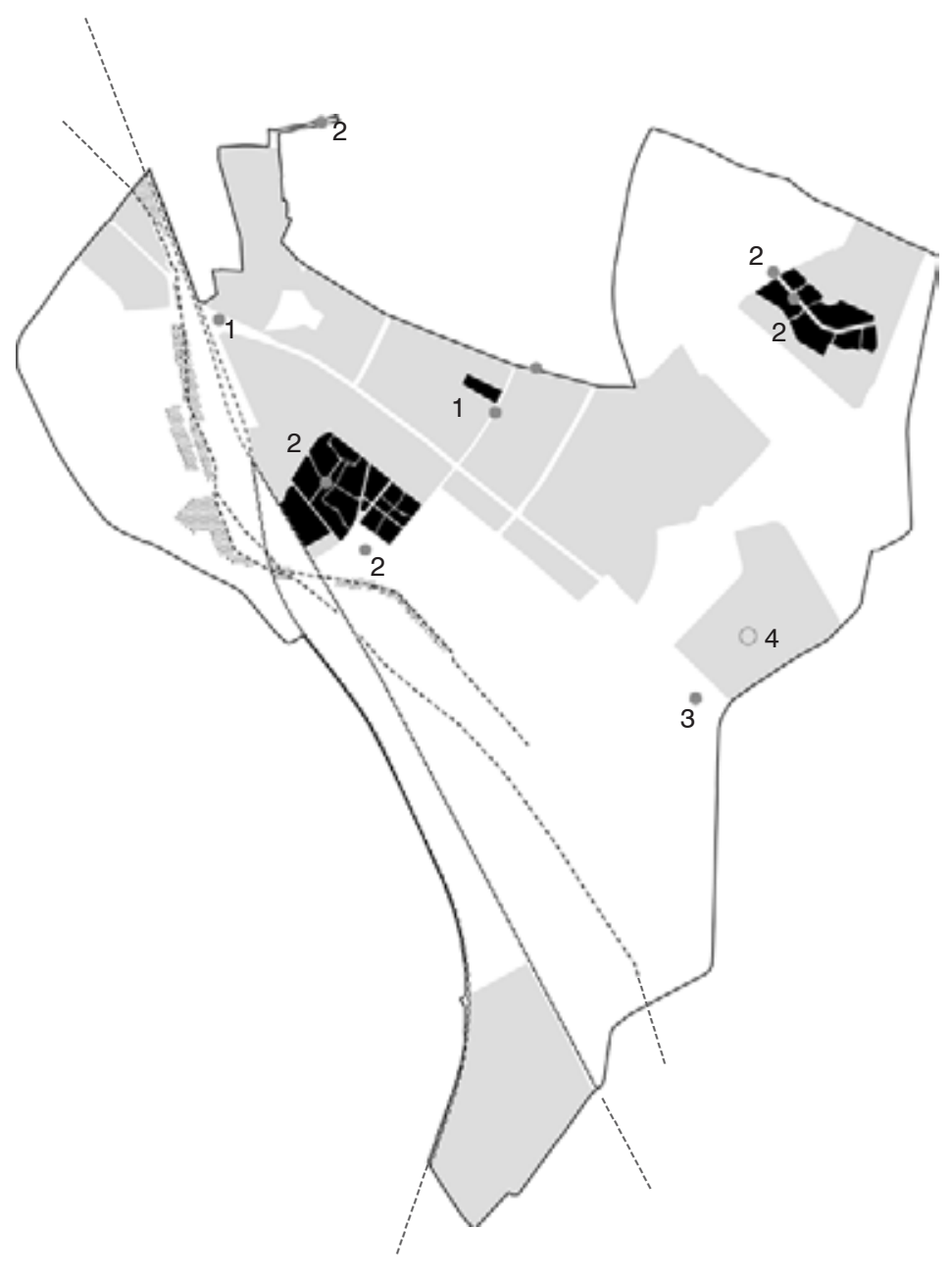

PELICULAS RODADAS

1. El techo (De Sica)

2. Mamma Roma (Pasolini)

3. Bellissima (Visconti)

4. Estudios de Cinecittá
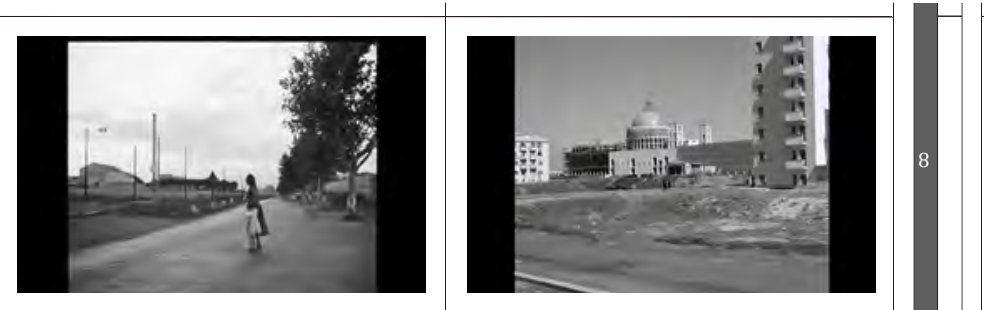

RM 8. Bellissima (Visconti). La via Tuscolana en frente de los estudios de Cinecittá

RM 8a. El techo (De Sica). La Iglesia de Don Bosco cista desde oriente. 
Mamma Roma y su hijo llegan a su nueva vivienda por la calle Sagunto, tomando posesión de su nuevo departamento, gran parte de las demás escenas están rodadas en las calles adyacentes y en el Parque de los Acueductos: se trata de la calle Lucio Sestio, en donde Mamma Roma tiene su puesto de Mercado; de la calle Lemonia, que marca el límite entre el Parque y la urbanización del Tuscolano; la Calle Valerio Publicola, en donde viven unas muchachas amigas de los compañeros de Ettore, y donde Mamma Roma aparece jalando su carrito desde el almacén hasta el mercado; la calle Quadraro que los chicos recorren al regresar a casa, o cuando se dirigen hacia la ciudad, la calle por la cual Ettore transita en motocicleta con su mamá hacia la Vía Appia, para estrenar el vehículo. En la última escena el rodaje regresa en la Calle Sagunto, que Mamma Roma recorre, como en la primera escena de la llegada a su nueva casa, esta vez ya sin esperanzas.

Ettore, en compañía de Bruna y de sus amigos, o también solo, se desplaza dentro del Parque paralelamente a la Calle Lemonia, en dirección Noroeste/Sureste. Se trata de un recorrido de poco menos de trescientos metros que tiene como meta final unas ruinas romanas de una Villa romana del II siglo después de Cristo ${ }^{51}$. Este recorrido, siendo el lugar una pequeña meseta más elevada respcto el nivel de la urbanización del Tuscolano INA-Casa, permite una visión de $360^{\circ}$ hacia el barrio; otros fragmentos de la villa aparecen en este recorrido, junto a un gran descampado utilizado como polvorienta cancha de futbol, en la esquina entre las calles Lemonia y Quadraro. Algunos recorridos secundarios parten de este camino, y llevan a los muchachos hasta la zona más cercanas al primer acueducto, denominado Marcio; estos desplazamientos corresponden a la necesidad de los chicos de apartarse con Bruna, la madre soltera amiga de la pandilla, y finalizan con una elipsis geográfica hacia una cañada que seguramente corresponde al trazado de un antiguo ferrocarril empezado por Mussolini y no acabado que se convierte en un túnel de más de ochocientos metros abajo del antiguo aeropuerto de Centocelle, del otro lado de la Tuscolana respecto al Parque de los Acueductos. Uno de los arcos de la entrada, aparece tapiado con un muro de toba, que esconde una especie de almacén, el lugar donde Ettore y sus amigos se acuestan con Bruna ${ }^{52}$.

Si tomamos como punto de referencia las ruinas, podemos distinguir tres "fondos" que Pasolini utiliza en sus planos generales y en sus panorámicas o planos de conjunto, y que incluyen casi siempre algunos restos arqueológicos en primer plano. El fondo, en dirección Suroeste hacia el Acueducto Marcio, es una ladera con césped que termina hacia esta infraestructura romana, en la cual se apoyan algunas construcciones informales; en alguna toma, dependiendo de la topografía, es visible el segundo acueducto romano presente en el Parque, el Acueducto Claudio ${ }^{53}$. En dirección opuesta es visible la vaguada hacia la Calle Lemonia con al fondo el Tuscolano en expansión, en otras tomas, aparece la cúpula de la iglesia de Don Bosco. En dirección Sureste aparece la línea del Acueducto Claudio y la de los edificios en construcción sobre la calle Lemonia; en el horizonte los Colli Albani, los antiguos volcanes que dieron origen a este valle. El escenario en dirección Norte es una vista de la Calle Quadraro, con las Torres ${ }^{54}$ del INA-Casa y las hileras ${ }^{55}$ filtradas por otros fragmentos de la Villa romana que aparecen en casi todos los planos rodados en este parque, y que son unas metáforas de la imposibilidad de armonizar pasado y presente (F.3.4.1/3).

\footnotetext{
${ }^{51}$ Conocidas actualmente como los restos de Villa delle Vignacce, un conjunto de termas y habitaciones suburbanas de un amigo del emperador Adriano, muy extenso y muy poco documentado.

52 Descubrimiento e hipótesis del autor de esta tesis: este tunnel es parte del que se conoce como "metropolitana de Mussolini", proyecto del Duce inacabado que servía para conectar esta zona periférica con el Centro de Roma.

53 El acueducto Marcio fue construido en el 144 A.C por el Pretor Quinto Marcio; el acueducto Claudio, entre el 38 y 55 D.C. por el imperador Claudio.

${ }^{54}$ del Arquitecto Mario De Renzi

${ }^{55}$ de los arquitectos Vagnetti y Tassotti.
} 


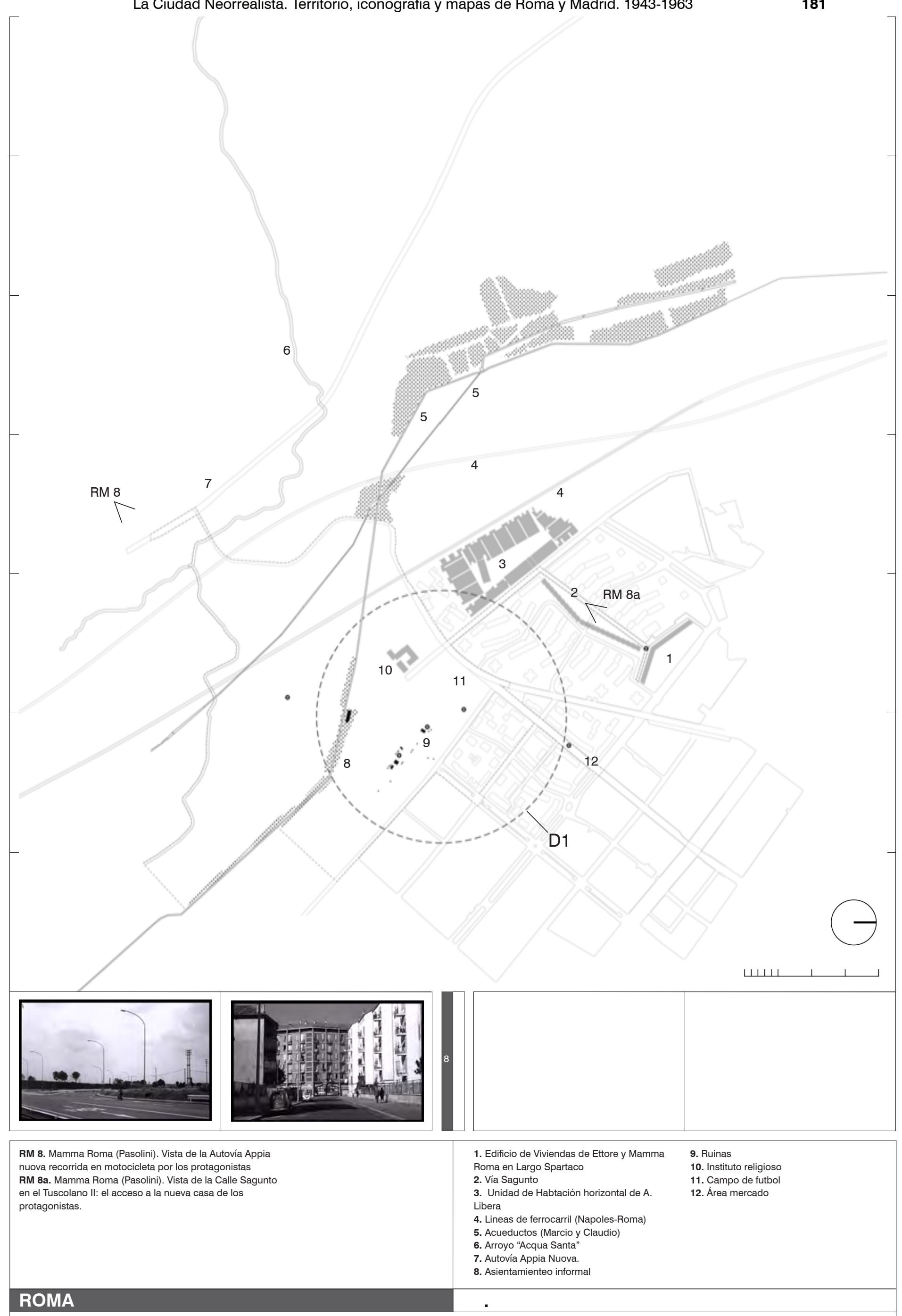


La periferia del Tuscolano como el Tercer Mundo, crece demasiado rápida, una modernización que arrasa con tradiciones y culturas locales, "realidades unificadas por la economía 'totalitaria' del consumo. Las ruinas romanas, integradas en el día a día precario del subproletariado, y las comunidades de propietarios, concebidas para el confort de la familia pequeño-burguesa, coexisten sin que la primeras se conviertan en el pasado de las segundas" 56 .

La técnica cinematográfica de Pasolini, es evidenciada a través de los movimientos de cámaras marcados en la cartografía, y también caracterizan su estilo y técnica de rodaje. La multiplicación de las cámaras depende de la técnica primitiva, muy utilizada por Pasolini, del picado y contrapicado, de la escasa utilización de panorámicas y del travelling: el paisaje se fragmenta en un collage de diferentes miradas que se multiplican de acuerdo con los recorridos de los personajes en los espacios. Nunca tenemos vistas desde arriba o cámaras que rodean al personaje o que lo siguen en el movimiento, Pasolini odiaba el movimiento de las figuras y crea su mundo cinematográfico a partir de planos estáticos. Pasolini era una autodidacta que, como explica Bertolucci -quien fue su asistente a la dirección de su primera película Accattone- descubre el cine por primera vez. El descubrimiento de la diferencia entre una panorámica y un travelling, entre en plano general y un primer plano, se produce en esta primera obra cinematográfica ${ }^{57}$; "Pasolini está acostumbrado en rodar pequeños planos de 2-3 minutos a lo máximo, todos planos medios y primeros planos que la cámara toma casi permaneciendo pegada al actor; en cambio los planos generales (o sea las vistas generales de los ambientes) y los movimientos de cámara están limitados, son técnicamente elementales, segmentos que luego son ordenados en secuencia en la fase de montaje" ${ }^{58}$.

Sin embargo, esta mirada casi naive hacia la técnica cinematográfica se convierte en un estilo, una forma de apegarse a lo que es para él el cine como superación del Neorrealismo. La técnica naive permitió al director no solamente manipular a los actores, sino también el ambiente y el paisaje, construyendo su propio espacio, alterando las perspectivas sobre los planos ortogonales de los encuadres y montándolos en su propio collage urbano. (F.3.4.1/4).

\section{EL BARRIO DE MURATORI Y DE RENZI}

La película Mamma Roma está en gran parte rodada en el barrio INA-Casa del Tuscolano ${ }^{59}$. EI edificio en donde la madre encontrará un nuevo hogar es el denominado "Boomerang", por su forma en "V" que se abre sobre la Plaza Spartaco. La llegada al bloque de viviendas, se hace a lo largo de la calle Sagunto, un eje central que articula todo el barrio, en una dirección contraria a la que normalmente sería la dirección de la llegada de la Tuscolana; al fondo de la calle se lee el portal de la entrada a la Unidad Horizontal el arco parabólico proyectado por Libera. En la toma en subjetiva de los protagonistas, hacia el otro lado de la calle, aparece otro arco-portal, bajo el bloque en "V" en donde madre e hijo irán a vivir. A lo largo de toda la película, los arcos, enmarcan los umbrales que corresponden a un cambio en la vida de los protagonistas: la entrada en el primer edificio donde está el departamento en renta de la Magnani, y el arco que esconde el almacén donde se produce la iniciación sexual de Ettore, en el parque. Antes de acceder a la vivienda, la cámara del director, se direcciona hacia una calle cerrada, abajo del bloque de Muratori, perpendicular a la calle Sagunto. En esta calle, chicos bien vestidos juegan ordenadamente. Mamma Roma saluda a los nuevos vecinos, disimulando su marcado acento romano.

\footnotetext{
56 (Pasolini, II mio cinema, 2015, p.23)

57 (Ibidem)

58 (Spila, 1999 p.34)

59 De Saverio Muratori y Mario de Renzi, en la segunda fase, y Adalberto Libera, en la tercera.
} 

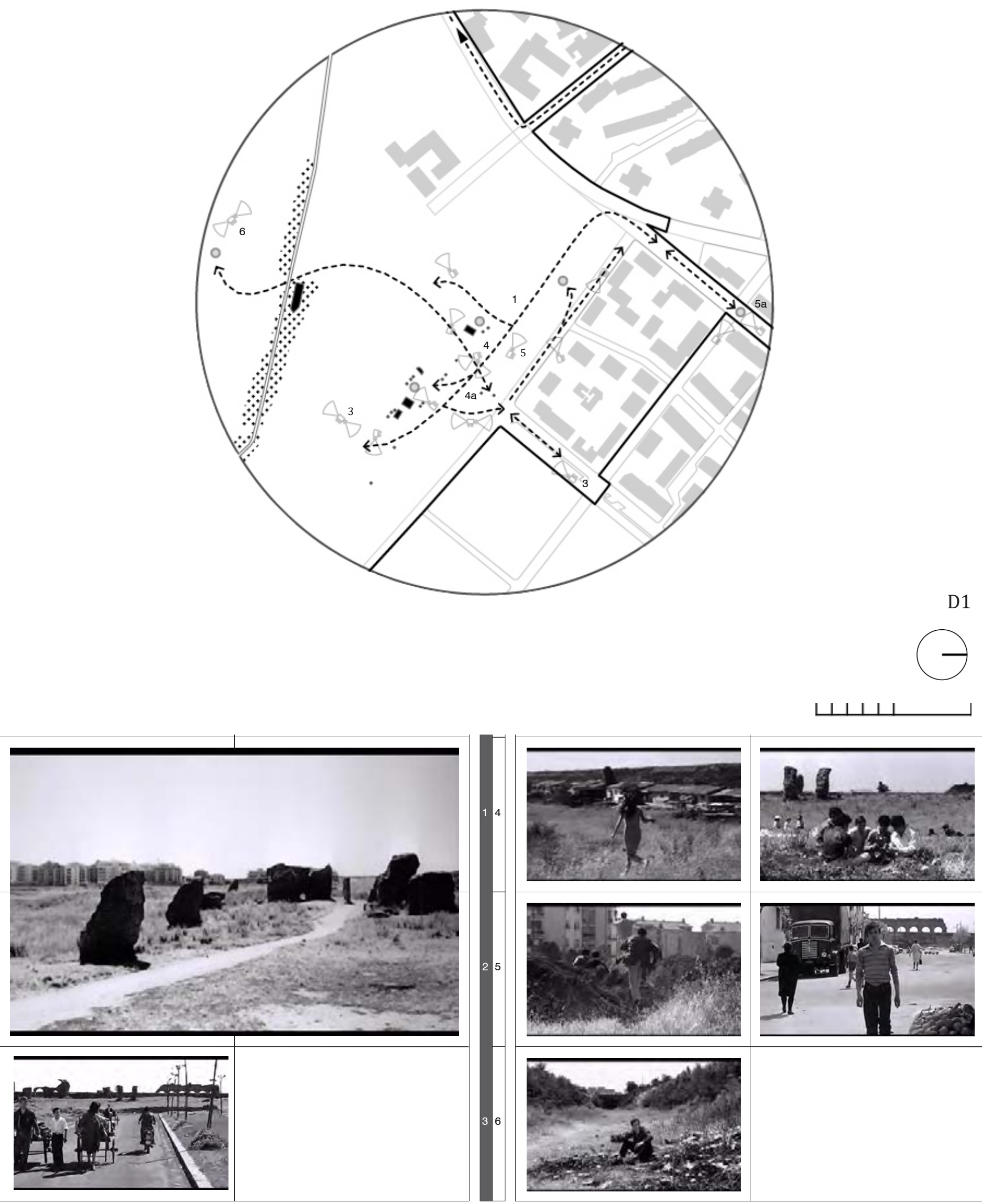

RM. Movimientos de cámara

1. Panoramica: las ruinas en el Parque de los acueductos 3. Recorrido de Mamma Roma hacia la calle del mercado

4. Encuentro con Bruna al fondo chabolas del acueducto

4a. Reunion de los amigos en el Parque

5. Escombros: en el fondo las torres del Tuscolano II

5a. Ettore avanzando en la calle del mercado.

6. La Vaguada de la pelea (Elipsis espacial) 
El edificio destaca por el orden de su composición y su estructura vista como en las Torres de Avenida Etiopia ${ }^{60}$ de Mario Ridolfi, así como por el uso no-estructural de la toba y del ladrillo.

Subiendo el departamento, se confirma la atmósfera pequeño-burguesa del barrio que se refleja en los acabados interiores de la vivienda: un departamento funcional, limpio y adecuado a las necesidades y a los deseos de rescate social de los protagonistas de la película. Abriendo la ventana aparece la ciudad en construcción: la periferia alrededor de Cinecittá, en la zona de la iglesia de Don Bosco, con su gran cúpula ${ }^{61}$.

En la mirada de Pasolini, a través de los ojos de sus personajes, el barrio INA-Casa es el ideal pequeño-burgués cumplido: las periferias modernas con sus bloques y sus jardines privados se presentan en toda su realidad, un espacio urbano que establece una ruptura con la historia, con la cultura, con las culturas locales, el intento de los protagonistas, de integrarse a este nuevo mundo fracasa. Pasolini desprecia este tipo de ciudad porque representa una falsa ilusión y el genocidio cultural de la Italia rural auténtica. A este mundo artificial Pasolini contrapone el espacio de los descampados, en el cual Ettore pasa su tiempo, entre un partido de futbol, una cita amorosa o simple vagabundeo; espacios de libertad, territorios de recuperación de la conciencia y de la identidad.

\section{INFRAESTRUCTURAS Y PAISAJE NATURAL}

En la película $E I$ techo la pareja protagonista hace un recorrido en autobús desde el pueblo de pescadores de la familia de ella, hacia el Tuscolano. Ya se ha analizado en el anterior capitulo cómo, desde las ventanillas del autobús, el paisaje marino con las cabañas de paja se convierte en la urbanización desarrollada a los dos lados de la avenida Tuscolana, en Roma. En uno de los encuadres a través de las ventanillas, aparece el parque de los acueductos y la línea del ferrocarril, también se puede observar parte de la urbanización informal que se ha desarrollado en el tiempo (y seguirá desarrollándose) en estos años a lo largo de la imponente estructura de los dos acueductos que en esta zona se cruzan. Esta zona es denominada históricamente Quadraro, y fue "apodada" por lo nazistas y los fascistas, "Nido di vespe", nido de avispas, porqué en tiempo de guerra esta presencia de los dos acueductos y del ferrocarril, las condiciones topográficas, y las fuertes relaciones sociales, facilitaban la posibilidad de esconderse para muchos de los partisanos y refugiados políticos. La pareja es feliz por haber dejado a sus espaldas este nuevo mundo; cuanto más el autobús se dirige hacia la "fábrica de sueños" Cinecittá, más los dos jóvenes se sienten seguros, por un mejor futuro laboral y económico.

La vieja "borgata" Quadraro o Cecafumo, fue uno de los poblados construidos a partir de los primeros años del siglo XX como área residencial, floreció bajo el fascismo también por la cercanía a los estudios cinematográficos de Cinecittá. Esta expansión, sobre todo después de la Primera Guerra Mundial, se desarrolla a partir de una lotización planificada, y de pequeños núcleos de edificación informal que crecen alrededor de toda la Via Tuscolana, una antigua calle de la Edad Media que desde la Puerta San Giovanni en la muralla Aureliana, llevaba hacia los Castillos Romanos o Colli Albani, la región de colinas que desde los tiempos de los romanos, era frecuentada por los nobles de Roma a cuenta de su agradable clima durante el verano ${ }^{62}$. El barrio INA-Casa como toda esta zona residencial y comercial, una de las más densas y pobladas de la Capital, toma el nombre de la calle Tuscolana. El mismo barrio más

\footnotetext{
${ }^{60}$ Las torres de Avenida Etiopía son consideradas ejemplo de Neorrealismo por esa sinceridad y honestidad en el uso de los materiales.

${ }^{61}$ Aunque, como se analizará más adelante, esta vista es una elipsis espacial.

${ }^{62}$ En estos lugares se encuentra el cerro Tuscolo, que da el nombre a este eje, zona de la antigua ciudad pre-romana de Tusculum.
} 
hacia el Sureste, sin una clara delimitación física, toma el nombre de Cinecittá, por la presencia de los estudios cinematográficos. Toda la zona INA-Casa colinda al Oeste con el Parque de los Acueductos, uno de los más importantes y bien conservados restos del Agro Romano o Campiña Romana, el nombre geográfico que se la da al paisaje rural que rodea la ciudad, caracterizado por la presencia de restos arqueológicos de distintas épocas, a veces de gran valor artístico que conviven con terrenos destinados todavía hoy a la agricultura y pastoreo, marcados por bosques puntuales e hiladas de pinos marítimos y piñoneros ${ }^{63}$. Es el paisaje que los pintores europeos del Grand Tour reproducían en sus lienzos, buscando una cierta atmósfera de decadencia, producida por las líneas sinuosas de la topografía que alterna llanos a pequeñas lomas, por la luz de tonos naranja típica de Roma y por la presencia de ruinas de arquitecturas romanas. El mismo paisaje, con otros significados, aparece en las películas neorrealistas, como un símbolo de la vida alrededor, de quien vive alejado del centro de Roma, donde los protagonistas se refugian, rechazados y rechazando la ciudad. En este paisaje rural se sienten protegidos por la semejanza con los lugares de donde provienen. Las calles que se ven en las películas son caminos polvorientos donde los actores se mueven sin puntos de referencia; es el paisaje de la Roma que crece desordenadamente con la especulación inmobiliaria de los propietarios y de los constructores, qienes, para hacer subir el valor de los terrenos, construyen en terrenos agrícolas cada vez más alejados, sin ningún criterio urbanístico, expandiendo el territorio municipal de una de las ciudades europeas actualmente con la mayor extensión de superficie administrativa ${ }^{64}$.

La ultima fase de actuación del barrio INA-Casa -la Unidad del arquitecto Adalberto Libera-, es parte de una banda de terreno comprendida entre el Parque de los acueductos y las primeras dos actuaciones del plan INA Casa; La unidad se inserta en un lote de forma trapecioidal, ubicado en el borde Sur-Oeste de la Calle Selinunte, que la separa de las otras actuaciones de INA-casa denominadas Tuscolano I y II, proyectadas por Saverio Muratori y Mario de Renzi. Este lote colinda al Norte con una pequeña área actualmente abandonada y destinada, en una primera versión del proyecto, a una conexión vehicular y a un área deportiva; al Sur con un Edificio Escolar de primaria a lo largo del eje de Calle del Quadraro, que conecta la Tuscolana con el otro eje de la Vía Appia Nueva, una calle estatal que sigue el trazado de la antigua calle consular Romana, conectando Roma con Brindisi, ciudad en el tacón de la bota de la península de la Península italiana.

El paisaje frente a la Unidad de Libera es el de los acueductos romanos Claudio y Marcio, que justo en esta zona del parque se cruzan, y el del ferrocarril que se duplica en dos líneas, una con dirección hacia los Castelli Romani, y la otra hacia Nápoles. Estas líneas surcan estas áreas y parecen remarcar el concepto de limite, presente en el proyecto de Libera. Las dos direcciones se cruzan en este punto, justo enfrente del campo deportivo en el lado norte de la unidad, viajando en dos niveles diferentes. Es un paisaje de infraestructuras, de mucha complejidad por la cantidad de trazos que se han acumulado en distintas épocas, así que los acueductos y el ferrocarril conviven con sendas, carreteras y vallas de parcelas agrícolas. Es el paisaje infraestructural que aparece en la iconografía de la cinematografía neorrealista, y que marca un territorio todavía profundamente rural, urbanizado demasiado rápido. Mientras que en los terrenos cercanos a la vía Tuscolana se desarrolló un planeamiento tradicional con manzanas más o menos abiertas, con un trazo ortogonal a este eje, en esta zona más al Oeste, más al borde, hacia el ferrocarril, el conjunto Tuscolano II de Muratori y De Renzi se

\footnotetext{
63 Se trata de una zona del "Parco Regional de la Appia Antica" (Creada por la "Regione Lazio" en el 1988 para tutelar un área en muy serias condiciones de degrado y abandono) una muy extensa área con protección histórica, arqueológica, paisajística y natural

${ }^{64}$ Es la capital del Europa Continental con el territorio más extenso: 1290 Km2. Fuente Wikipedia.
} 
hace más orgánico, y se diferencia del resto de la urbanización. El trazo de esta intervención intenta relacionarse con el paisaje, proponiendo un asentamiento que enfatiza perspectivas, áreas libres y vida pública. Con la tercera fase de la Unidad de Libera, estas relaciones se harán más fuertes, dejando completamente cualquier referencia urbana, proyectando el conjunto como un fragmento de paisaje neorrealista.

\section{EL ACUEDUCTO CLAUDIO: ENTRE DESCAMPADOS Y CHABOLAS}

En el parque de los acueductos, se encuentran los restos de estas grandes estructuras de época romana y otros restos de villas y cisternas, escombros, campos de futbol y asentamientos informales, (estos últimos aprovechando las estructuras antiguas para facilitar su construcción).

Es interesante una zona del parque, cerca de la unidad, que es paradigmática de la complejidad de este paisaje: una zona más al sur de la unidad, el acueducto Marcio, que en este punto alcanza una altura de 28 metros, que se pone en dirección tangencial al acueducto Claudio, y que, con una deviación en ángulo recto, lo sobrepasa. En este mismo tramo del Marcio, las dos líneas de ferrocarril lo atraviesan junto a la calle de Vía del Quadraro, que conecta el barrio Tuscolano con la vía Appia Nueva. Los dos acueductos vuelven a cruzarse en correspondencia de la antigua Torre Fiscale, edificio del Siglo XIII de 30 metros de altura que se injerta sobre el acueducto, aprovechando su estructura como cimentación; se genera en este punto un enclave, un espacio cerrado entre muros ${ }^{65}$. Estos arcos fueron ocupados por inmigrantes y, al día de hoy, todavía se pueden observar los restos de la "ciudad lineal" informal que se generó aprovechando las estructuras romanas existentes: se trata de restos de revoque, de azulejos, de fragmentos de techos de chapa empotrados entre los arcos del acueducto. El proceso era muy sencillo, y de fácil intuición: se empezaba con la ocupación de la crujía de un arco, un espacio entre 5 o 6 metros cuadrados, que representaba el primer núcleo de la futura casa, solo hacía falta añadir una especie de estructura-porche, un techo y tres paredes pegados al núcleo inicial, para obtener un lugar donde poder vivir ${ }^{66}$. Este tejido lineal, por la necesidad de seguir el trazo del acueducto, fue derribado hasta 1974, cuando la construcción de las 3.150 viviendas de Ina-Casa Tuscolano, en los años 50', no había sido suficiente para solucionar el problema de estas familias. Algunos de estos alojamientos, que constituyen el núcleo más antiguo, cerca de la calle Tuscolana, se han transformado en un tejido consolidado de viviendas de una o dos plantas adyacentes al acueducto.

Estos lugares son los que Pasolini iba visitar para para estar con la gente que más le interesaba, la misma de la cual habla en sus novelas y en sus películas, hay fotos que muestran al director en estos conjuntos pegados al acueducto, hay composiciones poéticas que hablan exactamente de estos lugares. Las estructuras del acueducto Claudio y las edificaciones informales que se apoyan en ellas, aparecen en muchos de los planos de Mamma Roma, como fondo de los paseos de Ettore en el parque; estas imágenes hacen parte de un inconsciente óptico, una imagen de una realidad a pocos metros de la vivienda oficial, que existe a pesar de su imposibilidad y de la dificultad en ser contada.

\footnotetext{
${ }^{65}$ Este espacio trapecioidal, con un lado curvo de más de dos hectáreas de superficie fue transformada en una especie de castillo fortificado desde el cual se podían controlar muy bien las vías de acceso a la ciudad, en ocasión de la guerra gótica (535-553). Los Godos ocuparon esta área y tapearon la zona inferior de los arcos. Por esta razón se le denominó Campo Barbárico, nombre que permanece ancora hoy a indicar esta zona. La fuente es un dibujo de Michael Zeno Diemer, pintor e ilustrador bávaro (1867 1939) que viajó a Italia al final del siglo XIX, la pintura está conservada en el Deutsches Museum de Munich (Alemania). Es difícil no pensar que esta configuración espacial no haya influenciado A. Libera en el diseño de la Unidad horizontal.

66 En algunos casos se encuentran nichos escavados en los pilares del arco, una especie de armarios empotrados.
} 


\subsubsection{Cerca de la ciudad.}

\section{RECORRIDOS}

En Cerca de la ciudad, rodada en 1952 por Luís Lucía, por gran parte de la película "la acción transcurre en un barrio de chabolas, concretamente en el Pozo del tío Raimundo" 67 , aunque se han detectado otros escenarios que construyen la iconografía del asentamiento en el cual está ambientada la película.

Cerca de la ciudad se abre con un prólogo, en el cual se presentan los intentos de una troupe cinematográfica de rodar un documental sobre Madrid; en la primera batería de planos, se filman escenas de la vida cotidiana en el centro de la capital, como la preparación de churros, los basureros o la limpieza de una calle con una manguera, unas escenas en el estilo de las películas "sinfonías de una ciudad" de los años '20 y '30, como explica la voz en off, que comunica al espectador, la voluntad de rodar una película "reinventando al Neorrealismo", para contar una historia más auténtica; para lograrlo el director esconde su troupe en un camión, y empieza a rodar a varias personas que pasan por la acera, en la calle Alcalá, buscando la inspiración para el guion. El camión enfoca su atención sobre un cura que pasa caminando, y el director decide seguirlo, para encontrar la historia de su película ya que "las películas de curas ahora están de moda" como explica el narrador; después de unos segundos, el cura desaparece en el metro de la estación Sevilla, y el director decide dirigirse entonces hacia la Plaza de Toros de Ventas para rodar una película folclórica, habiendo fracasado el intento de rodar una película neorrealista. En Ventas por casualidad, reaparece el cura, y el director que ya se había resignado a rodar una clásica historia castiza, en uno de los lugares más turísticos de la capital española, vuelve a enfocar su atención hacia el cura, siguiéndolo en la dirección de la Carretera de Aragón.

Después de esta introducción que define en esta película la contraposición entre centro y periferia, aparecen los títulos de cabecera, con la silueta obscura del cura, Don José interpretado por Alfonso Marsillach, desplazándose en el asentamiento informal en los alrededores de Ventas, pasando el arroyo Albroñigal (hoy M-30) en lo que hoy corresponde al desarrollo de viviendas entre El Carmen y la Elipa: se trata del lugar que ya se ha analizado, hablando del paisaje urbano de Los golfos de Saura. Los títulos de cabecera ocultan en parte los fotogramas que describen como en un documental la condición real de los asentamientos informales en esta zona de la ciudad, no tan lejos de los estudios CEA, en los arrabales que ocupan toda el área entre la Ciudad lineal y Ventas. Sin embargo, en la tesis se han descubierto otros decorados rodados en otras áreas de Madrid y se ubican en los vértices de un triángulo casi equilátero (de $20 \mathrm{Km}$ de lado). En el Noreste la Iglesia de San Juan Bautista que da el nombre a todo el barrio, y donde se rodó Mi tío Jacinto; En el Oeste la Casa de Campo y en el Sureste el Pozo del tío Raimundo. Después del recorrido inicial del cura en los arrabales de Ventas, la acción se desplaza en el Pozo del tío Raimundo en el Sureste de la capital, aunque es difícil distinguir el punto exacto de este raccord geográfico; la línea de horizonte nos ayuda en reconocer el Barrio de La Elipa, con la Plaza de toros de Ventas al fondo y Entrevías-El Pozo, en el cual en un horizonte más amplio aparecen los arrabales al Sur de la capital.

Otra ambientación que es posible distinguir, por la presencia del Palacio Real y del Almudena en la línea de horizonte, es la Casa de Campo, escenario utilizado por Luís Lucía, para la casa del perista, que al final de la película, será objeto del robo de los niños y de la detención por parte de los policías. En la presencia de este personaje se ve claramente la diferencia de esta

67 (López Juan, 2008) 
película, en comparación con la de De Sica o Nieves Conde: "Claro que Luís Lucía sabía que no podía ni debía inquietar demasiado al espectador, y así contra quien procede el marginado es contra quien, dentro de esa misma marginación, los explota, los engaña, los estruja a su favor: un chamarilero que trafica con los pequeños hurtos que compra a ínfimo precio" ${ }^{6}$. La diferencia con el cine de De Sica es evidente; en Milagro en Milán, así como en los arrabales de los limpiabotas, también el personaje más negativo es víctima de un problema que tiene raíces más profundas y de naturaleza política y social. Aun así, Cerca de la ciudad tenía el valor de "subrayar la desatención por parte de los poderes públicos de la marginación que estaba empezando a rodar una serie de importantes capitales - Madrid como emblemático resumen de todas ellas - y cómo la Iglesia ocupaba ese vacío administrativo y asistencial. Todo expuesto poco antes que Franco accediese a la firma del Concordato con la Santa sede (1953), que daba carta de naturaleza a la labor pastoral y asistencial"69. Ya se han analizado en el primer capítulo los significados de estas obras de evangelización de los suburbios pobres, y algunas fotografías de la época encontradas en el archivo del fondo Santos Yubero, parecen fotogramas sacados de Cerca de la ciudad, con las imágenes de los curas con sus trajes obscuros, presentándose a las puertas de las infra-viviendas, en un paisaje desertizado. La imagen del cura de la película, sin embargo, es una anticipación de lo que pasará después de pocos años en el barrio. En el 1956 con la llegada de Padre Llanos se construye la chabola-capilla de San Raimundo, y con el grupo de voluntarios universitarios se empieza el trabajo de asistencia sanitaria y educativa. A pesar de las similitudes, es distinta la imagen de Don José/Alfonso Marsillach, de la del Padre Llanos, el cura Rojo, que operó en un Barrio en oposición a las políticas de régimen, parecida fue seguramente la forma de acercarse a los habitantes, sin prejuicios, aceptando el contexto ambiental sin imponer una cultura sobre la otra y este aspecto es evidente en el episodio de la taberna, en el cual el cura empieza a cautivar la atención y la empatía de los clientes anticlericales a través de "chistes de curas".

Permanece hasta el día de hoy el recuerdo de padre Llanos y esta imagen cinematográfica del cura que se acerca al tejido informal, explorando, como lo hizo el director Luís Lucía, lugares desconocidos y estableciendo relaciones con gente excluida ${ }^{70}$ (F.3.4.2/1).

\section{EL POZO Y ENTREVÍAS.}

Si se analizan las fechas, antes de 1952, fecha de estreno de la película de Lucía, no hay otros acercamientos al fenómeno del chabolismo tan claros y profundo en términos iconográficos como en esta obra cinematográfica, tampoco en el cine italiano, donde habrá que esperar hasta 1956 con El Techo para tener una centralidad del paisaje urbano informal parecida a la de Cerca de la Ciudad. En Limpiabotas, de 1946, se veía el interior de la chabola de uno de los protagonistas, pero no se entendía claramente el contexto urbano ni se ofrecían imágenes panorámicas del exterior. En Milagro en Milán, de 1951, el decorado principal de la película es un conjunto de chabolas de chapas y madera, pero se trataba de una escenografía ficticia, aunque muy realista y geográficamente posible, por el contexto en el cual De Sica la ubicaba, un descampado al lado de las vías del tren, con los condominios de la periferia en el fondo. En España, solamente en Surcos, de 1951, aparecía -entre las primeras veces en el Cine españolun asentamiento informal en el cual se pueden distinguir calles y agrupaciones de viviendas, aunque estos planos están limitados a una sola secuencia de la película.

En la cartografía desarrollada no ha sido posible ubicar con exactitud los lugares del rodaje; sólo se han planteado algunos posibles escenarios y recorridos de los personajes, utilizando planimetrías que reportan las posiciones de los asentamientos informales de la época.

\footnotetext{
68 (Torres Nebrera, 2009 p. 198)

69 lbídem p.197

${ }^{70}$ Entrevistas realizadas con los habitantes en el verano del 2012 contenidas en el documental Flores de Luna. ("Flores de luna" de J.V. Córdoba, 2008)
} 


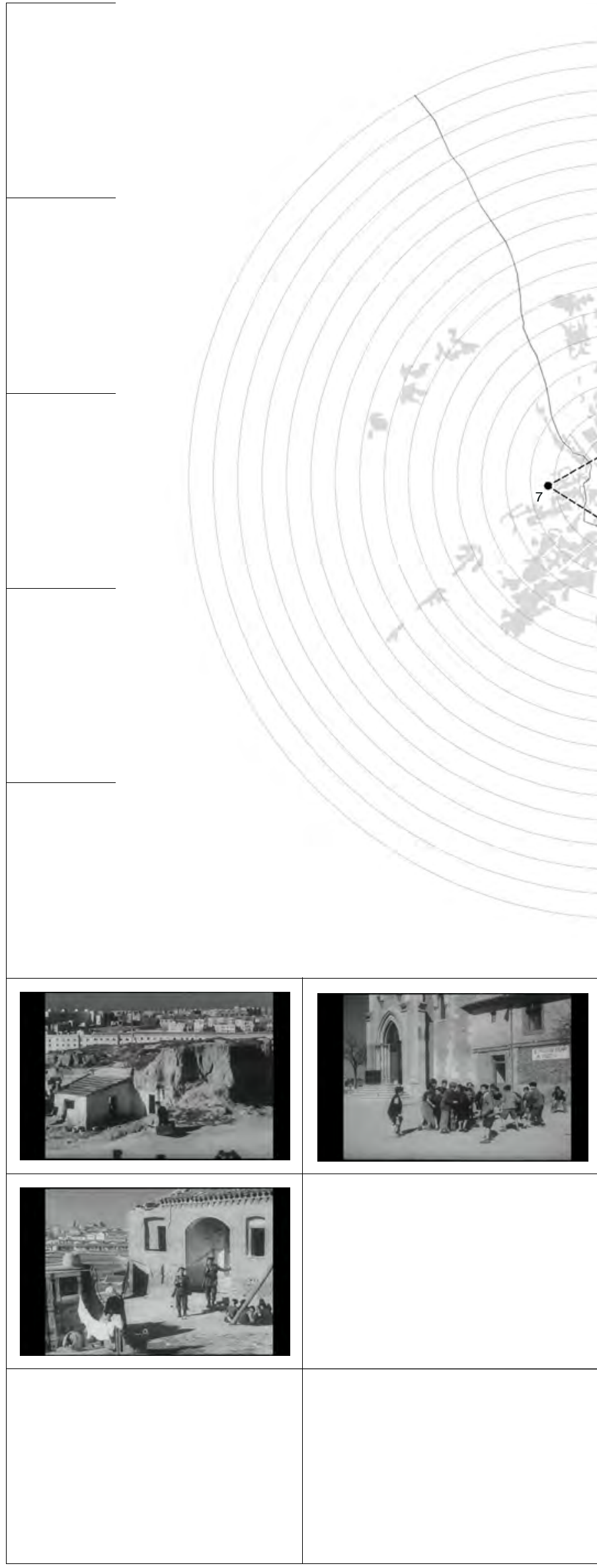

ESTRUCTURA SECUENCIAL DE LOS RECORRIDOS DEL PADRE JOSÉ

Oh 03' 21". Padre José toma el metro en Sivilla (Paseo de Alcalá)

Oh 07 ' $09^{\prime \prime}$. Llegada en la plaza de Ventas

Oh 08 ' 22". Exploración por la barriada de Ventas Elipsis espacia

Oh 28' 33". Llegada en la explanada de San Juna Bautista (Ciudad Lineal) Elipsis espacial

Oh 58' 02". Visita en el barrio de Entrevías - El Pozo Elipsis espacia

1h 00 ' 12". Casa del ususrero: panoramica de Madrid desde la Casa de Campo

DISTANCIA TOTAL RECORRIDA (CÁMARA): 25km

DISTANCIA REAL RECORRIDA (REAL - HIPOTESIS) $3 \mathrm{Km}$.

DISTANCIA MAXIMA DEL CENTRO RECORRIDA (CÁMARA): $6 \mathrm{Km}$

TIEMPO TOTAL RECORRIDO (FÍLMICO): 47' 22" (de 12'37" a 1h 00' 12")

TIEMPO TOTAL RECORRIDO (NARRACIÓN): indefinido 
A este trazo se ha sobrepuesto lo del futuro poblado dirigido por Sáenz de Oíza, que fue construido menos de cuatros años después del rodaje de la película.

Otra capa que hemos sobrepuesto en el mapa es la de unos movimientos de rodaje en el cortometraje de Juan Vicente Córdoba, Entrevías, de 2008, en el cual se establece una fuerte relación entre el poblado de Oíza y el ferrocarril; este mismo director es autor de otra película, Flores de Luna, un largometraje de 2008 en el cual aparecen imágenes de los antiguos asentamientos del Pozo y Entrevías, junto a los antiguos protagonistas, primero de la sobrevivencia en la "época del lodo", y luego de las luchas vecinales junto al mismo Padre Llano, que lograrán obtener una vivienda digna, sin ser expulsados de su propio barrio ${ }^{71}$ (F.3.4.2/2).

En todas las películas analizadas los arrabales parecen tener bien definidos los elementos que constituyen sus fronteras: a veces se trata de sistemas topográficos, hundimientos 0 elevaciones del territorio y de límites naturales como ríos; otras veces se trata de límites artificiales como infraestructuras y puentes. Los terrain vagues así como aparecen en la "Ciudad neorrealista", están caracterizados por estos límites que a pesar del crecimiento de la ciudad, se mantienen en el tiempo, en contraposición al concepto abstracto de espacio como continuum indeterminado, en el que como explica García Roig, hablando del espacio de frontera de los western americanos, "términos como spatium o extensio forman parte de sus componentes (y) la definición de espacio concebido como lugar nos aproxima a lo que constituye su esencia fenomenológica, a aquello que lo hace físicamente perceptible, es decir la naturaleza de sus límites" 72 . A diferencia de la mayoría de las películas analizadas en Cerca de la ciudad el terrain-vague aparece como un continuum con limites no bien definidos. La enorme extensión del territorio, la fragmentación de los decorados operada por Luís Lucía y la cantidad y complejidad de signos del "paisaje-palimpsesto" se unen a la presencia de una topografía compleja, que al subir y al bajar de la cámara modifica la percepción del horizonte y los límites espaciales. En el recorrido de Don José, primero entre Ventas y La Elipa, luego en El Pozo y al final en San Juan Bautista, el paisaje es iconográficamente homogéneo, se trata de unas laderas secas con las chabolas que muchas veces crecen empotradas en ellas como en una ciudad rupestre, estableciendo un límite al mismo tiempo natural y construido. Al subir estos talúdes, como hace el cura en su recorrido inicial llegando a la iglesia de San Juan Bautista, los limites de la topografía desaparecen y se muestra la línea de cielo de Madrid en un sinfín urbanizado. A diferencia de la línea de horizonte de los western y de su valor simbólico que hace referencia a un espacio sin frontera casi místico, "dualidad en sí misma, separación y confusión de lo tangible representado por el cielo"73, en Cerca de la Ciudad y las películas neorrealistas en general, este elevarse sobre topografías, chabolas y derribos, representa la búsqueda de una relación con la ciudad, esperanza para el futuro y con un espacio físico-natural como búsqueda de una relación con las raíces y con la forma perdida de la ciudad del pasado ${ }^{74}$. En el recorrido de Don José, en la secuencia inicial hemos detectado los siguientes límites, configurados como líneas construidas en el encuentro de diferentes elementos naturales y artificiales: Talud / edificios /cielo; Descampado / Madrid /cielo; Talud / Madrid / cielo; Talud / chabolas / cielo; Agua / tierra /chabolas / tierra.

La cámara se desplaza paralelamente al cura a una distancia variable, a veces aprovechando las laderas para lograr tomas en picado y contrapicado; se trata de encuadres con un cierto nivel de dificultad técnica por las condiciones del terreno, que constituyen la escena más lograda de la película.

\footnotetext{
${ }^{71}$ En esta película, además de fotogramas con imágenes de los años '50, aparecen fragmentos de películas neorrealistas: El Techo, Cerca de la Ciudad, Milagro en Milán y Surcos.

72 (García Roig, 2007 p.94)

${ }^{73}$ Ibidem

${ }^{74}$ Véase el documental de P. Pasolini: "La forma de la ciudad" (1974)
} 
LEYENDA SECTOR 2 (Valmelaina-Nomentano)

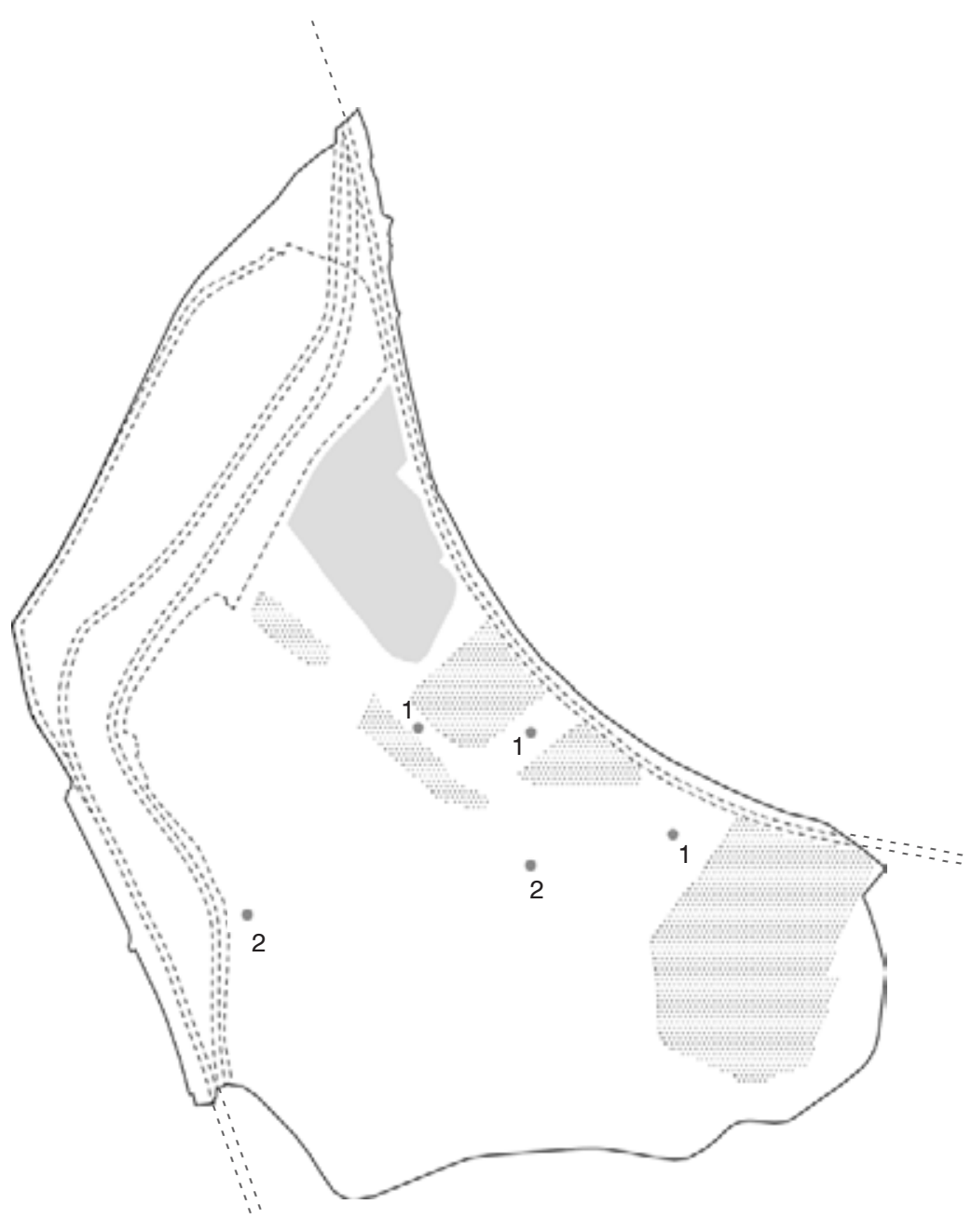

\footnotetext{
Mancha urbana Tejido informal

$\because$ Infraestructura Divienda popular
}

Vacíos

PELICULAS RODADAS

1. Cerca de la ciudad (Lucía)

2. Entre vías (Cordoba)
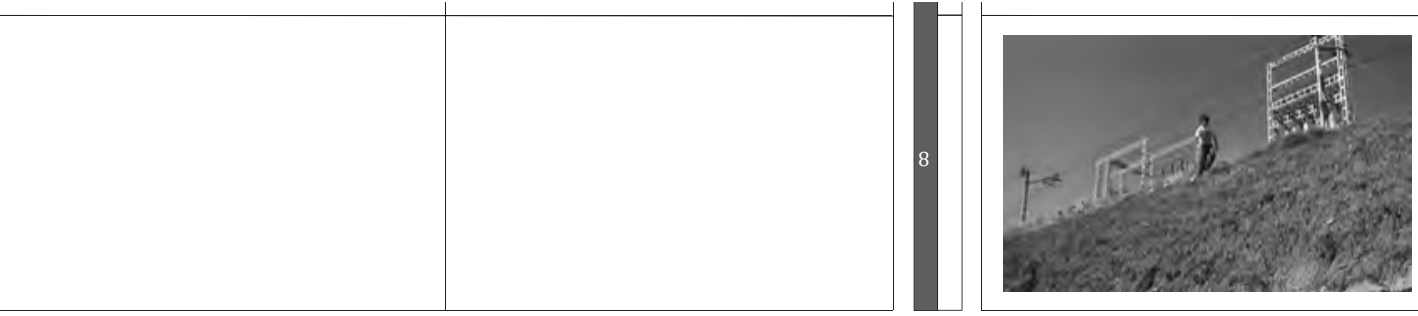

MD 8. Entre vías (Córdoba). Lás vías del Ferrocarril 
Otra secuencia del rodaje que podemos ubicar entre el Pozo y Entrevías es un plano general que representa a dos niños que recogen desechos en un basurero, y encuentran un recorte de periódico con un artículo sobre el cura y su labor en favor de los niños del barrio. En este plano el límite está constituido por el encuentro del basurero, con la pradera atrás y el caserío al fondo que cierra el límite superior del encuadre; de la basura sale humo, y otras personas están recogiendo material del suelo, al fondo un asentamiento informal que podría ser El Pozo, y una pradera con colinas y algunas sendas; en el horizonte el skyline de Madrid, que podría corresponder a la periferia Suroeste de Carabanchel. Es una imagen dramática, que el tono alegre del diálogo de los dos niños ${ }^{75}$ no logra disminuir (F.3.4.2/3).

\section{FLORES DE LUNA}

El documental Flores de Luna, de Juan Vicente Córdoba, reconstruye la historia de estos lugares que fueron unos de los asentamientos informales más extensos de la capital española, que aparecen en Cerca de la ciudad, y que probablemente fueron utilizados también en otras películas que necesitaban ambientar la escena en barrios chabolistas. En este lugar se desarrollaron dos intervenciones de vivienda pública: una es la de Entrevías, que hemos encontrado en algunos documentales NO-DO, tanto en construcción como recién acabada (1956); la otra intervención, de la cual habla Flores de Luna, se realiza en el Pozo, finalizada hasta 1983, después de años de luchas por parte de los pobladores para ser reconocidos y apoyados en la construcción de viviendas dignas. En la toponimia, el lugar toma el nombre de "Pozo del tío Raimundo". El tío Raimundo parece ser un hombre que mandó a construir un pozo para dar de beber a las caballerías de hortelanos ${ }^{76}$.

En la actualidad no quedan restos del pozo y ni siquiera venía señalizado en los parcelarios agrarios. "El Pozo del tío Raimundo se halla en el antiguo terreno de Ahijones y sus primeros habitantes empezaron a llegar en 1925 año en el cual se construyeron una taberna al borde de un paso de nivel de ferrocarril y una vaquería. En dicho año llegó un vecino de Martos (Jaén) en busca de trabajo. Estas tres edificaciones eran las únicas existentes antes de la guerra civil. Entre 1940-1947 llegaron siete familias al pozo tres de ellas procedentes asimismo de Martos. Es a partir de 1948 cuando van a llegar los inmigrantes procedentes de Ciudad Real, Córdoba y Toledo. Empieza el fenómeno del chabolismo: se va consolidando un tejido denso de casas asentadas según un trazo de calles paralelas con dirección principal según el eje NoresteSuroeste. Se distinguen tres zonas de asentamientos chabolistas: la primera que se denomina Entrevías viejo, está caracterizada por ser un barrio de ciudad informal con bandas de edificación de treinta metros y calles bastante anchas. Es una zona que se irá consolidando y las viviendas más modernas y dignas substituirán a las más antiguas manteniendo el antiguo trazado. La parte de chabolas más al Este era un asentamiento más precario, con un tejido más denso y una orientación de la manzana más parecida a la del futuro poblado dirigido. Al otro lado de la ronda del Sur, la zona ocupada por el actual barrio del Pozo, fue una zona de infraviviendas que se quedó hasta finales de los '70, constituyendo una de los asentamientos informales más duradero de la capital.

Es importante la relación entre las chabolas existentes y la nueva intervención del Poblado de Entrevías, el primero de los poblados dirigidos proyectado y construido por Sáenz de Oíza, en 1956, con el apoyo de Jáime Alvear y Manuel Sierra. El poblado se construye con derribos parciales de las casas existentes. Se crea un proceso de modificación del tejido: el informal que poco a poco deja paso al del proyecto.

\footnotetext{
${ }^{75}$ Los chicos están muy contentos por el recorte de periódico porqué piensan llevarlo al cura y ganarse una merienda.

${ }^{76}$ (Alvear \& alii, Barrio de Entrevías, 1963)
} 


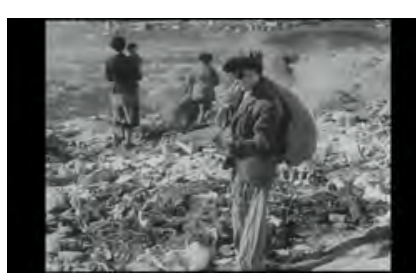

MD 8. Cerca de la ciudad (Lucía): Niños buscando en la basura en la s laderas de Entrevías: al fondo Madrid (hipotesis) 
En algunas imágenes aéreas tomadas durante el proceso de construcción del barrio y utilizadas para algunos noticiarios de NO-DO se ve perfectamente la "convivencia" entre las dos tramas urbanas ${ }^{77}$. En muchos casos los mismos dueños dejaban las chabolas para moverse a las nuevas casas autoconstruidas en un proceso de participación bastante logrado.

En estas imágenes, además, se aprecia la diferencia de escala, de geometría y orientación de la trama urbana y se percibe un orden cartesiano, una claridad y una salubridad que correspondían al del INV, que se ha analizado en el primer capítulo de esta tesis. La totalidad de las chabolas del denominado Entrevías Nuevo será derribada a principio de los años '60, para la construcción de los nuevos bloques y torres de viviendas.

En el plano de expropiación se representa la parcelación agrícola y las denominaciones de las distintas localidades: las tres fases del poblado se desarrollarán en una franja de territorio que comprende de Oeste a Este, y de Norte a Sur: Entrevías Viejo; Entrevías Nuevo; Ahijones; La Mesa Imagen; Las Sepulturas; Barrio obrero; La Viña; Cerro de la Plata. Las parcelas siguen el relieve topográfico pendiente hacia Suroeste y la división de las parcelas agrarias, se trata de lotes estrechos y largos en la mayoría de los casos perpendiculares a las sendas y a los caminos principales ${ }^{78}$. (F.3.4.2/4).

\section{GEOLOGIA, TOPOGRAFIA Y VEGETACIÓN}

El barrio nace sobre un terreno de naturaleza yesosa de elevada cota con pendiente hacia mediodía sobre el valle del Manzanares ${ }^{79}$. Se podría decir que Entrevías replica la estructura topográfica de la ciudad de Madrid entera. Morfológicamente se trata de terrazas aluviales excavadas por la acción del Manzanares y que hacia Sur se separan en tres plataformas semicirculares desde las cuales se aprecian unas vistas sobre Madrid y las cumbres de la sierra de Guadarrama. Por la importancia de los yacimientos paleontológicos y arqueológicos encontrados a lo largo de las terrazas del Manzanares la comunidad de Madrid en 1993 declaró la zona bajo la protección de Bien de Interés Cultural (BIC). La presencia de la Sierra es un elemento importante porque como en la ciudad árabe, Madrid y Entrevías tienen la Sierra protectora a su lado y a sus espaldas, esta condición está bien marcada desde la llegada por la estación de trenes en su puerta de acceso al barrio: la mirada hacia el Norte con la Sierra en el fondo es la primera imagen que tenemos en llegar.

La vegetación natural de la región, en la actual comunidad de Madrid, es el bosque mediterráneo de alcornoques y encinas que se alterna a praderas, trigales y pastizales. El contraste entre el valle del Tajo y del Manzanares y las montañas, dan a la comunidad autónoma de Madrid una notable variedad ecológica. En las zonas alrededor del Manzanares como para otros ríos de la comunidad, prevalece la vegetación de ribera de los humedales y también pequeños bosques de olmos, fresnos y chopos. Las actividades agrícolas también han condicionado la morfología del paisaje de la comunidad, principalmente en el área del futuro barrio de Entrevías; la mayoría de las parcelas agrícolas son campos de cereales y algunas huertas: esta iconografía de los campos de Castilla, permanece.

\footnotetext{
77 Noticiario NO-DO "Sesenta mil viviendas" (1965)

${ }^{78}$ Todos los documentos originales del Proyecto de Ejecución del Poblado dirigido de Entrevías de F.J. Sáenz de Oíza, J. de Alvear Criado y M. Sierra Nava, citados en este trabajo de investigación han sido consultados en el ACMFE Archivo Central del Ministerio de Fomento de España.

79 (Moneo, El poblado dirigido de Entrevías, 1961 p.7)
} 


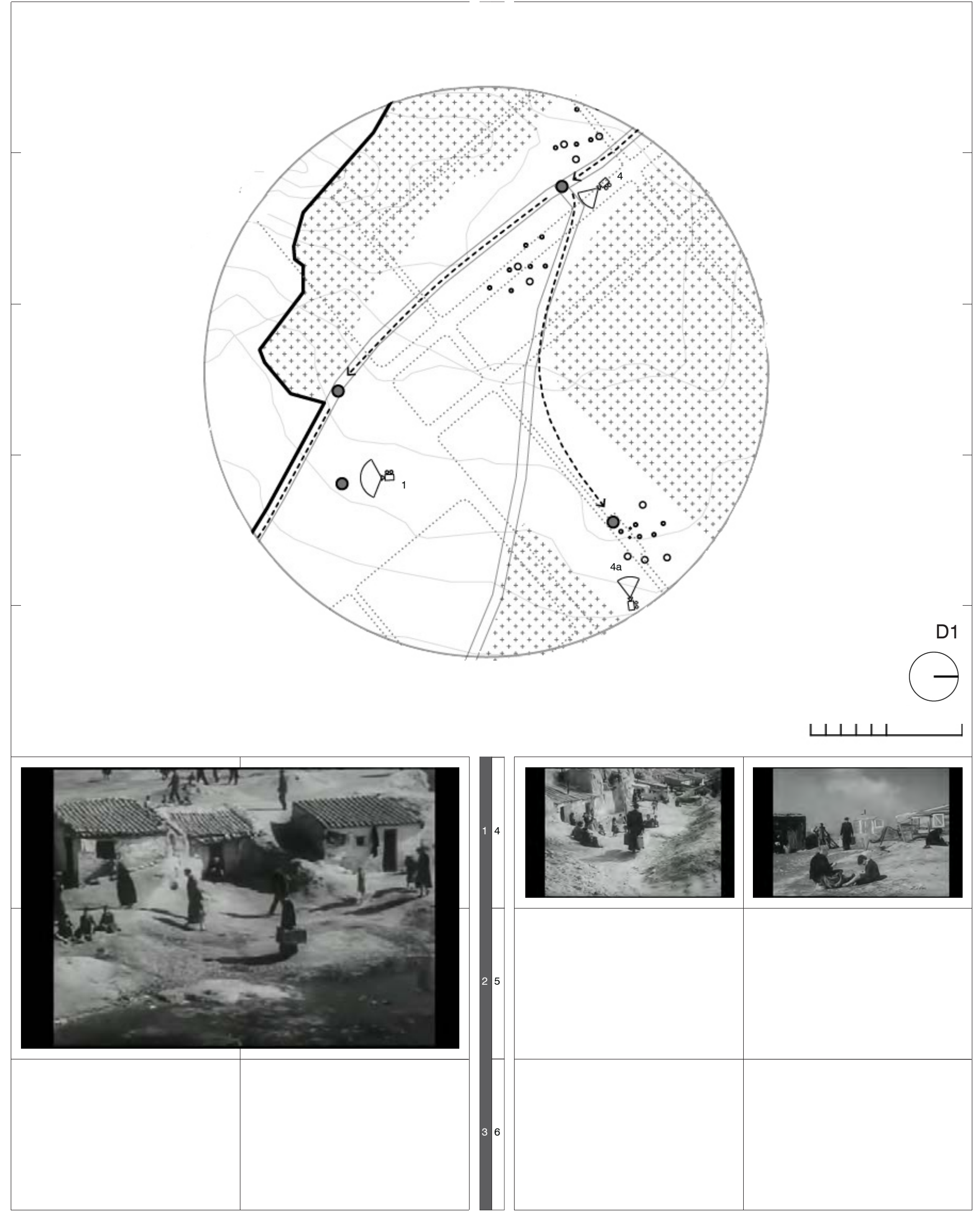

MD. Movimientos de cámara

1. Panoramica: Chabolas con drenaje (hipotesis Entrevías)
MD. Movimientos de cámara

4. Plano conjunto: asientamiento en la ladera (hipotesis Entrevías)

4a. Plano conjunto: vista del asientemiento hacia sureste.

\section{MADRID}


PAISAJE: ENTRE TRIGALES Y CHABOLAS.

Unos versos de Antonio Machado nos dan la imagen del paisaje de Entrevías, así como lo encontraron los primero pobladores: "Oh tierra triste y noble, / la de los altos llanos y yermos y roquedas, / de campos sin arados, regatos ni arboledas (...)"80. Cuando se empezó a construir el poblado dirigido, las chabolas ya habían invadido todos los terrenos, y solamente algunos trigales marcaban el límite de la ciudad. Los asentamientos informales ocupaban un territorio en prevalecencia agrícola con campos de cereales, huertas y algunas aldeas que representaban un paisaje típicamente castellano. Rafael Moneo describe el Paisaje de Entrevías casi imaginando esta fase de pasaje en la cual todavía no había empezado el crecimiento rápido de los años '50: "El paisaje es allí extraño las ultimas casuchas de la ciudad con los primeros campos de trigo, con los primeros rebaños. En una de Ellas leemos el teléfono del dueño: <parcelas buen precio>. Todo al nuestro alrededor está como quemado: no crece la hierba. Una acacia empolvada. Postes de alta y baja. Los silbidos del tren. Los gritos de los niños. Vendedores de agua y de tomate. Al fondo el Cerro de los Ángeles, como azul y el murmullo del Madrid, como un mar". ${ }^{81}$

Antes de 1936 había un pequeño núcleo urbano, el único de este lado del ferrocarril, no distante del núcleo de Vallecas y de sus expansiones y actualmente denominado Entrevías Viejo. El crecimiento de chabolas en esta zona conservó el trazo bastante regular de las antiguas calles ortogonales al ferrocarril, y muchas chabolas se enquistaron entre las edificaciones existentes. Esta parte de Entrevías no fue objeto de planes de absorción del chabolismo, y solo a partir de 1958 se presentó el proyecto de demolición y reconstrucción, siempre conservando el trazado original. Otro gran núcleo construido que se formó a partir de la emigración del 1952 y 1953, es el denominado Pozo Viejo, ubicado en el lugar hoy ocupado por el moderno barrio del Pozo, así como en Entrevías Viejo. En los años 1955 y 1956 se edificó el mayor número de chabolas, hubo domingos en los cuales se llegaron a levantar hasta cincuenta; es en esta temporada que nacen otros cuatros núcleos espontáneos en el área hoy ocupada por el barrio de Entrevías, crecidos muy aprisa, con condiciones de vida muy bajas. Algunos documentos fotográficos de la época, ya analizados en el primer capitulo, describen el paisaje físico y social que caracterizaba las áreas del futuro poblado dirigido: se trata de imágenes que revelan condiciones de vida extremas y un paisaje totalmente desértico. En algunas fotos vemos la llegada de un cura en visita a una chabola, (F.1.1.1/1). En otras dos fotos, aparece la inauguración del alumbrado del Pozo del tío Raimundo, aparece una fiesta de barrio y muchas personas celebrando la llegada de la luz; (F.4.3.3). En las vistas áereas del documental NO-DO 60000 viviendas, con Entrevías en construcción, se percibe el paisaje inhóspito descrito, el paisaje de Cerca de la ciudad de Luís Lucía: los campos agostados junto a los montículos de escombros y a las pocas maquinarias empleadas en la obra; la colonización del territorio que se produce primero con la construcción de las manzanas, y luego los sistemas de conexiones. Los fotogramas describen los problemas que mencionan los mismos autores del proyecto del Poblado dirigido: la falta de agua antes de todo, y la total ausencia de infraestructuras que complicaron la construcción. El famoso pozo del tío Raimundo, solamente servía para alimentar las actividades de algunas aldeas de la zona y pronto con la creciente urbanización se perdieron sus trazas. Las plataformas áridas sobre el valle del Manzanares, no tenían condiciones para un fácil suministro hídrico. Así que los albañiles que construyeron estos poblados, tuvieron que trabajar en condiciones mínimas, sin tener agua a disposición ${ }^{82}$.

\footnotetext{
80 (Machado \& Ribbans, 1989)

81 (Moneo, op.cit., p.7)

82 (Sáenz Guerra \& Alberdi Jimenez, 1996 p.70)
} 


\subsection{Recorridos y exploraciones de los cineastas.}

\subsubsection{Los viajes de las cámaras: topología del rodaje.}

Los situacionistas, el movimiento Fluxus, y antes de ellos, los dadás y los surrealistas, anticiparon las experiencias de los land-artists de la segunda mitad de los sesenta, en la exploración de nuevos territorios dentro del espacio urbano. La importancia de estos movimientos artísticos estuvo en la posibilidad de concebir la obra de arte desvinculada de su materialidad física: el mero acto de caminar se convirtió en "práctica estética", en un proyecto de manipulación del espacio y del tiempo.

Las exploraciones realizadas por los directores neorrealistas a partir de los años ' 40 en lugares desconocidos de Roma y Madrid, anticipan algunas de las experiencias de la Land-art y son contemporáneas a las de otras vanguardias artísticas, como el situacionismo. Los directores, en búsqueda de los decorados más adecuados, ejercieron una acción concreta sobre el territorio a través de recorridos que, con la recomposición del montaje cinematográfico, se convertirían en una visión crítica del territorio explorado. Como estos directores, algunos Landartistas como Amish Fulton concibieron su obra como largas caminatas y exploraciones; lo que luego se expone en la galería de arte es una especie de bitácora de la experiencia artística realizada, un reporte de lo ocurrido, análisis e investigación al mismo tiempo ${ }^{1}$; de la misma manera podríamos entender las películas cinematográficas como una síntesis de lo ocurrido en la realidad del rodaje, una síntesis estético formal de las experiencias y exploraciones urbanas realizadas antes y a lo largo del rodaje: se trata de una arqueología del escenario, "el trabajo que precede, que sigue, o que atraviesa las propias filmaciones" ${ }^{2}$.

En este trabajo de investigación se ha analizado, en la mayoría de estas películas, cómo el nomadismo y la deriva prevalecen sobre las acciones de quedarse y demorar; los directores y los autores de las películas neorrealistas llegan a desarrollar una nueva iconografía de Roma y de Madrid a través de una nueva "topología del rodaje", y de la posibilidad del montaje cinematográfico de yuxtaponer puntos de vistas y encuadres. Si en muchos casos, sobre todo en Italia, la Arquitectura interpretará al Neorrealismo por sus aspectos más superficiales, convirtiendo en estilo arquitectónico los aspectos culturales nostálgicos que se han analizado en esta tesis bajo la definición de "paisaje-tiempo", por otro lado, algunas intervenciones de vivienda colectiva de la época se acercarán a esta nueva lectura más profunda del paisaje urbano ofrecida por el cine. A partir de la iconografía del "paisaje-movimiento" y del "paisajeausencia", se ha identificado una nueva ciudad que "se presenta como un espacio del estar, atravesado por todas partes por los territorios del andar" ${ }^{3}$ Se trata de una nueva ciudad en donde se ha generado una red de territorios, nuevos paisajes interconectados entre ellos:

"han crecido unos espacios de tránsito unos territorios en constante transformación, tanto en el tiempo como en el espacio, unos océanos recorridos por una multitud de extranjeros que se ocultan en la ciudad. Ahí surgen nuevos comportamientos, nuevas maneras de habitar, nuevos espacios de libertad. La ciudad nómada vive en ósmosis con la ciudad sedentaria, se nutre de sus desechos ofreciendo a cambio su propia presencia en tanto que nueva naturaleza.

\footnotetext{
1 (Fulton, 1990)

2 (Mancini \& Perrella, 1986 p.228)

${ }^{3}$ (Careri, 2002 p.154)
} 
Es un futuro abandonado generado espontáneamente por la entropía de la ciudad"4.

Hemos analizado el movimiento en relación al tiempo como esencia de la materia fílmica, un movimiento que pone en relación los personajes con el espacio, con los objetos, la Arquitectura en el transcurso temporal de la acción. Hablando de Rossellini André Bazín describe las características de algunos de los personajes de sus películas:

"sus personajes están como obsesionados por el demonio de la movilidad: los hermanitos de Francisco de Asís ${ }^{5}$ no tienen otra manera de dar gloria a Dios que las carreras. Y lo mismo pasa con la alucinante marcha hacia la muerte del niño de Germania, anno zero. Es que el gesto, el cambio, el movimiento físico, constituyen para Rossellini la esencia misma de la realidad humana. Es también el atravesar los decorados, cada uno de los cuales de paso, atraviesa todavía más a los personajes" 6 .

En el Neorrealismo es difícil distinguir el movimiento de la escenografía, por eso coincide la película con la existencia de sus personajes, una realidad que no "significa acumular apariencias; es más bien despojarla de todo lo que no es esencial"7 para que quede solo lo que es puro, como el rodaje del movimiento de los personajes.

Esta esencialidad en la grabación del movimiento es un recurso para fortalecer la idea de realismo que necesita una nueva técnica cinematográfica, un trabajo sutil de la cámara que sigue, como en el cine de Antonioni, el movimiento de los personajes. En el Cine del director de Ferrara, "solo en los movimientos son reales el tiempo y el espacio" ${ }^{8}$. Para desarrollar esta técnica es necesario un conocimiento anterior del espacio, un levantamiento mental y real de la escena para construir sutiles arquitecturas de relaciones entre los personajes, los objetos del decorado y el lugar.

Como plantea este trabajo de investigación el movimiento de la cámara en la ciudad es una de las acciones "proyectuales" desarrolladas por los directores y que construyen el nuevo paisaje urbano. La superposición de las cartografías realizadas en el capítulo anterior genera un nuevo paisaje, constituido por los movimientos de los recorridos de los cineastas en el territorio.

Iñaki Abalos subraya la importancia de las nuevas técnicas paisajísticas desarrolladas por Uvedale Price a finales del siglo XVIII y sus analogías con el lenguaje cinematográfico; fue con Price que surgió la noción del pintoresco y se desarrolló una nueva forma de mirar el paisaje que "introduce la idea de la sucesión y con ella la duración de la experiencia estética; algo que demanda una técnica nueva, la de organizar el espacio en el tiempo mediante recorridos entendidos como secuencias concadenadas"; en esta nueva mirada de Price encontramos toda una analogía con la técnica cinematográfica en la cual el director como un paisajista, selecciona un recorrido y la organización escenográfica de los diferentes escenarios. La visualización gráfica del recorrido, propuesta en esta tesis, cobra importancia al ser la representación de esta organización escenográfica y de las conexiones entre espacio y tiempo en la narración cinematográfica.

\footnotetext{
${ }^{4}$ Ibídem p.157

5 Se trata de la película de Rossellini "Francisco juglar de Dios" (1950)

${ }^{6}$ (Bazin, 1990, pp. 389-390)

7 lbídem

${ }^{8}$ (Ropars-Wuilleumier, 1964 cit. García Roig, 2005 p.40)

${ }^{9}$ (Gostoriza \& et, 2007 p.135)
} 
En la época del nacimiento de la estética pintoresca encontramos otra analogía con el mundo del Cinema, "como consecuencia del interés por el movimiento del observador en relación a la organización coreográfica de los escenarios, se extiende el interés por la técnica del paralaje, por el cambio en la presencia de las cosas que deriva del movimiento y posición de los observadores" ${ }^{10}$, técnica presente en toda la Cinematografía neorrealista.

La selección de decorados y las conexiones establecidas por los directores entre estos lugares, a lo largo del rodaje cinematográfico, constituyen una operación estética en la ciudad y una nueva lectura del paisaje de las capitales española e italiana. Un gran cambio en la relación Cine y Ciudad se estableció en la Posguerra con la preferencia por los decorados en exteriores, y con la mayor movilidad de la cámara: "con la movilidad de la cámara, la ilusión del viaje será característica inherente a toda narración fílmica, considerable siempre como relación significante entre diversos espacios" 11 .

El nuevo paisaje urbano, descubierto por los directores es un territorio umbral, un paisaje no definido en el cual la imagen de Roma y Madrid aparece "borrosa", la suma de arrabales, lugares abandonados, paisajes de ruinas y escombros, que los directores encuentran también en las áreas más céntricas de la ciudad. El paisaje creado por los cineastas neorrealistas es una nueva visión urbana que influencia la producción y la visión del espacio urbano real en la Posguerra de Italia y España, una metáfora invertida respceto a la que se presentaba antes de la guerra, en la cual en el cine se representaba la ciudad, y esta con su potente iconografía influenciaba el espacio cinematográfico. Como los nómadas, los directores construyen un espacio de vectores y recorridos que permanecen en el lugar y como los Land-artistas, los dadá, los surrealistas y los situacionistas, hacen del deambular en territorios urbanos y suburbanos desconocidos, una experiencia estética novedosa; los protagonistas de las películas trazan vectores que no solamente existen en la imagen fílmica, sino que toman parte de la memoria colectiva del lugar, generando un paisaje cultural que permanece en el tiempo.

(F.4.1.1/1).

10 (Abalos, Estética pintoresca, arquitectura y cine, 2007)

11 (Vila Mustieles, 1997 p.147) 


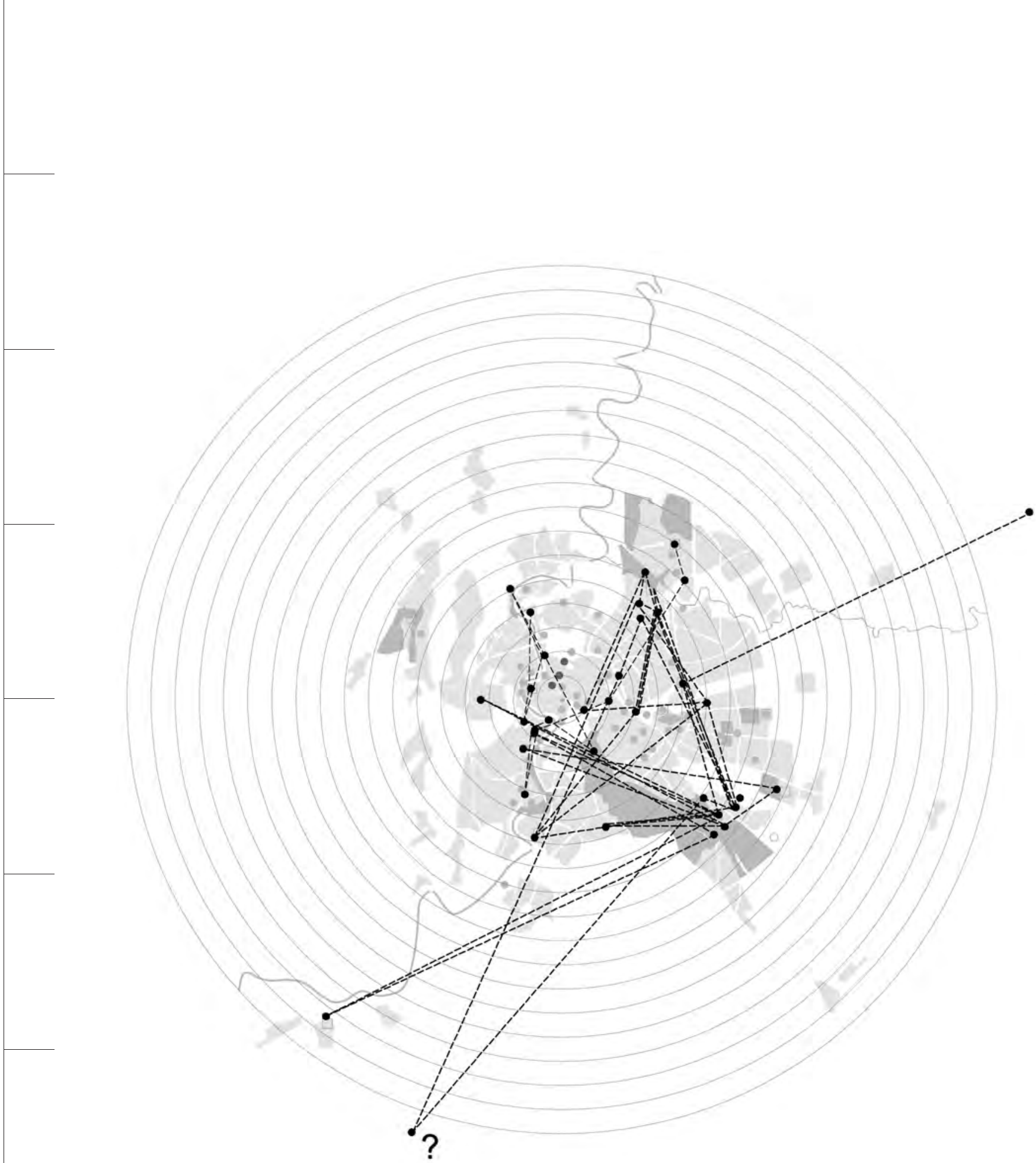

RM : Suma de decorados y vectores 
En la cinematografía analizada, la relación establecida con el espectador es de tipo dinámico; aunque este "ocupa un asiento fijo, está en constante movimiento, identificado con el objetivo de la cámara, que varía sin cesar la distancia y dirección. Esta variación constante del punto de vista se traduce en la movilización del espacio presentado, que va mostrando sus diversas facetas y relaciones locales, del mismo modo que un edificio al ser observado en movimiento"12. Esta percepción "multipersperctiva" del espacio, típica de la visión del historiador Paul Frankl, que se refiere a una nueva forma de mirar el espacios arquitectónico, la podemos aplicar al paisaje urbano, que ya no es el paisaje estático, de postal, típico de las películas anteriores a la Posguerra, sino que tanto en Roma como en Madrid, se convierte en un paisaje de fragmentos, fotogramas que se suman en los ojos de los espectadores creando una imagen compleja de las capitales, un paisaje de contradicciones en constante movimiento: la imagen urbana termina de ser estática, un "fondo escenográfico", para volverse un paisaje dinámico en constante mutación, vivo y activo como los personajes.

Nos interesan, en este capítulo los resultados de este proceso de sobreposición de cartografías e iconografías con el fin de identificar no solamente las similitudes, sino también las diferencias entre la Ciudad Neorrealista de Roma y Madrid (F.4.1.1/2).

12 (ibidem p.148) 


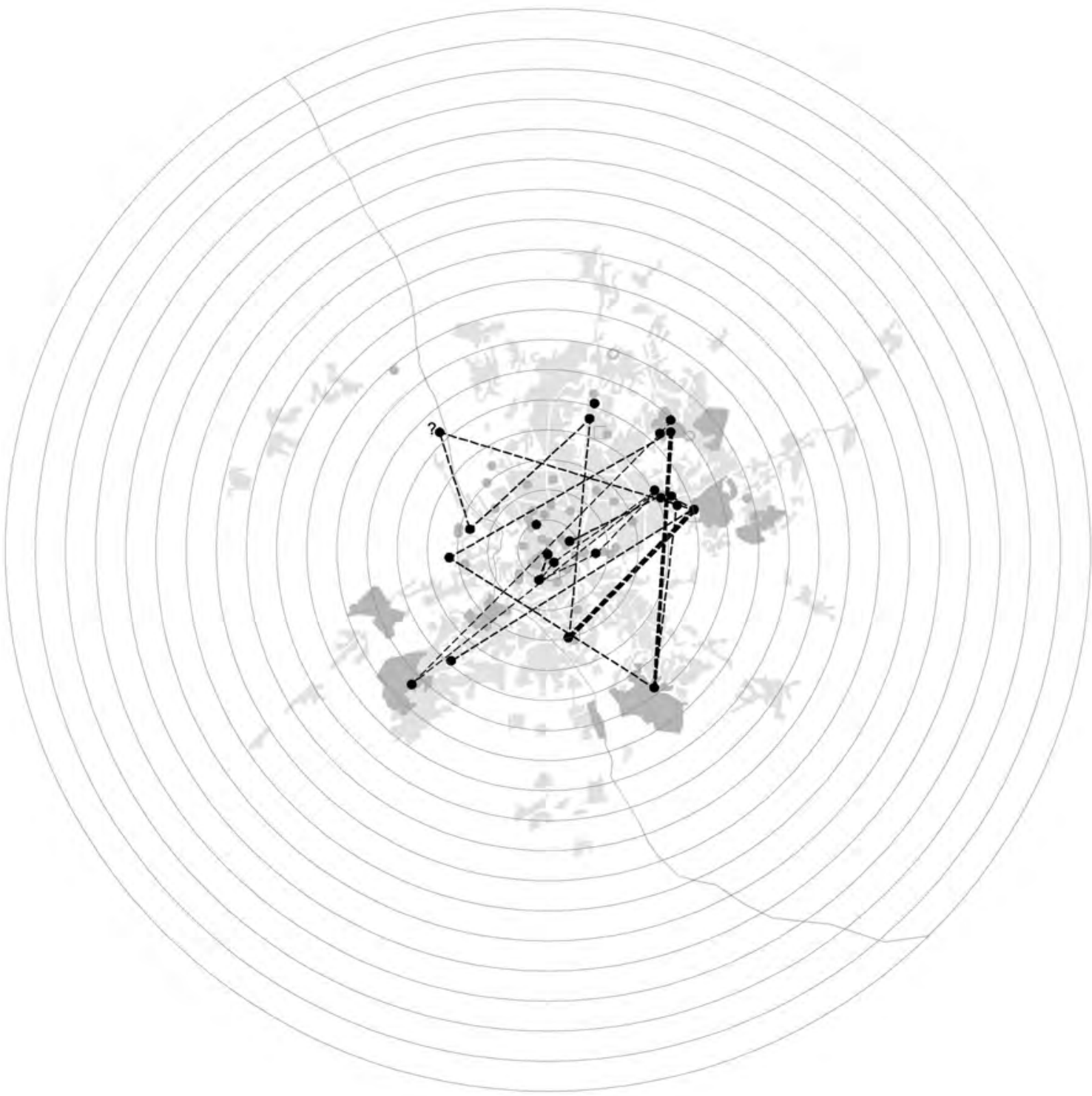

MD : Suma de decorados y vectores 


\subsubsection{Psicogeografias: Elipsis y montajes.}

En este paisaje-movimiento, podemos distinguir vectores que se producen a una escala urbano-territorial y los que se refieren a movimientos locales, que definimos como "viajes domésticos", y que es posible relacionar con los lugares donde los protagonistas viven, a una escala más reducida.

En la gran escala se han detectado tres tipologías de movimientos que corresponden a tres diferentes interpretaciones del espacio urbano. A cada ruta, corresponde una sedimentación de imágenes generada por el movimiento de las cámaras, que siguen a los protagonistas en sus viajes, experiencias de nomadismo y desplazamientos en diferentes lugares del territorio urbano, situaciones típicas de los guiones del Cinema Neorrealista. Las características de estos vectores nos permiten también de evidenciar diferencias entre el espacio urbano de las dos capitales.

\section{VECTORES LINEALES}

En las películas Ladrón de Bicicletas y Mi tío Jacinto, hemos detectado una tipología de recorrido representado por vectores lineales que se producen según una dirección prevalente: la de Este-Oeste, desplazándose los protagonistas desde el Este marginal de las dos capitales hacia el centro de la ciudad. Esta configuración geométrico-direccional del vector tiene que ver con el guión de las dos películas: se trata de la historia de dos viajes sin regreso al hogar: las dos películas concluyen con acontecimientos que marcan un antes y un después, produciendo una condición de crisis y de cambio quizá definitivo en las vidas de las protagonistas, que no permite la narración del "retorno al hogar".

Ya se había considerado visto una posible iconografía moderna del Tíber, como terrain-vague, en el episodio de los suicidas de Amor en la ciudad, película dirigida por Antonioni. De Sica fortalece esta imagen del río estructurando un recorrido a través de paisajes marginales: desde el descampado de Ostiense-Marconi en el sur de la Capital, con el Skyline de industrias y los inmensos descampados de la ciudad en construcción, hasta las laderas abandonadas de las zona del ponte Duca d'Aosta en el norte de la ciudad (en donde Antonio pierde de vista a Bruno y baja hasta la orilla del río, por una ladera polvorienta, bajo un puente monumental de arquitectura fascista, con su obscura arquería). La Roma que aparece en la pantalla es una ciudad con una espacialidad inédita y la iconografía de los suburbios se extiende hacia el centro de la ciudad.

En mi tío Jacinto, el viaje se produce desde la periferia marginal - na mezcla del barrio San Juan Bautista y de Carabanchel alto-, hasta lugares centrales, lugares típicos de la capital española, el Retiro, la Latina y el Rastro, con una etapa intermedia de gran importancia en la narración, que regresa al final de la película: la Plaza de Ventas. El centro en la película de Vajda, como en la de De Sica es una "centro-periferia", un poco más pintoresco del Tíber de Ladrón de bicicletas, pero igualmente popular y marginal, con la representación de las calles del Rastro y de la Latina. En la película de Vajda se generan vectores lineales que, sobreponiéndose, definen un único largo trayecto desde el extremo Noreste hasta el punto opuesto, el límite Suroeste, pasando por el centro histórico de la capital española. Vajda como De Sica opera una re-interpretación de los lugares, etapas de un largo viaje. El espacio exterior de Ventas se convierte en un enorme descampado lleno de basura, en donde los protagonistas buscan colillas que Jacinto recoge del suelo con movimientos de torero: se trata de una "des-monumentalización" de este espacio alejándose de cualquier pintoresquismo, un espacio en el cual los dos se mueven con prisa, para no ser alcanzados por los basureros, 
formado por puntos, líneas y superficies y rodado por el director, alternando diferentes planos generales y planos conjuntos.

En Madrid existen dos capitales que coexisten separadamente: esta condición de segregación sigue hasta el día de hoy. La "España vacía" según Sergio del Molino es un espacio del añorar ${ }^{13}$, del extrañar un pasado que en la época Neorrealista era la España campesina, la de Jaén y Martos, de Castilla y de Extremadura. Este vacío es también un desierto real, se trata de el anillo vacío que rodea la capital hasta las costeras del reino y que se reproduce en escala reducida también adentro de la capital: un núcleo compacto y afortunado, rodeado por unas laderas desiertas (pobladas por los que vienen de fuera: migrantes y viajeros).

En Roma la situación es diferente y el espacio vacio se alterna a zonas más densas, creando un paisaje hibrido: un campo atreviesado por infraestructuras. En el recorrido por el centro, De Sica tiene la posibilidad de explorar territorios al margen como el río de la capital, que representa una frontera adentro de la ciudad, un corredor que conecta las periferias con el centro, una ciudad densa que de repente se convierte en vacío por las grandes laderas y los descampados alrededor del Tiber: De Sica toma esta posibilidad de poder utilizar planos más amplios, usa el río y sus alrededores como espacio de dramatización. En la Madrid de Vajda esta posibilidad está limitada: centro y periferia se hallan en una contraposición estética y espacial total. Así que el director utiliza una elipsis espacial para enriquecer la iconografía del viaje entre San Juan Bautista y el Centro, añadiendo el escenario de Carabanchel, con sus amplios descamapados con infraestructuras. Después del viaje de Bruno y Antonio desde la periferia extrema, se produce otro viaje alrededor del Tiber, que permite a los dos protagonistas moverse con rapidez, casi para no perderse en el Laberinto del Centro, que los dos parece no conocer bien. Este laberinto del casco histórico, en cambio, es un lugar de oportunidades para Pepote y Jacinto así que, por gran parte de la película, la acción permanece en este sector de Madrid. Los protagonistas de Mi tio Jacinto se desplazan de una cabaña aislada, rodeada por un pueblo informal y una ladera desierta, hacia "otro pueblo" que es el centro de la capital. El recorrido a lo largo de Ladrón de bibicletas, articula distintos fragmentos de la ciudad, entre un fragmento y otro se abren espacios desiertos; en Mi tío Jacinto no hay alternancia, se pasa del desierto de la periferia a la densidad del centro: es en este lugar que los dos protagonistas parecen ganar optimismo a pesar del fracaso. En la película española, la zona central de Madrid parece un lugar en el cual poder recobrar una identidad; en Ladrón de bicicletas no hay lugares en los cuales recuperar dignidad y esperanza.

Dentro de los "viajes domésticos", los movimientos que los protagonistas cumplen en su entorno más familiar, en Ladrón de bicicletas los protagonistas de la familia Ricci definen cuatro vectores, dos perpendiculares y los otros dos paralelos al conjunto habitacional.

En Mi tío Jacinto, la cámara no sigue totalmente el movimiento de Pepote, quien se desplaza en el lugar donde vive con su tío, la chabola y el gran descampado bajo la iglesia de San Juan Bautista, sin embargo, las escenas rodadas nos permiten reconstruir lógicamente el recorrido que el pequeño cumple en búsqueda del desayuno y del dinero para pagarlo; se trata de un recorrido circular de una hora, alrededor de su casa, de 8 a 9 de la mañana, de la casa hacia la tienda en la "Quinta de la Paloma", y del anfiteatro natural donde juegan los niños de regreso hacia la chabola. A través de este itinerario descubrimos la condición de vida de los protagonistas, el aislamiento de su vivienda, aspecto fortalecido por la difícil topografía del lugar, por las inundaciones y por la hostilidad de los vecinos. En particular la topografía

${ }^{13}$ (Molino, 2017) 
domina la existencia de los protagonistas, los separa físicamente y psicológicamente, dificulta los movimientos, hace que las lluvias se vuelvan peligrosas y que la casa se inunde. Pepote se desplaza en las zonas alrededor en búsqueda de lo esencial para vivir: comida, dinero y diversión, después de encontrarlo, solo le queda regresar a la vaguada escondida en donde vive, despertar a su tío y empezar su viaje hacia la ciudad. En general, en comparación con los recorridos de Pepote que producen vectores que siguen las curvas de nivel de la topografía natural, alrededor de la chabola donde vive con su tío, los recorridos de Antonio Ricci son más rigidos, limitados y condicionados por la presencia del grande bloque de vivienda social, que, a pesar de todo, representa para ellos el punto de partida para construir su nueva vida como ciudadanos.

\section{POLIGONOS ESTRELLADOS}

Geometrías poligonales, en forma de estrellas, están definidas por los vectores de los recorridos urbanos realizados por los protagonistas de El techo y Los Golfos. En la película de Saura, los protagonistas, a diferencia de las dos analizadas anteriormente, son "dueños" de su propia ciudad; tienen un barrio y un hogar de referencia, se mueven con seguridad en él, y la construcción del lugar a través de los movimientos de los protagonistas coincide con la geografía de este sector de la capital española, sin incongruencias; sin embargo, prefieren desplazarse más lejos para aprovechar las oportunidades que la ciudad ofrece, y que no tienen en su lugar de origen: Madrid aparece como una ciudad extensa, con paisajes muy diferentes entre ellos, un collage urbano del cual no es fácil identificar las conexiones, un mapa mental que tenemos que reconstruir a partir de la geografía urbana de la capital, con territorios muy lejanos y sin congruencia entre ellos. Los vectores de este espacio complejo no siguen una única dirección y se cruzan en diferentes puntos del mapa de la capital, trazando una estrella con cinco vértices. En esta "polarización urbana", el centro solo es uno de los muchos puntos que forman una constelación de lugares periféricos, cada uno utilizado para diferentes actividades criminales. La imagen del espacio urbano presente en la película de Saura corresponde al estilo del director, quien estructura la narración por secuencias independientes: "la obra, del mismo modo que está abierta temporalmente, lo está espacialmente. El espectador es el que debe reconstruir los lugares los recorridos y los movimientos de los actores" ${ }^{14}$. Los "viajes domésticos" de los protagonistas describen una condición de aislamiento del barrio en el cual regresan a dormir; se trata de vectores que, a partir del Puente de La Elipa, desvían hacia una zona con márgenes indefinidos, que las tomas rodadas en las nieblas del amanecer contribuyen a crear. Estos movimientos exactos describen el gran vestíbulo vacío que separa el arrabal de la ciudad, donde solo se ubica una fuente. El puente representa una gran frontera que los habitantes atraviesan, alejándose de la ciudad formal. El mismo recorrido de esta travesía está presente en El techo, de De Sica, los protagonistas necesitan buscar un lugar escondido, un espacio residual, separado visualmente de la ciudad "oficial". La condición topográfica del Fosso de Sant'Agnese y la presencia del Ferrocarril, dificultan el movimiento que desde la Avenida Etiopía lleva a el lugar escogido por la construcción de la chabola; otros vectores de movimiento definenen las características del lugar: la bajada hacia el Río Aniene para el abastecimiento de agua y la llegada de algunos vecinos del cercano conjunto de chabolas, realmente existente.

En la película El Techo, tanto como en la película de Carlos Saura, la ciudad aparece un cual territorio de conexiones complejas entre lugares distantes, entre los cuales la pareja protagonista se mueve para construir su vida. En la vida urbana de Roma en 1956, los lugares donde ganar dinero, alojarse, cultivar afectos y relaciones familiares, descansar y divertirse, aparecen segregados y distantes: las constantes idas y venidas representadas por los

\footnotetext{
14 (Deltell \& Garcia Fernandez, 2006 p.265)
} 
vectores trazados en el mapa son la confirmación de una ciudad cada vez más extensa; ya no hay solo un movimiento pendular, sino múltiples movimientos en las áreas periféricas, con el centro que queda fuera de estos recorridos; los extremos de estos vectores son "vacant lot" lugares en construcción que revelan una ciudad demasiado extensa y segregada. El nuevo paisaje urbano, aparece en las ventanillas de un autobús, es un paisaje dinámico construido por frames no hay tiempo para detenerse y observar, la nueva iconografía se imprime rápidamente en el subconsciente de los personajes. Esta nueva imagen urbana que se va generando, por etapas es un conjunto de lugares anónimos: andamios, carreteras, descampados, barrios populares en construcción, infraestructuras, praderas y ríos. Reconocer que las películas están rodadas en Roma y Madrid ya no es tan fácil: pocos fotogramas describen una vista del Coliseo de noche (en la oscuridad), mientras que en Los golfos la única imagen que podría hacer pensar a la capital española es la del estadio de Chamartín.

En El techo, la vida y los desplazamientos en la ciudad se producen a lo largo del perímetro de un triángulo que pone en relación con los vértices, tres distintas periferias de la ciudad sin tocar el centro: el Tuscolano, Ostiense-Marconi y el Nomentano. Antes de empezar esta triangulación casi obsesiva de la capital, la pareja, después de la boda, viaja hacia un pueblo no identificado, probablemente en la costa del Mar Tirreno, no lejos de Roma, y de ahí regresan a la capital llegando al barrio Tuscolano, lugar lleno de obras, que se llena de esperanzas en los ojos de los dos jóvenes. En el baricentro del triángulo está el barrio de San Lorenzo, en donde los protagonistas buscarán rentar un departamento en un edificio que será evacuado por peligro de derrumbe: este intento naúfrago en el que fue el barrio histórico del Neorrealismo, es casi el símbolo del fin de una época, un cambio en la ciudad que De Sica representa con esta obra cinematográfica.

La ciudad y los recorridos descritos por Saura describen la ciudad actual que se ha definitivamente polarizado según una lógica de división socio-economica. Los protagonistas cumplen sus recorridos para saquear la ciudad formal, su mapa territorial corresponde a las ocasiones para ganar dinero robando y delinquiendo; su conocimiento se extiende hasta el subsuelo de las líneas de alcantarrillado, que utilizan para escapar. Saura, a través del montaje fragmentado de su estilo, refuerza esta cartografía alternativa de la capital española. En este collage el elemento castizo tiene un valor iconográfico importante, porque define un paisaje cultural que es motivo de orgullo para sus habitantes: una fusión entre periferias industriales, informalidad y cultura campesina de los pueblos de origen, principalmente andaluces. La guitarra flamenca que enmarca con sus melodías las largas panorámicas del barrio de La Elipa en el almanecer, está describiendo el amanecer de un pueblo dentro de una metrópolis. Solo algunas tomas exteriores de la chabola de uno de los protagonistas nos recuerdan que se trata de infravivienda suburbana. Otros elementos de esta Madrid rural son la placita de entrenamiento de Ventas, que como ya hemos subrayado parece un fragmento de Andalucía en la capital, y la explanda con la fuente al lado del puente, que separa la ciudad del arrabal, constituyendo una verdadera frontera entre dos mundos. Los protagonistas "despojan" a la ciudad para luego regresar a su "pueblo", sin embargo, estos hijos de migrantes andaluces, de Jaén o de Martos, no se esconden, ya son ciudadanos que intentan llevar su cultura dentro del territorio urbano. En El techo de De Sica, el recorrido de Natale y Luisa, que tiene la misma estructura poligonal del recorrido propuesto por Saura, no incluye un punto de referencia, un hogar; es solamente al final de la película que los dos protagonistas logran convertirse de nómadas en estanciales, construyendo su propia chabola: todo lo contrario de Los golfos, que son estanciales que vivien gran parte del día como nómadas. 
Todos los personajes analizados hasta ahora, incluyendo a Pepote y Jacinto (quizá los únicos que parecen haber nacido en Madrid), actúan como migrantes y buscan construir su propio mapa de la ciudad a través de las oportunidades que encuentran. El Abroñigal (actualmente ocupado por la autovía M-30) parece ser una frontera de separación insuperable, que divide dos mundos inconciliables: esta frontera es un vacío enorme.

En El techo, los protagonistas ocupan estos vacíos residuales, generados por la presencia de infraestructuras naturales y artificiales: los protagonistas de las películas italianas parecen aprovechar estos espacios para no alejarse demasiado de la ciudad, quieren ser parte de ella. Otra vez la diferencia entre las dos capitales, española e italiana está en esta dimensión rural, esta segregación clara entre dos mundos, ahí donde en Roma estos dos mundos casi logran coexistir en el mismo espacio, generando un territorio hibrido.

\section{ABANICOS}

El trazado de vectores en forma de abanico corresponde a los recorridos de los directoresprotagonistas en Mamma Roma y en Cerca de la ciudad; se trata de películas en las cuales el centro de la acción está en el barrio marginal donde los protagonistas residen. Los vectores trazados en los viajes de la cámara, corresponden a tímidas búsquedas, escapadas hacia una ciudad respecto a la cual los protagonistas son extraños.

En Cerca de la ciudad estos vectores solamente corresponden a miradas hacia el horizonte, ya que los protagonistas nunca salen de su barrio chabolista; estas miradas son elipsis espaciales que Luís Lucía añade para enriquecer la iconografía del arrabal. Los vectores generados por estos posicionamientos de cámara en el extrarradio madrileño definen un triángulo-abanico que como baricentro tiene la zona del Pozo del tío Raimundo.

Cerca de la ciudad, contrasta con las películas analizadas en esta tesis por la escasa articulación del trazado de recorridos: una película más estancial, respecto a la condición de nomadismo que prevalece en las otras obras neorrealistas, en ella los protagonistas nunca salen del arrabal. En la película de Luís Lucía muchos rodajes se realizan en interiores con secuencias casi de estilo teatral, y algunos de los decorados interiores están reconstruidos en Ios cercanos estudios CEA; sin embargo, por las escenas rodadas en decorados exteriores, Cerca de la ciudad se puede considerar como la película neorrealista con la iconografía del chabolismo más real, casi de Cine-documental, en comparación por ejemplo con Milagro en Milán, realizada solamente un año antes, en el 1951.

En Mamma Roma el sistema de vectores genera un abanico a partir del origen de todos los movimientos: el barrio Tuscolano, destino final y punto de partida para nuevos viajes. Ettore y su madre se desplazan en la ciudad que habitan, pero no la conocen realmente a fondo, casi la temen y creen haber encontrado un refugio seguro en el barrio popular en el cual se mudan a vivir; sus recorridos siempre son de breve duración y con un regreso al hogar. En la película de Pasolini el primer vector es el de Guidonia-Prenestino, el lugar de origen de la pareja. El segundo vector es el recorrido hacia el hospital de Tor Marancia, un barrio periférico cercano al Tuscolano hacia el Oeste, en donde Ettore encuentra su destino fatal. El tercer vector se direcciona hacia el centro, en los barrios de Trastevere y San Pedro, que corresponden al lugar de trabajo que Anna Magnani consigue para el hijo. Por último, los vectores hacia dos Barrios INA-Casa que enriquecen y fortalecen la iconografía de los nuevos conjuntos habitacionales, que corresponden al sueño pequeño burgués de Mamma Roma: el conjunto habitacional de Acilia a más de 10 kilómetros del Tuscolano, que Ettore y Mamma Roma recorren en ocasión del estreno de la motocicleta regalada por la madre al hijo; y el barrio de Torre Spaccata en el cual el protagonista se encuentra con Bruna (F.4.1.2). 

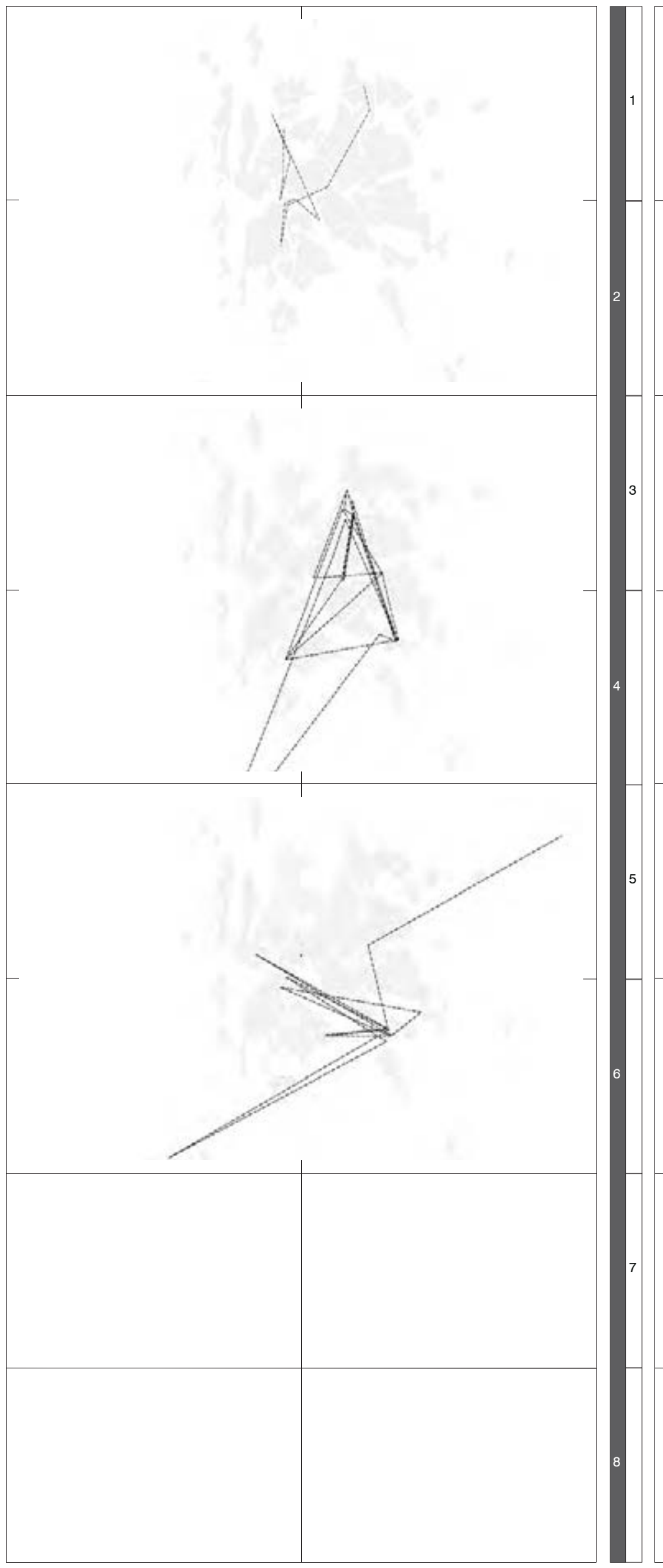

RM 1-2. Vectores: Ladrones de Bicicetas (De Sica)

RM 3- 4. Poligonos estrellados: El techo (De Sica)

RM 5-6. Abanicos: Mamma Roma (Pasolini)

MD 1-2. Vectores: Mi tío Jacinto (Vajda)

MD 3- 4. Poligonos estrellados: Los golfos (Saura)

MD 5-6. Abanicos: Cerca de la ciudad (Lucía) 
Estos últimos dos recorridos, desvelan un interés del poeta hacia este tipo de intervenciones arquitectónicas y su relación con el paisaje urbano. Los movimientos de Pasolini en la periferia Sureste de la capital en la película Mamma Roma, describen un collage periférico como los de Los golfos de Saura; sin embargo en Pasolini hay una descripción más articulada de estos espacios al margen de la capital, con una topología del rodaje más variada: todos lugares muy conocidos por Pasolini, por haber vivido ahí, por las frecuentaciones con los habitantes y por haber sido también las ambientaciones de sus obras literarias y periodísticas, anteriores a su actividad como director. Podemos decir que Pasolini más que cualquier otro director de la época, fue un gran conocedor de la ciudad periférica, "la ciudad neorrealista": por eso el radio de los recorridos cumplidos en Mamma Roma supera los 20 kilómetros: el más largo entre las películas analizadas. A pesar de la fragmentación típica del estilo cinematográfico de Pasolini, que como en Saura fortalece la función del montaje, la periferia de Pasolini es un lugar específico, geográficamente e iconográficamente coherente. La misma riqueza y variedad de los recorridos pasolinianos a escala territorial y urbana, está presente en la escala barrial y doméstica; podemos contraponer los movimientos lineales a lo largo de las calles principales del barrio, a las derivas que se desarrollan en la topografía del Parque de los Acueductos, entre ruinas y barrancass, una distinción clara y funcional a la narración cinematográfica en donde nunca se pierde la vinculación entre el paisaje y el movimiento de los protagonistas.

La imagen urbana presente en Mamma Roma y Cerca de la ciudad es la misma; los desplazamientos no cuentan como en Los Golfos o en El Techo, con un paisaje urbano diferente en cada escena: aquí toda la ciudad aparece como un único gran arrabal. Cualquier desplazamiento de la cámara o mirada panorámica describe una ciudad en la cual la periferia parece tener una superficie más extendida en comparación con el centro, un paisaje marginal sin límites que envuelve lo que era la "forma" original de la ciudad. Luís Lucía quiere marcar desde el principio una distancia física y psicologica dese la "verdadera" ciudad que el mismo titulo expresa, una lejanía que los encuadres panorámicos cuentan muy bien. En cambio, en Mamma Roma el espectador nunca duda de encontrarse en la capital; como subraya la protagonista, se trata de una Roma para una clase social respetable. Si en la película Cerca de la ciudad se pone en discusión si la vida de los protagonistas es una vida digna de un ciudadano, en Mamma Roma, como en la película de Saura, se presenta una ciudad que es un collage de periferias, una hiper-periferia deconstruida y reconstruida a partir de una selección de lugares de este sector de la capital italiana: una iconografía que siempre se refiere a la imagen de Roma, la Iglesia de Don Bosco con su cúpula enorme, las ruinas romanas y la campiña, el dialecto de los protagonistas, el estilo de la vivienda popular ${ }^{15}$ y los mercados. También los varios ejemplos de INA-Casa monstrados por Pasolini, como hemos visto en el capitulo anterior, confirman cierto interés de los directores italianos hacia la arquitectura contemporánea que se iba desarrollando, elementos menos presentes en el Cine español.

\section{RECORRIDOS ENTRE CENTRO Y PERIFERIA}

Ya se ha anlizado cómo varias películas de las dos cinematografías se rodaron en un sector entre centro y periferia que se ha denominado "Sector uno". La presencia de importantes estaciones de ferrocarril, de fábricas y vivienda popular, caracterizan esta zona en Roma entre la Via Casilina y la Estación de Termini, y en Madrid entre San Francisco el Grande, Delicias y Legazpi. Subrayando diferencias, podemos decir que en Madrid prevalece la iconografía del tejido industrial-productivo, mientras que, en Roma, el del residencial popular. Dos parejas buscando una vivienda se mueven por este sector: en El techo, los protagonistas no podrán rentar una casa en la zona de San Lorenzo (cerca de Termini), porque está a punto de caerse; en Madrid, la pareja de El inquilino, de Nieves Conde, deberá dejar su casa en este sector,

\footnotetext{
${ }^{15}$ Nos referimos al estilo del Barrio INA - Casa del tuscolano inspirado por cierta arquitectura vernacula.
} 
porque será derribada por una constructora para erigir nuevos alojamientos. La solución de irse a los arrabales es planteada por las dos parejas, y en los dos casos representa algo extremo, un último recurso. Natale y Luisa construirán una chabola al Norte de la ciudad, el matrimonio de $E I$ inquilino no encontrará tampoco esta solución y quedará en la calle (en la versión no censurada). La definición de estos barrios infromales en estas dos películas nos ayuda a definir la imagen que los directores perciben. El Prenestino, el barrio chabolista donde quieren ir a vivir no encontrando casas en renta, es definido por el último arrendatario como el lugar donde viven "Ios salvajes". El vendedor de la casa, en el arrabal que visitan los protagonistas de El inquilino, califica la vivienda "con vista a la ciudad", riéndose. La arquitectura de los arrabales rurales madrileños, es vernácula, parece a veces una arquitectura de Exteramadura o de Andalucía, así como aparece en esta escena de El inquilino; en Roma esta arquitectura informal es más bien una arquitectura de "sobrevivencia", una edilica hecha de desechos de la ciudad formal, que logra ser aceptada por las autoridades y poco a poco se convierte en formal ${ }^{16}$, fenómeno casi ausente en Madrid. Los directores describen e intuyen esta peculiar característica del paisaje urbano romano, una ciudad que parece no tener soluciones para estos problemas, simplemente los engloba dentro de su tejido en expansión. Al mismo tiempo los directores españoles intuyen que esta Madrid "vacía" que crece alrededor de la Madrid compacta, nunca será parte de ella.

En Roma hay una aceptación de una ciudad informal que convive con la ciudad formal; en Madrid parece que esta aceptación todavía no existe: los arrabales no son Madrid. Esto explica cómo estos arrabales madrileños han cambiado tanto el día de hoy y, al contrario de Roma, quedan muy pocos vestigios de este tejido informal y rural. La capacidad de Roma de englobar sin demoler, habla mucho de la diferencia con Madrid. La entropía es una característica que diferencia la ciudad italiana, que sigue consumiendo territorio, sin llenar sus vacíos, sin sustituir su tejido informal. En Roma, cuanto más nos alejamos del centro, más se hace complejo el paisaje urbano, así que en un radio menor de un kilómetro, nos encontramos con la vivienda en bloque popular de Bellíssima, el barrio chabolista del Prenestino de El techo, los descampados de Villa Gordiani de Accattone (con su mezcla de edificios de baja altura y ruinas de casas rurales), y la Parroquia de Santa Elena de Roma, ciudad Abierta, con un tejido más denso y formal de finales de principio de siglo XX; los directores italianos se dan cuenta de esta diversidad y la celebran, la convierten en su ciudad, la Ciudad Neorrealista. Si Roma ya no tiene forma y los directores no parecen buscarla, Madrid todavía conserva su estructura y su rigor a precio de una fuerte segregación de sus zonas periféricas; la condición topográfica de la capital española, como ya se ha analizado, contribuye a esta separación. Así que, en Delicias, así como en Embajadores o en Los ensanches, la ciudad es "inaccesible e inexpugnable" para los migrantes. Esta ciudad compacta para la clase media, está rodeada de zonas industriales alrededor del Manzanares o del Abroñigal; luego la ciudad vuelve a subir con sus laderas desiertas, desde ahí empieza la nueva urbe, la Ciudad Neorrealista española, desde la cual es posible todavía mirar "la forma de ciudad". Los directores españoles, se meten este mundo elevado, en esta vasta topografía de alto llano y observan a sus habitantes. En El último Caballo, Neville exalta esta condición de separación topográfica para representar este pequeño paraíso que el protagonista busca a lo largo de la película. En la pradera de San Isidro, la ciudad parece lejana, quizá la vida es más pobre pero más sencilla y sana, un concepto que parece regresar en la descripción del barrio chabolista donde se refugia uno de los hermanos de Surcos.

\footnotetext{
${ }^{16}$ Se has descritos estos mecanismos de transformación en el Primer capítulo.
} 
La única película que describe un poco este umbral entre los dos altos llanos es quizá Los golfos, donde Saura describe este paisaje infraestructural de los ríos con escombreras y actividades más industriales, un territorio más entrópico que se parece al de la capital italiana.

\section{ELIPSIS}

Se ha definido como "elipsis" la supresión de algún acontecimiento dentro de la linealidad temporal del relato o la historia. A través de la técnica del montaje es posible la recomposición de los fotogramas, para atribuir nuevos significados. La continuidad lógica de los planos toma el nombre de raccord y sirve a "una orientación psicofisiológica del espectador ${ }^{17}$. El espacio cinematográfico se configura en el espectador como una imagen mental a través de una suma de imágenes fragmentadas con un proceso muy similar al de la percepción del espacio arquitectónico, "al punto de vista único del teatro, fundado en la escenografía clásica, se opone la multiperspectividad, suturada por el montaje, característica de la escenografía cinematográfica" ${ }^{18}$. La elipsis, junto al montaje, permite comprimir o dilatar el tiempo y el espacio cinematográfico que solo a través de la técnica del plano secuencia coincide con el tiempo y el espacio real. Esta técnica nos ayuda a definir el proceso de construcción de una nueva iconografía del paisaje a través de un proceso de selección, omisión y yuxtaposición de decorados.

En este trabajo de investigación, más que las elipsis temporales que aceleran el tiempo cinematográfico, nos interesan las "elipsis espaciales" que como se ha analizado en el segundo capítulo crean una incongruencia entre la topología del rodaje y los tiempos de recorridos. Las elipsis espaciales presentes en Ladrón de bicicletas, alteran el paisaje del Tíber, fortaleciendo su imagen anti-pintoresca; De Sica por ejemplo utiliza el umbral de la Porta Portese para generar un raccord entre este lugar y el descampado de Ostiense-Marconi, ubicado un kilómetro más al sur.

En Mamma Roma el montaje del paisaje periférico del Tuscolano se suma a imágenes de otros conjuntos habitacionales INA-Casa, bastante más distantes; la imagen de la iglesia de Don Bosco que Mamma Roma y Ettore observan varias veces desde su ventana, no corresponde a la vista real que es posible alcanzar desde el edificio donde viven. Pasolini selecciona fotogramas e imágenes según su necesidad estético-figurativa, con la idea de construir una "híper-periferia", así como Luís Lucía funde diferentes vistas -no todas de el barrio de El Pozopara lograr una imagen de arrabal madrileño más contundente; quizá la idea de rodar la película en la pequeña parroquia de San Juan Bautista, muy cerca de los estudios de CEA, no era suficientemente dramática, y el director logra componer su propia iconografía periférica, sumando descampados, topografías, chabolas y basureros, buscando lugares en donde Madrid apareciera como muy distante. Dentro de esta lógica formal-estética podemos incluir también la incongruencia espacial de Vajda que, en mi Tío Jacinto, funde el territorio al Noreste de San Juan Bautista con Carabanchel, el lugar donde la pareja toma el tranvía para Ventas. El Techo y Los golfos, son las películas que más utilizaron la elipsis, tanto temporal como espacial. En la idea de Pasolini y Saura la representación de la "imagen borrosa" de la ciudad, no es posible a través de una panorámica coherente de escenarios -como en Ladrón de bicicletas o Mi tío Jacinto-, sino a través de un recorrido fragmentado, que representa a través del montaje de diferentes escenas y decorados, una ciudad compleja y extensa, que es el resultado del montaje de diferentes perspectivas y que, como en la ciudad de los land-artistas, "es un inmenso territorio estético, "una tela sobre la cual se dibuja mientras se anda, un soporte que no es una hoja en blanco, sino un intricado dibujo de sedimentos históricos y

\footnotetext{
17 (Vila Mustieles, 1997 p.148)

18 Ibídem
} 
geológicos a lo que simplemente, se añade uno más" ${ }^{19}$. La obra cinematográfica se convierte en un registro del recorrido hecho por los protagonistas y el director; un viaje que es la suma de miradas y experiencias físicas en un paisaje en constante mutación.

\subsection{Estancias y hábitats}

\subsubsection{Ruinas, andamios y armazones.}

Podemos asociar la acción de detenerse a "la culminación de muchas obras de arte, o al menos de todos aquellas completadas" ${ }^{20}$. El saber parar como el caminar es una "práctica estética" que necesita un aprendizaje; es necesario pensar el "caminar y detenerse no como procesos contradictorios sino como parte de un mismo proceso. Visto en perspectiva, la parada es una gran oportunidad para seguir actuando con el mismo espíritu de ir, pero en un espacio de estar. (...) si uno se detiene es porque antes andaba caminando" ${ }^{21}$.

La construcción de las primeras esculturas-arquitecturas, los menhires, está asociada a esta acción de detenerse para marcar puntos a lo largo de un camino. El construir podría entenderse como un fijar un punto en un espacio después de haberlo recorrido y explorado. En la Ciudad Neorrealista, los protagonistas se mueven y se detienen en puntos que están marcados por construcciones que operan como landmarks. Estos marcadores, se configuran como edificios en construcción, vallas, recintos, ruinas y topografías y corresponden a un deseo estancial de los personajes, marcan un espacio sedentario que "está estriado por muros, recintos y recorridos entre estos recintos, mientras que el espacio nómada es liso, marcado tan solo por unos trazos que se borran y reaparecen con las idas y venidas". El espacio vacío de los nómadas contrasta con este espacio de los sedentarios, lleno y más denso $^{22}$. Los directores ocupan el espacio, descubriendo lugares que antes no existían porque no eran representados: en esta operación de descubrimiento, los directores "hacen arquitectura" crean espacios de oportunidad, antes invisibles.

En el paisaje urbano periférico presente en las películas neorrealistas la diferencia entre espacio nómada y estancial, no es tan evidente, se trata de una ciudad en espera de una forma futura y con fragmentos del pasado que flotan en un territorio de incertidumbre. La arquitectura, en este archipiélago "anti-urbano" refleja esta nueva condición. El paisaje tiene las cualidades de caducidad y ausencia que reflejan las características nómadas de la ciudad y de sus habitantes. Esta condición se expresa a través de tres elementos de la iconografía arquitectónica: las "ruinas", los "armazones" y las "topografías", que hemos ubicado en los mapas de la "topología del rodaje" en las dos capitales.

Esta cartografía se ha desarrollado con la idea de definir la estructura de un posible "proyecto" de la ciudad neorrealista, tomando como referencia el territorio de Roma y Madrid; se trata de un proyecto efímero, la representación contemporánea de un territorio en continua mutación, destinado a fijar una imagen que se pierde en el tiempo: "Si en las cartografías antiguas sólo se dibujaba lo que se habitaba, las representaciones contemporáneas parecen ir por el camino contrario: se hace urgente la necesidad de mapas que representan los países

\footnotetext{
${ }^{19}$ (Careri, Walkscapes: el andar como práctica estética, 2002 p.126)

${ }^{20}$ (Careri, Stopscapes, un glosario, 2015 p.50)

21 (Ibídem p.49)

22 (Deleuze \& Guattari, Mille plateaux: Capitalisme et schizophrénie., 1980) cit. en (Careri, Walkscapes: el andar como práctica estética, 2002 pp. 28-30)
} 
inexplorados, las rutas inciertas, y la ciudad "no representativa", fuera del control del poder: cartografía enmarcadas en el ámbito de acciones espontáneas e inesperadas” ${ }^{23}$.

\section{RUINAS}

La película de Rossellini Alemania Año Cero, impactó la cinematografía y la cultura mundial, al presentar en la pantalla la realidad abrumadora de una Berlín totalmente derrumbada al final de la guerra. El pequeño protagonista se mueve en las calles totalmente desiertas y llenas de escombros que generan topografías en las cuales crece la maleza, una imagen apocalíptica en la cual la naturaleza vuelve a ocupar los territorios urbanos. A partir de esta tabula rasa de la película de Rossellini, esta iconografía se reproduce de forma constante en el Cinema Neorrealista, desde Nieves Conde hasta De Sica, de Pasolini a Saura.

En la cinematografía neorrealista las ruinas, los escombros y los desechos, se representan como un objet trouvé que se contrapone al orden racional urbano, restos arqueológicos de un mundo desaparecido que coexisten con las ruinas de la nueva civilización, los esqueletos de los edificios en construcción. En las cartografías desarrolladas las ruinas se convierten en landmark que definen un "mundo paralelo", una ciudad dentro de la ciudad convencional, un paisaje hecho de restos, bloques de granito, desechos, edificios a punto de derrumbarse, etc.: una nueva iconografía que anticipa el recorrido en Passaic de Robert Smithson y es el resultado de una nueva entropía urbana que está generándose en estos años de rápido crecimiento urbano.

En Roma y Madrid las ruinas como ya se ha analizado son una referencia simbólica a los recientes acontecimientos de la guerra, están presentes en las dos fimografías analizadas, sin embargo, se muestran con más desenvoltura en la filmografía romana. Se trata de una ciudad de ruinas que desde siempre es, como su Arquitectura, de toda época, tipo y forma; a veces las ruinas del pasado se mezclan con las del presente. En Roma ciudad abierta, los escenarios en ruina rodados, son realmente los afectados por los bombardeos de los aliados entre 1943 y 1944 sobre todo en el barrio de San Lorenzo que aparece también en "El techo", donde los protagonistas quieren rentar un piso en un edificio en ruina, a punto de caerse. Otras ruinas importantes son las de Mamma Roma, que describe el paisaje arqueológico del Parque de los Acueductos, al sur de la capital, y las ruinas de casas derribadas en el Pigneto, el barrio donde vive el protagonista de Accattone.

En la capital italiana los signos del pasado son algunas características de su iconografía, es difícil distinguir, también en el cine, la época de sus restos; el deterioro urbano de las periferias -de ciudad de tercer mundo, como decía Pasolini-, los edificios abandonados o en construcción, y las chozas, crean un paisaje autóctono.

En Madrid esta iconografía es menos visible, principalmente la que se liga a los acontecimientos de la Guerra Civil. En la capital española no se han podido identificar las ruinas de algunas escenas de Surcos, que casi seguramente se ubican en el centro de la ciudad: cuando el hijo menor escapa de casa hace una siesta en un edificio casi completamente derrumbado, sin techo; en el centro se encuentra también la escena del derribo de la casa de los protagonistas de El inquilino, en la zona de la Latina. No faltan en los documentales NO-DO las imágenes de derribos de casas destruidas o chozas, una imagen de reconstrucción después de tanta destrucción; la acción de la excavadora al levantar escombros era celebrada en estos noticiarios como un ritual de purificación (F.4.2.1/1).

${ }^{23}$ (García, 2012) 

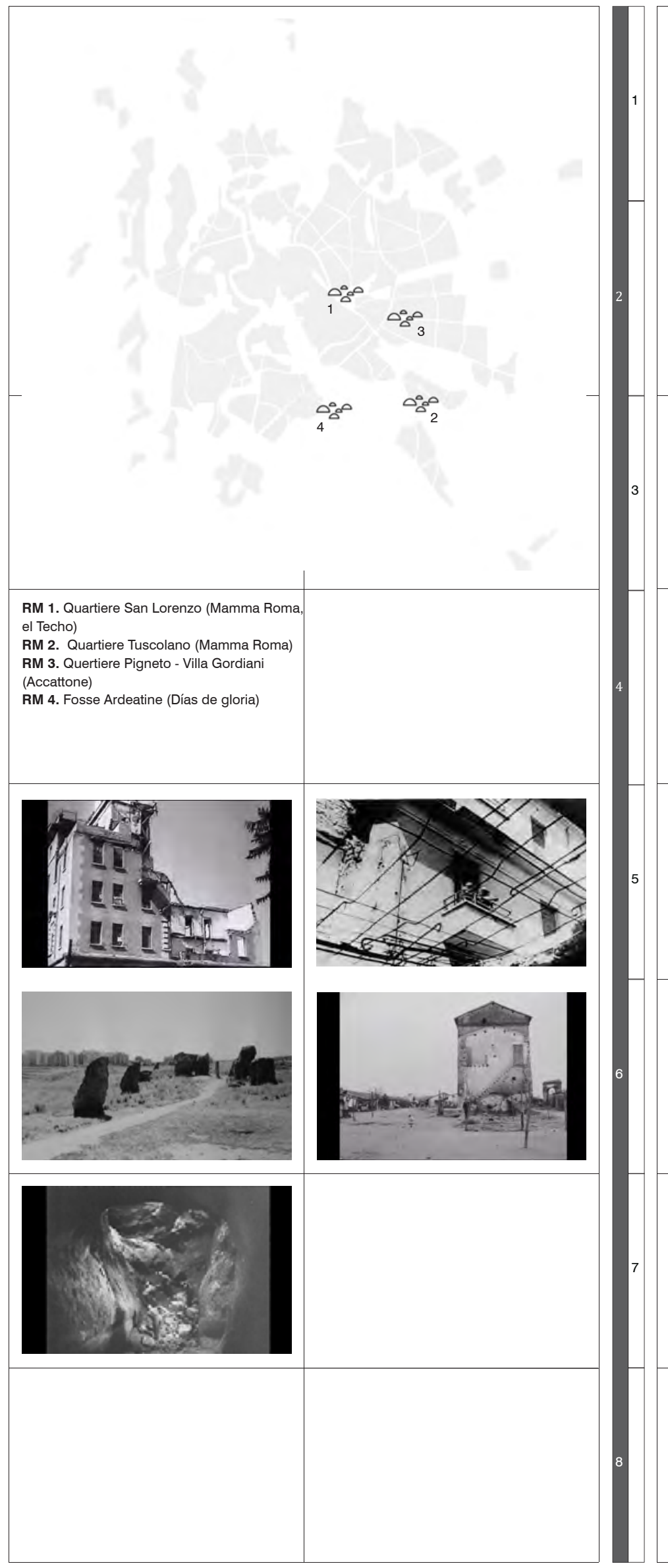

MD 1. Casco Historico (Surcos, Los chicos)

MD 2. Barrio de Ventas - La Elipa (Cerca de

la ciudad, Los golfos)

MD 3. El Pozo del Tio Raimundo (Cerca de

la ciudad)

صి

1

$$
\begin{gathered}
0 \\
0 \\
0
\end{gathered}
$$

RM 5. Roma ciudad abierta (Rossellini)

RM 6. Mamma Roma (Pasolini) - Quartere Tuscolano

RM 6. Accattone (Pasolini) - Quartere Pigento, Villa Gordiani

RM 7. Días de gloria (AAVV) - Fosse Ardeatine
MD 5. Surcos (Nieves Conde) - Casco histórico

MD 5. El inquilino (Nieves Conde) - Casco histórico

MD 6. Los golfos (Saura) - La Elipa

MD 7. Cerca de la ciudad (Lucía) - Pozo del Tio Raimundo, Entravías 
En Los golfos, las rocas de granito donde los protagonistas se reúnen y que parecen ruinas de un templo antiguo, se encuentran cerca del actual Puente de La Elipa; el basurero humeante de escombros, que sirve de decorado de una escena de Cerca de la ciudad, se encuentra en El Pozo, y aunque aparezca pocos segundos, es uno de los paisajes más duros contados en fotogramas del Cine Español. Otra imagen poderosa en la capital española de convivencia, es la de la construcción del poblado de Entrevías, y sus manzanas que crecen en medio del tejido de chabolas que poco a poco se van derribando. En España, pueblos abandonados como Belchite y sus ruinas bélicas, son un testigo quizá más doloroso que el Barrio de San Lorenzo en Roma. Los fotogramas de Paisá, de Rosselini, en donde un soldado de Estados Unidos se sienta a hablar con un chico sobre un monticulo de escombro, adentro de un edificio derrumbado, teniendo como fondo una torre campanaria, representan esta condición de convivencia con los signos de traumas pasados: una condición fundamental de la Ciudad Neorrealista. En Roma, más que en Madrid, se produjo esta tolerancia, este saber vivir en una ciudad inacabada.

Algunas arquitecturas de la época se hacen intérpretes de esta nueva realidad presente en el espacio cinematográfico. En Italia, el monumento de las Fosas Ardeatinas en Roma de Mario Fiorentino, se configura como una gran tumba, un gesto monumental que recompone los desechos de la guerra; el recuerdo y las imágenes de estos derrumbes nazis para esconder las víctimas ${ }^{24}$ están presente en la película-documental Días de gloria de 1945 compuesto de varios documentos audiovisuales rodados, entre otros cineastas, también por Visconti y De Santis. En Milán el monumento a las víctimas de los campos de concentración de BBPR, en el Cementerio Monumental de la ciudad lombarda, que hace levitar un cubo de tierra en el interior de una efímera estructura espacial metálica, también es una reflexión, como las Fosas Ardeatinas sobre el concepto de monumento, de memoria, de fragmentos del pasado que se recomponen para dar un nuevo significado. En España encontramos un análogo en los concursos de Arquitectura realizados por el escultor Jorge Otéiza, síntesis entre Escultura y Arquitectura. Una analogía sutil con los monumentos bélicos italianos se puede identificar en la propuesta de concurso para una Capilla del Camino de Santiago, al cual participó el escultor vasco junto a Sáenz de Oíza y a Romany; Otéiza esculpió un alto-relieve, como una ruina encontrada en los campos de Castilla que, como en el monumento de los BBPR, está empotrada en una elegante estructura aérea (F.4.2.1/2).

\footnotetext{
${ }^{24}$ El monumento recompone los restos de las 320 víctimas de la deshumana venganza de las SS después del atentado partisano de Vía Rasella de 23 de marzo de 1944 que causó la muerte de 32 soldados alemanes. Para ocultar los cuerpos de las victimas los nazis los depositaron en unas minas de toba en el sur de la capital (Vía Ardeatina) que fueron derrumbadas con carga de explosivos.
} 

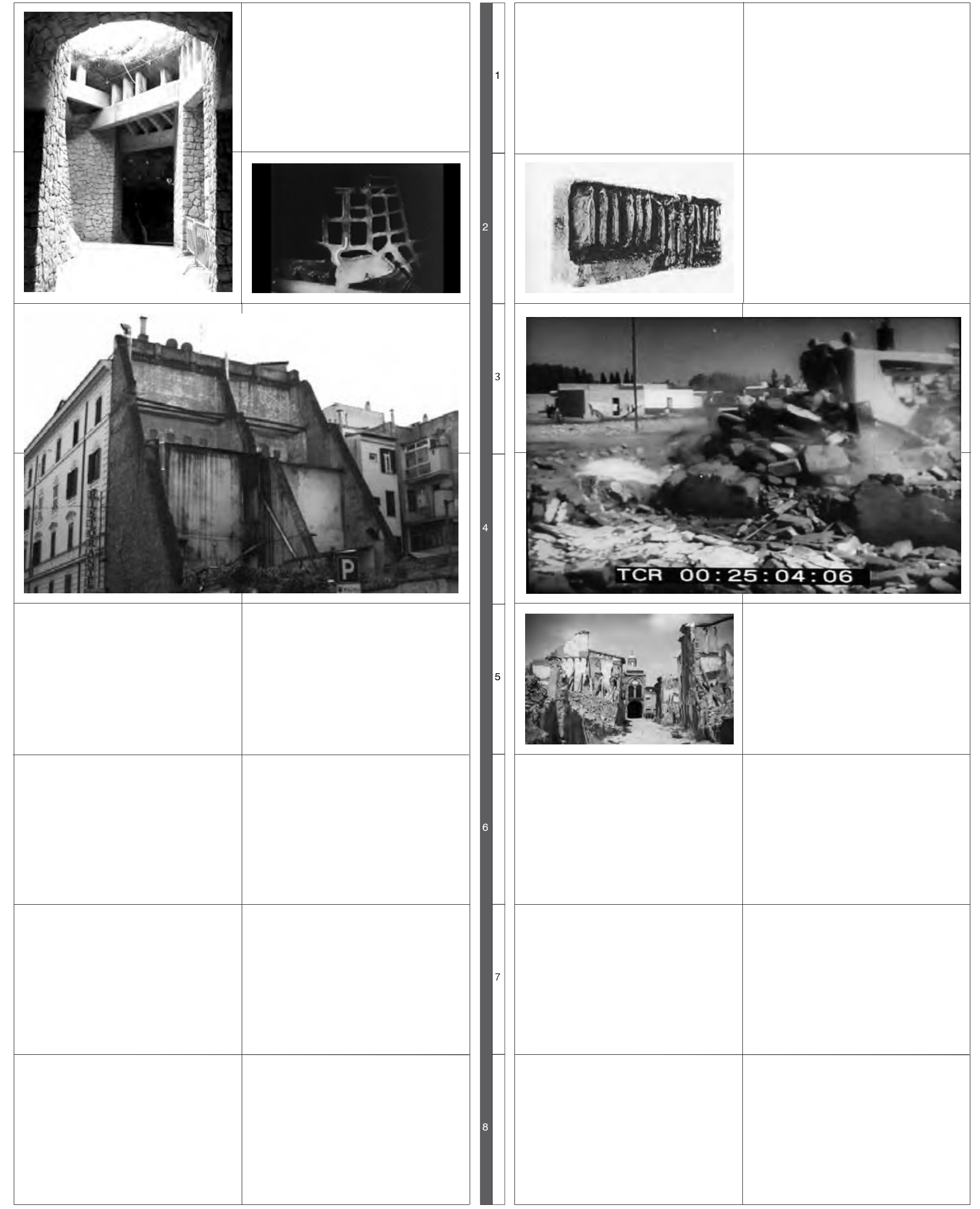

RM 1-2. Mario Fiorentino: Monumento a los martires de las Fosse Ardeatine (1944): vistas de los espacios interiores, tuneles y tumbas.

RM 2. Días de gloria (AAVV): Fotogramas con ruinas de las Fosas Ardeatine

RM 3-4. Imagen de una manzana del barrio romano de San Lorenzo, con los signos del bombardeo del 1943

MD 2. J. Oteiza: altorelieve para la Capilla en el camino de Santiago. (1954) MD 3-4. Documental 60.000 viviendas. (NO-DO): Derribos de asientamientos informales. MD 5. Ruinas del Pueblo de Belchite (Zaragoza). 


\section{ANDAMIOS}

En Ladrón de bicicletas el enorme andamio/estantería en donde el funcionario del Monte de Piedad, almacena las sábanas de la familia Ricci es, como subraya el Reichlin, una metáfora de la masividad de los edificios de viviendas que empiezan a construirse en esta época ${ }^{25}$ : Este depósito de lencería y objetos es una metáfora existencial -almacén de vidas en espera-, pero también una configuración espacial arquitectónica presente en la ciudad real y virtual de la época, metáfora de lo provisional, de la ilusión y del sueño: los andamios de los edificios en construcción, como metáfora de oportunidades y los andamios monumentales de las escenografías de Cinecittá entre las cuales Anna Magnani y su hija se pierden en la secuencia inicial de Bellísima de Visconti (1951), son la misma imagen que doce años después y en el mismo lugar aparecerá en la escena final de $81 \frac{1}{2}$, de Fellini, en donde el alter-ego del director construirá un andamio sin escenografía, metáfora del fin de un época. Esta imagen de Fellini se volvió un icono que trasciende el espacio de Cinecittá, una imagen capaz de sintetizar la calidad efímera de la arquitectura Italiana de la Posmodernidad, sus andamios y estructura de tubi Innocenti ${ }^{26}$, desde las instalaciones de la Estate romana hasta el "Teatro del mondo" de Rossi: un interés por la espacialidad escenográfica barroca, lo temporal y lo lúdico en oposición al clima político de los años ' $70^{27}$. El uso de los montajes con andamios que llega de la época fascista, y que se convierte en los etéreos montajes de Persico, Nizzoli, Pagano y Albini, en los años '30, hasta llegar al Monumentos a las víctimas de los campos de concentración alemanes de BBPR de 1946 en Milan que tiene su referencia también en el montaje de Walter Gropius en la Exposición de Materiales no Férreos en Berlín en 1934.

En la España franquista de hormigón y ladrillo, no hay lugar para la ligereza y lo efímero de la arquitectura metálica, solo algunos arquitectos, llevarán a imaginar otros materiales y metodologías: entre todos ellos sobresale Sáenz de Oíza y su Capilla en el Camino de Santiago de 1954: una estructura "miesiana" de vigas reticuladas de acero, flotando en los campos de castilla, un monumento efímero como el de BBPR en Milán. Acerca de la génesis del poético andamio que constituye el techo de la capilla, Sáenz de Oíza explica que "en aquel momento había viajado mucho por Castilla, y había hecho fotografía de los postes de alta tensión. Discutía con Otéiza y Romany si los postes destruían el paisaje castellano o lo realzaban. En Madrid los predios del C.E.A. los estudios cinematográficos en la manzana 89 de la Ciudad Lineal fueron ocupados por un parque de atracciones construido por la Sociedad de Espectáculos que se constituyó en 1902: entre las atracciones como cafés, teatros, cuadriláteros para la lucha y toboganes, se encontraba una gran estructura de armazones de acero y cables denominada "Máquina voladora" para el entretenimiento de la población madrileña ${ }^{28}$

Roma es una ciudad de ilusiones: no es un caso que en Roma se encuentren junto a Cinecittá, el Vaticano y el Gobierno. El andamio vertical es seguramente una de sus iconografías más recurrentes, y los directores la representan como parte del paisaje urbano; Madrid es más una ciudad horizontal, de topografías naturales, de tierra y de techos de barro. (F.4.2.1/3).

\footnotetext{
25 (Reichlin, 2002)

${ }^{26}$ Se trata de una patente desarrollada en Italia para construir andamios que consisten tubulares de acero y unas juntas tridimensionales atornilladas, con patente de 1933 adaptando la inglesa Scaffolding.

${ }^{27}$ (Szacka, 26)

28 (Caldito, 2009)
} 


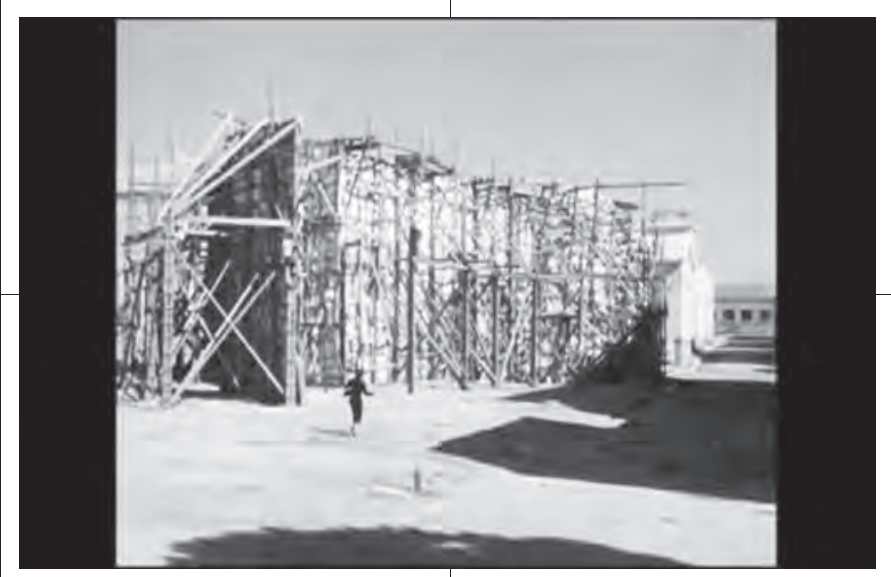

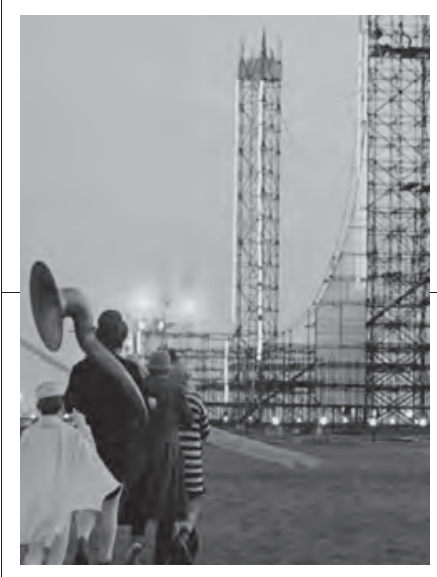
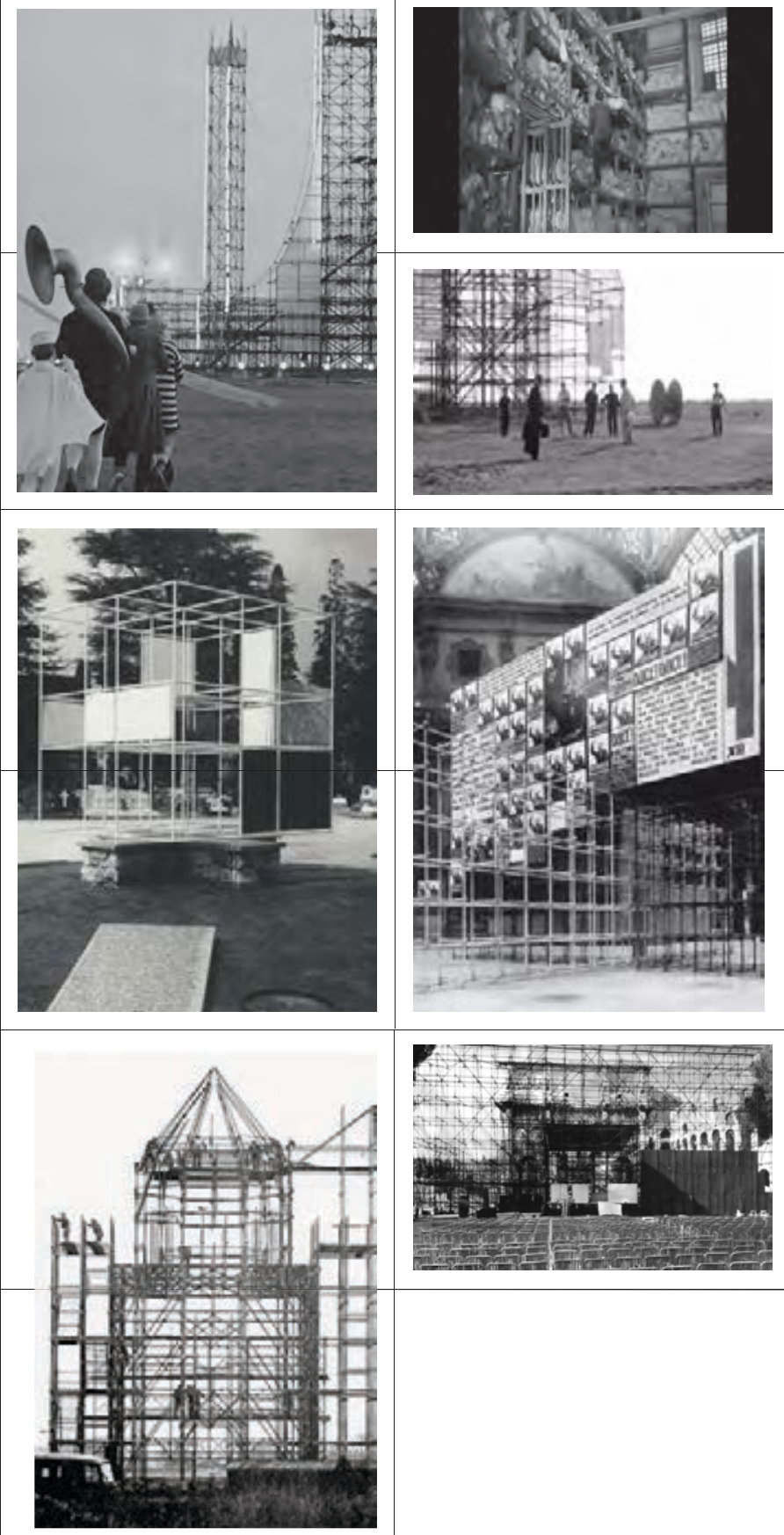

1-2. Bellissima (Visconti)

RM 3-4. 8 y $1 / 2$ (Fellini)

RM 5-6. BBPR Monumento a los caidos en los campos de concentración en Milán (1946)

RM 5-6. E. Persico, M. Nizzoli: Montaje en la Galería Vittorio E. Il en Milán (1934)

RM 7-8. A. Rossi. El Teatro del mondo en construcción (1979)

RM 7. AAVV Montaje para la Estate Romana (1977)
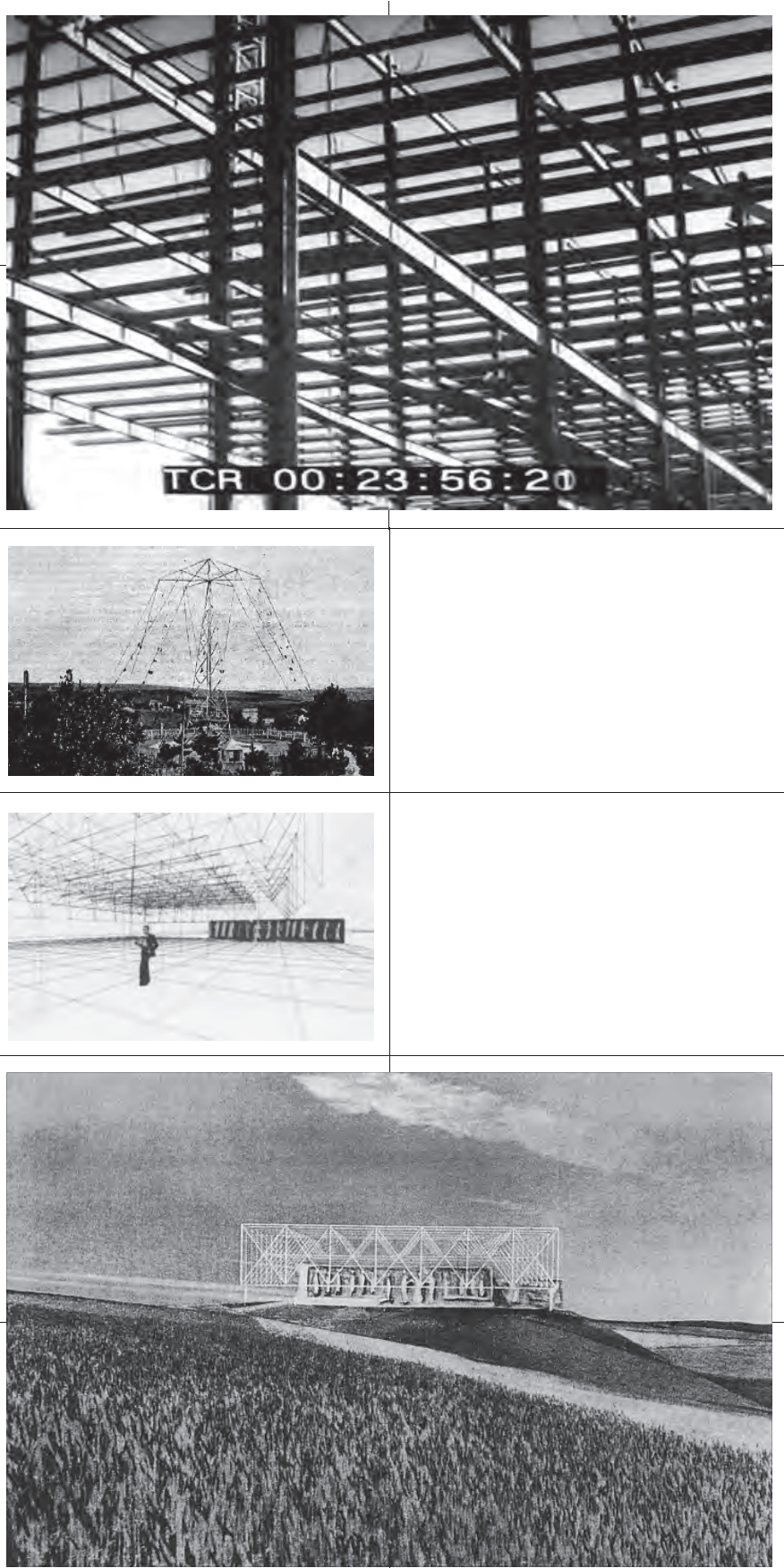

MD 1-2. Nuevos hogares (Imagenes NO-DO)

MD 3. La maquina voladora en el antiguo parque de atracciones que sera el C.E.A.

MD 4-5-6. F. J. Sáenz de Oíza, J. L. Romaní, J. Oteiza: Capilla en el camino de Santiago. (1954) 


\section{ARMAZONES}

En la película El Techo, De Sica describe una Roma de edificios en construcción que, para los protagonistas, significan nuevas oportunidades laborales; el director pretende describir el mundo de la construcción de viviendas en la capital a mitad de los '50: es decir, las diferentes condiciones laborales y las técnicas constructivas, desde el aprendizaje en obras formales, hasta la autoconstrucción espontánea.

Podemos decir que el elemento iconográfico de los armazones, aparece en el Cine español más en segundo plano, más como fondo, sin tener la misma importancia que asume en las películas italianas. En Madrid fotogramas importantes para la definición de una iconografía de armazones podrían ser las imágenes del esqueleto de una torre, probablemente la Torre Madrid, en los fotogramas finales de Esa Pareja Feliz y en Historias de la Radio, en la cuales aparece un conjunto habitacional en construcción en la avenida Concha Espina. Otro armazón es el que aparece en el Verdugo, futura residencia para el protagonista y su esposa. Quizá la mejor representación de un armazón es la que protagoniza la escena central de Calle mayor de Bardem, donde el siniestro diálogo entre la pareja protagonista tiene como teatro una siniestra vivienda en construcción ${ }^{29}$. Al contrario de El techo, la Madrid en construcción no es una oportunidad para todos; no se habla de este oficio como posible salida laboral, los protagonistas parecen alejados en general del mundo de la construcción que aparece como aquello a lo que se aferran algunos pocos hombres de negocio. En Mi tío Jacinto, el protagonista será rechazado de la obra en la cual busca trabajo, por haber pedido un adelanto. El edificio en construcción que aparece en los fotogramas parece ser de una escala muy limitada, el director no se muestra interesado en el carácter escenográfico del armazón de hormigón armado, y prevalece en cambio la imagen de un gran depósito de ladrillos huecos, el material más utilizado en la Madrid de la época: el barro más que el concreto. La imagen de los armazones de los edificios en construcción se sobrepone a la de edificios de viviendas en altura con esqueleto de hormigón visto.

Entre las películas analizadas, en El Techo aparecen las Torres de Avenida Etiopía, de Ridolfi, y en Mamma Roma aparece el edificio en línea de Largo Espartaco, de Saverio Muratori. Bruno Reichlin habla de las torres de Avenida Etiopía, utilizando la definición del arquitecto italiano Giancarlo de Carlo: "una versión bárbara y robusta" de la arquitectura de Perret, planteada en la reconstrucción de Le Havre ${ }^{30}$; la estructura vista de las Torres de Ridolfi y del Edificio Boomerang de Muratori, plantean un tipo de Neorrealismo que deja atrás el pintoresco y lo vernáculo, y se enfoca en la verdad constructiva asociada a una expresividad en el uso de materiales, texturas y colores ${ }^{31}$. Es indudable que las torres INA-Casa de Viales Etiopía llaman el interés no solo de De Sica sino también de Monicelli, quien incluye la imagen de una de las torres en construcción en una escena de Rufufú. Es posible que las torres de Ridolfi hubiesen llamado la atención de diferentes directores como "arquitectura-armazón" que se inspiraba en la ciudad en construcción; como símbolo de un rigor constructivo, y geométrico en oposición a la ciudad de las chabolas y de los descampados. Bruno Reichlin propone también un posible valor didáctico de estas arquitecturas de Ridolfi -autor del Manuale dell' Architetto-, que contrastan con la baja calidad constructiva de la chabola de Natale ${ }^{32}$. A los ojos de los directores estos valores de racionalidad estético-constructiva, junto con las grandes dimensiones de estos bloques, se asociaban a una idea de masividad y control capitalista de las existencias; (F.4.2.1/4).

\footnotetext{
${ }^{29}$ Aunque esta escena probablemente no fue rodada en Madrid.

${ }^{30}$ (Reichlin, 2002).

${ }^{31}$ Ridolfi propone un realismo constructivo cercano a las ideas realistas y socialistas de Karel Teige

${ }^{32}$ Natale usa los ladrillos dobles hueco para la construcción de muros de carga
} 


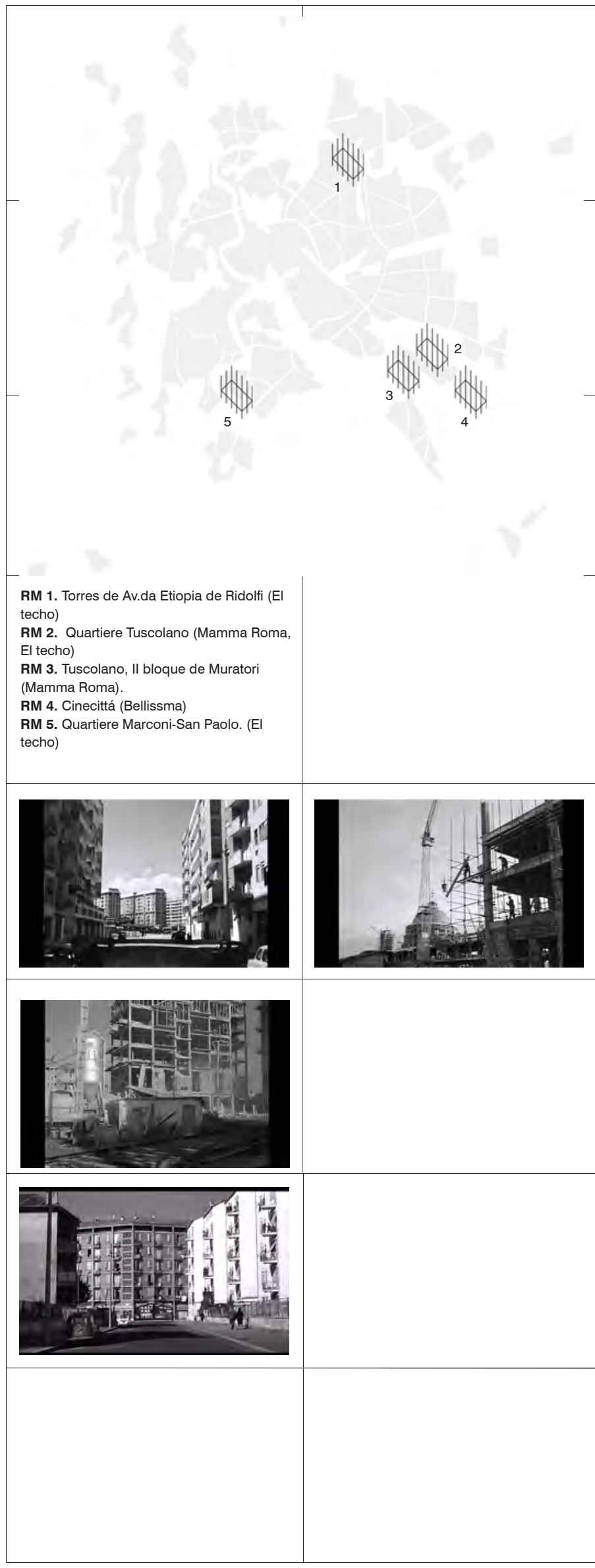

RM 5. El techo (De Sica) - Torres de Av.da Etiopia de M. Ridolfi RM 5. El techo (De Sica) - Quartiere Tuscolano en construcción

RM 6. El techo (De Sica) - Quartiere Marconi San Paolo en construcción

RM 7. Mamma Roma (Pasolini) - El Bloque de S. Muratori en el Tuscolano II

RM 7. Bellissima (Visconti) - Andamios y decorados en Cinecittá

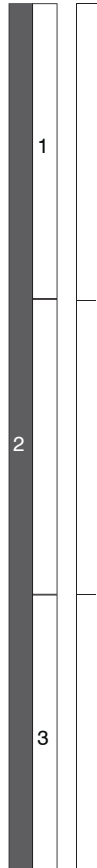

MD 1. Edificios en Construccipon en Av.da Concha Espina (Historias de la Radio)

MD 2. Torres en la calle S. Prisca en La Elipa (Los golfos)

MD 3. Bloques en la calle Castillo de Uclés (El pisito).

MD 4. Torres en el poblado de Caño Roto (NO-DO).
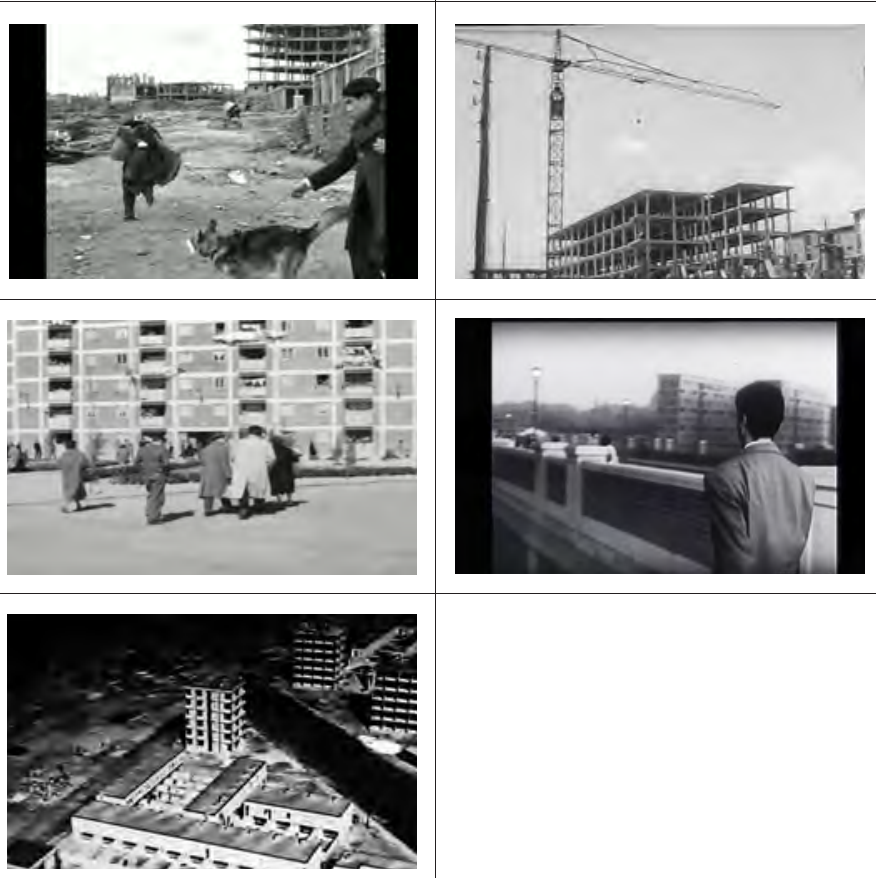

MD 5. Historias de la Radio (Sáenz de Heredia) - Av.da Concha Espina. MD 5. El verdugo (Ferreri) - No identificado

MD 6. El pisito (Ferreri) - Calle Castillo de Uclés en San Blás

MD 6. Los golfos (Saura) - La Elipa

MD 7. Documental NO-DO: "60.000 viviendas"(AAVV) - Caño Roto 
En Mamma Roma, el valor escultórico del portal del edificio, con estructura aparente de hormigón, aparece en los encuadres de Pasolini como elemento estéticamente extraño a la cultura de los personajes, así como toda la arquitectura del conjunto. En Madrid, la imagen de la estructura de hormigón aparente en bloques de viviendas, como en la capital italiana, asume el valor de inalcanzable y masivo ante las nuevas arquitecturas urbanas. En una célebre escena de EI Pisito, de Ferreri, los protagonistas se encuentran en una de las periferias de reciente construcción de la capital española, al fondo se ve un conjunto habitacional de torres, con estructura de hormigón aparente, que caracteriza esta edificación masiva; se trata del conjunto habitacional Francisco Franco, desarrollado por la Obra Sindical del Hogar en 1957, en San Blas, en el sector Este de la capital, y diseñado por el arquitecto Peral Buesa. En algunos fotogramas, casi en campo vacío, la cámara fija encuadra algunos de los áridos espacios abiertos entre las torres del conjunto, entre los cuales aparece la pareja, minúscula, acercándose a la cámara desde el fondo del encuadre; la protagonista se queda sola esperando a su novio, perdida y agotada en la explanada, a pleno sol y rodeada por los esqueletos de hormigón. Fracasado este intento de búsqueda, los dos toman un tranvía que los llevará a una zona que parece todavía más alejada, en un lugar donde el coche es cercado por una manada de ovejas; en la realidad los dos siguientes encuadres están rodados en el mismo conjunto Francisco Franco, mirando hacia la calle Catillo de Uclés. La imagen del conjunto es todavía más dura que la anterior, la avenida desierta, la secuencia sin fin de las torres en perspectiva, todas idénticas con sus acabados en hormigón y sus cerramientos en ladrillo aparente, con pequeñas ventanas cuadradas pegadas a la trabe superior.

Carlos Sambricio habla del conjunto, subrayando su baja calidad urbano-arquitectónica, que el director Ferreri parece detectar en su película, describiéndolo como "un dudoso damero de aparcamientos y plazas ajardinadas ahogadas por las elevadas volumetrías de los bloques" 33 . En Los golfos, de Saura, las cuatro torres de viviendas que aparecen del otro lado del puente de La Elipa, que marcan un contraste con la informalidad del barrio "bajo el puente", donde viven los protagonistas, se encuentran en la Calle Santa Prisca y pertenecen al conjunto habitacional ubicado entre esta Calle, la Calle Santa Genoveva y la Calle Felicidad. Se trata de un barrio construido por la Obra Sindical del Hogar denominado "Barriada La Elipa" ${ }^{34}$. El conjunto es un desarrollo bastante logrado de la $\mathrm{OSH}^{35}$; además de los bloques de 8 plantas de doble crujía - los que aparecen en la película de Saura - el conjunto se compone de bloques de 5 plantas, de 2 plantas adosadas y torres en "H" de 5 y 11 plantas. ${ }^{36}$

El esqueleto de hormigón aparente es una constante de la edificación de estos años junto a la variante más pobre de estructura mixta de muros de carga de ladrillo y losas de viguetas de hormigón (F.4.2.1/5).

\footnotetext{
33 "se trata de una de las actuaciones más densas (267 viv. /Ha): una aleatoria combinación de bloques de doble crujía de 4 plantas (borde Norte) y de torres lineales de 10 plantas con una sola caja de escaleras y 4 viviendas por plantas". (Sambricio, La vivienda en Madrid en la década de los 50: el Plan de Urgencia Social., 1999 p. 143)

34 En el Catalogo de la exposición "Un siglo de Vivienda social" del 2003 (Sambricio, Un siglo de vivienda social 1903 - 2003 : centenario del Instituto de Reformas Sociales, 2003 p.140) aparece la foto de un bloque de ocho plantas y doble crujía que aparece con el siguiente subtitulo: "M. Durán Loriga. Parcela H de San Blás 1960".

35 Aunque "su construcción en varias épocas deja apreciar su falta de estructura unitaria. Resulta agradable la sensación de zona exclusivamente peatonal que tiene el barrio. Los espacios internos no están, sin embargo, bien tratados" (Moya Gonzalez, 1983 p.166)

${ }^{36}$ El barrio que dispone de un colegio, un cine y una iglesia, se caracteriza por la vía perimetral que soluciona la circulación rodada, con aparcamientos en la periferia (ibídem)
} 

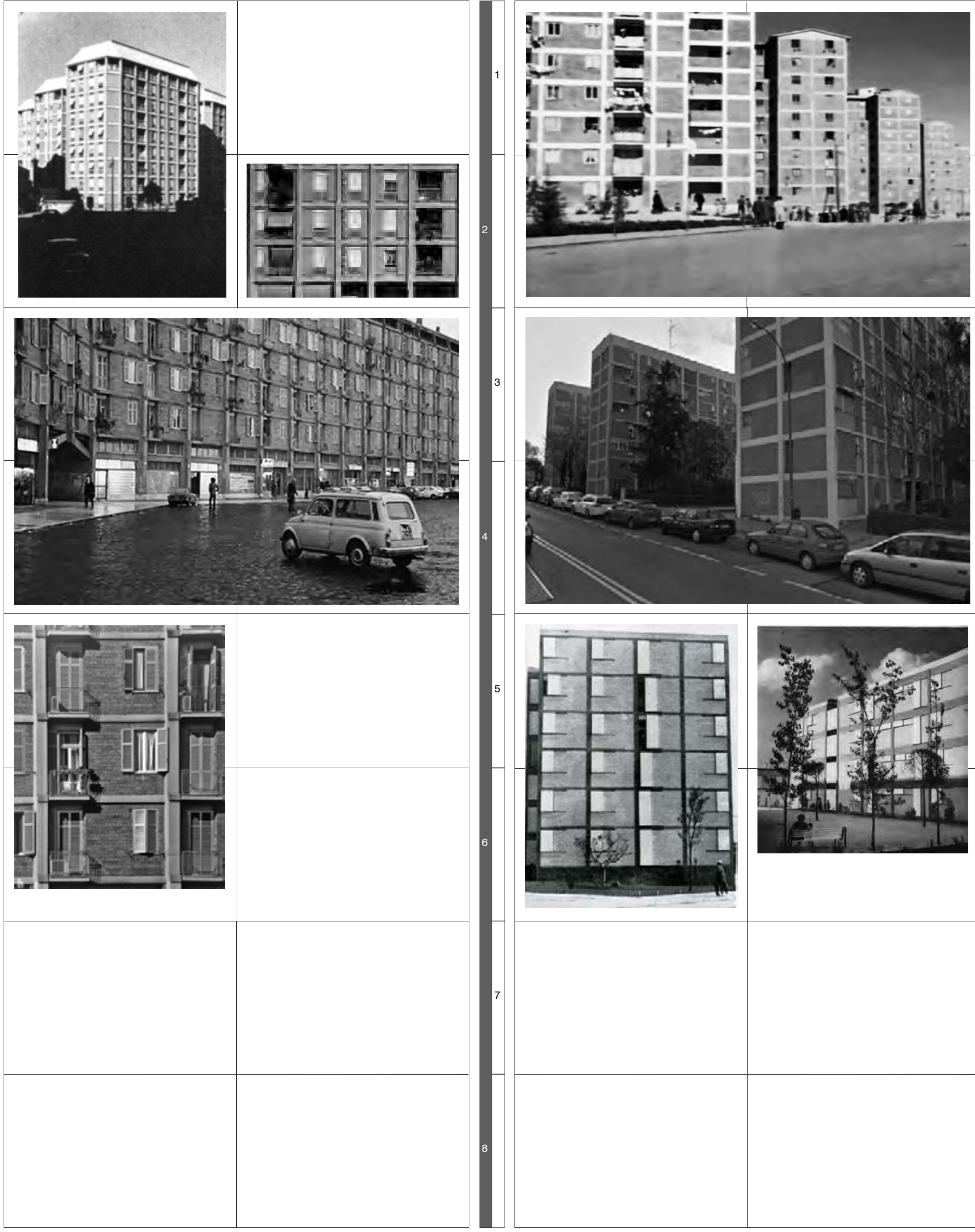

RM 5. Mario Ridolfi: Torres de Av.da Etiopia (1951)

RM 3-4-5-6. S. Muratori, M de Renzi: Bloque en "V" en el barrio INA-Casa Tuscolano II (1950)

MD 1-2. Luís Peral: Buesa conjunto de viviendas F.Franco en las Calles Hermanos García Noblejas y Castillo de Uclés (1957)

MD 3-4. M. Durán Loriga (?) Bloques-torre en la Calle Santa Prisca en Barriada La Elipa (1960).MD 5-6. A. Vásquez de Castro, J. L. Íñiguez de Onzoño: poblado dirigido de Caño Roto (1957)

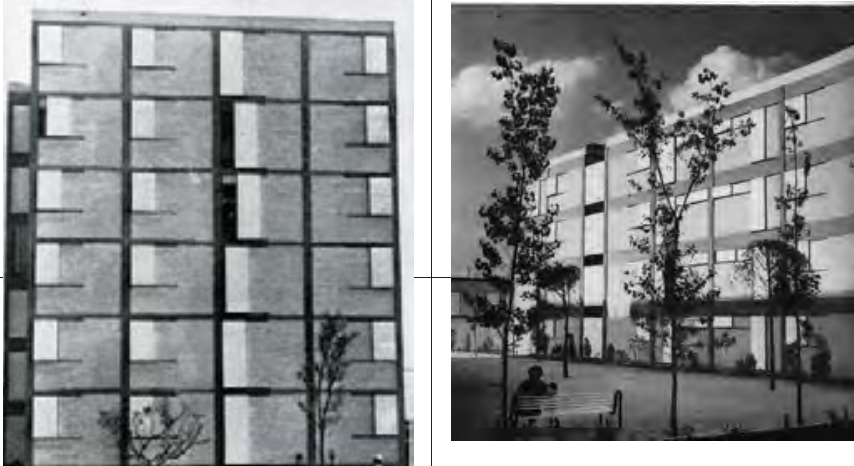


En los documentales NO-DO aparece la vivienda en construcción después de la aprobación de Franco del Plan de Urgencia Social; se trata de fotogramas tomados desde un helicóptero, en los cuales aparece un sinfín de estructuras de pilares, vigas y cartelas de ladrillo, una entera ciudad-armazón en el territorio árido de la periferia de la capital española: una imagen poderosa, que no pudo no haber impactado a los directores y los arquitectos de la época, además de revistas españolas que empezaron a reportar los ejemplos italianos de vivienda social $^{37}$.

Entre las arquitecturas madrileñas que más podemos acercar al ejemplo de Ridolfi, sin duda la de Caño Roto, en Carabanchel, ocupa un lugar de relieve; las torres de seis plantas se caracterizan por una estructura de hormigón y unos muros de cerramiento de ladrillo aparente de color claro que permiten una composición abstracta de los alzados, una robustez y claridad constructiva como en las torres romanas: "la imagen de vivienda barata española se deshace gracias a la limpieza de la solución que se plantea en Caño Roto, recogiendo, es cierto, intentos anteriores con una frescura desconocida hasta entonces" ${ }^{38}$. Las Torres de Avenida Etiopia y las de Caño Roto constituyen el punto de contacto más evidente entre las culturas arquitectónicas de los dos países en estos años, una "aspiración a la realidad" que, como se ha analizado en el pimer capítulo, se produce a través de una mediación entre la abstracción del movimiento moderno y el deseo de verdad y realismo constructivo típico de la Posguerra, junto al interés en materiales y texturas bajo la luz.

\subsubsection{Topografías neorrealistas.}

Si por un lado los directores describen un paisaje urbano de armazones que identifican con la vivienda moderna y masiva; por otro lado, en sus películas muestran un espacio vacío y horizontal que se presenta como un territorio de posibilidad y libertad, en oposición a la malla cartesiana de las estructuras verticales. A la ciudad en construcción los directores contraponen la imagen horizontal de complejas topográfias.

Los territorios en las periferias -y también en el centro- de Roma y Madrid, como los espacios explorados por Robert Smithson en sus recorridos, son una superposición de diferentes capas geológicas, entre lo natural y lo artificial, la historia y la modernidad, el hacinamiento y el abandono. La imagen es contradictoria, ya no hay una diferencia marcada entre ciudad y campo, los lotes baldíos y en construcción configuran una nueva imagen de la ciudad en la cual vuelve a revelarse su estructura orográfica y natural (Alemania año cero); el espacio urbano se presenta como un palimpsesto en el cual conviven diferentes trazos del pasado y del futuro; por un lado, ruinas y elementos naturales, por el otro, armazones de edificios en construcción y nuevas arquitecturas. Ya hemos analizado en el segundo capítulo esta iconografía de Vacant lot o Terrain Vague haciendo referencia a sus calidades de indeterminación y ausencia; nos interesa ahora subrayar su valor espacios para la creación y la representación como fuente de inspiración tanto por los directores como para los arquitectos y los artistas y como material para un nuevo paisaje urbano: lo que definimos usando la expresión "topografía neorrealista".

Podemos afirmar que Madrid, es más una ciudad de topografías, la imagen del Cine se enfoca en esta constante presencia de la "meseta" como espacio de construcción de la Ciudad

\footnotetext{
37 (Vagnetti, 1954)

${ }^{38}$ (Baldellou, Neorrealismo y arquitectura. El 'problema de la vivienda' en Madrid,1954-1966, 1995 pp.3637)
} 
Neorrealista española. Las variaciones altimétricas están exaltadas en la filmografía en pelculas como Los golfos o Mi tío Jacinto, estas variaciones de la topografía están asociadas a una condición social desfavorable.

Queda clara la aversión de los directores hacia los bloques en altura; en Pasolini el último fotograma de la secuencia final de Mamma Roma se repite obsesivamente cinco veces a lo largo de la película, es la imagen de la ciudad de los nuevos bloques de viviendas, una imagen que parece cristalizar toda la desesperación de los protagonistas. En la mayoría de las películas madrileñas analizadas siempre hay una escena que describe las condiciones de separación producidas por el Manzanar o el Abroñigal, entre el altollano del Centro y los de las periferias en el Este y/o en el Sur de la ciudad. Estas vaguadas separan la ciudad de lo que no lo es, y pertenece más a la meseta, un territorio áspero, en el cual moverse es más difícil en un constante bajar y subir, condición que no está presente en el centro de Madrid, y que es bien descrita en las secuencias iniciales de Cerca de la ciudad, de Lucía. Estas descripiciones construyen una iconografía espacial, en antítesis con la ciudad cartesiana del grid estructural de andamios y armazones de hormigón.

Esta dificultad para desplazarse es menor en la periferia romana, que ya ha sido "domesticada" por los constructores, facilitando los recorridos de sus habitantes. Más que en Roma, en Madrid las topografías sirven para mirar la ciudad y su forma desde lejos, percibiendo que el espacio alrededor de la ciudad está desconectado de ella y pertenece más al mundo rural, y que además está modificando "la forma de la ciudad", una forma cada vez más alterada e incomprensible. Las nuevas infraestructuras, que aparecen en las películas romanas, parecen haber ganado esta condición de separación entre ciudad y periferia, y aunque continúan los enormes territorios de campiña y los descampados, la ciudad en expansión parece querer acabar con todo eso; hay cierta sensación de transformación en curso, un desorden y una segregación que son el precio del desarrollo futuro. Esta entropía de la periferia romana parece pertenecer ya al espacio urbano; la especulación en el sector imobiliario creó un gran territorio urbano caótico y descontrolado, pero menos segregado: un paisaje palimpsesto, como se ha definido en el segundo capítulo.

Lucía y Nieves Conde describen muy bien la característica de la topografía Neorrealista madrileña: las chabolas se encrustan en las laderas de los altillanos arcillosos para ahorrar dos o tres paredes, facilitando la construcción, lo mismo que hacen los constructores informales italianos utilizando las arcadas de los acueductos romanos, aunque el sistema constructivo español parece inspirado en la arquitectura rupestre y rural de la tradición, una relación más profunda con la tierra, un paisaje ancestral que se produce en "la época del lodo" ${ }^{39}$, como los primeros pobladores del Pozo del tío Raimundo, definían esta temporada en los cuales los aguaceros convertían los descampados en enormes pantanos.

Se ha mapeado este paisaje presente en las películas analizadas en el capítulo anterior: en Ladrones de Bicicletas, las laderas del Río Tíber y de Val Melaina; en Mi Tío Jacinto, la cañada de San Juan Bautista hacia el antiguo río Abroñigal; el descampado del Nomentano en la Calle Vasi y las riberas del Rio Aniene, en El Techo; el paisaje seco del cauce del antiguo arroyo de La Elipa, en Los Golfos; los barrios chabolistas de Surcos y El Inquilino. En Accattone, de Pasolini, quizá tenemos uno de los ejemplos más interesante de esta iconografía, se trata de la escena de la primera cita del protagonista, Vittorio, con Stella, su nueva conquista, un paseo para llegar a una gran explanada verde con los nuevos bloques de vivienda recién construidos como fondo; en la escena, los dos se sientan a conversar, una imagen parecida a una

${ }^{39}$ Este apodo es utilizado por un habitante de El Pozo en la pelicula Flores de luna (J.V. Cordoba 2008) 
secuencia de El pisito, de Ferreri. Vittorio y Stella para llegar a la explanada, recorren un terreno totalmente ocupado por montículos de escombros, entre los cuales juega solo un niño y un terreno ocupado por taludes artificiales de tierra, con unas palmeras, probablemente movimientos de tierra de una obra, un paisaje que parece de Africa, de "tercer mundo", que Pasolini asimilaba a cualquiera de las periferias del mundo avanzado.

A través de las topografías los directores neorrealistas, buscaban "subirse" a la ciudad para analizarla, cambiar el punto de vista de la cámara, pero también observar a sus nuevos habitantes.

La topografía es un tema arquitectónico-espacial presente en la arquitectura Italiana de la Posguerra a través de una de las obras más estudiadas que ya se ha citado en esta tesis: el Monumento de las Fosse Ardeatine de Mario Fiorentino realizado en la capital entre 1946 y 1948: una gran masa de concreto suspendida sobre una excavación que, como subraya Manfredo Tafuri, expresa un contraste respecto al efímero armazón del monumento de los caídos de los BBPR en Milán. En España los concursos de arquitectura desarrollados por Otéiza, como el del monumento a Battle y Ordoñez en Montevideo (1958), también establecen una relación entre topografía y volúmenes puros, flotando en el espacio (F.4.2.2/1).

Algunos arquitectos como Libera y Sáenz de Oíza, parecen indicar otras vías en la forma de ocupar estos territorios; en el barrio Tuscolano y en Entrevías construyen hábitats horizontales, topografías artificiales que establecen una estrecha relación con las condiciones orográficas de los vacíos que ocupan. Libera y Sáenz de Oíza plantean un modelo alternativo de baja altura y alta densidad que no tendrá éxito en el desarrollo de la vivienda pública de la Posguerra en Italia y en España, países que en todo el siglo XX sufrieron más que otros países europeos, las presiones de la especulación de los capitales privados ${ }^{40}$. Libera miró a la Medina árabe, conocida a través de un viaje a África; Sáenz de Oíza llevó a España los conocimientos técnicos sobre urbanización que aprendió en su viaje de estudio a EEUU, influenciado por el modelo de baja altura de Hilberseimer. Estos arquitectos adaptarán estas visiones a los contextos romanos y madrileños, mostrando una alternativa posible ${ }^{41}$. Tafuri habla del conjunto de Libera utilizando el adjetivo "polémico", una unidad de habitación "cerrada en su propio rigor teórico y geométrico" 42.

El conjunto de Libera denominado Tuscolano III o Unidad de habitación horizontal aparece en la película Mamma Roma como fondo del paseo de llegada de los protagonistas en el nuevo barrio INA- Casa y en la secuencia final cuando Anna Magnani corre desesperada en la misma calle, después de haber recibido la noticia de la muerte del hijo.

En la escena del primer recorrido de Ettore con sus amigos descubrimos el paisaje que rodea la INA-Casa del Tuscolano y la Unidad de Libera; se trata del valle de origen volcánico del Parque de los Acueductos, que se ha revisdo en el capítulo anterior. Se ha analizado esta escena de cinco minutos que se compone de 22 planos, excluyendo los primeros planos de los personajes en secuencias de rápidas conversaciones. En los primeros tres planos se ve el grupo de Ettore y sus cinco amigos subir la ladera y luego con plano panorámico subjetivo de $180^{\circ}$ descubrimos el paisaje del Parque de los Acueductos con las ruinas de la antigua villa romana.

\footnotetext{
40 (Benevolo, La città nella storia d'Europa, 1993)

41 (Colella, El paisaje del hábitat horizontal: la Unidad del Tuscolano en Roma y el Poblado de Entrevías en Madrid, 2016)

42 (Tafuri, Storia dell'architettura italiana, 1944-1985, 1986 p. 45)
} 

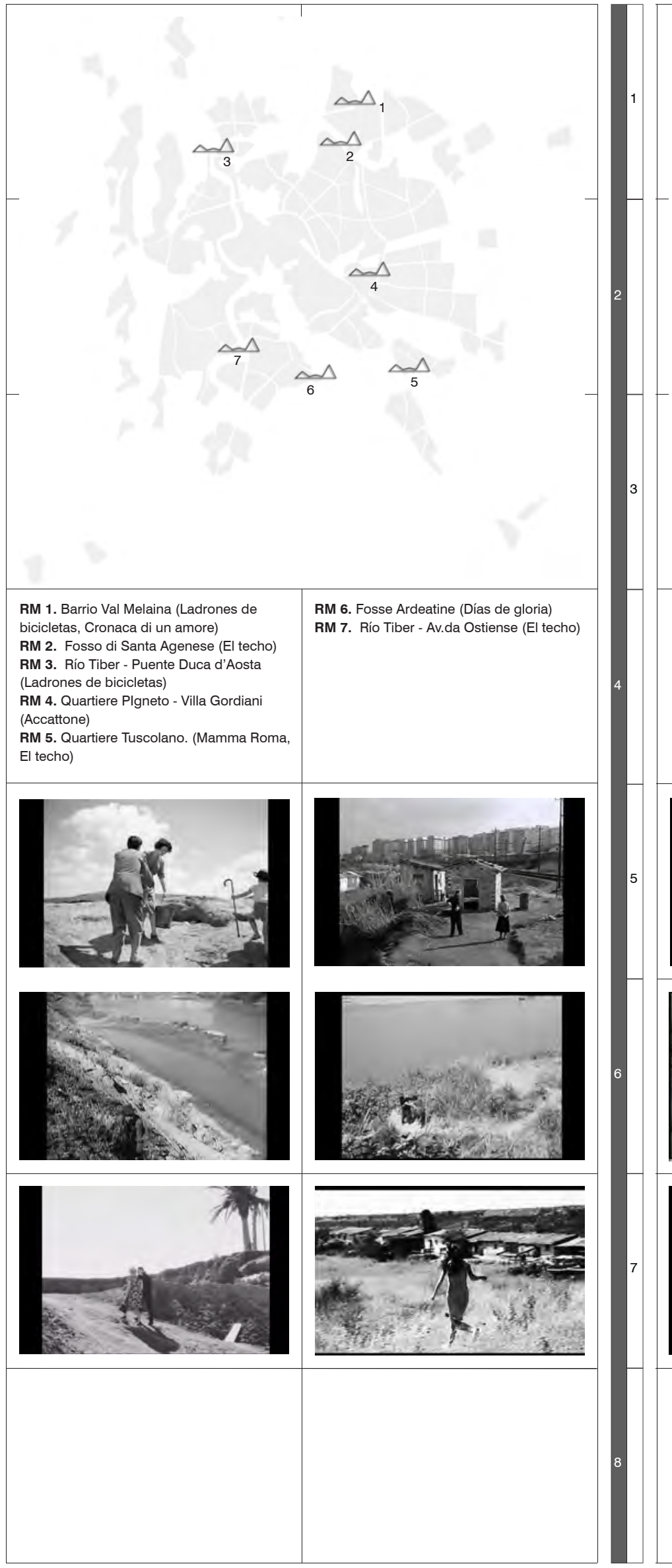

MD 1. Barriada de San Juan Bautista (Mi Tío Jacinto)

MD 6. Cada de Campo (El cochecito)

MD 2. Vaguada del antiguo arroyo de La

Elipa (Los golfos)

MD 3. Descampado en el barrio de San Blas (El pisito).

MD 4. Asientamientos informal del Pozo del

Tio Raimundo (Cerca de la ciudad).

MD 5. Poblado de Caño Roto (NO-DO).
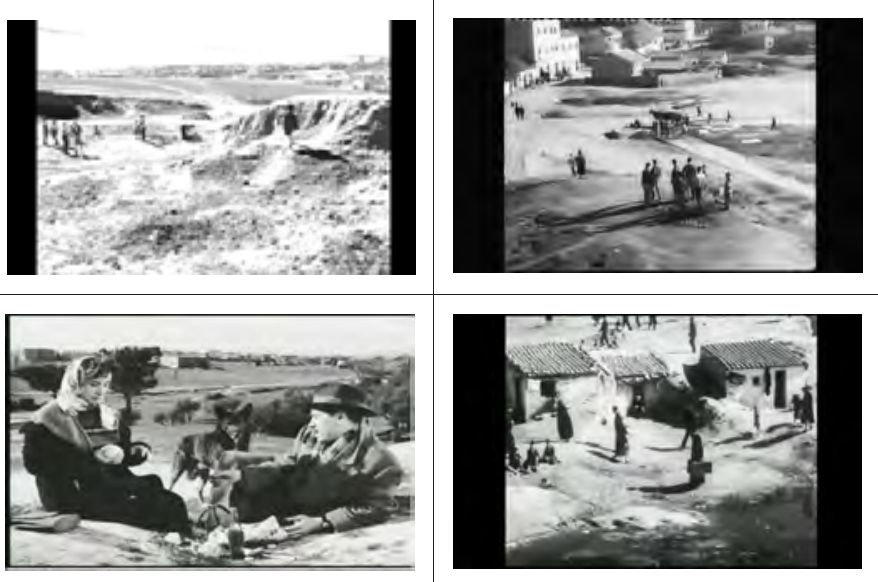

RM 5. Ladrones de Bicicetas (De Sica) - Quartiere Val Melaina

RM 5a. El techo (De Sica) - El Fosso de S. Agnese

RM 6. Ladrones de Bicicetas (De Sica) - Río Tiber, Puente Duca d'Aosta

RM 6a. Bellissima (Visconti) - Río Tiber, Av.da Ostiense

RM 7. Accattone (Pasolini) - Barrio de Villa Gordiani, Centocelle

RM 7a. Mamma Roma (Pasolini) - Barrio Tuscolano Parque de los Acueductos

MD 5. Mi tío Jacinto (Vajda) - Barriada de San Juan Bautista

MD 5a. Los golfos (Saura) - Vaguada del antiguo río de la Elipa

MD 6. El pisito(Ferreri) - San Blás

MD 6a. Cerca de la ciudad (Lucía) - barriada del Pozo del tio Raimundo

MD 7. El cochecito (Ferreri) - Casa de Campo 
En el siguiente plano los chicos bajan del talud y aparecen a un nivel inferior las hileras de las chabolas pegadas al acueducto; en el plano $n^{\circ} 5$ dos chicos se separan del grupo y bajan hacia dos chicas sentadas en medio de montículos de tierra negra de derribo. En el sexto encuadre, en un plano panorámico de conjunto, de derecha hacia izquierda, aparecen en secuencia las torres del INA-Casa, las ruinas romanas con las líneas de arcadas de los acueductos detrás de ellas, incluso un arco de la villa, en ruinas, en el cual uno de los compañeros de Ettore se detiene después de haber robado el gorro de una de las chicas. En los planos 16 y 17, de picado y contrapicado, los chicos bajan por la pendiente de la ladera del llano del parque, y se dirigen hacia un grupo de chicas de mayor edad, teniendo como fondo los bloques de la Vía Tuscolana recién construidos; en el contrapicado, los chicos corren, en un plano general, con las ruinas romanas, como escenografía, a sus espaldas.

En la película de Pasolini se pueden reconocer todos los elementos que Libera utiliza para el desarrollo de su proyecto: la topografía natural que genera una plataforma elevada, con la presencia de las ruinas, los muros de los acueductos con los techos de las chabolas, el arco, las líneas horizontales de los acueductos que, como un recinto, encierran el paisaje de la campiña romana; un paisaje que en la película de Pasolini y en la arquitectura de Libera, se opone al paisaje de las torres verticales del conjunto INA-Casa.

El conjunto de Entrevías fue construido a partir de 1956 después del rodaje de la película de Luís Lucía realizado en 1952; a pesar de la imposibilidad de reconocer los decorados y los puntos de vista de la cámara en el barrio chabolista de El Pozo, podemos reconocer el paisaje suburbano en el cual Sáenz de Oíza planteó el trazado de Entrevías ${ }^{43}$.

El territorio en el cual se mueve el cura, Alfonso Marsillach, es un paisaje árido de dunas de arcilla, con profunda barrancas y altiplanos; las chabolas de ladrillo y piedras blancas, con techo de tejas, se empotran en estas laderas, aprovechan de estas murallas naturales de tierra, así como las chabolas del Tuscolano aprovechan las estructuras existentes de los acueductos. En una escena, en la mitad de la película, un grupo de niños aparece en un extenso basurero lleno tierra de derribo y desechos, probablemente en el límite entre El Pozo y Entrevías, teniendo a la Ciudad de Madrid como fondo (F.4.2.2/2).

\footnotetext{
${ }^{43}$ (Sáenz Guerra \& Alberdi, 1996)
} 

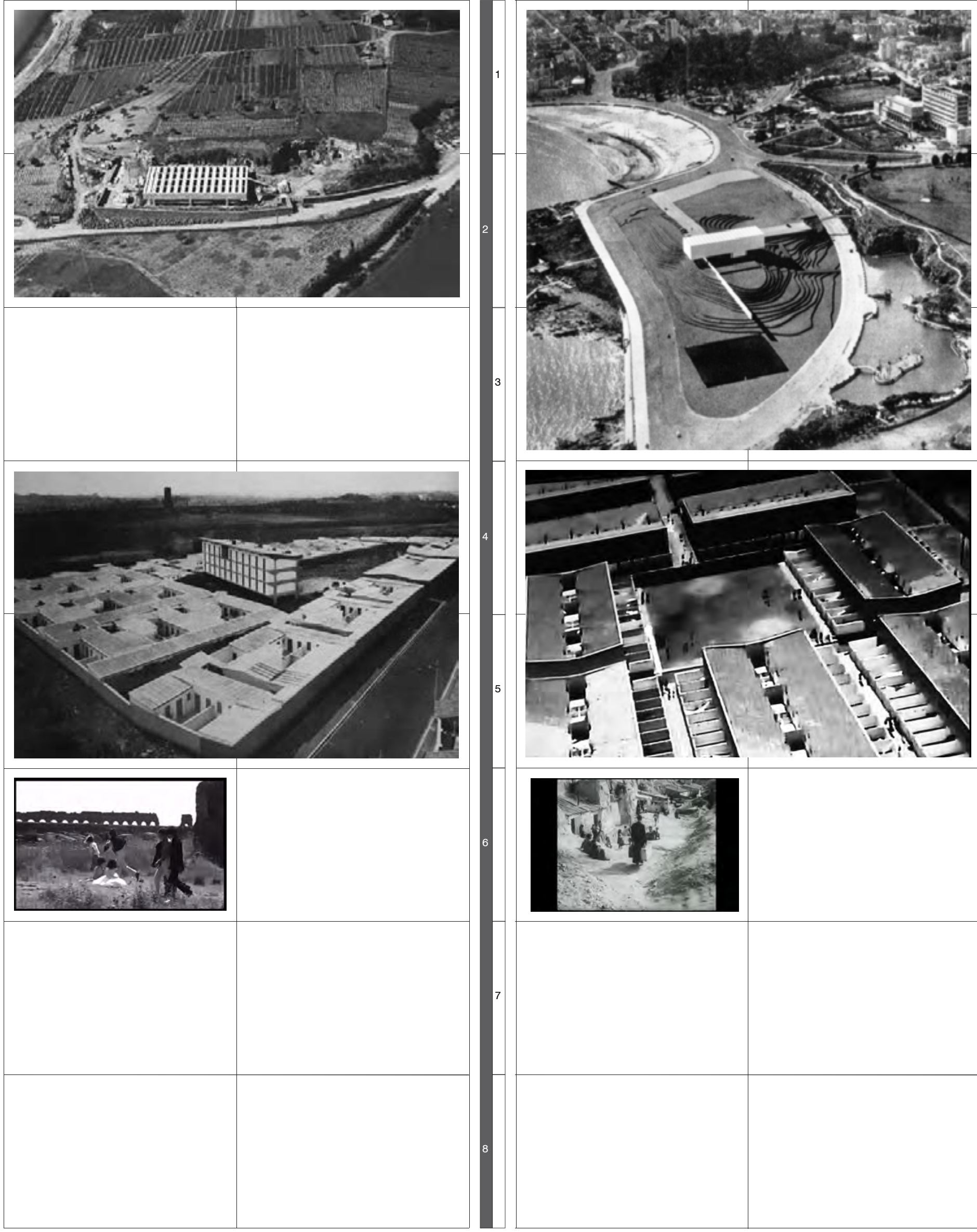

RM 1-2. Mario Fiorentino: Monumento a los martires de la Fosse Ardeatine. (1944)

RM 4-5. Adalberto Libera: Unidad de habitación horizontal en el Tuscolano (1950-54)

RM 6. Mamma Roma (Pasolini)

MD 1-2-3. Jorge Oteiza: monumento a Battle y Ordoñez en Montevideo (1958)

MD 4-5. Sáenz de Oíza, vistas áereas del poblado dirigido de Entrevías, Fotogramas de

noticiarios NO-DO de la época de construcción (1956)

MD 6. Cerca de la ciudad (Lucía)
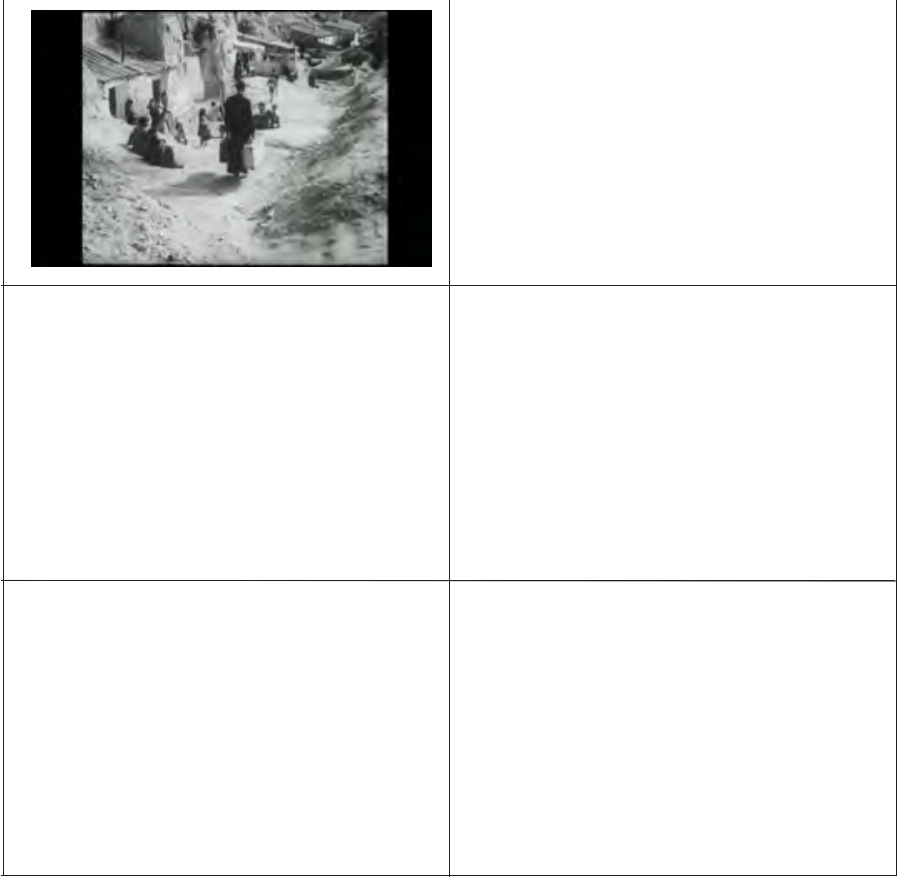


\subsection{Paisaje autóctono}

\subsubsection{Roma y Madrid: entropía y vacio}

La diferente compacidad del tejido urbano de Roma y Madrid es una característica que influye en la naturaleza de los espacios periféricos, en donde grandes lotes baldíos y los espacios naturales caracterizan un territorio en constante expansión hasta el día de hoy. Nos encontramos con un Green Archipelago, como en la definición que Ungers da de Berlín en su proyecto de rescate de la capital alemana de 1977. En el proyecto Ungers imagina una ciudad de islas construidas dentro de un ciudad con un límite definido, dentro de este límite los espacios verdes oportunamente diseñados tenían la función de "intensificar en vez de disminuir la sensación metropolitana" ${ }^{44}$. La comprensión del valor estético de estos espacios, es uno de los descubrimientos de los directores del Cinema Neorrealista italiano y español. Antonioni, Rossellini, Ferreri, Neville y Nieves Conde, son los primeros que exploran los territorios vacíos de la ciudad periférica, incluyéndolos en la geografía urbana a través del rodaje. Como en el proyecto de Ungers estos territorios nunca aparecen en la filmografía analizada como espacios naturales, sino como territorios en simbiosis con el espacio metropolitano; si todavía el día de hoy percibimos estos espacios como residuales, fragmentos de un vasto océano construido, tenemos que imaginar una situación diferente en los años '50 y '60, cuando estos espacios realmente constituían un sinfín, en el cual los nuevos barrios de promoción oficial aparecían como islas. En sus trabajos cinematográficos los cineastas definen las características físicas de estos lugares no urbanizados a través de la selección de encuadres y tomas, y los modifican creando escenografías efímeras y pequeñas arquitecturas, como las chabolas de los protagonistas de El techo, de De Sica, o de Mi Tío Jacinto.

En general podemos encontrar diferencias entre el vacío de la periferia romana y el de Madrid. El primero, por ejemplo, es un territorio híbrido, caracterizado por los fenómenos de entropía debidos a la expansión urbana, ya no pertence al espacio rural, aunque todavía conserva algunas condiciones de este; está caracterizado por infraestructuras que generan espacios residuales sin uso y landmarks: edificios en construcción, depósitos de aguas, chabolas fabricas, antiguos caminos, ruinas, etc. Roma, aunque conserva su centro, se extiende ya en este territorio con fragmentos acabados, formalmente definidos, de una ciudad.

Roma es quizá un Green Archipelago, más que Madrid; es una ciudad que consume su territorio rural, aunque en aparencia éste parece sobrevivir. Roma es centrípeta, en el sentido que atrae hacia sí las fuerzas externas y las engloba hacia su interior. Los que vienen de fuera no se incorporan en su núcleo, sino que se quedan en su citoplasma, haciendo que la célula crezca cada vez más para poder incluir todos sus elementos. La imagen de ovejas que pastan entre torres de viviendas y cables de alta tensión, es quizá una imagen que representa esta estructura y este desorden rural y urbano aparentemente incluyente de la capital italiana.

Al revés, Madrid es una ciudad centrifuga: expulsa hacia el exterior las fuerzas que vienen de fuera y que buscan ser incluydas; los pocos que logran compactarse allí ocupan minúsculas fisuras en su interior, espacios libres en un núcleo denso. Todo en el exterior es un anillo vacío y antiurbano; su periferia es rural porque Madrid está en medio de un gran epsacio desértico y rural que ocupa gran parte de la península ibérica. La capital española crece, expulsando los elementos incompatibles con la ciudad consolidata hacia el exterior, y lo que era campo, meseta o desierto se vuelve una periferia vacía, con asietamientos irregulares o de carácter suburbano y el mínimo de infraestructuras necesarias (F.4.3.1).

\footnotetext{
44 (Aureli, 2011)
} 

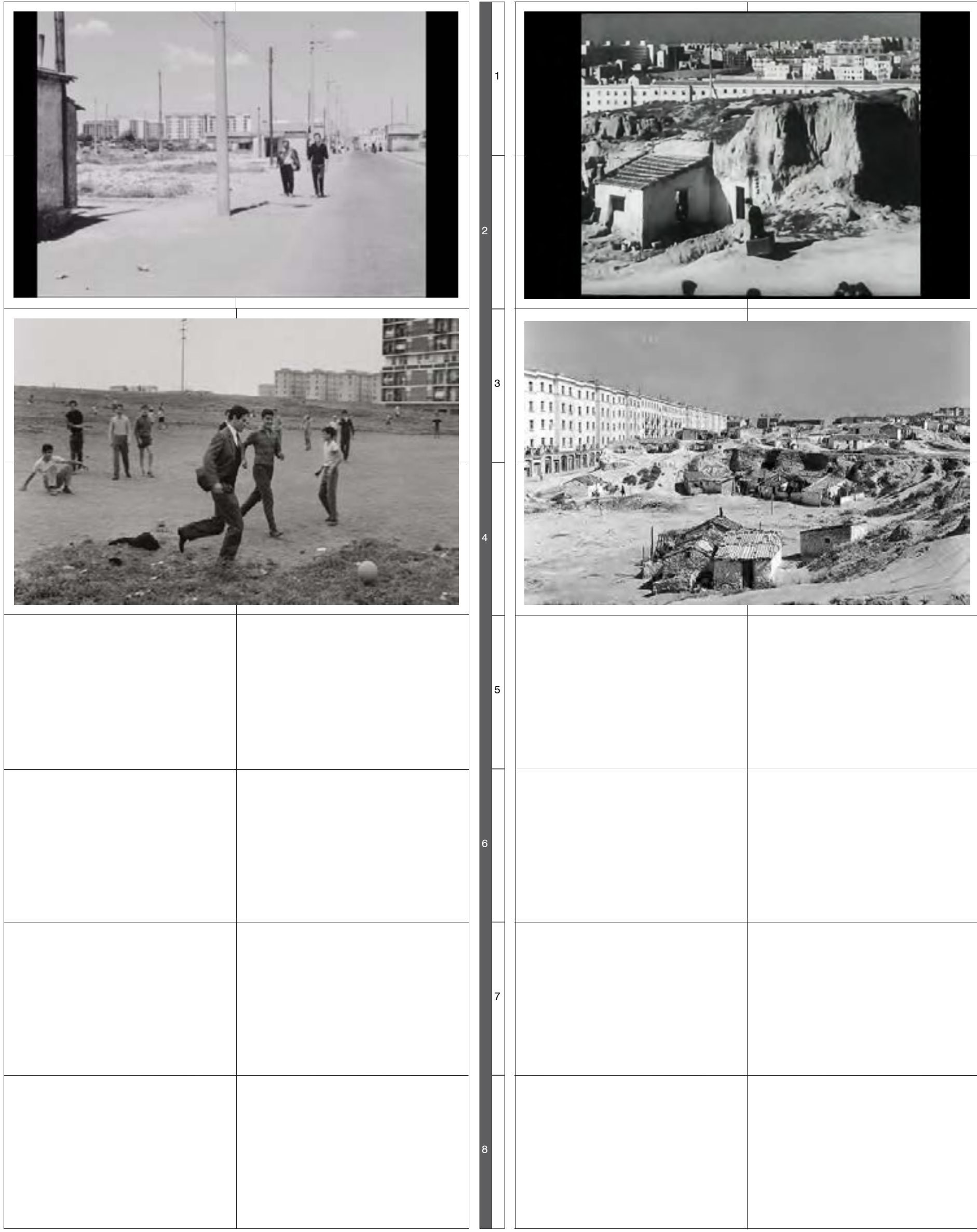
Estos fenómenos en las dos capitales siguen hasta el día de hoy. Sergio del Molino explica esta condición de Madrid hablando de España en general: La capital de España de los '50 y del día de hoy, repite a una escala pequeña las características de la península ibérica:

"Hay dos Españas, pero no son las de Machado. Hay una España indistinguible en todos sus rasgos de cualquier sociedad urbana europea, y una España interior y despojada que he llamado 'España vacía' la comunicación entre ambas ha sido y es difícil, a menudo parecen países extranjeros el uno del otro. $Y$, sin embargo, la España urbana no se entiende sin la vacía, los de la segunda están en las casas de la primera" 45 .

Como explica el escritor hay un mundo rural que no se quiere ubanizar y un mundo urbano que rechaza lo rural. Del Molino subraya esta diversidad de España en comparación con el "paisaje medio" europeo, y llega a justificar con eso también la diversidad de la periferia de Madrid, de los "hijos de la dehesa" que rechazan la Madrid del centro y de los ensanches.

Películas como Surcos contaban que lo que prometió Franco, el rescate de la España profunda y campesina, no se había realizado y el dictador dejaba que esta gente humilde y orgullosa tuviese que dejar su tierra para hacinarse en las calles de Lavapies. Surcos pasó la censura solamente porqué era el producto cultural del nucleo duro del falangismo al cual Franco debía mucho ${ }^{46}$.

Ahora este espacio vacío que rodea la capital al final de la Guerra Civil, inicialmente se urbaniza con cierta dificultad, a partir de poblados de absorción y dirigidos que intentan sustituir a los asientamientos informales. Todo este territorio, por la escasa presencia de infraestructuras, se va consolidando más como un espacio rural, como una extención del campo hacia la ciudad. Esta situación causó que la gente que viviera en estos lugares, no se sintiera del todo parte de la ciudad, estaban en Madrid "pero paseaban por un pueblo" 47 . Este espacio periférico, fue también un espacio segregativo, Madrid seguía siendo una ciudad céntrica, así que cuanto más lejos de su nucleo compacto, más baja la clase social, más fuerte la ligazón con el campo: esta gente humilde miraba a la ciudad como una pesadilla, algo de lo cual escapar, así como aparece en El ultimo caballo de Neville.

A pesar de la rapidez con la cual Italia y España dejaron de ser rurales, en España y en Madrid, los habitantes migrantes tardaron varias generaciones para absorber este cambio. En los '80 y '90, pasó algo inédito para los nietos de los que habían llegados a Madrid: "el barrio periférico sustituye al pueblo como fuente de identidad (...) se habían llevado la España vacía a la ciudad" ${ }^{48}$. Y esta generación ya no podía regresar a la tierra de origen, porqué esta ya no existía. Lo mismo pasó en Roma, aunque todo más de prisa, se siguió hablando de periferias y de sus problemas, pero no hubo un fenómeno como el Cine Quinqui español, o la música rock de Madrid. Pasolini dejó de hablar de los "Ragazzi di vita", y los padres habían dejado de añorar los pueblos de los abuelos más rápidamente que los españoles. Así que las periferias romanas, seguían segregadas y olvidadas y esto hasta el día de hoy. Seguía siendo diferente también el paisaje y su desarrollo; se iba construyendo y expandiendo el territorio comunal sin límites, haciendo que en la ciudad se generara cada véz más entropía, un híbrido entre vacios rurales y metrópolis.

\footnotetext{
${ }^{45}$ (del Molino, 2017 p.9)

46 (Ibídem p.685)

47 ibidem

48 (Ibidem p. 2802)
} 


\subsubsection{Materia y textura.}

El descubrimiento de la actividad de Giuseppe Pagano, como fotógrafo, ha confirmado la influencia que este arquitecto tuvo en la cultura de la Posguerra. Algunas de sus imágenes anticipan los resultados del Cine Neorrealista ${ }^{49}$, las que sirvieron para sus investigaciones sobre la arquitectura rural italiana, así como la fotografía más abstracta, resultados de su personal búsqueda artística. Las imágenes de texturas de suelos, muros y techos, se refieren a un mundo iconográfico contrapuesto al de la arquitectura racional y fascista, de superficies blancas y abstractas. La forma en la cual Pagano mira al Partenón de Atenas, fotografiando el muro consumido e irregular de la celda interior del templo, es emblemática de una búsqueda de los aspectos materiales y temporales en la Arquitectura, más que de su orden y geometría, a través de la descripción de sus pátinas de desgaste y de sus texturas, que identifican un origen de la Arquitectura en el mundo natural, en el universo mineral, en los entramados vegetales, la tierra cultivada, y los fenómenos atmosféricos que transforman la calidad de las superficies. En el Cine Neorrealista se representan las mismas texturas de las fotos de Pagano ${ }^{50}$. Los muros dejan ver los signos del tiempo a través de la áspera estructura de mampostería o ladrillo; los directores utilizan estas superficies para exaltar las luces y las sombras en los terrain vague, para potenciar efectos dramáticos, en oposición con la fragilidad de los protagonistas, como la sombra del protagonista de Calle Mayor, de Bardem, que se proyecta sobre el enorme muro de piedra del pueblo de Cuenca en uno de sus paseos nocturnos, y el ejemplo italiano presente en una escena de La calle, de Fellini, en el cual un muro de mampostería en ruinas se contrapone a la fragilidad de la protagonista Gelsomina, quien se detiene frente la estructura en la penumbra (2.4.4/1). En el segundo capítulo se ha utilizado la expresión "ciudad de barro" para definir un aspecto iconográfico de las dos ciudades objeto de esta investigación, que se caracterizan por el uso frecuente de este material de construcción. Junto a los fenómenos atmosféricos típicos de la imagen fotográfica del Cinema Neorrealista, los directores describen una ciudad hecha de texturas y materiales muy pobres.

En Mi tío Jacinto, en la escena inicial de la película, podemos ver a Pepote, quien, aprovechando de un aguacero, se pone a jugar con la ladera de barro, empotrando un molinillo, al lado, la chabola de madera en la cual duerme su tío: una secuencia en la cual se definen claramente las características principales del suelo del lugar, un terreno de arcilla, que alimenta la cercana fábrica de tejas y de ladrillos, en contraste con la madera de desecho de la casa de los protagonistas. Encontramos la cerámica en la película de Vajda en la imagen de la obra con los ladrillos doble-hueco almacenado y en el muro perimetral de la gran Plaza de Ventas.

Entre los suelos, el revestimiento en piedra de las calles de La Latina, y las baldosas de concreto de los espacios exteriores de Las Ventas, contrastan con los espacios sin pavimentar de la Periferia de San Juan Bautista y de Carabanchel. Los barrios periféricos se diferencian de la ciudad histórica por la casi total inexistencia de acabados en pisos y pavimentaciones: los terrenos polvorientos de los descampados se insinúan hasta el interior de los conjuntos habitacionales, contribuyendo a definir la imagen "inacabada" de estos territorios periféricos, sin diferencias entre espacios privados y públicos. En un plano-detalle de la película de Vajda, podemos apreciar la textura de estas baldosas en la plaza de Ventas, un fotograma que podemos asociar a la famosa secuencia "zoom" de Humberto $D$. de De Sica en la cual el

49 (Saggio, L'opera di Giuseppe Pagano tra politica e architettura, 1984 p.114).

${ }^{50}$ Una dualidad entre materialidad y modernidad, presente también en las películas de Jacques Tatí: Mi tío (Mon oncle) de 1958 y Playtime de 1967 
protagonista mira hacia el suelo de adoquines desde su ventana, hasta llegar a un planodetalle que nos habla de la desesperación y las ideas suicidas del personaje.

En Ladrón de bicicletas, en la escena en la cual el oficial de la agencia de empleo llama a Ricci para ofrecerle trabajo, la escalera y el basamento de la vivienda popular de Valmelaina aparecen revestidos por un almohadillado rehundido; esta textura contrasta con la de la escalera que aparece en la escena rodada en el Puente de estilo fascista Duca d'Aosta en el cual Bruno, después de haberse alejado y perdido, es alcanzado por el padre, el blanco de esta arquitectura, contrasta con el gris de los muros enfoscados de la periferia; sin embargo, podemos afirmar que hay una diferencia con la imagen de la arquitectura mussoliniana: el mármol en estas escenas revela su aspereza y porosidad en un plano medio largo que De Sica usa para describir la mirada del niño que ve a su padre alcanzarlo. Esta imagen tan diferente de una imagen abstracta y monumental de la Arquitectura, la encontramos también en Los golfos, en el lugar en donde los cinco amigos se reúnen para planear sus robos y para soñar su futuro, ya hemos visto en el anterior capítulo que se trata de unos talleres de talla y reventa de mármoles y granitos en La Elipa.

Saura como De Sica, utiliza la luz solar para subrayar las asperidades de estas piedras amontonadas, que generan un lugar ancestral y magnético en el cual la cámara del director se desplaza con un dolly. El sonido diegético de la escena está representado como en otras escenas de la película, por un tocador de guitarra andaluza que aparece por un instante, sentado entre los bloques de piedra y manteniendo una cierta distancia de los protagonistas, reunidos en el centro de la escena. Los bloques de granito, más allá de significados metafóricos sobre la existencia de los protagonistas, interesan al director para componer un paisaje que sirve para reforzar una diferencia entre el barrio de los golfos y la ciudad "civilizada"; la composición de Saura es análoga a la que Antonioni crea con ladrillos doblehueco y hueco sencillo en la Eclipse, detrás de la cual aparece la protagonista, Mónica Vitti en su vagabundeo por el barrio Eur, dirigiéndose despacio hacia el lugar de la cita con su nuevo amante. La diferencia con Saura es que lo bloques de granito son objets trouvés, un decorado realmente existente en el barrio de La Elipa, mientras que los ladrillos de Antonioni parecen estar dispuestos, como diseño de arte, por el mismo director que, en Desierto rojo había pintado de blanco los árboles de un bosque, para obtener un determinado efecto estético y lumínico. ${ }^{51}$ (F.4.3.2/1).

El techo, de De Sica es la película que más describe esta autonomía estética de la representación de materiales y texturas, contribuyendo al proyecto y a la construcción del paisaje neorrealista. El verdadero protagonista de la película es la construcción: el joven esposo Natale, aprende a construir en las grandes obras de la periferia de la capital; sin embargo, su vivienda en la orilla del Río Aniene, será el resultado de una construcción rápida e imprecisa, hecha con un apresurado aparejo de ladrillos doble-hueco, utilizados erróneamente para construir muros de carga. A lo largo de la película podemos ver todos los materiales de construcción que aparecen, en primer plano, mostrando su textura: el muro de mampostería de la casa de los padres de la pareja en la casita obrera en el Nomentano y en la casa rural de la familia de ella, fuera de la capital; las columnas de hormigón armado de las viviendas en construcción; el muro de ladrillo y la pared fisurada del edificio en renta, en San Lorenzo; la carpintería de madera de la ventana dejada en medio del predio interesado por el intento fracasado de autoconstrucción, en el barrio Prenestino; y por fin los ladrillos doble- hueco.

\footnotetext{
${ }^{51}$ En la composición cerámica de Antonioni encontramos también el interés del maestro ferrarés por la pintura de su conterráneo Giorgio Morandi, y por la investigación de este pintor sobre los temas del silencio y de la ausencia, a través de sus naturalezas muertas (Roffi, 2016)
} 

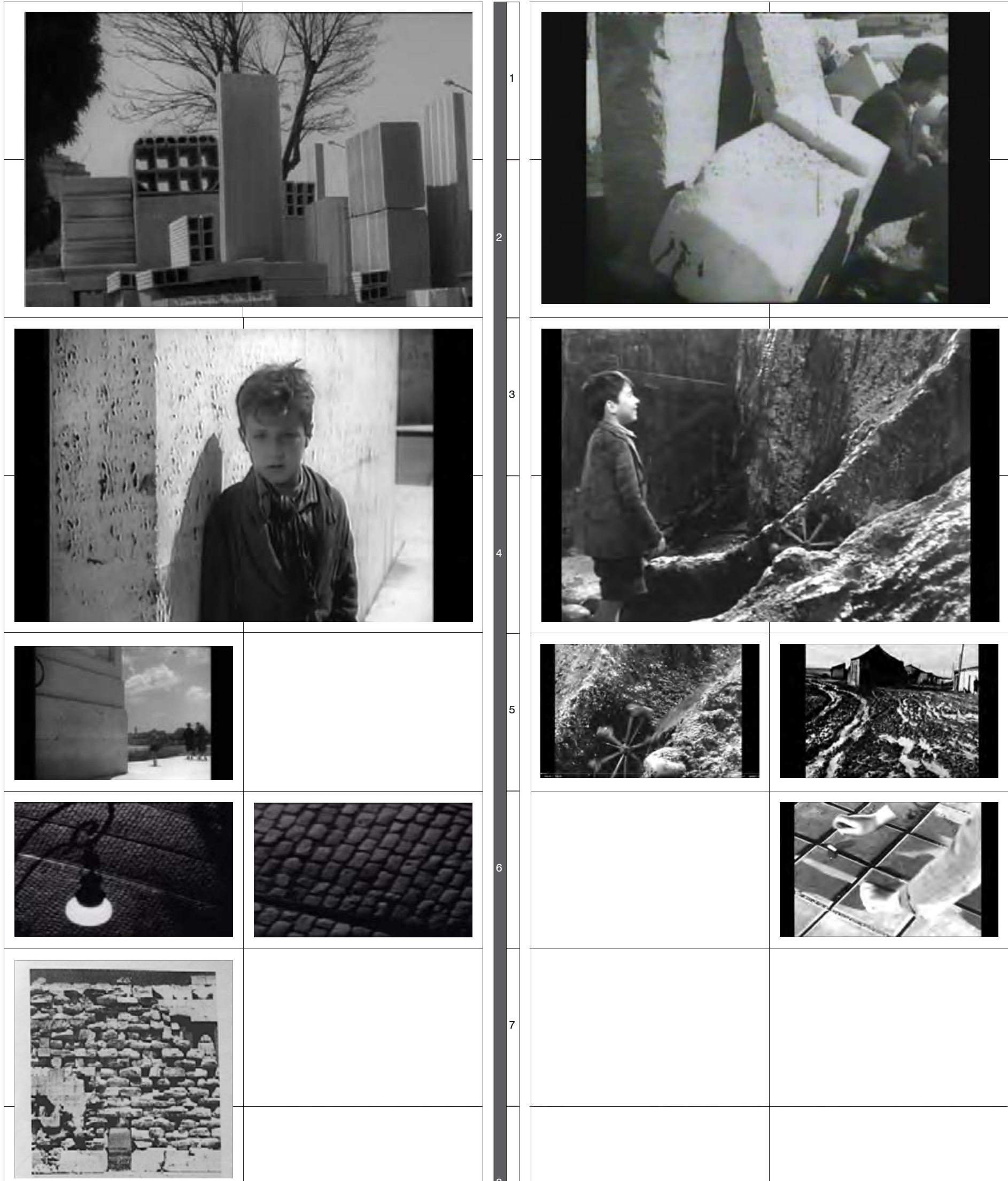

RM 1-2. Eclipse (Antonioni): BARRO

RM 3-4-5. Ladrones de bicicletas (De Sica): TRAVERTINO

RM 6. Umberto D. (De Sica): ADOQUÍN

RM 7. G. Pagano : fotografía de la pared exterior de la celda del Partenón de Atenas
MD 1-2. Los Golfos (Saura): GRANITO

MD 3-4-5. Mi tío Jacinto (Vajda): BARRO

MD 5. Flores de Luna (Cordoba):TIERRA

MD 6a. Mi tío Jacinto (Vajda): BALDOSAS DE CEMENTO 
En El techo aparece el paisaje de la capital, descompuesto en sus elementos básicos, los elementos arquitectónicos y los materiales de construcción, los protagonistas se mueven por esa ciudad "sin acabar", y construirán su chabola, que dejarán sin concluir su estructura principal: el techo.

Una larga secuencia de Calle Mayor describe, como en El techo, el paisaje de la ciudad en expansión; la vivienda que la pareja protagonista recorre en una visita a su futura casa, es un enorme e inhóspito esqueleto de hormigón armado con cerramientos de fábrica de ladrillos. En Cerca de la ciudad, en algunos fotogramas que representan la llegada del cura en la barriada de Ventas, encontramos la descripción de las características constructivas de muchos de los barrios chabolistas de la capital española; se trata de grandes laderas de tierra y barro que los asentamientos formales aprovechan para ahorrar una pared de la vivienda; los techos de tejas contribuyen a esta imagen de casas "empotradas" en las movidas topografías de las periferias de la capital española.

En Mamma Roma, las ruinas del Parque de los acueductos y su textura de conglomerado de piedra y cemento, contrastan con las superficies lisas de los edificios de INA-Casa; este contraste es visible en un fotograma de la película, Ettore apoya la cabeza de lado sobre un fragmento de estas ruinas, que aparecen en el lado izquierdo de la toma, mientras que, en el fondo, en la parte derecha del encuadre aparece una de las torres del arquitecto De Renzi, de la avenida del Quadraro, en el conjunto habitacional delTuscolano.

En otras dos escenas aparece otro material típico de la ciudad de Roma, como el conglomerado de cemento: la toba. Dos muros de mampostería en bloques de este material aparecen en la valla del hospital, en la cual Ettore se apoya esperando a sus compañeros; y en la gran tapia que cierra el espacio abovedado, en el cual Bruna acompaña a Ettore para estar solos.

La toba es el material que caracteriza el edificio en donde Mamma Roma y su hijo alojan en el Tuscolano: se trata del edificio en "V" de Muratori y De Renzi, un armazón estructural de hormigón armado con cerramientos de mampostería realizada alternando dos hileras de bloques de toba y ladrillos cerámicos. La toba regresa en los muros perimetrales de la Unidad de habitación del Tuscolano de Libera; se trata de un revestimiento en opus poligonal o almohadillado rústico que contrasta con los acabados de las viviendas y de los pasillos de distribución, y permite a la unidad integrarse totalmente con el paisaje volcánico de la campiña romana.

En las Torres de Avenida Etiopia, de Mario Ridolfi que aparecen en El techo, de De Sica y en Rufufú, de Monicelli, el armazón que hemos visto en el edificio en "V" del Tuscolano, se completa con un cerramiento más convencional de ladrillos doble-hueco y un aplanado de yeso; sin embargo, Ridolfi enriquece esta fachada a través de los ligeros retranqueos y volados de las superficies de cerramiento con respeto a la estructura, y a través de unas superficies bicolores de azulejos que ocupan la zona del antepecho bajo cada ventana. Con menos detalles en el diseño de los cerramientos y de las estructuras, podemos asociar a las torres de Ridolfi, las viviendas que aparecen en Los golfos cerca del Puente de La Elipa, con el mismo acabado de armazón de hormigón visto y superficies de guarnecido.

Otras analogías en el uso de materiales con la arquitectura de Ridolfi y la del edificio en "V" del Tuscolano las encontramos en los edificios en altura de Caño Roto, de Vásquez de Castro, en los cuales el armazón de hormigón de color gris contrasta con el ladrillo silico-calcáreo de color gris claro. (F.4.3.2/2). 

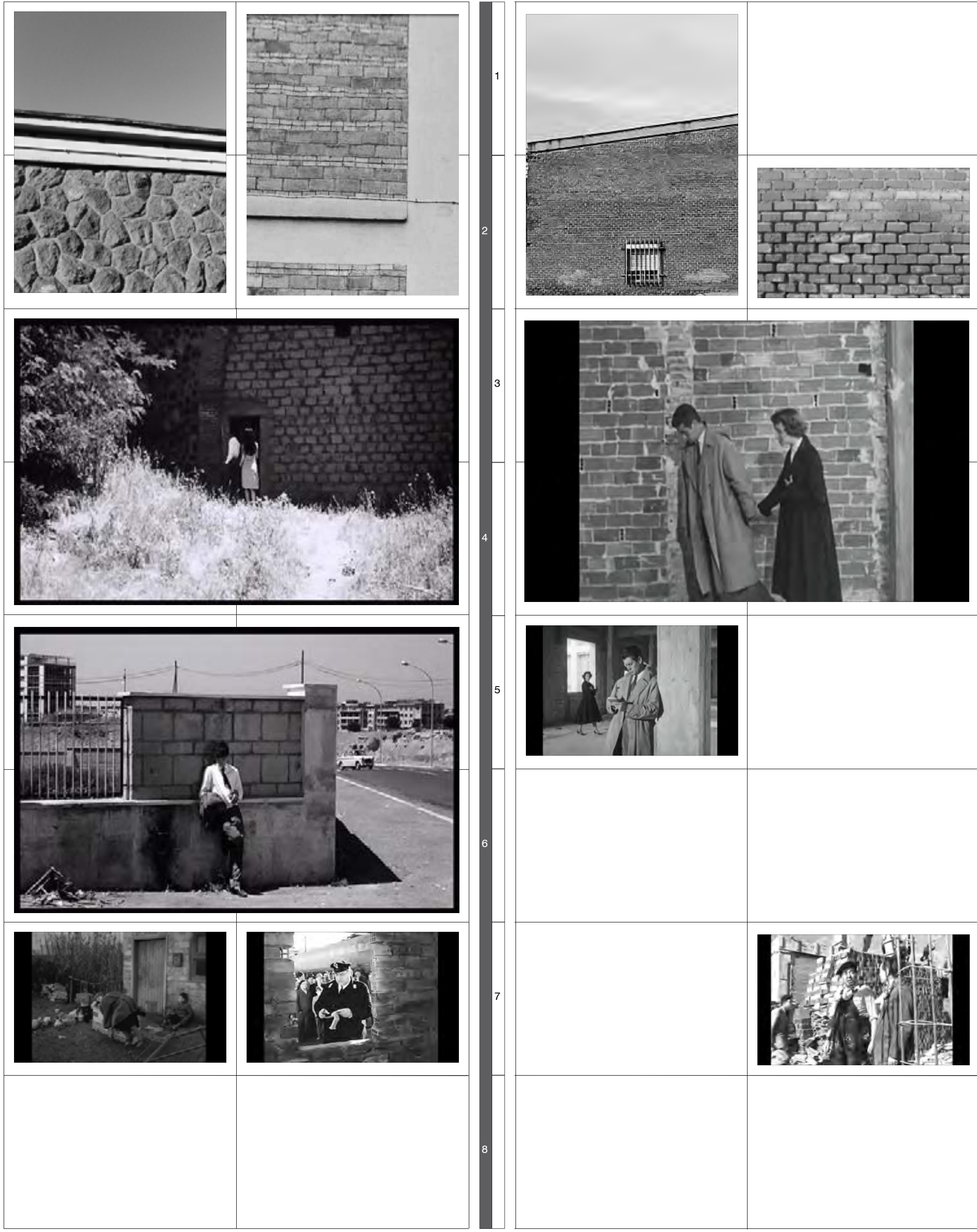

RM 1-2. A. Llbera: Unidad de habitación horizontal. TOBA, CONCRETO.

RM 1-2. S. Muratori, M. De Renzi: HORMIGÓN, BARRO.

RM 3-4-5-6. Mamma Roma (Pasolini): TOBA

RM 7. El techo (De Sica): LADRILLO DOBLE HUECO

MD 1-2. F. J. Sáenz de Oíza: Poblado dirigido de Entrevías. BARRO

MD 3-4. Calle Mayor (Bardem): BARRO

MD 5. Calle Mayor (Bardem): HORMIGÓN

MD 7a. Mi tía Jacinto (Vajda): LADRILLO HUECO 
En Entrevías, el lugar de rodaje de Cerca de la ciudad, la escasez de los medios, llevará a Sáenz de Oíza y sus colaboradores a la esencial solución de cerramientos y muros de carga de $1 / 2$ pie de ladrillo, acabado que contrasta con la carpintería metálica negra de las ventanas, con la intención de generar un efecto miesiano. La imagen del ladrillo aparente, que será la imagen típica de la Arquitectura social en la Madrid de la Posguerra no será aceptada por la población del poblado dirigido de Oíza, y en fases sucesivas, los habitantes revestirán el ladrillo con una capa de guarnecido y pintura blanca, regresando al poblado la antigua imagen de poblado andaluz del asentamiento informal de El Pozo, parcialmente derribado para la construcción del poblado dirigido.

\subsubsection{La ciudad en blanco y negro.}

Hay una imagen del Neorrealismo que sin duda hace referencia a los colores de Renato Guttuso, y de algunos artistas italianos que podemos adscribir al Neorrealismo en pintura; esta paleta cromática neorrealista se refleja en los conjuntos habitacionales italianos del INA-Casa: se trata de los ocres, los amarillos, los rojos de la tradición vernácula y popular y que encontramos también en los edificios del Empirismo sueco. En esta tesis interesa la imagen "en blanco y negro" de Roma y Madrid que aparece en el Cine, y cómo los directores operan en la percepción de la materia y de la forma del espacio urbano bajo la luz.

El Neorrealismo como explica Deleuze es este "ascenso de situaciones puramente ópticas (...), fundamentalmente distintas de las situaciones sensorio motrices de la imagen-acción en el antiguo realismo" ${ }^{52}$. En este nuevo cine de contemplación los decorados exteriores prevalecen sobre los interiores, implementando el uso de la luz natural, de una forma nunca explorada antes. Los directores, utilizan la luz en la fotografía hasta sus máximas expresiones: el blanco del sobre-exposición y el negro de la ausencia de luz en los paisajes nocturnos. En Eisenstein es una "unidad dialéctica" que se divide en negro y blanco y que configura una nueva cualidad cinematográfica presente también en el cine expresionista; Deleuze contrapone a esta dialéctica el "celebre gris luminoso de la escuela francesa" 53 que es un color que el filósofo asocia a la luz como movimiento. El filósofo francés, en "La imagenmovimiento" contrapone diferentes formas de entender la luz; una como dependiente del movimiento y típica por ejemplo del expresionismo alemán; y otra manera, que corresponde a la escuela francesa en la cual la luz vale por sí misma; en este segundo tipo de cine existe una identidad entre imagen y movimiento, que corresponde a la identidad de materia y luz: "la imagen es movimiento como la materia es luz" ${ }^{54}$. En el Cine Neorrealista prevalece seguramente este valor del gris, como "color-movimiento" más que la dialéctica del blanco y negro del cine de Eisenstein o la de luz-tinieblas del Expresionismo, aunque en algunas películas como la Tierra tiembla de Visconti es indudable la influencia de la cinematografía de los grandes maestros de los años '20.

Podemos decir que la invención del realismo en la Cinematografía neorrealista tiene una de sus reglas fundamentales en la utilización de la luz natural, la luz filtrada por los fenómenos atmosféricos y la ausencia de luz de los rodajes nocturnos. En el Cine español el punto más alto en el uso de la luz es alcanzado por el director de la fotografía de Los golfos, Juan Julio

\footnotetext{
52 (Deleuze, La imagen-tiempo: estudios sobre cine 2, 1987 p.13)

53 (lbidem p.71)

54 La luz - sigue el filósofo francés - "no es otra cosa que movimiento. (...) No es, a la manera de Eisenstein, la unidad dialéctica que se divide en negro y blanco, o que resulta de estos como una nueva cualidad. Pero menos aún, a la manera expresionista el resultado de un violento combate entre la luz y las tinieblas, o de un abrazo de lo claro con lo oscuro. El gris, o la luz como movimiento, es el movimiento alternativo (Deleuze, La imagen-movimiento: estudios sobre cine 1, 1984 p.71)
} 
Baena, que realizó la primera iluminación propiamente realista del Cine Español, que el Cine Italiano ya había alcanzado con las películas de Rossellini, como Roma ciudad abierta. En la película de Saura "cada escenario, cada lugar que se retrataba, imitaba la luz exacta que tenía en ese lugar y en ese momento" ${ }^{5}$; se produce de esta manera un "feísmo" de la imagen que se vuelve poco definida por la rapidez del movimiento representado en los fotogramas, sin luz artificial adicional: se reproducen "a veces lugares tétricos y demasiado oscuros (...), o, en otras ocasiones son los claroscuros los que rompen la imagen e impiden ver con claridad las acciones de los protagonistas (...) y, por último, el grano del negativo distorsiona la imagen y empobrece la nitidez de lo filmado (...)"56.

Ante esta luz matizada y poco nítida, se presenta, desde las primeras películas Italianas que se adscriben al movimiento Neorrealista, la luz filtrada por los fenómenos atmosféricos, que contrasta con lo estático del claroscuro de la cinematografía anterior: En Obsesión, de Visconti y en Gente del Po, de Antonioni, rodadas en la Llanura Padana, cercana al Río Po, es evidente cómo la condición atmosférica produce una calidad fotográfica única y hasta hora inexplorada en la cinematografía mundial. Gente del Po tiene una analogía en la fotografía de estilo documental con Los golfos; tanto Saura como Baena habían empezado su carrera profesional en el mundo del cine documental. La imagen borrosa de la llanura Padana en Visconti y en Antonioni, como la luz gris del amanecer en la barriada de La Elipa en la secuencia panorámica inicial de Los golfos de Saura, corresponde a una nueva lectura del paisaje urbano y suburbano, y a un nuevo punto de arranque en la estética cinematográfica. Encontramos esta misma búsqueda en las exaltaciones de fenómenos atmosféricos como la tempestad marina en La tierra tiembla o en el famoso aguacero de Ladrón de bicicletas. En esta última, el fenómeno atmosférico y el cambio de la luz en el decorado, coinciden con el tiempo real. Antes de llegar a Porta Portese en el camión de la basura que los acompaña a este mercado de objetos robados, vemos primero al viento mover los árboles, luego al cielo que oscurece, y al fin las primeras gotas que mojan los cristales del vehículo, con una toma subjetiva, percibimos que el viaje se vuelve peligroso, las calles y la ciudad desaparecen, a través de los vidrios mojados la luz es completamente gris. La misma luz aparece en la escena de Mi tío Jacinto en la cual Pepote juega con la ladera atrás de la chabola en la cual vive y que con la lluvia se convierte en una cascada.

En el paseo nocturno de Anna Magnani en Mamma Roma, en el último recorrido como prostituta antes de mudarse al Tuscolano con su hijo, Pasolini utiliza el fondo negro de la pantalla en la noche y la escasa luz del alumbrado para iluminar los personajes que aparecen y desaparecen en la obscuridad en un largo travelling de un único plano secuencia. El negro profundo de la noche aparece también en la escena final de Muerte de un Ciclista de Bardem, la mirada de la cámara dentro del coche que ilumina los troncos de los árboles al lado de la carretera totalmente oscura

Hablando del Nuevo Cine de autores como Bresson, Resnais, Jacquot y Techiné, Deleuze habla de una "nueva rítmica y un cine serial y atonal, una nueva concepción del montaje". En esta nueva concepción cinematográfica el corte -el intersticio entre dos series de imágenes"puede entonces extenderse y manifestarse en sí mismo, como la pantalla negra, la pantalla blanca y sus derivados, sus combinaciones (...)"57.

55 (Deltell \& Garcia Fernandez, 2006 p. 261)

${ }^{56}$ (ibídem p.262)

${ }^{57}$ Ibídem p.284 
En el Neorrealismo encontramos largas secuencias nocturnas que constituyen un "corte" en la narración cinematográfica, en estos fotogramas con escasa iluminación artificial, la ciudad pierde su forma, para convertirse en una imagen de ausencia, y negación. La Ciudad Neorrealista desaparece como iconografía y como referencia espacial; aparecen elementos escasamente iluminados por la luz artificial como árboles, fragmentos de muros y postes, y escenarios en los cuales los protagonistas se mueven, casi siempre en una condición de crisis y/o inseguridad. En secuencias nocturnas se producen la fuga de casa y el nomadismo del hijo menor de Surcos; los paseos nocturnos de El último caballo, (en los cuales Fernando Fernán Gómez, busca un refugio para el caballo que intenta hacer vivir en la ciudad), también el recorrido nocturno de Stella en Accattone, en el cual la joven, abandonada en la Vía Appia Antigua, llorando, regresa hacia la ciudad.

En algunas fotos de archivo de Entrevías se han encontrado imágenes de la fiesta que se produjo en una zona del barrio chabolista de El Pozo, probablemente en la primera mitad de los años '50, en ocasión de la llegada del alumbrado público en los espacios públicos de la barriada ${ }^{58}$. La gente se reúne en plazas y calles iluminadas por elementos puntuales, disfrutando de la luz artificial, metáfora de urbanidad: una ciudad en la que, cuanto más nos alejamos del centro, más se vuelve escasamente iluminada y oscura (F.4.3.3).

\footnotetext{
${ }^{58}$ Fondo Santos Yubero en AGCM (Archivo General de la Comunidad de Madrid)
} 

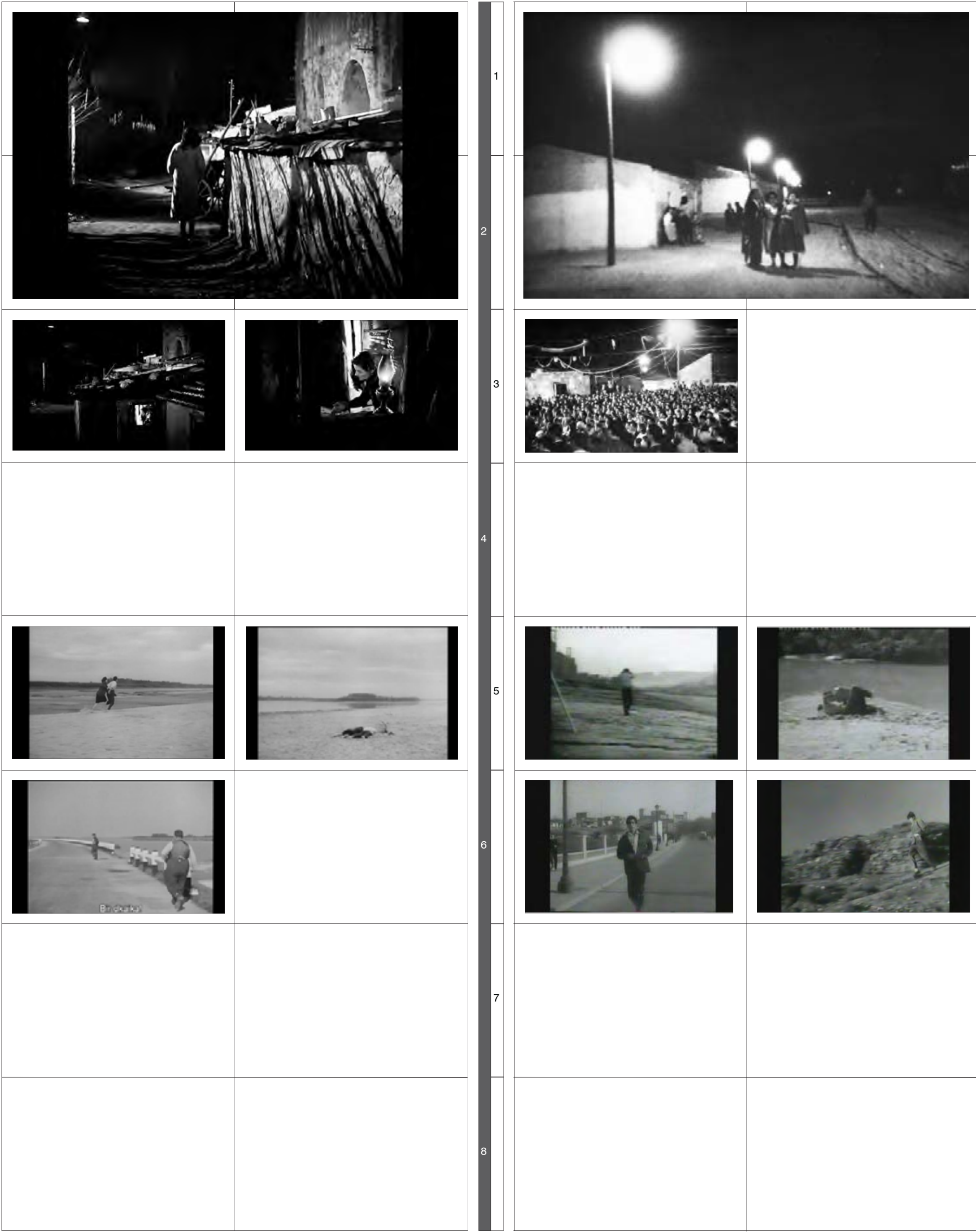

BLANCO Y NEGRO

RM 1-2-3-4. Fotogramas de "El amor en la ciudad" (AAVV 1953) con una imagen de unas chabolas construidas a lo largo del acueducto, probablemente el Claudio en el Tuscolano. GRISES

RM 5-6. Fotogramas de "Obsesión" (Visconti 1943). Vistas de las playas del delta del Po e imagen de la carrettera en Paviole (Canaro) en la Provincia de Rovigo.
BLANCO Y NEGRO

MD 1-2-3. Fiesta para el alumbrado en el barrio chabolista de "El Pozo". Fuente: Fondo Fotográfico Santos Yubero. ARCM (Archivo Regional Comunidad de Madrid).

GRISES

MD 5-6. Fotogramas de "Los golfos" (Saura 1960). Vistas de la zona del puente de La Elipa y playa de un Río no identificado (5a). 
Introducción / Superestructura / Infraestructura / Estructura / Resultados / Conclusiones 
LA CIUDAD NEORREALISTA HACIA UN MANIFIESTO.

La "Ciudad Neorrealista" definida en este trabajo de investigación es una "meta-categoría" de la ciudad, capaz de resumir aspectos que configuran problemas y soluciones del espacio urbano contemporáneo, más allá de fenómenos locales.

En este sentido la "Ciudad Neorrealista" también es una definición meta-histórica. Sus orígenes se encuentran en la revolución industrial, se desarrolla en el siglo XX y se proyecta hacia el futuro.

Las características de la "Ciudad Neorrealista" se producen en diferentes contextos y épocas, es una categoría que el cine, con su inigualable sensibilidad estético-iconográfica identifica dentro de la ciudad, haciendo visible una ciudad alternativa, una ciudad dentro de la ciudad, generada por sus conflictos y que por eso es a la vez problema y solución.

\section{DECÁLOGO}

1 - La Ciudad Neorrealista es una ciudad de refugiados, una ciudad habitada por migrantes: los que llegan de otros lugares y se establecen en ella. Es una ciudad de nueva fundación, ya que los que llegan no conocen su estructura y funcionamiento y necesitan re-inventarla, o a veces construirla desde cero. La Ciudad Neorrealista también es la ciudad de los que ya viven en ella y que por diferentes razones se convierten en refugiados, en búsqueda de nuevos caminos y nuevos territorios adentro dentro de su misma ciudad.

2 - La Ciudad Neorrealista es multicultural e híbrida, es a la ciudad de Blade Runner, es acogedora para los que, perdiendo su identidad inicial, están listos para absorber nuevas identidades. La diversidad es su valor tanto étnico como cultural.

3 - La Ciudad Neorrealista es una ciudad de frontera y potencialmente sin límites, sus territorios, aunque cuando se encuentran entre campo y ciudad, no tienen una identidad definida no son urbanos y tampoco rurales; la mayoría de las veces se trata de territoriosresiduo "de abandono de terrenos anteriormente explotados, pueden ser terrenos yermos, o llenos de vidas" ": se trata de los terrain vague del centro y sobre todo de la periferia; otras veces son reservas, lugares difíciles de explotar y por eso desocupados. "Su existencia se debe al azar o a las dificultades de acceso, que hacen que su explotación sea imposible y muy costosa. Surge por sustracción del territorio antropizado" ${ }^{2}$.

4 - La Ciudad Neorrealista se adapta a la ciudad dentro de la cual se desarrolla. Siendo una ciudad dentro o al margen de la ciudad -una "metacategoría" de la ciudad- es igual y diferente dependiendo de la urbe en la cual se desarrolla: la Ciudad Neorrealista madrileña es igual y diferente a la Ciudad Neorrealista romana. La Ciudad Neorrealista absorbe las características autóctonas de la ciudad que la hospeda y permite descifrar más fácilmente las características esenciales del lugar en el cual se desenvuelve.

5 - La Ciudad Neorrealista, es una ciudad de vectores y sus habitantes son nómadas; muchos directores cinematográficos han relatado sus movimientos; estos movimientos nunca se acaban, a veces se generan nuevas rutas, otras veces se repiten los antiguos caminos. La Ciudad Neorrealista representa la esencia de la ciudad en su ser lugar de encuentro, de llegadas y partidas, de movimientos más que de estancias. Su mejor representación es el medio cinematográfico o el mapa.

\footnotetext{
${ }^{1}$ (Clément, 2004, p. 6)

2 ibidem
} 
6 - La Ciudad Neorrealista es básicamente una ciudad informal en dos sentidos; por un lado, es imposible atribuirle una forma definida, y por otro, su esencia se opone a la ciudad legalizada y desarrollada por el capital. En este sentido es un espacio libre, de creatividad y expresión. Es la ciudad investigada por Dadá, por surrealistas, situacionistas y land-artistas. "todos los ordenamientos generan residuos" ${ }^{3}$, espacios que escapan del control y que se convierten en posibilidad de libertad. Las dos ciudades conviven y cada una recibe la forma de la otra.

7 - La Ciudad Neorrealista tiene su iconografía y su estructura espacial. Este vocabulario es lo mismo en todas las ciudades, su sintaxis, diferente. Hemos reconocidos dos tipologías espaciales generales de la Ciudad Neorrealista: la topografía, y el andamio o estructura efímera.

8 - La Ciudad Neorrealista es un palimpsesto, y sus territorios están marcados por vestigios y ruinas que constantemente se re-interpretan. Las ruinas son también las estructuras en construcción de la ciudad que crece y se extiende; son los edificios abandonados y ocupados en espera de ser derribados, son los barrios populares y descuidados que sobreviven en el centro de la ciudad; son los decorados abandonados de las películas. Es posible visitar estos lugares en épocas diferentes y a través del cine investigar estas re-escrituras urbanas.

9 - La Ciudad Neorrealista se genera por una ósmosis entre cine y espacio, y más en general entre lo virtual de la representación artística y la vida real; siendo un territorio de creación y libertad ha inspirado e inspira una constante narración de sí misma a través de todas las artes. El cine es el medio ideal para representarla y ha generado su iconografía, sus escenarios y sus mitos.

10 - La Ciudad Neorrealista es un espacio de desafío, resistencia y libertad: la Ciudad Neorrealista es la ciudad.

Frente a una ciudad cada vez más cristalizada en estructuras espaciales definidas por el capital, se siguen generando hábitats alternativos, desarrollados por los que, como los protagonistas de las películas de los años ' 50 , quedan excluidos de la ciudad formal, y buscan otras formas de ser ciudadanos, ocupando espacios residuales y de frontera, alterando el paisaje urbano. Frente a los fenómenos actuales de hiper-turistificación de las ciudades fenómeno que interesa a Roma y a Madrid- y la consecuente comerzalización de sus territorios, la Ciudad Neorrealista, representa un baluarte de resistencia contra el aburrimiento y la monotonía espacial y cutural. Es por eso y desde siempre un espacio de interés y regeneración para artistas, poetas, arquitectos y directores de cine.

¿quiénes son los nuevos habitantes de la ciudad neorrealista contemporánea?

Si hablamos de la ciudad occidental (Europa y América) ya no se trata de un movimiento del campo a la ciudad. Vemos como los nuevos migrantes son los refugiados y los clandestinos o inmigrados regulares provenientes de otros países, que escapan por motivos económicos y/o humanitarios, los fracasados de la crisis económica de 2008, los que muchos definen gitanos y que en la realidad son poblaciones estanciales que provienen del Este de Europa. La Arquitectura, el Urbanismo y el Paisajismo, no se ocupan de estos espacios ya que son territorios que quedan fuera de la ciudad formal.

${ }^{3}$ Ibídem p.12 
La presencia de migrantes es un factor esencial en el desarrollo de una ciudad y de su economía; su inclusión y aceptación no ha sido constante a lo largo de la historia. Lo mismo ocurre con los que no viven en la economía formal y que en consecuencia no tienen acceso a una vivienda digna. Hemos identificado en este trabajo, a través de la cinematografía, seis niveles en la tipología de hábitat, desde el refugio ocasional de una noche hasta la vivienda popular y burguesa ${ }^{4}$. La diversidad cultural y el intercambio entre culturas es un factor de conflicto, pero históricamente también de crecimiento. La distopía de Babel que aparece en Blade Runner de Ridley Scott es en realidad presentada al espectador como condición inevitable e increíblemente fascinante de la ciudad del futuro. Los inmigrantes de Surcos o de Rocco y sus hermanos son categorías eternas de la ciudad, presentadas por el Cine Neorrealista como problema y al mismo tiempo esperanza.

Sobre la definición de vacíos urbanos en los cuales es más fácil el desarrollo de la Ciudad Neorrealista, hemos utilizado en estas conclusiones ciertas definiciones propuestas por Gilles Clement en su Manifiesto del Tercer paisaje, por la intuición de este autor francés de asociar el desarrollo de un nuevo paisaje a la ausencia de estructuras de poder. Se analizó, en los anteriores capítulos, cómo la diferencia entre Roma y Madrid se relaciona con la variada cantidad y distribución de este paisaje de vacíos residuales.

\section{ROMA VS MADRID: EL SOL DEL MEMBRILLO Y SACRO GRA}

Para sintetizar lo que hemos profundizado en el cuarto capítulo, evidenciando el valor de la Ciudad Neorrealista como categoría meta-histórica, como espacio que se re-interpreta constantemente, podemos citar dos películas italianas y españolas rodadas en las dos capitales en años más recientes. Sacro Gra, dirigida por Gianfranco Rosi y ganadora del festival de Venecia en 2013 y El sol del Membrillo dirigida por Víctor Erice, y ganadora del festival de Cannes en 1992. Se trata en los dos casos, de "falsos documentales" así como lo fue Las Hurdes, de Buñuel, y que sin embargo se proponen como documentos importantes para este trabajo de investigación porque refuerzan el análisis comparativo y las diferencias, anotadas en el último capítulo de esta tesis, entre Roma y Madrid.

Sacro Gra habla de la gran autopista circular que corre alrededor de toda la capital italiana definiendo un umbral y una frontera; la película describe fragmentos de vida de algunos personajes que viven a la sombra de esta gigantesca infraestructura. La naturaleza residual del paisaje alrededor de este anillo artificial -una moderna muralla Aureliana- facilita las "especiales" existencias de los protagonistas: un botánico que estudia el sonido de unos insectos parásitos, un principe decaído y su familia, un pescador de anguilas, unas prostitutas, etc.

La presencia de la infraestructura vial nos hace imaginar una ciudad utópica, como la New Babilon de Constant, y nos hace reflexionar sobre la idea de Ciudad Neorrealista romana que sigue siendo un archipiélago de residuos imposible de controlar y ordenar. En la capital, pedazos de la antigua campiña romana conviven con infraestructuras, con fragmentos de una ciudad inacabada, con desarrollos de vivienda popular, con ruinas y con naves industriales: un desorden urbanístico que se convierte en un territorio inexplorado e inexplorable. Es la ciudad inacabada de las películas de los años ' 50 , que sigue sin acabarse hasta el día de hoy.

En Sol del Membrillo, el pintor Antonio López, junto a su mujer, mantiene una pequeña casa rural con un patio trasero lleno de árboles frutales, justo atrás de la estación de trenes de Chamartín (F.5.1).

\footnotetext{
${ }^{4}$ Ref. Ficha 2.5.2
} 

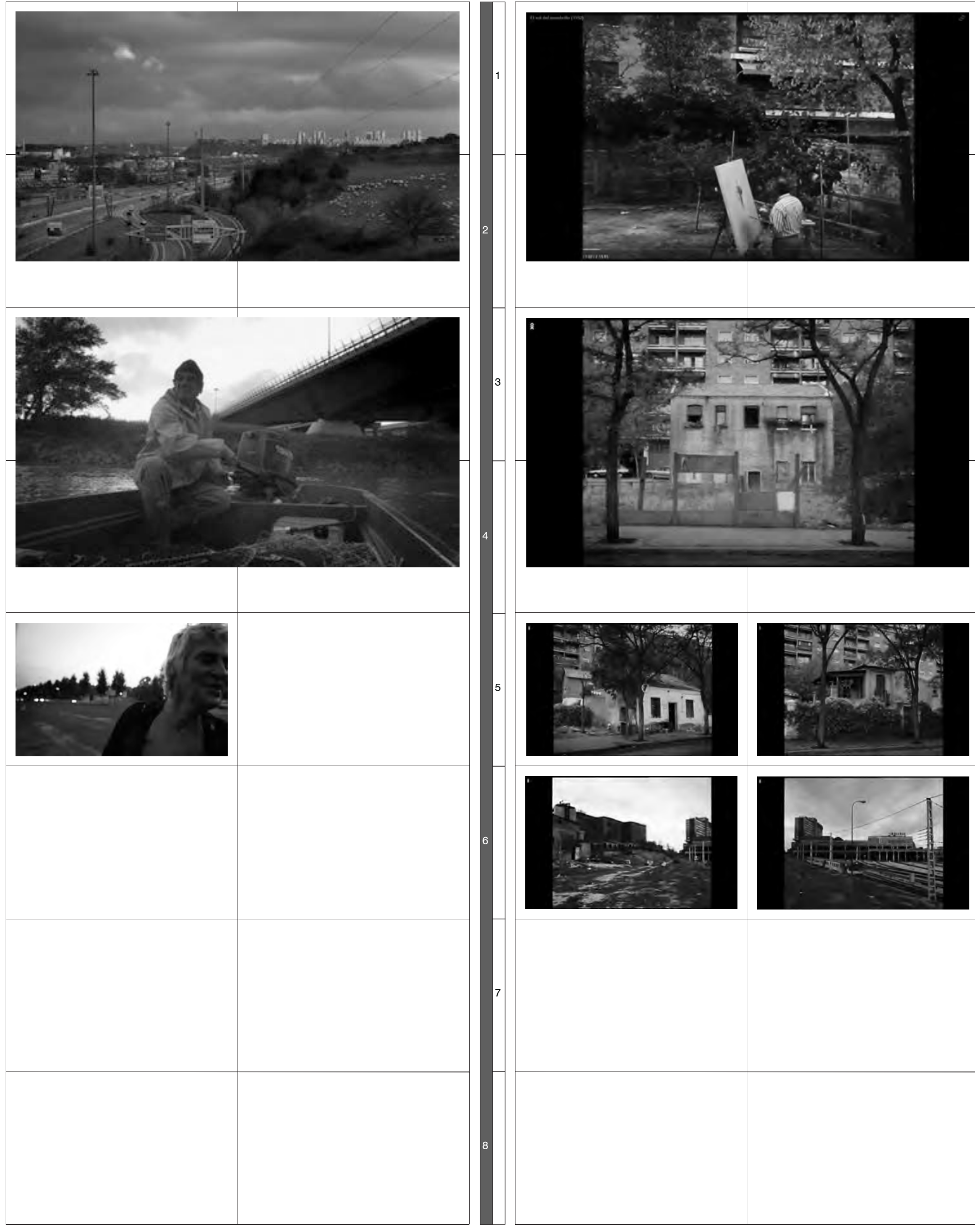

RM 1-2. Sacro Gra (Rosi): el paisaje del anillo de autopistas de Roma

RM 3-4. Sacro Gra (Rosi): uno de los "habitantes", el pescador de anguilas del Tiber

RM 5 . Sacro Gra (Rosi): uno de los "habitantes, una prostituta.

MD 1-2. El sol del membrillo (Erice): el patio en la casa-estudio del pinto

MD 3-5. El sol del membrillo (Erice): las casas en la calle del pintor

MD 6. El sol del membrillo (Erice): el paisaje de "frontera" de la estación de Chamartín
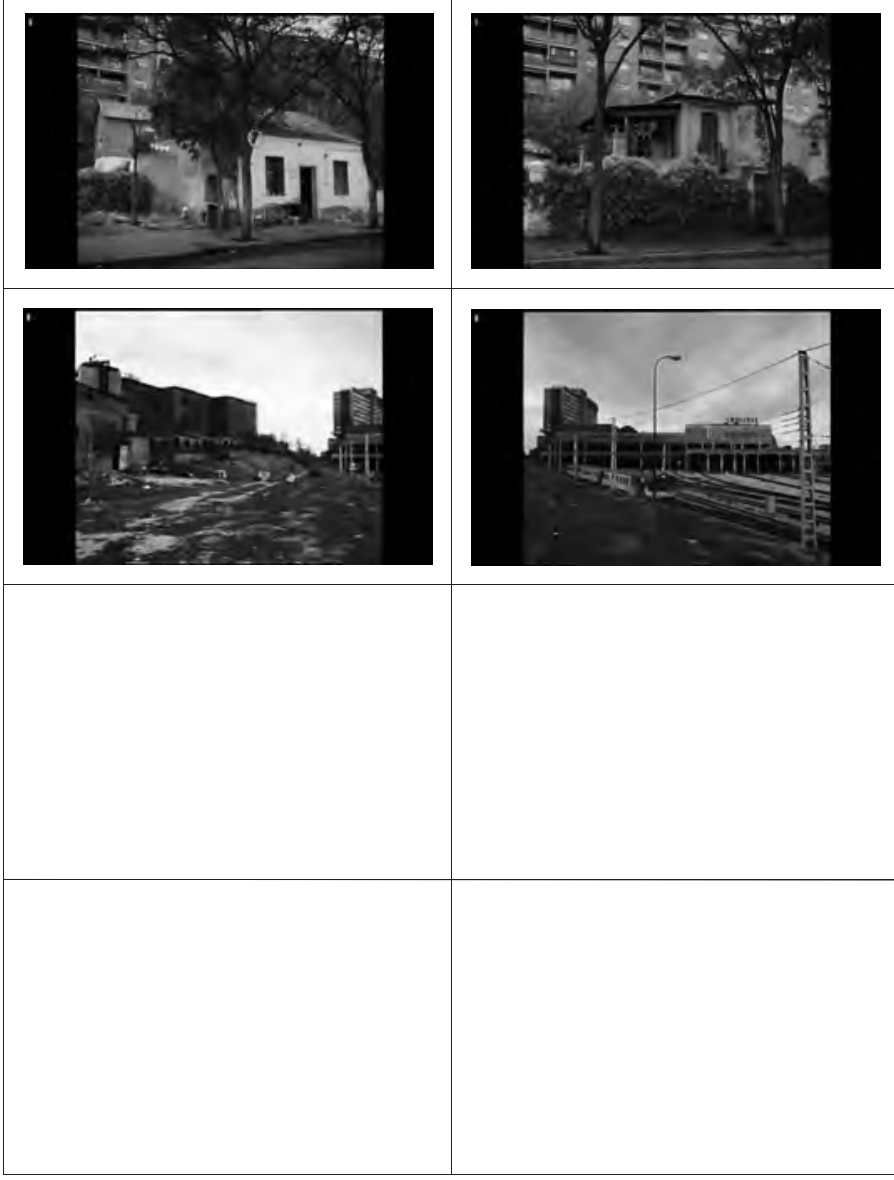
Algunos fotogramas muestran la situación de esta zona en la cual, como por milagro, arquitecturas vernáculas sobreviven en medio de una urbanización de bloques modernos de vivienda. Es una situación que expresa plenamente las condiciones de Madrid, su nostalgia del campo que ya es parte del ADN de sus habitantes. De vez en cuando unos fragmentos del "campo" de este desierto rural que envuelve la capital española, emergen como grietas en el tejido urbano

Antonio López, en su patio trasero y en su ritual meticuloso de reproducción pictórica del árbol membrillero, parece pertenecer a otro contexto en una situación de aislamiento y de resistencia; los sonidos en off nos recuerdan donde estamos ubicados, entre trenes, aviones, coches y bloques de altura. El pedazo de campo que ha traído el pintor de la ciudad, y que Madrid esconde y protege, es representado en el póster oficial de la película presentado en Cannes: un fotomontaje del cruce entre Alcalá y la Gran Vía, en el cual el pintor aparece arrodillado, cuidando su árbol. Este contraste entre campo y ciudad que se reproducía en el extrarradio descrito en las películas del Neorrealismo español, como sucede en Cerca de la Ciudad, se repite en la película de Erice describiendo la situación actual de la capital española: La ciudad se ha compactado, algunos de los antiguos vacíos han desaparecido, sin embargo, no desaparecen los testigos del antiguo éxodo rural, como restos arqueológicos entre las formas de la ciudad contemporánea

\section{EXPLORACIONES Y VECTORES}

"La actividad principal de los habitantes será la deriva continua. El cambio de paisaje a cada hora provocará una desorientación absoluta. Posteriormente, en el momento de los gestos dicha deriva abandonará parcialmente el dominio de la experiencia y pasará al de la representación". (Gilles Ivain) ${ }^{5}$

Los cineastas neorrealistas recorren la ciudad en búsqueda de nuevos escenarios que puedan describir la realidad en mutación. En estas exploraciones, la tesis reconoce más similitudes con las derivas teorizadas y realizadas por los situacionistas a principios de los 60', que resignifican las exploraciones en el territorio realizadas por los movimientos artísticos anteriores. Los surrealistas habían dejado el sinsentido nihilista de los dadás y sus visitas suburbanas, y habían empezado sus deambulaciones con la finalidad creativa de explorar lo que se escondía en el inconsciente. Ya analizamos como el mismo Buñuel criticando la actitud elitista de muchos de sus compañeros parisinos, abandonó con Las Hurdes los clásicos escenarios urbanos de las anteriores producciones dirigiéndose hacia el realismo extremo de un mundo rural, primitivo y más real. Sin embargo, las exploraciones de Buñuel miran a una relación muy fuerte entre el paisaje y sus habitantes, siempre con la finalidad de una búsqueda de una "realidad más atrás", la realidad de la psique, sin finalidades de crítica social, o búsqueda de posibles soluciones: actitud presente, en cambio, en el Cine Neorrealista.

Un aspecto en común con la ciudad situacionista, son las nuevas formas con la cual los neorrealistas miran hacia el espacio urbano, superando y enriqueciendo las "visitas" Dadá y las deambulaciones surrealistas. Los neorrealistas creen que el contexto urbano puede influir en la psique de los protagonistas cinematográficos de las exploraciones y de los vagabundeos, y de los espectadores, como anticipaba Benjamin ${ }^{6}$. Las psicogeografías realizadas por Debord en 1957, tienen una analogía con los mapas de vectores de esta tesis

\footnotetext{
5 (Ivain \& Vaneigem, 2006 p.20)

6 la cámara con "sus bajadas y sus subidas, sus interrupciones y sus aislamientos, sus extensiones y sus aceleraciones, sus ampliaciones y sus reducciones (...) nos inicia en el inconsciente óptico como el psicoanálisis lo hace en el inconsciente pulsional (Benjamin, 2013)
} 
que representan la ciudad recorrida por los protagonistas: una ciudad de fragmentos que el montaje cinematográfico permite juntar en nuestro inconsciente, y que al mismo tiempo corresponde a la selección operada por el cineasta.

El segundo aspecto que vincula a la Ciudad Neorrealista con la Situacionista es la visión urbana antagónica a la ciudad burguesa. En los directores italianos y españoles hay una mirada que exalta los estilos de vida de los humildes protagonistas que viven al margen de la ciudad; si por un lado estos estilos de vida están motivados por la dificultad de satisfacer las necesidades más básicas y la consecuente dificultad en encontrar un lugar dentro de la "ciudad formal", por otro lado los directores describen estas experiencias humanas como más auténticas y libres en paisajes que se caracterizan por una nueva y salvaje estética urbana respecto a la ciudad convencional y burguesa, que aparece ajena y obsoleta. En el Neorrealismo, como en el Situacionismo predomina la exaltación de la condición "nómada" sobre la estancial, y aunque no se haga presente el sentido lúdico de las derivas del movimiento de Debord (con la excepción de Milagro en Milán y Los inútiles), se reproduce en el cine de la Posguerra una ciudad que es posible describir y mapear a través de largos vectores que atraviesan territorios vacíos conectando sectores de ciudad muy distantes: se ha subrayado en los capítulos anteriores como en Ladrones de Bicicletas o en Mi tío Jacinto se recorren distancias de más de 30 kilómetros en uno o dos días.

La búsqueda de territorios urbanos inexplorados, residuales y desertizados, corresponde a una voluntad de cambio y transformación, como el viaje iniciático que uno de los hijos de Surcos cumple alejándose de su núcleo familiar, buscando otra forma de vivir; o como los paseos de El ultimo caballo en búsqueda de la "anti-ciudad" para poder lograr el sueño de vivir en la naturaleza que los protagonistas encuentran en una finca en la pradera de San Isidro. En Italia destacan los ejemplos paradigmáticos de Los inútiles de Fellini, casi unos modernos flaneurs que viven el espacio urbano a través de recorridos existenciales y lúdicos, muchas veces nocturnos; las derivas de Gelsomina y Zampanó en La calle y el vagabundeo sin esperanza de Humberto $D$.

Las cartografías de vectores presentadas en esta tesis describen visiones urbanas que tienen en común una constante búsqueda a través de la práctica de la exploración y del nomadismo; la iconografía de los fotogramas describe este nuevo paisaje del movimiento entre los nuevos fragmentos urbanos. Los Land-artistas a partir de los '70 empezaron a recorrer la ciudad y el espacio natural con finalidades estéticas. Robert Smithson y Amish Fulton se concentraron en exploraciones territoriales poniendo en relación el espacio y el tiempo, experiencias que presentaron al público a través de películas y documentos fotográficos. En Smithson encontramos conceptos análogos a los desarrollados en el Cinema Neorrealista, como el del paisaje de la entropía urbana, con una iconografía no lejana respeto a la que se ha analizado en este trabajo de investigación: las ruinas, los escombros, las infraestructuras industriales, los descampados, no son tan diferentes de las imágenes del recorrido fotografiado por Smithson en Passaic.

Otro concepto que se desarrolló a raíz del movimiento Land-art fue el de campo expandido, de la crítica de arte Rosalind Krauss: como los Land-artistas ampliaron el radio de acción de la escultura hacia nuevas disciplinas como la arquitectura y el paisajismo, podemos decir que el Neorrealismo salió en esta época de los límites de la pantalla cinematográfica para interpretar y proponer una nueva visión del paisaje urbano y de la arquitectura. El fenómeno del Land-art explorado por Krauss es expresión de estas invasiones de campo entre diferentes disciplinas artísticas y culturales; como la Land-art el nuevo Cine de la Posguerra se convierte en una 
práctica estética que re-interpreta el paisaje urbano, estableciendo una relación de simbiosis con la arquitectura y la ciudad ${ }^{7}$.

La ciudad neorrealista entre los años '50 y '60 tiene una similitud con las visiones de la Berlín de Ungers en su proyecto de 1977: "The Green Archipelago" en el cual imagina un gran líquido amniótico de espacios verdes en el cual navegan los fragmentos de la ciudad alemana dividida por la guerra y sus consecuencias políticas; una visión parecida a la planteada por los mapas situacionistas.

Finalmente, otra visión urbana parecida a la planteada por esta tesis y muy reciente cronológicamente es el mapa de Stalker-Osservatorio Nomade realizado y presentado en 1995, después de una larga Camminata por los territorios vacíos de la capital; un mapa como un planisferio en el cual el océano es el inmenso territorio de la incertidumbre urbana que rodea y se insinúa entre la ciudad tradicional.

\section{TOPOGRAFÍAS - ANDAMIOS}

La "topografía neorrealista" es sin duda la categoría iconográfico-espacial que más sintetiza los resultados de este trabajo de investigación; esta imagen morfológica y tipológica se convierte en elemento simbólico y catalizador de diferentes significados. Es elemento espacial, antes de todo, que encuentra su máxima expresión en los inmensos terrain-vague de las periferias de Roma y Madrid, en los descampados polvorientos que se convierten en lugares del alejamiento, de marginalidad y de contemplación, pero también de libertad y de expresión. Lugares que descubren los cineastas Neorrealistas entre los pliegues de la ciudad en crecimiento, lugares antes inexistentes, que nacen y desaparecen en poco tiempo, resultado de una ciudad que pierde su forma. La topografía es también un elemento natural: la ciudad compacta desaparece y se revela el soporte: el Abroñigal, el altillano de Madrid, el Tiber, el Aniene, la cuenca volcánica del Sur de la capital italiana.

La topografía es también un concepto que asociamos a una estructura de gestión del poder de tipo horizontal, y que hace alusión a una ciudad y un territorio popular e informal, en contraste con la ciudad vertical e institucional de los edificios del poder y de las torres de la vivienda de promoción oficial, un modelo de ciudad que los cineastas neorrealistas cuestionan en sus obras.

La topografía como elemento natural y estereotómico (como las chabolas-cuevas de algunas barrancas madrileñas), está marcada por elementos más ligeros, a veces efímeros y tectónicos, que este trabajo denomina andamios; bajo esta definición incluimos los esqueletos de los nuevos edificios y las ruinas de los de las épocas anteriores; los armazones de cemento armado, y las ligeras estructuras de madera y acero de los decorados cinematográficos; las construcciones efímeras de los pobladores y de los nómadas urbanos. Los andamios complementan las topografías, generando una abstracción iconográfica de La Ciudad Neorrealista. Se puede decir que estas estructuras caracterizan cualquier paisaje de las metrópolis contemporáneas: aunque como hemos analizados en el último capítulo de esta tesis, en la Madrid de la Posguerra el andamio estaba menos presente y representado.

\footnotetext{
${ }^{7}$ Citando Hegel y "la necesidad primitiva del arte" que Rosalind Krauss llama "construcción de lugares", podemos considerar "la arquitectura como una disciplina que opera dentro de un campo propio expandido" así que en su interior podemos incluir la escultura, el paisaje y el recorrido (Krauss, 1985 cit. En Careri, 2002 p.110).
} 


\section{RUINAS}

No solamente la guerra, sino también los conflictos entre lo público y lo privado son representados a través de los paisajes de las ruinas, los escombros, las colinas artificiales de las excavaciones en los terrenos objetos de futura edificación; las ruinas se cargan de significados políticos, son el resultado de las especulaciones que transforman el suelo urbano, generando entropía. Es paradójico que las periferias sin pasado se llenen de ruinas, como monumentos de una historia presente que modifica rápidamente y constantemente el territorio. El paisaje de las ruinas de la Ciudad Neorrealista es el mismo de muchas metrópolis contemporáneas que se nos presentan a través de los modernos medios de comunicación: las ciudades de China interesadas en mutaciones sin precedentes, y las ciudades del cercano Oriente como eternos campos de batalla. La Ciudad Neorrealista es un palimpsesto, y sus territorios están marcados por vestigios y ruinas que reinterpretamos. Las ruinas son también los antiguos decorados de las películas, los escenarios que a veces sobreviven y a veces desaparecen devorados por el desarrollo urbano.

\section{REGRESOS: CRONOLOGIAS DEL DECORADO}

En verano de 2018 se ha decidido regresar a visitar los decorados de algunas de las películas analizadas en el tercer capítulo de esta tesis.

"Todas las ciudades son geológicas y no podemos dar un paso sin encontrarnos con fantasmas, cargados con todo el prestigio de sus leyendas. Evolucionamos en un paisaje cerrado cuyos puntos de referencia nos conducen incesantemente hacia el pasado. Algunas esquinas en movimiento, algunas perspectivas huidizas, nos permiten entrever ciertas concepciones originales del espacio, pero esta visión sigue siendo fragmentaria. Hay que buscarla en los lugares mágicos de los cuentos de folclore y de los escritos surrealistas: castillos, muros interminables, pequeños bares olvidados, la caverna del mamut, el hielo de los casinos". ${ }^{8}$

Las ruinas y las capas geológicas que describe Gilles Ivain en su "Formulario para un nuevo urbanismo" no son solamente las ruinas reales, sino también las ruinas de los escenarios una vez que se acaba la filmación.

Esta tesis se abre a nuevos campos de investigación en Arquitectura y Urbanismo sobre la evolución espacial de los decorados cinematográficos, comparando su apariencia en las películas y su realidad al día de hoy. En sus investigaciones sobre el Cine de Antonioni, Mancini y Perella hablan de "arqueología del escenario" y de "eternos regresos", refiriéndose al experimento realizado en colaboración con la RAI (Radiotelevisión Italiana), en el cual el director ferrarés regresa a la Isla de Lisca Bianca, en Sicilia en 1983, filmando en un cortometraje $^{9}$ los mismos lugares que fueron utilizados para rodar parte de La aventura película de 1960; este pequeño homenaje acompaña a una serie de investigaciones del equipo de Mancini y Perella para reubicar todas las tomas realizadas en 1960, e identificar los restos de una pequeña escenografía (la casa del pescador), de la cual encuentran todavía algunos fragmentos de yeso armado y mobiliario. Sería posible repetir el experimento de Lisca Bianca para todas las películas analizadas en esta tesis, investigando en este caso como Roma y Madrid se han modificado a casi sesenta años de distancia del rodaje ${ }^{10}$. A la cartografía urbana de las dos décadas cinematográficas analizadas se podría sobreponer otra cartografía actual, y averiguar cómo los escenarios se han transformado. Se podría indagar

\footnotetext{
8 (Ivain \& Vaneigem, 2006 p.9)

${ }^{9}$ Inserto girato a Lisca Bianca (Michelangelo Antonioni) 1983

${ }^{10}$ (Mancini \& Perrella, 1986)
} 
quizá la mayor capacidad de "inercia" de la capital italiana respecto a la española, su incapacidad de cambiar o más bien de conservar sus restos, con los paisajes de la informalidad que no se derriban, sino simplemente evolucionan y se vuelven "formales". Es sorprendente encontrar en Vía Ettore Giovenale en el Barrio Pigneto, un callejón que toma el nombre de la película de Pasolini, Accattone con la misma casucha de un solo nivel donde vivía el protagonista y que se conserva dentro de un tejido de urbano de baja altura y alta densidad que poco ha cambiado después del rodaje de 1961.

En Madrid, algunas zonas de Delicias y de Legazpi que hemos visto en Surcos y en Los Golfos, no han perdido su carácter más popular, sobrevive el Matadero y el conjunto habitacional enfrente de aquel, a lo largo del Paseo de la Chopera.

Casi todos los decorados analizados mantienen restos arqueológicos que pertenecen al rodaje cinematográfico de la época neorrealista. La iglesia de San Juan Bautista, en el lugar donde se rodó Cerca de la ciudad y Mi tío Jacinto, queda ahora enclaustrada en un desarrollo de viviendas en bloques lineales. La zona de Entrevías y El Pozo se han convertido en una topografía de baja altura y alta densidad, y al día de hoy su enfoscado y su pintura blanca esconden el acabado de ladrillo aparente tan querido por Sáenz de Oíza y lo hacen parecerse a un pueblo andaluz.

Regresando a Roma, en el Parque de los Acueductos ya no se encuentran las chabolas pegadas a los arcos que aparecen en Mamma Roma, sin embargo, todavía se encuentran restos de repellados y pedazos de chapas metálicas incrustadas en la antigua estructura. Muchos de los encuadres de Pasolini se podrían repetir en las calles del Barrio del INA-Casa que ha mantenido su aspecto original. El parque donde se refugiaba Ettore ya no es un descampado, y se ha convertido en un espacio verde público, siguen sin embargo las ruinas de la Villa romana con las cuales el protagonista interactúa en varias tomas. El Mercado de Anna Magnani ya no se localiza en la calle, se ha construido un edificio techado para hospedarlo. En general, el día de hoy en este barrio romano de edificación popular, se advierte una sensación de aislamiento; los arquitectos con sus construcciones y su urbanismo "empático" crearon una isla que hoy se pierde en el océano de la especulación edilicia: el paisaje de la "ciudad sin forma" que mira Pasolini a través de los ojos de Anna Magnani desde la ventana de su casa al final de la película, ojos de dolor y rencor que contemplan cómo la "ciudad sin forma" ha triunfado, expandiéndose sin límites. La Madrid de Los Golfos es la zona del Puente de La Elipa que, con excepción de la infraestructura y algunos bloques de vivienda social, es hoy irreconocible. Ya no existe el Abroñigal, convertido en M-30, ni los descampados y los asentamientos informales hacia San Blas, hoy densamente construidos y poblados. En este sector la capital madrileña parece haber expulsado totalmente la Madrid vacía y campesina contada en las películas. Tampoco queda la placita de toros de entrenamiento de la Ventilla, otro de los muchos escenarios castizos que aparecen en la película de Saura. En la capital italiana bajando en la ribera del río Aniene, en el área que fue escogida por De Sica para rodar El techo se ha encontrado una multitud de personas que frecuentan estos lugares, acampándo u ocupando espacios con pequeñas arquitecturas efímeras. Sorprenden las vallas, los refugios improvisados, las muchas personas que bajan a este terreno residual de la ciudad, perdido entre ferrocarriles -hoy más extensos todavía- y viaductos vehiculares, buscando refugio entre la densa vegetación de la ribera. No tan distante de este lugar sigue la escalera de la vivienda de Val Melaina, desde la cual el oficial repartía empleos en el comienzo de Ladrones de bicicletas; este lugar ha cambiado, los descampados han sido ocupados por bloques de alta densidad, de la misma altura del edifico de los Ricci (F.5.2). 

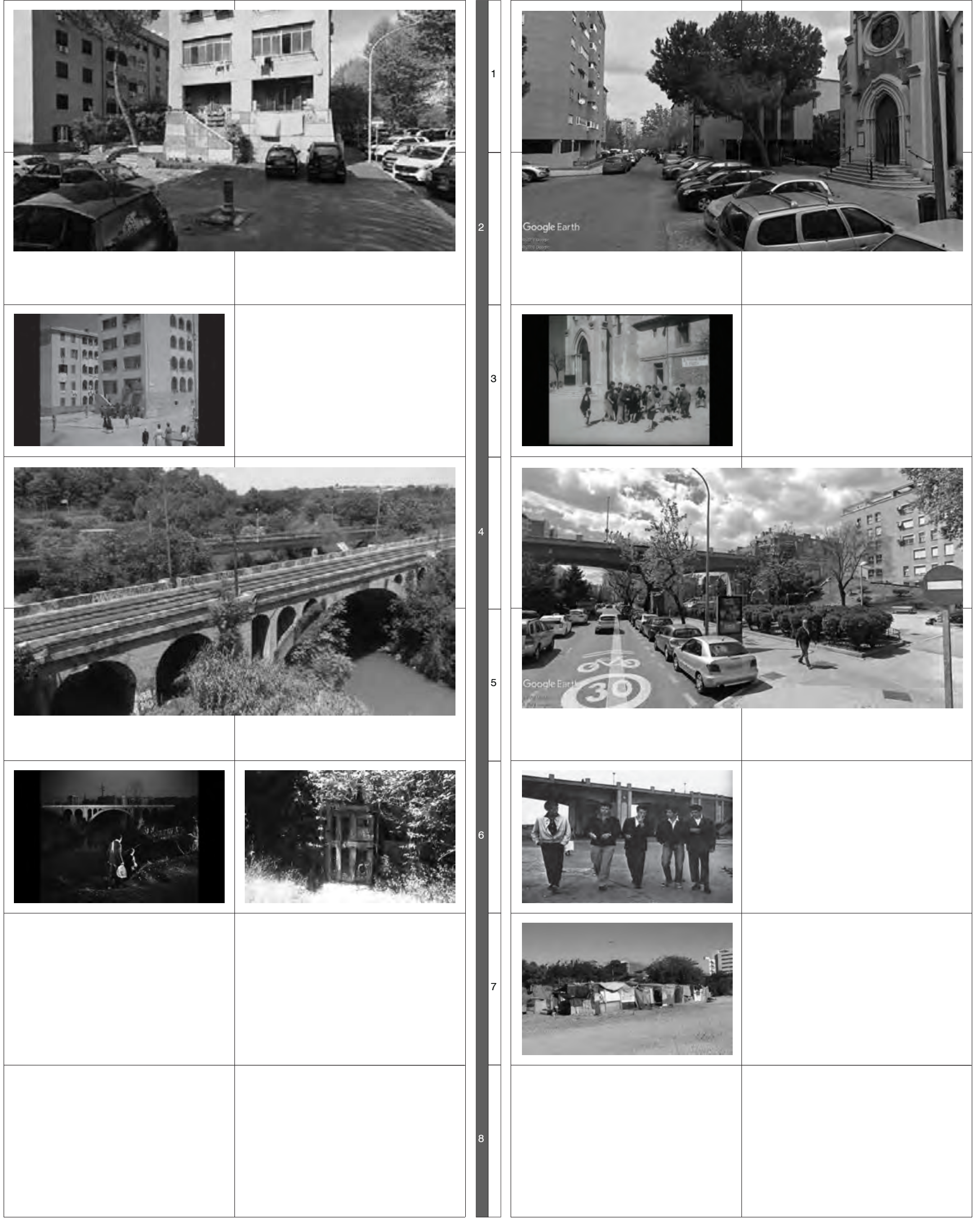

RM 1-2. Imagen actual de la vivienda popular de Valmelaina en la calle del Gran Paradiso RM 3. Fotograma de Ladrones de bicicletas con la vivienda de Valmelaina

RM 4-5. El puente Delle Valli: estado actual

RM 6. El puente Delle Valli: fotograma de la pelicula El techo

RM 6a. El puente Delle Valli: la entrada de una ocupación abusiva en los mismos lugares

de la chabola de El techo de De Sica

MD 1-2. Imagen de la actual iglesia de San Juan Bautista en el barrio homónimo MD 3. La Iglesia de San Juan Bautista en un fotograma de Cerca de la Ciudad MD 4-5. El Puente de La Elipa: estado actual

MD 6. El Puente de La Elipa: fotograma de la pelicula Los golfos

MD 4-5. Imagen de una reciénte asientamiento en los terrenos del Museo del Ferrocarril en Delicias. 
Una placa metálica en la esquina del conjunto rodado por De Sica, arriba de la escalera, recuerda a esta afortunada película y su director: esta toma de rodaje es quizá una de las pocas que se podría volver a realizar el día de hoy. El bloque de viviendas de los Ricci se percibe como el más deteriorado y de bajo nivel social de la zona, se mantiene como un estigma de degradación y pobreza sobre este conjunto, en comparación con el tejido urbano aledaño: parce haberse quedado en 1948

El espacio de las riberas del Tíber, aparece en Accattone, en Bellisima, en Amor en la ciudad y en Ladrones de bicicletas. Es un territorio donde refugiarse, un lugar de libertad y resistencia: un espacio todavía "no resuelto" de la capital italiana, y que fue un descubrimiento de una cinematografía que buscaba otros puntos de vista en la observación de la ciudad.

De la misma forma, buscando una mirada diferente, tiene que interpretarse el interés del Neorrealismo madrileño para el sector Este de la ciudad, con La Elipa, El Carmen, Arturo Soria y en el sector Oeste con la Casa de Campo y la pradera de San Isidro: lugares desde los cuales era posible observar Madrid y su cinturón vacío, de chabolas, naves, viviendas rurales y polvorientas topografías: una iconografía que fortalecía las historias contadas. El día de hoy esta separación entre la ciudad y su "anillo vacío" se ha colmado: el vacío ya está ocupado, por desarrollos inmobiliarios y grandes parques metropolitanos. Sin embargo, la Madrid de "los hijos de la Dehesa" como la define Sergio del Molino en su La España vacía ${ }^{11}$ sigue existiendo: el sueño de Fernando Fernán Gómez en El último caballo, es el sueño de muchos madrileños de ahora que siguen deseando regresar a su pueblo natal, a la "España vacía" aunque como explica del Molino eso sea un "país que nunca existió". Así que los fragmentos de vida rural que encontramos dentro del compacto tejido madrileño, son espacios de creatividad y nostalgia, como los de Antonio López en El sol del membrillo de Víctor Erice.

Esta España rural, no se borra de las cabezas de los madrileños, a veces se reproduce en los poblados dirigidos que todavía sobreviven como los de Fuencarral, de Caño Roto o Entrevías; a veces son reconstrucciones cinematográficas como el restaurante asador de Penélope Crúz en Volver de Almodóvar, en un extenso descampado de Puente de Vallecas que los vecinos del barrio querían mantener una vez finalizado el rodaje. A veces sobreviven las pesadillas bajo la forma de asentamientos que parecen llegar de una película de Nieves Conde; se trata de la ciudad lineal e informal de la Cañada Real Galiana en el sector Sureste de la ciudad que empezó como unos pequeños huertos al lado de una vía de trashumancia, o los más recientes núcleos chabolistas de "El gallinero", en la misma área, y la ocupación de los terrenos al lado del Museo del Ferrocarril en Delicias, por unos residentes de origen rumano ${ }^{12}$. El conflicto entre campo y ciudad nunca se soluciona en la capital española, a pesar de los aportes culturales de los barrios periféricos que se "adueñaron" de la ciudad en los años '80, revindicando sus orígenes rurales en oposición a la Madrid burguesa de los Ensanches. Afuera de Madrid sigue el desierto de Castilla-La Mancha, que separa la ciudad del mundo rural de pueblos y comarcas: este vacío que en los '50 llegaba casi hasta el Centro de la Ciudad, solo se ha recorrido de unos kilómetros; también la infravivienda de las ocupaciones en el centro de la ciudad, se traslada hacia las afueras desérticas, expulsada por las instituciones.

Esta dicotomía parece ausente en la Roma actual; quizá porqué en Italia los pueblos se han fusionado con los grandes centros urbanos creando la cittá diffusa que en pocas décadas ha ocupado gran parte del territorio italiano.

\footnotetext{
11 (Molino, 2017)

${ }^{12}$ los dos asentamientos fueron desalojados en el 2018.
} 
Así que los romanos no dejan de soñar como los madrileños de regresar al pueblo; sin embargo, no se ilusionan y están concientes que eso ya no existe; las ovejas de la campiña romana que pacen entre descampados y centros comerciales, ya no se parecen a las de los paisajes idílicos del Gran Tour, sino a una distopia de ciencia ficción. Este paisaje hibrido y entrópico ha alimentado las sugestiones de la película Sacro Gra, así como los fragmentos rurales que de repente aparecen en Madrid han inspirado El sol del membrillo. En esta No-stop city $^{13}$ que es la periferia romana no faltan los asentamientos irregulares, donde encuentran un hogar los habitantes de la etnia Rom, creando pequeñas ciudades dentro de la ciudad, los Campo nomadi, espacios informales que la alcaldía de la capital ha decidido institucionalizar como posible solución residencial, llegando a construir el campo más grande de la ciudad y uno de los más grandes de Europa en Castel Romano, en la periferia Suroeste de la ciudad.

\section{CREACIÓN}

Todos estos paisajes culturales, generados por el Neorrealismo y que se repiten en la contemporaneidad, son terreno fértil para la creación artística, para la iconografía y territorios de las Metrópolis del siglo XXI. ¿De qué forma?

Por un lado, existen prácticas de actuación en el territorio de la Ciudad Neorrealista. Los directores se mueven hacia la periferia y hacia los espacios residuales, porque se dan cuenta que en estos lugares está generándose una "nueva ciudad" a partir de sus nuevos habitantes. Ya no están interesados en lugares consolidados, buscan lugares indefinidos, ciudadanos que todavía averiguan una forma de serlo. En este proceso de cambio, hubo un momento -muy breve- en la primera década de la Posguerra, en el cual quizá se creía en la posibilidad de regresar a una "normalidad" del fenómeno urbano, a la "forma de la ciudad" que Pasolini exalta nostálgica y dramáticamente en sus películas. Sin embargo, la ilusión duró pocos instantes, y siempre citando al director y escritor italiano, cualquiera de las periferias de una ciudad italiana en esta época -y añadimos española- no era tan diferente a cualquier suburbio de las grandes metrópolis del tercer mundo. Después de 70 años, las cosas no han cambiado, solo es diferente el lugar de origen y/o el pasado de los que buscan convertirse en nuevos ciudadanos.

Aunque actualmente no exista un movimiento cinematográfico tan interesado en el espacio habitado y construido y en su relación con los cambios sociales, como lo fue el Neorrealismo italiano, todavía podemos explorar la filmografía actual en busca de descripciones de la ciudad y el paisaje urbano contemporáneo, indagando donde se ubica la Ciudad Neorrealista hoy; quizá actualizando los mapas de esta tesis.

Se podría actuar con recorridos de exploraciones como la experiencia realizada por Francesco Careri en la primavera de 2007 junto a sus estudiantes ${ }^{14}$. Careri recorrió las dos riberas del Tíber, desde su desembocadura en el Mar Tirreno (Ostia) hasta los últimos territorios periféricos al Norte de la ciudad italiana (Labaro y Fidene); descubriendo en este recorrido una población multiétnica de 9000 personas y sus formas de asentarse y sobrevivir. También se puede actuar con posibles intervenciones artísticas, como la de Smithson, en 1969 en Roma, Asphalt Rundown, una obra que consistía en toneladas de asfalto derramadas en una ladera periférica llena de escombros en la capital italiana.

También podemos reflexionar sobre la Iconografía Neorrealista buscando nuevas imágenes de la Ciudad Contemporánea, no necesariamente ligadas al estereotipo de la "arquitectura

${ }_{13}^{13}$ En 1970 el arquitecto Italiano Andrea Branzi del Colectivo Archizoom desarrolló la No-stop city

${ }^{14}$ (Stalker, 2007) 
urbana". Estas acciones de ocupación, de construcción de andamios y estructuras provisionales, esta valorización del elemento natural y topográfico, no entendido como paisaje artificial sino como "reserva", son todas operaciones que definimos como Neo-realistas, en oposición a visiones modernistas y posmodernistas. Nos hemos dado cuenta de que aquello que la crítica definía ya como una "imagen borrosa de la ciudad", en oposición a la verdadera ciudad, el centro, no tuvo correspondencia en la realidad: la ciudad nunca ha regresado a su morfología original. Por otro lado se produce una ósmosis entre cine y ciudad: se trata de la fuerza de los cineastas de influenciar nuestra mirada como arquitectos; pensamos en la potencia iconográfica de las torres de Avenida Etiopia vistas por De Sica, con la chabola del Rio Aniene en primer plano, la mirada de Anna Magnani, mirando el barrio Tuscolano desde la ventana de su casa, la fuerza del lugar "inventado" por Vajda, la cañada donde vive Jacinto con su sobrino, o la casa corrala de Lavapiés descrita con picados y contrapicados por Nieves Conde en Surcos. La ósmosis continúa y es abordada en el ensayo del arquitecto Renato Nicolini, donde surge la idea de Sacro Gra de Rosi ${ }^{15}$, una visión cinematografía que visualiza, como en un render de proyecto, las ideas del arquitecto-urbanista.

Nos gusta pensar que, como ciertas ideas arquitectónicas han influido sobre la iconografía de los directores de cine, así algunos cineastas influyeron con su mirada en algunos arquitectos. Es notable la obsesión estética por los andamios de obra aparentes, en la arquitectura italiana del siglo pasado, en los montajes de exposiciones y festivales. La parrilla estructural (muro trabeato), como tema de composición de fachada, se halla también en la mejor arquitectura de la Posguerra en los dos países, en las extraordinarias topografías de viviendas de baja altura y alta densidad de Libera, Sáenz de Oiza o Vázquez de Castro, que supieron adaptarse a los estilos de vida de los campesinos que migraban a la ciudad. Toda esta arquitectura que se produjo en esta época fue capaz de reinterpretar el movimiento moderno.

Es posible, el día de hoy, una nueva forma de pensar los proyectos urbanos que miren a la Ciudad Neorrealista como punto de partida, proyectos que tomen las sugestiones cinematográficas como posible lecturas iconográficas y espaciales del territorio; proyectos que trabajen en áreas residuales para sectores marginados de la población urbana, que se plantean la ligereza, lo efímero y más en general una nueva materialidad, fuera de la producción edilicia comercial, en búsqueda de una nueva iconografía inmaterial, que valoren los soportes naturales del territorio urbano, las reservas y los residuos de áreas naturales: fortaleciendo los vacíos. Proyectos que plantean el reúso de espacios, nuevas formas de transportes que favorezcan derivas y nomadismo; proyectos multiétnicos y multiculturales.

\section{LA MÁQUINA DE LA VISIÓN: ÓSMOSIS CINE / ESPACIO}

"La cuestión no consiste hoy en saber si el cine puede prescindir del espacio sino más bien, si los espacios pueden prescindir del cine. El urbanismo va a la deriva, la arquitectura se desplaza sin cesar, la vivienda es tan sólo la anamorfosis de un umbral. Mal que les pese a los nostálgicos de la historia, Roma no está ya en Roma; la arquitectura no mora en la arquitectura sino en la geometría, en el espacio-tiempo de los vectores; la estética de lo edificado se disimula en los efectos especiales de la máquina de comunicación, artefactos de transferencia o transmisión, el arte desaparece incesantemente bajo la intensa iluminación de los proyectores y propagadores. Después de la arquitectura-escultura comienza la era de la facticidad cinematográfica, tanto en sentido literal como figurado (...) La

\footnotetext{
${ }^{15}$ Renato Nicolini: "Una macchina célibe" en (Bassetti, Matteucci, Nicolini, \& Rosi, 2013)
} 
ciudad no es ya un teatro (ágora, foro) sino el puro cine de las luces de la ciudad". 16

Como describe Paul Virilio en este fragmento de su ensayo "Estética de la desaparición"17, el cine opera una revolución que trasciende los límites de la pantalla y, a través de nuestro inconsciente óptico, influye sobre nuestra percepción del espacio: "Roma ya no está en Roma" ${ }^{18}$. Virilio llega a imaginar nuevos sistemas de visión automatizada, en los cuales unos nuevos aparatos gestionarán los fenómenos perceptivos como una elaboración progresiva de datos.

A partir del ya citado concepto de campo expandido de Rosalind Krauss, el cine junto al Neorrealismo, se convierte en una herramienta de exploración espacial, extendiendo su investigación hacia el territorio del Urbanismo y de la Arquitectura. Al mismo tiempo con un proceso de ósmosis inversa y como plantea Paul Virilio, cada vez la ciudad real se funde más con una arquitectura de puntos de vistas, luces, reflectores, vectores de movimiento; "la estética de lo edificado se disimula en los efectos especiales de la máquina de comunicación, artefactos de transferencia o transmisión ${ }^{19}$ " y el espacio urbano real, a través del cine y de las nuevas herramientas de producción digital de la imagen, se convierte en una arquitectura aumentada.

La iconografía y la estructura espacial del territorio real, como en un gran hipertexto, se enriquecen desde distintas fuentes de información, incluyendo lo virtual de la representación cinematográfica, el video-arte y las páginas web que recopilan árticulos, historias y leyendas. Los actuales procesos de búsqueda de imágenes a través el reconocimiento de siluetas, colores y morfologías, existentes en la red, constituyen la aplicación de una nueva forma de ver, anticipada por Virilio en su ensayo de hace más de 25 años.

La realidad aumentada, posible hoy a través de nuevos softwares y aplicaciones accesibles a todo usuario, brinda la posibilidad de asociar a un paisaje y a un territorio una cantidad de informaciones y datos a los cuales, gracias a las nuevas tecnologías, es posible acceder de forma inmediata. Se habla de big-data o datos masivos para referirnos a la cantidad creciente de información y a la posibilidad de acumularla para generar lecturas, que puedan encontrar patrones de repetición, lo que nos sirve para analizar cada vez más objetivamente la realidad.

En el territorio de la arquitectura y del urbanismo, esta cantidad de datos se sobrescriben sobre un territorio-palimpsesto, generando una cartografía territorial, una "arquitectura aumentada", más compleja, donde ahora somos capaces de leer, interpretar y tener juntas a través de tecnologías GIS y sistemas de mapeo satelital.

A través del uso de tags y keywords, es posible facilitar la lectura y la búsqueda de información dentro de este laberinto de datos, desarrollando nuevos léxicos de visualización y sintaxis de interpretación, generando los "paisajes culturales" dentro de los cuales se producen los análisis comparativos, como el que proponemos en este trabajo de investigación. El Cine permite la construcción de un "paisaje cultural" inter-activo, que será posible desarrollar también a través de la gestión de los datos presentes en la red.

El paisaje urbano a través del arte cinematográfico vincula la dimensión espacial a la temporal; Jean Mitry afirmaba que: "el cine es la única entre todas que es a la vez un arte del espacio y

\footnotetext{
${ }^{16}$ (Virilio, Estética de la desaparición, 1988 p.72-73)

${ }^{17}$ En parte ya anticipado por Walter Benjamin en su célebre "La obra de arte en su época de reproducción mecánica",

${ }^{18}$ lbídem

${ }^{19}$ Ibídem
} 
un arte del tiempo" ${ }^{20}$. En realidad la arquitectura comparte con el cine esta cualidad bidimensional, esto tiene que ver con la capacidad de relacionarse con la experiencia estética en el tiempo, como las prácticas de paralaje producidas por los paisajistas creadores del pintoresquismo a finales del siglo XVIII' ${ }^{21}$.

Otro aspecto en común entre arquitectura y Cine, subrayado por Walter Benjamin es la cualidad de ser arte para masas, por la característica de facilitar un entendimiento rápido que hace que todos sean "expertos" y puedan juzgar, además que tanto el Cine como la arquitectura tienen la cualidad de la distracción ${ }^{22}$ que causa una "profunda transformación de la percepción ${ }^{23}$ ", argumento principal de la estética. Arquitectura y Cine se complementan en la Ciudad Neorrealista, generando una nueva percepción del espacio urbano.

En su ensayo sobre visión Virilio introduce el concepto de "visiónica", mismo que podemos asociar en esta tesis a la posibilidad que tenemos actualmente de procesar imágenes y documentos para poder realizar un mapeo eficaz de datos que no solamente describen una realidad física, sino que permiten vincular informaciones de diferentes saberes y culturas ${ }^{24}$.

La cartografía es la herramienta poderosa que permite vincular la representación de datos y acontecimientos, y corresponde a los modernos sistemas de geo-referenciación (GIS). La "topografía", entonces, es quizá la iconografía que más corresponde a esta idea de territorio, y está ampliamente representada en la cinematografía de los dos países como imagensimbólica, como voluntad de exploración del territorio: el Neorrealismo lo hizo forma contundente, utilizando todos sus recursos: tiempo, tomas, montajes y guion.

Sobre estas topografías el movimiento y su representación son elementos fundamentales como paradigma de la modernidad, presentes en la representación cinematográfica más que en otras expresiones artísticas. Para Deleuze el movimiento caracteriza una existencia proyectada hacia la innovación, en oposición a lo estático, sinónimo de decadencia: esta filosofía del movimiento encuentra en el Cine una síntesis y una metáfora de la vida, un arte capaz de representar los flujos y las heterogeneidades de la existencia ${ }^{25}$.

\section{ANNA MAGNANI, CARMEN MAURA: DOS MIRADAS}

En sus escritos sobre teoría cinematográfica, Pasolini habla de una "semiología de la realidad" para definir el arte cinematográfico. Para el escritor y director italiano, la realidad ya es una forma de lenguaje, una representación; "el cine al reproducir la realidad, (...) nos hace tomar conciencia de ella y nos permite entenderla y conocerla sobre otras bases; nos revela de forma evidente su dimensión cultural”26.

\footnotetext{
20 (Mitry, 1989 p.32)

21 (Abalos, Estética pintoresca, arquitectura y cine, 2007 pp. 129-142)

22 "La masa, en cambio por el hecho mismo de su distracción, recoge la obra de arte en su seno, le transmite su ritmo de vida, la inunda con sus olas. La arquitectura es uno de los ejemplos más llamativos. Siempre representó el prototipo de un arte cuya recepción, reservada a la colectividad, se efectuaba en el marco de la distracción. Las leyes de esa recepción son sumamente reveladoras" (Benjamin, 2013 p. 99-100)

${ }^{23}$ Ibídem p.101

24 "¿No se habla de una nueva disciplina técnica, la 'visiónica', de la posibilidad de obtener una visión sin mirada, donde la video-cámara se serviría de ordenador que asume para la máquina y no ya para un telespectador, la capacidad de análisis del medio ambiente, la interpretación automática del sentido de los acontecimientos, en los dominios de la producción industrial, de la gestión de stocks o también, en la robótica militar?” (Virilio, 1989 p.77)

25 (Deleuze, Conversaciones, 1972-1990, 2014)

26 (Mariniello S. , 1999 p 22)
} 
Pasolini, identificando el Cine con la realidad, explica que la Semiología del cine sólo debería ser parte de la más amplia Semiología general de la realidad; "el film se podría definir como 'palabras sin lengua': en efecto los distintos films para ser comprendidos no remiten al cine sino a la realidad misma. (...) reconocemos la realidad en los films que se expresa en ellos para nosotros como hace cotidianamente la vida" ${ }^{27}$.

El plano-secuencia es la técnica cinematográfica que permite una absoluta correspondencia entre cinema y vida. Sin embargo, para Pasolini, solamente a través del montaje el rodaje cobra significado, porque establece una distancia temporal entre la acción cinematográfica y la interpretación del director; de la misma forma como, explica Pasolini, en la vida solamente a través de la muerte podemos dar un significado a las acciones que transcurren en ellas en un tiempo sin fin, creando una distancia suficiente para interpretar los acontecimientos de la existencia. El montaje es un corte como la muerte para la vida: este corte radical permite dar un sentido.

El cine de Pasolini busca en el montaje una constante re-interpretación de la realidad, el director italiano utiliza escenarios y personajes generando enlaces y articulaciones semánticas. Hay una superación del Neorrealismo, que en el plano-secuencia encontraba su técnica más eficaz. El paisaje, que Pasolini utiliza en sus rodajes, es una realidad que vive en función de sus personajes y que el cine interpreta asignándole un significado, el paisaje autónomamente en Pasolini no tiene valor -cosa que en cambio pasaba en el Neorrealismoel decorado vive solamente en función de sus personajes. Encontramos algunos de los conceptos pasolinianos también en el primer cine de Saura. El estilo de Los golfos de Saura quería superar al Neorrealismo italiano a través de un lenguaje que cada vez más se acercara al estilo del documental, en el cual el paisaje como en el cine de Pasolini interactúa con los personajes a través del mecanismo del montaje de fondos y situaciones a veces no coherentes, sin una correspondencia real entre narración espacial y decorados, juntando fragmentos distantes de un "universo periférico" imaginario e hiperrealista. En el primer cine neorrealista, el paisaje aparecía más estático respecto al paisaje de Saura y Pasolini, buscando una relación casi filológica entre territorio y rodaje; los directores descubrieron además la arquitectura que los arquitectos de la época iban desarrollando y la convirtieron en decorados de una nueva iconografía urbana; un paisaje hostil que los directores representaban con cierta curiosidad estética, sin todavía la profundidad de análisis de Pasolini.

Así como conclusión de este trabajo podemos sobreponer a la escena final de Mamma Roma de Pasolini de 1962, la de ¿Qué he hecho yo para merecer esto? de Almodóvar, presentada 22 años después en 1984 y rodada en Madrid; a la mirada final de Anna Magnani hacia la periferia de la ciudad eterna, corresponde la de Carmen Maura hacia los suburbios de la capital española. Se han seleccionados ocho fotogramas por cada película para evidenciar las analogías espacio-temporales entre estas dos escenas de obras diferentes en estilo, técnica y fecha, aunque en las secuencias finales se podría hablar casi de una sobrescritura, un homenaje que Almodóvar hace al trabajo de Pasolini.

1. Regreso a casa. / 2. Acceso al apartamento vacío. / 3. Mirada hacia la cama del hijo que se ha ido. / 4. Apertura de la ventana. / 5. Deseo de arrojarse al vacío. / 6. Contracampo de la mirada de la protagonista perdida en el vacío. / 7. Plano general sobre la ciudad periférica. / 8 . Titulo del final ${ }^{28}$.

${ }^{27}$ Pasolini, "Discurso sobre el plano-secuencia o el cine como semiología de la realidad" De Problemas del Nuevo cine. (Varios autores) Alianza Editorial, Madrid, 1971. Traducción de Augusto Martínez Torres.

${ }^{28}$ La duración de la Escena de Mamma Roma es de 3' y 45" en "Que he hecho yo..." es de 4' y 34". 
Todos los encuadres seleccionados son planos medios, medios largos y medios americanos excepto por las dos tomas finales la 7 y la 8.

La escena madrileña tiene un final diferente, ya que antes del título final el hijo regresará con la mamá, aunque no cambia, en la toma panorámica final, la representación del barrio periférico, el conjunto habitacional llamado "la colmena" en el barrio de la Concepción en el cual los protagonistas viven, en el mismo sector donde se grabaron Cerca de la ciudad y Mi tío Jacinto la periferia Oeste de la capital, muy cerca de Las Ventas.

El fotograma final antes de los créditos en Mamma Roma es, en cambio, la vista hacia los conjuntos habitacionales alrededor de la Iglesia de Don Bosco, en el barrio Tuscolano. Este fotograma regresará otras cuatro veces a lo largo de la película de Pasolini, cargándose de un valor simbólico de crítica hacia la nueva ciudad y de la imposibilidad de un rescate que esta genera, que se ha analizado en el tercer capítulo; se trata de una toma incoherente, con lo que se puede observar realmente desde la ventana del edificio de Saverio Muratori, en el cual Anna Magnani vive con su hijo. Una toma que evidencia la crítica del director italiano hacia la nueva "forma della citta" 29 resultado de la especulación. Es posible yuxtaponer otros dos fotogramas el 5 y el 7 dentro de las dos escenas seleccionadas. En el $5^{\circ}$ de Mamma Roma, la cámara, encuadrando la ventana que la protagonista abre para suicidarse revela el cielo como fondo más allá de la vivienda, los actores de espalda se proyectan hacia este elemento atmosférico. En la película de Almodóvar, el director madrileño encuadra de espaldas Carmen Maura que está sola, mirando abajo desde el balcón de la vivienda: en el fondo no aparece el cielo u otro elemento natural, sino la composición de balcones y ventanas de uno de los bloques de "la colmena". Si en la película de Pasolini el drama y el vacío corresponden a un elemento natural, casi de liberación, en la película española, la naturaleza desaparece y el fondo abstracto es un elemento artificial, un muro de alojamientos que no permite visualizar el paisaje. La mirada hacia abajo de Carmen Maura, hacia el jardín donde aparecerá el hijo -y no hacia el vacío como en la escena de la Magnani- corresponde a la solución de los conflictos y al final "feliz" de la película. La reunión con el hijo no existe en Mamma Roma, y la visión de la protagonista hacia la ciudad en construcción finaliza con la imagen del skyline del Tuscolano un plano panorámico que se repite a lo largo de toda la obra cinematográfica como un presagio. Aun con estas diferencias en la parte final de la escena, Que he hecho yo... acaba con una imagen del barrio de la Concepción del otro lado de la autovía M30; este paisaje es una mirada hacia el lugar donde residen los protagonistas, y corresponde a la mirada del director, mientras que en Mamma Roma la mirada hacia la periferia corresponde a un hipotético punto de vista de la protagonista; además de esta variación del sujeto hay también una diferencia en la espacialidad representada, entre la posición de Anna Magnani y la agobiante imagen de la periferia romana, un gran descampado, un vacío que preserva su carácter de topografía natural e irregular.

En el espacio entre "La Colmena" y la posición de la cámara de Almodóvar se ubica la gran autovía extraurbana M30, de más de diez carriles que separan los bloques de vivienda de cualquier contacto con los territorios de la incertidumbre y de la naturaleza que caracterizaban las periferias de la Ciudad Neorrealista. En la película de Almodóvar, respecto a la de Pasolini, ya no queda ningún desconcierto, los protagonistas están atrapados en una ciudad que ya no tiene espacios vacíos o elementos naturales desde los cuales observar la ciudad que crece; los protagonistas parecen resignados, y de alguna forma definitivamente adaptados y atrapados (F.5.3).

\footnotetext{
29 "La forma de la cittá" 1974 (Pasolini)
} 


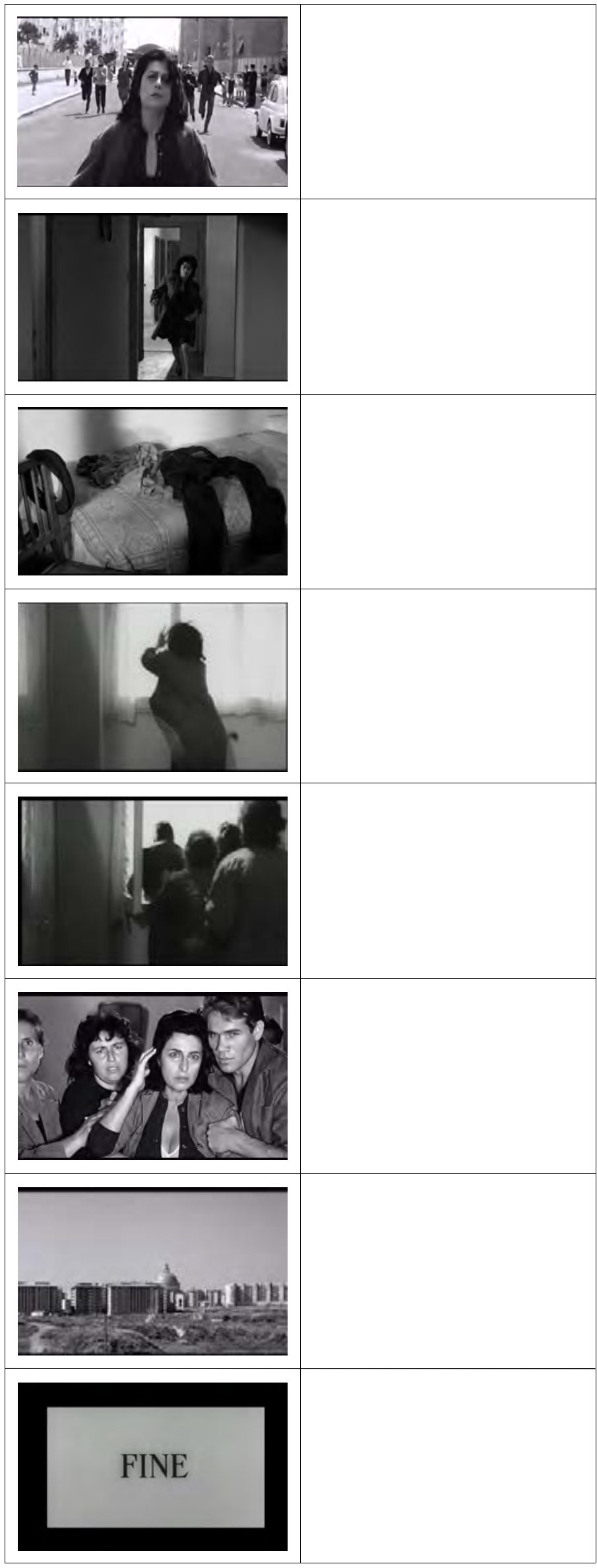

RM 1-8. Mamma Roma (Pasolini)
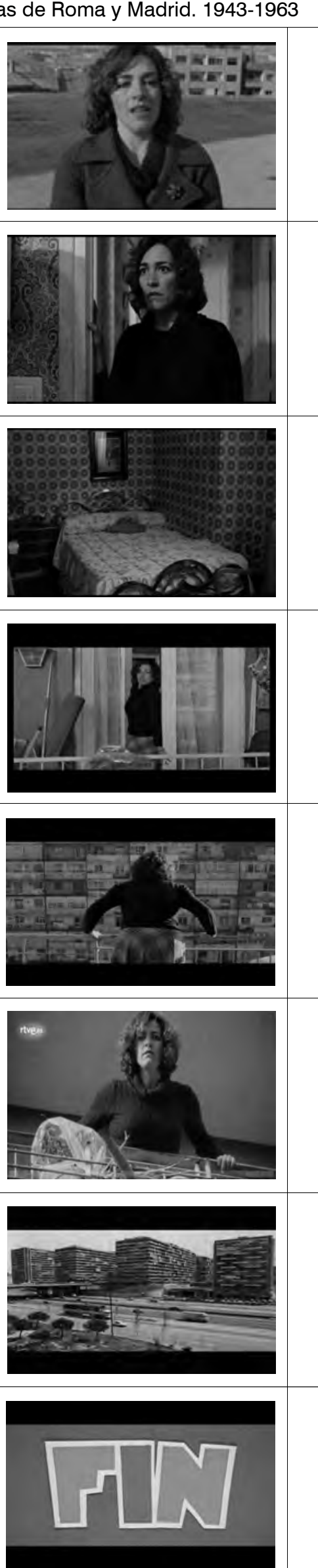

MD 1-8. ¿Que he hecho yo para merecer esto? (Almodovar) 
Los dos barrios el romano INA-Casa del Tuscolano y el Barrio de la Concepción de Madrid, quedan relacionados en el tiempo con sus directores y con las películas rodadas es estos lugares. Un eco de las dos obras sigue hasta la fecha en el espacio virtual de la red y en el paisaje cultural que se produce a través de la memoria colectiva de los habitantes.

El ejercicio de comparación a distancia, geográfica y temporal, basado sobre una secuencia casi igual por la sucesión de planos, nos permite establecer un paralelo entre las dos ciudades, un proceso de transformación urbana común a las dos capitales que Almodóvar, a una distancia temporal de más de 20 años, describe perfectamente, con un nuevo desencantado realismo, como si Madrid fuera la Roma que Pasolini había dejado hacia dos décadas, actualizando el rodaje de Mamma Roma.

El montaje, según la teoría de Pasolini, permite coordinar las acciones rodadas dándoles un sentido, transformando el presente en pasado y descifrando el significado de las acciones representadas. Las imágenes del paisaje urbano de las periferias romana y madrileña que los dos directores incluyen, son parte de esta operación de atribución de un significado a las acciones; el espacio urbano influye sobre la vida y sobre el valor que esta adquiere con el cine. En los ojos desesperados de la Magnani y de Maura se produce esta transferencia de la ciudad en el cine y en la vida representada en la narración cinematográfica. Con un proceso inverso y complementario al mismo tiempo, también la imagen cinematográfica de la mirada de las dos protagonistas -y de los directores- se transfiere en las dos ciudades quedando grabada en ellas para siempre: la superposición de una iconografía "imaginaria" sobre un espacio real; un proceso de ósmosis entre materia fílmica y espacio urbano que empieza en la Posguerra y se ha enriquecido en el tiempo, hasta la cinematografía contemporánea; una operación de constante escritura y sobre-escritura de fragmentos de ciudad también geográficamente e históricamente distantes. 


\section{BIBLIOGRAFÍA Y FUENTES}




\section{Cinema}

Abalos, Iñaki. «Estética pintoresca, arquitectura y cine.» En Paradigmas: el desarrollo de la modernidad arquitectónica visto a través de la historia del cine, de Doménico Chiappe, \& Jorge Gorostiza López, 129-142. Madrid: Fundación Telefónica, 2007.

Barber, Stephen, y Rafael Jackson. Ciudades proyectadas: cine y espacio urbano. Barcelona: Gustavo Gili, 2006.

Bazin, André. ¿Qué es el cine? . Madrid: Rialp, 1990. Primera edición: Qu'est-ce que le cinéma ? (en 4 volumes), Éditions du Cerf, collection «Septième Art», 1958

Berger, John Antonioni Michelangelo. «Gente del Po.» Javier Eder, Diciembre 2012: http://www.edder.org/?p=931.

Bloch-Robin, Marianne. «Los Golfos et Deprisa, deprisa de Carlos Saura : de la conquête impossible du centre par la marge à l'omniprésence de la périphérie.» Pandora, ㄲo 9 (2009): 163 - 177.

Boccolari, Giorgio. «Zavattini all'estero.» Biblioteca Panizzi. 05 de Agosto de 2017. http://lakota.netribe.it/zavattini/Sezione.jsp?idSezione $=24$.

Brunetta, Gian Piero. Storia del cinema italiano. Roma: Editori riuniti, 2000.

Buñuel, Luis. «El cine, instrumento de poesía.» Litoral, № 235 (2003): 158-163.

Burch, Noel. Praxis del cine. Madrid: Fundamentos, 1985.

Caldito, Angel. historias cinematográficas. 30 de Septiembre de 2009. http://historiascinematograficas.blogspot.mx/2009/09/los-estudios-cea-de-parque-de.html.

Cerón Gómez, Juan Francisco. El cine de Juan Antonio Bardem. Murcia: Universidad de Murcia. Servicio de Publicaciones, 1998.

Colella, F. «La Ciudad neorrealista. Territorio, iconografía y mapas de la Roma de Ladrones de Bicicletas.» Bitácora arquitectura, (U.N. México,Ed.) n40 (Julio-Noviemb. 2018): 36-47.

Crespi, Alberto. «Roma, città aperta e set della storia Via Montecuccoli dal film d i Rossellini all'arsenale delle nuove Br.» L'Unitá, 28 de Diciembre de 2003, Roma ed.: 5.

D'Avino, Mauro, y Lorenzo Rumori. Roma, si gira!: gli scorci ritrovati del cinema di ieri. Roma: Gremese, 2012.

Deleuze, Gilles. Conversaciones, 1972-1990. Valencia: Pre-Textos, 2014.

—. La imagen-movimiento: estudios sobre cine 1. Barcelona: Paidós, 1984.

—. La imagen-tiempo: estudios sobre cine 2. Barcelona: Paidós Ibérica, 1987.

Deltell, Luis, y Emilio Carlos Garcia Fernandez. Madrid en el cine de la década de los cincuenta. Madrid: Área de Gobierno de las Artes, 2006.

Eisenstein, Sergei, y Pietro Montani. Teoria generale del montaggio. Venezia: Marsilio, 1985.

Fernández, Miguel Anxo. Las imágenes de Carlos Velo. Ciudad de México: Universidad Nacional Autónoma de México, 2007.

Franju, George. Eyes Without a Face. The Criterion Collection, 2004.

García Roig, José Manuel. «Identificación de un cineasta. La obra de Michelangelo antonioni en la cultura y el arte de su tiempo.» Editado por Mairea. La ventana indiscreta, cuadernos del aula de cine y arquitectura de la ETSAM, № 2 (Abril 2005): 7-41.

Garcia Roig, Jose Manuel. «Horizontes lejanos, horizontes de grandeza, horizontes del oeste.» Editado por Escuela Técnica Superior de Arquitectura de Madrid ETSAM. La ventana indiscreta (Mairea), no 5 (Mayo 2007): 83-118.

González Cubero, Josefina. «La arquitectura de los sentimientos. Centrados y descentrados en el cine de Michelangelo Antonioni.» Editado por ETSAM (Escuela Técnica Superior de Arquitectura de Madrid). La ventana indiscreta. Cuadernos del Aula de Cine y Arquitectura de la ETSAM (Mairea Libros), № 2 (2005): 83-108.

Gorostiza, Jorge, y Claudio Utrera. Cine y arquitectura. Las Palmas: Comisión de Cultura de la E.T.S. de Arquitectura, 1990. 
Gorostiza, J. y et alii. Paradigmas: el desarrollo de la modernidad arquitectónica visto a través de la historia del cine. Madrid: Fundación Telefónica, 2007.

Gorostiza López, J., \& Guterrez Cabrero, L. A. La construcción de la ficción: espacio arquitectónico - espacio cinematográfico. Madrid: Universidad Politecnica de Madrid, Escuela Técnica Superior de Arquitectura. 2016.

Gubern, Román. Historia del cine español. Madrid: Cátedra, 2004.

Jiménez, Guillermo. «A tomar viento a la farola.» La Opinión de Málaga, 17 de Noviembre de 2013: s/n.

Licata, Antonella, y Elisa Mariani Travi. La città e il cinema. Bari: Dedalo, 1985.

López Juan, Aramis Enrique. «El cine español como fuente documental para el estudio de los barrios marginales.» Editado por Universidad de Alicante. Instituto Universitario de Geografía. Investigaciones Geográficas, № 47 (Septiembre-diciembre 2008): 139-157.

Mancini, Michele, y Giuseppe Perrella. Michelangelo Antonioni architetture della visione. Roma: Coneditor, 1986.

Mariniello, Silvestra. Pier Paolo Pasolini. Madrid: Cátedra, 1999.

Minghelli, Giuliana. Landscape and Memory in Post-Fascist Italian Film: Cinema Year Zero. New York: Routledge, Taylor \& Francis Group, 2013.

Mitry, Jean. Estética y psicología del cine. Madrid: Siglo XXI, 1989.

Monterde, José Enrique, y et alii. Historia del cine español. Madrid: Cátedra, 1995.

Monterde, J. E., \& Porter i Moix, M. (Monterde, José Enrique, and Miquel Porter i Moix. El Neorrealismo en España: tendencias realistas en el cine español. Tesi doctoral, Universitat de Barcelona. Facultat de Geografia i Història, 1992,

Pantaleón Panaro, Carlos, y Luís Gutierrez Cabrero. Del espacio fílmico al espacio protofílmico : del espacio arquetípico al espacio fenomenológico : una propuesta pedagógica. Madrid: Universidad Politecnica de Madrid, Escuela Técnica Superior de Arquitectura, 2012.

Pasolini, Pier Paolo. Il mio cinema. Bologna: Edizioni Cineteca di Bologna, 2015.

Pasolini, Pierpaolo. «Discurso sobre el plano-secuencia o el cine como semiología de la realidad .» En Problemas del nuevo cine, de Manuel Pérez Estremera, \& Della Volpe Galvano, 61-76. Madrid: Alianza, 1971.

Pérez Perucha, Julio. Antología crítica del cine español 1906-1995 : flor en la sombra. . Madrid: Cátedra, 1997.

Quintana, Angel. El cine italiano, 1942-1961: del neorrealismo a la modernidad. Barcelona: Paidós, 1997.

Reichlin, Bruno. «Figures of Neorealism in Italian Architecture (Part 1).» Grey Room (MIT press) 1, ํㅡ 5 (2001): 78-101.

Reichlin, Bruno. «Figures of Neorealism in Italian Architecture (Part 2).» Grey Room (MIT press) 1, no 6 (2002): 111-133.

Rhodes, John David. Stupendous, Miserable City: Pasolini's Rome. Minneapolis: University of Minnesota Press, 2007.

Rodríguez Martínez, Saturnino. El NO-DO, catecismo social de una época. Madrid: Complutense, 1999.

Roffi, Stefano. «Michelangelo Antonioni andò a lezioni di regia dal pittore Giorgio Morandi.» Stilearte.it. 28 de Septiembre de 2016. http://www.stilearte.it/michelangelo-antonioni-alezioni-di-regia-dal-pittore-giorgio-morandi/.

Ropars-Wuilleumier, Marie Claire. «El espacio y el tiempo en el universo de Antonioni.» Études Cinematographiques, № 36-37 (Octubre-Diciembre 1964).

Sánchez Vidal, Agustín. Luis Buñuel: obra cinematográfica. Madrid: Ediciones J.C., 1984.

Sorlin, Pierre, y Nuria Pujol i Valls. Cines europeos, sociedades europeas, 1939-1990. . Barcelona: Paidós, 1996 
Spila, Piero. Pier Paolo Pasolini. Roma: Gremese, 1999.

Torres Hortelano, Lorenzo J. World Film Locations: Madrid. Bristol (GB): Intellect, 2011.

Torres Nebrera, Gregorio. «Imágenes fílmicas de la España del franquismo.» Editado por Departamento de Literatura Española Universidad. Anales de Literatura Española (Biblioteca Virtual Miguel de Cervantes), № 21 (2009): 189-212.

Vila Mustieles, Santiago. La escenografía: cine y arquitectura. Madrid: Cátedra, 1997.

Visconti, Luchino. «Con Ossessione, venti anni fa, si parlò per la prima volta di Neorealismo.» L'Europeo, 28 de Agosto de 1962: -.

Zumalde Arregi, I. «Surcos.» En J. Pérez Perucha, Antología crítica del cine español 1906-1995 : flor en la sombra (pág. 296). Madrid: : Cátedra, 1997.

\section{Paisaje y territorio.}

Abalos, Iñaki. Atlas pintoresco. Barcelona: Editorial Gustavo Gili, 2005.

Bassetti, N., Matteucci, S., Nicolini, R., \& Rosi, G. Sacro romano GRA persone, luoghi, paessaggi lungo il Grande Raccordo Annulare. Macerata: Quodlibet, 2013.

Careri, Francesco. Walkscapes: el andar como práctica estética. Barcelona: Gustavo Gili, 2002.

—. «Stopscapes, un glosario.» En Densidades, de AA. VV., 49-55. Ciudad de México: Arquine, 2015.

—. Pasear, detenerse. Barcelona: Gustavo Gili, 2016.

Clément, G. (2004). Manifiesto del tercer paisaje. Barcelona: Gustavo Gili. Titulo original: Manifeste du Tiers paysage, publicado por Éditions Sujet/Objet, Paris, 2004

Colella, Federico. «El paisaje del hábitat horizontal: la Unidad del Tuscolano en Roma y el Poblado de Entrevías en Madrid.» Revista de Arquitectura. Revista de la Universidad Católica de Colombia 18, № 2 (2016): 50-59.

Conti, Sergio, y Piero Bonavero. Riflessi italiani: l'identità di un paese nella rappresentazione del suo territorio. Milano: Touring club italiano, 2004.

Cullen, Gordon. Townscape. New York: Reinhold Book Corp, 1968.

De Sola-Morales, Ignasi. «Terrain vague.» Quaderns (COAC, Collegi d Arquitectes de Catalunya), № 212 (1996): 34-43.

Fulton, Hamish. Hamish Fulton: Selected Walks, 1969-1989. Buffalo, N.Y.: Fine Arts Academy, 1990.

García, Concepción. «Genealogía mínima del no-lugar.» Jot Down Cultural Magazine., Julio 2012. http://www.jotdown.es/2012/07/genealogia-minima-del-no-lugar/.

Hilberseimer, Ludwig. The New City. Principles of Planning. Chicago: Paul Theobald, 1944.

Jakob, Michael. Il paesaggio. Bologna. Bologna: II mulino, 2009.

Molino, S. d. La España vacía: viaje por un país que nunca fue. Madrid: Turner.2017. (edición digital).

Ortega, Nicolás. Estudios sobre historia del paisaje español. Madrid: Catarata, 2002.

Stalker, O. N. «Sui letti del fiume.» (F. d. Universitá Roma Tre, Editor) (Marzo - Junio de 2007). Obtenido de https://suilettidelfiume.wordpress.com/

Turco, Angelo. «Paesaggio e identita nell'Italia repubblicana.» En Riflessi italiani L'identità di un Paese nella rappresentazione del suo territorio, de Sergio Conti, 51-54. Milano: Touring club italiano, 2004.

\section{Ciudad, vivienda y cultura Neorrealista}

Alonso, Matilde. «En los márgenes de la arquitectura.» En La recomposición de la ciudad informal, de Juan Luis Piñón, 209-226. Valencia: CICl. Universidad Politécnica de Valencia, 2001.

Alvear, Jaime, y et alii. «Barrio de Entrevías.» Arquitectura COAM (COAM Colegio Oficial Arquitectos Madrid), no 58 (Octubre 1963): 2-29. 
Angeletti, Paolo. Case romane: la periferia e le case popolari. Roma: Prospettive, 2009.

Astengo, Giovanni. «Nuovi quartieri in Italia.» Urbanistica, no 12 (1953): 9-10.

Baldellou, Miguel Ángel. «Editorial.» Arquitectura (COAM - Colegio Oficial de Arquitectos de Madrid), no 301 (1995): 7.

Baldellou, Miguel Ángel. «Neorrealismo y arquitectura. El 'problema de la vivienda' en Madrid, 1954-1966.» Arquitectura (COAM - Colegio Oficial de Arquitectos de Madrid) (COAM), no 301 (1995): 20-51.

Balsells, David, Juan Manuel Bonet, y Ennery Taramelli. Mirades paral/leles: la fotografia realista a Itàlia i Espanya : del 20 de juny al 3 de setembre de 2006. Barcelona: MNAC, 2006.

Bataller Enguix, José Javier, y Ramón López de Lucio. Guía del urbanismo de Madrid / s. XX. Madrid: Madrid: Área de Gobierno de Urbanismo, Vivienda e Infraestructuras, Ayuntamiento de Madrid, 2004.

Benevolo, Leonardo. La città nella storia d'Europa. Roma: Laterza, 1993.

Bonelli, Renato. «Edilizia economica: politica dei quartieri.» En Architettura urbanistica in Italia nel dopoguerra: l'immagine della Comunità, de Marcello Fabbri, 252-259. Roma: Gangemi, 1986.

Cánovas, Andrés, Carmen Espegel, Escuela Tecnica Superior de Madrid ETSAM, y Grupo de Investigacion Vivienda Colectiva GIVCO. Poblado Dirigido de Entrevías. Madrid: GIVCO, DPA ETSAM, Universidad Politécnica de Madrid, 2010.

Casciato, Maristella. «L'invenzione della realtá: realismo e neorealismo nell'talia degli anni cinquanta.» En La grande ricostruzione : II piano Ina-Casa e I'talia degli anni cinquanta, de Paola Di Biagi, 205-221. Roma: Donzelli, 2001.

Cerrini, Filippo. Tesis: II quartiere INA-casa al Tuscolano in Roma : I'unità d'abitazione orizzontale : linee guida per un piano di recupero. Editado por Stefania mornati, \& Sergio Poretti. 1 vols. Roma: Università degli studi di Roma Tor Vergata, Facoltà di ingegneria, Dipartimento di ingegneria civile, dottorato in ingegneria edile: architettura e costruzione, 16. ciclo, 2005.

Clementi, Alberto, y Francesco Perego. La Metropoli "spontanea": il caso di Roma, 1925-1981: sviluppo residenziale di una città dentro e fuori dal piano. Bari: Dedalo, 1983.

Colella, Federico. «Paisajes Neorrealistas. Cultura y arquitectura habitacional multifamiliar en Italia y España en la posguerra. 1943-1963.» Contexto -Revista de la Facultad de Arquitectura Universida Nuevo León X, no 12 (Marzo 2016): 77-86.

Colella, Federico. «Políticas habitacionales en Italia y España en la posguerra 1949-1954 / Postwar Housing Policies in Italy and Spain 1949-1954.» Editado por Injaviu. Instituto Javeriano de Vivienda y Urbanismo. Cuadernos de vivienda y urbanismo (Pontificia Universidad Javeriana) 9, no 17 (enero-junio 2016): 50-67.

Dal Co, Francesco. Storia dell'architettura italiana: il secondo Novecento. Milano: Electa, 1997.

Di Biagi, Paola. «La "città pubblica" e I'Ina-Casa.» En La grande ricostruzione: il piano Ina-Casa e I'Italia degli anni cinquanta, de Paola Di Biagi, 3-32. Roma: Donzelli, 2001.

-. La grande ricostruzione : II piano Ina-Casa e I'Italia degli anni cinquanta. Roma: Donzelli Editore, 2001.

Díez Molina, Carmen. «Reflexiones sobre los años de la reconstrucción Italiana, a partir de la experiencia del Tiburtino en Roma.» Arquitectura (COAM, Madrid), no 301(1995): 14-19.

Fabbri, Marcello. l'urbanistica italiana dal dopoguerra a oggi: storia, ideologie, immagini. Bari: De Donato, 2001.

Fernández Galiano, Luis. «Participación del usuario y autoconstrucción: el caso e Entrevías.» Jano: arquitectura, decoración y humanidades, № 52 (Noviembre 1977): 18-25.

Fernández Galiano, Luís, Justo F. Isasi, y Antonio Lopera. La quimera moderna: Ios poblados dirigidos de Madrid en la arquitectura de los 50. Madrid: Herman Blume, 1989. 
Franco Alonso, Óscar. «Evolución reciente del fenómeno chabolista: el nuevo chabolismo madrileño.» En La ciudad y el miedo. VII Coloquio de Geografía Urbana, de Obdúlia Gutiérrez, 61-70. Girona: Universidad de Girona. Grupo de Geografía Urbana. AGE, Asociación de Geógrafos Españoles, 2005.

García de Cortázar, Fernando, y José Manuel Gonzáles Vesga. Breve historia de España. Madrid: Alianza editorial, 1994.

Gregotti, Vittorio. L'architettura del Realismo critico. Bari: Laterza, 2004.

Grijalba, Alberto. «Equívocos, amigos y dós puentes. Italia/España.» Modelos alemanes e italianos para España en los años de la postguerra: actas preliminares: Pamplona, 2526 marzo 2004. Pamplona: T6 Ediciones, 2004. 13-20.

Guccione, Margherita, M.Margarita Segarra Lagunes, y Rosalia Vittorini. Guida ai quartieri romani Ina Casa. . Roma: Gangemi, 2002.

Hierro, Maria del Carmen, y Silvia Gamez. «Poblado de absorción de Entrevías. Ios domingueros.» Nueva Forma, № 93 (Octubre 1973).

Insolera, Italo. Roma moderna: un secolo di storia urbanistica; 1870-1970. Torino: Einaudi, 1993.

INU, Istituto Nazionale di Urbanistica. L'INA-Casa al IV Congresso Nazionale di Urbanistica. Venezia: I.N.U., 1952.

INV, Instituto Nacional de la Vivienda. Entrevías: transformación urbanística de un suburbio de Madrid. Madrid: OSH - Obra Sindical del Hogar, 1965.

Kim, Son-ung. La narrativa neorrealista de Jesús Fernández Santos (1954-1964). Editado por Epicteto Díaz Navarro. Madrid: UCM, Universidad Complutense de Madrid, Facultad de filología, Departamento de Filología Española II (Literatura Moderna y Contemporánea), 2002.

Libera, Adalberto. «Gli spazi all'aperto della abitazione nel clima mediterraneo.» Architetti, no 12-13 (Febrero-Abril 1952): 108-109.

Libera, Adalberto. «ll quartiere Tuscolano a Roma.» Comunitá, no 31 (Junio 1955): 46-49.

Libera, Adalberto. «La scala del quartiere residenziale.» En Esperienze urbanistiche in Italia, de Istituto Nazionale di Urbanisica INU, 131. Roma: INU, 1952.

Libera, Adalberto. «Unità di abitazione orizzontale.» Domus, no 318 (1956): 1-2.

Machado, Antonio, y Geoffrey Ribbans. Campos de Castilla: 1907-1917. Madrid: Catedra, 1989. Primera edición: 1912

Márquez, Ricardo. «Barrio de San Juan Bautista. - Toma cinematográfica.» Historias matritenses. 19deAbrilde2009.http://historiasmatritenses.blogspot. $\mathrm{mx} / \mathrm{search}$ ?q=mi+tio + jacinto (último acceso: 11 de Diciembre de 2017).

-. «El tranvía 12 ... uniendo Canillejas y Carabanchel Alto.» Historias matritenses. 21 de Febrerode2012.http://historiasmatritenses.blogspot.mx/search?q=avenida + + caraban chel+alto (último acceso: 11 de Diciembre de 2017).

- Recorrido visual por las plazas de toros de Madrid. 12 de Febrero de 2016. http://historiasmatritenses.blogspot.mx/2016/02/recorrido-visual-por-las-plazas-de.html.

Moneo, Rafael. «El poblado dirigido de Entrevías.» Hogar y Arquitectura (OSH - Obra Sindical del Hogar), no 34 (1961): 3-23.

Moya Gonzalez, Luís. Barrios de promoción oficial: Madrid 1939-1976: la politica de la promoción publica de vivienda. Madrid: COAM,Colegio Oficial de Arquitectos de Madrid, 1983.

Nicoloso, Paolo. «Genealogie del Piano Fanfani. 1939-50.» En La grande ricostruzione: il piano Ina-Casa e I'Italia degli anni cinquanta, de Paola Di Biagi, 33-62. Roma: Donzelli, 2001.

Pasolini, Pier Paolo. La religión de mi tiempo. Barcelona: Icaria, 1997. Primera edición italiana:

La religione del mio tempo. Milano: Garzanti, 1961

—. Ragazzi di vita. Milano: Garzanti, 1955. 
—. L'intervista a Pier Paolo Pasolini . "Dix de Der". (P. Bouvard, Entrevistador). Paris: Antenne 2, (31 de Octubre de 1975). Obtenido de https://www.youtube.com/watch?v=w9Ef1y_OY-U

Poretti, Sergio. L'INA Casa: il cantiere e la costruzione. Roma : Gangemi, 2002.

Quaroni, Ludovico. «ll paese dei barocchi.» Casabella Continuità, no 215 (1957): 29-40.

Quesada Marco, Sebastián. Diccionario de civilización y cultura españolas. Madrid: Istmo, 1997.

Quilici, Vieri. Adalberto Libera: l'architettura come ideale. Roma: Officina Edizioni, 1981.

Remiddi, Gaia, y Antonella Greco. II moderno attraverso Roma: guida alle architetture romane di Adalberto Libera. Roma: Palombi, 2003.

Sáenz Guerra, Francisco Javier. Francisco Javier Sáenz de Oiza, José Luis Romany, Jorge Oteiza: Una capilla en el camino de Santiago = A chapel on St. James Way, 1954. Madrid: Rueda, 2004.

Sáenz Guerra, Javier, y Rosario Alberdi. Francisco Javier Sáenz de Oiza. Madrid: Pronaos, 1996.

Saggio, Antonino. L'opera di Giuseppe Pagano tra politica e architettura. Bari: : Dedalo, 1984.

Salzano, Edoardo. Fondamenti di urbanistica: la storia e la norma. Roma - Bari: Laterza, 2010.

Sambricio, Carlos. «De la arquitectura del nuevo Estado al origen de nuestra contemporaneidad: el debate sobre la vivienda en la década de los cincuenta.» R.A. Revista de Arquitectura 04 (2000): 75-90.

- La vivienda en Madrid en la década de los 50: el Plan de Urgencia Social. Madrid: Electa España, 1999.

Sambricio, Carlos. «Que coman república:introducción a un estudio sobre la reconstrucción en la España de la postguerra.» Cuadernos de arquitectúray urbanistica (COAC), no 1 (Enero 1977): 21-33.

—. Un siglo de vivienda social 1903 - 2003 : centenario del Instituto de Reformas Sociales. T.2. Vol. 2. 2 vols. Madrid: Nerea, 2003.

Szacka, Léa-Catherine. Effimero: or the postmodern italian condition. 2017 de Octubre de 26. http://leacatherineszacka.com/EffimeroBiennaleVenise/effimero.php.

Tafuri, Manfredo. «Architettura e realismo.» En L'avventura delle idee, de Vittorio Magagno Lampugnani, 123-145. Milano: Electa, 1985.

—. Storia dell'architettura italiana, 1944-1985. Torino: G. Einaudi, 1986.

Témime, Emile, Albert Broder, y Gérard Chastagnaret. Historia de la España contemporánea, desde 1808 hasta nuestros días. Barcelona: Ariel, 1982.

Torres Balbás, Leopoldo, Luis Cervera Vera, Fernando Chueca Goitia, y Pedro Bidagor Lasarte. Resumen histórico del urbanismo en España. Madrid: Instituto de Estudios de Administración Local, 1954.

Tosi, Antonio. Case, quartieri, abitanti, politiche. Milano : Libreria Clup, 2005.

Vagnetti, Luigi. «El problema de la vivienda en Italia. Plan Fanfani.»Informe de la Construcción, no 64 (1954): s.p.

\section{Textos teóricos generales}

Augé, M. Los "no lugares": espacios del anonimato: una antropología de la sobremodernidad. Barcelona: Gedisa, 2005.

Primera edición francés: Augé, M. Non-lieux: introduction à une anthropologie de la surmodernité. Paris: du Seuil. 1992

Aureli, Pier Vittorio. The Possibility of an Absolute Architecture. Cambridge, Mass: MIT Press, 2011.

Benjamin, Walter. La obra de arte en la época de su reproducción mecánica. Buenos Aires Madrid: Amorrortu, 2013. 
Primera edición: Das Kunstwerk im Zeitalter seiner technischen Reproduzierbarkeit; publicado originalmente en la revista Zeitschrift für Sozialforschung, Frankfurt, 1936

Debord, Guy. La sociedad del espectáculo. Valencia: Pre-Textos, 2012. Primera edición: La Société du spectacle, Buchet-Chastel, Paris, 1967

Deleuze, Gilles, y Félix Guattari. Mille plateaux: Capitalisme et schizophrénie. Paris: Les Editions de minuit, 1980.

Deleuze, Gilles. Conversaciones, 1972-1990. Valencia: Pre-Textos, 2014.

Eyck van, Aldo. Writings. The child, the city and the artist. Collected Articles and other writings 1947-1998. Editado por Vincent Ligtelijn, \& Francis Strauven. Amsterdam : Sun Publishers, 2008.

Herreros, Juan. (Transferencias por un pensar técnico. Madrid, CF+S, \& U. (ETSAM, Edits.), Marzo 2006. http://habitat.aq.upm.es/boletin/n38/ajher.html.

Ivain, Gilles: Kotányi, Attila, y Raoul Vaneigem. Urbanismo situacionista. Barcelona: Gustavo Gili, 2006. Procedencia de los textos: "Formulaire pour un urbanisme nouveau", publicado originalmenteen la revista Internationale Situationniste, 1 junio de 1958, págs. 15-20; "Programme élementaire du bureau d'urbanisme unitaire", publicado originalmente en la revista Internationale Situationniste, 6 agosto de 1961, págs. 16-19

Koolhaas, Rem. La Ciudad genérica. Barcelona. Barcelona: Gustavo Gili, 2011. Titilo original: "The Generic City", publicado originalmente en Domus, 791, marzo de 1997.

Krauss, Rosalind E. The Originality of the Avant-Garde and Other Modernist Myths. Cambridge, Mass: MIT Press, 1985.

Rossi, Aldo. L'architettura della città. Padova: Marsilio, 1966

Sassen, Saskia, y et alii. Densidades. Ciudad de México: Arquine, 2015.

Virilio, Paul. Estética de la desaparición. Barcelona: Anagrama, 1988. Primera edición francés: Esthétique de la disparition : essai sur le cinématisme, Éditions Balland, 1980

Virilio, Paul. La máquina de visión. Madrid: Cátedra, 1998. Primera edición francés: La Machine de vision: essai sur les nouvelles techniques de représentation, éd. Galilée, 1988.

\section{Filmografía escogida - Cine Neorrealista en Italia y España 1943-1963*}

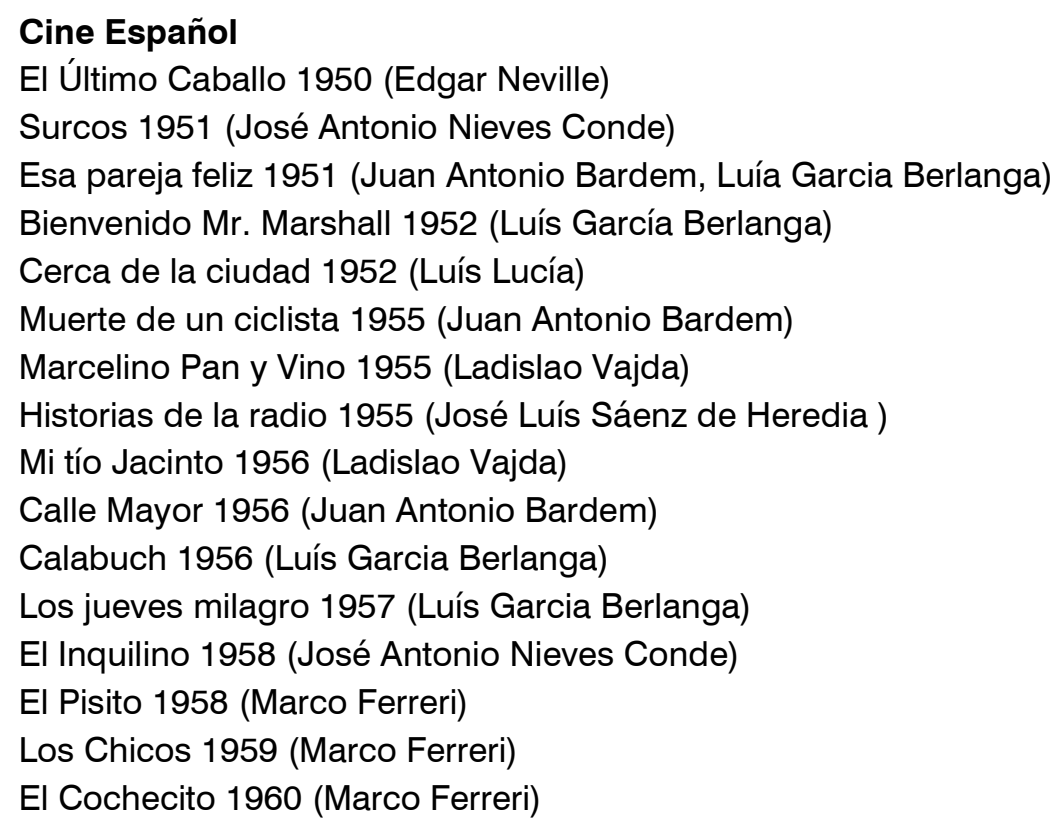

\footnotetext{
"En orden cronológico. Se integra esta información con la sección "Fichas técnicas" en los "ANEXOS"
} de esta tesis 
Plácido 1961 (Luis García Berlanga)

Los Golfos 1961 (Carlos Saura)

El Verdugo 1963 (Luis García Berlanga)

Del Rosa al amarillo 1963 (Manuel Summers)

DOCUMENTALES Y CORTOS

Las Hurdes, tierra sin pan 1933 (Luís Buñuel)

Documentales '50 - '60 NO-DO

Flores de luna 2008 (Juan Vicente Córdoba)

La Guerra Civil española 2004 (Archivos Instituto Luce)

Entre vías 1995 (Juan Vicente Cordoba)

\section{Cine Italiano}

Obsesión / Ossessione 1943 (Luchino Visconti)

Roma ciudad abierta / Roma cittá aperta 1945 (Roberto Rossellini)

El limpiabotas / Sciusciá 1946 (Vittorio De Sica)

Paisà 1946 (Roberto Rossellini)

Ladrón de bicicletas / Ladri di biciclette 1948 (Vittorio De Sica)

La tierra tiembla / La terra trema 1948 (Luchino Visconti)

Bajo el sol de Roma / Sotto il sole di Roma 1948 (Renato Castellani)

Cronica de un amor / Cronaca di un Amore 1950 (Michelangelo Antonioni)

Milagro en Milán / Miracolo a Milano 1951 (Vittorio De Sica)

Bellisima / Bellissima 1951 (Luchino Visconti)

Europa '51 / Europa '51 1952 (Roberto Rossellini)

Humberto D / Umberto D. 1952 (Vittorio De Sica)

Amor en la ciudad / L'amore in Cittá 1953 (A.A.V.V.)

Los inutiles / I vitelloni 1953 (Federico Fellini)

La calle / La strada 1954 (Federico Fellini)

El techo / II tetto 1955 (Vittorio De Sica)

El ferroviario / II ferroviere 1956 (Pietro Germi)

Rocco y sus hermanos / Rocco e $i$ suoi fratelli 1960 (Luchino Visconti)

Accattone 1961 (Pier Paolo Pasolini)

Mamma Roma 1962 (Pier Paolo Pasolini)

DOCUMENTALES Y CORTOS

Días de Gloria / Giorni di gloria 1945 (Luchino Visconti)

Gente del Po / Gente del Po 1947 (Michelangelo Antonioni)

Nettezza Urbana 1948 (Michelangelo Antonioni)

La ricotta episodio en Ro.Go.Pa.G 1963 (Pier Paolo Pasolini)

La forma della cittá 1974 (Pier Paolo Pasolini)

\section{Otra filmografía citada}

El hada de los repollos / Fée aux Choux 1896 (Alice Guy)

Cabiria 1914 (Giovanni Pastrone)

El chico / The kid 1921(Charles Chaplin)

Nanuk, el eskimal / Nanook of the North 1922 (Robert Flaherty)

La Revoltosa 1924 (Florián Rey)

Paris que duerme / París qui dort 1925 (René Clair)

Nana 1926 (Jean Renoir)

Moana 1926 (Robert Flaherty)

Berlín, sinfonía de una gran ciudad / Berlin: Die Sinfonie der Großstadt 1927 (Walter Ruttmann) 


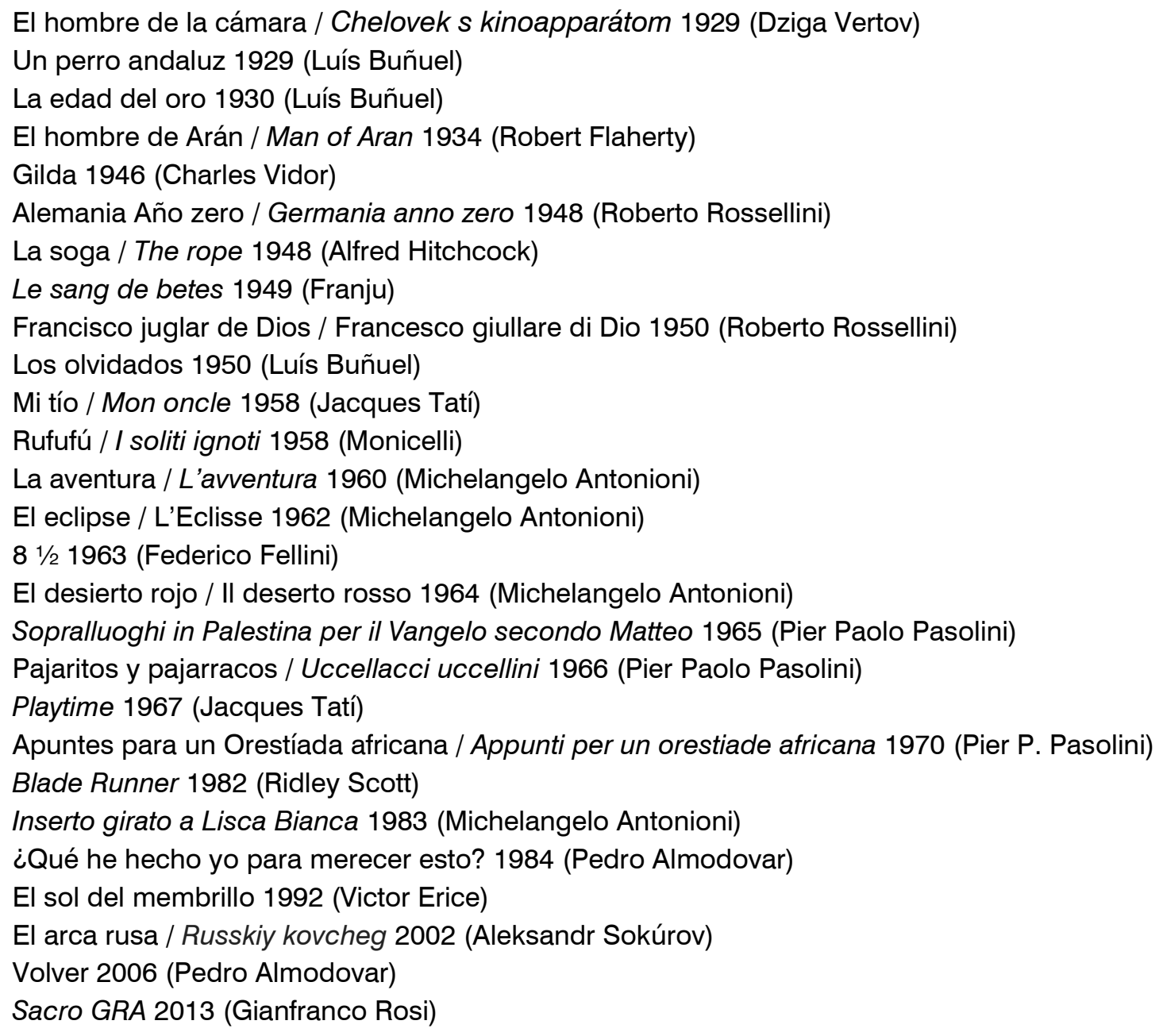




\section{INDICE ANEXOS}

- ANEXO I: Fichas técnicas de las obras cinematográficas analizadas.

- ANEXO II: Cuadros temáticos

- ANEXO III: Línea de tiempo

- ANEXO IV: Paralelos

- ANEXO V: Vuelta

- ANEXO VI: Glosario 
Anexos

ANEXO I: FICHAS TÉCNICAS DE LAS OBRAS CINEMATOGRÁFICAS ANALIZADAS.

Se presentan Las fichas técnicas de las cuarentas películas analizadas junto a la ubicación de los principales decorados. (F-5.4a-v) 


\section{“OBSESIÓN” 1943}

Guion

Visconti, Alicata, De Santis

Dirección

Luchino Viscont

Fotografía

Aldo Tonti y Domenico Sala

Escenografía

Gino Franzi

Imagen

Vestuario: Marina De Matteis

Sonido

Producción

I.C.I Industrie Cinematografiche Italiane S.A.

Montaje

Mario Serandrei

Musica

Giuseppe Rosati

Topología del rodaje (decorados principales):

Canaro Ro (Rovigo)/ Polesella (Rovigo)/ Ferrara / Ancona
"EL ÚLTIMO CABALLO" 1950

Guion

Edgar Neville

Dirección

Edgar Neville

Fotografía

César Fraile

Escenografía

Sigfrido Burmann

Imagen

Make up: Rodrigo Gurrucharri

Sonido

Ramón Arnal

Producción

Edgar Neville

Montaje

Gaby Peñalba

Musica

José Muñoz Molleda

Topología del rodaje (decorados principales):

Pradera de San Isidro / cava baja - arco cuchilleros / Grán Via / Arena Ventas
RM 1. OBSESIÓN: Topología del rodaje en la

capital italiana y distancia del centro.

Cartografía desarrollada a partir del Plan

general de 1962
MD 1. EL ÚLTIMO CABALLO: Tpología del

rodaje en la capital italiana y distancia del

centro. Cartografía desarrollada a partir del

Plan general de 1953 


\section{"ROMA CIUDAD ABIERTA" 1945}

Guion

Sergio Amidei, Federico Fellini, Celeste Negarville, Roberto Rossellini Dirección

Roberto Rossellini

Fotografía

Ubaldo Arata

Escenografía

Rosario Megna

Imagen

Vestuario: Marina De Matteis

Sonido

Raffaele Del Monte

Producción

Giuseppe Amato, Ferruccio De Martino,

Rod E. Geiger, Roberto Rossellini (todos sin creditos)

Montaje

Eraldo Da Roma, Jolanda Benvenuti (sin creditos)

Musica

Renzo Rossellini

Topología del rodaje (decorados principales):

Via Casilina / Circonvallezione Casilina / Via Ostiense / Via R. Montecuccoli / Quartiere

Prenestino / Ponte Tiburtina / Via Tasso

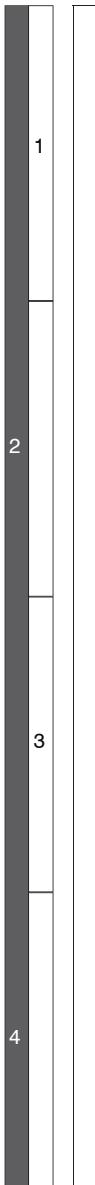

"SURCOS" 1951

Guion

Eugenio Montes (idea)

Natividad Zaro

Gonzalo Torrente Ballester

José Antonio Nieves Conde

Dirección

José Antonio Nieves Conde

Fotografía

Sebastián Perera

Escenografía

Antonio Labrada

Imagen

Make up: Carmen Martín. Vestuario: Juan Esplandiu

Sonido

\section{Producción}

Atenea Films, Felipe Gerely, Francisco Madrid

Montaje

Margarita de Ochoa

Musica

Jesús García Leoz

Topología del rodaje (decorados principales):

Lavapiés / Latina / Delicias / Legazpi

\section{RM 1. ROMA CIUDAD ABIERTA: Topología}

del rodaje en la capital italiana y distancia

del centro.

Cartografía desarrollada a partir del Plan

general de 1962
MD 1. SURCOS: Tpología del rodaje en

la capital española y distancia del centro.

Cartografía desarrollada a partir del Plan

general de 1953 


\section{“EL LIMPIABOTAS” (Sciusciá) 1945}

Guion

Sergio Amidei, Adolfo Franci, Cesare Giulio Viola, Cesare Zavattini Dirección

Vittorio de Sica

Fotografía

Anchise Brizzi

Escenografía

Ivo Battelli, Giulio Lombardozzi

Imagen

Sonido

Tullo Parmegiani

Producción

Giuseppe Amato, Paolo William Tamburella

Montaje

Niccolò Lazzari

Musica

Alessandro Cicognin

\section{Topología del rodaje (decorados principales):}

"Sciuscia":

Villa Borghese / Via Veneto / Porto fluviale (Ostiense) / San Michele (carcel para menores)

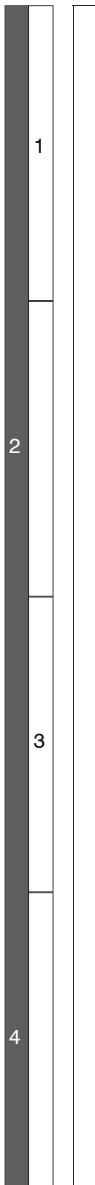

"ESA PAREJA FELIZ" 1951

Guion

Juan Antonio Bardem, Luis García Berlanga

Dirección

Juan Antonio Bardem, Luis García Berlanga

Fotografía

Willy Goldberger

Escenografía

Bernardo Ballester, Francisco Pina y López

Imagen

Make up: Asunción Sánchez . Vestuario: Humberto Cornejo

Sonido

Felipe Fernández

Producción

Miguel Ángel Martín Proharán, José María Ramos

Montaje

Pepita Orduna

Musica

Jesús García Leoz

Topología del rodaje (decorados principales):

Calle Moratín 8 (Centro) / Casa de Campo

MD 1. ESA PAREJA FELIZ: Topología de

rodaje en la capital española y distancia

del centro. Cartografía desarrollada a partir

del Plan general de 1953 


\section{"PAISÀ" 1946}

Guion

Sergio Amidei, Roberto Rossellini, Federico Fellini, Rod E. Geiger Dirección

Roberto Rossellini

Fotografía

Otello Martelli

Escenografía

Imagen

Sonido

Ovidio Del Grande

Producción

Roberto Rossellini, Rod E. Geiger, Mario Conti

Montaje

Eraldo Da Roma

Musica

Renzo Rossellini

Topología del rodaje (decorados principales):

Maiori / Napoli / Firenze

Roma: Vía de Fori Imperiali, Vía del Corso.

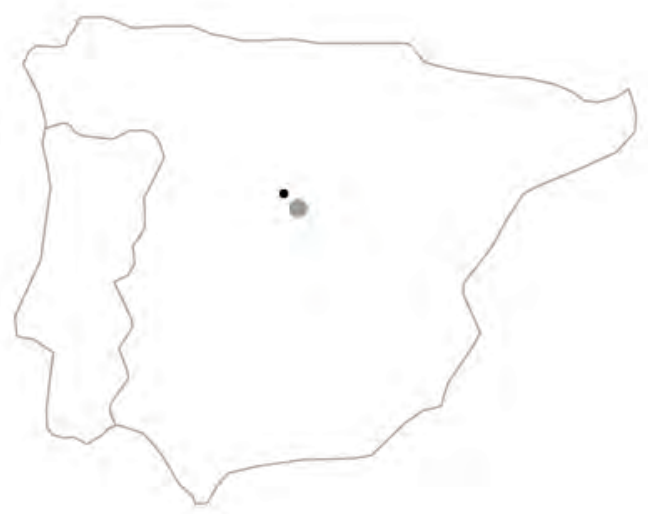

"BIENVENIDO, MISTER MARSHALL" 1952

Guion

Juan Antonio Bardem, Luis García Berlanga, Miguel Mihura Dirección

Luis García Berlanga

Fotografía

Manuel Berenguer

Escenografía

Francisco Canet, Francisco Rodríguez Asensio

Imagen

Make up: Antonio Florido. Vestuario: Eduardo de la Torre

Sonido

Antonio Alonso

Producción

Vicente Sempere

Montaje

Pepita Orduna

Musica

Jesús García Leoz

Topología del rodaje (decorados principales):

Guadalix de la sierra (Comunidad de Madrid)

MD 1. BIENVENIDO, MISTER MARSHALL:

Topología del rodaje en España. 


\section{“LADRÓN DE BICICLETAS” (Ladri di Biciclette) 1948}

Guion

Cesare Zavattini, Vittorio De Sica, Suso Cecchi d'Amico, Oreste Biancoli, Adolfo Franci, Gerardo Guerrieri e Gherardo Gherardi

Dirección

Vittorio De Sica

Fotografía

Carlo Montuori

Escenografía

Antonio Traverso

Imagen

Sonido

Biagio Fiorelli (como Gino), Bruno Brunacci (sin créditos)

Producción

P.D.S. Giuseppe Amato, Vittorio De Sica.

Montaje

Eraldo Da Roma

Musica

Alessandro Cicognini

Topología del rodaje (decorados principales):

Borgata Val Melaina(Via Gran Paradiso)/ Via Maiella (Sempione)/ Piazza Vittorio / Porta Portese / Chiesa Nereo e Achilleo (Caracalla)/ Trastevere / Ponte Duca d'Aosta / Luntotevere

Flaminio / Via Pietra da Cortona

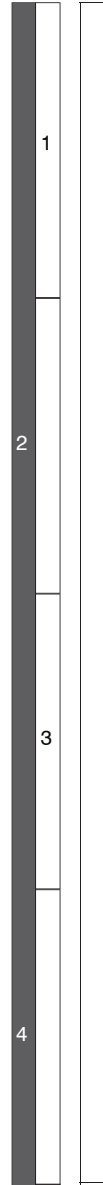

“CERCA DE LA CIUDAD” 1952

Guion

José Luis Colina, Luis Lucía

Dirección

Luis Lucía

Fotografía

Alfredo Fraile

Escenografía

Bernardo Ballester, Eduardo Torre de la Fuente

Imagen

Make up: Carmen Martín.

Sonido

Ramón Arnal

Producción

Alejandro Arias Salgado

Montaje

Antonio Ramírez de Loaysa

Musica

Juan Quintero

Topología del rodaje (decorados principales):

Calle Alcalá / Calle de faustina peñalver ciudad lineal (San Juan Bautista) / El Pozo del Tío Raimundo
RM 1. LADRÓN DE BICICLETAS: Topología del rodaje en la capital italiana y distancia del centro.

Cartografía desarrollada a partir del Plan general de 1962
MD 1. CERCA DE LA CIUDAD: Topología

del rodaje en la capital española y distan-

cia del centro. Cartografía desarrollada a

partir del Plan general de 1953 


\section{“LA TIERRA TIEMBLA” (La terra trema) 1948}

Guion

Luchino Visconti, Antonio Pietrangeli (sin creditos)

Dirección

Luchino Visconti

Fotografía

G.R. Aldo

Escenografía

Imagen

Sonido
Ovidio Del Grande

Producción

Salvo D'Angelo (Universalia)

Montaje

Mario Serandrei

Musica

Willy Ferrero

Topología del rodaje (decorados principales): Aci Trezza (Catania)

\section{“MUERTE DE UN CICLISTA" 1955}

Guion

Juan Antonio Bardem, Luis Fernando de Igoa Dirección

Juan Antonio Bardem

Fotografía

Alfredo Fraile

Escenografía

Enrique Alarcón

Imagen

Make up: Francisco Puyol

Sonido

Alfonso Carvajal

Producción

Manuel J. Goyanes

Montaje

Margarita de Ochoa

Musica

Isidro B. Maiztegui

Topología del rodaje (decorados principales):

Topologia del rodaje (decorados principal
Paseo y Carrettera de Extremadura / C.U. /

Calle San Leonardo (plaza de España) / Hipodromo Zarzuela
RM 1. LA TIERRA TIEMBLA: Topología del

rodaje en Italia.
MD 1. MUERTE DE UN CICLISTA:

Topología del rodaje en la capital española

y distancia del centro. Cartografía desarrol-

lada a partir del Plan general de 1953 
"BAJO EL SOL DE ROMA" (Sotto il sole di Roma) 1948

Guion

Renato Castellani, Sergio Amidei, Emilio Cecchi, Ettore Maria Margadonna, Fausto Tozzi Dirección

Renato Castellan

Fotografía

Domenico Scala

Escenografía

Dario Cecchi

Imagen

Make up: Otello Fava. Vestuario: Dario Cecch

Sonido

Producción

Sandro Ghenzi, Antonio Roi

Montaje

Giuliano Betti

Musica

Nino Rota

Topología del rodaje (decorados principales):

San Giovanni / Ponte Lungo / Ponte Tuscolano / Via Satrico / Via Vetulonia / Parco dell Caffarella - Appia Antica / Via Frangipane - Colosseo

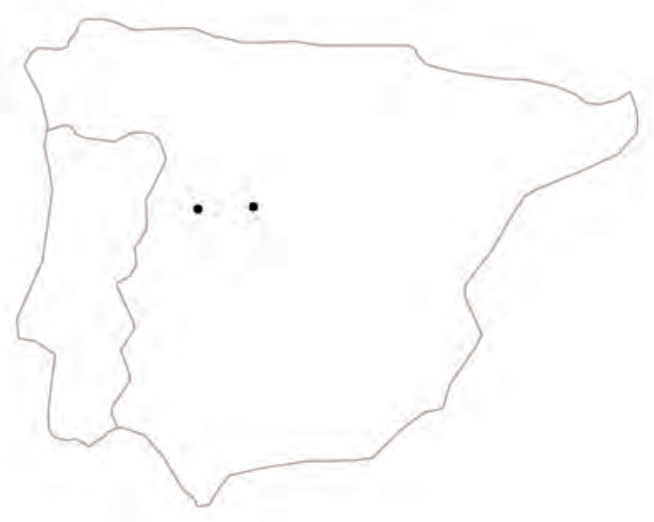

\section{“MARCELINO PAN Y VINO” 1955}

Guion

Ladislao Vajda, José María Sánchez Silva

Dirección

Ladislao Vajda

Fotografía

Heinrich Gärtner

Escenografía

Antonio Simont

Imagen

Make up: José María Sánchez Hair stylist: Carmen Sánchez. Vestuario: Agapito Mar-

jaliza

Sonido

Alfonso Carvajal, Jesús Moreno

Producción

Vicente Sempere (administración)

Montaje

Julio Peña

Musica

Pablo Sorozábal

Topología del rodaje (decorados principales):

La alberca (Salamanca)/ El Espinar (Segovia)

MD 1. MARCELINO PAN Y VINO: Topología

del rodaje en España
Topología del rodaje en la capital italiana y

distancia del centro.

Cartografía desarrollada a partir del Plan

general de 1962 


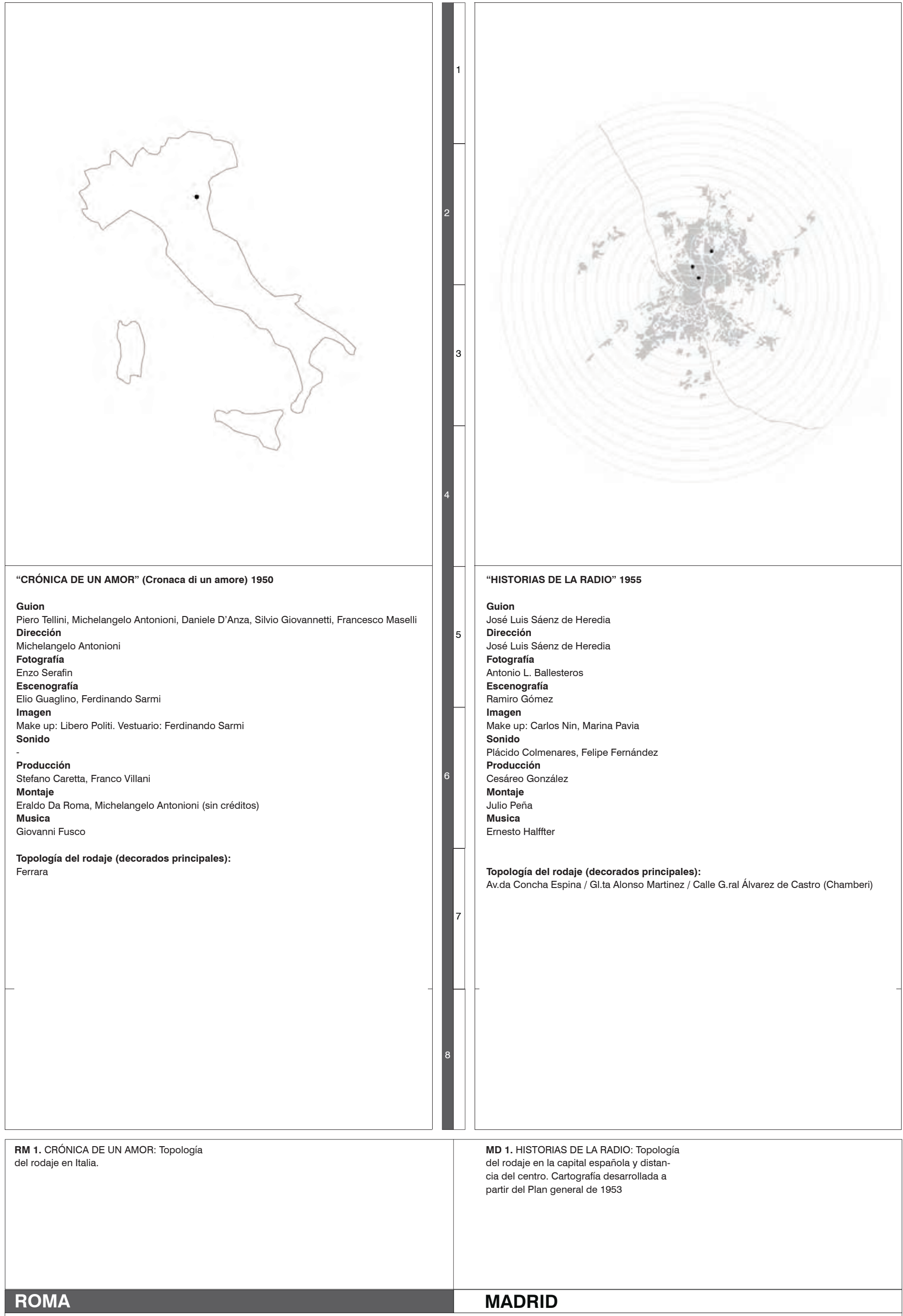




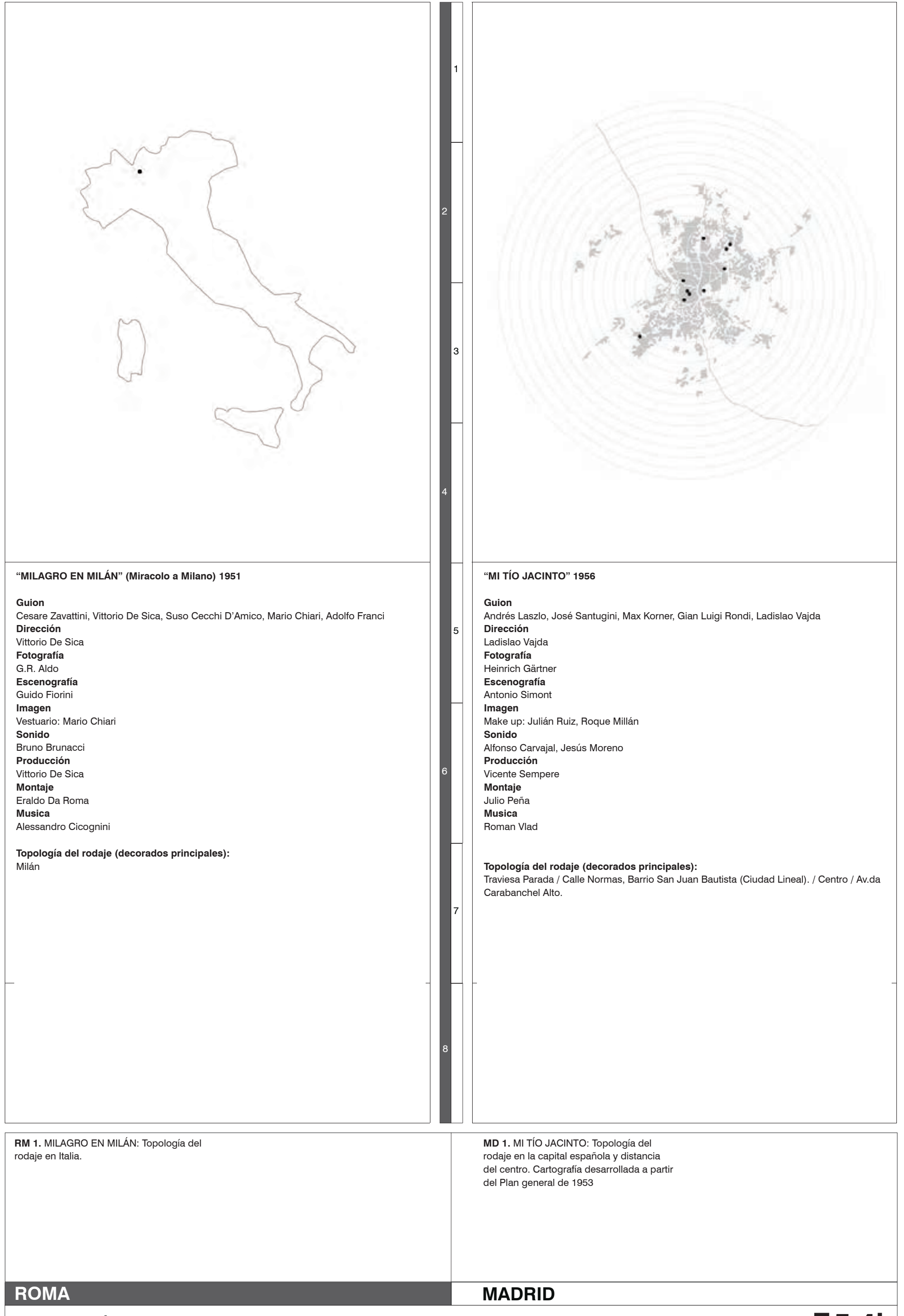




\section{“EUROPA 51" 1952}

Guion

Roberto Rossellini, Sandro De Feo, Mario Pannunzio, Ivo Perilli, Brunello Rondi Dirección

Roberto Rossellini

Fotografía

Aldo Tonti

Escenografía

Ferdinando Ruffo

Imagen

Vestuario: Fernanda Gattinoni

Sonido

Piero Cavazzuti, Paolo Uccello

Producción

Carlo Ponti, Dino De Laurentiis, Roberto Rossellini.

Montaje

Jolanda Benvenuti

Musica

Renzo Rossellin

Topología del rodaje (decorados principales):

Parioli-Via Archimede / Primavalle / Ponte Marcon

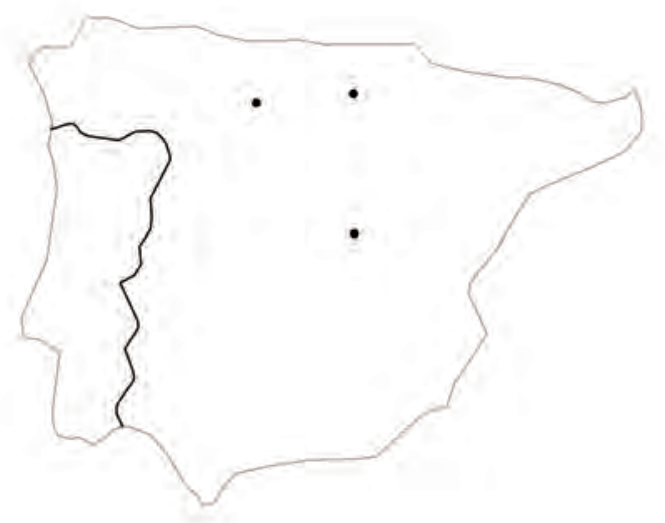

\section{“CALLE MAYOR" 1956}

Guion

Carlos Arniches, Juan Antonio Bardem

Dirección

Juan Antonio Bardem

Fotografía

Michel Kelber

Escenografía

Enrique Alarcón

Imagen

Make up: Carmen Martín. Hair stylist: Dolores Clavel

Sonido

Fernando Bernáldez

Producción

Cesáreo González, Manuel J. Goyanes

Montaje

Margarita de Ochoa

Musica

Joseph Kosma, Isidro B. Maiztegu

Topología del rodaje (decorados principales):

Palencia / Cuenca / Logroño 


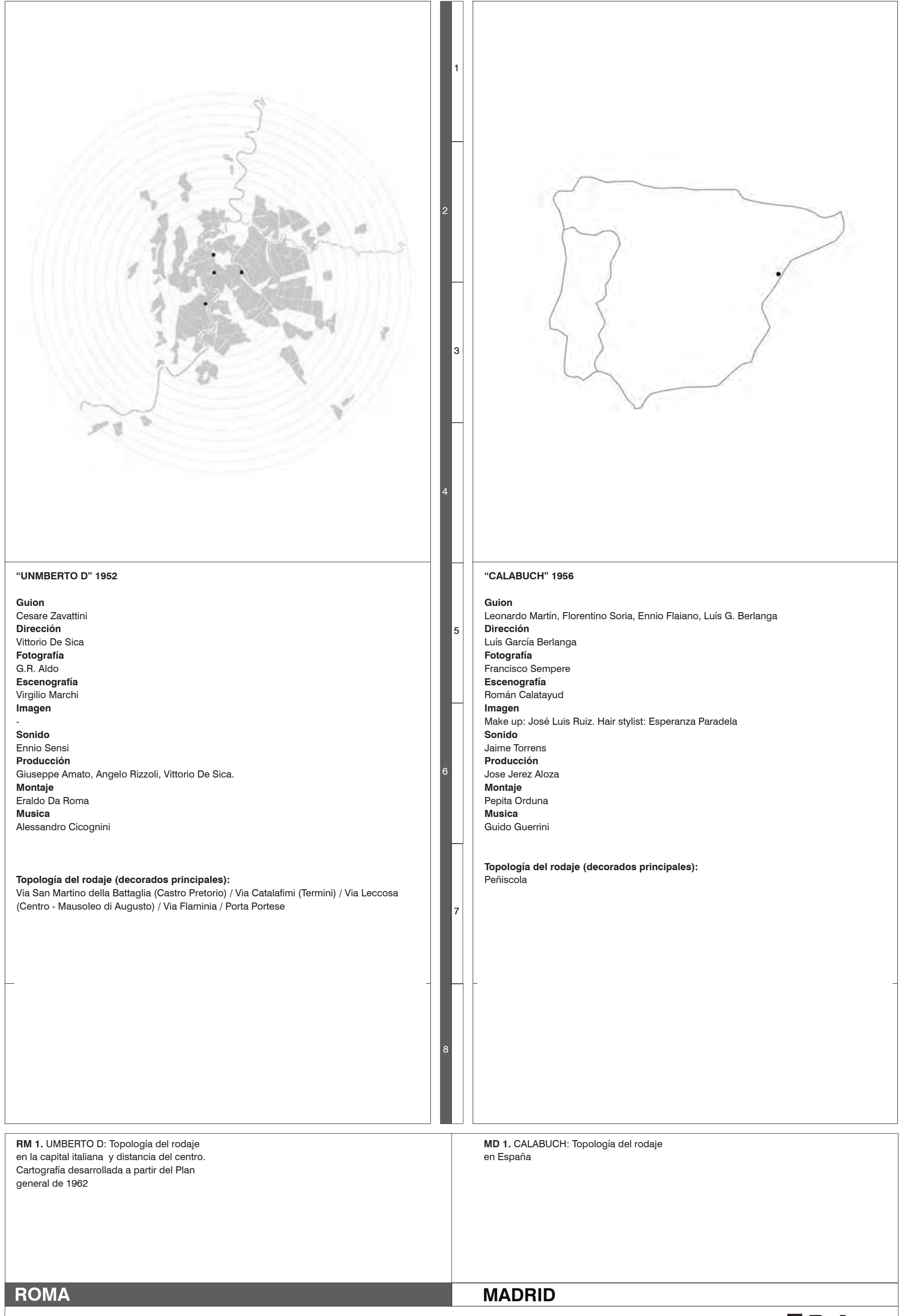




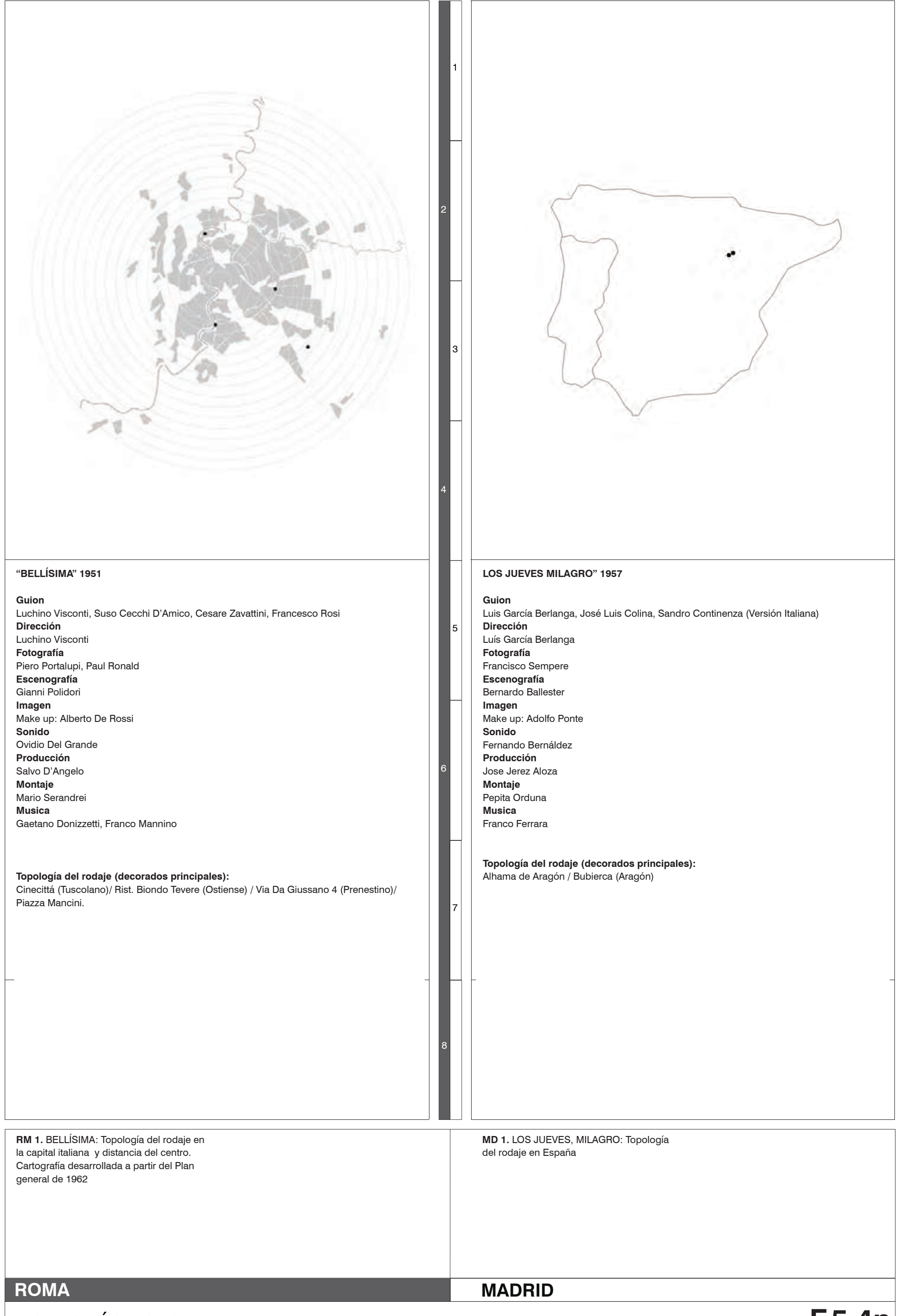




\section{“EL AMOR EN LA CIUDAD” (L’amore in cittá) 1953}

Guion

Michelangelo Antonioni, Aldo Buzzi, Dino Risi, Luigi Chiarini, Federico Fellini, Marco Ferreri, Alberto Lattuada, Cesare Zavattini, Vittorio Veltroni, Luigi Malerba, Tullio Pinelli Dirección

Michelangelo Antonioni, Federico Fellini, Alberto Lattuada, Carlo Lizzani, Francesco Maselli,

Dino Risi e Cesare Zavattini

Fotografía

Gianni Di Venanzo

Escenografía

Gianni Polidori

Imagen

Make up: Raimondo Van Riel

Sonido

Mario Messina, Giovanni Paris

Producción

Marco Ferreri, Riccardo Ghione, Cesare Zavattini

Montaje

Eraldo Da Roma

Musica

Mario Nascimbene

Topología del rodaje (decorados principales):

Prenestino / Pigneto / Centocelle / Via Casilina / Verano / Portuense / Trastevere / Puente S.

Angelo / Puente Mazzini / Testaccio / Salario / Termini / Tuscolano.

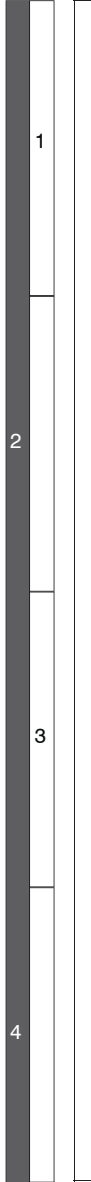

"EL INQUILINO" 1958

Guion

José Antonio Nieves Conde, José Luis Duro, José María Pérez Lozano, Manuel Sebares Dirección

José Antonio Nieves Conde

Fotografía

Francisco Sempere

Escenografía

Enrique Alarcón

Imagen

Make up: Julián Ruiz Hair stylist: Esperanza Paradela

Sonido

Alfonso Carvajal

Producción

Rafael Carrillo - Films Españoles Cooperativa

Montaje

Margarita de Ochoa

Musica

Miguel Asins Arbó

Topología del rodaje (decorados principales):

Calle de la Palma (Malasaña) / La Latina / Carabanchel / San Francisco el Grande

MD 1. EL INQUILINO: Topología del rodaje

en la capital española y distancia del

centro. Cartografía desarrollada a partir del

Plan general de 1953 del centro.

Cartografía desarrollada a partir del Plan

general de 1962 


\section{“LOS INUTILES” (I vitelloni) 1953}

Guion

Federico Fellini, Ennio Flaiano, Tullio Pinelli

Dirección

Federico Fellin

Fotografía

Carlo Carlini, Otello Martelli, Luciano Trasatti

Escenografía

Mario Chiari

Imagen

Vestuario: Margherita Marinari Make up: Michele Bomarzi

Sonido

Producción

Danilo Fallani, Luigi Giacosi. Peg Films, Cite Films

Montaje

Rolando Benedetti

Musica

Nino Rota

Topología del rodaje (decorados principales):

Ostia / Castel Fusano / Viterbo / Firenze

\section{“EL PISITO” 1958}

Guion

Marco Ferreri, Rafael Azcona

Dirección

Marco Ferreri, Isidoro Ferry

Fotografía

Francisco Sempere

Escenografía

Antonio Cortés

José Paredes

Imagen

Make up: José Luís Ruiz Hair stylist: Mercedes Paradela

Sonido

Jesús Jiménez

Producción

José Manuel M. Herrero

Montaje

José Antonio Rojo

Musica

Federico Contreras

Topología del rodaje (decorados principales):

Gran Vía / San Blas / Arturo Soria / La Cebada / Calle de los Realojos (Sn Blas) / Avenida Hermanos García Noblejas (San Blas)
RM 1. LOS INUTILES: Topología del rodaje

en Italia.
MD 1. EL PISITO: Topología del rodaje en

la capital española y distancia del centro.

Cartografía desarrollada a partir del Plan

general de 1953. 


\section{“LA CALLE” (La strada) 1954}

Guion

Federico Fellini, Ennio Flaiano, Tullio Pinelli

Dirección

Federico Fellin

Fotografía

Otello Martelli, Carlo Carlini

Escenografía

Mario Ravasco

Imagen

Vestuario: Margherita Marinari Make up: Eligio Trani

Sonido

R. Boggio, A.Calpin

Producción

A.Cittadini, D. Fallani, L. Giacosi, G. Morra. Ponti-De Laurentiis Cinematografica

Montaje

Leo Catozzo

Musica

Nino Rota

Topología del rodaje (decorados principales):

Fiumicino / Rocca di mezzo ('Aquila) / Roma (Viale Corinto - Ostiense-Marconi)

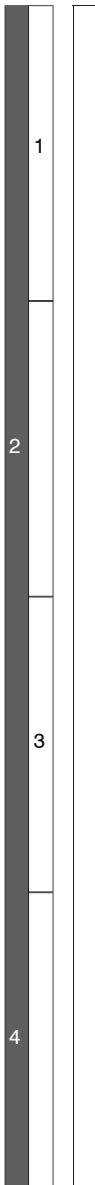

"LOS CHICOS" 1959

Guion

Marco Ferreri, Leonardo Martín

Dirección

Marco Ferreri

Fotografía

Francisco Sempere

Escenografía

Francisco Canet

Imagen

Make up: José Echevarría Hair stylist: Maria Luisa del Campo

Sonido

G. Basagaña, J. Torrens

Producción

Faustino Ocaña, Manuel Torres

Montaje

José Antonio Rojo

Musica

Miguel Asins Arbó

Topología del rodaje (decorados principales):

Callao / Calle del Rosario / Calle de San Francisco / La Latina / Instituto San Isidro / Ventas

/ Viaducto Segovia / Calle Antonia Mercé (Goya) /Avenida Felipe II (Goya)

MD 1. LOS CHICOS: Topología del rodaje

en la capital española y distancia del

centro. Cartografía desarrollada a partir del

Plan general de 1953 


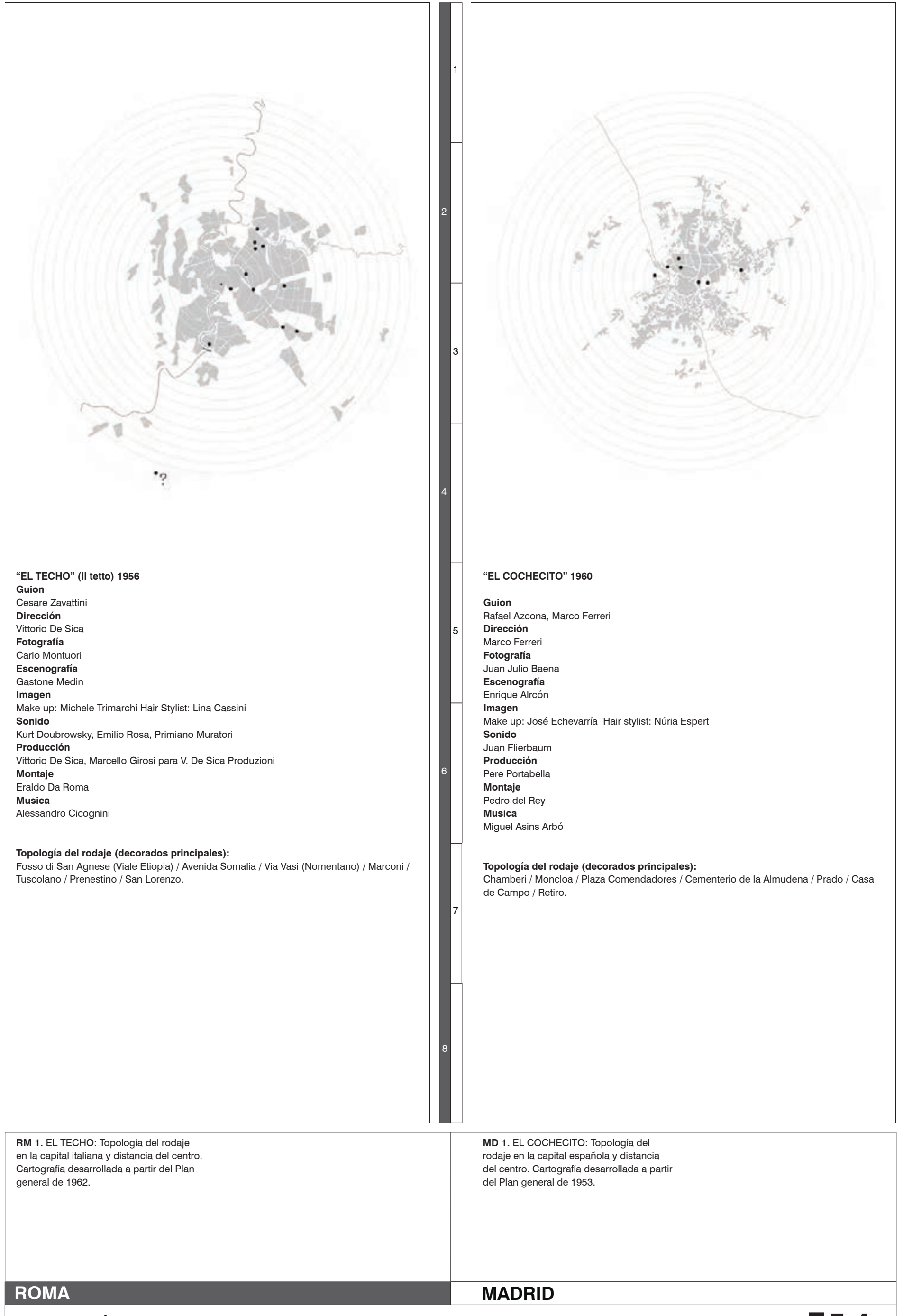




\section{"EL FERROVIARIO" (II ferroviere) 1956}

Guion

Alfredo Giannetti, Luciano Vincenzoni, Pietro Germi

Dirección

Pietro Germi

Fotografía

Leonida Barboni

Escenografía

Carlo Egidi

Imagen

Make up: Franco Freda Hair Stylist: Amalia Paoletti

Sonido

Raffaele Del Monte, Rocco Roy Mangano, Vittorio Massi, Luigi Salvi

Producción

Carlo Ponti - Excelsa Film

Montaje

Dolores Tamburini

Musica

Carlo Rustichelli

Topología del rodaje (decorados principales):

Calle Prenestina / Plaza Caballini / San Lorenzo.

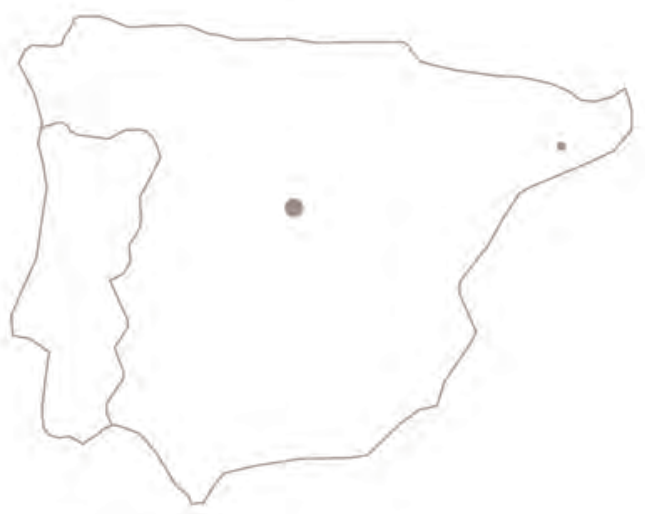

"PLACIDO” 1961

Guion

Rafael Azcona, José Luis Colina, José Luis Font, Luis García Berlanga Dirección

Luis García Berlanga

Fotografía

Francisco Sempere

Escenografía

Andrés Vallvé

Imagen

Make up: Rodrigo Gurrucharri Hair stylist: Vicenta Salvadó

Sonido

Felipe Fernández

Producción

Alfredo Matas - Jet Films

Montaje

José Antonio Rojo

Musica

Miguel Asins Arbó

Topología del rodaje (decorados principales):

Manresa (Cataluña) / Madrid (Estudios CEA).
RM 1. EL FERROVIAL: Topología del rodaje

en la capital italiana y distancia del centro.

Cartografía desarrollada a partir del Plan

general de 1962.
MD 1. PLACIDO: Topología del rodaje en

España 
"ROCCO Y SUS HERMANOS" (Rocco e i suoi fratelli) 1960

\section{Guion}

Suso Cecchi D’Amico, Pasquale Festa Campanile, Massimo Franciosa, Enrico Medioli,

Luchino Visconti

Dirección

Luchino Visconti

Fotografía

Giuseppe Rotunno

Escenografía

Mario Garbuglia

Imagen

Make up: Giuseppe Banchelli Hair Stylist: Vasco Reggiani

Sonido

Giovanni Rossi

Producción

Goffredo Lombardo - Titanus, Les Films Marceau

Montaje

Mario Serandrei

Musica

Nino Rota

Topología del rodaje (decorados principales):

Milano / Civitavecchia (Rm) / Roma (Parroquia Francesco Saverio Cabrini - Via della Marsica en el Barrio Nomentano)

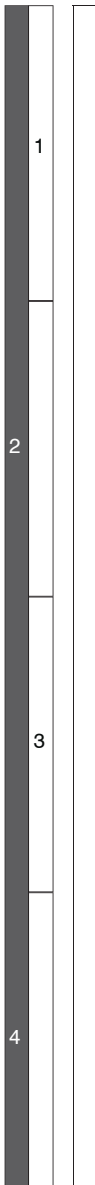

“LOS GOLFOS" 1961

Guion

Carlos Saura, Mario Camus, Daniel Sueiro

Dirección

Carlos Saura

Fotografía

Juan Julio Baena

Escenografía

Enrique Alarcón

Imagen

Make up: Ricardo Vázquez

Sonido

Felipe Fernández

Producción

Pere Portabella

Montaje

Pedro del Rey

Musica

José Pagán, Antonio Ramírez Ángel

Topología del rodaje (decorados principales):

Avd.a Marques de la Corbera / Calle Francisco Villaespesa. (Ventas) / Legazpi / Arena Vista Alegre
RM 1. ROCCO Y SUS HERMANOS:

Topología del rodaje en Italia.
MD 1. LOS GOLFOS: Topología del rodaje

en la capital española y distancia del

centro. Cartografía desarrollada a partir del

plan general de 1953 


\section{“ACCATTONE" (Accattone) 1961}

Guion

Pier Paolo Pasolini, Sergio Citti

Dirección

Pier Paolo Pasolini

Fotografía

Tonino Delli Colli

Escenografía

Flavio Mogherini

Imagen

Make up: Cesare Biseo

Sonido

Luigi Puri

Producción

Alfredo Bini - Cino Del Duca

Montaje

Nino Baragli

Musica

Carlo Rustichelli (director)

Topología del rodaje (decorados principales):

Prenestino / Pigneto / Centocelle / Via Casilina / Verano / Portuense / Trastevere / Ponte sant'angelo / Ponte Mazzini / Testaccio / Villa Gordiani (Prenestina)

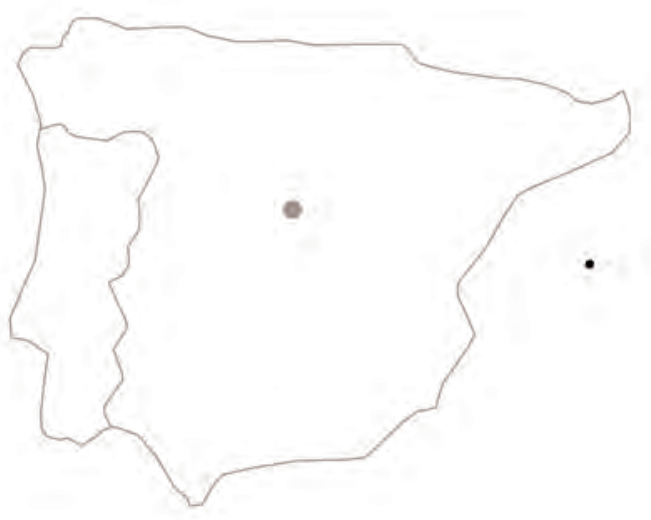

"EL VERDUGO” 1963

Guion

Rafael Azcona, Luis García Berlanga, Ennio Flaiano

Dirección

Luis García Berlanga

Fotografía

Tonino Delli Colli

Escenografía

Luis Argüello, José Antonio de la Guerra

Imagen

Make up: Francisco Puyol. Hair stylist: María Teresa Gamborino

Sonido

Felipe Fernández

Producción

Nazario Belmar, Moris Erga - Naga Films (Madrid) / Zabra Films (Roma)

Montaje

Alfonso Santacana

Musica

Miguel Asins Arbó

Topología del rodaje (decorados principales)

Madrid ( Plaza de la Marina y Paseo de Recoletos en el Centro y Areopuerto de Barajas) / Mallorca (Isla de Mallorca)
RM 1. ACCATTONE: Topología del rodaje en la capital italiana y distancia del centro. Cartografía desarrollada a partir del Plan General de 1962
MD 1. EL VERDUGO: Topología del rodaje

en España. 
"MAMMA ROMA" (Mamma Roma) 1962

\section{Guion}

Pier Paolo Pasolini

Dirección

Pier Paolo Pasolini

Fotografía

Tonino Delli Colli

Escenografía

Flavio Mogherini

Imagen

Make up: Marcello Ceccarelli Hair stylist: Amalia Paoletti

Sonido

Leopoldo Rosi, Renato Cadueri

Producción

Alfredo Bini

Montaje

Nino Baragli

Musica

Carlo Rustichelli (director)

Topología del rodaje (decorados principales):

Guidonia / Casal Bertone / Tuscolano / Viale Romanisti(Torre spaccata)/ Acilia / Porta Portese / Ramapa Brancaleone (San Pietro)/ Tor Marancia

\section{“DEL ROSA AL AMARILLO" 1963}

Guion

Manuel Summers

Dirección

Manuel Summers

Fotografía

Francisco Fraile

Escenografía

Imagen

Sonido

Producción

Manuel Summers, Juan Miguel Lamet, Francisco Lara Polop

Montaje

Antonio Gimeno

Musica

Antonio Pérez Olea

Topología del rodaje (decorados principales): Calle Juan Bravo / Plaza Marqués de Salamanca
RM 1. MAMMA ROMA: Topología del

rodaje en la capital italiana y distancia del

centro. Cartografía desarrollada a partir del

Plan General de 1962
MD 1. DEL ROSA AL AMARILLO: Topología

del rodaje en la capital española y distan-

cia del centro. Cartografía desarrolada a

partir del Plan general de 1953 


\section{ANEXO II: CUADROS TEMÁTICOS}

Se trata de las matrices de análisis utilizadas para el desarrollo de las fichas iconográficas. Estas fichas representan la infraestructura / "vocabulario" desarrollada en el segundo capítulo de este trabajo de investigación. (F.5.5.1-2) 
Campos (Agricultura)

Animales

Vernacular

Agua (texturas)

Cielo, aire, atmósferas

Guerra

Oficios

Fiestas, mercados, procesiones, circos

Derivas (urbanas y suburbanas)

Derivas (rurales)

Derivas nocturnas

Trenes (vehiculos)

$\sum$ Juegos de niños

i Vehiculos pequeños

Vagabundeo, ambulantaje

Aceras

Tramvías, autobuses, metro

Multitudes

Manifestaciones, propaganda

Migraciones, viajes, mudanzas

Ambientes de trabajo

Texturas pisos y suelos (texturas)

Landmarks (palos y objetos)

Signos (rotulos, carteles, publicidad)

Acueductos

Carretteras y autovías

Ferrocarriles

Puentes

Parques urbanos

Luces nocturnas

Postes electricos y telegraficos

Cables

Bodegas, tiendas

Bares, café, Restaurantes

Paisajes industriales

Ríos y canales

Horizontes

Obras (en construcción)

Limites, fronteras y umbrales

Muros

$\frac{\pi}{0}$ Plazas (encuentros)

Calles (encuentros - soledad)

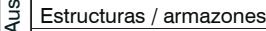

Descampados

Taludes y laderas

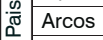

Desechos, residuos y fragmentos

Ruinas

Estructuras éfimeras, andámios

Ciudad desertizada no acabada

Ventanas

Techos

Interiores domésticos populares

Balcones

Ladrillos (texturas)

Ciudad informal

Torres de viviendas

Bloques de viviendas

Pasillos (interiores)

Patios interiores

Hacinamiento doméstico

Interiores fascista y burgueses

Acampados

Escaleras

Sótanos

Casa Hibrida (taller y nómada)

Suburbio recién acabado

Buhardilla

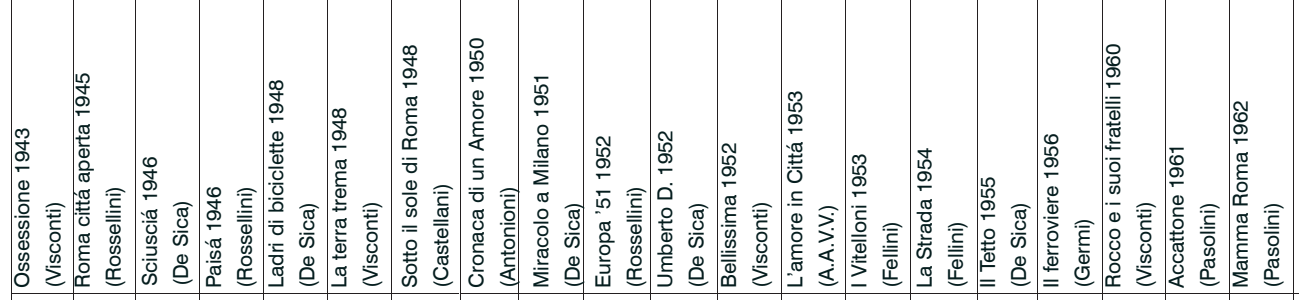

RM. Columna (y): Peliculas

Lineas (x): Temas iconograficos

*** Este analisis ha sido sintetizado en la estructura del capitulo 2 
Campos (Agricultura)

Animales

Vernacular

Agua (texturas)

Cielo, aire, atmósferas

Guerra

Oficios

Fiestas, mercados, procesiones, circos

Derivas (urbanas y suburbanas)

Derivas (rurales)

Derivas nocturnas

Trenes (vehiculos)

$\sum$ Juegos de niños

i Vehiculos pequeños

Vagabundeo, ambulantaje

Aceras

Tramvías, autobuses, metro

Multitudes

Manifestaciones, propaganda

Migraciones, viajes, mudanzas

Ambientes de trabajo

Texturas pisos y suelos (texturas)

Landmarks (palos y objetos)

Signos (rotulos, carteles, publicidad)

Acueductos

Carretteras y autovías

Ferrocarriles

Puentes

Parques urbanos

Luces nocturnas

Postes electricos y telegraficos

Cables

Bodegas, tiendas

Bares, café, Restaurantes

Paisajes industriales

Ríos y canales

Horizontes

Obras (en construcción)

Limites, fronteras y umbrales

Muros

. $\frac{\pi}{0}$ Plazas (encuentros)

Calles (encuentros - soledad)

$\stackrel{?}{\gtrless}$ Estructuras / armazones

Descampados

Taludes y laderas

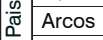

Desechos, residuos y fragmentos

Ruinas

Estructuras éfimeras, andámios

Ciudad desertizada no acabada

Ventanas

Techos

Interiores domésticos populares

Balcones

Ladrillos (texturas)

Ciudad informal

Torres de viviendas

Bloques de viviendas

Pasillos (interiores)

Patios interiores

Hacinamiento doméstico

Interiores fascistas y burgueses

A Acampados

Escaleras

Sótanos

Casa Hibrida (taller y nómada)

Suburbio recién acabado

Buhardilla

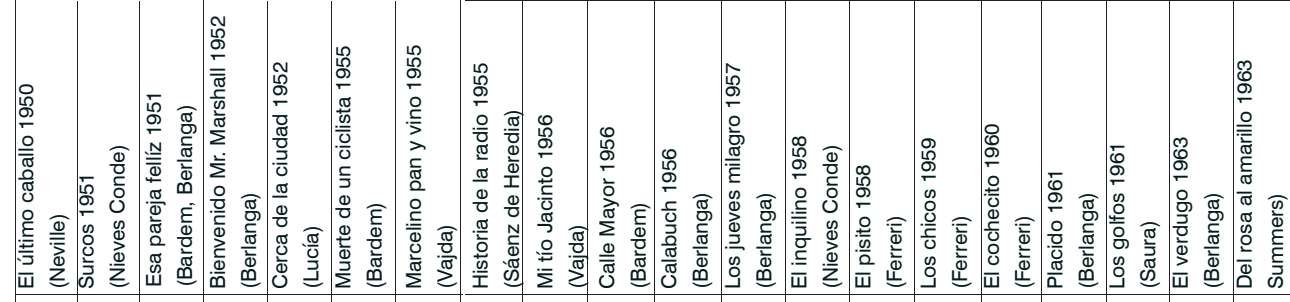

MM. Columna (y): Peliculas

Lineas (x): Temas iconograficos

*** Este analisis ha sido sintetizado en la estructura del capitulo 2 


\section{ANEXO III: LÍNEA DE TIEMPO}

Se presentan en paralelo los principales acontecimiento histórico-culturales, en el lapso de tiempo analizado en este trabajo de investigación y en relación con las fechas de realización de algunas de las películas analizadas. (F.5.6) 
La Ciudad Neorrealista. Territorio, iconografía y mapas de Roma y Madrid. 1943-1963

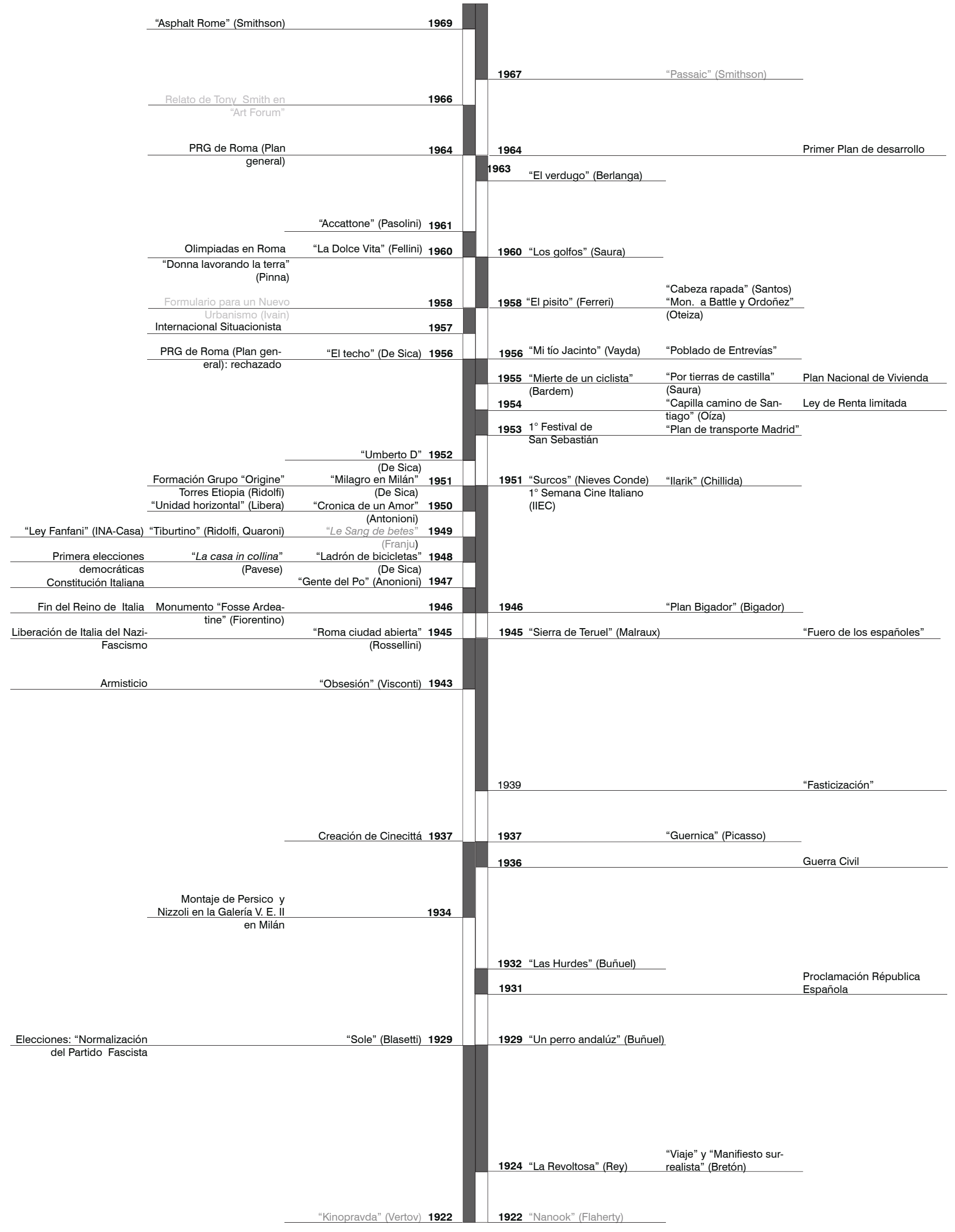

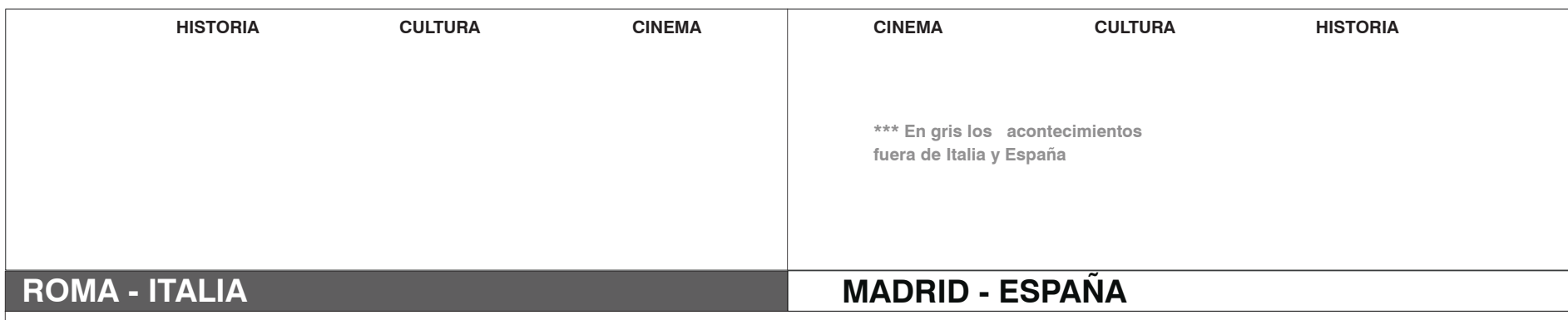




\section{ANEXO IV: PARALELOS}

Se ha descartado en este apartado el análisis de todas las colaboraciones y coproducciones cinematográficas entre los dos países. Se presenta únicamente el análisis de las similitudes presentes en las películas escogidas en términos de historia, personajes y contenidos.

Roma ciudad abierta 1945 (R. Rossellini) / Cerca de la ciudad 1952 (L. Lucía)

En las dos películas el protagonista es un cura y su capacidad de apoyar a su comunidad: las Barriadas chabolistas de Ventas y Entrevías en Madrid y el Barrio Casilino en la Roma ocupada por los Nazis. Las historias están inspiradas por la realidad de las luchas partisanas y el papel que jugaron algunos valientes religiosos en Italia y en España; seguramente la historia del padre Llanos - "el cura rojo" - en Entrevías tiene parecido con la de Alfonso Marsillach, protagonista de Cerca de la Ciudad, aunque el primero llegó en esta barriada solamente en 1955, tres años después de la película de Luís Lucía.

El limpiabotas (Sciusciá) 1946 (V. De Sica) / El último caballo 1950 (E. Neville)

La presencia de un caballo es el elemento común en las dos películas que, sin embargo, tienen tonos narrativos diferentes, como en general gran parte de la cinematografía de los dos países en esta época: más dramática la italiana, amarga y a veces grotesca la española. En El limpiabotas el caballo es para los protagonistas un medio para escaparse de la realidad cotidiana, rencontrando a la infancia perdida; en El último caballo, el animal que Fernán Fernández trae del cuartel donde estaba alistado, es un elemento de ruptura con el medio urbano y su estilo de vida que el protagonista rechaza en búsqueda de un sentimiento autentico e infantil hacia la naturaleza.

La tierra tiembla 1948 (L. Visconti) / Las Hurdes, tierra sin pan 1933 (L. Buñuel)

La película de Visconti - como el anterior documental Gente del Po de Antonioni de 1947 - es un documento dramático de la vida rural en Italia en la primera mitad del siglo XX. La revolucionaria calidad estética de la investigación antropológica que Visconti realiza sobre la condición de los pescadores sicilianos, caracteriza también el mediometraje que Luís Buñuel realizó en 1933 describiendo las condiciones de un pueblo olvidado de Extremadura. Falta en Buñuel un real interés social, que anima la obra de Visconti. El director español buscaba otros lenguajes narrativos para expresar su interés hacia la investigación sobre el ánimo humano.

Ladrones de Bicicletas 1948 (V. De Sica) / Mi Tío Jacinto 1956 (L. Vajda)

Las dos películas tienen como protagonistas una pareja de un hombre adulto y un niño de 7-8 años: padre e hijo en la película de De Sica, tío y sobrino en la de Vajda. Las dos parejas cumplen un viaje desde la periferia extrema hasta el centro de la ciudad, con la finalidad de encontrar algo que podría facilitar un rescate social: la bicicleta robada en la película italiana, el traje de torero en la película española.

Crónica de un amor 1950 (M. Antonioni) / Muerte de un ciclista 1955 (J. A. Bardem)

En las dos películas aparece como protagonista la actriz italiana Lucía Bosé; en las dos películas un delito genera una atmosfera de suspenso que los directores alimentan a través de una atenta selección de los escenarios urbanos y suburbanos. En las dos películas la relación amorosa entre los protagonistas está marcada por las consecuencias de actos trágicos. 
Europa '51 1952 (R. Rossellini) / Cerca de la ciudad 1952 (L. Lucía)

El tema del compromiso hacia la sociedad se funde con la espiritualidad humana. Los protagonistas, aunque diferentes - un cura en la película española - y una mujer aristocrática en la película italiana, actúan como misioneros en el difícil contexto social de los barrios periféricos de las dos capitales.

Humberto D. 1952 (De Sica) / El Inquilino 1957 (J. A. Nieves Conde)

El tema del desahucio y la consecuente búsqueda de un nuevo alojamiento, en un contexto urbano de profundas desigualdades, es el argumento de las dos películas.

Humberto D. 1952 (De Sica) / El Cochecito 1960 (M. Ferreri)

Una reflexión sobre la viejez, la soledad y la incomprensión entre generaciones, en el difícil contexto de la ciudad, son los temas principales de las dos películas, protagonizadas por dos adultos mayores. Humberto D. encuentra su única distracción y amor en un pequeño perro; mientras que Don Anselmo proyecta sus sueños en un cochecito.

Los inutiles 1953 (Fellini) / Calle Mayor 1956 (J. A. Bardem)

El paralelo entre las dos películas se puede establecer en el tema del engaño hacia una mujer ingenua, por parte de los protagonistas y su grupo de amigos, rechazando sus responsabilidades en una vida de provincia llena de aspiraciones y necesitada de los recursos para realizarlas.

El techo 1955 (De Sica) / El Pisito 1958 (M. Ferreri)

Las dos películas están protagonizadas por unas parejas con la necesidad de encontrar un hogar para poder vivir juntos y formar una familia. Más allá de los tonos cómicos y grotescos de la película española, en las dos obras cinematográficas es evidente la denuncia hacia un desarrollo urbanístico inaccesible para gran parte de la población.

Rocco y sus hermanos 1960 (Luchino Visconti) / Surcos 1951 (J. A. Nieves Conde)

Estas dos películas están protagonizadas por dos familias campesinas emigradas en Madrid y Milán. Para los padres y los hermanos es imposible adaptarse a un contexto urbano hostil.

Accattone 1961 (P. Pasolini) / Los Golfos 1961 (C. Saura)

En las dos obras, que superan el lenguaje Neorrealista, hay la descripción de la vida cotidiana de algunos jóvenes de la periferia suburbana de las dos capitales y los robos que realizan para cumplir sus deseos.

Mamma Roma 1962 (P. Pasolini) / ¿Que he hecho yo para merecer esto? 1983 (P.Almodovar)

En la escena final el director madrileño - como homenaje al director italiano - reproduce las tomas de la escena final del regreso de la Mamá a su piso con el sentimiento de desesperación por la ausencia del hijo. 
Anexos

\section{ANEXO V: VUELTA}

Se incluyen en esta sección, los levantamientos fotográficos y recorridos virtuales, realizados en el 2018 en búsqueda de los decorados originales analizados en el tercer capítulo de este trabajo de investigación. (F.5.7) 

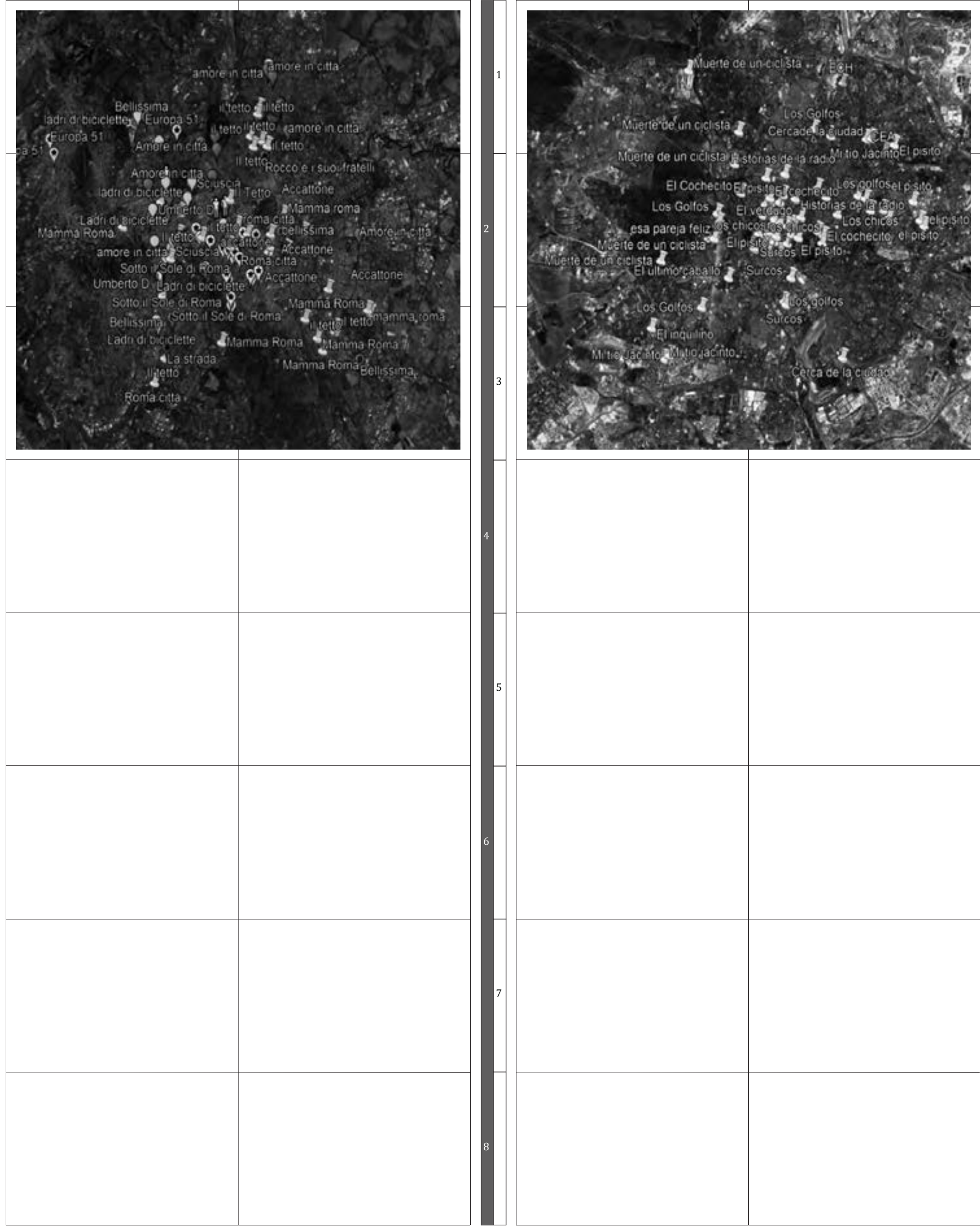

RM 1. Imagen satelitar (G-earth) 

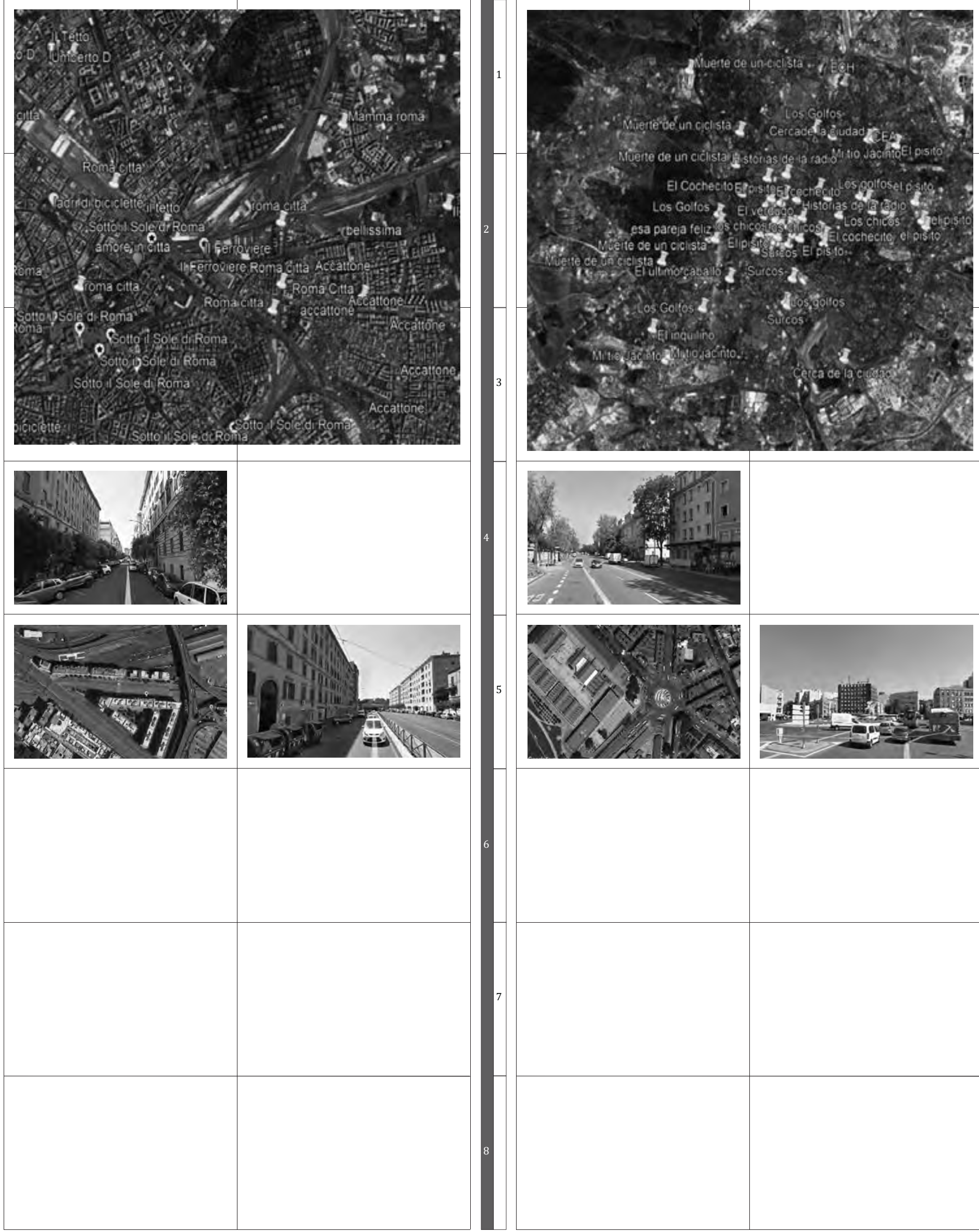

RM 1-2-3. Imagen satelitar (G-earth)

RM 4. Roma ciudad abierta (Rossellini): La Calle Montecuccoli escenario de la famosa escena de la muerte de Anna Magnani

RM 5. "El ferroviario" (Germi): Calle Prenestina Vecchia e Imagen satelitar de la misma
MD 1-2-3. Imagen satelitar (G-earth)

MD 4. Los Golfos (Saura): Paseo de la Chopera

MD 5. "Surcos" (Nieves Conde): Glorieta de Legazpi e Imagen satelitar de la misma 

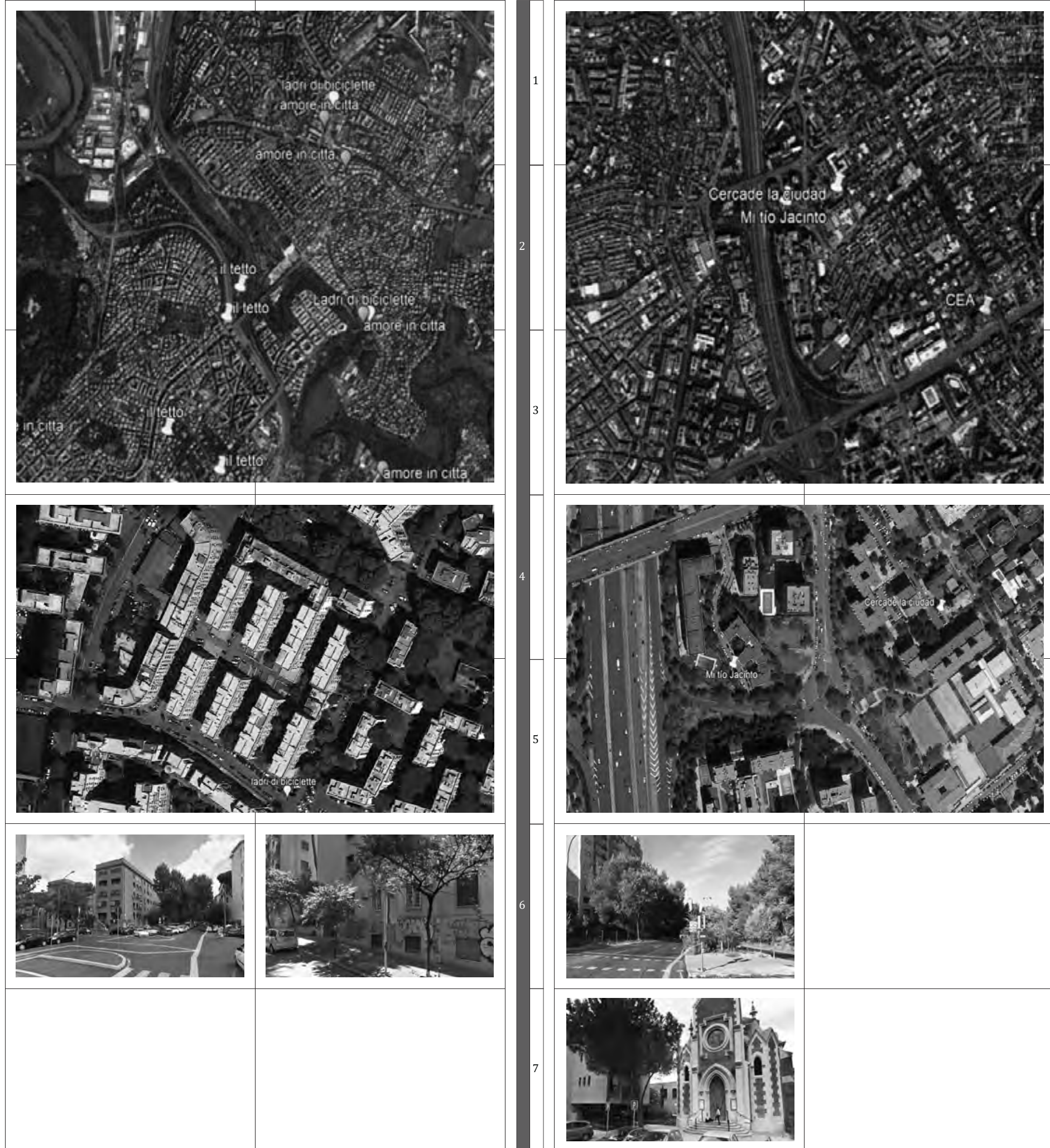

RM 1-2-3. Imagen satelitar (G-earth) del Sector "2"

RM 4-5. Ladrón de bicicletas (De Sica): Imagen satelitar (G-earth) del conjunto habitaciona de Calle del Gran Paradiso

RM 6. Puntos de vista del conjunto habitacional de Calle del Gran Paradiso según las tomas de la pelicula de De Sica
MD 1-2-3. Imagen satelitar (G-earth) del Sector "2"

MD 4-5. Mi tío Jacinto (Vajda): Imagen satelitar (G-earth) de area de San Juan Bautista en la zona del actual Calle de Torrelaguna.

MD 6. Punto de vista desde la zona de San Juan Bautista según una de las tomas panoramicas de Vajda.

MD 7. Punto de vista de la Parroquia de San Juan Bautista que aparece en la pelicula de Luís Lucía "Cerca de la ciudad". 

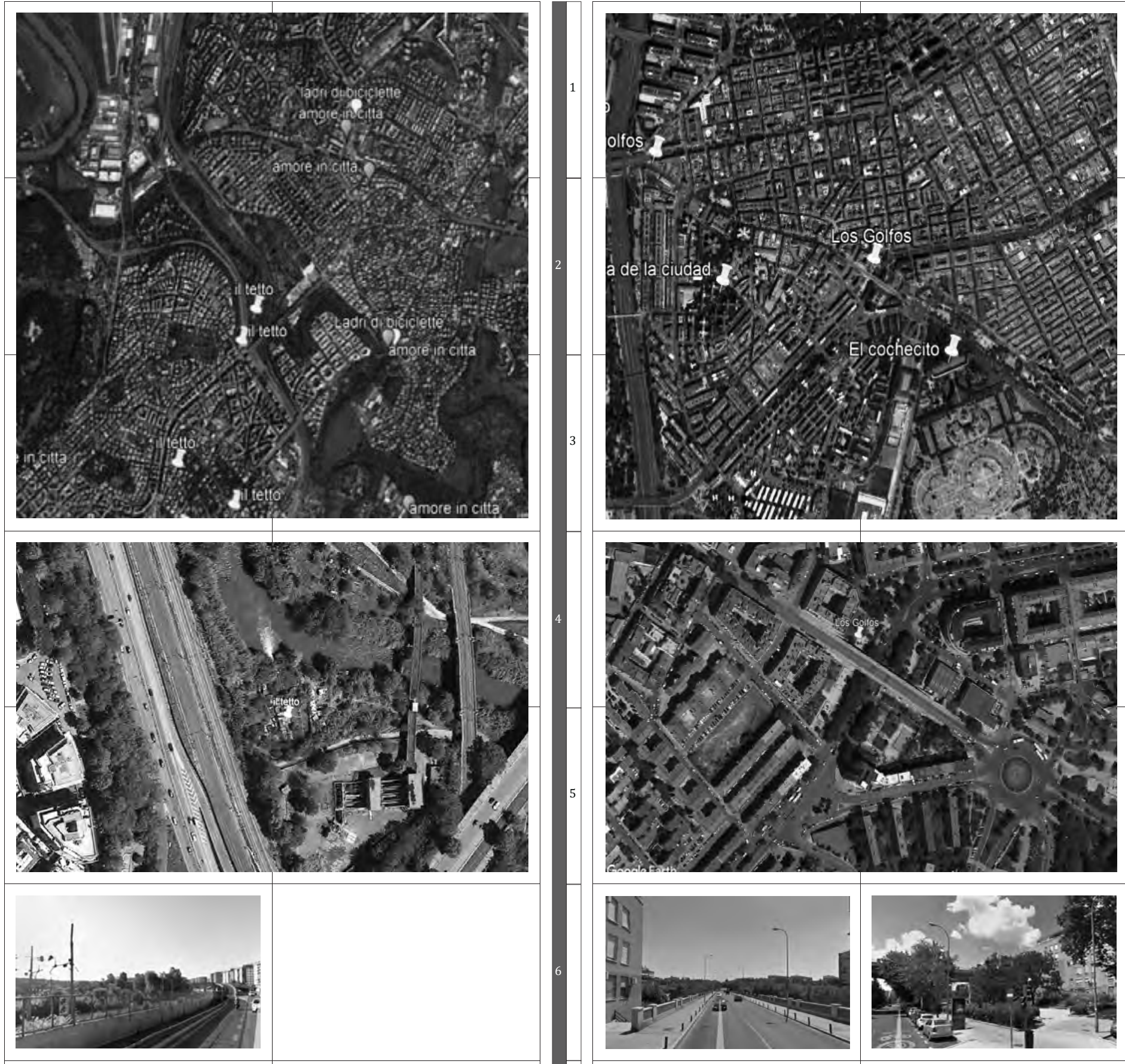

RM 1-2-3. Imagen satelitar (G-earth) del Sector "2"

RM 4-5. El techo (De Sica): Imagen satelitar (G-earth) del área del Puente dell Valli

RM 6. Punto de vista del conjunto habitacional de las "Torres de Viale Etiopia" de Mario

Ridolfi según la toma de la pelicula de De Sica

MD 1-2-3. Imagen satelitar (G-earth) del Sector "3"

MD 4-5. Los golfos (Saura): Imagen satelitar (G-earth) del area del puente de La Elipa

MD 6. Puntos de vista de la zona de la zona del puente de La Elipa según las tomas de la pelicula de Saura 

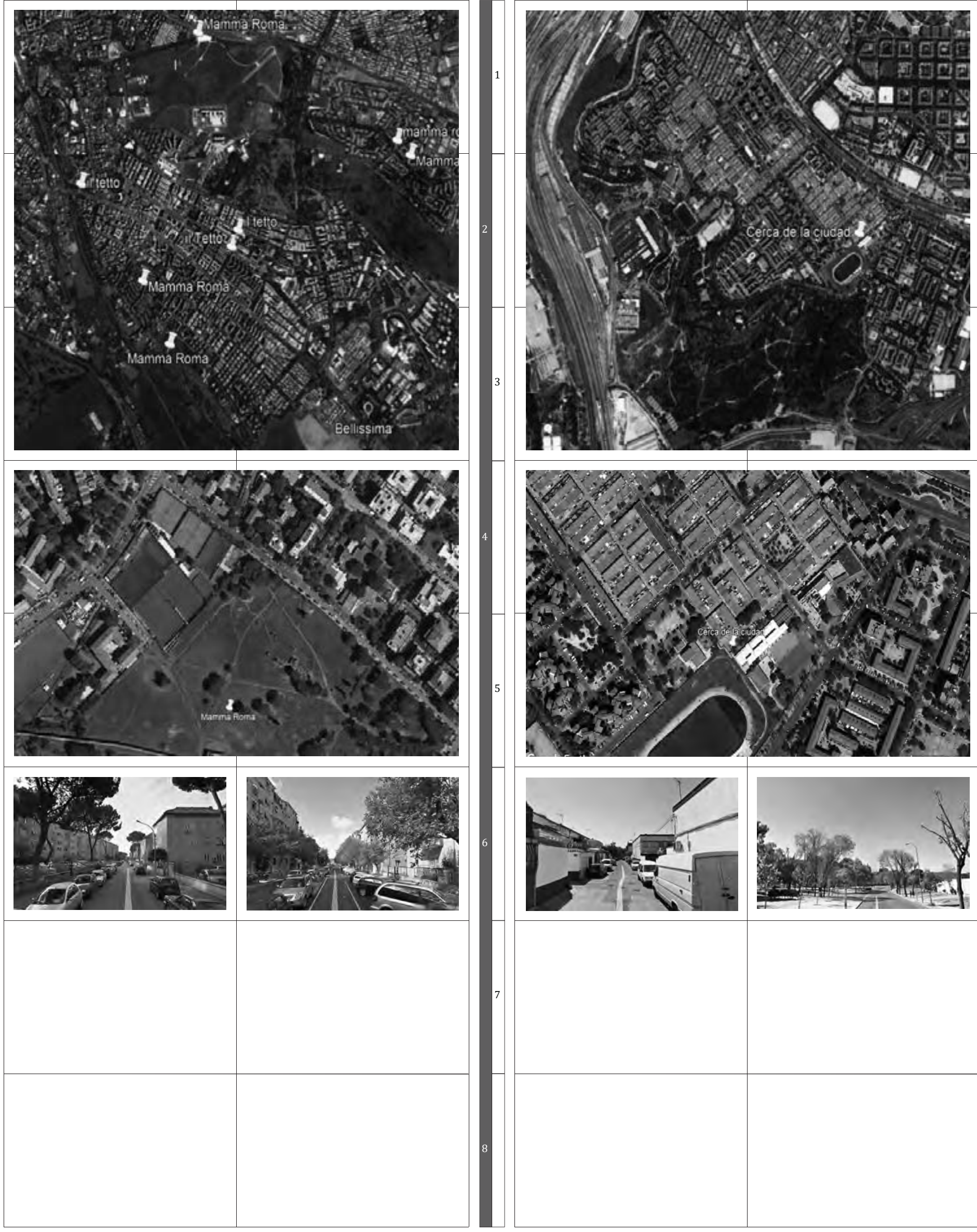

RM 1-2-3. Imagen satelitar (G-earth) del Sector "4"

RM 4-5. Mamma Roma (Pasolini): Imagen satelitar (G-earth) del área del Parque de los Acueductos.

RM 6. Puntos de vista del conjunto habitacional del conjunto INA-Casa Tuscolano según la toma de Pasolini.

MD 1-2-3. Imagen satelitar (G-earth) del Sector "4"

MD 4-5. Cerca de la ciudad (Lucía): Imagen satelitar (G-earth) del area de Entrevías / El Pozo.

MD 6. Puntos de vista de la zona de la zona de Entrevías según las tomas de Lucía (hipótesis) 


\section{ANEXO VI: GLOSARIO DE CINEMA Y VISIÓN}

\section{Arquitectura aumentada}

Es el fenómeno de ósmosis entre espacio fílmico y espacio real que expresa la posibilidad del Cine de construir un paisaje cultural que permanece en el tiempo. Toma el nombre de las tecnologías de la "realidad aumentada" y se desarrolla como espacio virtual de informaciones cinematográficas e históricas que se sedimentan en los imaginarios urbanos alimentando su iconografía.

\section{Cronología del decorado}

Es La descripción de un escenario y sus modificaciones espaciales en el tiempo.

\section{Campo / Contracampo}

Es el espacio visual que abarca el punto de vista de la cámara, según el ángulo del encuadre; el contracampo es el espacio visual simétrico a campo y de punto de vista geométricamente opuesto

\section{Decorados / Escenarios}

La localización en donde se desarrolla una escena, a través de diferentes tomas se llama escenario o decorado. En la cartografía desarrollada se trata de los diferentes puntos que generan un vector y unos recorridos cinematográficos y urbanos.

\section{Elipsis}

En el arte cinematográfico la elipsis corresponde a una omisión en la consecutio temporal o espacial de la narración cinematográfica: el espectador percibe una continuidad en la secuencia cinematográfica, aunque se han eliminados los pasos intermedios. En esta tesis entendemos como elipsis espacial también una incoherencia entre lugar, distancia y tiempo necesario para recorrerla, la elipsis en este caso corresponde a una necesidad estética del director que monta diferentes escenarios a veces muy distantes en una secuencia temporal continua, utilizando un raccord en el escenario y en las tomas con el fin de homogeneizar los diferentes decorados.

\section{Espacio (real y fílmico)}

Distinguimos en este trabajo, entre espacio real y espacio fílmico o cinematográfico. En la cinematografía neorrealista, los directores salen de los estudios de rodaje, buscando la coincidencia entre espacio real y narración fílmica. En la relación espacio - tiempo, los movimientos y los recorridos de los protagonistas se describen a través de planos-secuencia que buscan la coincidencia entre cinema y realidad.

\section{Fotograma}

Corresponde a la unidad mínima en la representación cinematográfica: cada unidad temporal de 1 segundo se reproducen 24 fotogramas (Cine mudo: 16-18 FPS; Cine: 24 FPS; Cine digital: 30 FPS o más)

\section{Fuera de campo o En Off}

Se entiende todo lo que no es presente en el encuadre cinematográfico, pero que se sigue desarrollándose y que influye sobre la narración.

Noel Burch en su praxis del Cine introduce el concepto de Mirada en off para definir el espacio fuera de campo describiendo algunas secuencias de la película de 1926 Nana de Jean Renoir: 
"La segunda manera como el realizador puede definir el espacio fuera de campo es mediante la mirada en off. A menudo, en Nana, una secuencia o una subsecuencia (...) empieza con un primer plano o plano cercano de un personaje que se dirige a otro fuera de campo, y a veces la situación es tal, la mirada tan intensa, tan esencial, que ese personaje fuera de campo (y por tanto el espacio imaginario en que se encuentra) toma tanta o más importancia que el personaje del encuadre y el espacio del campo. Los criados de Nana constantemente están asomando la cabeza por una puerta para ver quien se halla en el espacio de detrás del decorado, y de nuevo este espacio y este personaje invisibles toman una importancia por lo menos igual a lo que se ve. Por último, la mirada hacia la cámara (...), sirve para definir el espacio de detrás de la cámara donde se halla el objeto de esta mirada"'.

El concepto de fuera de campo está relacionado también con el sonido cinematográfico; este puede ser producido por una fuente que el espectador si conoce y que, sin embargo, por algunos instantes desaparece del encuadre o también puede ser generado por algo que no se identifica claramente y que podemos distinguir en dos tipologías:

FUERA DE CAMPO ACTIVO: corresponde al sonido, a la acción o a la voz que captura la atención del espectador que busca la fuente del sonido (como un grito, un sonido de pasos, etc.). Es una tipología de sonido que generalmente forma parte del guion y es importante que aparezca en fuera de campo.

FUERA DE CAMPO PASIVO: corresponde al sonido ambiente y no crea una expectativa en el espectador: se trata de un decorado sonoro.

\section{Imagen-movimiento}

En la primera parte de sus estudios Gilles Deleuze había relacionado el tiempo al movimiento para definir el únicum de la "materia cinematográfica" y la imposibilidad de separar la imagen presente en los fotogramas del movimiento que los une.

\section{Imagen-tiempo}

En su ensayo "La imagen-tiempo" segunda parte de sus estudios sobre el medio cinematográfico, Gilles Deleuze se ocupa de la memoria y del tiempo como materia de la imagen fílmica; el filósofo francés evidencia como el arte cinematográfico tiene la posibilidad de representar y alterar las múltiples relaciones entre espacio y tiempo, los cruces entre segunda (el encuadre), tercera (la realidad filmada) y cuarta dimensión (los tiempos).

\section{Montaje}

La fase final de realización de una obra cinematográfica es la en la cual los varios fragmentos de película, correspondientes a los planos rodados, son escogidos y empalmados para generar las escenas. Estas últimas se unen para formar las secuencias que construyen la película.

Según Pasolini el montaje corresponde a lo que la muerte representa respecto a vida: un corte-relectura que es capaz de dar significado a las acciones humanas ${ }^{2}$.

\section{Panorámica o Travelling}

Es un tipo de plano que se produce mediante el desplazamiento de la cámara en el escenario a través del auxilio de sistemas mecánicos como grúas o vías. (eje. Dolly Cam)

1 (Burch, 1985 p.29)

2 (Pasolini P. , 1971) 


\section{Picado/Contrapicado}

El primero es un plano que corresponde a un ángulo oblicuo de la cámara que filma desde arriba y mirando hacia abajo, en oposición al contrapicado en donde el ángulo es obtenido con la cámara filmando desde abajo hacia arriba. En el Neorrealismo este tipo de plano es una herramienta que describe la difícil condición topográfica en asentamientos informales y terrenos baldíos. Crea inquietud en el espectador y dinamismo en las escenas rodadas.

\section{Raccord}

Es el enlace o la continuidad que en el Cine se establece entre diferentes planos sin ningún salto, creando una coherencia espacial y/o temporal. Se puede lograr un raccord a través de diferentes herramientas: mirada, posición, maquillaje, vestuario, montaje, etc...

\section{Recorridos}

Son los "viajes" que los protagonistas realizan dentro de la ciudad para alcanzar sus metas o simplemente sus "derivas". Los recorridos corresponden a la visión espacial de los directores que exploran los nuevos territorios urbanos a través de los personajes de sus obras. En este trabajo de investigación los recorridos se componen de diferentes vectores que conectan los diferentes escenarios.

\section{Tiempo (real y fílmico)}

En este trabajo se distingue entre tiempo real o narrativo y tiempo fílmico o cinematográfico. El tiempo cinematográfico puede comprimir o dilatar el tiempo real-narrativo. Una acción que en la realidad se desarrolla en un día podría ser comprimida en la duración de 90 minutos del rodaje cinematográfico.

\section{Topología del Rodaje}

Con esta expresión se define en esta investigación, el análisis de la ubicación geográfica de los escenarios y decorados utilizados para el rodaje de una obra cinematográfica. Además de las investigaciones después del rodaje, se pueden incluir bajo esta definición también los análisis sobre el territorio hechas por los directores antes de la realización final de la película.

\section{Unidades del rodaje}

\section{SECUENCIA}

Se compone de una serie de escenas con el propósito de desarrollar una temática o unidad narrativa dentro de la obra cinematográfica. Puede desarrollarse en diferentes lugares también sin correspondencia entre tiempo cinematográfico y tiempo narrativo.

\section{ESCENA}

Serie de planos que forman parte de una misma acción que está marcada por un mismo espacio y tiempo. Se habla de diferentes escenarios o decorados para definir estos cambios espaciales. Cuando hay un cambio de decorado o de tiempo en la narración cinematográfica, se produce también un cambio de escena.

\section{TOMA}

Un director roda una película a través de un conjunto de planos para describir una acción cinematográfica que tiene el nombre de toma; una misma acción puede ser descripta por diferentes planos - diferentes puntos de vista o encuadres - que en el montaje final el director selecciona para determinar los que realmente se van a utilizar para la realización de la escena. 


\section{PLANO}

Corresponde a la unidad mínima en una toma cinematográfica, Corresponde a un encuadre, enfoque, ángulo y posición concreta de la cámara. Hay diferentes tipos según el ángulo de la cámara:

- Plano Secuencia: cuando un plano sigue la acción sin ninguna interrupción o montaje. Es una secuencia que se roda en un solo plano.

- Primer Plano: se encuadra por entero la cara de un personaje desde el cuello hasta la parte superior de la cabeza; también puede ser una parte de una figura humana o un objeto por entero.

- Primerísimo Plano: se encuadra un rostro al detalle desde la barbilla hasta la frente o una parte de un objeto, ocupando todo el encuadre.

- Plano Medio: en la descripción de un personaje el P. medio encuadra la parte superior de la figura humana, cortada por la cintura o a la altura del pecho, excluyendo caderas y piernas.

- Plano Americano: es un formato de encuadre que muestra un personaje casi por entero desde las rodillas hacia arriba.

- Plano Conjunto o Entero: Corresponde a un encuadre de la figura humana describiendo por entero que posición ocupa en el espacio. Muestra un personaje por entero.

- Plano general: muestra el lugar en donde se desarrolla la acción y se enfoca en el espacio del decorado.

- Gran Plano general: Sirve para definir una escala paisajística y territorial muy utilizado en el género western; los personajes, si se encuentran en el encuadre, casi desaparecen en el paisaje, que es el verdadero protagonista de este plano.

\section{Vectores}

En este trabajo de investigación los recorridos se componen de diferentes vectores que conectan los diferentes decorados de la película a una escala territorial y urbana.

\section{Zoom}

Es un movimiento en el plano que corresponde a una modificación de la lente de distancia focal variable, logrando un alejamiento o un acercamiento a un objeto o sujeto, sin un movimiento real de la cámara. 
